\title{
DIVERSIDADE, RELAÇÕES RACIAIS E EDUCAÇÃO EM DIREITOS HUMANOS
}

Maria Letícia Puglisi Munhoz

\begin{tabular}{llllll} 
Dissertação & de & Mestrado & \multicolumn{3}{c}{ apresentada ao } \\
Programa de & Pós-Graduação & em & Direitos \\
Humanos da & Faculdade & de & Direito & da \\
Universidade de São Paulo. & & &
\end{tabular}

Orientadora: Profa. Dra. Gislene Aparecida dos Santos

UNIVERSIDADE DE SÃO PAULO

São Paulo

2009 


\section{AGRADECI MENTOS}

À minha orientadora, Profa. Dra. Gislene Aparecida dos Santos, não só pela paciência e dedicação, mas pelo importante fato de ter me oferecido a raríssima oportunidade de poder ter profundos debates e reflexões sobre o espaço que ocupamos, o que sentimos e o que buscamos em uma sociedade racista, permeada pela discriminação racial e preconceito. Acima de tudo por sua sensibilidade, sua inteligência especial e sua amorosidade na condução deste projeto. Tudo isso me autoriza dizer que, se não fosse pela pessoa dessa orientadora, o projeto não teria saído do coração e sido colocado no papel.

Ao Sr. J. C. Benício, profissional que atua na área, que foi a pessoa com quem aprendi a ver, pela primeira vez, os negros que convivem comigo. Além disso, ver os negros que me ensinaram - os poetas, músicos, escritores, dançarinos, diversos profissionais negros, e, mais ainda, que minha estória está intimamente ligada à estória das pessoas negras neste país. E me despertou para essa busca, para entender como funcionamos em nossas relações sociais permeadas pelo fenômeno do racismo.

Ao Instituto AMMA Psique e Negritude, nas pessoas da Sra. M. L. da Silva e Sra. J. Dias, que me forneceram todo o apoio, conhecimento teórico e prático, para que eu pudesse continuar meu aprendizado.

À Comunidade Internacional de Direitos Humanos, que por meio dos programas educacionais, estimulou-me a aprender em espaços de convivência multi-étnicas e pesquisar o assunto.

Aos meus pais, que viram nesse caminho uma esperança, pela enorme capacidade de doação e apoio às minhas realizações. Às minhas irmãs por todo o carinho.

Aos entrevistados e entrevistadas que se dispuseram a se emocionar e refletir comigo sobre os aspectos do racismo.

À FAPESP, que deu o suporte financeiro para a realização dessa pesquisa. 


\section{RESUMO}

Considerando os princípios da igualdade, solidariedade e direito à diferença, que regem a Constituição Federal e os documentos internacionais de Direitos Humanos, o presente trabalho, com base em produção teórica da área da psicologia social, antropologia, direito e educação e experiência empírica, investiga os componentes presentes nas relações sociais entre os jovens brancos e negros, que se caracterizam como componentes fornecidos pela cultura brasileira que contribuem para a perpetuação das condutas preconceituosas e da discriminação étnico-racial contra os negros e, conseqüentemente, a desigualdade racial no Brasil.

Para a investigação empírica, foram realizadas entrevistas, por meio de um questionário semi-estruturado, com os jovens brancos e negros cotistas que são alunos de algumas universidades brasileiras que implementaram a política de ação afirmativa por meio de cotas raciais.

Tudo isso com a finalidade de produzir elementos que venham contribuir para o desenvolvimento de programas educacionais que tenham como objetivo efetivamente promover a eliminação da discriminação racial e o convívio mais igualitário nas relações sociais em um contexto de diversidade, como é o caso da Educação em Direitos Humanos.

Palavras-chave: direitos humanos, discriminação racial, igualdade, solidariedade, educação, diversidade. 


\begin{abstract}
Considering that the fundaments of the Brazilian Federal Constitution and the international documents of Human Rights lies under the principals of equality, solidarity and the rights of diversity, this research, based on academic theory of the social psychology, anthropology, law and education subject, including also empiric research, investigates the Brazil cultural components that lies in the youths white and black social relations, and contribute for the perpetuation of ethnic prejudices behaviors and racial discrimination against black population, and, therefore, to the racial inequality in Brazil.
\end{abstract}

The empiric investigation was realized through some interviews using semiframework questionnaires on white and black students in some Brazilians universities witch implemented the politic of affirmative action of racial ñquoteò

The purpose of this was to produce elements that will contribute to the development of educational programs that have, as their goal, effectively promote the elimination of the racial discrimination and the equality conviviality at the social relations in the diversity context, accordant with the Human Rights Education.

Key words: human rights, racial discrimination, equality, solidarity, education, diversity. 


\section{SUMÁRIO}

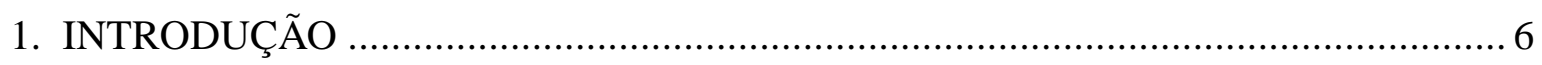

2. UNIVERSALISMO E RELATIVISMO E DIREITOS HUMANOS ......................... 12

3. O PRINCÍPIO DA IGUALDADE, SOLIDARIEDADE E DIVERSIDADE ............... 14

4. POLÍTICA DE AÇÃO AFIRMATIVA POR MEIO DE COTAS RACIAIS NAS

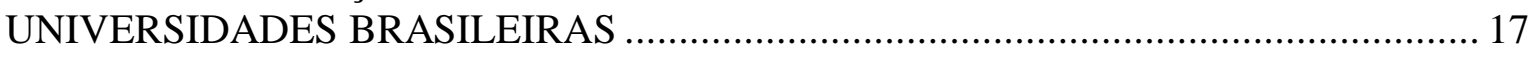

5. PRECONCEITO, DISCRIMINAÇÃO E RACISMO ............................................. 27

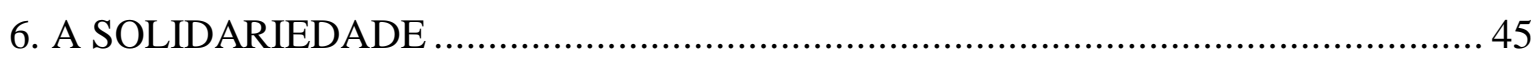

7. EDUCAÇÃO EM DIREITOS HUMANOS ....................................................... 49

7.1. Definições e objetivos da educação em direitos humanos..................................... 49

7.2. Discussão sobre educação em direitos humanos .................................................. 54

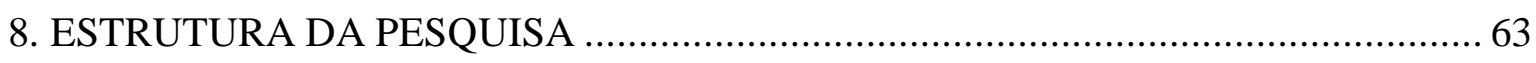

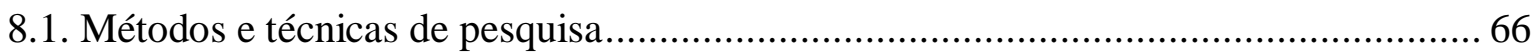

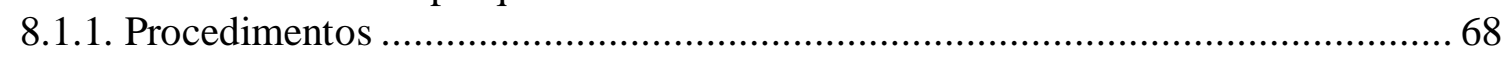

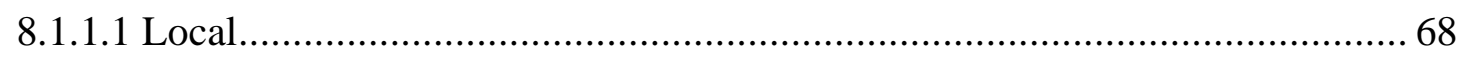

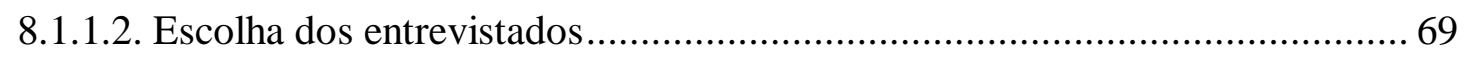

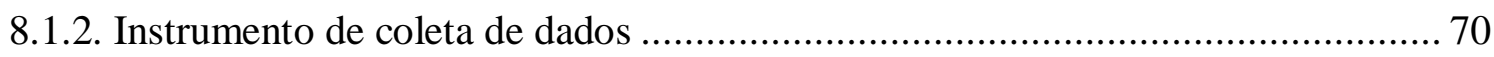

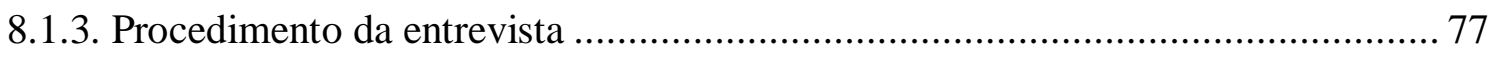

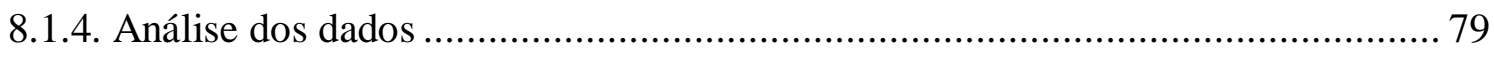

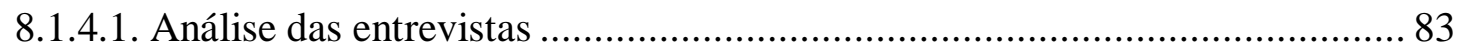

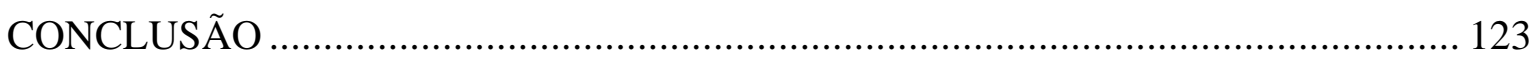

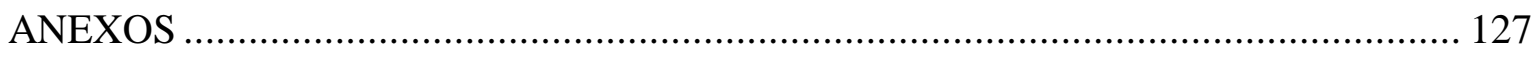

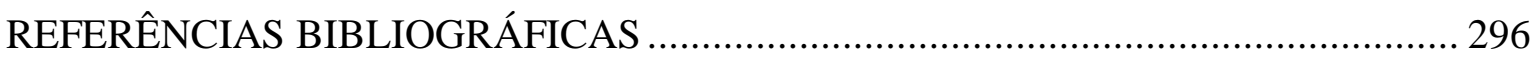




\section{INTRODUÇÃ̃}

A comunidade internacional de direitos humanos tem se desenvolvido no âmbito da elaboração de documentos que possuem a finalidade de determinar as diretrizes para a construção de uma sociedade que respeite a paz, os direitos fundamentais do ser humano e a dignidade humana. Assiste, no entanto, a episódios cada vez mais violentos e sociedades com dificuldade de garantir a não violação dos direitos humanos ou promover o exercício desses direitos pelos indivíduos.

A violência e as situações de conflitos ocasionadas pela intolerância diante da diversidade étnica e racial têm sido alguns dos maiores focos de preocupação dos sistemas regionais de direitos humanos e da própria Organização das Nações Unidas, uma vez que representam uma das principais causas desses conflitos violentos, situações essas que se apresentam sempre com características bem peculiares às realidades locais, mas que também trazem elementos comuns para análises mais generalizadas (ALVES, 2005).

Neste contexto, a educação em direitos humanos tem sido referenciada em inúmeros documentos como um dos principais instrumentos para a transformação dessa realidade.

Com efeito, tem se entendido que a realização de uma sociedade com base nas recomendações dos direitos humanos se dará por meio de uma transformação da atual para uma na qual se valorizem os direitos humanos, por meio de comportamentos guiados por valores, crenças, práticas e cultos voltados para esse fim. Assim, apesar da importância dos sistemas legislativo e judiciário dos Estados nesse processo de internalização e/ou fortalecimento dos direitos humanos nos países, estes, por si sós, são ineficientes em consolidar os princípios dos direitos humanos, pois possuem como ação mais direta a de coagir comportamentos, mas não necessariamente transformar valores e condutas humanas presentes nas relações sociais cotidianas. 
A efetivação da educação em direitos humanos, por sua vez, enfrenta o desafio de encontrar conteúdos programáticos e metodologias significativos para atingir os objetivos a ela conferidos.

Consoante o mencionado acima, tendo em vista a importância para a atualidade do convívio igualitário dos cidadãos na diversidade étnico-racial, que é uma das metas que mais se busca na implementação dos direitos humanos, tanto para que se criem alternativas construtivas para os conflitos violentos, quanto para que se elimine a exclusão de grupos ao acesso a todo o patrimônio da humanidade, ou para que todos os indivíduos possam se enriquecer com a diversidade que possuímos, a educação em direitos humanos deve se ater, como tem feito, especialmente a esse tema.

Considerando particularmente o Brasil, observamos, apesar de o princípio da igualdade e solidariedade ser consagrado em sua Constituição Federal, proclamado como um valor que pretendemos cultuar, que o que se evidencia é a exclusão de grupos chamados de ñminoriasò, justamente em decorrência da diversidade que apresentam. No que concerne à diversidade-étnico-racial no Brasil, avaliamos que a situação à qual a população negra tem sido submetida perpetua a convivência injusta, porque desigual e prejudicial e destrutiva para toda a sociedade.

Sendo assim, é mister que a educação em direitos humanos tenha sua atenção voltada para formas de atingir e transformar o fenômeno do racismo, do preconceito e da discriminação racial contra a população negra, aprofundando-as. É nesse contexto que o presente trabalho pretendeu, com base em produção teórica da área da psicologia social, antropologia, educação a respeito do assunto e experiência empírica, investigar os componentes que estão presentes nas relações entre brancos e negros, que são produtos da cultura racista que vivemos $\mathrm{e}$ fazem perpetuar as condutas preconceituosas e discriminatórias e, conseqüentemente, a desigualdade racial no Brasil. Isso para que sirvam de elementos para os programas de educação em direitos humanos e outros correlatos, cuja meta seja a eliminação da discriminação racial nas relações sociais, funcionando, de acordo com Norberto Bobbio, como instrumento para a efetivação das diretrizes e princípios previstas e almejadas pela comunidade internacional de direitos humanos (BOBBIO, 1991). 
É do entendimento dos juristas Comparato (1993) e Flávia Piovesan (2006) que as políticas afirmativas que se dão na forma de criação de direitos determinados pela diferença de grupos como mulheres, pessoas com deficiências, idosos, negros etc. têm sua fundamentação teórica e jurídica no princípio da igualdade e no princípio da solidariedade, que fazem parte dos fundamentos dos direitos humanos e da Constituição Federal. Com efeito, no caso da política pública brasileira de ação afirmativa com base em critérios de cotas raciais para o acesso às universidades, que tem como objetivo gerar a igualdade de oportunidade à formação universitária para jovens pretos, brancos pobres e indígenas, propondo a reserva de vagas para alunos que realizaram integralmente sua formação na rede pública, para pretos, pardos e indígenas em instituições federais de ensino, por meio de discriminação positiva e de acordo com a porcentagem de negros e pardos em cada unidade da Federação.

Este trabalho não pretende discutir a coerência jurídica e política da política de ação afirmativa por meio de cotas nas universidades, posto que aqui, em conformidade com o argumento acima, já se parte da convicção do carácter justo e pertinente da proposta. Nem irá, igualmente, discutir as consequiências sociológicas e políticas da medida para a população negra e sociedade brasileira e sua eficácia reparativa, posto que aqui já se admitem positivas. De fato, apóia-se no entendimento de que a política de ação afirmativa é um instrumento de empoderamento político da população negra, que representa um importante passo da política brasileira no caminho da consolidação da democracia no país (PINHEIRO, 2001).

Na verdade, o fenômeno do racismo, como toda ideologia, afeta a sociedade de uma forma complexa, de maneira que, além dos campos políticos e jurídicos, em outras esferas há que se intervir para mais efetivamente provocarmos uma transformação. As condutas preconceituosas e discriminatórias geradas pelo racismo ocorrem no âmbito das relações sociais, cotidianas e corriqueiras, de formas, muitas vezes, bastante sutis, mas não menos prejudiciais, afetando profundamente os indivíduos, psicologicamente inclusive.

As universidades que implementaram a política de ação afirmativa por meio de cotas, em seus campus, promoveram um ambiente de convívio entre brancos e negros que talvez seja inédito em nossa história e possivelmente na história dos indivíduos que estão vivenciando a experiência de serem alunos lá, isto é, é provável que em alguns casos as 
pessoas que se relacionam nesse ambiente não teriam a oportunidade de fazê-lo em outra ocasião ou espaço. Trata-se, portanto, de um ambiente que, de acordo com o estigma brasileiro, sempre esteve reservado a uma população socialmente privilegiada, composta em sua grande maioria por pessoas brancas, e, a partir da implementação da política, cumprindo os desígnios do projeto Ministerial da Diversidade na Universidade, passou a proporcionar o convívio entre negros e brancos e, juntamente com isso, as idéias do direito de compartilhamento do lugar de privilégio entre brancos e negros e da igualdade de oportunidades de desenvolvimento.

Ou seja, de maneira indireta, as políticas de acesso por cotas raciais trazem como decorrência um convívio $\ddot{i}$ mesmo que forçado pela lei $̈$ entre esses diferentes, que, na maioria dos casos, estão compartilhando o mesmo ambiente pela primeira vez. Esse ambiente, no entanto, apesar de público, não é neutro, assim como o encontro dessas pessoas não se assemelha a encontros de grupos diferentes que nada sabem uns sobre os outros. Ao contrário, a relação entre essas pessoas não está isenta dos efeitos do racismo que historicamente atua na cultura brasileira, pois não é impermeável a eles. Por isso tudo, os conflitos latentes ou presentes nas relações raciais da sociedade brasileira estarão presentes nas relações entre os alunos que estão vivendo essa experiência e na relação deles com a instituição, de forma mais visível.

Com efeito, diz Segato (2008), em sua abordagem sobre os efeitos da implementação da política de ação afirmativa por meio de cotas raciais e do debate em torno dela:

ñEficácia reparadora: (...) as cotas acusam, com sua implementação, a existência do racismo (...); Eficácia experimental: (...) Constitui um verdadeiro laboratório de experimentação sociológica e pedagógica, um campo de observação onde os resultados da intervenção podem ser periodicamente verificados e submetidos à crítica. (...) Eficácia política: (...) tem, ainda, um efeito secundário, porém de extraordinária relevância: nele, a nação aceita publicamente sua responsabilidade pela prática sistemática do racismo ao longo de sua história. (...) Esse processo de aceitação de responsabilidade, tema absolutamente atual da filosofia contemporânea, é o 
único capaz de levar uma sociedade nacional à reconciliação e a paz.ò (SEGATO, 2006/2007, p. 83-85)

Nesse sentido, parto do pressuposto de que a relação das pessoas submetidas a essa experiência traz, mais explicitamente, as tensões e os conflitos em geral silenciados entre os brancos e negros (o preconceito sofrido e silenciado, percebido e não revelado, praticado e não dito) e os vícios que em geral dificultam ou impossibilitam que esses elementos sejam percebidos. Produz o efeito de uma verdadeira lupa sobre o que ocorre nas relações cotidianas no ambiente social, por meio das situações inerentes à experiência universitária. $\mathrm{O}$ fato de esses jovens terem passado pelo processo de disputa por vagas universitárias e, portanto, por um processo em que se vivencia um alto grau de competitividade, corresponde às circunstâncias sociais que José Leon Crochik (1995) descreve como impulsionadoras da manifestação de preconceitos e atitudes de discriminação. Assim, como primeiras experiências, revelam situações que apontarão fatores a serem observados em futuros programas direcionados à promoção da igualdade racial, sendo essa a razão da escolha do ambiente a ser pesquisado.

A visualização desses conflitos deve ser entendida como uma vantagem, na medida em que, a partir daí, esses fatores podem ser trabalhados. Em outras palavras, a criação desse ambiente de diversidade nas universidades pelas instituições que implementaram a política de cotas raciais pode promover a manifestação de tensões e conflitos pelos estudantes. Se os aspectos suscitados não forem observados e trabalhados, a política não alcançará a eficácia desejada, podendo criar outro ambiente de reprodução e/ou multiplicação de preconceitos raciais, discriminação racial e, conseqüentemente, desigualdade racial, em vez de contribuir para a sua superação. Por outro lado, a implementação dessa política se constitui em um verdadeiro laboratório para a preposição de uma metodologia voltada para a solidariedade, de forma que, se os elementos suscitados forem trabalhados, como se propõe, importantes resultados poderão ser obtidos em direção à promoção da igualdade nas relações raciais brasileiras e, portanto, poderemos nos beneficiar do enriquecimento que o convívio igualitário na diversidade pode proporcionar.

Assim, a partir da implementação da referida política em algumas universidades, tendo como base a produção teórica na área da psicologia social sobre o tema, pretende-se discutir os aspectos que são produzidos pela cultura do racismo e reproduzidos pelas 
atitudes dos indivíduos, presentes nas relações sociais entre as pessoas negras e brancas envolvidas diretamente com essa experiência, analisando como influenciam na experiência dos estudantes na efetivação dos objetivos da política e de seus fundamentos, a saber, os princípios da igualdade, da diversidade e solidariedade. Tudo para que sirvam como aspectos orientadores de propostas programáticas das atividades de educação em direitos humanos voltadas para a eliminação da discriminação racial.

É de salientar que a identificação dos fatores que são suscitados nas relações entre os estudantes brancos e negros cotistas nessa experiência diferenciada tem como objetivo coletar um conteúdo útil para a elaboração de medidas educacionais que possam transformar as tensões e conflitos na direção do convívio construtivo entre negros e brancos. Portanto, sob o ponto de vista deste trabalho, os elementos coletados não têm nenhuma relação com uma avaliação negativa da política; ao contrário, como já mencionado, a política cria uma oportunidade única para se desenvolverem métodos e técnicas de educação em direitos humanos. 


\section{UNIVERSALISMO E RELATI VISMO E DIREITOS HUMANOS}

Nos últimos 50 anos, instalou-se um debate entre a pretensão universalista dos Direitos Humanos e os defensores do relativismo cultural (corrente fortemente pautada nas concepções antropológicas relacionadas à não superioridade de um povo sobre outro) sobre a possibilidade de se estabelecer uma ética-moral universal para todos.

Segundo Vicente Barreto (2002), a idéia central do relativismo consiste em afirmar que nada pode atender ao bem-estar de todo ser humano, isso porque os seres humanos não são semelhantes em nenhum aspecto que comporte generalizações. Esse argumento resulta de uma constatação antropológica da existência na humanidade de diferentes valores, hábitos e práticas sociais, que se expressam sobre variadas formas culturais, e, por isso, é impossível o estabelecimento de normas universais de comportamento social. Aponta que há quem defenda que os Direitos Humanos são uma moralidade mínima, uma espécie de religião global, imperialista.

Os argumentos universalistas, por outro lado, demonstram que algumas necessidades são comuns a todos os seres humanos e que há valores que conduzem à satisfação de necessidades compartilhadas por todos eles.

Com efeito, como argumenta Flávia Piovesan (1997) a respeito do debate internacional sobre a universalidade dos direitos humanos, a Declaração Universal de Direitos Humanos não representaria um mínimo denominador comum de distintos sistemas e culturas, mas o ideal comum a ser atingido por todos os povos e todas as nações, e, nesse sentido, os princípios universais dos Direitos Humanos seriam escolhas políticas e, assim, não precisam representar a essência cultural dos povos e nações e também não trazem prejuízo ou aniquilamento cultural.

Nas palavras de Michael Freeman (2002), ño universalismo dos direitos humanos pode ser compatível com o respeito à diversidade cultural, por que os defensores dos direitos humanos podem tolerar ou celebrar todas as culturas, com a condição de que elas 
não oprimam e aviltem aqueles que estão sob o seu poderò (FREEMAN, 2002, p. 312). Como propõe Boaventura dos Santos (2003), ñé o princípio da unidade na diversidadeò.

É com esse fundamento que a superação do racismo e as ações de Educação em Direitos Humanos serão discutidas neste trabalho. 


\section{O PRINCÍPIO DA IGUALDADE, SOLIDARIEDADE E DIVERSIDADE}

\section{Igualdade}

A noção de igualdade como justo foi criada na Grécia, como elemento fundamental a contrapor o poder arbitrário dos governantes, isto é, como garantia de que a legislação, escrita, a ser aplicada a um indivíduo deveria ser aplicada a todos, independentemente da vontade subjetiva do aplicador da lei. ñO princípio da Igualdade desenvolvido por Aristóteles representou para os gregos a essência da democracia uma vez que, além de ser relacionado diretamente com a idéia de justiça, veio contrapor a política tirânica em que um homem governava detendo a lei em suas próprias mãos, e para estabelecer as leis escritas como uma forma de criação de direitos iguais a todosò (COMPARATO, 1993, p. 2).

Dentro do sentido formal do princípio da igualdade está o conceito de Aristóteles da justiça distributiva, do qual se entende a igualdade proporcional, em que se deve o tratamento aos indivíduos na medida de suas desigualdades como forma de se obter a verdadeira relação de igualdade entre os diferentes e, assim, estabelecer a igualdade de exercício dos direitos previstos em um ordenamento jurídico para que se efetue o postulado ñtodos são iguais perante a leiò. É esse conceito que permeia o princípio da igualdade defendido pelos artigos da Constituição Federal Brasileira de 1988.

\section{Solidariedade}

Sendo assim, conforme dispõe Comparato (1993), o princípio jurídico da igualdade dá nascimento a direitos determinados, sem que isso se caracterize como uma discriminação, isto é, a partir de um critério de diferenciação, desde que uma desigualdade de tratamento jurídico possa ser justificada por um objetivo de interesse público, ela não quebra o princípio da igualdade, ao contrário, faz com que o princípio seja efetivamente 
realizado. Não se trata de proteger um indivíduo ou uma determinada minoria, mas de criar um direito a todos que se encontram em uma situação descrita de modo geral e impessoal pela norma jurídica, para que todos tenham sempre acesso em ñigualdade de condiçõesò. E, nas palavras do autor: ñA igualdade perante a lei (...) é a verdadeira garantia para a evolução harmônica da humanidade, cuja grande riqueza (...) é feita pela unidade de suas diferençasò (COMPARATO, 1993, p. 78).

A partir do séc. XIX, diante da extrema atenção dada às liberdades privadas e ao individualismo próprio das sociedades burguesas, e da constatação da necessidade de se atentar aos componentes sociais que ocasionam desigualdades e de se elaborarem diretrizes que compensassem essas desigualdades sociais para se garantir as liberdades sociais, com base no conceito da justiça distributiva de Aristóteles, desenvolveram-se o princípio da solidariedade e os chamados direitos sociais.

Conforme dispõe Comparato, ñcom base no princípio da solidariedade, passaram a ser reconhecidos como direitos humanos os chamados direitos sociais, que se realizam pela execução de políticas públicas, destinadas a garantir amparo e proteção social aos mais fracos e mais pobres, ou seja, àqueles que não dispõem dos recursos indispensáveis para viver dignamenteò (COMPARATO, 2006, p. 538), assim como o direito à educação formal, à saúde etc.

\section{Diversidade}

Conforme diz Boaventura dos Santos, vivemos durante muito tempo sob o domínio exclusivo do monoculturalismo.

Roger Rios (2008) expõe que a luta para se eliminar o tratamento privilegiado a pessoas de diferentes classes sociais, durante a Revolução Francesa, foi um momento histórico importante e o reconhecimento e o direito à diferença não atuam de forma diversa a essa etapa de evolução humana, ao contrário, fortalecem a efetivação do princípio da igualdade defendido nessa revolução. 
Conforme discorre Lindgren Alves (2006), a palavra multiculturalismo está associada a políticas públicas destinadas a valorizar a diversidade cultural. Mas não só isso, essas políticas são permanentes e têm como objetivo trazer para o ordenamento jurídico e para a vida pública interesse de grupos que não estavam representados. Trata-se de uma política permanente, que busca uma sociedade que conviva com a diversidade, a partir de direitos específicos. Assim, por exemplo, é o caso de criar o direito específico a pessoas indígenas de irem a uma escola em que se ensine a cultura indígena.

Outras formas de criação de políticas específicas para grupos diferenciados, no entanto, são as políticas de ações afirmativas voltadas à promoção da igualdade. São provisórias, isto é, como princípio, devem existir somente enquanto persistir a condição de desigualdade que a política pretende alterar. Com efeito, o direito à educação é um dos direitos sociais previstos em nossa Constituição e em documentos internacionais de Direitos Humanos. Esse é um mesmo direito para todos. A partir desse direito universal é que se criam os direitos específicos relacionados à educação, como é o caso da política de ação afirmativa por meio de cotas implementada em algumas universidades públicas do Brasil. O fundamento dessa política invoca o direito à diferença em relação à população negra e indígena, assim como pleiteia o reconhecimento ao direito específico de grupos minoritários de ingressar na universidade por meio especial, tudo para a promoção do direito à igualdade de oportunidade de educação.

Contudo, para que políticas e leis sejam feitas especificamente para um grupo, é necessário que esse grupo seja reconhecido como um grupo que possui características diversas da maioria, que essa diferenciação traga como conseqüência prejuízos sociais a esse grupo pouco representado nos espaços públicos e que essas características demandem tratamentos diferenciados.

Esse tem sido o papel das estatísticas relacionadas à população negra e indígena, de fornecer subsídios para as ações de discriminação positiva direcionadas especificamente a esses grupos. 


\section{POlítica de AÇÃo AFIRMATIVA POR MEIO DE COTAS RACIAIS NAS UNIVERSIDADES BRASILEIRAS}

\section{Breve histórico sobre a política de cotas no Brasil}

A expressão tem origem nos Estados Unidos, nos anos 60, quando das reivindicações democráticas internas como o movimento dos direitos civis começam a ser eliminadas as leis segregacionistas e o movimento negro americano, apoiado por liberais e progressistas brancos, pressiona o Estado para que, além de garantir leis antisegregacionistas, viesse a assumir uma postura ativa para a melhoria das condições da população negra.

A partir daí, as ações afirmativas também foram experimentadas na Europa Ocidental, na Índia, Malásia, Austrália, Canadá, Nigéria, África do Sul, Argentina, Cuba, entre outros países. Nesses diferentes contextos, as ações afirmativas assumiram formas diversas, tais como: ações voluntárias, programas governamentais ou privados, leis e orientações a partir de decisões jurídicas ou agências de fomento.

As principais áreas de contemplação das ações afirmativas são: o mercado de trabalho, como contratação, qualificação e promoção de funcionários; o sistema educacional, especialmente o ensino superior; a representação política. Seu público alvo variou de acordo com as situações existentes e abrangeu grupos como minorias étnicas, raciais, pessoas com deficiências especiais e mulheres.

O primeiro registro no Brasil de uma mobilização no sentido de solucionar o problema da discriminação racial no mercado de trabalho ocorreu em 1968, quando os técnicos do Ministério do Trabalho e do Tribunal Superior do Trabalho se manifestaram favoravelmente à criação de uma lei que obrigasse as empresas privadas a manter uma porcentagem mínima de empregados negros em seus quadros de funcionários, variando entre $20 \%, 15 \%, 10 \%$. Entretanto a lei não chegou a ser elaborada. 
Somente em 1980 houve a primeira formulação de um projeto de lei nesse sentido, pelo deputado Abdias Nascimento, propondo uma ação compensatória para o afrobrasileiro, que consistia em $20 \%$ de vagas para mulheres negras e $20 \%$ para homens negros no serviço público, bolsa de estudos, incentivos às empresas do setor privado para a eliminação da prática de discriminação racial, introdução da história das civilizações africanas e do africano no curriculum de ensino do Brasil. Contudo o projeto não foi aprovado pelo Congresso Nacional.

Já na década de 1990, verificamos maior movimentação nacional em torno da política de ação afirmativa: Em 1995, aconteceu no Brasil a primeira política de cotas adotada nacionalmente, na legislação eleitoral, que estabelecia uma cota mínima de $30 \%$ de mulheres para as candidaturas de todos os partidos políticos. Nesse mesmo ano, a Marcha Zumbi enviou ao governo federal o Programa de Superação do Racismo e da Desigualdade Racial, propondo ações afirmativas para o acesso de negros a cursos profissionalizantes e universidades. Por decreto se instituiu o GTI ï Grupo de Trabalho Interministerial $\ddot{i}$ para desenvolver políticas de valorização e promoção da população negra e o GTEDEO ï Grupo de Trabalho para a eliminação da Discriminação no Emprego e na Ocupação ï para implementar as medidas da convenção da Organização Internacional do Trabalho (OIT), pela qual o Brasil se compromete a implementar política nacional de promoção de igualdade de oportunidades no mercado de trabalho. No poder legislativo, surgiram propostas de ações afirmativas nos projetos do Deputado Florestan Fernandes (PT/SP), em 1993, projeto de emenda constitucional; da Senadora Bendita da Silva (PT/RJ), em 1995, Projetos de lei 13 e 14; do Deputado Federal Paulo Paim (PT/RS), em 1995, Projeto de lei 1239; do Deputado Federal Luiz Alberto (PT/BA), 1998, Projetos de lei 4567 e 4568; do Senador Antero Paes de Barros (PSDB), 1999, Projeto de lei 298. Até o final da década de 90 , nenhum desses projetos foi aprovado ou implementado.

Foi em 2001 que o Ministério do Desenvolvimento Agrário assinou portaria que cria uma cota de $20 \%$ para negros participarem da estrutura institucional do Ministério e do INCRA. No mesmo ano foi criada a política de cotas de contratação de negros (20\%), mulheres $(20 \%)$ e portadores de deficiências físicas (5\%) para os cargos de assessoramento do Ministério da Justiça e em 2002, foi criada pelo Ministério de Estado das Relações Exteriores a política de concessão de 20 bolsas de estudo federais a afrodescendentes que se preparam para o concurso de admissão ao Instituto Rio Branco. 
No âmbito do ensino superior, uma lei estadual do Rio de Janeiro estabeleceu, em 2001, que 50\% das vagas dos cursos de graduação das universidades estaduais fossem destinadas a alunos oriundos de escolas públicas, e outra, em 2002, estabeleceu que nas mesmas universidades se deveria destinar $40 \%$ dessas vagas a candidatos negros e pardos. No Paraná, em 2002, também foi criada a lei que estabelece três vagas, em cada uma das cinco universidades estaduais, destinadas a membros da comunidade indígena da região.

O projeto de reforma universitária encaminhado pelo Ministério da Educação propõe, entre outras coisas, a reserva de vagas para alunos que realizaram integralmente sua formação na rede pública, para negros, pardos e índios. Esses alunos teriam direito a vagas em instituições federais de ensino, por meio de discriminação positiva e em acordo com a porcentagem de negros e pardos em cada unidade da Federação. O projeto, ainda em discussão, também poderá envolver instituições públicas estaduais e privadas, como já ocorre por meio do Programa Universidade para Todos Pro-Uni. Apesar de o projeto se encontra em tramitação no Congresso, iniciativas independentes neste mesmo sentido foram tomadas por instituições do ensino superior, por exemplo, em São Paulo, pela UNIFESP, UNICAMP, em Brasília pela UNB, no Rio de Janeiro pela UERJ.

\section{Fundament os}

A política de ação afirmativa por meio de cotas tem como fundamento jurídico esses princípios expostos acima. Com efeito, o direito à educação é um dos direitos sociais previstos em nossa Constituição e em documentos internacionais de Direitos Humanos; inclusive se relaciona com o que vem se entendendo por direito ao desenvolvimento. Da mesma forma, o direito especifico de grupos minoritários de ingressar na universidade por meio especial vem ao encontro do que se entende por princípio da igualdade.

Segundo Flávia Piovesan, (2006), a Declaração Universal de 1948 introduz a concepção contemporânea de direitos humanos, marcada pela universalidade e indivisibilidade dos direitos, considerando universalidade na concepção de que a condição humana é o requisito único para a titularidade de direitos e o ser humano como um ser essencialmente moral, dotado de unicidade existencial e dignidade. A indivisibilidade dos 
direitos humanos combina o discurso liberal e o discurso social da cidadania, conjugando o valor da liberdade ao valor da igualdade, na medida em que considera os direitos econômicos, sociais e culturais em mesmo grau de importância e necessidade ao desenvolvimento e à garantia da dignidade da pessoa que diretos civis e políticos.

Fazendo uma análise sobre as fases dos direitos humanos, essa intelectual enfatiza que a primeira fase dos direitos humanos foi marcada pelas conseqüências da Segunda Guerra Mundial, que seria ña tônica do temor da diferença (ou da diferenciação)ò gerada pelo nazismo, o que levou a comunidade internacional de direitos humanos a uma atenção especial à proteção geral com base na igualdade formal.

No entanto, no decorrer da evolução dos direitos humanos ao longo dos anos, verificou-se a insuficiência do tratamento do indivíduo de forma genérica e abstrata, quando constatada a vulnerabilidade de determinados grupos se não tratados por proteção especial e particularizada. Ao contrário, determinadas violações de direitos exigem respostas específicas e diferenciadas, por exemplo, com relações às mulheres, às crianças e à população afrodescendente.

Nesse mesmo sentido, expõe Kabenguele Munanga (2006) que, depois da Segunda Guerra, os liberais esperavam que a Declaração Universal de 1948 resolvesse o problema das minorias, pois seriam protegidas indiretamente por meio das garantias dadas a todos os indivíduos de seus direitos civis e políticos fundamentais, já que esses diretos fundamentais são sempre exercidos em comunidade com outros indivíduos e, portanto, o reconhecimento de tais diretos individuais protegeria a vida do grupo, sem a necessidade de se considerar se o indivíduo pertencia a qualquer grupo distinto. No entanto, verificouse que esse modelo de Estado neutro perante as questões provocadas pela diversidade dos grupos étnico-culturais seria incapaz de resolver as questões resultantes das controvérsias concernentes às minorias.

Flávia Piovesan (2006) considera que, diante deste contexto, no âmbito dos direitos humanos, ao lado do direito à igualdade surge também, como direito fundamental, o direito à diferença. Assim, a diferenciação não mais seria utilizada para a aniquilação de direitos, mas, ao invés, para a promoção de direitos. E assim, como parte da concepção de igualdade, destaca três vertentes: 
a) igualdade formal: todos são iguais perante a lei;

b) igualdade material no que corresponde à justiça distributiva social (orientada pelo critério sócio-econômico);

c) igualdade material correspondente à justiça enquanto reconhecimento de identidades (orientada por critérios de gênero, orientação sexual, idade, raça, etnia e demais critérios).

Foi, então, nesse contexto que se aprovou a Convenção sobre a Eliminação de Todas as Formas de Discriminação Racial, trazendo as propostas para enfrentar a problemática da discriminação no âmbito do direito internacional dos direitos humanos, das quais se destacam duas estratégias com essa finalidade: a repressivo-punitiva e a estratégia promocional que tem como objetivo promover, fomentar e avançar a igualdade.

O documento oficial brasileiro sobre a Conferência das Nações Unidas contra o Racismo ocorrida em agosto e setembro 2001 defende a adoção de ações afirmativas para a população afro-descendente, nas áreas de educação e trabalho, e nas recomendações finais endossa a importância de os Estados adotarem ações afirmativas como medidas especiais compensatórias voltadas a aliviar a carga de um passado discriminatório daqueles que foram vítimas da discriminação racial, xenofobia e outras formas de intolerância.

Esse é um dos fundamentos jurídicos para a criação da política pública brasileira de ação afirmativa com base em critérios de cotas raciais para o acesso às universidades no qual se espelhou o projeto de Reforma Universitária encaminhado pelo Ministério da Educação, que propunha a reserva de vagas para alunos que realizaram integralmente sua formação na rede pública, para negros, pardos e índios. Esses alunos teriam direito a vagas em instituições federais de ensino, por meio de discriminação positiva e em acordo com a porcentagem de negros e pardos em cada unidade da Federação.

Essa política está em concordância com os compromissos que o Estado Brasileiro assumiu com a comunidade internacional para a implantação dos princípios da ñDeclaração dos Direitos Humanosò e seus tratados, especificamente da ñConvenção 
Internacional da Eliminação de Todas as Formas de Discriminação Racialò, adotada pela Assembléia Geral das Nações Unidas em 21 de dezembro de 1965 e ratificada pelo Brasil em 27 de março de 1968, que, entre outras coisas, em seu artigo $2^{\circ}$, estabelece que ños Estados Partes condenam a discriminação racial e comprometem-se a adotar, por todos os meios apropriados e sem dilações, uma política destinada a eliminar a discriminação racial em todas as suas formas e a encorajar a promoção de entendimento entre as raçasò.

Assim, na busca de encontrar instrumentos e aprimorá-los para a efetividade concreta dos direitos humanos declarados e seus fundamentos, ao se desenvolver na prática, deve se analisar se a política de ação afirmativa por meio de cotas, na forma em que é vivenciada nas universidades brasileiras, efetivamente implementa os princípios da igualdade e da solidariedade em que é fundada ou, em decorrência de uma sociedade preconceituosa e racista e da presença do preconceito e discriminação nas relações sociais nas universidades, encontra desafios para promover a efetiva igualdade de oportunidades para os jovens negros e brancos.

\section{Breve exposição dos argumentos contrários à implementação de política de cotas nas universidades}

Segundo expõe Munanga (2006), do debate atual em torno da política de cotas, podem-se retirar, esquematicamente, as seguintes idéias:

a) a política afirmativa de cotas nas universidades ameaça a identidade nacional ou a unidade nacional, reforçando uma exaltação da consciência racial que não existe no Brasil, posto que somos uma nação que já tem uma consciência de si própria como um povo miscigenado e que convive harmonicamente com isso. Essa exaltação forçada poderia acarretar em conflitos raciais que atualmente não existem na sociedade brasileira;

b) o Brasil estaria pressionado internacionalmente para implementar as políticas de cotas, o que estaria fazendo por uma imposição, algo que não vem ao encontro das demandas próprias do Brasil; 
c) já está demonstrado pela ciência biológica que raças humanas não existem, por isso não tem significado prático realizar políticas que enfatizam a diferença racial;

d) é uma política paternalista, de cunho assistencialista;

e) a política de cotas acarretaria uma diminuição da qualidade de ensino da população brasileira;

f) para a democratização do ensino, seria necessária política mais abrangente que considere o aspecto social da pobreza no Brasil, isto é, haveria de ser uma política para todos os que não têm acesso à educação, independentemente do aspecto étnico-racial;

g) a implementação da política de cotas, na prática da convivência entre alunos em uma universidade que por imposição legal vive uma situação artificial, pode acarretar em experiências constrangedoras e de grande sofrimento para o discriminado.

\section{Breve exposição dos argumentos favoráveis à implementação de política de cotas nas universidades}

a) A política de ação afirmativa sob o viés do Princípio da Igualdade:

Flávia Piovesan (2006) argumenta que a igualdade e a discriminação pairam sob o binômio da exclusão-inclusão. E, sendo assim, não é suficiente proibir a exclusão para se garantir a inclusão. Portanto, somente o combate repressivo à discriminação não é suficiente para se avançar na igualdade, mas é necessário conjugá-lo com a ação de promoção da igualdade. Nesse âmbito, da estratégia promocional, é que se colocariam as políticas compensatórias capazes de estimular a inserção e inclusão de grupos socialmente vulneráveis nos espaços sociais, mencionadas no parágrafo $4^{\circ}$ do artigo $1^{\circ}$ da ñConvenção para a Eliminação de Todas as Formas de Discriminação Racial (1969)ò como medidas especiais.

ñArt. $1^{\circ}, \S 4$. Não serão consideradas discriminação racial as medidas especiais tomadas com o único objetivo de assegurar o progresso adequado 
de certos grupos raciais ou étnicos ou de indivíduos que necessitem da proteção que possa ser necessária para proporcionar a tais grupos ou indivíduos igual gozo ou exercício de direitos humanos e liberdades fundamentais, contanto que tais medidas não conduzam, em consequiência, à manutenção de direitos separados para diferentes grupos raciais e não prossigam após terem sido alcançados os seus objetivosò

Na ñDeclaração e Programa de Ação adotados na III Conferência Mundial de Combate ao Racismo, Discriminação Racial, Xenofobia e Intolerância Correlata de Durban (2001)ò, as recomendações finais endossam a importância de os Estados adotarem ações afirmativas como medidas especiais compensatórias, voltadas a aliviar a carga de um passado discriminatório daqueles que foram vítimas da discriminação racial, xenofobia e outras formas de intolerância.

Segundo Flávia Piovesan (2006), nesse sentido se situam as ações afirmativas, como medidas especiais e temporárias que cumprem uma finalidade pública decisiva ao projeto democrático, tendo as seguintes características:

ï asseguram a diversidade e a pluralidade social;

ï viabilizam o direito à igualdade, com a crença de que a igualdade deve se moldar no respeito à diferença e à diversidade;

ï buscam remediar um passado discriminatório;

ï objetivam acelerar o processo de igualdade, com o alcance da igualdade substantiva por parte de grupos vulneráveis, e, por meio dela, transitar-se da igualdade formal para a igualdade material e substantiva;

ï a não adoção de tais medidas eficazes a romper o legado de exclusão étnico-racial compromete a plena vigência dos direitos humanos no país, da democracia, sob pena de termos democracia sem cidadania.

b) Em relação ao argumento de que a política afirmativa de cotas nas universidades ameaça a identidade nacional ou a unidade nacional, reforçando uma exaltação da consciência racial que não existe no Brasil, e, por isso, poderia acarretar em conflitos raciais que atualmente não existem na sociedade brasileira (argumento ñà), Munanga (2006) observa que, considerando que o conteúdo da raça é social e político, e que existe uma desigualdade social historicamente construída entre as raças branca e negra, que não 
se confunde com questões econômicas de todos os pobres brasileiros, no Brasil já existe um trabalho do Movimento Negro, desenvolvido há 30 anos, de conscientização de negros e mestiços em torno da mesma identidade de grupo. Assim, ñafirmar que a definição bipolar dos brasileiros em raças negras e brancas nasce das políticas de ação afirmativa ainda em debate é ignorar a história do Movimento Negro Brasileiroò(MUNANGA, 2006, p. 53). Ademais, os conflitos violentos entre a raça branca e negra já existem na sociedade brasileira e se revelam nas práticas do racismo, como demonstram os dados sobre exclusão, violência policial, mortalidade juvenil e outros. Ignorar isso é tentar manter invisível a desigualdade que decorre dos componentes étnico-raciais que dividem a sociedade.

c) Com relação ao outro argumento, de que o Brasil estaria pressionado internacionalmente para impor as políticas de cotas (argumento ñbò), no entender de Munanga (2006), pensar assim também é menosprezar o Movimento Negro Brasileiro, que sempre reivindicou políticas para reduzir a desigualdade racial.

d) A respeito do argumento ñcò, de acordo com Munanga (2006), a ideologia racista não precisa de um conceito de raça para se reproduzir, uma vez que ño racismo hierarquiza, desumaniza e justifica a discriminação existenteò decorrente das diferenças fenotípicas por ela simbolizada. Dessa forma, a solução não está na negação das diferenças ou na erradicação da raça, mas sim na luta e numa educação que busquem a convivência igualitária das diferenças.

e) Com relação ao argumento de que a política de ação afirmativa por meio de cotas nas universidades é uma política paternalista, que acarretaria na diminuição da qualidade de ensino da população brasileira (argumentos ñdò e ñeò), em entrevista concedida pelo Ministro Tarso Genro, relator do Agravo de Instrumento n. 2005.04.021.006358-2 sobre o sistema de cotas na Universidade do Paraná, elucida-se que a média dos alunos que entram para o Exame Nacional do Ensino Médio para o PROUNI (em que $36 \%$ de bolsas foram concedidas a afrodescendentes) é superior àquela obtida pelos alunos tanto das escolas públicas como das privadas no mesmo exame. Segundo o Ministro, a política seria paternalista se fosse permanente. 
f) A respeito do argumento ñfò, ainda o relator Ministro Tarso Genro discute que é simplismo alegar que as ações afirmativas na política de cotas nas universidades têm como objeto reparar no presente as injustiças do passado, isto é, prestar uma compensação pelo sofrimento da escravidão, e somente isso. Na verdade, as políticas afirmativas de cotas nas universidades estariam corrigindo injustiças presentes, verificadas na desigualdade de acesso ao estudo universitário aos negros em comparação com os brancos. Ainda que se argumente que para que todo o ensino brasileiro seja democratizado é necessária uma política mais abrangente que a de cotas nas universidades para negros e indígenas, a política de cotas é adequada a proporcionar aquilo que chama de uma ñelite novaò, um novo cenário social, com diversificação racial, que contribuirá muito para a construção de uma sociedade pluralista e democrática que o Brasil requer.

Ademais, com relação a esse tema, no texto de Munanga (2006) encontramos o argumento no sentido de que é essencial se entender que a política afirmativa pretende abrir um espaço público institucionalizado à diversidade, e que isso, por si só, já traz vantagens aos estudantes, povo e democracia brasileira. 


\section{PRECONCEITO, DISCRIMINAÇÃO E RACISMO}

Fábio Konder Comparato (2005), ao argumentar sobre o princípio da dignidade humana, inerente ao complexo dos fundamentos dos Direitos Humanos, diz que a descoberta da estrutura do DNA descoberta por Watson e Crick em 1953 revelou que cada ser humano possui um patrimônio genético único, salvo no caso de gêmeos homozigóticos. Em suas palavras, observa que ña ciência veio confirmar a visão filosófica (...) de que o caráter único e insubstituível de cada ser humano, portador de um valor próprio, veio demonstrar que a dignidade da pessoa existe singularmente em todo o indivíduoò (COMPARATO, 2005, p. 30).

Ao lado disso, também já foi constatado pela ciência que a classificação de indivíduos por raças não se justifica, uma vez que a estrutura genética dos integrantes do gênero humano não apresenta diversificação de espécies, isto é, as características que diferenciam fisiologicamente grupos de indivíduos como cor de pele, de olhos, formato de nariz e cabelo, por exemplo, são determinadas por elementos que não fazem parte da estrutura genética do ser humano. Dessa mesma análise, concluiu-se, inclusive, que existem mais diferenças genéticas entre pessoas pertencentes a mesmos grupos étnicos, povos de mesmas culturas e países, do que entre pessoas que vivem em locais, pertencem a grupos étnicos e/ou possuem cores de peles diferentes.

Em contraposição aos argumentos utilizados durante o decorrer da história da humanidade para justificar práticas de tratamento desigual às pessoas que possuem características físicas e/ou étnicas diversas, essa constatação científica, em que se demonstra a semelhança entre os seres humanos, tem sido intensamente utilizada para fortalecer os argumentos de que a igualdade de tratamento a todos os seres humanos é a forma mais justa de conduta dos indivíduos e das instituições para o desenvolvimento da sociedade atual.

Não por isso devemos entender que condutas racistas e as práticas de discriminação racial baseadas em característica fenotípicas, étnicas e culturais não ocorrem. Com efeito, o 
jurista Celso Lafer (2005), em parecer dado em processo judicial brasileiro que versava sobre a prática do crime de racismo, elucidou que, ñse o racismo não pode ser justificado por fundamentos biológicos, no entanto, persiste como fenômeno social e é este fenômeno social, e não a óaçaQ̂ o destinatário jurídico da repressão prevista pelo art. $5^{\circ}$, XLII, da Constituição de 1988, e sua correspondente legislação infraconstitucionalò, a saber: ña prática do racismo constitui crime inafiançável e imprescritível, sujeito à pena de reclusão, nos termos da leiò(LAFER, 2005, p. 58-59).

Explicando a ocorrência do fenômeno do racismo no Brasil, Kabengele Munanga (1996) atenta para o fato de que a sociedade brasileira é uma sociedade plural e essa pluralidade ou diversidade historicamente construída não é vivida tranqüila e harmoniosamente como deixou entender o mito da democracia racial brasileira. Pelo contrário, deu origem aos preconceitos raciais e étnicos que se conjugam para construir o racismo à moda brasileira. No entanto, ainda persiste a tendência social de se identificar com a idéia de que não somos ñ̃ão racistas assimò, que os brasileiros são afeitos à mistura racial, tratam-se bem na diversidade e falar sobre esse assunto poderia nos trazer uma desarmonia em um campo em que já somos harmônicos.

No entendimento de José Leon Crochick (1995), apesar de alguns intelectuais acreditarem que quanto menos se falar sobre o preconceito, melhor, posto que o fenômeno seria inevitável à constituição do indivíduo e muito arraigado à cultura para poder ser enfrentado, ño preconceito deve ser entendido e combatido, quer nos seus aspectos oriundos da subjetividade, quer nos seus fatores objetivosò (CROCHICK, 1995, p. 96), uma vez que, mesmo que venha se perpetuando na cultura, isso não significa que seja inerente a ela. Acredita que o esclarecimento é uma forma de combatê-lo, pois a ñpolítica do silêncioò ï conforme diz $\ddot{i}$ sobre o preconceito colabora para o esquecimento das violências de viés racistas praticadas pelo mundo e impede a manifestação daqueles que desejam se opor a elas.

Nesse sentido, Bobbio (2002) afirma:

ñão existe preconceito pior do que o de acreditar não ter preconceitos. Não há nada mais irritante que um anti-racismo preconceituoso, que se recusa a levar em conta as reais razões do racismo. Para parafrasear uma afirmação 
que triste mas injustamente ficou célebre graças a Leonardo Sciascia, convidaria a que desconfiássemos dos profissionais do anti-racismo. A mim importa tentar compreender o racismo antes de condená-lo, o que é até bastante fácil, já que o racismo é tão mal-afamado que ninguém se declara publicamente racista (razão pela qual as pesquisas de opinião não são muito confiáveis). Em vez disso, deve-se preocupar compreendê-lo, porque, se por óacismoô se entende, numa primeira aproximação, uma atitude de desconfiança para com o outro ï e especialmente para o outro que intervém inesperadamente em nossa vida $̈$, há um pouco de racismo em cada um de nós, e não há nada pior que o moralismo barato, pois ele, geralmente, quando é barato, é também hipócrita. Em segundo lugar, e sobretudo, apenas tentando compreender suas razões é que podemos tentar corrigi-lo e, em hipótese extrema, eliminá-lo.ò(BOBBIO, 2002, p. 122-123)

São essas as razões que nos conduziram a discutir este tema.

De acordo com Marilena Chauí (1993), pode-se definir o racismo de três formas: a forma T̃histórica, que considera o racismo como um conceito e uma ideologia que se constituíram apenas no século XIX, quando a idéia de raça, em sentido biológico e genético, tornou-se critério social e político de diferenciaçãoò, a forma ña-histórica, que considera o racismo como uma forma milenar e difusa de estabelecer diferenças, classificações e hierarquias entre os seres humanos; e a forma que o considera como uma relação de ideologias temporais e dinâmicas, sujeitas a transformações históricas, de modo que o racismo difuso dos gregos e romanos, na antiguidade, ou o racismo explícito do século XIX, são momentos de uma história ideológicaò(CHAUÍ, 1993, p. 1).

Norberto Bobbio (2002), em seu livro Elogio da Serenidade, expõe que a mera verificação da diversidade não gera necessariamente conseqüências nocivas a um bom convívio em sociedade e, portanto, não faz parte daquilo que se pode definir como racismo. ñA constatação da diversidade entre os seres humanos não é reprovável: os seres humanos são de fato diferentes entre siò, diz. ñA atribuição de valores e juízos ao diferente é o que caracteriza o preconceito e a discriminaçãoò (BOBBIO, 2002, p. 103). E assim explica o preconceito: ñentende-se por preconceito uma opinião ou um conjunto de opiniões (...) que é acolhida acrítica e passivamente pela tradição, pelo costume ou por uma 
autoridade de quem aceitamos as ordens sem discussãoò (BOBBIO, 2002, p. 103). Continuando, esclarece que os preconceitos coletivos são, por sua vez, aqueles que compartilhados por um grupo social inteiro e dirigidos a outro grupo social; derivam de um modo distorcido com que um grupo social julga o outro, gerando incompreensão, rivalidade, inimizade, desprezo ou escárnio. A conseqüência principal do preconceito coletivo é a discriminação.

Segundo Rios (2008), as expressões preconceito e discriminação foram muitas vezes utilizadas de formas correlatas pela legislação, como é o caso da Lei ${ }^{\circ} 7.716$, de 5 de janeiro de 1989, que tinha como objeto punir ños crimes de preconceito de raça ou de corò, por meio do seu artigo $1^{\circ}$, que foi alterado pelo artigo $1^{\circ}$ da Lei $n^{\circ} 9.459$, de 13 de maio de 1997: ñSerão punidos, na forma desta Lei, os crimes resultantes de discriminação ou preconceito de raça, cor, etnia, religião ou procedência nacional". No entanto, segundo o autor, entende-se por preconceito as percepções mentais negativas em face de indivíduos e grupos socialmente inferiorizados, e, por discriminação, a materialização dessas atitudes na forma de condutas omissivas ou comissivas que produzem a desigualdade.

Com relação a esse assunto, o tratado internacional de Direitos Humanos chamado de ñConvenção para a Eliminação de Toda forma de Discriminação Racialò, aprovado em 1965, apresenta a seguinte definição a respeito da discriminação racial:

ñArtigo $1^{\circ}$. Discriminação racial é qualquer distinção, exclusão, restrição ou preferência baseada em raça, cor, descendência ou origem nacional ou étnica, que tenha o propósito ou o efeito de anular ou prejudicar o reconhecimento, gozo ou exercício em pé de igualdade dos direitos humanos e direitos fundamentais.ò

Para Rios (2008), o conceito jurídico da discriminação que a Constituição Federal traz em seu bojo, em acordo com o documento internacional, ñaponta para a reprovação jurídica das violações do princípio isonômico, atentando para os prejuízos experimentados pelos destinatários de tratamentos desiguaisò(RIOS, 2008, p. 19).

Existem dois tipos de discriminação: a discriminação direta e a discriminação indireta. 
A discriminação direta ocorre pela conduta que tem a intenção de prejudicar pela diferenciação. Configura-se quando há um tratamento desigual motivado por um critério de diferenciação, previsto na lei como proibido. A discriminação direta pode ser implícita ou explícita.

A discriminação indireta ocorre por meio de práticas neutras que ocasionam a desigualdade de tratamento. Essa discriminação, portanto, não se configura por uma conduta prevista juridicamente como proibida. Ocorre por meio de atos, decisões, meios empregados para se obter um resultado que exclui determinado grupo. É o caso da discriminação institucional, por exemplo.

Assim, podemos entender que as práticas de racismo institucional, presentes no cotidiano das relações e processos das instituições brasileiras, ofendem os princípios da Constituição Federal, e especificamente o artigo $3^{\circ}$ :

ñArt. $3^{\circ}$. Constituem objetivos fundamentais da República Federativa do Brasil:

(...)

III - erradicar a pobreza e a marginalização e reduzir as desigualdades sociais e regionais;

IV- promover o bem de todos, sem preconceitos de origem, raça, sexo, cor, idade e quaisquer outras formas de discriminaçãoò

No entanto, o ordenamento jurídico brasileiro cria obrigações de modo claro e direto somente relacionadas à discriminação na sua forma direta, intencional (RIOS, 2008). Na Constituição, por exemplo:

ñArt. $5^{\circ}$

XLII - a prática do racismo constitui crime inafiançável e imprescritível, sujeito à pena de reclusão, nos termos da lei;ò

Na promoção dos Direitos Sociais: 
ñArt. $7^{\circ}$ São direitos dos trabalhadores urbanos e rurais, além de outros que visem à melhoria de sua condição social:

XXX - proibição de diferença de salários, de exercício de funções e de critério de admissão por motivo de sexo, idade, cor ou estado civil;

XXXI - proibição de qualquer discriminação no tocante a salário e critérios de admissão do trabalhador portador de deficiência;

Art. 227. É dever da família, da sociedade e do Estado assegurar à criança e ao adolescente, com absoluta prioridade, o direito à vida, à saúde, à alimentação, à educação, ao lazer, à profissionalização, à cultura, à dignidade, ao respeito, à liberdade e à convivência familiar e comunitária, além de colocá-los a salvo de toda forma de negligência, discriminação, exploração, violência, crueldade e opressão.ò

Segundo Leon Crochik (1995), o preconceito e a discriminação racial (cultural ou étnica) de um indivíduo ou grupo acontecem no âmbito das relações sociais, ou seja, nos ambientes familiares, de lazer e entretenimento, de trabalho, nas relações amorosas, sexuais, enfim, em todos os lugares e circunstâncias em que a relação entre dois ou mais indivíduos se dá.

Por isso, para entender o preconceito, precisamos recorrer a várias áreas do saber, uma vez que as relações sociais estão permeadas pela cultura. Tudo que compreende a esfera da cultura tem ligação com o comportamento preconceituoso e/ou discriminatório do indivíduo ou de um grupo.

Com efeito, dispõe José Leon Crochik (1995) que o preconceito ocorre como consequiência da combinação de características individuas do ser humano e das características culturais da sociedade em que vive, e, além disso, do processo de socialização desse indivíduo com a sociedade com que vai interagir. Sendo assim, o processo de socialização de um indivíduo está relacionado com a cultura e com a história dessa cultura. No entanto, a forma como esse indivíduo responderá aos conflitos impostos pelo processo de socialização é que acarretará o comportamento preconceituoso ou não. E, nesse sentido, a cultura contribui, funcionando como uma estimuladora de criação de preconceituosos, ou ao contrário, como uma promotora do desenvolvimento de indivíduos maduros, solidários e saudáveis. Nas palavras do autor: గ̃̃ara enunciar o óbvio não existe 
indivíduo sem cultura, mas a cultura pode facilitar ou dificultar o desenvolvimento do indivíduo, o que não é tão óbvioò (CROCHIK, 1995, p. 17).

O presente estudo irá tratar não das características individuais do ser humano pressuposto ao desenvolvimento do preconceito, mas das características culturais da sociedade e do processo de socialização que atualmente contribuem para a perpetuação do racismo na nossa sociedade.

Isso porque, para Crochik, a experiência e a reflexão são as bases da constituição do indivíduo na sua relação com a cultura. Uma relação sadia entre o indivíduo e a cultura é aquela em que ele reconhece nela uma possibilidade de desenvolvimento de si mesmo e dos outros. Em outras palavras, o indivíduo é produto da cultura e, por sua singularidade, diferencia-se dela. Essa singularidade permite ao indivíduo a autonomia de consciência e a espontaneidade da experiência, possibilitando uma visão crítica sobre a mesma e a autonomia para fazer escolhas, dentro dela. Quando o indivíduo, por outro lado, não consegue fazer essa diferenciação, será seu reprodutor ou estará sempre a contrapondo, sem, no entanto, reconhecer esse processo. Nesses dois casos, o desenvolvimento do preconceito é propício.

Os fatores que fazem do indivíduo um sujeito capaz ou não de fazer essa diferenciação são matéria tratada por Crochik (1995), a partir de uma análise do psiquismo humano, sob a ótica de ensinamentos de Freud a respeito da personalidade narcísica do indivíduo e sua relação com a cultura.

Segundo o autor, a projeção é parte do processo psíquico do indivíduo, pelo qual este exerce o pensamento, a possibilidade de perceber o outro e de se conhecer. No entanto, essa projeção pode acontecer sem que os limites entre o indivíduo e outro sejam percebidos. Nesse caso, o indivíduo, ao invés de se perceber, perceber o outro e diferenciar-se do outro, por meio da projeção, anula ou o outro, ou a si mesmo. Quando o indivíduo anula o outro, vivencia a relação sem enxergar a realidade do que o outro é, e, assim, o outro se torna a extensão daquilo que o indivíduo não admite possuir, não aceita em si mesmo, não consegue reconhecer em si, mas enxerga no outro. 
Quando, por outro lado, o indivíduo anula a si mesmo na relação, enxerga o outro da forma como a sociedade lhe caracteriza, por meio dos estereótipos e estigmas, sem que, enquanto sujeito, reflita sobre isso. Assim, atribui ao outro características que também não são reais a respeito desse outro.

Contudo, nos dois casos, ocorre a não projeção e, portanto, a não relação real, de forma que a visão do indivíduo sobre o outro está distorcida da realidade. $\mathrm{O}$ autor explica que nesses casos de indiferenciação do indivíduo com relação à cultura e ao outro ocorre o que chama de ñfalsa projeçãoò, que propicia o preconceito e as condutas discriminatórias, pois em razão disso ocorre a impossibilidade de a pessoa refletir sobre as experiências que vivência na cultura, criar uma expressão crítica e agir com autonomia. Assim, o indivíduo não percebe a sua visão distorcida sobre a realidade.

Ocorre que a diferenciação do indivíduo, por sua vez, também é estimulada ou dificultada pela cultura e pelo processo de socialização do indivíduo. Com efeito, na medida em que, nesse processo, são proporcionadas ao indivíduo oportunidades de reflexão sobre as suas reações diante da experiência que vive com o outro, esse indivíduo terá mais possibilidades de realizar a diferenciação. Se, por outro lado, a cultura induz o indivíduo a negar ou desvalorizar a reflexão sobre as suas experiências e a aceitação dos conflitos e das reações que advêm delas, diminui as possibilidades para a diferenciação.

Nesse caso, quando as reações são consideradas pela cultura e, conseqüentemente, pelo indivíduo como fragilidades, o resultado será que o indivíduo tenderá a entendê-las como ameaçadoras a sua própria existência. Assim, o indivíduo não estabelecerá uma relação com a cultura e o outro, de forma real, posto que estes lhe proporcionarão as experiências e as reações que lhe ameaçarão. Em outras palavras, tentará se livrar da experiência proporcionada pela relação com o que o outro realmente é e tenderá a anular a si ou ao outro, falseando a realidade, atribuindo ao outro características que não vê em si, componentes esses associados à fragilidade mencionada acima e aos estereótipos produzidos pela cultura.

Assim, o sujeito não consegue ver na cultura a oportunidade para o seu desenvolvimento e nem para o desenvolvimento dos outros. Nas palavras do autor: 
ño preconceito diz respeito a um mecanismo desenvolvido pelo indivíduo para poder se defender de ameaças imaginárias, e assim é um falseamento da realidade, a qual o indivíduo foi impedido de enxergar e que contém elementos que ele gostaria de ter para si, mas que se vê obrigado a não poder tê-los; quanto maior este desejo de poder se identificar com a pessoa vítima do preconceito, mais este tem que ser fortalecido.ò (CROCHIK, 1995, p. 25-26)

É por isso que Miriam Chnaiderman (1996) argumenta que o racismo não tem a ver com a diferença, mas com a transformação do diferente no mesmo. Segundo a autora, a abordagem do racismo não deve ser analisada somente sobre o aspecto da dificuldade em se lidar com as diferenças, uma vez que o que leva ao racismo não é a incapacidade do indivíduo de suportar a diferença, mas, ao contrário, a ameaça de se ver semelhante àquele a que se atribui características que não gosta em si mesmos.

Esse fenômeno, considerado no âmbito do que ocorre coletivamente, manifesta-se socialmente da seguinte forma: o grupo discriminador, ao anular o outro grupo, não enxerga a realidade dos membros desse último e atribui a eles a extensão daquilo que seu grupo, em razão de seus valores culturais, condena e não consegue reconhecer em si mesmo.

Nesses casos, pode ocorrer a projeção mais genérica que se expressa no objeto como um todo (em um grupo como um todo), ou a projeção mais específica que se atém às características mais específicas atribuídas a esse objeto (a esse grupo). O primeiro tipo de projeção está mais ligada a fatores sociais e o segundo a motivos pessoais.

No primeiro caso, a fragilidade do ego busca clichês para se posicionar frente ao mundo confuso e ameaçador e o indivíduo adere a idéias socialmente aceitas, mesmo às racistas, homofóbicas, sexistas etc., por conveniência de estar camuflado na cultura. No segundo, estão presentes os conflitos oriundos de uma identificação, ocasionando reações diversas, por exemplo: o caso de o indivíduo presenciar uma situação em que uma pessoa está sendo humilhada ou fragilizada por alguma enfermidade ou deficiência pode fazer com que, por um lado, o indivíduo se identifique com ela e procure ser solidário, por outro, em razão da mesma identificação, tenha medo de também ser atingido e busque 
absolutamente se afastar daquela situação, procurando diferenciar-se ao máximo daquela vítima, por vezes até repetindo a mesma atitude humilhante em relação a outro que considere mais frágil.

É de se observar que nas duas hipóteses o indivíduo que está sendo objeto do preconceito não é individualizado, mas pertence a um grupo escolhido como o outro do indivíduo que exerce o preconceito. Assim, as características que o indivíduo que exerce o preconceito atribui ao indivíduo que é vítima do preconceito são escolhidas pelo primeiro, podendo elas ser emprestadas da cultura (na projeção genérica) ou criadas a partir de motivos individuais (na projeção específica); mas essas características não são realmente próprias do indivíduo vítima do preconceito.

É como se verifica no seguinte exemplo: supondo que o objeto escolhido para a projeção seja o grupo de homossexuais. Assim, no primeiro caso, o indivíduo que exerce o preconceito adere à idéia de que todo homossexual tem um distúrbio mental que influencia seu comportamento social, tem uma sensualidade exagerada, é mais sensível etc. e, estando diante dele, relacionar-se-á com ele a partir desses valores, reagindo a eles, sem se dar conta da pessoa real que está à sua frente. No segundo caso, o indivíduo que exerce o preconceito, ao se deparar com um homem que demonstra sensibilidade e fragilidade diante de uma situação humilhante, ao se identificar pode lhe ser solidário, se afastar como uma rejeição à própria fragilidade e sensibilidade ou ainda vir a ter uma atitude violenta contra esse mesmo indivíduo, que, da mesma forma que no exemplo anterior, não foi considerado como uma pessoa real, com suas características reais pessoais, mas foi the atribuído as característica que o indivíduo que exerce o preconceito não aceitam em si, como parte de si próprio.

Contudo, o indivíduo vítima do preconceito não é visto a partir de suas características individuais. Essas, ao contrário, podem ficar totalmente despercebidas aos olhos do indivíduo que exerce o preconceito, em um processo em que o indivíduo vítima não chega a ser considerado como um indivíduo em si, independentemente da idéia de grupo a que pertence. Temos, então, que aquilo que o indivíduo atribui como sendo característica do outro indivíduo que julga pertencer a um outro grupo constitui características ilusórias, posto que parte da construção cultural da sociedade a que pertence 
(no segundo caso de projeção) ou do próprio indivíduo que exerce o preconceito (primeiro caso de projeção).

Como base teórica para fundamentar a análise das entrevistas deste trabalho dissertativo, considerar-se-á apenas o caso da projeção genérica. Isso porque o trabalho não pretende se dedicar à análise dos componentes individuais da personalidade propícia a desenvolver o preconceito, mas sim a manifestação do preconceito e das atitudes discriminatórias que têm como pano de fundo os componentes sócio-culturais atuais que contribuem para a perpetuação do racismo contra o negro no Brasil.

Com efeito, segundo o jurista Roger Raupp Rios (2008), o tratamento dos indivíduos como membros de um grupo inferiorizado ou excluídos por meio de estigmas $̈$ o que sem si configura um dano $\ddot{i}$, ocasiona a desigualdade e é combatido pela Constituição Federal. A omissão diante das realidades e a neutralidade de procedimentos que acarretam no prejuízo de grupos discriminados, sob a aparente igualdade formal de todos, configuram ofensa à igualdade e ao direito a antidiscriminação.

Conforme ensina Crochik (1995), apesar de parecer que a projeção genérica é mais superficial e menos prejudicial, na verdade ocorre o inverso, verifica-se a menor indiferenciação do indivíduo em relação à sociedade. Considerando que, quanto mais frágil se encontra o ego em determinada situação, quanto mais confusão existe em torno do ego, maior a busca por estabilidade no mundo externo, o indivíduo, no caso da projeção genérica, tenta compensar essa fragilidade com a afirmação do grupo ao qual pertence e a negação do grupo que elege como contrário ao seu. Tem atitudes preconceituosas mais moderadas, uma vez que justamente não pretende trazer à consciência a manifestação do conflito, ao contrário, esforça-se para deixá-lo invisível, nas palavras do autor, ñcamufladoò(CROCHIK, 1995, p. 28).

Contudo, nesse processo de socialização do indivíduo, a cultura contribui para o comportamento preconceituoso do indivíduo, da seguinte forma:

a) fornece os elementos históricos e culturais para a justificativa racional dos preconceitos, que são os estereótipos; 
b) fornece os elementos morais para o desenvolvimento dos tabus.

Com relação ao item ñaò, segundo Crochik (1995), o estereótipo é um elemento do fenômeno preconceito, é um produto cultural que se relaciona diretamente com os mecanismos psíquicos do indivíduo.

Com efeito, o indivíduo que tende ao desenvolvimento do preconceito, manifesta esta tendência em relação a vários objetos, ou pessoas ou grupos, seja o grupo dos homossexuais, negros, judeus, deficientes físicos etc., mostrando que o preconceito tem mais relação com as características do indivíduo preconceituoso do que com as características do objeto. No entanto, as características que atribuirá a esses grupos, ou as reações que este indivíduo terá em relação a cada grupo, serão diferentes. Nesse caso, conforme explica o autor, a fixidez do conjunto de idéias e comportamentos diante de um mesmo grupo, isto é, a repetição da mesmas idéias atribuídas a um mesmo grupo e das mesmas reações diante desse grupo, acontece porque essas idéias e reações são produzidas pela cultura, sob a forma de estereótipos.

Já o estigma, apesar de muito próximo ao estereótipo, de acordo com Erving Goffman (1982), possui outra definição. O estigma se diferencia do estereótipo na medida em que se manifesta nas relações raciais sociais, mas é definido como um atributo de um estereótipo social. No estigma, dois pontos de vista existem: o olhar da sociedade que julga o indivíduo estigmatizado como desacreditável e o olhar do indivíduo estigmatizado que se sente desacreditado. Nisso se revela que a pessoa envergonhada tem vergonha de se envergonhar.

Segundo esse intelectual, o papel dos normais e o papel dos estigmatizados são parte do mesmo complexo, assim, o estigmatizado e o normal são parte um do outro. $\mathrm{O}$ estigma não envolve ñum conjunto de indivíduos concretos que podem ser divididos em duas pilhas, a do estigmatizados e a dos normaisò, envolve ñum processo social de dois papéis no qual cada indivíduo participa de ambosò em algumas conexões sociais ou momentos da vida. ñO normal e o estigmatizado não são pessoas, mas sim perspectivasò (GOFFMAN, 1982, p. 149) geradas nas relações sociais. Se o atributo que determina a condição de estigmatizado é permanente, então, o indivíduo que o possui desempenhará o papel de estigmatizado em quase todas as situações sociais. Mesmo assim, o atributo 
estigmatizador não determina se o indivíduo é normal ou estigmatizado, mas somente o momento em que o indivíduo irá desempenhar o papel de normal ou estigmatizado. Por isso é que aquele que é estigmatizado em determinado momento por determinado atributo, em outro momento manifesta preconceitos normais em relação a atributos de outro estigmatizado.

Assim, a cultura fornece o pano de fundo para o jogo da falsa projeção em que os indivíduos desempenham seus papéis de discriminador e discriminado. Ou seja, a cultura cria os estereótipos e coage os indivíduos a agir por meio deles.

Com relação ao item ñbò, temos que o preconceito funciona ou é vivido como um tabu, como um fato que vivemos com angústia no passado, ou desejos que temos, e que condenamos ou nos envergonhamos, e, de forma imaginária, toda vez que algo nos remete a essa situação ficamos em estado de defesa, e, como um tabu, nossas reações diante dessa situação são sempre as mesmas.

Com efeito, conforme expõe o referido professor, baseando-se no conhecimento de Freud, a cultura desvaloriza o processo de reflexão e de experiência genuína, desencorajando a diferenciação do indivíduo da cultura, e ainda estimula o processo oposto de indiferenciação do indivíduo da cultura, a não reflexão pelo indivíduo, a não experimentação livre do indivíduo, a não oportunidade de conhecer a si mesmo por meio da propagação de idéias tais como: só pensa quem não tem o que fazer; aquele que experimenta a vida livremente é um ingênuo que não está preparado e é infantil pois age assim por não conhecer os perigos da vida que podem lhe causar o mal; deve se dar valor ao ser humano que sabe sobre tudo; mesmo que superficialmente, tenha decisões rápidas, e que não pense muito. Deve-se evitar o conflito (CROCHIK,1995).

ñOs conflitos (...) entre os desejos e a possibilidade de sua realização na cultura são substituídos pela adesão imediata a uma realidade colocada como inexorável, na qual a não conformidade expressa através da reflexão crítica e da experiência ingênua é relegada a um defeito do sistema cognitivo ou como uma extravagância.ò(CROCHIK, 1995, p. 101) 
Dessa forma, a cultura dificulta o desenvolvimento psíquico do indivíduo e conseqüentemente o desenvolvimento do indivíduo no sentido de se relacionar de maneira saudável consigo e com a coletividade. Isto é, cultua a não experimentação e reflexão pelo indivíduo sobre a sua realidade e sobre si mesmo, a desvalorização do processo de socialização sadia do indivíduo em sua cultura em que as pessoas possam experimentar formas de relação com outros indivíduos, refletir sobre as mesmas, reconhecer a si mesmo e ao outro e a cultura como instrumentos para seu desenvolvimento.

A ocorrência disso na sociedade brasileira pode ser evidenciada pelos dados da pesquisa da Folha de S. Paulo/Datafolha de 1995, que demonstra que quase $90 \%$ da população reconhece a presença da discriminação racial no Brasil e concorda que negros sofrem mais do que os brancos. Entretanto, os entrevistados continuam a negar terem preconceitos eles próprios. Dos pesquisados, $87 \%$ que se autoclassificaram como brancos e 91\% dos que se autodefinem como pardos dizem não ter preconceitos contra negros, assim como $87 \%$ dos negros entrevistados negam ter qualquer preconceito contra brancos. $\mathrm{E}$ mais, $64 \%$ dos negros e $84 \%$ dos pardos negam ter, eles próprios, sofrido alguma forma de preconceito racial (FRY, 2000, p. 217-218). Para Peter Fry (2000), enquanto a maioria dos brasileiros concorda que o racismo existe, eles próprios ou não discriminam, ou discriminam, mas negam, concluindo-se que sofrem discriminação sem reconhecer.

Nota-se que, assim como a discriminação relacionada à questão de gênero, muitos brasileiros e inclusive negros naturalizam o preconceito racial e vivem a discriminação como uma situação normal.

Por isso, a cultura pode desempenhar outro papel que não o exposto acima, como o de auxiliar para que o indivíduo possa controlar as projeções, ter maior consciência sobre este fenômeno, sobre si e sobre o outro. Como diz Crochik,

ña cultura tem sua cota de responsabilidade na formação de preconceitos, não só pelo conteúdo que pode fornecer, mas, também, e, principalmente, pelas configurações psíquicas que fortalece. Em outras palavras, uma cultura que não favorece a reflexão e a experiência, fortalece a existência de indivíduos que não conseguem conviver com a própria fragilidade.ò (CROCHIK, 1995, p. 107) 
De acordo com Maria Aparecida Silva Bento (2003):

ñas característica humanas como medo, ressentimentos, insegurança são reprimidas pela cultura e projetadas sobre o ouro desconhecido. A sociedades muito repressoras que punem ou censuram a expressão de aspectos humanos fundamentais considerados negativos, favorecem a proliferação de pessoas que podem negar partes de si próprias, projetá-las no outro e dirigir sua agressividade contra o outro.ò(BENTO, 2003, p. 40)

A tarefa de saber de tudo é impossível. Para isso, os indivíduos se servem de explicações já prontas e curtas para reagir aos objetos da cultura, que, ao mesmo tempo, não fornecem elementos para a reflexão e para uma consciência crítica, produzindo os estereótipos. Ao contrário, o terceiro elemento que a cultura fornece é a estrutura de exclusão, a luta individualista pela sobrevivência e a alienação.

Uma sociedade extremamente competitiva encontra na cultura o reforço do padrão ou você humilha ou é humilhado, ou é opressor ou oprimido, ou é rico ou é pobre, ou está por cima ou está por baixo. Em todos os casos, a mensagem é a de que demonstrar força para impor nossas vontades e limites é necessário à nossa sobrevivência e a natureza frágil deve ser vencida. A exposição de força é incentivada pela cultura, ao passo que a identificação com a fragilidade é desvalorizada, desencorajada e ridicularizada. A fragilidade é um problema a ser combatido. Não é à toa que os preconceitos são desenvolvidos e as atitudes de discriminação ocorrem contra grupos que representam para o preconceituoso a fragilidade que não podem expressar $\ddot{i}$ as mulheres, os homossexuais, os deficientes mentais e físicos, as crianças, os idosos. Lembra o autor que também pode ocorrer a partir de alguma característica que se contrapõe a essa cultura do produto, como a intelectualidade, por exemplo, no caso dos judeus.

Em todos os casos, porém, o autor nos alerta para o fato de que ñesquecer a nossa fragilidade é permitir que ataquemos a nós mesmos quando visamos ao outro como inimigoò(CROCHIK, 1995, p. 107). 
Maria Aparecida Silva Bento (2003), seguindo essa linha, dedica-se a analisar esse fenômeno na relação entre negros e brancos na sociedade brasileira.

A respeito do silêncio que circunda a experiência violenta do racismo na forma da escravidão ocorrido no Brasil, da mesma forma como foi debatido acima, a autora aponta que existe uma tendência a ações de todos os setores da sociedade brasileira no sentido de, por meio do silêncio, apagar e esquecer esse passado doloroso, envergonhoso, por demais agressivo e violento.

Paulo Sérgio Pinheiro (2001), discorrendo sobre um dos temas relevantes ao exercício da cidadania, diz que, apesar do sistema legal brasileiro, que relaciona os direitos do cidadão em seus documentos oficiais, sobre os quais a população tem conhecimento, o exercício da cidadania, isto é, desses direitos, na concepção dos brasileiros, está vinculado com a idéia de privilégio. Isso é assim por que, por um lado, as instituições públicas, por vezes corruptas, ineficientes e/ou preconceituosas e discriminatórias, atuam de forma diferenciada diante do usuário que tem poder econômico (é assim, principalmente, no cotidiano de uma delegacia e do poder judiciário), e por outro a cultura brasileira ï que influencia o cidadão e as instituições públicas ï perpetua uma situação de origem histórica em que alguns têm acesso ao que desejam e outros não, dependendo de sua proximidade com alguém de poder, e não dos direitos estabelecidos em lei. É a cultura do ñocê sabe com quem está falando?ò. Essa característica está arraigada não somente na mentalidade da autoridade que exerce suas funções nas instituições públicas, como também na mentalidade de muitos cidadãos brasileiros que de antemão não crêem ser sujeitos de direitos, independentemente de terem uma condição econômica favorável.

Nesse mesmo contexto, encontram-se o direito à educação e, mais ainda, o acesso à educação universitária. Na concepção social, a universidade é um lugar de privilegiado.

A política de ação afirmativa por meio de cotas (intencionalmente ou não) acaba produzindo uma alteração nesse quadro, ou ainda, vem questioná-lo. O que importa ao presente trabalho, no entanto, é que o cotista, que por sua condição racial ou social, de acordo com o imaginário social, não pertencia ao grupo dos privilegiados, passa a freqüentar o espaço como um deles sem, contudo, ser um deles. Por outro lado, o aluno não cotista vivencia uma situação, ainda que justa, inusitada, de ñdividirò o espaço público 
ñseuò (conferido pelo direito universal àquele que é neutro), mas que de alguma forma não parece mais tão seu assim.

Assim, segundo Silva Bento, a ñpolítica do silêncioò pode ser ocasionada, em parte, por uma sensação de culpa, como um ñecalcamento coletivo de um ato transgressivo cometido em comumò (BENTO, 2003, p. 45), e, em outra parte, pelo fato de que o esclarecimento vem problematizar a noção de privilégio com a qual as pessoas não querem se defrontar. No entanto, ele defende que esse tema é um permanente desconforto para todo o brasileiro e, portanto, deve ser trazido à baila.

Edith Piza (2003) concorda que o silêncio a respeito do racismo, da discriminação racial e do preconceito presentes nas relações sociais brasileiras é uma característica marcante e frequiente da forma como a sociedade brasileira se relaciona com o assunto. No entanto, relaciona esse fato com o fenômeno da ñfronteira invisívelò que existe na relação do branco com o negro, que proporciona ao branco a invisibilidade do negro como indivíduo, mas somente como grupo racializado, e a invisibilidade do branco enquanto ser racializado, mas tão-somente como um ser único. Em suas palavras:

ñÉ essa excessiva visibilidade grupal do outro e a intensa individualização do branco que podemos chamar de đúgarôde raça. Um đ́ugarôde raça é o espaço de visibilidade do outro, enquanto sujeito em uma relação, na qual a raça define os termos desta relação. Assim, o lugar do negro é o seu grupo como um todo e o do branco é o de sua individualidade. Um negro representa todos os negros. Um branco é uma unidade representativa apenas de si mesmo. Não se trata, portanto, da invisibilidade da cor, mas da intensa visibilidade da cor e de outros traços fenotípicos aliados a estereótipos sociais e morais, para uns, e a neutralidade racial, para outros. As conseqüências dessa visibilidade para negros é bem conhecida, mas a da neutralidade do branco é dada como ónaturalô já que é ele o modelo paradigmático de aparência e de condição humana.ò(PIZA, 2003, p. 72)

Edith Piza evidencia em seu estudo sobre a relação do branco com o negro que no comportamento do branco em relação ao negro não se verifica uma relação em que se reconhece o eu e se reconhece o outro e as diferenças entre eles, mas uma relação em que o 
negro não existe enquanto outro e, portanto, não há com quem se comparar para que se visualizem as diferenças. ñA não-percepção de si é a condição para a não percepção do outroò (PIZA, 2003, p. 86), ou seja, verificar as diferenças no indivíduo negro seria enxergar-se como ser racializado e esse não é um processo proporcionado pela cultura da qual se falava acima, não acontece justamente pela impossibilidade ou não oportunidade para a reflexão.

Observa-se a partir do seu trabalho de pesquisa que ñas entrevistadas, em muitos casos, não sabem, não lembram e não vêem pessoas negras a seu redor e há um visível esforço de memória para incluir, no contexto do diálogo, um dado não percebidoò. São professoras de escolas públicas que ao narrar suas estórias falam de um contexto em que as diferenças raciais estão presentes, mas não são reconhecidas, não são significativas ou conscientemente percebidas.

Cabe ressaltar que, conforme conclusões da própria autora, a discriminação racial não é notada ou dificilmente é percebida, as fronteiras entre negros e brancos são sempre muito elaboradas de forma que as falas exibem sentimentos confusos, ansiedade ou medo, e, além disso, a possibilidade de aprender com o outro a partir da semelhança e diferenças fica prejudicada.

Essa dificuldade de falar sobre raça ou de perceber a raça branca como tal não acontece com os negros, que, segundo Edith Piza (2003), são mais conscientes em relação a racialização desses grupos.

Contudo, a cultura também pode estimular a solidariedade. 


\section{A SOLIDARIEDADE}

Segundo Lia Diskin (2002), a conduta solidária está vinculada à cooperação, empatia grupal, diálogo grupal, apoio mútuo, confiança, disposição para a solução de problemas.

Para Comparato (2006), pode ser definida como um sentimento que leva os seres humanos a se auxiliarem mutuamente e à noção de que somos indivíduos com vínculos e estamos ligados a uma história e a nossos descendentes e ascendentes. Comprometemo-nos com a sociedade em que vivemos, na medida em que ña solidariedade prende-se à idéia de responsabilidade de todos pelas carências ou necessidades de qualquer indivíduo ou grupo socialò(COMPARATO, 2006, p. 584).

Comparato (2005) expõe que, segundo Kant, por sua racionalidade, o ser humano é um ser capaz de ter a si mesmo como objeto da própria reflexão, possui a capacidade de criar leis e princípios para si mesmo e a faculdade de agir de acordo com eles, e é daí que decorre a dignidade humana, própria de todos os seres humanos.

O trabalho do filósofo Kant, segundo esse autor, também nos remete ao tema da solidariedade, na perspectiva da solidariedade atingida por meio da característica da racionalidade humana, do que se depreende o seguinte conceito:

ñse o fim natural de todos os homens é a realização de sua própria felicidade, não basta agir de modo a não prejudicar ninguém. (...) Tratar a humanidade como um fim em si implica o dever de favorecer, tanto quanto possível, o fim de outrem. Pois, sendo o sujeito um fim em si mesmo, é preciso que os fins de outrem sejam por mim considerados também como meus.ò(COMPARATO, 2005, p. 23)

José Leon Crochik (1995) acrescenta que, para a solidariedade ocorrer, devemos atentar a alguns aspectos. Em seu entendimento, a solidariedade está relacionada com a 
identificação de um indivíduo com o outro desde que o objeto da identificação com uma fragilidade seja reconhecimento como pertencente a si mesmo; é o que torna possível ao indivíduo, em âmbito cultural, ser solidário e não agressivo. Isto é, segundo o autor, a solidariedade, e não a agressividade, só existe quando um indivíduo pode se identificar com o outro sem ter que ocultar esta identificação, pode se ver como o outro, sem ter que se anular ou anular o outro.

Com efeito, Adorno (2003), em seu texto denominado Educação em Auschwitz, expõe que ña incapacidade para a identificação foi, sem dúvida, a condição psicológica mais importante para tornar possível algo como Auschwitz em meio a pessoas mais ou menos civilizadas e inofensivasò (ADORNO, 2003, p. 134).

Sendo assim, a alteridade, a capacidade de perceber as necessidades do outro e suas inúmeras diferenças, no plano subjetivo, quando não prejudicada pela falsa projeção que falseia a imagem do outro, está relacionada à possibilidade de se reconhecer algo em comum no outro, o que, no plano dos direitos humanos, chamaríamos de dignidade humana. Também é a partir do reconhecimento da dignidade humana no outro que se tem a possibilidade de evidenciar as diferenças sem querer anulá-las ou se anular.

Relacionando esse tema à questão do racismo no Brasil, encontraremos outros aspectos que devem ser considerados, na perspectiva da promoção dos direitos humanos e da igualdade racial.

Com efeito, Gislene Aparecida dos Santos (2005), ao abordar as conseqüências do mito da democracia racial no Brasil, nos leva a compreender a dificuldade que enfrentamos em reconhecer as diferenças e os conflitos que isso representa, quando tratamos do tema diversidade. Em suas palavras:

ñas assimetrias que existem na sociedade são mascaradas pela edificação de uma falsa imagem de democracia, da reiteração da idéia do país-paraíso, no qual seria inconcebível a existência de qualquer forma de violência e autoritarismo.ò(SANTOS, 2005, p. 67) 
Assim, explica que a idéia de uma convivência harmônica na diversidade estaria associada a uma convivência em que não se poderia reconhecer a hierarquização criada em torno das diferenças raciais, os conflitos ocasionados pela discriminação racial presente na dinâmica das relações sociais que geram a desigualdade, enfim, a habilidade da sociedade brasileira em excluir pessoas com base na diferença.

Segundo a autora, justamente para mantermos a idéia de uma sociedade harmônica, temos a tendência de não querer olhar para as diferenças, que, nesse contexto, chegam a tornar-se ameaçadoras, até para a construção da democracia.

Ora, enfrentar o racismo na perspectiva de eliminá-lo nada mais é do que reconhecermos as desigualdades que construímos a partir da diferença étnico- racial. E a diferença étnico-racial não é outra coisa senão um componente da diversidade brasileira.

No entanto, não é surpreendente as pessoas acreditarem que a diversidade é ótima e não é um problema para elas, nas relações sociais no Brasil. Mas é um fenômeno de se espantar as pessoas não relacionarem o racismo $\ddot{i}$ a diferenciação e hierarquização das raças $і ̈$ a um dos componentes da diversidade. O que se verifica, na realidade, é que é possível lidar com o diverso até a medida em que isso não nos ameace e que nos leve a enxergar que não lidamos tão bem com o diverso como gostaríamos, que é justamente o que o racismo e suas consequiências danosas vêm nos mostrar.

Portanto, ao se falar em solidariedade, a cooperação e a disposição para a solução de problemas, como coloca Diskin (2002), o sentimento que leva os seres humanos a se auxiliarem mutuamente e a noção de que somos indivíduos com vínculos e ña idéia de responsabilidade de todos pelas carências ou necessidades de qualquer indivíduo ou grupo socialò como menciona Comparato (2006, p. 584), no plano das relações entre brancos e negros, na perspectiva da aplicação do princípio da igualdade, não estamos tratando de outra coisa senão da explicitação e valorização das diferenças entre negros e brancos e do reconhecimento das desigualdades produzidas socialmente em função dessas diferenças.

A título de ilustração, vale citar a fala de um dos jovens negros entrevistados, ao ser perguntado sobre a semelhança e a diferença entre a pessoa branca e a pessoa negra: 
acho que tem muita diferença, tem muita diferença. Tem uma carga histórica cultural de discriminação, de rebaixamento, falta de oportunidades, de desleixo do Estado com ela, e a pessoa pode ter as mesmas condições de uma pessoa branca, mas algum diferencial no meio social ela vai ter por ser branca, acho que tem muita diferença. Até o negro rico tem diferença. (...) As semelhanças? Tem, acho que os dois são idênticos. A diferença é cultural, como a sociedade trata. São pessoas idênticas, capazes e plenas das suas faculdades. 


\section{EDUCAÇÃO EM DIREITOS HUMANOS}

\subsection{Definições e objetivos da educação em direitos humanos}

A construção do conceito, objetivos, métodos da Educação em Direitos Humanos se deu a partir de um diálogo entre o processo de formalização dos direitos humanos por meio das declarações, convenções e tratados dos direitos humanos e a prática de atividades educacionais realizadas em várias regiões de todo o planeta. Essas atividades formais e principalmente não formais se identificaram com as intenções dos princípios e artigos dos documentos internacionais e regionais dos direitos humanos. Esse diálogo vem, aos poucos, trazendo parâmetros para as atividades e produções teóricas a respeito da Educação em Direitos Humanos. No entanto, é um campo ainda não claramente delimitado. Muitos conceitos ainda estão em debate e experimentação. Ademais, a própria diversidade dos objetos e metodologias utilizados nas aplicações da Educação em Direitos Humanos em torno do planeta, muitas vezes, relacionam-se com a diversidade de circunstâncias e necessidades regionais e locais, como também com a diversidade de público a que a Educação em Direitos Humanos se destina.

A idéia de uma educação em direitos humanos, ao menos com essa denominação, surgiu, em âmbito internacional, com a incorporação do artigo 26 , parágrafo $2^{\circ}$, à própria Declaração Universal de Direitos Humanos de 1948:

ñParágrafo segundo: A instrução será orientada no sentido do pleno desenvolvimento da personalidade humana e do fortalecimento do respeito pelos direitos humanos e pelas liberdades fundamentais. A instrução promoverá a compreensão, a tolerância e a amizade entre todas as nações e grupos raciais ou religiosos, e coadjuvará as atividades das Nações Unidas em prol da manutenção da paz.ò

Após esse momento, a comunidade internacional de direitos humanos traçou e adotou a Recomendação da Conferência Geral da UNESCO de 19 de novembro de 1974, ocorrida em Paris, intitulada Recomendação sobre Educação para a Compreensão, 
Cooperação e Paz Internacionais e Educação relacionada a Direitos Humanos e Liberdades Fundamentais, como um plano de ação para essa educação.

A partir daí, a recomendação pela utilização da educação como meio de promover o exercício dos direitos humanos foi e tem sido mencionada e enfatizada nos documentos internacionais de direitos humanos, como em 1978, no documento que resultou da Conferência Internacional de Viena.

Após essa declaração, na medida em que esforços foram sendo realizados para a implementação das recomendações da UNESCO para uma educação para a paz e em direitos humanos, a Regional de Educação para a América Latina da UNESCO reconheceu práticas de educação popular como atividades que já desenvolviam programas compatíveis com a idéia do que se entendia por educação em direitos humanos. Entre elas, principalmente o programa de educação popular do Consejo de Educación de Adultos de América Latina (CEAAL), que, desde 1982, tem se dedicado à construção de uma democracia latino-americana por meio da educação popular.

Consoante esse movimento, o Instituto Interamericano de Direitos Humanos foi criado em 1980, por um convênio entre o Estado de Costa Rica e a Corte Interamericana de Direitos Humanos, e se dedica principalmente a realizar cursos interdisciplinares em direitos humanos.

Outra iniciativa importante foi a do Conselho da Europa, por meio do seu Conselho de Cooperação Cultural (CDCC), que, em 1985, por meio da Recomendação do Comitê de Ministros do Conselho da Europa para o ensino e aprendizado sobre Direitos Humanos nas Escolas, adotou a promoção da educação em direitos humanos nas escolas européias e tem sistematizado experiências que vêm servindo de exemplos para instituições de vários países.

Dando continuidade às proposições do tema em âmbito internacional, destacaramse a Conferência Inter-governamental sobre a Educação para a Compreensão, Cooperação e Paz Internacionais e Educação relacionada a Direitos Humanos e Liberdades Fundamentais, com vistas a fomentar uma atitude favorável ao fortalecimento da segurança e do desarmamento, na sede da UNESCO, em 1983; a Consulta Internacional sobre os 
Meios de Melhorar a Ação Educativa em Nível Superior, a fim de dar aos estudantes o conhecimento necessário dos problemas relativos à paz e ao respeito aos direitos humanos e dos direitos dos povos, em 1986, em Atenas; o Congresso Internacional sobre o Ensino, a Informação e a Documentação em Matéria de Direitos Humanos, em Malta, em 1987; o congresso internacional por ocasião da celebração do trigésimo aniversário do Plano de Escolas Associadas, em Búlgara de Sofia, em 1993; a Declaração de Montreal e Plano de Ação Mundial de Educação em Direitos Humanos e em Democracia, adotado em 11 de março de 1993 pela UNESCO; e a 44 ${ }^{\text {a }}$ Conferência Internacional da Educação realizada em Genebra em 1994, que considerou vigente as recomendações de 1974 e aprovou a Declaração e o Plano de Ação Integrado sobre a Educação para a Paz, os Direitos e a Democracia.

No Brasil, o primeiro movimento de que se tem conhecimento no sentido de formulação e realização de uma educação em direitos humanos ocorreu pela Comissão Justiça e Paz, em 1985, com o suporte do Instituto Interamericano de Direitos Humanos.

Não obstante, inúmeras experiências educacionais, principalmente no âmbito nãoformal, foram realizadas desde então, alguns delas servindo como referências para elaboração de programas de educação em direitos humanos, apesar de não terem sido sistematizadas com essa denominação.

No decorrer desse processo, a educação em direitos humanos tem sido evidenciada nas convenções e pactos de direitos humanos, inclusive naqueles que versam sobre a discriminação racial, como um forte instrumento de transformação social e promoção dos direitos humanos, e vem ganhando profundidade na sua definição.

A Convenção Internacional sobre a Eliminação de Todas as Formas de Discriminação Racial adotada em 1965, em seu artigo $7^{\circ}$, dispõe:

ñOs Estados Membros comprometem-se a tomar as medidas imediatas e eficazes, principalmente no campo do ensino, educação, cultura, e informação, para lutar contra preconceitos que levem à discriminação racial e promover o entendimento, a tolerância e a amizade entre nações e grupos raciais e étnicos, assim como propagar os propósitos e os princípios da 
Carta das Nações Unidas, da Declaração Universal dos Direitos Humanos, da Declaração das Nações Unidas Sobre a Eliminação de todas as Formas de Discriminação Racial e da presente Convenção.ò

Como uma continuidade à Década da Educação em Direitos Humanos, as Nações Unidas iniciaram o Programa Mundial de Educação em Direitos Humanos, focado na educação primária e secundária, para ser realizado durante o período de 2005 a 2007. Esse programa retoma e amplia a definição, os princípios e objetivos expostos no documento da Década de Educação em Direitos Humanos. Dessa forma, adotam que:

ñEducação em Direitos Humanos busca o desenvolvimento de uma compreensão sobre nossa responsabilidade comum de tornar os Direitos Humanos uma realidade em toda comunidade e na sociedade em geral. Neste sentido, ela contribui, a longo prazo, para uma prevenção dos abusos e conflitos que violam os direitos humanos, para a promoção da igualdade e do desenvolvimento sustentável e pela intensificação da participação popular nos processos de tomada de decisões em um sistema democrático.ò

Nesse programa mundial foram explicitados os princípios que deverão fundamentar as atividades de Educação em Direitos Humanos, a saber:

ï Promover a interdependência, indivisibilidade e universalidade dos direitos humanos, incluindo os direitos civis, políticos, econômicos, sociais e culturais e o direitos ao desenvolvimento;

ï Cultivar o respeito e apreciação a diferenças, e a oposição à discriminação baseada em raça, sexo, língua, religião, política ou outra opinião, nacionalidade, etnia, ou origem social, condição física ou mental, e em outras bases;

ï Encorajar análises de problemas crônicos e emergentes de direitos humanos (incluindo pobreza, conflitos violentos e discriminação), em busca de soluções consistentes com standards de direitos humanos ;

ï Empoderar comunidades e indivíduos para identificar os direitos humanos que atendem suas necessidades e para assegurar que serão atendidos; 
ï Construir os princípios dos direitos humanos junto com os diferentes contextos culturais e considerar o desenvolvimento social e histórico de cada país;

ï Favorecer a aquisição de conhecimento e das habilidades para o uso dos instrumentos de direitos humanos e mecanismos de proteção dos direitos humanos em nível local, nacional, regional e internacional;

ï Fazer uso de pedagogias participativas que incluam conhecimento, análise crítica e habilidades para ações que promovam os direitos humanos;

ï Favorecer para que o ambiente de ensino e aprendizado encoraje a participação e envolvimento com os direitos humanos e o completo desenvolvimento da personalidade;

ï Ser relevante para o cotidiano dos educandos, engajando os em um debate sobre caminhos e significados para a transformação daquilo que está expresso abstratamente nas normas de direitos humanos para a realidade de suas condições sociais, econômicas, culturais e políticas.ò

No Brasil, em 2003, iniciou-se o processo de elaboração do Plano Nacional de Educação em Direitos Humanos pelo Comitê Nacional de Educação em Direitos Humanos, formado por especialistas, representantes da sociedade civil, instituições públicas e privadas e organismos internacionais.

Conforme se expõe nesse documento, a comunidade nacional tem entendido a Educação em Direitos Humanos como:

ñum processo sistemático e multidimensional que orienta a formação do sujeito de direitos, articulando a seguintes dimensões: apreensão de conhecimento historicamente construído sobre direitos humanos e a sua relação com os contextos internacional, nacional e local; afirmação de valores, atitudes e práticas sociais que expressem a cultura dos direitos humanos em todos os espaços da sociedade; formação de uma consciência cidadã capaz de se fazer presente nos níveis cognitivo, social, ético e político; desenvolvimento de processos metodológicos participativos e de construção coletiva ï utilizando linguagens e materiais didáticos orientados à mudança de mentalidade $\ddot{i}$ bem como práticas individuais e sociais que 
gerem ações e instrumentos em favor da defesa, promoção e ampliação dos direitos humanos.ò

Assim como em outros documentos internacionais que versam sobre a Educação em Direitos Humanos, entre eles o das Nações Unidas e de outros países, o Plano Nacional de Educação em Direitos Humanos, ao responder a pergunta que ficou recorrente nos debates internacionais a respeito de para quem deveria ser direcionada a atividade de Educação em Direitos Humanos, também planeja sua ação classificando a atividade em Educação em Direitos Humanos na educação básica, fundamental, superior, para funcionários públicos, profissionais do poder judiciário e segurança, educação superior, não formal e para os meios de comunicação.

\subsection{Discussão sobre educação em direitos humanos}

Uma das maiores aquisições das sociedades modernas é o reconhecimento universal da dignidade humana (ANDORNO, 2001).

Com efeito, Roberto Andorno (2001) nos aponta para o fato que, atualmente, a dignidade humana é reconhecida unanimemente em âmbito jurídico e político, universalmente, demonstrando a grande importância dessa concepção para o ser humano da atualidade pelo fato de ter sido mencionada 15 vezes na Declaração Universal do Genoma Humano e Direitos Humanos, aprovada em 1997.

Avalia que essa importância está diretamente (e paradoxalmente) ligada ao fato do reconhecimento internacional da coexistência das diversidades e das particularidades.

Teoricamente, existe uma dificuldade em se definir o conceito de dignidade humana. Como diz Andorno, é mais fácil entendermos o que é contrário à dignidade humana do que o que está de acordo com ela. Ensina que, de acordo com o dicionário 
inglês, dignidade significa um estado de ser merecedor de honra e respeito [tradução própria]. ${ }^{1}$

Comparato (2000) diz que a palavra de origem latina, na condição de substantivo (Dignitas), refere-se a louvor, empenhado sempre na forma positiva para significar ñmérito ou cargo honorífico do Estadoò(COMPARATO, 2000, p. 61). Esclarece que a concepção da palavra, conforme se pode absorver do pensamento ocidental judaico, relaciona-se à idéia de ñuma certa participação do homem na essência divinaò, ao passo que daquilo que se aprende da tradição grega a palavra está relacionada com a idéia de que o homem ñestá acima de todas as criaturasò (COMPARATO, 2000, p. 62).

Com efeito, o filósofo Kant, a partir da convicção de que a racionalidade é a especificidade que define o ser humano e o diferencia de todos os outros seres, defende a concepção de que o ser humano tem uma dignidade, e não um preço, posto que não é uma coisa. Como princípio ético, existe enquanto um fim em si mesmo, não como um meio para se servir uma vontade, e, portanto, assim deve ser considerado (COMPARATO, 2005).

A dignidade é o fundamento dos direitos humanos. Há que se notar que, no entanto, conforme pondera Comparato (2000), ña dignidade de cada homem consiste em ser, essencialmente, uma pessoa, isto é, um ser cujo valor ético é superior a todos os demais no mundoò (COMPARATO, 2000, p. 74), e o significado de ser uma pessoa, a racionalidade humana, ñão se limita à racionalidade lógica e geométricaò (COMPARATO, 2000, p. 65), mas foi sendo construído a partir da composição de teorias filosóficas, que passam a considerar o ser humano também como o único ser dotado de ñvontadeò e, portanto, de agir livremente de acordo com suas escolhas, que, em realidade, são preferências valorativas, e que, por sua vez, revelam e asseguram que o ser humano também é definido por suas características instintivas e emotivas. ñOs valores, com efeito, não são objeto de uma percepção lógica, mas emotivaò (COMPARATO, 2000, p. 65).

\footnotetext{
${ }^{1}$ Em inglês: ñstate of being worthy of honour or respectò. Roberto Andorno. The paradoxal notion of human dignity. Rivista Internazionale de Filosofia del Diritto, serie V, ano LXXVIII, n. 2, aprile/giugno, 2001, p. 152.
} 
O princípio da dignidade humana também fundamenta o princípio da igualdade e da solidariedade. Com efeito, é na idéia de que todos são dignos que se reafirma o conceito de que a todos deve ser garantida a igualdade de direitos e que todos devem ser respeitados na medida de suas especiais necessidades coletivas para que sociedade sobreviva sadia.

Tendo o exposto acima como referência, passo a abordar o tema educação em direitos humanos.

Conforme se retira da obra de Aberto Dias de Carvalho (1994), a educação está ligada a um projeto antropológico de futuro utópico, isto é, a educação não está comprometida a ensinar o que e como vivemos àquele que está se iniciando em nossa sociedade e cultura, mas o que queremos ser; o que escolhemos hoje, ser amanhã, enquanto ser humano, cultura e sociedade. A esta, é implicado o poder transformador esperado por ideais políticos e sociológicos, na medida em que possui a função intrínseca de dialogar com o projeto antropológico da humanidade. Nesses termos, dialoga com o projeto dos direitos humanos.

A efetivação da educação em direitos humanos, por sua vez, enfrenta o desafio de encontrar conteúdos programáticos e metodologias significativos para atingir os objetivos a ela conferidos. A discussão em torno do tema, internacional e nacional, tem apontado para a adequação de conteúdos transdisciplinares e abordagens do pensamento complexo que promovam a experiência da análise não fragmentada da realidade, dos conflitos, dos problemas e desafios da atualidade (CARVALHO, 1994).

Com efeito, na atividade de interpretar os documentos internacionais, aplicar e analisar atividades de Educação em Direitos Humanos, na qualidade de educadores de instituições formais do ensino, educadores populares, sociólogos, políticos, psicólogos, etc. profissionais debatem, nacional e internacionalmente, de maneira minuciosa, sobre os objetivos e a metodologia adequada à prática da Educação em Direitos Humanos, conforme se expõe a seguir.

Para Abrahan Magendzo (1995), os direitos humanos são o suporte normativo e ético para a educação para a paz e/ou para a cidadania. Segundo ele, a Educação em Direitos Humanos é uma educação política, transversal, que tem sua origem em um 
contexto histórico e local, de forma que, na América Latina, por exemplo, teve lugar e importância como um movimento contrário às violações sofridas durante as ditaduras militares. É, neste caso, o fundamento ético para a reconstrução democrática e é a responsabilidade ética e política que um indivíduo deve ter para si, para outro e sua sociedade. Em sua opinião, a educação em direitos humanos é voltada para a emancipação política, não somente em seu aspecto formal, mas em seu aspecto prático do cotidiano da vida das pessoas, na medida em que contribui para que as pessoas passem a exercer maior participação política na vida societária.

Remetendo-se à experiência brasileira, segundo o pensamento de Flavia Schilling (2004), o tema da Educação em Direitos Humanos vem acompanhado do processo de construção da democracia no país e, portanto, se concentrou na discussão sobre a democracia e o papel da lei.

E em conformidade com o que foi exposto, Maria Victória Benevides (2000) nos alerta para o fato de existirem expressões diversas para programas educacionais que às vezes são semelhantes, ou, ao invés, pensa-se estar se falando da mesma coisa quando, na verdade, não se está: é o caso da Educação em Direitos Humanos e da educação para cidadania ou ainda educação para a democracia. Benevides esclarece que existem ñprogramas educacionais que se auto-denominam para cidadania e que possuem, como conteúdo programático, a educação moral e cívicaò (BENEVIDES, 2000, p. 6). Por outro lado, segundo ela, não há direitos humanos sem democracia, como não há democracia sem direitos humanos, o que torna a educação para a democracia, ou educação para a cidadania democrática, aquela voltada ñà formação do cidadão participativo e solidário, consciente de seus deveres e direitosò (BENEVIDES, 2000, p. 6). Em relação especificamente à educação em direitos humanos, a autora coloca algumas características que a definem, tais como o aprendizado ligado ñà vivência do valor da igualdade em dignidade e direito para todosò e ñao desenvolvimento de sentimentos e atitudes de cooperação e solidariedadeò (BENEVIDES, 2000, p. 6), compreendendo solidariedade como uma atitude de tolerância ativa com relação ao outro, que difere da idéia da tolerância passiva de simplesmente aceitar o outro, e o aprendizado ligado ao senso de responsabilidade no sentido de desenvolver a capacidade para se ñperceber as conseqüências pessoais e sociais de cada escolhaò (BENEVIDES, 2000, p. 6). 
Há um conjunto de intelectuais que, sem negar o seu conteúdo emancipador e político, relacionam a educação em direitos humanos mais profundamente com a incorporação dos valores presentes nos documentos de direitos humanos, como uma forma de mudança da humanidade.

Para Silva (1995), a educação em direitos humanos significa a realização do ser humano das prerrogativas, aspirações e valores contidos nos documentos dos direitos humanos, por meio de um conjunto de ações e interações. Segundo o autor, hábito é uma repetição constante de comportamento consciente, ou não, e a educação como formação busca o desenvolvimento do ser humano no sentido de que os hábitos e esquemas básicos de comportamento tenham como núcleo organizador e meta a incorporação dos valores dos direitos humanos. A Educação em Direitos Humanos, portanto, deve se encarregar de hábitos que reconheçam os valores dos direitos humanos.

Contudo, além da emancipação política, isto é, da educação que envolva a crítica e a preparação do aluno para ser um sujeito ativo politicamente em sua comunidade, no entanto, a educação em direitos humanos, em conformidade com o que se verifica na lista das definições e objetivos expostos, demanda o desenvolvimento de outros aspectos do ser humano.

É importante que o ser humano se desenvolva também, e principalmente, no sentido de saber não violar diariamente os princípios dos direitos fundamentais, no lugar de somente saber exigi-los. Além disso, que ele seja um colaborador na promoção dos diretos humanos, na medida em que, com base nos princípios e orientações dos direitos humanos, possa alterar a realidade em que vive, transformando condutas e conflitos em soluções para o convívio saudável na democracia e diversidade. Isso requer, certamente, uma educação que vá além de conhecermos aquilo que gostaríamos que nós fôssemos, mas, junto a isso, que nos possibilite aprender a sê-lo.

Alberto Dias de Carvalho (1994), contrapondo a tendência da educação voltada à tecnologia somente quanto aos aspectos das especialidades, diz que ñum projeto educativo só é de fato educativo se se instituir como projeto antropológicoò (CARVALHO, 1994, p. 55), posto que assim estaríamos nos desenvolvemos a partir daquilo que escolhemos para o 
ser humano, o que significa exatamente a liberdade que temos de decidirmos nosso futuro, que nos diferencia dos outros seres terrenos.

Nesse sentido, atenta para o fato de que a própria tecnologia que o ser humano desenvolveu e pode conhecer nos leva a novos projetos antropológicos que não estão sendo considerados na educação. Coloca o autor:

ñNão há mais razão para que subsistam preconceitos quando a própria cultura tecnológica reencontrou os valores da pessoa humana. Mais do que isso, necessita deles para a sua sobrevivência. Não pode, pois, depender de apelos de circunstâncias ou de motivações estritamente políticas. Daí a importância do papel de uma educação tecnológica impulsionada por um projeto pedagógico amplo conseqüente que, ao formar para a produção científica e técnica, abra espaço, nesse mesmo ímpeto, para os valores da mudança, da complexidade e da alteridade, de cuja aceitação crítica depende a prossecução de uma solidariedade renovada e inabalável, entre os indivíduos, entre as culturas, entre os povos, entre os homens e a natureza.ò (CARVALHO, 1994, p. 166)

Se estamos falando de educação comprometida com a idéia de que o ser humano não é meio, mas o fim em si mesmo, é livre para fazer escolhas, dentro de uma gama de valores, que a escolha de valores se faz por meio de sentidos emocionais, instintivos etc., esse projeto antropológico deve ser considerado no projeto da educação em direitos humanos.

O direito é uma das formas de se conseguir a efetividade de princípios construídos e escolhidos por uma comunidade, nacional ou internacional. No entanto, não é a única. Ensinar as leis é fundamental para oferecer ao ser humano a capacidade para acessar seus direitos por meio das instâncias judiciais, bem como a política, sociologia e áreas afins, para o desenvolvimento e ações que envolvam a reivindicação dos direitos do cidadão. Contudo, de essencial importância é oferecer a esse indivíduo a possibilidade de conhecer os fundamentos das leis e políticas que funcionam como a sabedoria das ações, que não são, necessariamente, a de exigir direitos em tribunais. 
Os princípios nos guiam para tomar decisões diárias, para educar os filhos, para resolver conflitos diários, enfim, para conviver com amigos, profissionais, seres humanos, em comunidade. Como exposto acima, os valores estão imbricados com aspectos emocionais do ser humano, e, por isso, há a necessidade de considerarmos as emoções nos programas educacionais que visam à transformação comportamental do ser humanos nas relações sociais.

Especificamente, com relação ao projeto de eliminar a discriminação racial, em uma sociedade em que as formas de discriminação implícita e indireta estão presentes e causam prejuízos sociais, decorrem de preconceitos que induzem condutas discriminatórias que praticamos diariamente, muitas vezes, sem termos consciência disso, como abordar a discriminação racial sem falarmos das reações emocionais que ñeu tenho quando te vejo ?ò

Em função disso, a Educação em Direitos Humanos que se incumbe de criar caminhos para eliminar a discriminação racial efetiva-se com métodos e práticas que se contrapõem à cristalização dos preconceitos, às ações discriminatórias e do racismo, colaborando para alteração da lógica e da dinâmica vigente nas sociedades racistas: de que há ñum tipoò de ser humano melhor que outro.

Na dinâmica de uma sociedade racista, conforme nos ensina Goffman (1992), os indivíduos são atores e vítimas da discriminação, desempenhando cada qual seus papéis na qualidade de inferior ou superior. Contudo, o lugar de discriminador ou discriminado muitas vezes é inconsciente ou mascarado.

Desse modo, é tarefa de um programa educacional que tenha por objetivo alterar comportamentos sociais de discriminação, segundo Maria Aparecida Silva Bento (2003), necessariamente observar o seguinte:

ñainda que os impactos do racismo se manifestem de modo diverso na vida de negros e brancos, não é incomum a tendência a fugir ou esquecer as condições de discriminado e de discriminador; (...) nem sempre as pessoas estão desejosas de admitir que, se são brancas, em alguma instância são beneficiárias do racismo. Por outro lado, a condição de discriminado, sempre associada ao insucesso, incompetência e inferioridade, nem sempre 
á assumida prontamente. Dessa forma, em diferentes momentos, o tema pode provocar reações intensas e contraditórias nos participantes, tais como dor, raiva, tristeza, sentimentos de impotência, culpa, agressividade e etc. Não raro, por conta desses sentimentos, surgem argumentações que visam desqualificar o debate, colocar em dúvida dados estatísticos apresentados, tentativas de relativizar o problema com expressões que já se tornam clássicas. (...) É fundamental uma leitura acurada dessas reações por parte do educador, uma vez que costumam ser manifestações acabadas da ideologia da democracia racial brasileira que (...) traz em seu cerne a negação do preconceito e da discriminação.ò(BENTO, 2003, p. 148)

Para Bhikhu Parekh,

ñconcerne à educação não somente a socialização, mas também a humanização, que auxiliam os estudantes a se tornarem não somente bons cidadãos, mas também pessoas integradas com o bom desenvolvimento intelectual, moral e de outras capacidades e sensibilidades que os possibilitem se sentir em casa, no rico e diverso mundo humano.ò (PAREKH, 2000 [tradução própria] $)^{2}$

Argumenta, no entanto, que atenção especial deve ser dada à metodologia utilizada para esta formação, uma vez que, para que essa experiência seja vantajosa e não desastrosa, não é o bastante colocar no currículo diferentes religiões, culturas e sistemas de crença, mas se deve levar os alunos a um frutífero diálogo sobre as diferenças. Exemplifica dizendo que os indivíduos envolvem-se nos fatos sociais por meio de diferentes experiências que produzem diferentes julgamentos. Assim,

ñum dos objetivos centrais da educação deveria ser equipar os estudantes para participar desta conversa e, então, quebrar as fronteiras de suas simpatias e apreciar a complexidade da verdade e da irredutível diversidade

\footnotetext{
${ }^{2}$ Em inglês: r̃Education is concerned with humanization not just socialization, with helping students become not just good citizens but also integrated human beings with well-developed intellectual, moral and other capacities and sensibilities, and able to feel at home in he rich and diverse human worldò. PAREKH, Bhikhu. Rethinking Multiculturalism Ï Cultural Diversity and Political Theory. Cambridge, Massachusetts: Harvard University Press, 2000, p. 257.
} 
de interpretações, sem ansiosamente buscar uma resposta definitiva.ò (PAREKH, 2000 [tradução própria] $)^{3}$

Temos então que, se na trilha do multiculturalismo, devemos trazer para o espaço público a oportunidade da educação, para mídia etc. a história de várias etnias, suas religiões e aspectos culturais, na trilha do princípio da igualdade em que a diversidade deve ser considerada para se atingir a igualdade de direitos para a promoção da igualdade de oportunidades de desenvolvimento, é necessário que nos eduquemos na perspectiva de aprendermos a lidar com a diversidade nas relações sociais.

Assim, Magendzo (2006), intelectual dedicado à pesquisa sobre educação em direitos humanos na América Latina, mais recentemente inclui em seus escritos a pedagogia da alteridade. Esta daria uma atenção especial ao que significa o outro para cada indivíduo, diante da preocupação de se desenvolver uma idéia, não somente sobre o modo de as pessoas serem, mas a compreensão do ser a partir de ña relación de ser com lo Otro/Outra, com la responsabilidad com el Otro/Outra y al encontro com el Otro/Otraò (MAGENDZO, 2006, p. 64).

Comentando esse estudo, diz que a tendência das pessoas é reduzir a outro a si mesmo. Assim, nos responsabilizamos pelo outro por culpa, nos relacionamos com o outro como se fossem análogos ou instrumentos.

De qualquer forma, ainda se impõe o desafio de se desenvolver uma forma em que o indivíduo se desenvolva na habilidade da alteridade, de se relacionar com o outro, não a partir de si, mas a partir da certeza do inesperado, e isso ser bom.

\footnotetext{
${ }^{3}$ Em inglês: ñOne of the central aims of education should be to equip the student to participate in such a conversation and, thereby, to broaden her sympathies and get her to appreciate the complexity of truth and the irreducible diversiy of interpretations without nervously seeking for a final answer.ò PAREKH, Bhikhu. Rethinking Multiculturalism ï Cultural Diversity and Political Theory. Cambridge, Massachusetts: Harvard University Press, 2000, p. 229.
} 


\section{ESTRUTURA DA PESQUISA}

Conforme Daniel Sarmento (2006) resume, presentes nos debates em torno da política de ação afirmativa, os fundamentos mais freqüentes são: ñustiça compensatória, justiça distributiva, promoção do pluralismo e fortalecimento da identidade e auto-estima do grupo favorecidoò (SARMENTO, 2006, p. 154). A respeito da justiça distributiva, falase da igualdade de direito ao acesso à educação.

O significado na proposta da política de ação afirmativa por cotas raciais de eleger as universidades como o espaço de sua implementação está relacionado ao atributo de ñempoderamentoò que nossa sociedade e cultura conferem àquele que percorre o caminho acadêmico. E assim, apoiando-se nas reflexões de Amartya Sen a respeito dos instrumentos do desenvolvimento do indivíduo, temos que

ñoportunidades sociais são as disposições que a sociedade estabelece nas áreas de educação, saúde, etc., as quais influenciam a liberdade substantiva de o indivíduo viver melhor. Essas facilidades são importantes não só para a condução da vida privada (como por exemplo levar uma vida saudável, livrando-se de morbidez evitável, e da morte prematura), mas também para uma participação mais efetiva em atividades econômicas e políticas.ò (SEN, 2004, p. 56)

Nesse sentido, a referida política de ação afirmativa significa uma oportunidade social na medida em que busca em sua implementação a oferta da igualdade de oportunidade de desenvolvimento político, econômico, social dos jovens brancos e negros.

Essa oportunidade, isto é, a experiência de um estudante universitário, não se restringe apenas a frequientar as aulas e fazer as provas, mas seu desenvolvimento se dá na medida em que pode se relacionar com o ambiente social que a universidade proporciona, com as oportunidades de realizar pesquisas acadêmicas, participar e/ou liderar atividades 
esportivas, participar e/ou liderar atividades políticas em torno de Centros Acadêmicos e etc.

Na solicitação de bolsas para iniciação científica e similares, na formação de grupos de trabalho e estudos, no estímulo do aluno a participar nas aulas, todas essas relações de poder ligadas ao mérito acadêmico, os alunos as experienciam.

Os fenômenos do preconceito racial e da discriminação racial, na forma como são observados e definidos por José Leon Crochik (1995), Miriam Chnaiderman (1996), Erving Goffman (1982), Maria Aparecida Silva Bento (2003) e Edith Piza (2003), correntes nas relações sociais da sociedade brasileira, são parte fundamental da perpetuação da desigualdade econômica e social entre a população branca e negra presente no Brasil hoje. Esses mesmos fenômenos ocorrem nas relações sociais do meio universitário, uma vez que esta é parte daquela.

Assim, o presente projeto tem a seguinte estrutura:

\section{OBJETIVO GERAL:}

Este trabalho tem como objetivo investigar quais são os fatores presentes nas relações sociais entre jovens brancos e negros, que se caracterizam como componentes fornecidos pela cultura brasileira que propiciam o preconceito e a conduta discriminatória étnico-racial, e, portanto, possam servir como critérios orientadores dos programas educacionais que se propõem a abordar a questão do racismo contra os negros ${ }^{4}$, como é o caso do Plano Nacional de Educação em Direitos Humanos.

\section{OBJETIVOS ESPECÍFICOS:}

Levantar os componentes que se configuram como reações emocionais decorrentes da relação social entre os jovens brancos e negros que estão participando do programa de ação afirmativa por cotas raciais; os componentes que se caracterizam como estigmas e estereótipos; o fenômeno da invisibilidade dos membros do grupo étnico-racial, das

\footnotetext{
${ }^{4}$ A expressão ñnegrosò nesse trabalho está sendo utilizada para designar o sentido de pretos e pardos, correspondendo aos critérios do IBGE.
} 
condutas discriminatórias, dos danos e privilégios decorrentes do racismo para negros e brancos; as oportunidades de debate, reflexão e de elaboração sobre o assunto que a sociedade oferece a esses jovens brancos e negros; o conhecimento de que os jovens dispõem em torno do assunto;

Identificar se esses componentes prejudicam a integração e/ou o desenvolvimento dos alunos negros com a universidade, considerando a integração com os colegas e o acesso aos programas acadêmicos paralelos ao curso de graduação oferecidos pela instituição, o que acarretaria em obstáculos para a efetivação do objetivo da política de se promover a igualdade de oportunidades de desenvolvimento para todos;

Levantar os componentes que configuram, na teoria de Leon Crochik, a propensão desses jovens para atuarem solidariamente na busca de soluções para a eliminação da discriminação racial e no convívio igualitário de brancos e negros em um ambiente anteriormente considerado socialmente como um ñespaço ocupadoò somente por brancos.

\section{PROBLEMA:}

Quais são os fatores presentes nas relações sociais entre os jovens brancos e negros que estão participando do programa de ação afirmativa por cotas raciais, implementado em algumas universidades brasileiras, que se caracterizam como componentes fornecidos pela cultura brasileira que propiciam a ocorrência do preconceito e da conduta discriminatória étnico-racial?

\section{HIPÓTESES:}

Em função disso e do problema focalizado nesta pesquisa, estabeleci como hipóteses a serem comprovadas ou denegadas:

1 ï Existem componentes emocionais como culpa, vergonha, irritabilidade, raiva, exaustão, negação, medo, sensação de solidão, de tristeza, de não pertencimento, de impotência que se expressam por meio de contradição, confusão na fala, dissimulação, justificativa defensiva, todos decorrentes do racismo, nas relações raciais entre brancos e 
negros, e há poucas ou nenhuma oportunidade desses jovens na sociedade para debaterem, refletirem e entenderem essas emoções.

2 ï Os jovens reproduzem os estigmas e os estereótipos produzidos pela cultura, o fenômeno da invisibilidade dos membros do grupo étnico-racial, invisibilidade das condutas discriminatórias, dos danos e privilégios decorrentes do racismo para negros e brancos, e têm poucas ou nenhuma oportunidade de debater e refletir sobre isso.

3 ï Existe desconhecimento e confusão em torno do assunto Direito à Diversidade, Direito a Igualdade, discriminação positiva e negativa.

4 ï Existe uma diferença da integração de pessoas brancas e negras na universidade, decorrente do preconceito, discriminação racial direta e indireta, e do racismo institucional, considerando a integração dos jovens com os colegas e o acesso aos programas acadêmicos paralelos ao curso de graduação oferecidos, pela instituição, que podem refletir em maior dificuldade para os negros no momento da solicitação de bolsas para iniciação científica e similares, na formação de grupos de trabalho e estudos, participação em Centro Acadêmico etc.

5 ï Inexiste uma disposição das pessoas para a convivência igualitária na diversidade e para a atitude solidária ao negro e, portanto, para ações voltadas à eliminação do racismo, considerando que, apesar de existir, em torno da idéia da diversidade, o conceito de algo bom, justo e tranqüilo de ser vivido e implementado, há uma tendência em buscar igualar as pessoas e não explicitar as diferenças das pessoas socialmente agrupadas, no caso, do grupo negro, não considerando o racismo como parte da diversidade, e de subestimar toda a complexidade que existe em torno da aplicabilidade do convívio na diversidade.

\subsection{Métodos e técnicas de pesquisa}

O método escolhido para demonstrar minhas hipóteses é o método hipotético dedutivo, consagrado como caminho para a construção do conhecimento a partir da verificação de hipóteses formuladas em acordo com um arcabouço teórico determinado. $\mathrm{O}$ 
problema e as hipóteses propostas nesta pesquisa se fundamentam nos estudos psicosociais sobre o preconceito, a discriminação e as relações raciais entre brancos e negros.

As técnicas utilizadas são a de entrevistas e a pesquisa bibliográfica, pelos motivos a seguir expostos.

Para entender como o racismo contra os negros opera na sociedade brasileira, como se manifesta nas atitudes preconceituosas e discriminatórias, o que deve ser considerado uma manifestação preconceituosa e/ou discriminatória (para efeitos jurídicos, por exemplo), quais são as conseqüências para a criança, o jovem, o adulto negro que podem ser atribuídas a esses fenômenos (preconceito, discriminação racial, racismo), todas essas perguntas não encontram respostas na produção acadêmica teórica, pois envolvem um conhecimento ainda em construção.

Muitas questões a respeito das relações raciais não estão esclarecidas (o que leva a meu interesse pelo tema) ou evidenciadas em materiais teóricos. Com efeito, a experiência prática das pessoas em suas vidas cotidianas, relacionando-se umas com as outras, em ambientes nos quais pessoas diferentes podem interagir, e a reflexão sobre essas experiências podem nos fornecer elementos para desenvolvermos uma consciência sobre os fenômenos que influenciam positiva ou negativamente as experiências e proporcionam a evolução do conhecimento para as respostas às perguntas feitas acima.

Tive a expectativa de que, pelo fato de esses jovens terem passado pelo processo de disputa por vagas universitárias, e, portanto, por um processo em que se vivencia um alto grau de competitividade, essa experiência representasse as circunstâncias em que o psicólogo José Leon Crochik (1995) descreve como impulsionadora da manifestação de preconceitos e atitudes de discriminação.

Ademais, acreditei que, pelo fato de esses jovens estarem diretamente envolvidos com a política de ação afirmativa por meio de cotas raciais, estariam mais informados a respeito das discussões que envolvem o assunto preconceito, discriminação racial e racismo e inevitavelmente teriam vivido momentos de reflexão sobre essa experiência, isto é, sobre seus sentimentos diante dessa experiência, suas idéias etc. Isso os diferenciaria de 
grande parte da população que não reflete sobre a questão racial e os tornaria especiais para abordar as questões da minha pesquisa.

Por tudo isso, creio que a coleta dos depoimentos dos jovens acerca das suas experiências e, posteriormente, a reflexão e análise desse material por meio de categorias alicerçadas na teoria são a técnica ideal para a verificação da forma como o preconceito pode operar entre os jovens, comprovando ou denegando cada uma das hipóteses elaboradas por mim.

Portanto, para confirmar minhas hipóteses, realizei: 1) pesquisa bibliográfica acerca da psicologia social relacionada com o racismo e 2) investigação, por meio de entrevistas individuais em profundidade, dos elementos suscitados na relação dos indivíduos negros e brancos que caracterizam discriminação racial e atitudes de solidariedade que indiquem uma forma de lidar com a diversidade. Fiz isso por meio da observação de indicadores retirados do conteúdo teórico pesquisado, o qual, também, fundamentou a elaboração do questionário semi-aberto para as entrevistas.

\subsubsection{Procedimentos}

\subsubsection{Local}

As universidades escolhidas para a realização da pesquisa foram: Universidade de Brasília (UNB), Universidade Federal de São Paulo (UNIFESP) e Universidade Estadual do Rio de Janeiro (UERJ) porque são as mais antigas na implementação da ação afirmativa por meio de cotas raciais no Brasil e isso facilitaria o encontro de mais alunos cotistas e alunos que experimentaram a convivência com alunos cotistas.

Meu objetivo era encontrar pessoas com disponibilidade de tempo para participar da pesquisa, por isso, chegando nas universidades, o critério que utilizei para escolher os locais para abordar um possível entrevistado foi o de lugares onde os alunos ficassem em períodos de intervalos entre uma atividade e outra ou em momentos de lazer. 
A UNIFESP está instalada em um conjunto de casas e prédios, todos praticamente condensados em dois quarteirões do bairro da Vila Mariana, em São Paulo. Possui um prédio onde se localiza um Centro Acadêmico divido por áreas dos cursos da universidade e uma outra construção plana, com pátio, lanchonete e quadras esportivas, onde se desenvolve o outro Centro Acadêmico. Nessa universidade, esses foram os locais onde fiz contato com os entrevistados e realizei as entrevistas, durante um período de seis dias não consecutivos.

A UERJ está instalada em um prédio e todos os cursos são ministrados lá, divididos pelos andares. Em praticamente todos os andares há uma lanchonete, em torno da qual se reúnem os alunos que estão em intervalos de aula. Assim, elegi os dois andares que possuem as lanchonetes mais equipadas e mais freqüentadas, andares esses que correspondiam aos cursos de direito e de engenharia, e lá abordei os entrevistados e realizei as entrevistas, durante um período de dois dias consecutivos.

A UNB é uma universidade que possui um campus muito amplo e os cursos são bem espalhados. Para achar um lugar onde eu pudesse ver o maior número de alunos aglomerados possível, fui a um local chamado por eles de ñcebolãoò. No ñcebolãoò são ministrados os cursos de psicologia e antropologia e lá também estão os Centros Acadêmicos da psicologia e da antropologia, entre outros. É considerado o ponto central da universidade, onde estão as lanchonetes e um corredor com bancos, no meio de plantas, onde os alunos ficam em momentos de intervalos ou lazer. Foi lá que abordei os entrevistados e realizei as entrevistas, durante um período de três dias consecutivos.

\subsubsection{Escolha dos entrevistados}

A quantidade de sujeitos a serem entrevistados não foi pré-determinada.

Para a pesquisa empírica, a escolha dos entrevistados foi submetida a uma divisão em dois grupos: 1) estudantes beneficiários por reserva de vagas em função de cotas raciais; 2) estudantes não cotistas das mesmas universidades.

Os estudantes não terão suas identidades reveladas. 
Já foi dito que as experiências da implementação da política de ação afirmativa por meio de cotas raciais são a oportunidade de um ñaboratórioò experimental de convívio entre brasileiros negros e brancos que, seja por segregação espacial, seja por condições econômicas, seja por interesses culturais etc. ou pela diferença racial, raramente se relacionam em ambientes que propiciam a cumplicidade e um coleguismo como este.

O interesse da minha pesquisa era encontrar pessoas que tivessem a disponibilidade para falar sobre essa experiência. A entrevista era longa e suscitava elementos emocionais de relativa profundidade, exigia que o aluno se dedicasse por período correspondente ao seu ritmo para responder as questões e esse período precisava ser respeitado (algumas entrevistas duraram 40 minutos, outras quase 2 horas).

Assim, os critérios para escolher, entre esses jovens, os entrevistados foram:

a) escolher os indivíduos, independentemente de período ou ano e matéria que cursavam;

b) para não se correr o risco de ter que interromper a entrevista em função da falta de tempo do aluno, este foi um critério observado no princípio de todas as entrevistas: escolher os alunos que estavam com disponibilidade de tempo;

c) escolher uma amostra equilibrada quantitativamente entre jovens brancos e negros cotistas, uma vez que a comparação das respostas desses grupos será valiosa para a análise da relação entre esses jovens.

\subsubsection{Instrumento de coleta de dados}

A elaboração do questionário foi baseada nas hipóteses da pesquisa e no conteúdo teórico organizado, da seguinte forma:

Com referência aos ensinamentos dos intelectuais brasileiros, em sua maioria psicólogos sociais, antropólogos e sociólogos, a respeito da forma como negros e brancos têm se comportado nas relações sociais permeadas pela ideologia racista no Brasil e das explicações sobre as origens desses comportamentos, históricas, sociológicas e 
psicológicas, procurei por meio das perguntas identificar se o entrevistado manifestava alguma das atitudes ou condutas que, segundo o material teórico, podem ser caracterizadas como preconceito, discriminação racial e solidariedade e/ou algum dos sentimentos e/ou reações provocadas pelo assunto, também previstas no material teórico.

As perguntas foram organizadas e realizadas seguindo o seguinte critério: as perguntas, em geral, a princípio, eram feitas de forma mais estimuladora à fala livre do entrevistado. Se o entrevistado, mesmo falando, não esgotasse o assunto ou não abordasse o tema da questão, eram feitas perguntas mais focadas ao que se pretendia investigar. Muitas vezes, os entrevistados não abordavam o assunto, apesar das referidas tentativas, nesses casos, não se insistia. Primeiro era realizada a pergunta que introduzia o tema. Em seguida, no caso de não ter sido possível aprofundar o assunto na primeira resposta, era feita uma segunda pergunta para investigar se o entrevistado tinha consciência sobre a conduta, sentimento ou reação dele ou de outra pessoa ou da instituição e estimular a manifestação da opinião mais subjetiva do entrevistado.

Não foi estabelecida uma ordem rígida para as perguntas, com exceção de algumas que só faziam sentido se realizadas após outras. No entanto, atentando-se ao fato de que o tema tratado poderia levar os entrevistados facilmente à racionalização do assunto (isto é, a partir de um certo ponto da entrevista, assuntos já tratados estimulariam a resistência do entrevistado sobre o assunto, de forma que as respostas passariam a ser mais a reprodução de ñfrases feitasò e ñpoliticamente corretasò), rigidamente foi considerada a habilidade do questionário em aprofundar as questões durante a entrevista, de maneira a possibilitar ao máximo extrair a manifestação mais genuína e espontânea do entrevistado, sem contudo considerar a racionalização como fator de análise.

Foi utilizado roteiro idêntico para entrevistar os jovens brancos e negros cotistas.

Foram feitas entrevistas semi-dirigidas cujo objetivo foi obter a manifestação oral sobre o tema. Ou seja, não se pretendeu analisar outros elementos a não ser a mensagem explícita oralmente do entrevistado. Para abordar todo o tema, foram utilizadas as seguintes ferramentas: 
Um roteiro de questões semi-estruturadas para estimular respostas resultantes de reflexão, com a finalidade de se obter a opinião explícita do entrevistado sobre um tema, sobre si mesmo, sobre o outro e sobre a coletividade, incluindo os itens a seguir.

Para iniciar as entrevistas, foram utilizadas fotos de estudantes anônimos (retiradas de um quadro publicitário da internet) somente como fator eliciador de narrativas do cotidiano dos jovens no ambiente universitário, isto é, como uma maneira lúdica que proporciona a abordagem do tema em ambiente mais confortável e afetivo e estimula, assim, respostas mais subjetivas e detalhadas, no lugar da pergunta direta que provoca a resposta direta. Não foi meu objeto a análise da relação das respostas com as figuras, apenas a análise das respostas manifestadas oralmente pelo entrevistado.

Foram utilizadas duas estórias inverídicas como provocação para a exposição de valores diante de situação de conflito.

Foram utilizadas fotos de profissionais anônimos (retiradas de um quadro publicitário da internet), compostas do pescoço para cima, de estrutura física mediana (peso e altura), pela qual só se podia ver o rosto, parte do pescoço e ombros, de forma a não se poder identificar nada sobre o local onde estavam ou indicadores diferenciados de riqueza ou pobreza. Pretendi assim criar um quadro de pessoas que se pareciam muito, a não ser pelo fato de apresentarem características fenotípicas diferentes.

Os temas das questões foram: atividades dos jovens em grêmios, amizades, atividades sociais de lazer; oportunidades de trabalhos de pesquisa na universidade; raça, estigmas, diversidade, igualdade, preconceito e discriminação, racismo e direitos humanos.

Tudo conforme roteiro de entrevista abaixo:

\section{$\underline{\text { Roteiro da Entrevista: }}$}

1) Entre as fotos dos estudantes disponíveis, pedir para a pessoa escolher uma foto que se pareça mais com ele (FOTOS para Pergunta 1, em anexo). A partir da foto abordar a relação dela com a universidade com as perguntas: 
a) Quanto tempo você passa na Universidade, só o tempo das aulas? Você freqüenta lanchonete/bar com os colegas ou outras atividades de laser que a Univ. proporciona? Você faz todas as matérias, vem em todas as aulas?

b) Que oportunidades para a carreira acadêmica a universidade oferece aos alunos? Quais deles você utiliza? (ex. bolsas de iniciação científica, grupos de estudos e pesquisas etc.) Como foi o processo para você participar delas, isto é, como ficou sabendo e como foi a seleção?

c) Você participa de algum grêmio ou associação de estudantes na Universidade? Como chegou até lá?

d) Para quem respondeu sim, perguntar se a pessoa convidou ou auxiliou o processo de inserção de mais algum colega seu neste grêmio (etc.). Fale sobre esta pessoa.

e) Quem são os seus mais chegados amigos (as) aqui na universidade? Vocês vão a festas, estudam juntos, com que frequiência? Fale sobre esta pessoa.

2) Dar as fotos uma a uma para a pessoa (descendente de japonês, negro, branco) e perguntar: Descreva essas pessoas. Descreva essas três pessoas de forma que eu possa adivinhar de quem você está falando. (FOTOS para Pergunta 2, em anexo)

3) Pedir para a pessoa imaginar ser um diretor de teatro de uma peça que se passaria em um hotel. A partir das fotos disponíveis (FOTOS para Pergunta 3, em anexo), pedir para escolher os personagens que irão desempenhar os seguintes papéis profissionais:

Pianista (1) Médico (a) plantonista (2) Arrumadeira (dor) do hotel (3)

Motorista de ônibus (4) Professor (a) universitário (5) Cabeleireiro (a) (6)

Gerente do hotel (7) Porteiro (a) do hotel (8) Diretor (a) de Marketing de uma loja de departamento (9)

4) Conte-me um pouco sobre a estória de sua família: qual é a origem dela? Qual é a raça do seu pai (mãe, avó etc.)?

5) Você aprecia a diversidade entre as pessoas, o que acha do convívio entre pessoas diferentes? Por quê? Dê um exemplo. 
6) Na sua opinião, qual é a diferença entre uma pessoa negra e outra pessoa branca? E qual a semelhança? (No que você acha que você se assemelha ao negro (ou ao branco))?

7) Você teve aqui na universidade alguma experiência legal, que você gostou, com que você cresceu, na relação com algum colega negro (ou branco)? E ao contrário, alguma experiência que lhe prejudicasse?

8) Imagine se na sua classe oitenta por cento dos alunos fossem negros e vinte fossem brancos. Como você se sentiria? Você acha que isso pioraria seu rendimento escolar? Por quê? O que mais pioraria?

9) Você conhece algum cotista? Como soube que ele(a) é cotista?

10) Você acha que o aluno cotista que está cursando a universidade, que entrou por meio de cotas, está vivendo uma boa experiência? Quais dificuldades você imagina que ele tenha aqui na universidade? Você acha que você poderia ajudá-lo? Como? Você acredita que ele (ela) poderia ajudá-lo (ou contribuir com sua vida) em alguma coisa?

11) Você acredita que o aluno cotista terá mesmo desempenho nas matérias escolares que os outros alunos? E desempenho profissional?

12) Você acha que raças entre seres humanos existem? Quais são elas? Você poderia dar pelo menos cinco características sobre cada uma delas?

13) a) Você acha que o fato de você ser branca (o) (ou de uma pessoa ser branca) lhe auxiliou de alguma forma estar hoje na universidade? b) Por que você acha que existem menos alunos negros na universidade do que brancos?

14) a) Como foi o processo de ingresso na universidade, o vestibular: você sabia que estava participando de um processo de seleção em que havia cotas? Como você se sentiu? b) E depois que você entrou na universidade, como você se sentiu em estar cursando em uma universidade com cotistas? 
15) O que você pensava a respeito da política de cotas durante este período pré vestibular e vestibular (favor ou contra)? Depois que você entrou na universidade, você mudou de idéia sobre algum desses conceitos?

16 a) Nesta experiência de cursar uma universidade que realiza a política de cotas, o seu contato com os negros, a sua idéia sobre o negro, modificou? Em que aspectos?

b) E o seu contato com o racismo, a sua idéia sobre o racismo, modificou? Em que aspectos?

17) Você acha que existe discriminação racial aqui na Universidade? Como ela se manifesta? Se o entrevistado respondeu não: e em São Paulo (ou Rio de Janeiro, ou Brasília)? Se sim, como ela se manifesta?

18) Você já havia tido contato com alguma discussão sobre discriminação racial antes deste processo de vestibular? Ocorreu em que ambiente (escolar, familiar, amigos etc.)? Você conhece alguma revista, programa televisivo, educacional etc. que fala sobre os negros ou sobre os negros e brancos, ou sobre as relações raciais ou sobre racismo?

19) Se um homem (ou uma família) negro fosse dono de uma escola e contratasse só professores negros, você acha que ele seria racista? Você tem algum professor negro? (quantos?)

20) Estória hipotética ï primeira etapa:

Gilberto e João são colegas, estudantes de uma universidade. Estão participando de um concurso de monografias, patrocinado por essa universidade, que dará ao vencedor $\mathrm{R} \$ 2.500,00$. Só é permitido participar do concurso os (as) alunos (as) da universidade. O concurso é administrado pelo Grêmio de alunos, sendo que dois representantes do grêmio estão na secretaria, recebendo as monografias e documentação necessária à inscrição ao concurso, e um funcionário está na porta da entrada desta secretaria, organizando a fila dos alunos.

Acontece que o prazo final para a entrega de monografias está encerrando hoje, às 18:00 horas em ponto, e os amigos estão correndo, juntos, para entregar a monografia que acabaram de fazer, às 17:50hs. 
João é um garoto de 19 anos, de pele branca e cabelos castanhos e Gilberto é um garoto também de 19 anos, de pele negra e de cabelos pretos. No momento em que chegam à porta da secretaria, Gilberto deixa seu estojo cair no chão. Enquanto Gil se abaixa para coletar todos os lápis, borracha e canetas espalhados, João passa pela porta, cumprimentando o funcionário que lhe devolve o cumprimento com um acenar de cabeça, e segue em direção ao balcão de inscrição. Em seguida, Gil, apressado, movimenta-se em mesma direção, no entanto, na porta é interrompido pelo funcionário que lhe solicita a apresentação da carteirinha de estudantes, uma vez que somente estudantes da universidade podem participar do concurso. Com toda a pressa, Gil estava sem a carteirinha! Neste momento, João, que acabara de concluir e receber o protocolo de sua inscrição, percebe a situação: ñJá passa das 18:00 horas, Gil não conseguirá fazer a sua inscriçãoò. Gil e João trocam olhares, ambas sabiam que tinham deixado suas carteirinhas em casa.

Perguntas: Por que você acha que isto aconteceu? O que você faria se você fosse o João? e o Gil?

Segunda etapa:

Infelizmente aconteceu que Gil não conseguiu realizar a sua inscrição no concurso.

No dia seguinte, apresentou à administração do concurso uma reclamação por escrito explicando que sua inscrição não se realizou em razão de racismo, pelo fato de ser negro em uma sociedade racista, uma vez que foi discriminado por razões raciais quando foi impedido de entregar a monografia sob a justificativa de estar sem a carteirinha de estudante, sendo que a mesma não foi solicitada a seu colega branco. No documento, Gil requereu que, devido a todo este ocorrido, fosse realizada a sua inscrição no concurso, mesmo fora do prazo.

Mesmo sabendo que João correria o risco de se prejudicar ou até mesmo perder sua inscrição por revelar que também estava sem carteirinha, Gilberto pediu a seu colega que fosse sua testemunha neste processo administrativo.

Perguntas: O que você faria se você fosse o João? Você acha que Gilberto agiu corretamente? 
21) Você considera que os direitos dos negros e/ou a discriminação racial é uma questão de direitos humanos? O que você considera que é uma questão de direitos humanos ou $\mathrm{O}$ que é direitos humanos para você?

22) Se você fosse convidado a ir assistir uma palestra sobre racismo, você iria, você acha esse assunto importante, por que?

23) O que você considera que poderia ser feito para auxiliar na aproximação entre brancos e negros? E aqui nesta universidade, o que poderia ser feito? E em termos de conteúdo das aulas, algum conteúdo poderia ser valorizado?

24) a) Pergunta para a pessoa como ela se sentiu durante a entrevista (Somente como recurso para estimular a reflexão, pedir para o (a) entrevistado (a) escolher um objeto entre uma folha de papel, uma pedra, um copo de água e uma flor que represente o que sentiu e para que justifique sua resposta (OBS: Não se pretendeu analisar a escolha do objeto, mas somente a resposta que justifica a escolha). b) O que você acha sobre falar de racismo?

\subsubsection{Procedimento da entrevista}

$\mathrm{Na}$ abordagem do entrevistado, eu me apresentava como pesquisadora que fazia mestrado na Universidade de São Paulo, dizendo que o tema da minha entrevista era direitos humanos, que a entrevista envolvia perguntas, mas também a opinião das pessoas sobre fotos e estórias. Que a entrevista duraria em torno de 1 hora, não precisamente, e que eu estava procurando alunos que tivessem disponibilidade de tempo e vontade de participar das entrevistas. Que se a pessoa se sentisse desconfortável em responder a qualquer questão, não precisaria respondê-la, se quisesse parar a entrevista no meio, sair andando, poderia fazê-lo com liberdade, e se não quisesse autorizar, no final da entrevista, o seu uso acadêmico, também poderia fazê-lo, pois o uso dela estaria condicionado ao documento que assinaria no final.

Então, guiando-me pelas características fenotípicas dos jovens, eu ficava atenta para escolher um número equilibrado de entrevistados brancos e negros cotistas. 
Quando a pessoa manifestava interesse em participar da entrevista, mas não tinha tempo naquele momento, eu sugeria outros horários e datas possíveis, de forma que algumas entrevistas foram realizadas com hora marcada.

A abordagem do aluno cotista ocorreu da seguinte forma: para respeitar a decisão do estudante de revelar-se ou não como aluno cotista, na universidade em que comecei a desenvolver o meu trabalho empírico, fui à administração da instituição perguntar como poderia entrar em contato com os alunos cotistas. Então, foi recomendada uma série de atividades burocráticas, tais como ligar para a pessoa que especificamente coordenava o setor dos alunos cotistas, um psicólogo, que marcaria comigo uma reunião, e, a partir da sua avaliação, me concederia a autorização ou não para realizar as pesquisas. Foi me explicado que essas providências eram necessárias para garantir a preservação da intimidade desses alunos de não serem expostos a situações de discriminação e constrangimento pelo fato de serem cotistas etc.

Diante disso, fui ao centro acadêmico onde um aluno ï com funções de liderança $і ̈$ me informou que o centro tinha uma lista de emails dos alunos e uma específica dos alunos cotistas, que se incluíam nessa lista voluntariamente. Assim, combinamos que eu passaria para ele um email, falando das características da pesquisa, da minha necessidade etc. e ele passaria esse email para os alunos cotistas catalogados no ñemail-listò do Centro Acadêmico, pedindo para aquele que tivesse interessado respondesse o email para o meu endereço eletrônico. Eu recebi três retornos e realizei entrevistas com horários agendados.

Nas outras universidades, a abordagem do aluno cotista foi diferente. Fui diretamente aos locais onde estavam os estudantes e guiava-me pelas características fenotípicas. Em todas as entrevistas, eu não perguntava para os entrevistados se eram cotistas ou não e iniciava a entrevista sem saber, deixando que eles mesmos se pronunciassem a respeito disso espontaneamente.

Evidentemente, em todas as universidades, muitas vezes alunos abordados não tinham a disponibilidade de tempo necessária para a aplicação da entrevista e, às vezes, não pareciam realmente interessados, negando participar do proposto. Mas isso não aconteceu em freqüência relevante para ser especialmente observado. 
Foram entrevistadas 18 pessoas e analisadas 14 entrevistas.

Nenhuma das pessoas abandonou a entrevista no meio do processo.

\subsubsection{Análise dos dados}

O estudo é qualitativo e para a análise dos dados escolhi o método de análise de conteúdo por categorias semânticas (ou temáticas), uma vez que todas as perguntas buscaram a manifestação de idéias seguidas de uma reflexão, de uma reação emocional expressa relacionada ao tema tratado e verbalizados. Portanto, trata-se de desdobrar o texto em categorias, para tratar os dados brutos na forma de conteúdos a serem analisados, segundo as técnicas de Laurence Bardin, e em seguida em indicadores para a análise de conteúdo.

A eleição das categorias e indicadores foi realizada a partir das hipóteses do projeto de pesquisa, do componente teórico do trabalho e do conteúdo do material coletado e da sua transcrição.

As seguintes categorias e indicadores foram escolhidos:

1. Visibilidade da diversidade étnico-racial e a racialização de si e do outro .

Indicadores:

ï utilização do componente étnico-racial na descrição das pessoas das fotos de estudantes negros, brancos e asiáticos;

ï utilização do componente étnico-racial para descrever membros da família e a si próprio;

ï utilização do componente étnico-racial na descrição das relações sociais.

2. Visibilidade sobre a ocorrência da discriminação racial.

Indicador: 
ï visibilidade do tratamento desigual direto ou indireto que prejudica socialmente o negro, seja pela neutralidade, seja pela diferenciação negativa.

3. Visibilidade sobre as conseqüências do racismo, os danos e os privilégios.

Indicador:

ï visibilidade do prejuízo social para o negro.

4. Reprodução de estigma.

A partir da escolha, pelos entrevistados, de papéis profissionais para as pessoas das fotos de homens e mulheres; brancos(as) e negros(as), de faixas etárias de 20 a 30 anos, de 31 a 59 anos, acima de 60 anos, o indicador foi:

ï profissionais brancos(as) e negros(as) na ocupação de cargos profissionais de artista, que privilegiam conhecimento intelectual, que privilegiam o trabalho manual ou posições de chefia.

5. Reprodução de Estereótipo.

Indicador:

ï características atribuídas genericamente a todos os membros de um grupo.

6. Reações emocionais na relação com o preconceito.

Indicador:

Ï culpa, vergonha, irritabilidade, raiva, exaustão, confusão na fala, negação, medo, dissimulação, sensação de solidão, tristeza, sensação de não pertencimento, impotência, contradição, justificativa defensiva.

7. Formas e oportunidades de elaboração das experiências relacionadas ao racismo. Indicador:

ï oportunidades de reflexão sobre o tema racismo nos espaços sociais (família, escola, mídia, amigos).

8. Abordagem teórica sobre o tema.

Subcategoria 1: Diversidade x Igualdade x Racismo

Indicador: 
ï confusão sobre os agrupamentos na diversidade, sobre a diferenciação positivaï a diferenciação negativa (quando é um valor a diversidade e quando não é);

Subcategoria 2:Relação do racismo com os princípios de direito fundamentais

Indicadores:

ï reconhecimento da política como um direito fundamental e reconhecimento do direito a ser tratado desigualmente discriminação positiva).

9. Manifestação de propensão para a solidariedade.

Indicador:

ï crença de que a relação multi-étnica enriquece e auxilia a coletividade, na solução de problemas coletivos e individuais; disponibilidade para a busca real de soluções para o racismo.

10. Integração com as ofertas de desenvolvimento da universidade.

Indicadores:

ï integração com os colegas da universidade, oportunidades profissionais que surgem a partir dessa integração; acesso às oportunidades que o ambiente acadêmico oferece;

ï relação de coleguismo entre o entrevistado e os alunos

Após essa etapa, as informações geradas foram relacionadas à parte teórica do texto, para a análise e elaboração das conclusões acerca das hipóteses formuladas.

Abaixo, para uma melhor visualização, encontra-se o quadro de categorias e indicadores: 
Quadro de Categorias e Indicadores

\begin{tabular}{|c|c|c|}
\hline CATEGORIA & SUB-CATEGORIA & INDICADORES \\
\hline identidade & negra / branca / parda & \\
\hline $\begin{array}{l}\text { 1. A visibilidade da } \\
\text { diversidade étnico-racial } \\
\text { e a racialização de si e do } \\
\text { outro }\end{array}$ & & $\begin{array}{l}\text { utilização do componente étnico-racial na descrição } \\
\text { das pessoas das fotos de estudantes negros, brancos e } \\
\text { asiáticos }\end{array}$ \\
\hline $\begin{array}{l}\text { 2. Visibilidade sobre a } \\
\text { ocorrência da } \\
\text { discriminação racial }\end{array}$ & & $\begin{array}{l}\text { visibilidade do tratamento desigual direto ou indireto } \\
\text { que prejudica socialmente o negro, seja pela } \\
\text { neutralidade, seja pela diferenciação negativa }\end{array}$ \\
\hline $\begin{array}{l}\text { 3. Visibilidade sobre as } \\
\text { conseqüências do } \\
\text { racismo, os danos e os } \\
\text { privilégios }\end{array}$ & & visibilidade do prejuízo social para o negro \\
\hline 4. Estigma & $\begin{array}{l}\text { Na comunicação não } \\
\text { verbal }\end{array}$ & $\begin{array}{l}\text { escolha de papéis profissionais para as pessoas das } \\
\text { fotos de homens e mulheres; brancos(as) e negros(as); } \\
\text { de faixas etárias de } 20 \text { a } 30 \text { anos, de } 31 \text { a } 59 \text { anos, } \\
\text { acima de } 60 \text { anos. Indicadores: profissionais brancos } \\
\text { (as) İ negros (as) e cargos profissionais de artista, que } \\
\text { privilegia conhecimento intelectual, manual e posições } \\
\text { de chefia. }\end{array}$ \\
\hline 5. Estereótipo & & $\begin{array}{l}\text { características atribuídas genericamente a todos os } \\
\text { membros de um grupo, mitos }\end{array}$ \\
\hline $\begin{array}{l}\text { 6. Reações emocionais } \\
\text { na relação com o } \\
\text { preconceito }\end{array}$ & & $\begin{array}{l}\text { culpa, vergonha, irritabilidade, raiva, exaustão, } \\
\text { confusão na fala, negação, medo, dissimulação, } \\
\text { sensação de solidão, tristeza, sensação de não } \\
\text { pertencimento, contradição, justificativa defensiva }\end{array}$ \\
\hline $\begin{array}{l}\text { 7. Formas e } \\
\text { Oportunidades de } \\
\text { elaboração das } \\
\text { experiências relacionadas } \\
\text { ao racismo }\end{array}$ & & $\begin{array}{l}\text { oportunidades de reflexão sobre o tema racismo nos } \\
\text { espaços sociais (família, escola, mídia, amigos) }\end{array}$ \\
\hline $\begin{array}{l}\text { 8. Abordagem teórica } \\
\text { sobre o tema }\end{array}$ & $\begin{array}{c}\text { diversidade } \mathrm{x} \text { igualdade } \\
\mathrm{x} \text { racismo }\end{array}$ & $\begin{array}{l}\text { confusão sobre os agrupamentos na diversidade, sobre } \\
\text { a diferenciação positiva - a diferenciação negativa } \\
\text { (quando é um valor a diversidade e quando não é). }\end{array}$ \\
\hline $\begin{array}{l}\text { 9. Propensão para a } \\
\text { solidariedade }\end{array}$ & & $\begin{array}{c}\text { crença de que a relação multi-étnica auxilia a } \\
\text { coletividade, na solução de problemas coletivos e } \\
\text { individuais }\end{array}$ \\
\hline $\begin{array}{l}\text { 9. } \begin{array}{l}\text { Propensão para a } \\
\text { solidariedade }\end{array} \\
\end{array}$ & & $\begin{array}{c}\text { disponibilidade para a busca real de soluções para o } \\
\text { racismo }\end{array}$ \\
\hline $\begin{array}{l}\text { 10. Integração com as } \\
\text { ofertas de } \\
\text { desenvolvimento da } \\
\text { Universidade }\end{array}$ & & $\begin{array}{l}\text { Integração com os colegas da universidade; } \\
\text { oportunidades profissionais que surgem a partir dessa } \\
\text { integração; acesso às oportunidades que o ambiente } \\
\text { acadêmico oferece }\end{array}$ \\
\hline $\begin{array}{l}\text { 10. Integração com as } \\
\text { ofertas de } \\
\text { desenvolvimento da } \\
\text { Universidade }\end{array}$ & & relação de coleguismo entre o entrevistado e os alunos \\
\hline
\end{tabular}


Categoria 1: Visibilidade da diversidade étnico-racial e a racializacão de si e do outro:

Indicadores: a) utilização do componente étnico-racial na descrição das pessoas das fotos de estudantes negros, brancos e asiáticos;

b) utilização do componente étnico-racial para descrever membros da família e a si próprio;

c) noção sobre o conceito social de raça na utilização do componente étnico-racial na descrição das relações sociais.

\section{Indicador ñaò.}

Aos entrevistados foram apresentadas as figuras de estudantes abaixo e solicitado que as descrevessem.

A partir das respostas, analisou-se se os entrevistados utilizaram o componente étnico-racial na descrição das pessoas das fotos.
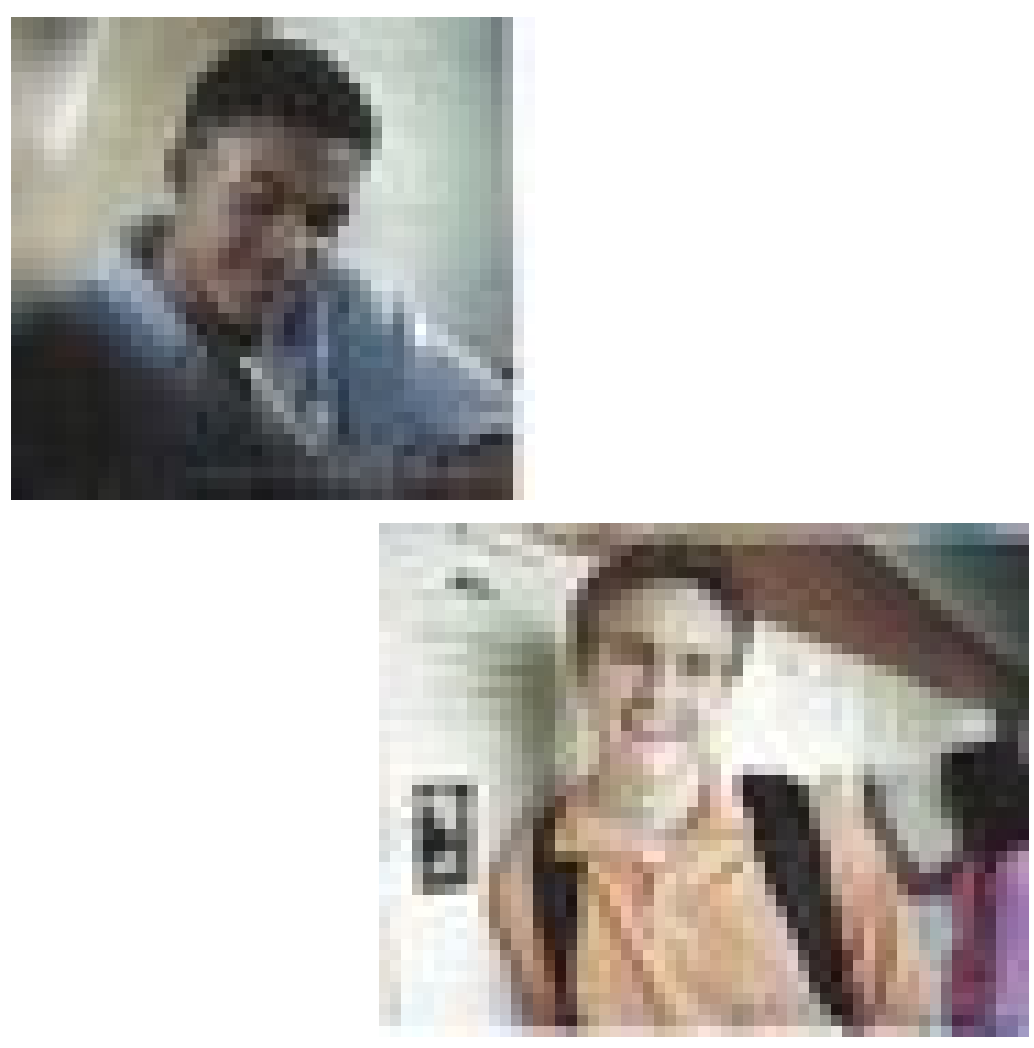

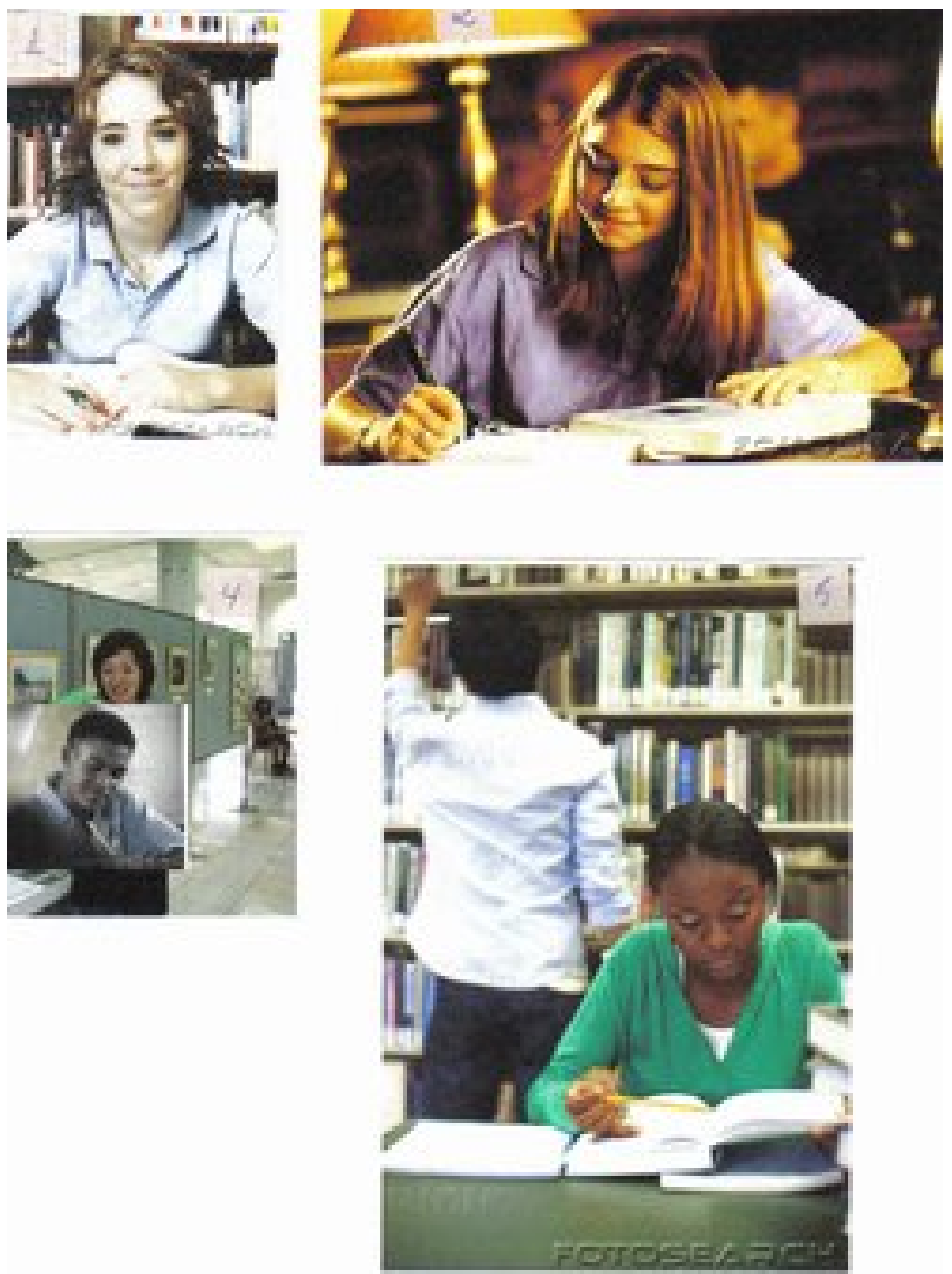


\section{Indicador ñ nò.}

Posteriormente, aos entrevistados foi perguntado sobre a origem de suas famílias, e, novamente, a partir das respostas, foi verificado se, no decorrer de suas falas, utilizaram o componente étnico-racial para descrever membros de suas família e a si próprio. Quando nenhum aspecto étnico-racial era mencionado, o entrevistado era diretamente questionado sobre a raça de sua mãe, ou pai etc.

\section{Indicador ñ cò}

Invariavelmente, nesse momento os entrevistado falavam sobre o entendimento que possuem acerca do conceito sobre raças. Quando não mencionavam, eram estimulados, por meio de perguntas, a falarem sobre isso. Sobre essas falas, analisou-se a forma como utilizaram o componente étnico-racial na descrição das relações sociais, isto é, se o associavam à diversidade genética, à diversidade de origem, cultural, física e, finalmente, ao conceito social de raça, do que se constata a desigualdade social decorrente da diferença racial e o racismo.

Assim, das respostas dos entrevistados, obteve-se o seguinte:

Indicador ñà̀

Dos 7 ENTREVISTADOS NEGROS (PRETOS E PARDOS), 2 (28,5\%) descrevem as primeiras fotos de pessoas brancas, não identificando a cor, etnia ou raça da pessoa. A partir do momento em que viram a foto da pessoa negra, utilizaram o componente cor, raça ou etnia para descrevê-la e o mesmo foi feito com relação à pessoa asiática, conforme o seguinte relato da entrevista:

a) A pessoa alegre, parece bem profissional, aparentemente feliz com o que está fazendo b) Uma criança estudando, alegre também por estar... Cara bem esforçada c) Uma aluna negra, ela não parece tão feliz como as outras. Ele parece mais com a cara assim, é esforçada assim d) Parece que está divulgando o livro, uma japonesa, tá num estande tal. 
Dos 7 ENTREVISTADOS BRANCOS, 5 (71\%) fazem o mesmo.

Assim, dos 14 entrevistados, verificou-se que 7 (50\%) demonstraram a tendência de ver a pessoa branca como um ser humano universal e a pessoa negra como um ser racializado, pertencente a um grupo racial.

Do total dos entrevistados que não apresentaram essa tendência, encontrou-se que:

Dos 14 entrevistados, 2 (14\%) descreveram todas as fotos, desde o início, vinculando as pessoas a uma cor, raça ou etnia. Entre eles, 1 é negro e 1 é branco.

Por outro lado, dos 7 ENTREVISTADOS NEGROS (PRETOS E PARDOS), 4 (57\%) descrevem as fotos de pessoas brancas e negras e não manifestam a cor, etnia ou raça das pessoas; e dos 7 ENTREVISTADOS BRANCOS, 1 (14\%) faz o mesmo. Assim, do total dos 14 ENTREVISTADOS, 5 (36\%) demonstram ter a tendência de não racializar ou não manifestar a raça das pessoas.

Assim, sobre o resultado total, esclarece o gráfico 1 abaixo:

\section{Gráfico I}

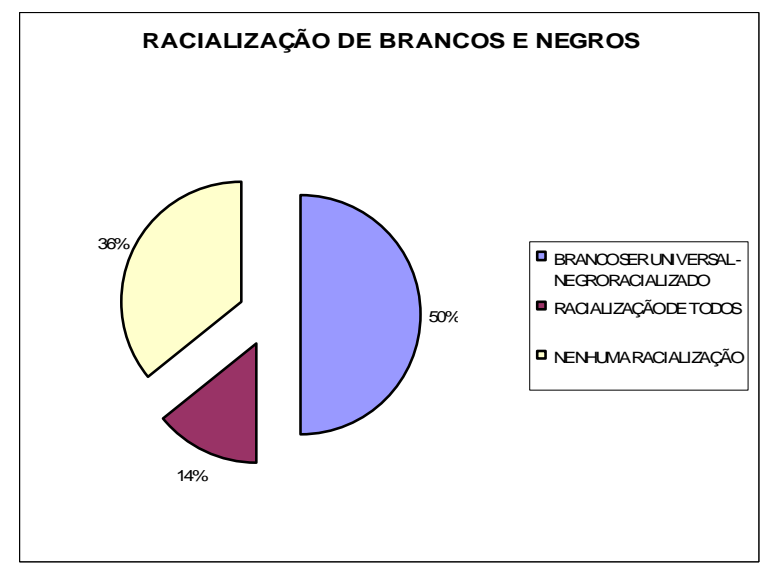

\section{Indicador ñò̀}

Com relação à racialização dos membros da família, constatou-se que, dos 7 ENTREVISTADOS NEGROS (PRETOS E PARDOS), 7 (100\%) identificaram com 
nitidez os componentes étnico-raciais dos membros de suas famílias, como se verifica no relato da entrevista abaixo:

(...) minha bisavó materna tem uma origem... provavelmente indígena, (......tipo, minha mãe (...), ela é indígena... meu bisavô na família materna (...) minha mãe ficava falando que ele era alemão, mas eu duvido, porque não tem nenhum nome alemão na minha família... acho que só diziam isso, por causa dos olhos azuis, (...) na minha família paterna, (...) é... ai, caramba... como eu vou dizer... minha... hum... acho que minha ascendência negra tá em maior parte na... na família paterna... (ENTREVISTADO NEGRO)

e dos 7 ENTREVISTADOS BRANCOS, 1 (14\%) fez o mesmo e 6 (86\%) não; esses últimos demonstram dificuldade em fazer isso, fizeram quando foram diretamente provocados e/ou apresentaram resistências em fazê-lo. Como se observa no relato da entrevista a seguir:

Pelo que sei, minha família veio da Itália, por parte de mãe, e, por parte de pai, veio de Portugal, é mais ou menos assim... Pergunta: Que raça que é sua mãe? Resposta: Não sei, ela não é cachorro, não, mas... ela é assim como eu, branquinha, assim... Fiquei meio chateado. (ENTREVISTADO BRANCO)

Assim, verifica-se que, do total dos 14 ENTREVISTADOS, 8 (57\%) racializaram membros de suas famílias e 6 (43\%) não, o que nos leva a crer que 57\% demonstram maior facilidade em se ver como membros de um grupo racial e 43\%, ao contrário, não costumam fazer isso e apresentam dificuldade em fazê-lo. É mister ressaltar que, dos entrevistados que demonstraram essa dificuldade (43\%), todos são brancos.

E, conforme ilustra o gráfico II abaixo: 


\section{Gráfico II}

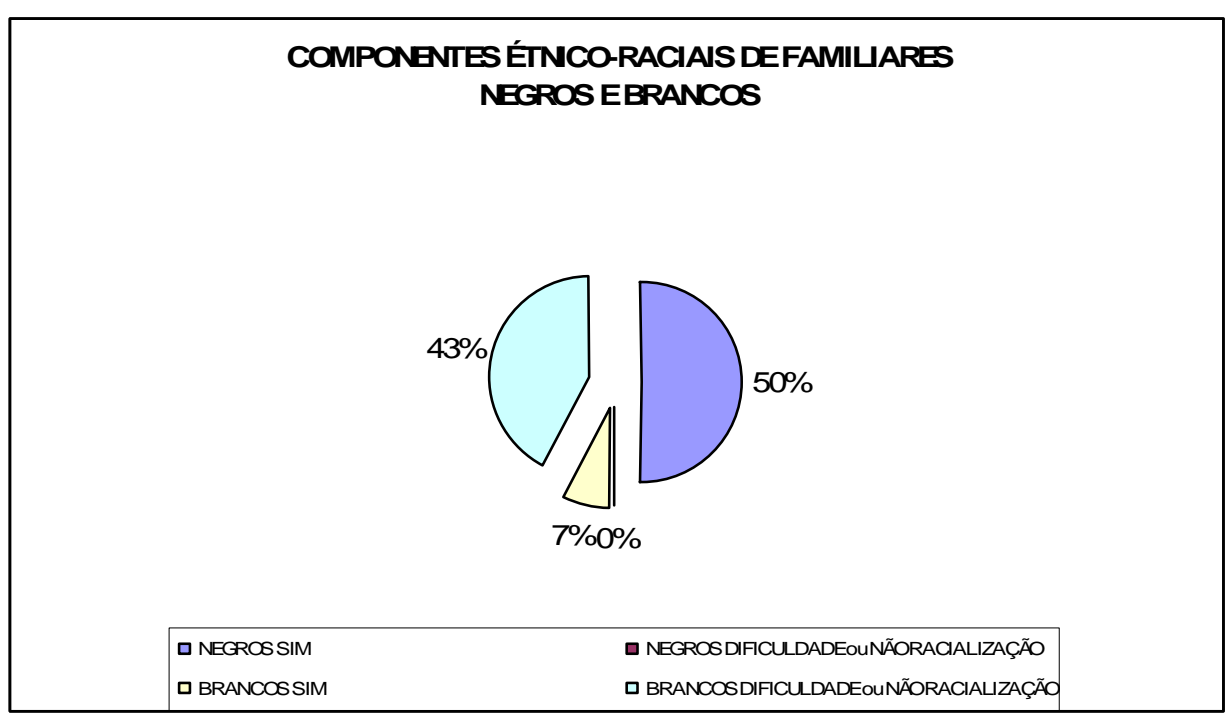

\section{Indicador ñ.ò:}

Foi analisado como os entrevistados utilizavam o componente étnico-racial na descrição das relações sociais, principalmente observando se os entrevistados aproximamse ou não do conceito social de raça, conforme definido por Celso Lafer (2005) e Munanga (1996).

Em todo o trabalho apareceram as seguintes considerações:

Do total dos entrevistados, verificou-se que 1(7\%) abordou o tema com muita confusão, não conseguindo agrupar as pessoas de forma que se sentisse satisfeito com a resposta, conforme relato de sua entrevista abaixo:

Ahn... bom, ahn... assim pensando em raça.. é, como... quase que... as etnias diferentes, né... ahn... eu não sei dizer bem... mas não dá pra diferenciar só pela cor... tipo, tem... ahn... ai, caramba... ah, eu não consigo dividir... eu posso dividir em grandes grupos, sei lá... assim, nos negros, os brancos... ahn... e os asiáticos... pensar em mais uma... os índigenas, acho que é um grupo diferente... uhm... os indígenas do 
extremo norte também são diferentes... os que... não sei se indígenas é o nome certo... os esquimós... ahn, tipo os Inuits (não sei bem o nome)... $a h n \ldots ;$ (ENTREVISTADO NEGRO)

2 (14\%) consideram a diferenciação de pessoas por raça algo depreciativo; 3 (21\%) acreditam que atualmente já vivemos em uma sociedade miscigenada e por isso não há sentido em separar as pessoas por raças; 2 (14\%) atribuem características genéticas a pessoas de diferentes raças mas negam o conceito social da diferenciação racial, como relato de entrevista a seguir:

Como conceito biológico existe. Porque raça não é nada mais do que uma especialização genética de certas características, isso existe. (...) biologicamente existe, mas não como base de discriminação ou preconceito, isso não existe...; (ENTREVISTADO BRANCO)

1 (7\%) atribui à raça a idéia de uma identificação positiva, $4(28,5 \%)$ não responderam e somente $1(7 \%)$ entrevistado trouxe para a definição das raças o conceito social, como se verifica abaixo:

...eu acho que esse conceito é válido no Brasil porque há uma exclusão direta de determinados grupos sociais... (ENTREVISTADO NEGRO)

Contudo, com relação a essa categoria, verifica-se que, entre os estudantes entrevistados, existe uma tendência de universalizar o branco e racializar o negro; em particular, os brancos não racializam a si mesmos e racializam os outros grupos étnicos, e brancos e negros demonstram rejeitar o termo raça para diferenciar as pessoas, não obstante, atribuir as diferenças componentes genético, associar a diferenciação por raça à prática de racismo e não conhecerem o conceito social de raça, que, conforme assume Lafer (2005), fundamenta a legislação brasileira sobre a matéria. 


\section{Categoria 2: Visibilidade sobre a ocorrência da discriminação racial:}

Indicador: visibilidade do tratamento desigual direto ou indireto que prejudica $\underline{\text { socialmente o negro, seja pela neutralidade, seja pela diferenciação negativa. }}$

Categoria 3: Visibilidade sobre as conseqüiências do racismo, os danos e os privilégios:

Indicador: visibilidade do prejuízo social para o negro, decorrente do racismo.

O conteúdo trabalhado nas categorias B e C surgiu de perguntas genéricas e mais específicas. Isto é, perguntou-se aos entrevistados sobre a ocorrência da discriminação racial na cidade onde vivem e na universidade e qual seria a razão de existirem mais brancos do que negros nas universidades. Além disso, foram utilizadas estórias e situações hipotéticas, algumas delas em que se invertiam os grupos negros e brancos na ocupação dos papéis de minoria e maioria, conforme é o caso da estória hipotética exposta na pergunta 20 do questionário anexo e das situações hipotéticas descritas nas perguntas 8 e 19 do mesmo questionário.

Da análise das entrevistas, obteve-se o seguinte:

Dos 7 ENTREVISTADOS NEGROS (PRETOS E PARDOS), todos (100\%) constatam a ocorrência da discriminação racial direta na universidade; todos (100\%) constatam a ocorrência da discriminação racial direta na cidade onde vivem; 3 (43\%) evidenciam a discriminação racial decorrente do racismo institucional na universidade e 4 (57\%) não, mas, destes, 3 (43\%) visualizam essa foram de discriminação quando é invertido o papel social dos grupos brancos e negros na ocupação de local de privilégio na sociedade. 4 (57\%) visualizam os danos e privilégios decorrentes do racismo para negros e brancos e $3(43 \%)$ não visualizam.

Dos 7 ENTREVISTADOS BRANCOS, 5 (71,5\%) constatam a ocorrência da discriminação racial direta na universidade e 2 (28,5\%) não; 6 (86\%) constatam a ocorrência da discriminação racial direta na cidade onde vivem e 1 (14\%) não; todos (100\%) não evidenciam a discriminação racial decorrente do racismo institucional na universidade, mas, destes, $4(57 \%)$ visualizam essa foram de discriminação quando é invertido o papel social dos grupos brancos e negros na ocupação de local de privilégio na 
sociedade. 1 (24\%) visualiza os danos e privilégios decorrentes do racismo para negros e brancos e $6(86 \%)$ não visualizam.

Assim, do TOTAL de 14 ENTREVISTADOS, constatou-se que 12 (86\%) visualizam a ocorrência da discriminação racial direta na universidade e 2 (14\%) não; 13 (93\%) visualizam a ocorrência da discriminação racial direta na cidade onde vivem e 1 (7\%) não; 3 (21,5\%) evidenciam a discriminação racial decorrente do racismo institucional na universidade e $11(78,5 \%)$ não, mas, destes, 7 (50\%) visualizam essa foram de discriminação quando é invertido o papel social dos grupos brancos e negros na ocupação de local de privilégio na sociedade e (50\%) não. 9 (64\%) não visualizam os danos e privilégios decorrentes do racismo para negros e brancos e 5 (36\%) visualizam.

É de salientar que um dos entrevistados, apesar de visualizar que a maior parte dos negros faz parte de classes sociais mais baixas, não relaciona esse fato ao racismo; a universidade é racista quando implementa a política de cotas por critério racial, o que impossibilita, por exemplo, sua irmã ter a mesma facilidade para entrar, porque não é negra, é branca.

Constata a discriminação direta na estória hipotética da pergunta 20 e a associa ao espaço de privilégio, como se verifica no relato da entrevista abaixo:

(...) o porteiro ao ver um rapaz negro... imaginou que ele não fosse aluno da escola... ao ver um branco, ele nem quis se indagar... (ENTREVISTADO NEGRO)

No entanto, ao ser perguntado sobre o privilégio do branco em ter acesso à Universidade, ele diz que acha que isso não ocorre:

Pergunta: Por que você acha que existem menos alunos negros na Universidade? Resposta: Uhm... Não sei... talvez aqui por ser uma população menor... ahn... ou também porque... a maior parte deles tá... tá incluída em classes sociais mais baixas... mas não sei... (ENTREVISTADO NEGRO) 
Outros são exemplos tirados das entrevistas da visibilidade da discriminação racial na universidade:

Muitos negros que entram por cotas têm problemas aqui, discriminam por terem entrado por cotas, principalmente aqueles que são contra as cotas... (ENTREVISTADO NEGRO)

A gente vê aqui que existe uma certa... não... uma certa tolerância dessa pessoa por um negro está aqui na universidade com ela. É difícil você ver um racista declarado que fala "eu sou racista", mas dependendo da atitude dele... (ENTREVISTADO NEGRO)

...é o que eu falei aquela olhada assim estranha... (ENTREVISTADA BRANCA)

Ressalta-se que, no processo de análise das entrevistas, aqueles entrevistados que atribuíram a desigualdade que observam existir entre brancos e negros aos aspectos unicamente econômicos foram considerados como entrevistados que não visualizam os danos causados à população negra decorrentes do racismo, pois, nesses casos, observou-se que os entrevistados visualizam a desigualdade e os danos à população negra, mas não a causa racial. É o caso em que se verifica no relato da entrevista a seguir:

Eu acredito que seja por uma questão histórica, assim, ah os... ligando mais com a questão econômica né... Então as pessoas que são negras geralmente elas são mais pobres (...) acho que é por isso que existem menos negros na universidade, por causa do ensino médio que não tá muito bom. (ENTREVISTADO BRANCO)

Nota-se que essa entrevistada, além de considerar que todos os negros cursam um ensino médio que não é bom, não relaciona o aspecto racial à causa da não ocupação dos negros nos ambientes de ensino privilegiado.

Fato interessante que surgiu das entrevistas foi a contradição apresentada a seguir. Com relação às conseqüências do racismo para cada grupo, a entrevistada constata que o 
fato de a universidade ser ocupada por uma grande maioria branca já caracterizaria um espaço de privilégio onde só estão os brancos, o que chama de cotas "para brancos de classe média alta". Por outro lado, menciona que existem os brancos que têm renda baixa e que estes, então, seriam "os excluídos dos excluídos", pois não estariam sendo contemplados por nenhuma política.

Por outro lado, demonstrando visualizar os danos decorrentes do racismo à população negra, outro entrevistado constata os danos e a diferença de desafios que tem que enfrentar, como negro, em comparação ao branco, para ter acesso à educação superior, atribuindo essa diferença à condição social desigual provocada pelas relações raciais, e não pelo fato de ter, pessoalmente, menos capacidade, mas menos oportunidades:

poxa, e com relação ao mérito... O que faz essa pessoa que faz vestibular mais apta do que outra pessoa que não teve oportunidades?! Eu penso da seguinte forma (...) porque vê é impossível, eu estaria concorrendo com pessoas... não tem condições de me preparar tão bem como as outras pessoas, não tem como... não tem um paralelo, não tem como eu competir... ela têm mais condições, se preparou melhor, tem um ensino de melhor qualidade, bem mais superior ao que eu tive no ensino médio, (...) O negro é mais prejudicado pela questão financeira do que o branco, se a gente parar para pensar, onde o negro mora, onde o branco mora... Claro, que tem branco que mora na favela, claro que tem negro... mas a maioria é negro, (...) mas se já prejudicam o negro de tantas formas, discriminam de tanta forma pro mal, de forma negativa, porque não discriminar de forma positiva inserindo o negro na universidade, dando a oportunidade de ele mudar, reverter essa situação e ser alguém. (ENTREVISTADO NEGRO)

E a opinião de uma entrevistada branca:

Na minha sala você pode contar nos dedos as pessoas negrasé porque eu sei que tem muita gente negra no país e a gente não convive com essas pessoas, tá muito dividido... 
Contudo, pode-se visualizar o seguinte nos gráficos III e IV abaixo:

Gráfico III

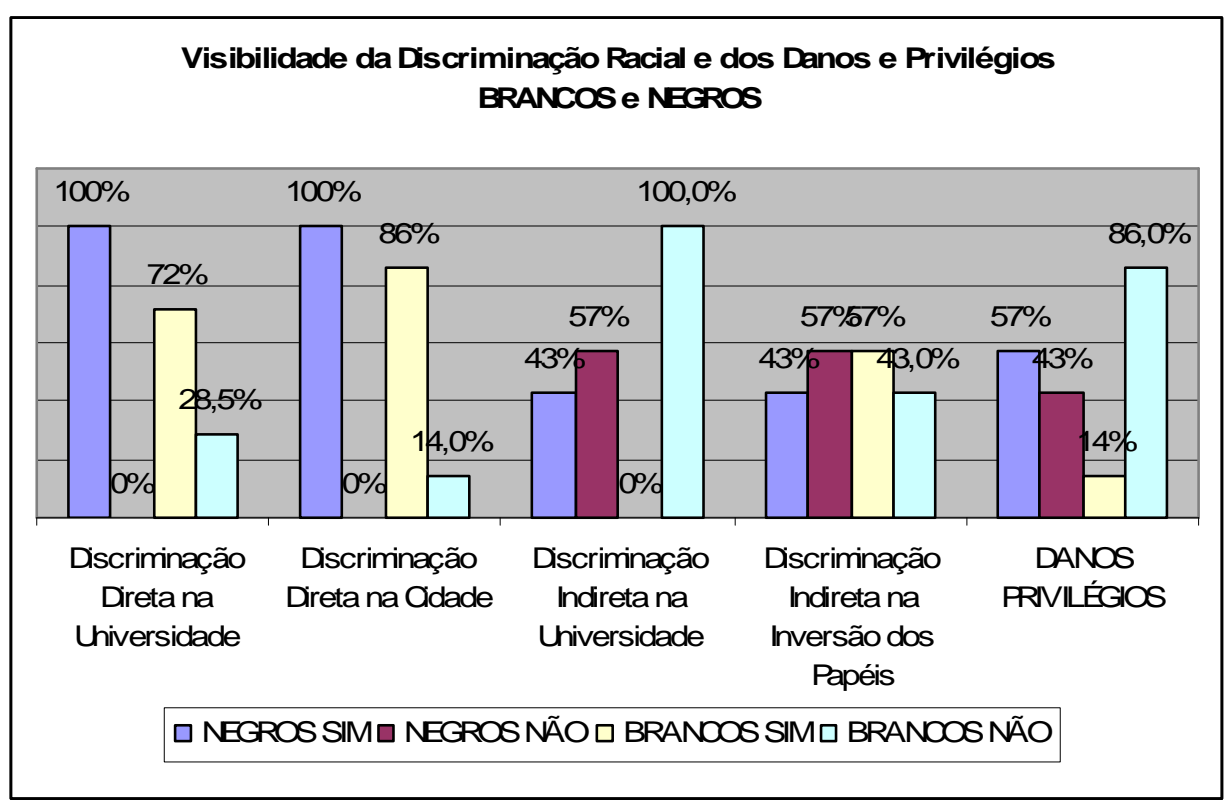

Gráfico IV

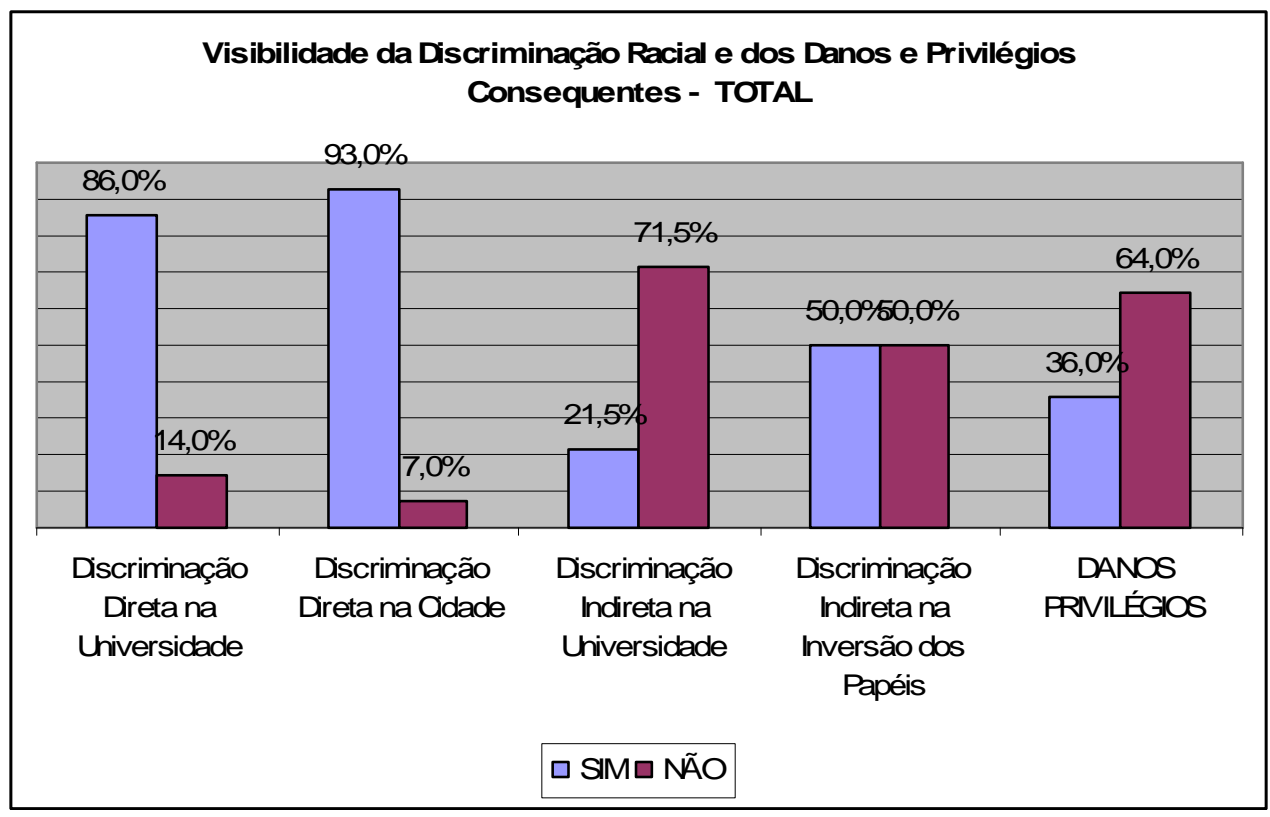




\section{Categoria 4: Reproducão de Estigma:}

Indicador: escolha de papéis profissionais para as pessoas das fotos de homens e mulheres; brancos(as) e negros(as); de faixas etárias de 20 a 30 anos, de 31 a 59 anos, acima de 60 anos. Indicadores: profissionais brancos (as) $\ddot{i}$ negros (as) e cargos profissionais de artista, que privilegiam conhecimento intelectual, manual ou posições de chefia.

Nessa etapa, foi entregue aos entrevistados um quadro com fotos de pessoas com idade em torno de 20 a 75 anos, em números iguais de pessoas brancas e negras, e um outro com a apresentação de forma escrita de cargos profissionais que poderiam estar envolvidos com a realidade de um hotel. Foi solicitado aos entrevistados que imaginassem que estariam sendo diretores de uma peça de teatro em que o cenário seria um hotel e que, assim, escolhessem, dentro das pessoas que compunham o quadro de figuras, aquelas que achariam adequados para desempenhar o papel dos personagens nas respectivas atividades profissionais (tudo conforme Pergunta 2 do questionário e quadro de fotos anexo).

Para a análise das respostas, considerou-se a seguinte qualificação: as profissões de Cabeleireiro (a), Arrumadeira (o), Porteiro (a) e Motorista foram consideradas como profissões que privilegiam o trabalho manual; as profissões de Médico e de Professor Universitário foram consideradas como profissões que privilegiam o trabalho intelectual e as profissões de Diretor de um Departamento de Marketing e Gerente do Hotel foram consideradas como posições de chefia. A profissão de Pianista foi considerada como profissão de artista.

Das respostas dos entrevistados, verificou-se o seguinte:

\section{Dos 7 ENTREVISTADOS NEGROS (PRETOS E PARDOS), 4 (57\%)} apresentaram uma tendência em reproduzir os estigmas sociais, ora escolhendo majoritariamente pessoas brancas para a ocupação das profissões que privilegiam o conhecimento intelectual ou posições de chefia e majoritariamente pessoas negras para a ocupação das profissões que privilegiam o trabalho manual e artístico. Ao contrário, 3 (43\%) não reproduziram o estigma social, demonstrando estar atentos a criar um quadro mais igualitário. 
Dos 7 ENTREVISTADOS BRANCOS, 6 (86\%) apresentaram uma tendência em reproduzir os estigmas sociais, ora escolhendo majoritariamente pessoas brancas para a ocupação das profissões que privilegiam o conhecimento intelectual ou posições de chefia e majoritariamente pessoas negras para a ocupação das profissões que privilegiam o trabalho manual e artístico. Ao contrário, 1 (14\%) não reproduziu o estigma social, demonstrando estar atento a criar um quadro mais igualitário.

Assim, do TOTAL de 14 ENTREVISTADOS, constatou-se que 10 (71,5\%) apresentaram uma tendência em reproduzir os estigmas sociais, ora escolhendo majoritariamente pessoas brancas para a ocupação das profissões que privilegiam o conhecimento intelectual ou posições de chefia e majoritariamente pessoas negras para a ocupação das profissões que privilegiam o trabalho manual e artístico. Ao contrário, 4 $(28,5 \%)$ não reproduziram o estigma social, demonstrando estar atentos a criar um quadro mais igualitário.

Observou-se que um dos entrevistados utilizou o número de negros e brancos nas profissões de forma paritária nas profissões que privilegia o conhecimento intelectual e de posição de chefia. No entanto, escolheu 4 pessoas negras para ocupar o lugar das 4 profissões que privilegiam o trabalho manual. Nesse ponto, demonstrou uma tendência em reproduzir o estigma social, como ilustram os gráficos V e VI abaixo.

\section{Gráfico V}

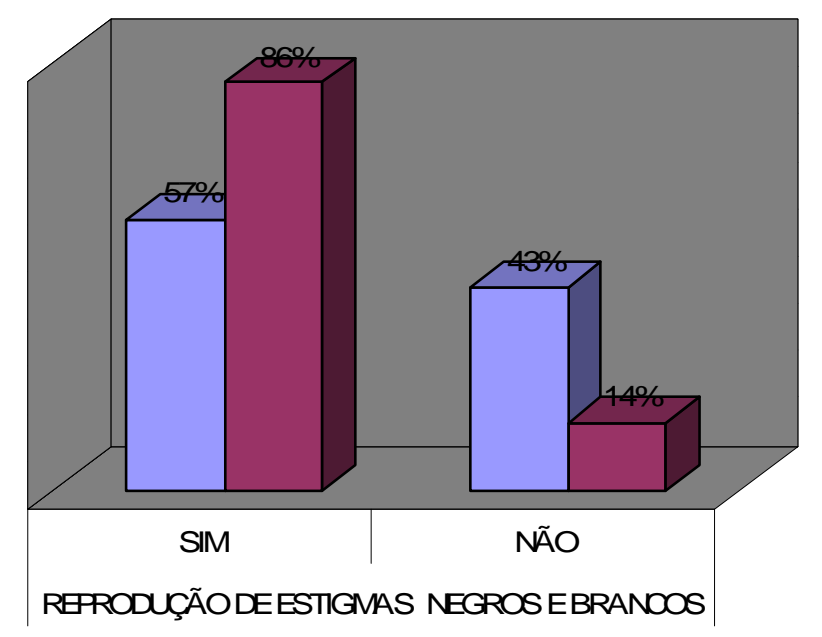




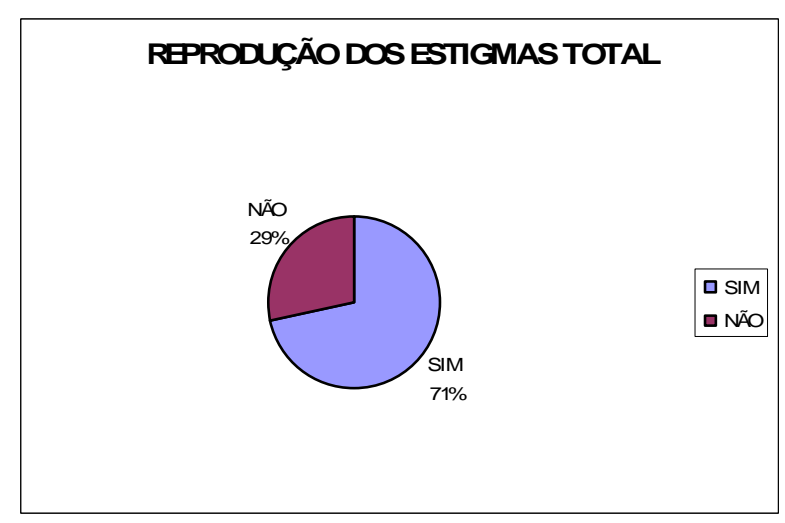

Gráfico VI

\section{Categoria 5: Reproducão de Estereótipo:}

Indicador: características atribuídas genericamente a todos os membros de um grupo na forma de um mito (não comprovadas ou realistas).

Com essa categoria, procurou-se identificar se existe a reprodução dos estereótipos criados pela cultura nas relações sociais entre os alunos das universidades, de forma significativa. Procurou-se evidenciar a quantidade de vezes que esse fenômeno apresentava-se nas entrevistas.

Verificou-se o seguinte:

Dos 7 ENTREVISTADOS NEGROS (PRETOS E PARDOS), somente se constatou a reprodução de estereótipos em 2 (28,5\%) entrevistas.

... a medula espinhal nos negros em relação aos brancos, não sei em relação aos asiáticos...se... chega um pouco mais próxima... é mais pra cima o cóccix do que nos brancos, assim... acho que pra médico...quer dizer, pra enfermagem, eles até devem ter que tomar cuidado, na hora de dar uma injeção... (ENTREVISTADO BRANCO)

os negros são mais assim, não seié batalhadores, eu acho. Eles seriam mais fortes, eu acho (ENTREVISTADA NEGRA) 
Dos 7 ENTREVISTADOS BRANCOS, somente se constatou a reprodução de estereótipos em 2 (28,5\%) entrevistas.

...o (...) negro, a maioria deles costumam ser mais bruto, sabe?... (ENTREVISTADO BRANCO)

é Isso também tem essas histórias que o negro aproveita de que ele é negro e fala que aconteceu um ato de racismo, né? (ENTREVISTADA BRANCA)

Observa-se que a entrevistada associa a todos os membros do grupo negro a idéia de que se aproveitam da condição de serem inferiorizados para obter vantagens injustas, revelando, nesse momento, a reprodução de um estereótipo que na dinâmica das relações sociais torna-se estigma. Isto é, a entrevistada não reconhece que todas as pessoas que estão em situação de vulnerabilidade tendem a desempenhar o papel de vítima para ter acesso aos bens que são disputados em uma relação de poder, nas relações sociais, mas atribui essa característica exclusivamente aos negros. Não reconhece a reivindicação legítima da pessoa vitimada pelo racismo como um direito a ser demandado, mas como uma ação infundada que parte dos negros.

Assim, do TOTAL de 14 ENTREVISTADOS, verificou-se somente $4(28,5 \%)$ situações de reprodução de estereótipos.

\section{Categoria 6: Reacões emocionais na relação com o preconceito:}

Indicador: culpa, vergonha, irritabilidade, raiva, exaustão, confusão na fala, negação, medo, dissimulação, sensação de solidão, tristeza, sensação de não pertencimento, impotência, contradição, justificativa defensiva.

\section{Dos 7 ENTREVISTADOS NEGROS (PRETOS E PARDOS), 5 (71,5\%)} apresentaram reações emocionais decorrentes do preconceito e/ou discriminação racial presentes na relação entre negros e brancos. Dessas reações, verificou-se a manifestação, em duas entrevistas $(28,5 \%)$, da sensação de medo, de sofrer discriminação e de ser excluído; 


\begin{abstract}
é mais por causa do medo, eu tinha muito medo de eu não conseguir acompanhar porque, ah, se eu precisava de tal nota no vestibular e eu não tive, então significa que eu não tenho o mínimo pra eu conseguir entender. (ENTREVISTADA NEGRA)
\end{abstract}

em duas entrevistas $(28,5 \%)$, da sensação de vergonha de ser cotista e de ser considerado menos capaz por ser cotista; em duas entrevistas, da sensação de solidão, em uma delas relacionada ao medo de ser o único cotista, e outra relacionada ao medo da segregação; em duas entrevistas (28,5\%), em duas, da sensação de impotência com relação diante da violência da discriminação; em uma entrevista (14\%), da sensação de desconforto, relacionado ao fato de ser constantemente discriminado na universidade; em uma entrevista (14\%), da sensação de vazio; em uma entrevista (14\%), da sensação de raiva diante da violência da discriminação; em uma entrevista (14\%), da sensação de tristeza e em uma entrevista (14\%), da sensação de susto decorrente do encontro com pessoas de outra etnia; em duas entrevistas $(28,5 \%)$, da sensação de satisfação em estar falando sobre o assunto. Em três entrevistas (43\%), verificou-se a utilização do recurso da negação em enfrentar o conflito da pergunta ou até de respondê-la, em uma delas (14\%) verificou-se a confusão diante das emoções.

Dos 7 ENTREVISTADOS BRANCOS, todos (100\%) apresentaram reações emocionais decorrentes do preconceito e/ou discriminação racial presentes na relação entre negros e brancos. Dessas reações, verificou-se a manifestação, em duas entrevistas $(28,5 \%)$ de irritabilidade, em uma entrevista (14\%), a sensação de intimidação, solidão e insegurança relacionadas à identificação com a circunstância em que estaria vivenciando o negro, em duas entrevistas $(28,5 \%)$, da sensação de desconforto em falar no tema, em uma entrevista (14\%), da sensação de impacto provocado pelo encontro com pessoas de diferente etnia; em uma entrevista (14\%), da sensação de raiva; em uma entrevista (14\%), de agressividade; em duas entrevistas (28,5\%), da sensação de obrigação e responsabilidade pela circunstâncias em que vivem os negros. Em três entrevistas (43\%), verificou-se a confusão e a dificuldade de identificação das emoções e em um das entrevistas (14\%), a utilização do recurso da dissimulação para se desviar do conflito da pergunta. 
Assim, do TOTAL de 14 ENTREVISTADOS, constatou-se que 12 (86\%) apresentaram reações emocionais decorrentes do preconceito e/ou discriminação racial.

A seguir, apresento os relatos da entrevista:

Solidão:

...comecei a achar que só eu... que só tava eu de cotista lá... (ENTREVISTADO NEGRO)

(...) só tinha branco e eu me sentia segregada... (ENTREVISTADA NEGRA)

...e e ia ficar sozinha... (ENTREVISTADA BRANCA)

Ressalata-se que essa manifestação surge no momento em que a entrevistada se coloca no lugar do discriminado.

Vergonha:

eu não contei pra ninguém, na verdade..., eu achei que quando alguém comentasse ou perguntasse disso, eu ficaria meio assim... ah, sou!... mas... (ENTREVISTADO NEGRO)

eu sou cotista, mas ninguém sabe que eu sou. E eu nunca falei para ninguém, Me falaram que ela fez. (...) Não foi ela. Nem cheguei a comentar com ela... (ENTREVISTADO NEGRO)

Susto

...me assustaria, eu me assustei quando só vi (...) negros. (ENTREVISTADO NEGRO)

Negação:

...não vejo grande diferença entre me relacionar com pessoa que seja, (...) fisicamente parecida comigo... ou diferente. (ENTREVISTADO BRANCO) 
Vazio:

...que não sei... acho que... hum...é algo que... ai caramba, como eu vou dizer... que me vai ajudar a preencher este espaço vazio... é... ficou evidenciado hoje... bom, não sei se vai ajudar mesmo a preencher... mas, pelo menos evidenciou este espaço, assim, em branco... que eu não dou tanta importância assim... (ENTREVISTADO NEGRO)

Impacto:

...você veria menos coisas impactando a gente sabe, às vezes a pessoa se impactam... (ENTREVISTADA BRANCA)

Intimidação:

Acho que no começo eu até ficaria intimidada... (ENTREVISTADA BRANCA)

Ressalata-se que essa manifestação surge no momento em que a entrevistada se coloca no lugar do discriminado.

Medo:

...eu não me sinto bem por falar que eu entrei nas cotas, assim... Rola uma discriminação mesmo... (ENTREVISTADO NEGRO).

...eu tinha muito medo de eu não conseguir acompanhar porque, ah, se eu precisava de tal nota no vestibular e eu não tive (...) Antes de eu entrar (...) eu achei que eu não ia poder conversar sobre isso com as pessoas que não são cotistas. (ENTREVISTADA NEGRA)

Irritabilidade:

...ele teria enviesado a análise dele, que é assim ele não tem uma prova que foi por racismo, assim você foi porque você caracteriza, é isso que eu critico, maçante... (ENTREVISTADO BRANCO) 
(...) ficar o tempo todo martelando nisso, nossa porque os negros são assim porque os brancos são assim (ENTREVISTADO BRANCO)

Raiva:

É assim ficaria indignado. Não chegaria a agressão física, mas eu iria discutir... (ENTREVISTADO NEGRO)

A reação acima surgiu a partir da estória hipotética da pergunta ñ̃ò̀.

Eu acho que sim. Eu acho não, eu tenho certeza. Porque as pessoas têm raiva. (ENTREVISTADA BRANCA)

Agressividade:

Eu ia tentar argumentar, mas se não desse, eu ia estrangular o cara. (ENTREVISTADO BRANCO)

A reação acima surgiu a partir da estória hipotética da pergunta ñ̃ò̀, quando o entrevistado se coloca no lugar do discriminado.

Tristeza:

O entrevistado chorou quando falou sobre ser cotista. Perguntei sobre a razão da emoção.

Resposta: (...) Tristeza pelo assunto, pelo modo como o assunto é visto hoje em dia. A questão da discriminação do racismo. (ENTREVISTADO NEGRO)

A entrevistada chorou quando falou sobre injustiça. Perguntei:

o que você sentiu? Resposta: (...) tristeza por ver que isso é tão forte e vê que eи sou parte disso, agir com esses preconceitos... (ENTREVISTADA BRANCA)

Desconforto:

...desconforto, um pouco por estar falando sobre isso. (ENTREVISTADO NEGRO) 
(...) não posso te dizer que me sentiria totalmente à vontade assim, porque isso seria mentira. (ENTREVISTADA BRANCA)

Ressalata-se que essa manifestação surge no momento em que a entrevistada se coloca no lugar do discriminado.

...não ser cumprimentado no elevador quando está sozinho com outra pessoa... (ENTREVISTADO NEGRO)

Insegurança:

....não ia conseguir. Como que eu iria fazer os trabalhos...? (ENTREVISTADA BRANCA)

Ressalata-se que essa manifestação surge no momento em que a entrevistada se coloca no lugar do discriminado.

Impotência:

Acho sinceramente que a situação estaria bem pior para ela assim, como ela vai reivindicar? Eu poderia dizer o quê? (ENTREVISTADA BRANCA)

...mas eu acho que eu não sei se eu ia conseguir (...) Acho que eles não iam aceitar. Acho que no fundo no fundo eles não iam aceitar... (ENTREVISTADA BRANCA)

...eu acho estranho porque eu não consigo entender o porquê... (ENTREVISTADO NEGRO)

Com relação a essa última manifestação, nota-se que o entrevistado expõe um desconforto decorrente da discriminação racial que vive na universidade (não ser cumprimentado no elevador quando está sozinho com outra pessoa) e manifesta uma sensação de impotência diante disso por não poder compreender a razão do comportamento discriminatório (eu acho estranho porque eu não consigo entender o porquê). Nesse ponto, 
verifica-se um aspecto não levantado nas hipóteses, mas que é relevante para o assunto: o desconhecimento das reações emocionais que um grupo possa ter em relação a outro.

De responsabilidade:

...eu tenho que fazer o máximo para não cometer nenhuma injustiça... (ENTREVISTADA BRANCA)

Satisfação:

...Fiquei feliz de ser ouvido e tal... (ENTREVISTADO NEGRO)

...fluiu bem, eu falei o que eu pensava, contei um pouco da minha experiência... Fluiu. (ENTREVISTADO NEGRO)

Negação:

...A gente nem lembra mais disso, (...) ou porque nunca teve isso mesmo. (ENTREVISTADA NEGRA)

...Olha, minha opinião para esse negócio de raça e preconceito para mim ele nem existe, então eu nem discuto. Para mim ele nem existe, para mim ele é irrelevante, então nem entro em discussão. (ENTREVISTADA NEGRA)

...às vezes tem umas inimizades com as pessoas, mas é porque o cara não gosta da pessoa, mas não tem nada a ver, assim, com... (...) algumas pessoas devem fazer piadas, de vez em quando, (...) mas fora a piada, não. (ENTREVISTADO BRANCO)

Dissimulação:

...ele como julgador escolheu pela competência porque é uma pessoa, se ele terceirizasse, colocasse uma fundação, uma Fundesp, para selecionar para ele, claro que é um plano mirabolante, e ela selecionasse por acaso não seria problema. (ENTREVISTADO BRANCO) 
Dificuldade em entender a reação emocional:

Pergunta: Como você se sentiria? Resposta: não sei. Sinceramente eu não sei... (ENTREVISTADA BRANCA)

Eu não sei como seria não. Eu teria que ver como ia ser. (ENTREVISTADA NEGRA)

(...) eu também não saberia o que fazer. Sei lá se assim, se você faz é porque você tem pena dela. E quando não faz é porque não está colaborando, sempre tem aquele julgamento externo, sempre tem aquela coisa... (ENTREVISTADO BRANCO)

Mas eu me sentiria (é ), não sei. (...) Eu acho que é difícil, nem eu mesmo sei. Como você falou assim da sala com alunos negros. Eu acho que eu agiria assim, mas será que na aula mesmo eu agiria assim? Eu não tenho tanta certeza. (ENTREVISTADA NEGRA)

Tive dificuldade de expressar minhas idéias. Ficaram confusas... (ENTREVISTADO BRANCO)

Assim, ilustram os gráficos VII e VIII:

Gráfico VII

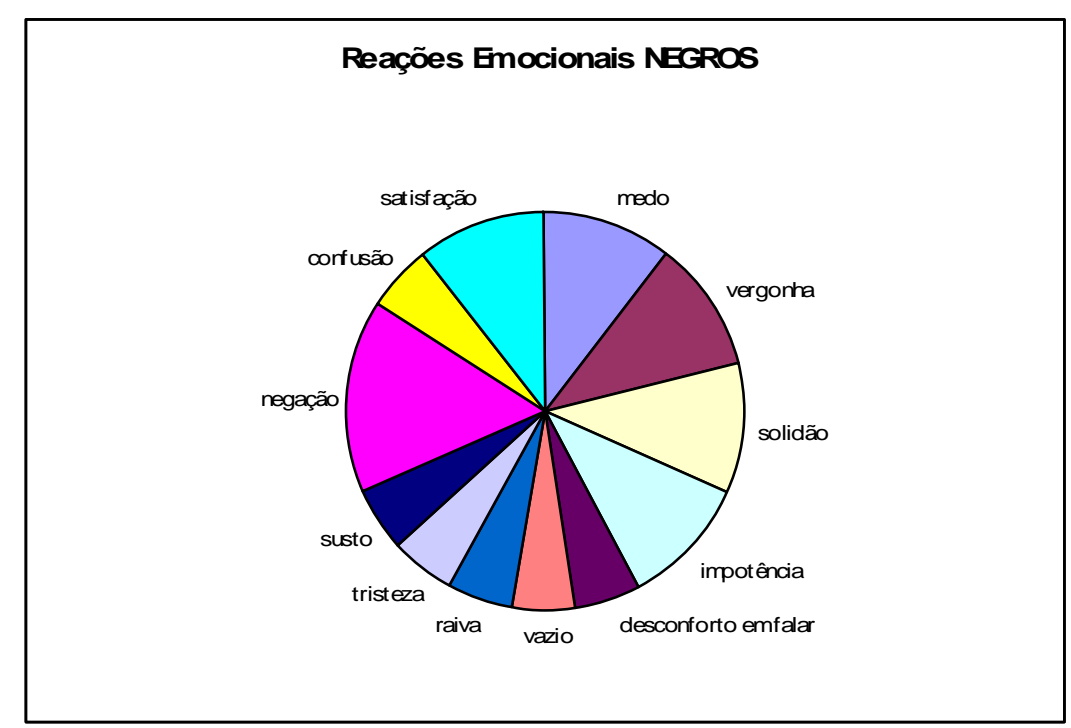


Gráfico VIII

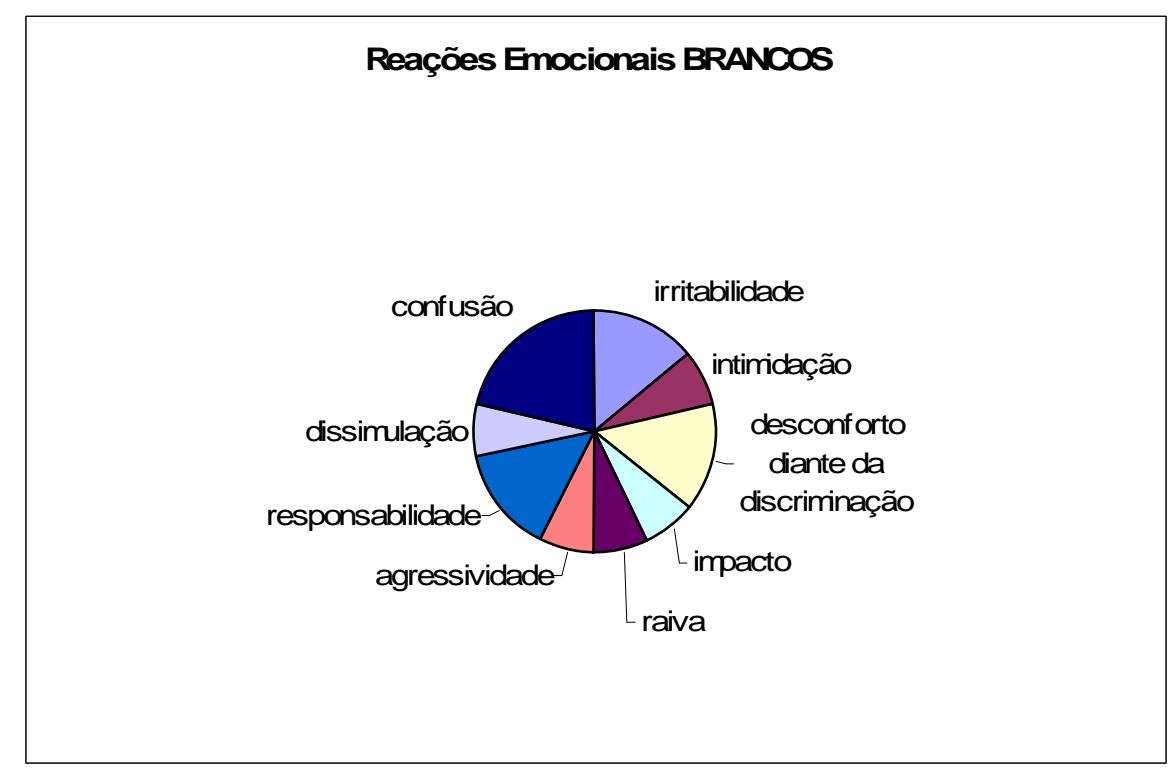

Categoria 7: Formas e Oportunidades de elaboracão das experiências relacionadas ao racismo:

Indicador: oportunidades de reflexão sobre o tema racismo nos espaços sociais (família, instituições de ensino, mídia, amigos).

Anteriormente ao ingresso na universidade, dos 7 ENTREVISTADOS NEGROS (PRETOS E PARDOS), 5 (71,5\%) revelaram não ter tido oportunidades de debate e reflexão sobre o racismo e $2(28,5 \%)$ revelaram que tiveram, sendo que 1 deles disse ter tido contato com o assunto no colégio, somente em situação provocada pelo debate em torno da política de cotas e outro manifestou que teve durante sua vida a oportunidade de conversar sobre isso com os amigos. Assim, conclui-se que a totalidade dos entrevistados não teve oportunidades significativas de debater e refletir sobre a questão, proporcionadas por instituições de ensino e meios de comunicação.

Durante o período em que os entrevistados estavam na universidade, em duas entrevistas $(28,5 \%)$ observou-se que a experiência de estar sendo aluno por meio de cotas na universidade gerou uma oportunidade de reflexão sobre o assunto, gerando mudanças para o entrevistado: 
Depois de entrar aqui? Alterou, porque antes de entrar aqui eu tinha essa visão de raças mesmo, de ter realmente essa diferenciação. (...)Por exemplo, numa matéria de antropologia que eu vim estudar mais essa questão aqui.. (ENTREVISTADO NEGRO)

é mais por causa do medo, eu tinha muito medo de eu não conseguir acompanhar porque, ah, se eu precisava de tal nota no vestibular e eu não tive, então significa que eu não tenho o mínimo pra eu conseguir entender. Mas não, depois que eu percebi que eu entrei aqui, percebi que o que faz a diferença é eu aqui. Antes do vestibular, já passou, já não influencia mais. (ENTREVISTADO NEGRO)

Antes de eu entrar, antes de eu conhecer as pessoas da sala, eu fiquei com medo, eu achei que eu não ia poder conversar sobre isso com as pessoas que não são cotistas. Eu pensei ñAh, acho que os meus amigos vão ser os cotistasò. Eu pensei assim, mas aí logo que eu entrei, eu já vi que não, que não ia ser assim, (ENTREVISTADO NEGRO)

a gente acaba, eu penso que, amadurecendo porque a gente é obrigado a pensar mais no assunto, a gente, sabe, ña gente ta aqui agora, e aí o que que isso significa? ò entendeu, a gente acaba vendo mais perto assim a opinião das pessoas, como elas reagem; aí a gente acaba amadurecendo nesse assunto. (ENTREVISTADA NEGRA)

Ademais, verificou-se em uma das entrevistas que a própria experiência de ser entrevistado gerou a oportunidade de reflexão.

É... ahn, assim...essa situação, assim... me mostrou... mostrou algumas coisas que eu nunca tinha pensado antes...ou que eu nunca dei muita importância (...) eu achava que não era uma coisa assim difícil de falar...mas... é", "por estar fortemente vinculada a...uma formação cultural que a gente teve..(...) eu enxergo o negro como arquétipo do... do...é...sei lá, do trabalhador industrial (...) algum tipo de imagem que 
acho estaria enraizada na...na nossa cultura.. (ENTREVISTADO NEGRO)

Por outro lado, observa-se que a experiência como cotista coloca o entrevistado em uma oportunidade de se deparar com o tema, mas não é oferecida oportunidade para a reflexão e nem ferramentas para a elaboração:

o professor de Anatomia tava falando... é... de variação anatômica...aí que fatores que dariam variação anatômica, aí um deles seria a etnia... aí eu comentei etnia... aí ele:-Isso...-ahn... aí ele perguntou como foi que eu passei ou qual era minha cor, eu não lembro...Você é branco.- eu: Não, pardo...aí...é...acho que nisso que eu falei-pardo - entenderam que eu sou cotista...mas eu não sei, não ficou muito claro... (ENTREVISTADO NEGRO)

Anteriormente ao ingresso na universidade, dos 7 ENTREVISTADOS BRANCOS, $3(43 \%)$ revelaram não ter tido oportunidades de debate e reflexão sobre o racismo e 4 (57\%) revelaram que tiveram, sendo que 2 deles disseram ter tido conversas no âmbito familiar, 2 tiveram a oportunidade de debater com amigos e 2 deles também mencionaram que tiveram contato com o assunto no colégio, somente em situação provocada pelo debate em torno da política de cotas. Assim, concluí-se que a totalidade dos entrevistados não teve oportunidades significativas de debater e refletir sobre a questão, proporcionadas por instituições de ensino e meios de comunicação.

Nota-se que uma das entrevistadas, ao ser perguntada sobre a oportunidade de debate e reflexão sobre o assunto, apresentou uma reflexão que se limita à relação que sua família tem com a empregada doméstica, atribuindo a ela aspectos afetivos, reproduzindo a idéia de se reduzir os aspectos danosos e desiguais da população negra criada pelo mito da democracia racial. 


\section{Gráfico IX}

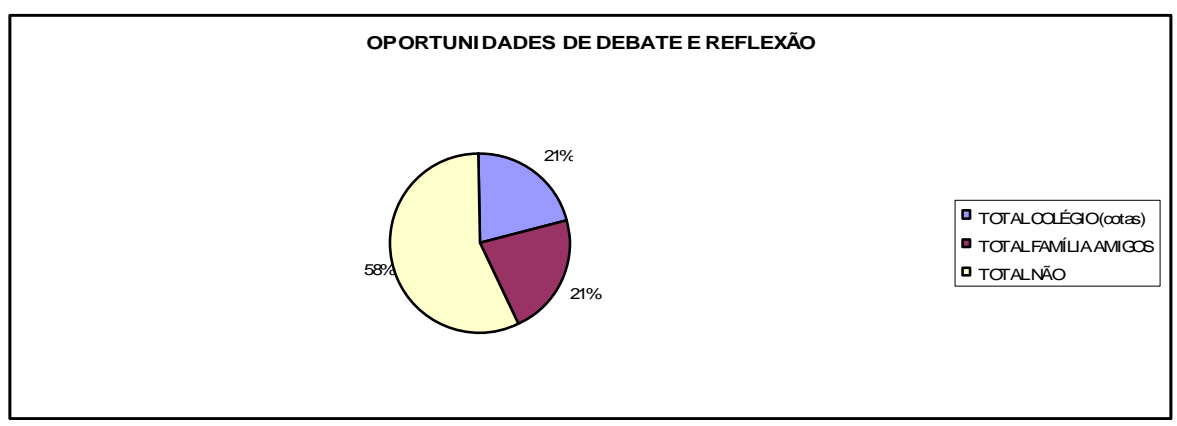

Durante o período em que os entrevistados estavam na universidade, em uma das entrevistas (14\%) observou-se que a experiência de estar sendo aluno por meio de cotas na universidade gerou uma oportunidade de reflexão sobre o assunto, ocasionando mudanças para uma entrevistada que declarou que uma matéria em seu curso foi bastante significativa para ela entender e elaborar o assunto, em suas palavras: "me abriu a mente".

Ademais, verificou-se em uma das entrevistas que a própria experiência de ser entrevistado gerou a oportunidade de reflexão. Observa-se que a experiência da entrevistada, na proposta da entrevista de elaboração do quadro de profissões, trouxe a oportunidade de refletir sobre a questão, manifestando sua conclusão de que pratica o preconceito e a conduta discriminatória.

Assim, do TOTAL de 14 ENTREVISTADOS, verificou-se que os jovens entrevistados não tiveram, antes de entrarem na universidade, oportunidades na sociedade em que vivem, de debate, reflexão e elaboração sobre os conflitos e temas relacionados ao racismo, de forma significativa, isto é, que tenham lhes proporcionado uma mudança de opinião, uma transformação comportamental. Verifica-se que a experiência na universidade tem colocado os alunos em contato com a questão e uma atividade educacional de um curso voltado à discussão sobre diversidade na área de antropologia ofereceu aos alunos uma possibilidade de sentirem-se mais confortáveis com o tema, em uma das universidades. No entanto, essa foi a única referência trazida pelos entrevistados. Falaram de redações que tiveram como tema a política de cotas e alguns poucos eventos realizados com esse tema, mas que por eles não foram considerados como lugares significativos para a reflexão sobre o racismo, pois não lembram com clareza do conteúdo. 
Porque as pessoas estão falando a mesma coisa, não acrescenta nada, sabe como que é? (ENTREVISTADO BRANCO)

.....mas...ah...eu lembro que no colégio tinha alguma coisa assim...é que não era a coisa, assim que eu mais gostava...(riso)...eu não ocupava muito minha cabeça com isso... (ENTREVISTADO NEGRO)

\section{H. Categoria 8: Abordagem teórica sobre o tema:}

Subcategorias: a) Diversidade x Igualdade x Racismo:

Indicador: Confusão a respeito do tema diversidade, sobre a diferenciação positiva $і ̈$ a diferenciação negativa e a valorização ou desvalorização da diferença.

Nessa etapa, a partir da fala livre estimulada pelas perguntas do questionário, procurou-se identificar a relação que os entrevistados estabelecem entre o entendimento que possuem a cerca da Diversidade e da Igualdade e do Racismo, quando estão tratando da relação entre brancos e negros. Para isso, pretendeu-se verificar se valorizam a diversidade e a igualdade, enquanto um conceito abstrato e, junto a isso, se valorizam as diferenças das pessoas no convívio social e finalmente se valorizam a diversidade étnicoracial do negro, isto é, se valorizam os aspectos das pessoas negras que seriam diferenciados em nossa sociedade em razão de suas características étnico-raciais.

Assim, verificou-se que:

Dos 7 ENTREVISTADOS NEGROS (PRETOS E PARDOS), todos valorizam abstratamente a idéia de Igualdade; 6 (86\%) valorizam abstratamente a idéia de Diversidade e 1 (14\%) não; 3 (43\%) valorizam as diferenças no convívio social, 3 (43\%) não e 1 (14\%) não respondeu; 4 (57\%) valorizam a diversidade étnico-racial dos negros, 2 $(28,5 \%)$ não enxergam ou não valorizam isso e 1 (14\%) não respondeu. Dos 7 ENTREVISTADOS BRANCOS, todos (100\%) valorizam abstratamente a idéia de Igualdade; todos (100\%) valorizam abstratamente a idéia de Diversidade; 1 (14\%) valoriza as diferenças no convívio social, 5 (71\%) não e 1 (14\%) não respondeu; nenhum valoriza a diversidade étnico-racial dos negros, 6 (86\%) não enxergam ou não valorizam isso e 1 (14\%) não respondeu. 
Assim, dos 14 entrevistados, todos valorizam abstratamente a idéia de Igualdade; $13(93 \%)$ valorizam abstratamente a idéia de Diversidade e 1 (7\%) não; 4 (28,5\%) valorizam as diferenças no convívio social, 8 (57\%) não e 2 (14\%) não responderam; 4 $(28,5 \%)$ valorizam a diversidade étnico-racial dos negros, 8 (57\%) não enxergam ou não valorizam isso e 2 (14\%) não responderam.

Observa-se que, com relação a esse tema da pesquisa, os entrevistados apresentaram bastante confusão e contradições:

Manifestou-se uma confusão em torno daquilo que é diferente entre os negros e os brancos: enquanto em um momento da entrevista o entrevistado considera os aspectos sócio-econômicos como um fator de diferenciação entre negros e brancos, em outro afirma a semelhança do contexto social entre brancos e negros:

\footnotetext{
Relato da entrevista:

a menos que a gente considere o meio social também, né... sei lá, se você fosse pegar a parte bruta da população negra (...) a gente ia encontrar eles (...) no setor de serviços, acho... ou na indústria, ... a parte branca estaria mais distribuída (ENTREVISTADO NEGRO) E elas (pessoas diferenciadas pela cor) estão no mesmo contexto social (ENTREVISTADO NEGRO)
}

Existiram manifestações considerando que a especificidade do ser humano é um valor, mas não que a diferença entre negros e brancos deva ser valorizada, ao contrário, demonstrando associar o negro a algo depreciativo.

Relatos da entrevista:

Pergunta: Que você acha da diversidade?Resposta: Acho fundamental. Muito bom. Bom tanto para ter essa riqueza cultural. Riqueza tanto cultural como acadêmica, ...(...) Aqui no caso seriam as pessoas pobres, as pessoas que freqüentaram escolas públicas que é uma merda. E não tiveram o preparo suficiente para entrar aqui, e as pesquisas indicam 
que essas pessoas são mais negras, não é? (...)...o foco não deveria tratar o negro como alguém diferenciado (ENTREVISTADO NEGRO)

Em outro caso, apesar de a entrevistada ver na diversidade uma oportunidade boa de se livrar de uma preocupação, a preocupação parece ser exatamente a de ser diferente. Assim, reflete a desvalorização da sociedade em relação àquilo que é diferente nos seres humanos, desvalorizando ela mesma o que é diverso dentro da diversidade, dizendo que o bom da diversidade é que ña diversidade já mistura tudo, e pronto, todo mundo é igualò.

Valorizou-se a diversidade quando se tratava da possibilidade de escolhas livre dos papéis sociais atribuídos aos grupos, no entanto, rejeitou-se a ação de falar sobre as diferenças quando isso é aplicado na relação entre negros e brancos.

Relatos da entrevista:

Acho que valoriza(...)Conviver com diversas culturas, conviveré Você pode ter uma opção (...) Acho que poderia parar de falar de diferença. (ENTREVISTADO NEGRO)

$\mathrm{Ou}$, em outros casos, a pessoa branca valoriza a diversidade, mas não vê a diversidade na relação com a pessoa negra.

Relatos da entrevista:

Só se acontecer alguma atitude. Mas qualquer pessoa teria essa mesma atitude, mas não é uma atitude porque ela é negra, são atitudes que as pessoas têm independente de...entendeu? (ENTREVISTADA BRANCA)

Pergunta:se tivesse uma palestra sobre ñO convívio em diversidadeò ? Resposta: eu iria, interessante que não fala só tipo o racismo, fala o convívio em todos os aspectos bons e ruins das pessoas, a todas as formas diferentes das pessoas viverem juntas. (ENTREVISTADA BRANCA) 
Nesse sentido, outro entrevistado não relaciona a diferença racial a algo que deva ser valorizado e respeitado, mas a algo que deve ser ñestringidoò na perspectiva de que o que deve ser valorizado e respeitado é a pessoa:

Relato da entrevista:

... a dignidade, com a liberdade e a igualdade que, em um convívio social, as pessoas devem ter. Restringindo as diferenças, evitando certos tipos de conduta, é...discriminatórias, preconceituosas, tal. Dignificando a pessoa humana, não por ela pertencer à determinada classe social, por ser de determinada raça, mas por ser pessoa (ENTREVISTADO NEGRO)

Para um entrevistado, o fato de simplesmente existirem pessoas com especificidades diversas no mesmo espaço, não existe racismo.

Relato da Entrevista:

Aqui (...) tem todo tipo de pessoa(...) E você não tem (...) separação, (...) não tem esse negócio de racismo (ENTREVISTADO BRANCO)

Por outro lado, apresentaram-se visões mias nítidas sobre o tema, como essa em que o entrevistado entende a racialização como uma forma positiva de valorizar a diversidade e relaciona a diversidade à democracia.

Eu acho que raça é uma especificação que veio para somar, acho que é uma identificação positiva, não é uma diferença segregadora assim. (ENTREVISTADO NEGRO)

Acho a diversidade boa...boa. A diversidade é a democracia, né? Tem que está muito ligado. É o que a gente quer para o Brasil e é isso que a gente não tem, né? (ENTREVISTADO NEGRO) 
Gráfico X

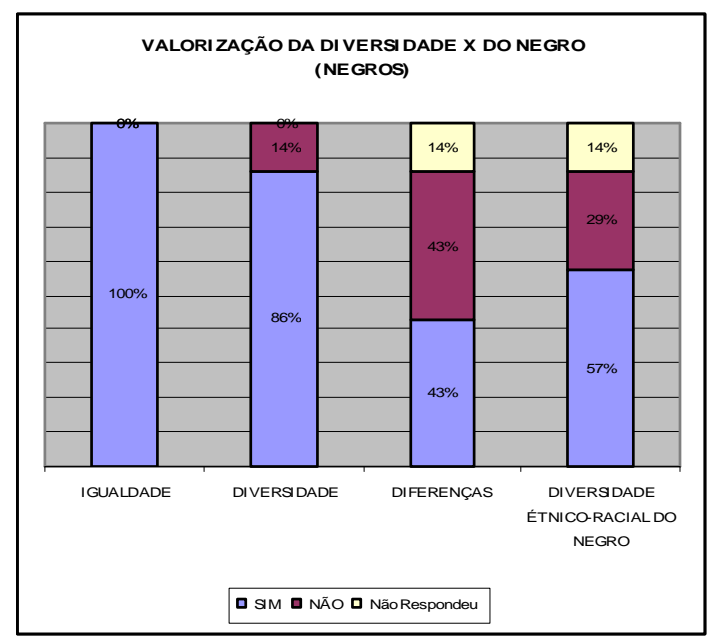

Gráfico XI

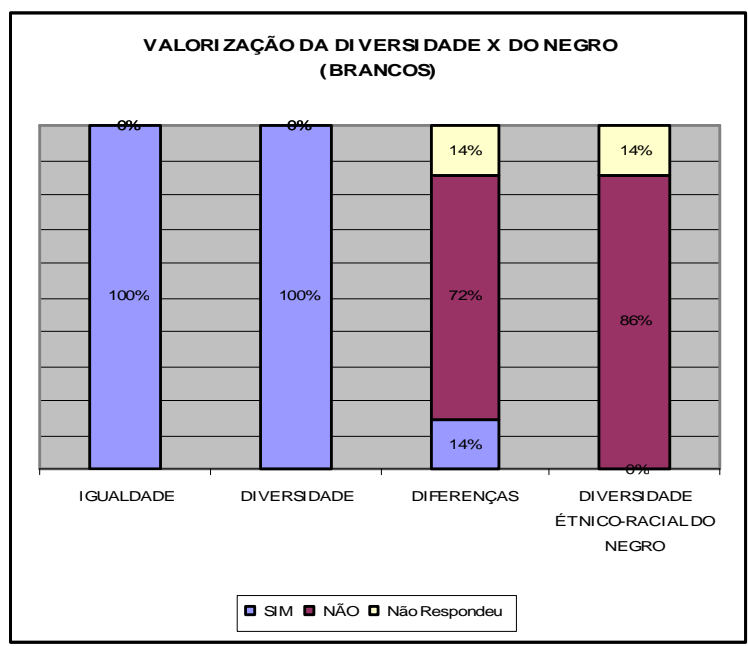

Gráfico XII

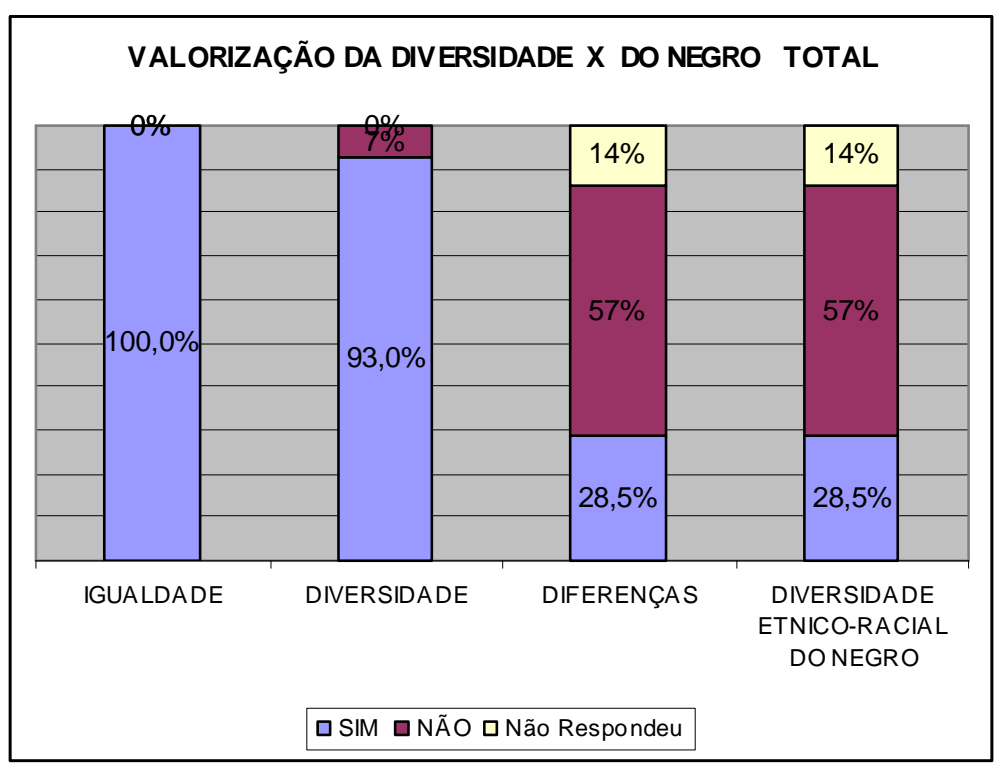

\section{Categoria 8: Abordagem teórica sobre o tema:}

Subcategoria: b) Relação do racismo com os princípios de direito fundamentais:

Indicador 1: reconhecimento da política como um direito fundamental.

Dos 7 ENTREVISTADOS NEGROS (PRETOS E PARDOS), $2 \quad(28,5 \%)$ associaram a política de cotas raciais a um direito, enquanto $2(28,5 \%)$ não associaram a política a um direito, mas sim a uma doação ou ajuda. 3 (43\%) entrevistados não responderam. Dos 7 ENTREVISTADOS BRANCOS, 2 (28,5\%) associou a política de cotas raciais a um direito, $2(28,5 \%)$ não associaram e $3(43 \%)$ não responderam. 
Assim, o TOTAL dos 14 entrevistados, 4 (28,5\%) associaram a política de cotas raciais a um direito, enquanto que $4(28,5 \%)$ não associaram e $6(43 \%)$ entrevistados não responderam.

Dos que não associaram a política a um direito, verificou-se a associação da política com as seguintes argumentações:

...o foco não deveria tratar o negro como alguém diferenciado que precisa de cuidados especiais. (ENTREVISTADO NEGRO)

por dar oportunidade pra uma minoria, eu acho que é interessante darem... darem...o é...darem uma vantagem assim (ENTREVISTADO BRANCO)

Você não tem base, você não tem cota pra passar, ninguém vai te ajudar, sabe? (ENTREVISTADA BRANCA)

Os que associaram a política a um direito, por sua vez, apresentaram os seguintes argumentos:

Ação afirmativa não é dar as coisas, é incluir socialmente determinadas pessoas (...) que por algum fator cultural, econômico não estariam dentro do...do sistema., do lado bom do sistema (...) não é dado (...) Não, não é um favor, é um direito (ENTREVISTADO NEGRO)

Porque todo mundo tem que ter direito à educação. Tem concurso só porque não tem vaga para todo mundo (...) você não sabe matemática, física e química, então você não pode entrar para fazer uma faculdade de direito? (ENTREVISTADO NEGRO) 


\section{Categoria 8: Abordagem teórica sobre o tema:}

Subcategoria: b) Relação do racismo com os princípios de direito fundamentais:

Indicador 2: reconhecimento do direito a ser tratado desigualmente (discriminação positiva).

Dos 7 ENTREVISTADOS NEGROS (PRETOS E PARDOS), 3 (43\%) entenderam a discriminação positiva como um direito, enquanto 4 (57\%) não. Dos 7 ENTREVISTADOS BRANCOS, todos (100\%) não entenderem a discriminação positiva como um direito.

Assim, o TOTAL dos 14 entrevistados, somente 3 (21,5\%) entenderem a discriminação positiva como um direito, enquanto $11(78,5 \%)$ não.

Salienta-se que, dessa análise, verificou-se que muitos entrevistados, na verdade, desconhecem a fundamentação da discriminação positiva e, não algumas vezes, mostraram confundir assuntos, chegando a manifestar concordar com a política de cotas e discordar da discriminação positiva como promoção da igualdade.

Relato da entrevista:

Eu acho que direitos humanos seriam tá dando esse espaço para pessoa, esse valor. Vendo a pessoa como humano, valorizado na medida de sua especificidade, claro...Acho que o respeito à diversidade. Pergunta: Você acha que o direito dos negros é um tema dos direitos humanos? Resposta: Por que ai você está diferenciando algo que não é diferençável. Direitos humanos, negros e brancos são humanos de qualquer jeito. (ENTREVISTADO BRANCO)

Ademais, nota-se que em algumas falas se associa a razão das cotas e da discriminação positiva à idéia de incapacidade meritória, de algo que alguém precisa porque não seria capaz de entrar de outra forma. Por isso, a rejeição em vincular essa idéia ao negro.

Relatos da entrevista: 
Primeiro, porque o negro é igual a qualquer outro, então eu acho que muito negro ai não é pobre. O negro ai que tem capacidade e tem um bom nível de escolaridade e pode passar tranqüilo na faculdade, sem precisar (ENTREVISTADO NEGRO)

Pergunta: Você acha que direito dos negros é tema de Direitos Humanos? Resposta: Eu acho que é. Acho que é muito pertinente. (...) Determinados grupos sociais têm umas demandas especiais em relação aos direitos humanos. (ENTREVISTADO NEGRO)

Pergunta: Você acha que direito dos negros é tema de Direitos Humanos?... se você encarar os direitos humanos do negro como um meio de segregação também preconceituosa do negro, então, acho negativo, mas é um subtema que tem que ser discutido praticamente, a realidade, e não segregar. Também direito dos brancos também seria algo preconceituoso se você pensar nesse sentido, mas... tem que pensar não como uma segreção mas como um subtema de um tema amplo que os negros sofrem na sociedade. Pergunta: E discriminação racial? Resposta: Acho que sim. Discriminação é. (ENTREVISTADO NEGRO)

\section{Gráfico XIII}

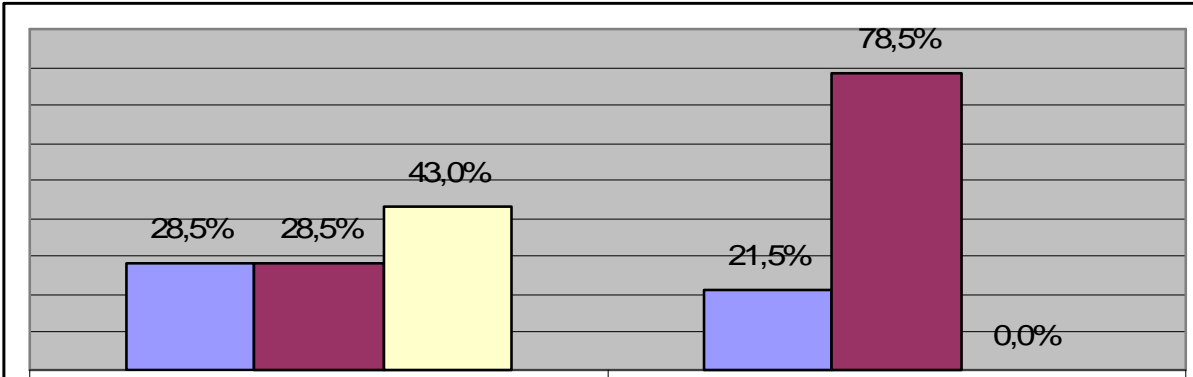

REOON-EOMENTODA POĹTCA COMD DIRETOFUNDAMENTAL
REOON-EGMENTODA DISCRIMNAÇÃO POSTIVA COMODIRETO 


\section{Categoria: 9. Manifestacão de propensão para a solidariedade:}

Indicador: crença de que a relação multi-étnica enriquece e auxilia a coletividade, na solução de problemas coletivos e individuais; disponibilidade para a busca real de soluções para o racismo.

\section{Dos 7 ENTREVISTADOS NEGROS (PRETOS E PARDOS), 6 (86\%)} demonstraram crer que a relação multi-étnica enriquece e auxilia a coletividade e 1 (14\%) não; 2 (28,5\%) demonstraram buscar soluções reais para o racismo, 4 (57\%) não e 1 (14\%) não respondeu. Dos 7 ENTREVISTADOS BRANCOS, 2 (28,5\%) demonstraram crer que a relação multi-étnica enriquece e auxilia a coletividade e $5(71,5 \%)$ não; 3 (43\%) demonstraram buscar soluções reais para o racismo e 4 (57\%) não.

Assim, do TOTAL dos 14 entrevistados, 8 (57\%) demonstraram crer que a relação multi-étnica enriquece e auxilia a coletividade e 6 (43\%) não; 5 (36\%) demonstraram buscar soluções reais para o racismo e 8 (57\%) não e 1 (7\%) não respondeu.

Contudo, considerando que para a caracterização da propensão para a solidariedade na relação entre brancos e negros previu-se a ocorrência dos dois indicadores na entrevista de cada jovem entrevistado, conclui-se que 5 (36\%) dos entrevistados demonstraram ter uma propensão para a solidariedade e 9 (64\%) não.

Gráfico XIV

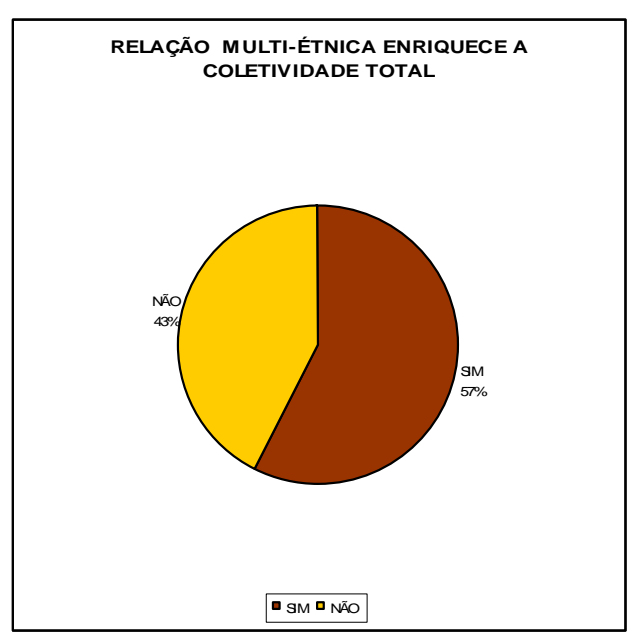

Gráfico XV

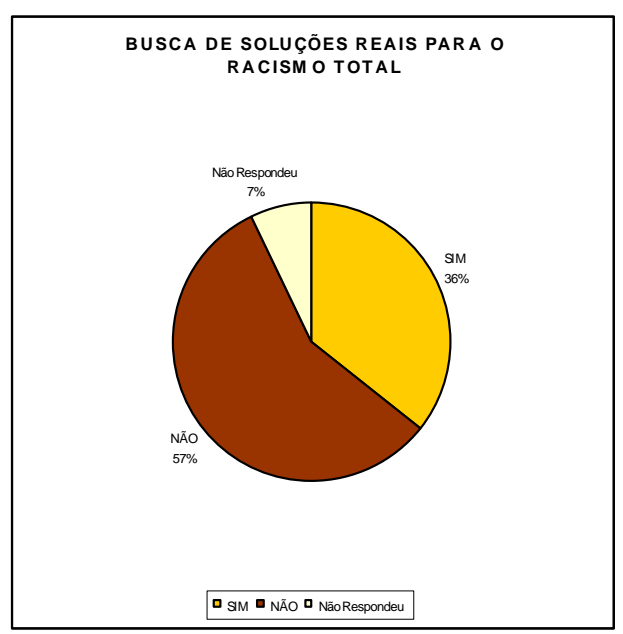




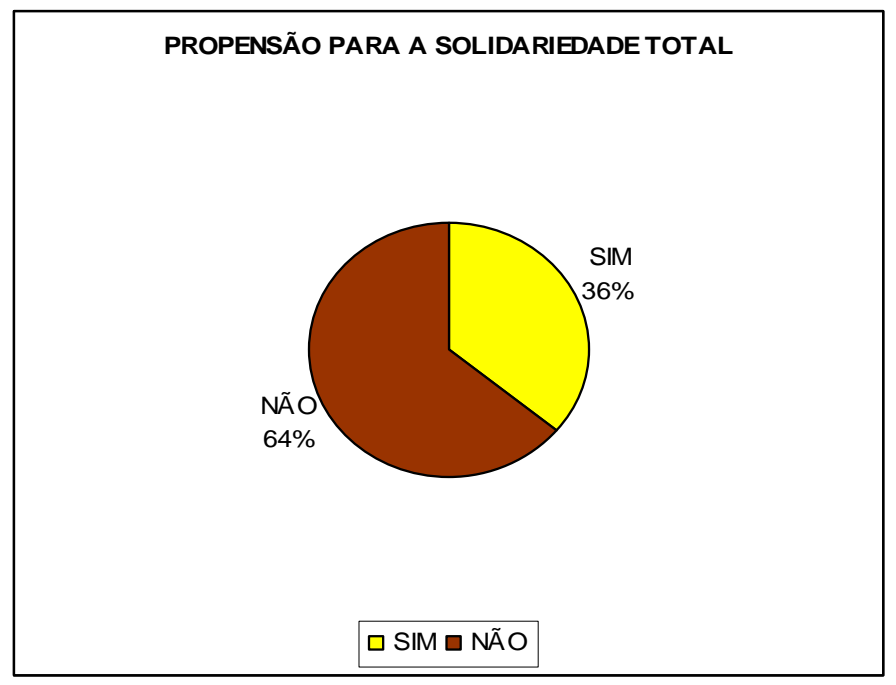

Relatos da entrevista:

acho que é que nem eu te falei, cada um tem um jeito. Seria negro, moreno, branco, mulato...(...). Quem é muito branquinho pega sol e fica moreno, quem é moreno e quer fica loiro fica loiro, não faço uma diferença essencial. (...)Pergunta: Essa idéia de diversidades entre as pessoa, o que você acha disso? Resposta:Eu acho legal. (...) Acho que tem muita gente que tenta travar este processo, acho que é uma coisa que não tem necessidade. Não tem porque ser, nada diferencia a pessoa,... (ENTREVISTADA BRANCA)

Busca de soluções:

Chamar evento só para os negros, tal. Coisa assim acaba mais aumentando essa diferenciação do que diminuindo. Acho que tem que tratar como qualquer outra (ENTREVISTADO NEGRO)

assim eu acho, eu não sei, eu não tenho nenhum política concreta para pensar nisso (ENTREVISTADO BRANCO)

Dependendo do que você faz parece muito forçado. Eu acho que as pessoas vão se integrando aos poucos... (ENTREVISTADO BRANCO)

Pergunta: Alguma coisa para melhorar a relação entre brancos $e$ negros, como eventos na universidade? Resposta: Acho que não precisa, 
já tem muito, já. (...)primeiro, acabar com as cotas, (...) Porque eu estou separando, Fazer atividades que os dois convivam juntos...atividades esportivas, por exemplo, é a melhor coisa para todo mundo ficar junto, ... esporte tanto une que na nossa faculdade tem campeonato de futebol e está todo mundo lá misturado. (ENTREVISTADO BRANCO)

Por outro lado, há manifestações mais realistas em torno do convívio na diversidade e buscas de solução, como demonstrou acreditar a entrevistada, ao afirmar que as experiências das pessoas na diversidade são enriquecedoras, percebendo o desafio que existe para que essa diversidade venha enriquecer e auxiliar a coletividade.

Relatos da entrevista:

Então com a diversidade é difícil, porque a diversidade tem pensamentos diferentes, tem pessoas com gosto diferentes e cultura diferente. (ENTREVISTADA BRANCA)

...por serem pessoas diferentes leva mais tempo para se chegar a um consenso, em um ponto final...Talvez leve mais tempo assim. Também pode dar um resultado melhor (...)não é só jogar um monte de gente diferente e falar: ñse virem! (...)ter um espaço para a gente falar sobre isso (ENTREVISTADA BRANCA)

Busca de soluções:

...Isso é uma coisa que tem que educar desde pequeno, as criancinhas, os bebês que estão nascendo tem que começar a criar com uma visão diferente. Não é só as novelas colocarem sempre as empregadas negras. Eé uma vez ou outra vamos mudar, vamos colocar um negro que é rico que vai se chamar foguinho e vai ter uma barba engraçada. E ele vai ser o engraçado da novela. Tem que começar ai, dos desenhos serem diferentes, os programas de televisão, os pais se conscientizarem e falarem com os filhos....Começa ai, na formação, né? (ENTREVISTADA BRANCA) 
Acho que a gente tem que lutar nessa discussão de direitos humanos pelos preconceitos morais que estão sedmentados nas cabeças das pessoas há vários séculos que ... isso foi jogado na cabeça de muita gente. E pra livrar um pouco disso, pra fazer a pessoa se integrar na sociedade sendo parte igual, tendo uma diversidade, claro, mas sendo uma parte igual entre o semelhante, é... tem muito essa discussão, assim (...)Vejo por parte de alguns uma falta de conhecimento, mas que com a convivência e o tempo vai se dirimindo (...) acho que precisa interagir... ver que não é ... só enquadrar em estereótipos que essa sociedade coloca... senta e conversa (ENTREVISTADO NEGRO)

Hum, eu acho que (...) o projeto de inclusão das cotas é um bom exemplo porque estaria colocando negros num ambiente que era só de brancos e isso acaba aumentando mesmo a convivência (...) as pessoas (...) nunca tinham conversado com um negro, mas daí (...) vamos conversar e ele vê que é normal, que é legal, dá um jeito. (ENTREVISTADA NEGRA)

\section{Categoria: 10. Integracão com as ofertas de desenvolvimento da Universidade}

Indicadores: a) Integração com os colegas da universidade, oportunidades profissionais que surgem a partir dessa integração; acesso às oportunidades acadêmicas que o ambiente universitário oferece.

b) Relação de coleguismo entre o entrevistado e os alunos.

Dos 7 ENTREVISTADOS NEGROS (PRETOS E PARDOS), todos (100\%) demonstraram ter acesso às oportunidades acadêmicas que o ambiente universitário oferece e todos demonstraram ter uma relação de coleguismo com os alunos. Dos 7 ENTREVISTADOS BRANCOS, 6 (86\%) demonstraram ter acesso às oportunidades acadêmicas que o ambiente universitário oferece e 1 (14\%) não; 6 (86\%) demonstraram ter uma relação de coleguismo com os alunos e 1 (14\%) não. 
Assim, do TOTAL dos 14 entrevistados, 13 (93\%) demonstraram ter acesso às oportunidades acadêmicas que o ambiente universitário oferece e 1 (7\%) não; 13 (93\%) demonstraram ter uma relação de coleguismo com os alunos e 1 (7\%) não. 


\section{CONCLUSÃ O}

A maioria dos entrevistados demonstra uma tendência de ver a pessoa branca como um ser humano universal e a pessoa negra como um ser racializado, pertencente a um grupo racial. Os entrevistados negros, no entanto, tem revelam ter facilidade em racializar os membros de suas famílias, enquanto que as pessoas brancas apresentam maior dificuldade em fazer isso. Parece que a idéia de se perceberem como membros de uma grupo racial é bastante distante.

A grande maioria dos jovens entrevistados identifica a ocorrência da discriminação racial direta contra o negro na sociedade, não identifica com nitidez a discriminação indireta e menos ainda a discriminação decorrente do racismo institucional, na universidade, mais próxima a eles, mas praticamente todos reconhecem o racismo presente na cidade onde vivem. De todo modo, a grande maioria não visualiza com clareza os danos decorrentes da discriminação à população negra e os privilégios à população branca. No entanto, a maioria dos entrevistados negros, de uma forma ou de outra mostram reconhecer a situação desvantajosa do negro na sociedade, identificando a presença do racismo e da discriminação racial na hierarquização dos grupos diversos que acarretam na desigualdade econômica e social e estavam mais a tentos a não reproduzir o estigma social do quadro das possibilidades profissionais.

A maioria dos entrevistados, mesmo constatando a referida discriminação, reproduz o estigma produzido pela cultura de reservar o lugar do profissional de capacidade intelectual e de chefia aos brancos e o lugar do profissional de capacidade manual aos negros.

Não se verificou, a partir das entrevistas, freqüente reprodução por parte dos jovens dos estereótipos produzidos pela cultura. Com relação a isso, pode-se concluir que estes já estão sendo questionados pelo processo de transformação social (ou pelo processo de mudanças culturais) gerado pela apropriação social da idéia da igualdade universal entre os seres humanos ï no sentido da semelhança genética, intelectual e psicológica $̈$, ou que, a 
partir da criação das normas internacionais e nacionais que punem a prática de discriminação racial e a disseminação do conceito moral de que praticar racismo é errado, evita-se falar sobre qualquer aspecto que diferencie os seres humanos pela cor, raça ou etnia.

Apesar disso, a pesquisa demonstrou que a maioria dos alunos, negros e brancos, cotistas e não cotistas, estão tendo acesso aos programas acadêmicos paralelos ao curso de graduação oferecidos, pela instituição, muitas vezes proporcionados pelas relações com os colegas e professores. Na verdade, a pesquisa revela que, com relação a isso, não há uma diferença relevante nas oportunidades que estão sendo aproveitadas pelos dois grupos, e, se há alguma, comparando as respostas dos entrevistados, verifica-se que as pessoas negras e pardas estão envolvidas em mais atividades acadêmicas do que as pessoas brancas, contrariando a hipótese 4, levantada neste trabalho.

A maioria dos entrevistados apresenta contradições em torno do tema diversidade, igualdade, racismo e direitos humanos. Em todas as entrevistas, relaciona a diversidade a algo muito positivo, mas não identificam a questão racial como parte dessa questão, e, a diversidade do grupo negro como algo também enriquecedor para a coletividade. Valoriza de uma maneira superficial a idéia genérica da diversidade, mas não as diferenças que atribuem aos grupos dos negros e de outros segmentos dos direitos humanos que as representam, na medida em que, mesmo se relacionando com pessoas diversas, não é nenhum fator associado a elas que enriquecem a relação. Ao contrário, demonstram que trazer à baila o fator da diferenciação atrapalha ou ameaça a boa relação, reforçando a tendência de valorizar o que as pessoas possuem de igual para reafirmar a igualdade entre as pessoas. Além disso, as diferenças atribuídas ao grupo dos negros e outros segmentos dos direitos humanos ainda são depreciativas, segundo o senso da maioria dos entrevistados.

Quando colocados diante dos desafios para o enfrentamento do racismo, pelos meios institucionais, os entrevistados, em sua maioria, demonstram não se preocupar em buscar soluções, ou buscar soluções reais, isto é, que resultem em transformações efetivas, revelando, assim, uma indisponibilidade para que realmente a transformação aconteça. Os entrevistados negros que foram mais enfáticos na busca dessas soluções, são mais direcionados ao enfretamento do racismo na perspectiva de se garantir os direitos para os 
negros, e menos na perspectiva de se criar uma sociedade em que a diversidade enriqueça e contribua para a coletividade.

Considerando que, a disponibilidade para a busca de soluções para a eliminação do racismo, e, para enfrentar os desafios reais de se criar uma sociedade que inclua, de forma igualitária, a diversidade em suas relações sociais (o que pressupõe, antes de tudo, a valorização, e não a depreciação, daquilo que é diverso) são os aspectos apontados nesse trabalho como fundamentais para a prática da solidariedade inter-étnica, pode se dizer que em todos os casos, a propensão dos indivíduos para essa solidariedade não é de fácil evidência (ou evidenciada).

Alguns entrevistados não manifestam reações emocionais. Isso poderia nos levar a crer que o assunto racismo não gera reações emocionais relevantes nas pessoas entrevistadas. No entanto, baseando-se no conteúdo teórico do trabalho, é mais seguro entender que esse fato deve ser atribuído à necessidade emocional dos entrevistados e entrevistadas em silenciar-se, em um ambiente que oferece muitos riscos de julgamento, condenação, preconceito, como é o proporcionado pela forma de entrevista no pátio de uma universidade, ou ao contrário, em um ambiente que oferece o risco da pessoa entrar em contato com a insegurança que o assunto lhe produz, como é o proporcionado pelo instrumento de entrevista, no qual se faz questões que esperam a reflexão e a respostas. Mais ainda, essa constatação deve ser associada ao fato de que o ambiente social em si gera essa insegurança por existir uma dificuldade em nossa sociedade de se falar livremente, ou até ter acesso consciente às próprias emoções, que o assunto racismo gera, uma vez que estas reações não são valorizadas pela cultura, ao contrário, são cultivadas como algo a se envergonhar (sexualidade, ódio, preconceito, dor, medo, etc.).

Outros entrevistados manifestam reações emocionais provocadas pelo tema racismo.

Nos dois casos, contudo, constata-se a falta de oportunidade que os jovens tiveram e tem de compreender essas emoções dentro de um contexto social, isto é, no lugar de julgá-las como um produto individual, compreendê-las como decorrentes de uma dinâmica das relações sociais produzida coletivamente pela cultura racista; e a falta de oportunidade de conhecerem teoricamente os conteúdos históricos, políticos, jurídicos em torno do 
assunto; o que lhes facilitaria encontrar respostas às dúvidas, contradições e confusões que o tema traz, e, exercitar o julgamento e a escolha das condutas mais apropriadas para si, para o outro e para a coletividade, nas situações conflituosas decorrentes do racismo que se apresentam cotidianamente nas relações sociais; bem como, o julgamento e a escolha do posicionamento mais apropriado para os grupos socialmente diferenciados, diante das políticas e dos instrumentos institucionalmente criados para tratar a questão.

Tudo isso são temas que podem ser trabalhados na área da educação, principalmente da educação voltada para a eliminação à discriminação racial e promoção dos direitos humanos. Da mesma forma, podem ser utilizados em programas educacionais nas universidades que implementam a política de cotas raciais. 


\section{ANEXOS}

\section{ANÁLISE DE ENTREVISTAS POR PESSOAS}

\section{ENTREVISTADOS NEGROS OU PARDOS}

\section{ENTREVISTADO A:}

Observa-se a tendência do entrevistado ver a pessoa branca como um ser humano universal e a pessoa negra como um ser racializado, pertencente a um grupo racial. Manifesta os componentes étnico-raciais dos membros de sua família e uma confusão em toda a fala na utilização do componente étnico-racial na descrição das relações sociais.

Apesar do entrevistado visualizar que a maior parte dos negros faz parte de classes sociais mais baixas, não relaciona esse fato ao racismo. Para o entrevistado, a universidade é racista quando implementa a política de cotas por critério racial, o que impossibilita, por exemplo, sua irmã ter a mesma facilidade para entrar, porque não é negra, é branca. Constata a discriminação direta na estória hipotética, e a associa ao espaço de privilégio ("...o porteiro ao ver um rapaz negro... imaginou que ele não fosse aluno da escola...ao ver um branco, ele nem quis se indagar..."). No entanto, ao ser perguntado sobre o privilegio do branco em ter acesso à Universidade, ele diz que acha que isso não ocorre. Assim, conclui-se que o entrevistado não entende que existem danos e privilégios aos brancos e negros decorrentes do racismo. Observa-se que só foi possível constatar a discriminação racial institucional quando foi invertido o papel social dos grupos branco e negros de ocupação de local de privilégio na sociedade.. Nota-se, também, sua tendência em reproduzir os estigmas sociais, escolhendo mais pessoas brancas do que negras para ocupar os papéis profissionais, e colocando os brancos majoritariamente nos papéis de profissionais intelectuais. Reproduz um estereótipo quando atribui característica física não comprovada a um grupo étnico que define como negro que demandaria um tratamento especial. 
Manifesta sensação de solidão ("comecei a achar que só eu... que só tava eu de cotista lá"), vergonha ("eu não contei pra ninguém, na verdade...", "eu achei que quando alguém comentasse ou perguntasse disso, eu ficaria meio assim... ah, sou!... mas...") e susto relacionadas com o tema ("me assustaria, eu me assustei quando só vi (...) negros"). Durante a entrevista, utiliza o recurso da negação: enquanto que na parte do relato acima, o entrevistado revela a sua reação de susto diante do grupo de pessoas negras, em outro momento do relato ele menciona que não vê ñgrande diferença entre me (se) relacionar com pessoa que seja, (...) fisicamente parecida comigo...ou, diferente". Além disso, apresenta confusão por meio da contradição: enquanto em um momento da entrevista, o entrevistado considera os aspectos sócio-econômicos como um fator de diferenciação entre negros e brancos, em outro afirma que "elas (pessoas diferenciadas pela cor) estão no mesmo contexto social".

O entrevistado teve oportunidades pouco significativas para debate, reflexão e elaboração sobre o tema; das três mencionadas, uma delas foi provocada pelo debate em torno da política de cotas. Observa-se que a experiência como cotista coloca o entrevistado em uma oportunidade de se deparar com o tema, mas não é oferecida oportunidade para a reflexão e nem ferramentas para a elaboração. O fato do entrevistado poder falar sobre o assunto na entrevista proporcionou a ele uma oportunidade de reflexão sobre o tema ("É... ahn, assim...essa situação, assim... me mostrou... mostrou algumas coisas que eu nunca tinha pensado antes...ou que eu nunca dei muita importância..."), de forma a constatar a existência de um vazio dentro dele. No final da entrevista, o entrevistado percebe a dificuldade do assunto e seu próprio preconceito ("eu achava que não era uma coisa assim difícil de falar...mas... é", "por estar fortemente vinculada a...uma formação cultural que a gente teve..(...) eu enxergo o negro como arquétipo do... do...é...sei lá, do trabalhador industrial (...) algum tipo de imagem que acho estaria enraizada na...na nossa cultura..").

O entrevistado manifesta uma confusão em torno da idéia de diversidade e racismo. Diante da sua manifesta constatação da existência de uma diversidade étnico-racial, considerou e refletiu sobre o aspecto racista da sua constatação (ñinha lugares que eu só via negros, assim 
andando, né...eu não considerei aquilo um pensamento racista, mas eu me assusteiò). O entrevistado não relaciona a política que objetiva atender ao direito coletivo específico com um direito seu, mas com uma doação. Não reconhece o direito à discriminação positiva aos direitos humanos, como forma de promoção da igualdade. Não apresenta disponibilidade para buscar soluções para a eliminação do racismo e demonstra não acreditar que a relação multi-étnica pode auxiliar na solução de problemas coletivos e individuais relacionados ao tema.

\section{ENTREVISTADO B:}

Observa-se a tendência do entrevistado de ver a pessoa branca como um ser humano universal e a pessoa negra como um ser racializado, pertencente a um grupo racial, mas identifica com clareza os componentes étnico-raciais de sua família. O entrevistado identifica a presença do racismo e da discriminação racial na hierarquização dos grupos diversos. Na universidade, manifesta a presença da discriminação racial, contra negros africanos. Contra si, não vê ou não diz. O entrevistado, em sua escolha, não reproduz o estigma social, demonstrando estar atento a criar um quadro mais igualitário.

Manifesta sensação de vergonha, medo de ser discriminado e raiva ao se identificar com o aluno negro que foi discriminado. Reconhece que aspectos emocionais difíceis de serem tratados estão presentes no assunto sobre discriminação. Manifestou tristeza e chorou durante a entrevista. O entrevistado demonstra não ter tido oportunidade de debater e refletir sobre o assunto no colégio, mas tem com amigos, e, que na universidade existiu um espaço de debate em uma matéria do curso. A experiência como aluno na universidade, trouxe mudanças para o entrevistado com relação ao assunto.

O entrevistado acha o termo raça depreciativo, pois lhe remete à idéia de inferioridade e superioridade, associa à idéia de avaliação de capacidade dos membros do grupo, e não somente de constatação da diversidade. Contradiz-se ao manifestar que a especificidade do ser humano 
é um valor, mas não acredita que a diferença entre negros e brancos deva ser valorizada. O entrevistado associa a diferenciação institucional positiva a algo depreciativo, a discriminação positiva à condição de "incapacidade" do grupo discriminado. O entrevistado revela uma confusão com relação à definição da conduta racista: na estória hipotética, considerou racista o ato do balconista ter dado tratamento diferenciado à pessoa negra e a branca, ao pedir lhe a carteirinha para entrar, no entanto, o fato do colega branco ajudar o seu colega negro a entrar, para o entrevistado, pode ser considerado um ato racista.

O entrevistado, apesar de considerar a diversidade fundamental e valorizar o direito à diversidade, entende a discriminação positiva do negro como "cuidados especiais" e não como um direito. O entrevistado não reconhece a discriminação positiva como um componente da aplicação do direito à igualdade e à diversidade, no propósito da eliminação da discriminação racial. Associa a razão das cotas à idéia de incapacidade meritória, de algo que alguém precisa porque não seria incapacidade de entrar de outra forma. Por isso, não gosta de vincular essa idéia ao negro.

O entrevistado acredita que a convivência multi-étnica é positiva e auxilia a coletividade, mas não acredita que valorizar, enfatizar a diferença seja uma forma de diminuir o racismo.

\section{ENTREVISTADA C:}

A entrevistada descreve todas as fotos, desde o início, vinculando a pessoas a uma cor, raça ou etnia. A entrevistada identifica com clareza os componentes etnico raciais dos membros de sua família. Apesar da entrevistada ter tranquilidade em se expressar racializando os grupos, não visualiza a diferenciação étnico-racial nas relações sociais atuais ou procura não ver e não utiliza o conceito social de raça na sua avaliação. Contudo, reconhece o fenômeno da racialização do grupo negro e a universalização do grupo branco. 
Visualiza a ocorrência da discriminação direta na cidade e na universidade, e a associa à idéia da faculdade ser um espaço de privilégios para branco. Com relação aos danos e privilégios, porém apresenta contradições em sua fala: em um momento, reconhece a diferença do branco e do negro na ocupação do espaço social, mencionando uma vulnerabilidade do negro ao ter a necessidade de se descaracterizar etnicamente para ser incluído (๕́ uma analogia que eu faço, então os brancos, eles não tem essa preocupação, já os negrosò), a maioria deles, tem essa preocupação de, dependendo do ambiente, querer se igualar, e, em outro, manifesta considerar que os danos e privilégios sociais, para os negros e brancos, são semelhantes; em um momento, percebe o prejuízo social que os negros sofreram em decorrência histórica, mas, em outro, atribui o fato do negro não estar na universidade à qualidade do ensino médio. Observa-se que só foi possível constatar a discriminação racial institucional quando foi invertido o papel social dos grupos branco e negros de ocupação de local de privilégio na sociedade. Nota-se, também, a tendência da entrevistada de reproduzir os estigmas sociais, escolhendo para os cargos que privilegia conhecimento intelectual e as posições de chefia as pessoas brancas e para os cargos que privilegiam o trabalho manual, os negros.

A entrevistada percebe que o fato das pessoas relacionarem as cotas a uma questão de desvantagem econômica social e não à questão racial facilita a aceitação dos cotistas na universidade, o que pode ser associado à idéia da entrevistada de que negro tem que ser descaracterizado etnicamente para ser incluído. Manifesta a sensação de medo de não dar conta de acompanhar a faculdade e de não conseguir se integrar com os colegas. Utiliza o recurso da negação: A entrevistada, em toda a entrevista, relaciona a discriminação positiva das cotas com a deficiência do estudo em escola pública. Evita mencionar o conflito racial entre brancos e negros em sua fala, e sempre se refere a ele, quando perguntada, como algo normal, já resolvido.

Além da oportunidade oferecida pela discussão sobre a política de cotas, a entrevistada não recorda de nenhuma outra oportunidade de debate sobre o tema racismo. A experiência como aluna na universidade, junto aos outros alunos brancos e negros, em um espaço em que é minoria e considerado de privilégio de brancos, foi uma oportunidade para a entrevistada constatar a suas iguais condições de acompanhamento e 
exercitar possibilidades de integração com as pessoas brancas. Para a entrevistada, a experiência lhe fez amadurecer em suas relações sociais em um mundo racista.

Apesar da entrevistada ver na diversidade uma oportunidade de se livrar de uma preocupação, a preocupação parece ser exatamente a de ser diferente. Assim, reflete a desvalorização da sociedade àquilo que é diferente nos seres humanos, desvalorizando ela mesma o que é diverso dentro da diversidade, dizendo que o bom da diversidade é que ña diversidade já mistura tudo, e pronto, todo mundo é igualò.

A entrevistada não reconhece a discriminação positiva como um componente da aplicação do direito à igualdade. Não vincula a política de cotas, com a qual concorda, com a discriminação positiva. A entrevistada não concorda que falar sobre o assunto racismo seja algo que contribua para a solução do problema, mas acredita que a convivência multi-étnica em um espaço onde brancos podem conversar com negros é algo de grande resultado para a questão ("Hum, eu acho que (...) o projeto de inclusão das cotas é um bom exemplo porque estaria colocando negros num ambiente que era só de brancos e isso acaba aumentando mesmo a convivência (...) as pessoas (...) nunca tinham conversado com um negro, mas daí (...) vamos conversar e ele vê que é normal, que é legal, dá um jeito.")

\section{ENTREVISTADA D:}

Observa-se a tendência da entrevistada de não racializar ou não manifestar a raça das pessoas, mas identifica com clareza os componentes etnico raciais dos membros de sua família.

A entrevistada visualiza a existência de condutas discriminatórias no processo de integração dos negros na universidade, que inclusive acarretaram em danos ao grupo discriminado. No entanto, não generaliza isso, isto é, não se pode dizer que a entrevistada constata que existe um 
racismo que gera danos frequentes ao grupo dos negros. A entrevistada visualiza a discriminação racial direta contra os africanos, mas não identifica contra si, na universidade. Não identifica a discriminação indireta institucional, somente quando é invertido o lugar do negro e do branco nos papeis sociais. Na cidade, a entrevistada visualiza condutas de discriminação racial direta contra si e indireta pela neutralidade produzida pela mídia. Identifica a presença do racismo e da discriminação racial na hierarquização dos grupos diversos. Observa-se que tem uma tendência em reproduzir o estigma social e um estereótipo de que os negros são mais fortes, batalhadores e brancos inteligentes.

A entrevistada utiliza o recuso da negação, recusando-se a discutir sobre raça e preconceito, dizendo que, para ela, isso nem existe. Manifesta a sensação de segregação diante de espaços escolares em que só tinham brancos, explicitando que se sentiria ñem casaò se estivesse hoje em uma sala de aula em que a maioria fosse de negros. Manifesta também a sensação de impotência, diante da injustiça provocada por uma discriminação, revelando que, de todas as atitudes que dispõem para reverter a situação, nenhuma delas adiantaria.

A entrevistada revela não ter tido oportunidades significativas para debater e refletir sobre o racismo. No entanto, mostra uma forma que encontrou para lidar com a questão: procura não pessoalizar a conduta discriminatória contra ela, e entender como algo que faz parte da vida em sociedade. Expressa a idéia de neutralidade, o que associa ao fato de existir preconceito contra o negros e brancos nessa sociedade.

Apesar da entrevistada não ter demonstrado entender exatamente o que ocasiona a desigualdade, compreende teoricamente a definição sobre a diferença entre diversidade e desigualdade. Valoriza a diversidade quando se trata da possibilidade de escolhas livre dos papéis sociais atribuídos aos grupos, no entanto, rejeita a ação de falar sobre as diferenças. Não reconhece a discriminação positiva como um componente da aplicação do direito à igualdade e à diversidade, no propósito da eliminação da discriminação racial, mas demonstra que acredita que a convivência multi-étnica é positiva, proporciona maior liberdade e possibilidades para a coletividade. 


\section{ENTREVISTADO E:}

Observa-se a tendência do entrevistado de não racializar ou não manifestar a raça das pessoas, mas identifica com nitidez os componentes étnico-raciais dos membros de sua família. O entrevistado visualiza a presença da discriminação racial direta na vida da universidade, constata a discriminação racial direta, na estória hipotética e a discriminação indireta na universidade. Com relação aos danos e privilégios decorrentes do racismo, constata a situação desvantajosa do negro na sociedade, identificando a presença do racismo e da discriminação racial na hierarquização dos grupos diversos que acarretam na desigualdade econômica e social. O entrevistado, em sua escolha, não reproduz o estigma social, demonstrando estar atento a criar um quadro mais igualitário.

O entrevistado, quando iguala a condição econômica do branco e negro, não vê diferença entre a situação do negro e do branco na sociedade ("o que difere o filho da Benedita de uma pessoa branca?"). Quando discorre sobre diversidade, identifica a diferença dos locais onde as pessoas foram criadas. Em outro momento, iguala a condição econômica do branco e do negro, e identifica a condição étnico-racial como fator de discriminação ("negro, de bermuda e camiseta, é vista de outra forma do que uma pessoa branca, mesmo morando lá, e com os mesmos trajes... preto e pobre é parecido mas não é igual para a sociedade, infelizmente").

O entrevistado manifesta um desconforto decorrente da discriminação racial que vive na universidade (não ser cumprimentado no elevador quando está sozinho com outra pessoa) e manifesta uma sensação de impotência diante disso por não poder compreender a razão do

comportamento discriminatório ("eu acho estranho porque eu não consigo entender o porquê"). Nesse ponto, verifica-se um aspecto não levantado nas hipóteses, mas que é relevante para o assunto: o desconhecimento das reações emocionais que um grupo possa ter em relação a outro. 
Concorda que seria bom para ele entender o porquê da conduta discriminatória, mas na terceira pergunta que tinha como objetivo insistir no assunto, o entrevistado recorre a dissimulação e a negação do problema ("Pergunta: Para melhorar a relação? Resposta: não, eu ... eu não tenho esse tipo de preconceito com essa pessoa...Mas eu quero super na boa, isso não me enche nem um pouco a cabeça (risos)")

O entrevistado diz que não teve oportunidades de debater e refletir sobre o assunto racismo no colégio, mas tem com amigos, e, que, na universidade, existiu um espaço de debate em uma matéria do curso. Demonstra que a experiência como aluno na universidade, trouxe mudanças para ele com relação ao assunto e ter tido oportunidade em sua vida para refletir sobre o assunto e encontrar uma forma de entendê-lo, explicando ñque algumas pessoas têm um certo preconceito mas não é inato, assim, uma maldade dela, é por não conhecer.ò

O entrevistado entende a racialização como uma forma positiva de valorizar a diversidade. Vê a discriminação positiva e especificamente a política de como um direito seu, direito à educação, independente do fato de que teria ou não condições de passar no vestibular da forma em que é feito. Acredita que a convivência multi-étnica é positiva, enriquece a coletividade e auxilia como uma ação contra o preconceito e para a eliminação do racismo; para ele a diferença soma e é importante para a sua própria existência.

\section{ENTREVISTADO F:}

Observa-se a tendência do entrevistado de não racializar ou não manifestar a raça das pessoas, mas identifica com nitidez os componentes étnico-raciais dos membros de sua família. 
O entrevistado visualiza a discriminação direta e decorrente de racismo institucional na universidade e constata a discriminação racial direta na estória hipotética. O entrevistado constata o fato discriminatório negativo de que, ainda que ele esteja exercendo um direito, as pessoas o tratam como se precisasse de um favor.

O entrevistado identifica a presença da discriminação racial na sociedade brasileira e relaciona ela com o conceito social de raça, ressaltando a diferença que existe entre negros e brancos em decorrência das posições que cada um ocupa na sociedade racista.. Aponta vários danos decorrentes do racismo à população negra ("Tem uma carga histórica cultural de discriminação, de rebaixamento, falta de oportunidades, de desleixo do Estado") que se contrapõem a situações de privilégios dos brancos, todos eles relacionados exclusivamente à diferença racial entre os grupos ("a pessoa pode ter as mesmas condições de uma pessoa branca mas... algum diferencial no meio social ela vai ter por ser branca (...) São pessoas idênticas, capazes e plenas das suas faculdades (...) A diferença é (...) como a sociedade trata."). O entrevistado utilizou o número de negros e brancos nas profissões de forma paritária nas profissões que privilegia o conhecimento intelectual e de posição de chefia. No entanto, escolheu 4 pessoas negras para ocupar o lugar das 4 profissões que privilegiam o trabalho manual. Nesse ponto, demonstra uma tendência em reproduzir o estigma social.

O entrevistado demonstrou ter se sentido bem em falar sobre o racismo.

Relaciona a diversidade com a democracia. Concebe a discriminação positiva, a cotas, como um direito. Rejeita a idéia de direitos universais na medida em que vê a necessidade da afirmação das demandas específicas dos negros para uma sociedade justa. No entanto, em outro momento, afirma que acha que não haveria discriminação se fosse implementado os direitos fundamentais para todos. Acredita que a convivência multi-étnica é positiva e enriquece a coletividade e auxilia como uma ação contra o preconceito. Demonstra buscar uma solução 
para uma vida melhor, mais justa, para as pessoas na sociedade, mas não demonstra com isso, necessariamente, a busca pela melhora da relação entre negros e os brancos, não mostra ver na relação muli-étnica algo fundamental para a melhoria de vida da sociedade.

\section{ENTREVISTADO G:}

Observa-se a tendência do entrevistado de não racializar ou não manifestar a raça das pessoas, mas identifica com nitidez os componentes étnico-raciais dos membros de sua família.

O entrevistado visualiza a presença da discriminação racial na sociedade brasileira, a discriminação racial direta, na estória hipotética, a discriminação racial decorrente do racismo institucional e a discriminação racial indireta na universidade; constata a existência da discriminação racial implícita nas atitudes, nas relações dentro da universidade, mencionando a idéia do espaço universitário ser mais do branco do que do negro.

O entrevistado constata os danos decorrentes do racismo à população negra e a diferença de desafios que tem que enfrentar, em comparação ao branco, para ter acesso à educação superior, atribuindo essa diferença à condição social desigual provocada pelas relações raciais, e não ao fato de ele pessoalmente ter menos capacidade. O entrevistado, em sua escolha, não reproduz o estigma social, demonstrando estar atento a criar um quadro diferente, em que as pessoas brancas ocupam majoritariamente as profissões que privilegiam o trabalho manual e, dentre outras, as profissões de posição de chefia foram ocupadas por pessoas negras.

O entrevistado demonstrou satisfação em estar falando sobre racismo. 
O entrevistado entende a oportunidade de ser um aluno universitário pelas cotas como um direito, justamente por ter menor condições de competir no processo seletivo do vestibular, o que decorre do fato de ter tido menos oportunidade de se prepara especificamente para isso, durante sua vida até ali. Reconhece o direito a ser tratado desigualmente como uma discriminação positiva, como uma forma de promoção da igualdade e da dignidade humana. Acredita que a convivência multi-étnica é positiva enriquece e auxilia a coletividade. O entrevistado demonstra se envolver com a idéia de promoção de um mundo mais justo e melhor para se viver, e não necessariamente com a melhora das relações raciais na diversidade.

\section{ENTREVISTADOS BRANCOS}

\section{ENTREVISTADO H:}

Observa-se a tendência do entrevistado ver a pessoa branca como um ser humano universal e a pessoa negra como um ser racializado, pertencente a um grupo étnico-racial. Apesar de utilizar um conceito genético para classificar os seres humanos por raças, não as diferencia socialmente. Nas questões e hipóteses colocadas pela entrevista, manifesta não ver a ocorrência da discriminação racial, nem na universidade, nem na sociedade. Demonstra não visualizar as consequências danosas provocadas pelo racismo à população negra, nem os privilégios à população branca. No entanto, em sua escolha, não reproduz o estigma social.

O entrevistado por várias vezes utiliza o recurso da dissimulação para se desviar do conflito apresentado pela pergunta e demonstra irritabilidade em algumas respostas. Revela a falta de oportunidades significativas de debater e refletir sobre o assunto. Dentre elas, menciona conversas na família e a gerada pelo debate em torno das cotas. 
O entrevistado não reconhece a discriminação positiva como um componente da aplicação do direito à igualdade, no propósito da eliminação da discriminação racial. Acredita que a afirmação da diferença do grupo negro é um "preconceito ao contrário pelo poder público". Entende que os Direitos Humanos ñé o mínimo para considerar uma vida dignaò, associa isso à promoção dos direitos sociais (saúde, alimentação, etc.), mas não relaciona a discriminação positiva e a discriminação racial com os temas de direitos fundamentais e direitos humanos.

Mesmo se relacionando com "pessoas diversas", para o entrevistado, não é esse o componente que enriquecem a relação. Ao contrário, demonstra que o fator da diferenciação é algo que atrapalha a relação que, na verdade, para o entrevistado, deve ser estabelecida a partir do que cada um é (em essência), reforçando a tendência de valorizar o que as pessoas possuem de igual para reafirmar a igualdade entre as pessoas. Assim, demonstra não acreditar que a diversidade que existe entre as pessoas é um fator que enriquece e auxilia a coletividade.

\section{ENTREVISTADO I:}

Observa-se a tendência do entrevistado ver a pessoa branca como um ser humano universal e a pessoa negra como um ser racializado, pertencente a um grupo étnico-racial. O entrevistado manifesta dificuldade em se identificar como um ser pertencente a uma raça, ou grupo étnico-racial, mas agrupa os membros de outra etnia. Nas questões e hipóteses colocadas pela entrevista, visualiza o preconceito na conduta da estória hipotética, não constata a discriminação racial na universidade, mas a visualiza na sociedade. Só foi possível visualizar a discriminação racial institucional quando é invertido o papel social dos grupos branco e negros de ocupação de local de privilégio na sociedade. Observa-se a tendência do entrevistado de reproduzir os estigmas sociais, escolhendo majoritariamente para os cargos que privilegia conhecimento intelectual as pessoas brancas e para os cargos que privilegiam o trabalho manual, os negros.

Durante a entrevista, o entrevistado manifesta contradições e irritabilidade. Revela encontrar dificuldades em saber qual reação teria diante das situações de conflito apresentadas pela entrevista, mas demonstra ter refletido sobre o assunto, percebendo o seu preconceito e 
tentando encontrar formas de lidar com isso, ter tido oportunidades de debater o assunto com amigos, mas nunca em ambientes institucionais, educacionais.

O entrevistado não concorda com a discriminação positiva como uma forma de promoção dos direitos fundamentais. Acredita que todos têm direito à educação, mas não vê na política de cotas um meio de garantia desse direito. Busca valorizar a dignidade humana de todas as pessoas. No entanto, não encontra na afirmação das diferenças um caminho para isso.

Apesar de, em um primeiro momento, manifestar que gosta da diversidade, em um segundo, revela que não relaciona o racismo à diversidade e acredita que a diferenciação coletiva é um fator negativo que pode segregar as pessoas. Demonstra não acreditar com tranquilidade que a relação multi-étnica enriquece e auxilia coletividade. Para ele, as diferenças representam algo para o que tem que se fazer "esforço para aceitar". Observa-se que o preconceito lhe incomoda, mas teme que a afirmação da diferença venha aumentar o preconceito e dividir as pessoas.

\section{ENTREVISTADA J:}

Observa-se a tendência da entrevistada de ver a pessoa branca como um ser humano universal. Demonstra dificuldade em se identificar como um ser pertencente a uma raça, ou grupo étnico-racial. Nas questões e hipóteses colocadas pela entrevista, a entrevistada visualiza a discriminação racial direta na universidade e na cidade. Observa-se a tendência da entrevistada de reproduzir os estigmas sociais, escolhendo majoritariamente para os cargos que privilegia conhecimento intelectual as pessoas brancas e para os cargos que privilegiam o trabalho manual, os negros. 
Ressalta a sensação de impacto que acontece com ela diante das pessoas negras. A entrevistada manifesta não ter tido oportunidades para debater e refletir sobre a questão do racismo durante a sua vida. Apresenta uma reflexão que se limita à relação que sua família tem com a empregada doméstica, atribuindo a ela aspectos afetivos, reproduzindo a idéia de se reduzir os aspectos danosos e desiguais da população negra criada pelo mito da democracia racial.

Preocupa-se em igualar todas as pessoas, no lugar de valorizar as diferenças dos grupos étnico-raciais. Observa-se que, apesar da entrevistada achar que a diversidade "é legal", a diferenciação entre as pessoas não lhe parecer ser uma coisa boa. A entrevistada reconhece que a pessoa negra é humana e, portanto, deve ser incluída ao rol dos sujeitos de direitos humanos, mas não compreende o que seria o direito específico dos negros gerado pela discriminação positiva. A entrevistada demonstra se relacionar com pessoas negras e gostar disso. No entanto, o seu interesse não é atribuído à diversidade dessas pessoas. Ao contrário, a entrevistada mostra querer desaparecer com as diferenças, e manter a idéia da igualdade, para que a relação se mantenha. A entrevistada leva a questão para o plano afetivo que existe na amizade entre as pessoas, demonstrando uma propensão a ter uma conduta solidária a solução dos danos causados pelo racismo, por essa via, mas demonstra não acolher a institucionalização da diferenciação, na situação em que a pessoa negra demanda.

\section{ENTREVISTADA K:}

Observa-se a tendência da entrevistada de ver a pessoa branca como um ser humano universal e a pessoa negra como um ser racializado, pertencente a um grupo racial. Quando provocada identifica-se como um ser pertencente a uma raça, ou grupo étnico-racial. Quando perguntada, a entrevistada utiliza componentes étnicos-raciais na descrição social, no entanto, não associa o conceito de raça socialmente construído a sua descrição, ao contrário, com relação a esse aspecto, acha que já estamos misturados. 
Nas questões e hipóteses colocadas pela entrevista, a entrevistada constata a discriminação racial contra os negros na universidade, constata que a discriminação por condição econômica traria desafios difíceis para o desempenho dela na universidade. Mas não associa a situação de discriminação racial que passam os negros a esses mesmos desafios e dificuldades, e, não visualiza as consequências danosas provocadas pelo racismo à população negra, nem os privilégios à população branca. Observa-se que só foi possível constatar a discriminação racial institucional quando foi invertido o papel social dos grupos branco e negros de ocupação de local de privilégio na sociedade. Manifesta a tendência de reproduzir os estigmas sociais, escolhendo para os cargos de posições de chefia as pessoas brancas e para os cargos que privilegiam o trabalho manual, os negros.

A entrevistada expressa a sensação de intimidação gerada pelo fato de se sentir uma minoria, na relação entre ricos e pobres. Quando hipoteticamente isso é sofrido pelo negro em relação aos brancos, acredita que reverter essa sensação seria relativamente simples, dizendo: "Mas depois não tem isso não, a gente fica amigo". No entanto, na hipótese levantada por ela da intimidação que sente, gerada na relação entre alunos de condição econômica diferente, a entrevistada expressa a sua sensação de solidão e insegurança, e, que a dificuldade apresentada seria impossível de ser revertida. Não associa a mesma dificuldade àquilo que os estariam passando. Em outro momento, revela a sua preocupação e sensação de obrigação e responsabilidade por não ser injusta com relação à discriminação racial, o que nos sugere que seja decorrente da identificação que faz. Revela que a competição para a vaga, junto ao critério racial, e a confusão sobre o tema, gera raiva nas pessoas envolvidas. Com relação às oportunidades de debate e reflexão sobre a questão, diz ter tido discussões no âmbito familiar e na igreja. No colégio e na universidade, e outras oportunidades institucionais, não. Contudo, revela ter tido a oportunidade de refletir sobre o assunto, encontrando em si mesma atitudes preconceituosas e discriminatórias, percebendo a dificuldade em transformá-las. 
A entrevistada associa a política de cotas a uma ñajudaò que se dá aos negros e pessoas do ensino público, não a um direito. Acredita que o recurso para enfrentar a questão do racismo seria uma educação sobre ética, e, demonstra não compreender a discriminação positiva como um caminho para o enfretamento da discriminação racial.

A entrevistada demonstra acreditar que as experiências das pessoas na diversidade são enriquecedoras para a coletividade, com as quais ela pode aprender. No entanto, em outro momento demonstra que nas suas relações, as contribuições adquiridas na relação com uma pessoa negra não se atribuem à diversidade racial, mas a sócio-econômica.

\section{ENTREVISTADA L:}

A descrição geral das fotos, o entrevistado racializa as pessoas, identificando a cor, etnia ou raça das pessoas, desde o início. Na descrição de sua família, não utiliza o componente étnico-racial e demonstra dificuldade em relacionar seu familiar com uma raça. Observa-se que não se identifica como um ser pertencente a uma raça, ou grupo étnico-racial e possui a tendência da entrevistada de ver a pessoa branca como um ser humano universal e a pessoa negra como um ser racializado, pertencente a um grupo diferenciado.

A entrevistada constata a discriminação nas relações dentro da universidade e a invisibilidade da mesma para algumas pessoas. Manifesta a semelhança física entre brancos e negros e constata a diferença cultural e de suas experiências. Não associa as diferenças às experiências de discriminador e discriminado, e as consequencias do racismo para cada grupo. Com relação a isso, apresenta uma contradição: constata que o fato da universidade ser ocupada por uma grande maioria branca, já caracterizaria um espaço de privilégio onde só estão os brancos, o que chama de cotas "para brancos de classe média alta". Por outro lado, menciona que existem os brancos que tem renda baixa e que esses, então, seriam "os excluídos dos excluídos", pois não estariam sendo contemplados por nenhuma política. Contudo, visualiza as consequências psicológica danosas do preconceito, mas somente para a população negra. 
Observa-se a tendência da entrevistada de reproduzir os estigmas sociais, escolhendo para os cargos de posições de chefia as pessoas brancas e para os cargos que privilegiam o trabalho manual, os negros.

A entrevistada revela que não sabe a reação que teria diante da situação de estar em um ambiente em que a maioria das pessoas seria negra. Manifesta que teve um desconforto por estar falando sobre o racismo, e reconhece a delicadeza do assunto. Manifestou tristeza provocada pela entrevista por ver ñque isso é tão forte e queò ela é ñparte disso, agindo com esses preconceitos...ò e, nesse ponto, pode se dizer que a experiência de ser entrevistada lhe proporcionou a possibilidade de reflexão sobre a questão. Manifesta também a confusão de emoções e dificuldade de escolher uma posição com relação ao evento da discriminação racial. Revela não ter tido oportunidades para a discussão e reflexão sobre a questão, mas declara que uma matéria em seu curso que aborda o racismo foi bastante significativa para ela entender e elaborar o assunto ("me abriu a mente").

A entrevistada não entende a discriminação positiva como uma forma de garantir os direitos fundamentais, os direitos humanos ("...Então nesse ponto eu acho que viola um grande direito (...) você perde isso o direito humano de todo mundo"). E , na sua fala, demonstra uma confusão em torno do assunto.

A entrevistada acredita que a relação multi-étnica enriquece e auxilia a coletividade e perceber o desafio que existe para que essa diversidade venha contribuir dessa forma. ("Talvez leve mais tempo assim. Também pode dar um resultado melhor"). Demonstra buscar soluções reais para o racismo ao manifestar que ações devem ser feitas com maior profundidade ("não é só jogar um monte de gente diferente e falar: ñ̃e virem!ò", " ... suporte psicológico para enfrentar esses preconceitos, criar grupos para falar "), ("ter um espaço para a gente falar sobre isso"). 


\section{ENTREVISATADA M:}

A entrevistada descreve as primeiras fotos de pessoas brancas, não identificando a cor, etnia ou raça da pessoa. A partir do momento que vê a foto da pessoa negra, utiliza o componente cor, raça ou etnia, para descrevê-la. A entrevistada manifesta a origem e não manifesta os aspectos etnico-raciais dos membros da sua família com clareza. Tem dificuldade em atribuir uma raça a seu membro familiar, mas aquilo que recusa fazer para sua família, faz com relação aos indígenas, grupo que estaria "mais afastados". Observa-se, assim, a tendência da entrevistada de ver a pessoa branca como um ser humano universal e a pessoa negra como um ser racializado, pertencente a um grupo racial.

A entrevistada constata a existência da discriminação racial direta contra os negros, na universidade. Constata a discriminação racial decorrente do racismo institucional quando foi invertido o papel social dos grupos branco e negros de ocupação de local de privilégio na sociedade, a universidade. Reconhece a condição privilegiada dos brancos e os danos à população negra na ocupação do espaço universitário, mencionando inclusive as associadas à implementação da política de cotas. Observa-se a tendência da entrevistada de reproduzir os estigmas sociais, escolhendo para os cargos de posições de chefia as pessoas brancas e para os cargos que privilegiam o trabalho manual, pessoas negras. A entrevistada associa a todos os membros do grupo negro a idéia de que se aproveitam da condição de serem inferiorizados para obter vantagens injustas, revelando, nesse momento, a reprodução de um estereótipo que na dinâmica das relações sociais, tornam-se estigmas. Isto é, a entrevistada não reconhece que todas as pessoas que estão em situação de vulnerabilidade tendem a se colocar em um papel de vítima para ter acesso aos bens que são disputados em uma relação de poder, mas atribui essa característica exclusivamente aos negros. Assim, demonstra que

não se disponibiliza a escutar a demanda da população negra como uma possível reivindicação real e justa feita em um espaço democrático e a visualizar o outro grupo como um conjunto de pessoas reais, sujeitos de direitos . 
A entrevistada revela que o tema tratado na entrevista é difícil, e que tem dificuldade de saber as emoções e reações que teria em torno dele. Percebe a sensação de maior vulnerabilidade que enfrenta a minoria, revela que sentiria desconforto, mas demonstra ter dificuldade em entender qual seria sua reação emocional se estivesse nessa situação. A entrevistada teve poucas oportunidades de debater o assunto, sendo um delas decorrente do debate sobre política de cotas. Manifesta ter tido a oportunidade de debater e refletir sobre o assunto com amigos. Observa-se que a experiência da entrevistada, na proposta da entrevista de elaboração do quadro de profissões, teve a oportunidade de refletir sobre a questão, manifestando sua conclusão de que pratica o preconceito e a conduta discriminatória.

A entrevistada não entende a discriminação positiva como uma forma de promover a igualdade e os direitos humanos. Demonstra acreditar que as experiências das pessoas na diversidade são enriquecedoras para a coletividade e percebe o desafio que existe para que essa diversidade venha enriquecer e auxiliar a coletividade. Apesar da entrevistada ter manifestado que a conduta da estória hipotética caracteriza-se como uma conduta racista, demonstra não ser solidária àquilo que a pessoa negra explicita como algo que lhe prejudica e aos mecanismos de luta explícita contra o racismo por via institucional.

\section{ENTERVISTDO N:}

O entrevistado descreve as fotos de pessoas brancas e negras e não manifesta a cor, etnia ou raça das pessoas. O entrevistado não identifica os componentes étnico-raciais de sua família, tem dificuldade de racializar membros da sua família e manifesta ter ficado incomodado com a pergunta ("ela não é cachorro, não, mas....Fiquei meio chateado").

O entrevistado visualiza as dificuldades que os cotistas enfrentam na relação com outros alunos. Mas não constata a discriminação racial, nem direta, nem a indireta constitucional na universidade e demonstra não estar certo de que ocorreu ou não a discriminação racial na conduta da 
estória hipotética. No entanto, constata a ocorrência de discriminação racial direta praticada contra os negros, e pelos negros contra os negros também, na cidade. Observa-se que só foi possível constatar a discriminação racial institucional quando foi invertido o papel social dos grupos brancos e negros de ocupação de local de privilégio na sociedade. Nota-se, também, a tendência do entrevistado de reproduzir os estigmas sociais, escolhendo para os cargos que privilegiam o trabalho intelectual as pessoas brancas e para a maioria dos cargos que privilegiam o trabalho manual, as pessoas negras; e a manifestação de um estereótipo, me que atribui uma característica física, ou comportamental, não comprovada a um grupo étnico que define como negro. (ña maioria deles costumam ser mais bruto, sabe?...ò).

O entrevistado manifesta as dificuldades que os cotistas enfrentam na relação com outros alunos, mas justifica, negando a causa racial e a enfrentar o conflito da pergunta. $\mathrm{O}$ entrevistado percebe e revela que o assunto the provoca confusão. Esse, em um momento, lhe provoca agressividade. Demonstra não ter tido oportunidades significativas de debater e refletir sobre o assunto, mas teve orientações morais sobre o que é correto ou incorreto pensar ou agir.

Para o entrevistado, o fato de simplesmente existirem pessoas com especificidades diversas no mesmo espaço, não existe racismo. Apesar de dizer que a diversidade é uma coisa boa, demonstra não acreditar que a relação multiétnica enriquece e auxilia a coletividade, e, não busca soluções reais para a melhora da relação multi-étnica. Acredita que o fato de juntar as pessoas é a "melhor coisa" para melhor a relação entre negros e brancos, desconsiderando os desafios para a eliminação das condutas discriminatórias. 
ENTREVISTADO A -COTISTA ï UNIFESP

\begin{tabular}{|c|c|c|c|c|}
\hline \multicolumn{5}{|c|}{ ENTREVISTADO A -COTISTA Ï UNIFESP } \\
\hline CATEGORIA & $\begin{array}{c}\text { SUB- } \\
\text { CATEGORIA }\end{array}$ & INDICADORES & ASPECTOS SIGNIFICATIVOS & RELATOS DE ENTREVISTA \\
\hline $\begin{array}{l}\text { identidade } \\
\text { étnica }\end{array}$ & $\begin{array}{l}\text { negra / branca } \\
\text { / parda }\end{array}$ & & & $\begin{array}{l}\text { aí, ele perguntou como foi que eu passei ou qual era minha cor, eu não } \\
\text { lembro...Vocêe é branco.- eu: Não, pardo.. }\end{array}$ \\
\hline $\begin{array}{c}1 . \quad \text { A } \\
\text { visibilidade da } \\
\text { diversidade } \\
\text { étnico-racial e } \\
\text { a racialização } \\
\text { de si e do outro }\end{array}$ & & $\begin{array}{l}\text { utilização do } \\
\text { componente } \\
\text { étnico-racial na } \\
\text { descrição das } \\
\text { pessoas das } \\
\text { fotos de } \\
\text { estudantes } \\
\text { negros, brancos } \\
\text { e asiáticos }\end{array}$ & $\begin{array}{c}\text { O entrevistado descreve as } \\
\text { primeiras fotos de pessoas brancas, } \\
\text { não identificando a cor, etnia ou } \\
\text { raça da pessoa. A partir do } \\
\text { momento que vê a foto da pessoa } \\
\text { negra, a vincula a uma cor, raça ou } \\
\text { etnia, a negra, utilizando a } \\
\text { expressão "morena". Só, então, } \\
\text { vincula a pessoa branca (da próxima } \\
\text { foto) a uma cor, raça e etnia, } \\
\text { utilizando a expressão "branca". } \\
\text { Observa-se a tendência do } \\
\text { entrevistado ver a pessoa branca } \\
\text { como um ser humano universal e a } \\
\text { pessoa negra como um ser } \\
\text { racializado, pertencente a um grupo } \\
\text { racial }\end{array}$ & $\begin{array}{l}\text { a)Tem uma que parece que tá numa exposição, ela tá exibindo um livro, } \\
\text { eu acho... (branca) b) Uma menina estudando num lugar confortável... } \\
\text { Acho que ela é loira ou tem cabelo castanho escuro...(branca) c) Uma } \\
\text { mocinha estudando na biblioteca... Hmm... Ela é morena, usa uma } \\
\text { blusinha verde...(negra) d) Uma foto que parece comercial daqueles de } \\
\text { campanha de conservação de livro didático...Tem uma mocinha com uma } \\
\text { iluminação branca muito forte no rosto dela, ela tá sorrindo... atrás tem } \\
\text { uma prateleira com livros... provavelmente ela tá numa biblioteca... } \\
\text { não...Ah, ela é branca, a luz branca reforça isso...(branca) }\end{array}$ \\
\hline
\end{tabular}




\begin{tabular}{|c|c|c|c|}
\hline $\begin{array}{c}\text { 1. A } \\
\text { visibilidade da } \\
\text { diversidade } \\
\text { étnico-racial e } \\
\text { a racialização } \\
\text { de si e do outro }\end{array}$ & $\begin{array}{c}\text { utilização do } \\
\text { componente } \\
\text { étnico-racial } \\
\text { para descrever } \\
\text { membros da } \\
\text { família e a si } \\
\text { próprio }\end{array}$ & $\begin{array}{c}\text { Apesar de o entrevistado ter } \\
\text { revelado maior dificuldade em falar } \\
\text { sobre o componente negro presente } \\
\text { em sua origem ("...é... ai, } \\
\text { caramba...como eu vou dizer... } \\
\text { minha...hum... acho que minha } \\
\text { ascendência negra tá em maior } \\
\text { parte na...na família paterna..."), } \\
\text { identifica os componentes étnico- } \\
\text { raciais dos membros de sua família: } \\
\text { tem "mãe indígena", "tem negro na } \\
\text { família do (...) pai" e seu bisavô } \\
\text { tem "nome alemão (...) por causa } \\
\text { dos olhos azuis". }\end{array}$ & 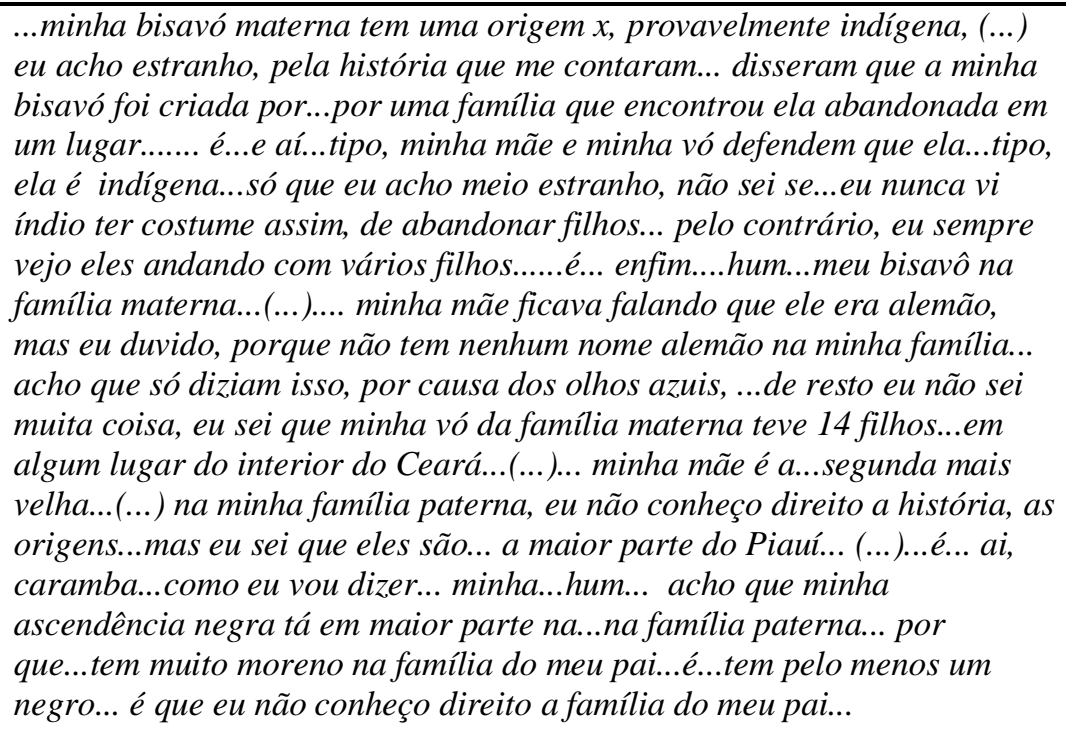 \\
\hline $\begin{array}{c}\text { 1. A } \\
\text { visibilidade da } \\
\text { diversidade } \\
\text { étnico-racial e } \\
\text { a racialização } \\
\text { de si e do outro }\end{array}$ & $\begin{array}{c}\text { noção sobre o } \\
\text { conceito social } \\
\text { de raça na } \\
\text { utilização do } \\
\text { componente } \\
\text { étnico-racial na } \\
\text { descrição das } \\
\text { relações sociais }\end{array}$ & confusão em todo o texto & $\begin{array}{l}\text { Pergunta: Você acredita que existem raças, entre os seres } \\
\text { humanos?.Resposta: Acredito. Pergunta: Que raças são essas?Reposta: } \\
\text { Ahn...bom, ahn... assim pensando em raça... é, como... quase que...as } \\
\text { etnias diferentes, né...ahn...eu não sei dizer bem... mas não dá pra } \\
\text { diferenciar só pela cor...tipo, tem...ahn...ai, caramba...ah, eu não consigo } \\
\text { dividir... eu posso dividir em grandes grupos, sei lá... assim, nos negros, os } \\
\text { brancos...ahn...e os asiáticos...pensar em mais uma...os indígenas, acho } \\
\text { que é um grupo diferente...uhm... os indígenas do extremo norte também } \\
\text { são diferentes...os que... não sei se indígenas é o nome certo...os } \\
\text { esquimós...ahn, tipo os Inuits (não sei bem o nome)...ahn... }\end{array}$ \\
\hline
\end{tabular}




\begin{tabular}{|c|c|c|c|}
\hline $\begin{array}{c}\text { 1. A } \\
\text { visibilidade da } \\
\text { diversidade } \\
\text { étnico-racial e } \\
\text { a racialização } \\
\text { de si e do outro }\end{array}$ & $\begin{array}{l}\text { noção sobre o } \\
\text { conceito social } \\
\text { de raça na } \\
\text { utilização do } \\
\text { componente } \\
\text { étnico-racial na } \\
\text { descrição das } \\
\text { relações sociais }\end{array}$ & $\begin{array}{l}\text { O entrevistado aponta os aspectos } \\
\text { sócio-econômicos como diferenças } \\
\text { e atribui, a diferença, aos negros e a } \\
\text { universalidade aos brancos ("a } \\
\text { parte bruta da população negra a } \\
\text { gente encontraria... a parte branca } \\
\text { estaria mais distribuída") }\end{array}$ & $\begin{array}{l}\text { Pergunta: qual que é a diferença entre uma pessoa negra e uma branca e } \\
\text { qual a semelhança? Resposta:Uhm...diferença...bom, diferença física...é... } \\
\text { que seria a cor...é...algumas estruturas anatômicas diferentes...(...) acho, } \\
\text { que de resto são semelhantes... (...) assim, a menos que a gente considere o } \\
\text { meio social também, né... sei lá, se você fosse pegar a parte bruta da } \\
\text { população negra... acho, que a gente ia encontrar eles, no...no setor de } \\
\text { serviços, acho... ou na indústria, né... a parte branca estaria mais } \\
\text { distribuída, não sei... não sei... eu tô especulando...(risos) }\end{array}$ \\
\hline $\begin{array}{l}\text { 2. Visibilidade } \\
\text { sobre a } \\
\text { ocorrência da } \\
\text { discriminação } \\
\text { racial }\end{array}$ & \multirow[t]{2}{*}{$\begin{array}{l}\text { visibilidade do } \\
\text { tratamento } \\
\text { desigual direto } \\
\text { ou indireto que } \\
\text { prejudica } \\
\text { socialmente o } \\
\text { negro, seja pela } \\
\text { neutralidade, } \\
\text { seja pela } \\
\text { diferenciação } \\
\text { negativa }\end{array}$} & \multirow{2}{*}{$\begin{array}{c}\text { invisibilidade e confusão pela } \\
\text { contradição Para o entrevistado, a } \\
\text { universidade é racista quando } \\
\text { implementa a política de cotas por } \\
\text { critério racial ("... as cotas são, em } \\
\text { si, uma coisa racista, acho, que tá } \\
\text { aí..."), o que impossibilita sua irmã } \\
\text { ter a mesma facilidade porque não é } \\
\text { negra, é branca. Mais a frente, } \\
\text { constata que na Universidade não } \\
\text { há professores negros ("hum,não...a } \\
\text { princípio não...") e que ele mesmo } \\
\text { consideraria racista uma } \\
\text { universidade que só contratasse } \\
\text { professores negros ("Acho que eu } \\
\text { acabaria pensando isso, sim...") . } \\
\text { Observa-se que só foi possível } \\
\text { constatar a discriminação racial } \\
\text { institucional quando foi invertido o } \\
\text { papel social dos grupos branco e } \\
\text { negros de ocupação de local de } \\
\text { privilégio na sociedade. }\end{array}$} & $\begin{array}{l}\text { Pergunta: Você acha que a universidade é racista? Resposta: Ah... Bom, } \\
\text { (...)... as cotas são, em si, uma coisa racista, acho, que tá aí... (...) Tipo, o } \\
\text { que acabei defendendo então como ideal era que houvesse, se fosse pra ter } \\
\text { cotas que fosse pra todos da rede pública, com um certo teto de renda, que } \\
\text { eles não tem acesso ao conhecimento e tal... (...) É porque aí eu peguei o } \\
\text { dado só pra negros mesmo, tinha restringido a busca, eu não sabia que } \\
\text { eles se estendiam até pardos também... e minha irmã, por exemplo, é } \\
\text { branca, ela não conseguiria entrar aqui também... eu não sei, acho que } \\
\text { isso é injusto, a princípio.. }\end{array}$ \\
\hline $\begin{array}{l}\text { 2. Visibilidade } \\
\text { sobre a } \\
\text { ocorrência da } \\
\text { discriminação } \\
\text { racial }\end{array}$ & & & $\begin{array}{l}\text { Se você entrasse em uma escola em que o dono fosse um homem negro e, } \\
\text { aí, você percebesse que todos os professores contratados também eram } \\
\text { negros, você acharia que o dono é racista?Resposta: Acho que eu } \\
\text { acabaria pensando isso, sim... Pergunta: Você tem algum professor } \\
\text { negro? Resposta: Hum, não... a princípio não... } \\
\text { Pergunta: Mas o ambiente na Universidade, você acha que ele não é } \\
\text { racista? Resposta: Hum.... É...que coisa não!? (riso)... Ah, eu não sei } \\
\text { responder...(riso) }\end{array}$ \\
\hline
\end{tabular}




\begin{tabular}{|c|c|c|c|}
\hline $\begin{array}{l}\text { 2. Visibilidade } \\
\text { sobre a } \\
\text { ocorrência da } \\
\text { discriminação } \\
\text { racial }\end{array}$ & $\begin{array}{c}\text { visibilidade do } \\
\text { tratamento } \\
\text { desigual direto } \\
\text { ou indireto que } \\
\text { prejudica } \\
\text { socialmente o } \\
\text { negro, seja pela } \\
\text { neutralidade, } \\
\text { seja pela } \\
\text { diferenciação } \\
\text { negativa }\end{array}$ & $\begin{array}{l}\text { Visibilidade da discriminação direta, } \\
\text { mas o entrevistado vincula a } \\
\text { discriminação ao espaço de } \\
\text { privilégio ("...o porteiro ao ver um } \\
\text { rapaz negro... imaginou que ele não } \\
\text { fosse aluno da escola...ao ver um } \\
\text { branco, ele nem quis se indagar...") }\end{array}$ & $\begin{array}{l}\text { Pergunta } 20 * \text { primeira etapa: Resposta....Ahn...Bom, provavelmente é } \\
\text { uma...ahn... a primeira pergunta, né... Por que você acha que isto } \\
\text { aconteceu...provavelmente por que...é...uhm, é uma escola aqui da } \\
\text { realidade...é aqui do Sudeste ou do Sul, sei lá...uhm.. e que a maioria é } \\
\text { branca, há poucos negros...é...o porteiro ao ver um rapaz negro... } \\
\text { imaginou que ele não fosse aluno da escola....ao ver um branco, ele nem } \\
\text { quis se indagar... }\end{array}$ \\
\hline $\begin{array}{l}\text { 3. Visibilidade } \\
\text { sobre as } \\
\text { conseqüências } \\
\text { do racismo, os } \\
\text { danos e os } \\
\text { privilégios }\end{array}$ & $\begin{array}{l}\text { visibilidade do } \\
\text { prejuízo social } \\
\text { para o negro }\end{array}$ & $\begin{array}{l}\text { invisibilidade e confusão pela } \\
\text { contradição O entrevistado diz } \\
\text { que "a maior parte deles (negros) } \\
\text { tá...tá incluída em classes sociais } \\
\text { mais baixas". No entanto, ao ser } \\
\text { perguntado sobre o privilegio do } \\
\text { branco em ter acesso à } \\
\text { Universidade, ele diz que acha que } \\
\text { isso não ocorre ("Pergunta: Você } \\
\text { acha que o fato de uma pessoa ser } \\
\text { branca auxilia ela estar na } \\
\text { Universidade? Resposta:Uhm...acho } \\
\text { que não... eu não sei.") }\end{array}$ & $\begin{array}{l}\text { Pergunta: Você acha que ofato de uma pessoa ser branca auxilia ela estar } \\
\text { na Universidade?Resposta:Uhm...acho que não... eu não sei. Pergunta: } \\
\text { Por que você acha que existem menos alunos negros na } \\
\text { Universidade?Resposta: Uhm....Não sei... talvez aqui por ser uma } \\
\text { população menor...ahn...ou também por que... a maior parte deles tá...tá } \\
\text { incluída em classes sociais mais baixas...mas náo sei...(riso) }\end{array}$ \\
\hline
\end{tabular}




\begin{tabular}{|c|c|c|c|c|}
\hline 4. Estigma & $\begin{array}{c}\text { na } \\
\text { comunicação } \\
\text { não verbal }\end{array}$ & $\begin{array}{l}\text { escolha de papéis } \\
\text { profissionais para } \\
\text { as pessoas das } \\
\text { fotos de homens } \\
\text { e mulheres; } \\
\text { brancos(as) e } \\
\text { negros(as); de } \\
\text { faixas etárias de } \\
20 \text { a } 30 \text { anos, de } \\
31 \text { a } 59 \text { anos, } \\
\text { acima de } 60 \text { anos. } \\
\text { Indicadores: } \\
\text { profissionais } \\
\text { brancos (as) - } \\
\text { negros (as) e } \\
\text { cargos } \\
\text { profissionais } \\
\text { artista, que } \\
\text { privilegia } \\
\text { conhecimento } \\
\text { intelectual, } \\
\text { manual e posições } \\
\text { de chefia. }\end{array}$ & $\begin{array}{l}\text { Observa-se sua tendência em } \\
\text { reproduzir os estigmas sociais, } \\
\text { escolhendo mais pessoas brancas } \\
\text { do que negras para ocupar os } \\
\text { papéis profissionais, escolhendo os } \\
\text { brancos nos papéis de } \\
\text { profissionais intelectuais. Das } 9 \\
\text { profissões, } 6 \text { foram preenchidas com } \\
\text { pessoas brancas e } 3 \text { com pessoas } \\
\text { negras; sendo que as profissões de } \\
\text { artista, as } 2 \text { que privilegiam } \\
\text { conhecimento intelectual, } 1 \text { das que } \\
\text { são de chefia e } 2 \text { das que privilegiam } \\
\text { trabalho manual foram preenchidas por } \\
\text { pessoas brancas; enquanto que } 1 \\
\text { posição de chefia e } 2 \text { das que } \\
\text { privilegiam trabalho manual foram } \\
\text { preenchidas por pessoas negras. }\end{array}$ & $\begin{array}{l}\text { Profissional Artista: Pianista - mulher branca (figura 29); } \\
\text { Profissão que privilegia conhecimento intelectual: Médico (a) plantonista - } \\
\text { homem branco (figura 32); Professor Universitário - homem branco (figura } \\
\text { 27); } \\
\text { Posições de chefia: Gerente do hotel - homem branco (figura 22); Diretor } \\
\text { (a) de Marketing de uma loja de departamento - homem negro (figura 18); } \\
\text { Profissões que privilegiam o trabalho manual: Arrumador (eira) do Hotel - } \\
\text { mulher negra (figura 20); Motorista de ônibus - homem branco (figura } \\
\text { 25); Cabeleireiro(a)) - mulher branca (figura 21); Porteiro(a) do Hotel ï } \\
\text { homem negro (figura 28); }\end{array}$ \\
\hline 4. Estigma & & $\begin{array}{c}\text { papéis sociais } \\
\text { para negros e } \\
\text { brancos }\end{array}$ & $\begin{array}{l}\text { O entrevistado atribui característica } \\
\text { social não comprovada a um grupo } \\
\text { étnico definido como negro e } \\
\text { característica genérica ao grupo } \\
\text { étnico branco. Expressa a idéia do } \\
\text { branco como universal e o negro } \\
\text { como diferente. }\end{array}$ & $\begin{array}{l}\text { se você fosse pegar a parte bruta da população negra... acho, que a gente } \\
\text { ia encontrar eles, no...no setor de serviços, acho... ou na indústria, né... } \\
\text { parte branca estaria mais distribuída, não sei... não sei... eu tô } \\
\text { especulando...(risos) }\end{array}$ \\
\hline
\end{tabular}




\begin{tabular}{|c|c|c|c|c|}
\hline 5. Estereótipo & & $\begin{array}{l}\text { características } \\
\text { atribuídas } \\
\text { genericamente } \\
\text { a todos os } \\
\text { membros de um } \\
\text { grupo, mitos }\end{array}$ & $\begin{array}{l}\text { O entrevistado atribui característica } \\
\text { física não comprovada a um grupo } \\
\text { étnico que define como negro que } \\
\text { demandaria um tratamento especial. } \\
\text { Expressa a idéia do branco como } \\
\text { universal e o negro como diferente. }\end{array}$ & $\begin{array}{l}\text {... a medula espinhal nos negros em relação aos brancos, não sei em } \\
\text { relação aos asiáticos... se... chega um pouco mais próxima... é mais pra } \\
\text { cima o cóccix do que nos brancos, assim... acho que pra médico...quer } \\
\text { dizer, pra enfermagem, eles até devem ter que tomar cuidado, na hora de } \\
\text { dar uma injeção... hum, deixe eu ver... ah, não sei, tá bom...(riso) }\end{array}$ \\
\hline $\begin{array}{l}\text { 6. Reações } \\
\text { emocionais na } \\
\text { relação com o } \\
\text { preconceito } \\
\text { (com o } \\
\text { diverso) }\end{array}$ & $\begin{array}{l}\text { na } \\
\text { comunicação } \\
\text { verbal }\end{array}$ & $\begin{array}{l}\text { culpa, } \\
\text { vergonha, } \\
\text { irritabilidade, } \\
\text { raiva, } \\
\text { exaustão, } \\
\text { confusão na } \\
\text { fala, negação, } \\
\text { medo, } \\
\text { dissimulação, } \\
\text { sensação de }\end{array}$ & $\begin{array}{l}\text { Sensação de SOLIDÃO ("comecei a } \\
\text { achar que só eu... que só tava eu de } \\
\text { cotista lá") }\end{array}$ & $\begin{array}{l}\text { Pergunta: Esse pessoal da república nenhum é cotista? Resposta: Não, na } \\
\text { minha turma só tem três cotistas...Pergunta: Como é que você sabe que } \\
\text { eles são cotistas? Resposta:Um porque me falou, outro porque eu fiquei } \\
\text { muito curioso e olhei as listas... porque tem lista do universal e tem lista } \\
\text { do cotas.. é, ai eu vi o nome deles lá. Pergunta: Por que você acha que } \\
\text { você olhou na lista? Resposta: Não sei, eu fiquei curioso. Acho que } \\
\text { quando eu olhei tinha duas pessoas na sala querendo saber a posição de } \\
\text { cada um na lista.. algumas pessoas não gostaram dessa história, mas } \\
\text { acho que todo mundo acabou dando uma olhadinha na lista depois que ... } \\
\text { depois desses comentários.Também porque eu comecei a achar que só eu... } \\
\text { que só tava eu de cotista lá... }\end{array}$ \\
\hline $\begin{array}{l}\text { 6. Reações } \\
\text { emocionais na } \\
\text { relação com o } \\
\text { preconceito }\end{array}$ & & $\begin{array}{l}\text { tristeza, } \\
\text { sensação de } \\
\text { não } \\
\text { pertencimento, } \\
\text { impotência, } \\
\text { contradição, } \\
\text { justificativa } \\
\text { defensiva }\end{array}$ & $\begin{array}{l}\text { SUSTO: relação com a diversidade } \\
\text { étnico-racial ("me assustaria", "eu } \\
\text { me assustei quando só vi (...) } \\
\text { negros") }\end{array}$ & $\begin{array}{l}\text { Pergunta: Se 80\% desses alunos fossem negros, como você se } \\
\text { sentiria?.Resposta: Bom, acho que... a primeira coisa, eu me surpreenderia, } \\
\text { (...) assim....me assustaria, porque eu não...não to acostumado, né...ahn, sei } \\
\text { lá quando...quando eu era pequeno, eu viajei pra Fortaleza de } \\
\text { onibus.......ai quando a gente passou pela Bahia... tinha lugares que eu só } \\
\text { via negros, assim andando, né...eu não considerei aquilo um pensamento } \\
\text { racista, mas eu me assustei quando só vi...é, não de ter ficado com medo, } \\
\text { eu fiquei surpreso, assim, sabe... quando eu só vi negros assim por lá... } \\
\text {...tá, acho que por não estar acostumado...ah, acho que você } \\
\text { entendeu...(risos ) Hum....acho que eu tomaria um susto e ficaria tímido, } \\
\text { assim no começo... mas....acho que eu nunca tive problemas de...me } \\
\text { relacionar com pessoas de outras etnias, assim...digamos, assim }\end{array}$ \\
\hline
\end{tabular}




\begin{tabular}{|c|c|c|}
\hline $\begin{array}{l}\text { 6. Reações } \\
\text { emocionais na } \\
\text { relação com o } \\
\text { preconceito }\end{array}$ & $\begin{array}{l}\text { NEGAÇÃO: Enquanto que na parte } \\
\text { do relato acima, o entrevistado } \\
\text { revela a sua reação de susto diante } \\
\text { do grupo de pessoas negras ("me } \\
\text { assustaria", "eu me assustei quando } \\
\text { só vi (...) negros"), nesta parte do } \\
\text { relato ele menciona que "... é que } \\
\text { eu não vejo grande diferença entre } \\
\text { me relacionar com pessoa que seja, } \\
\text { (...) fisicamente parecida } \\
\text { comigo...ou, diferente". }\end{array}$ & $\begin{array}{l}\text { Pergunta: .O que, que você acha dessa questão da diversidade? Você } \\
\text { gosta de se relacionar com pessoas diferentes? Resposta: Hum... é que eu } \\
\text { não vejo grande diferença entre me relacionar com pessoa que seja, } \\
\text { é... assim, fisicamente parecida comigo...ou, diferente assim...... }\end{array}$ \\
\hline $\begin{array}{l}\text { 6. Reações } \\
\text { emocionais na } \\
\text { relação com o } \\
\text { preconceito }\end{array}$ & Sensação de vazio & $\begin{array}{l}\text { e que não sei...acho que... hum...é algo que... ai caramba, como eu vou } \\
\text { dizer... que me vai ajudar a preencher este espaço vazio...é... ficou } \\
\text { evidenciado hoje... bom, não sei se vai ajudar mesmo a preencher...mas, } \\
\text { pelo menos evidenciou este espaço, assim, em branco...que eu não dou } \\
\text { tanta importância assim... }\end{array}$ \\
\hline
\end{tabular}




\begin{tabular}{|c|c|c|c|}
\hline $\begin{array}{l}\text { 6. Reações } \\
\text { emocionais na } \\
\text { relação com o } \\
\text { preconceito } \\
\text { (com o } \\
\text { diverso) }\end{array}$ & & $\begin{array}{l}\text { VERGONHA ("eu não contei pra } \\
\text { ninguém, na verdade...", "eu achei } \\
\text { que quando alguém comentasse ou } \\
\text { perguntasse disso, eu ficaria meio } \\
\text { assim... ah, sou!... mas...") }\end{array}$ & 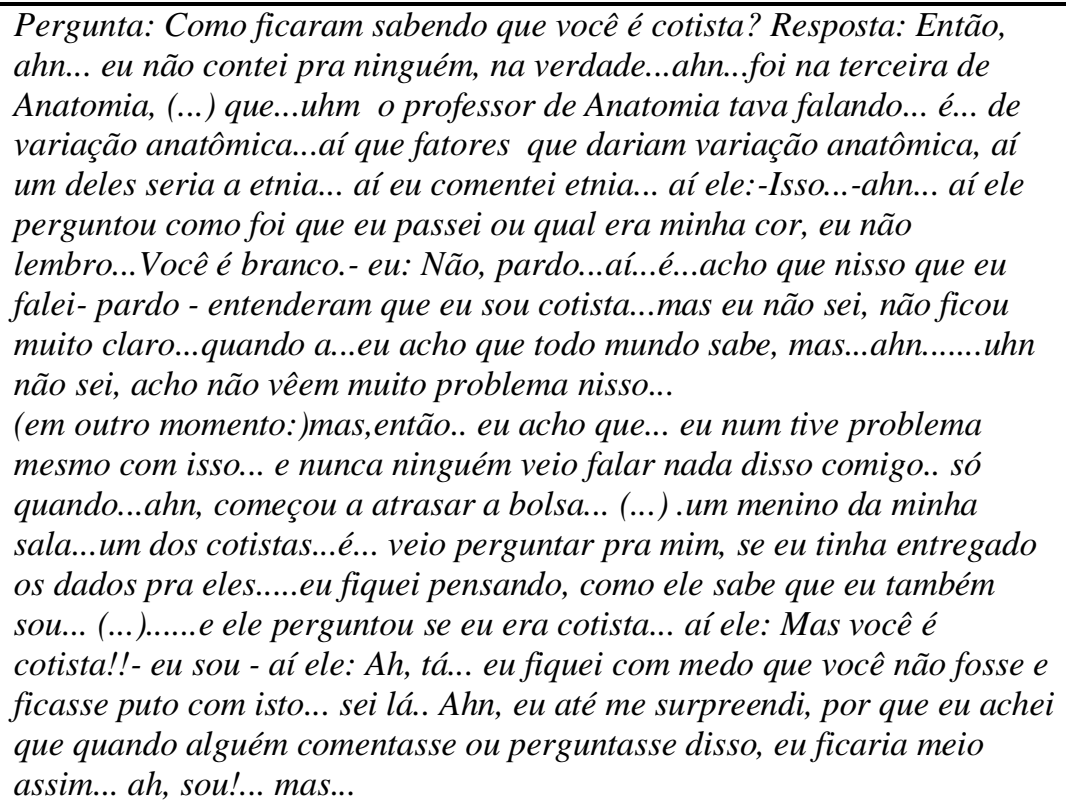 \\
\hline $\begin{array}{l}\text { 7. Formas e } \\
\text { Oportunidades } \\
\text { de elaboração } \\
\text { das } \\
\text { experiências } \\
\text { relacionadas ao } \\
\text { racismo }\end{array}$ & $\begin{array}{l}\text { oportunidades } \\
\text { de reflexão } \\
\text { sobre o tema } \\
\text { racismo nos } \\
\text { espaços sociais } \\
\text { (família, escola, } \\
\text { mídia, amigos) }\end{array}$ & $\begin{array}{l}\text { De acordo com o entrevistado, ele } \\
\text { teve oportunidades pouco } \\
\text { significativas ("...mas eu não sei, eu } \\
\text { não lembro...", "...eu não ocupava } \\
\text { muito minha cabeça com isso..."), } \\
\text { sendo que, dentre as três citadas, a } \\
\text { "redação no colégio"," "algum } \\
\text { programa de TV"e "em uma das } \\
\text { reuniões do DCE", a última foi } \\
\text { provocada pela discussão sobre a } \\
\text { política de cotas ("foi sobre a } \\
\text { política de cotas em si...") }\end{array}$ & 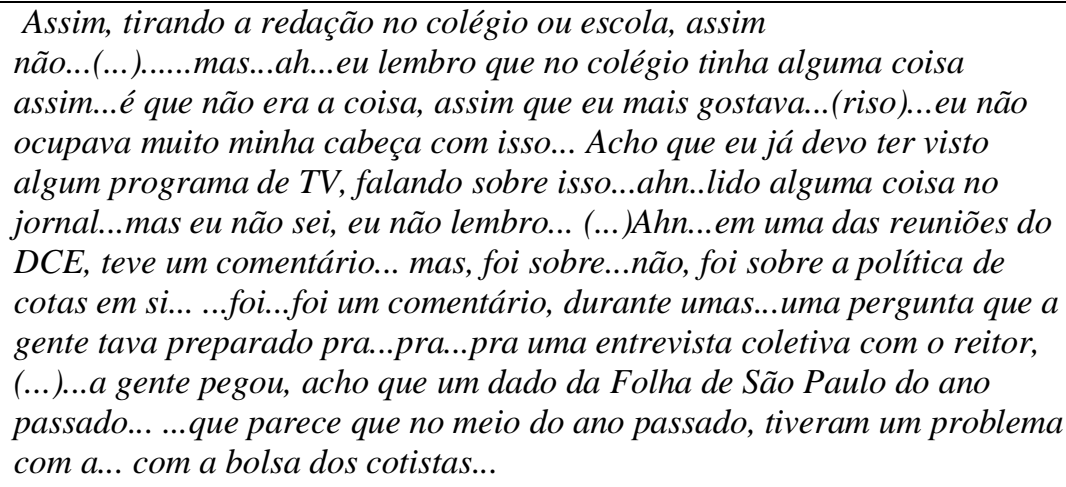 \\
\hline
\end{tabular}




\begin{tabular}{|c|c|c|c|}
\hline $\begin{array}{l}\text { 7. Formas e } \\
\text { Oportunidades } \\
\text { de elaboração } \\
\text { das } \\
\text { experiências } \\
\text { relacionadas ao } \\
\text { racismo }\end{array}$ & $\begin{array}{c}\text { oportunidades } \\
\text { de debate sobre } \\
\text { o assunto, } \\
\text { reflexão e } \\
\text { elaboração }\end{array}$ & $\begin{array}{l}\text { A experiência como cotista coloca o } \\
\text { entrevistado em uma oportunidade } \\
\text { de se deparar com o tema, mas não } \\
\text { é oferecida oportunidade para a } \\
\text { reflexão e nem ferramentas para a } \\
\text { elaboração ("Ahn, eu até me } \\
\text { surpreendi, por que eu achei que } \\
\text { quando alguém comentasse ou } \\
\text { perguntasse disso, eu ficaria meio } \\
\text { assim... ah, sou!... mas...", "...acho } \\
\text { que nisso que eu falei- pardo - } \\
\text { entenderam que eu sou } \\
\text { cotista...mas eu não sei, não ficou } \\
\text { muito claro.."). }\end{array}$ & 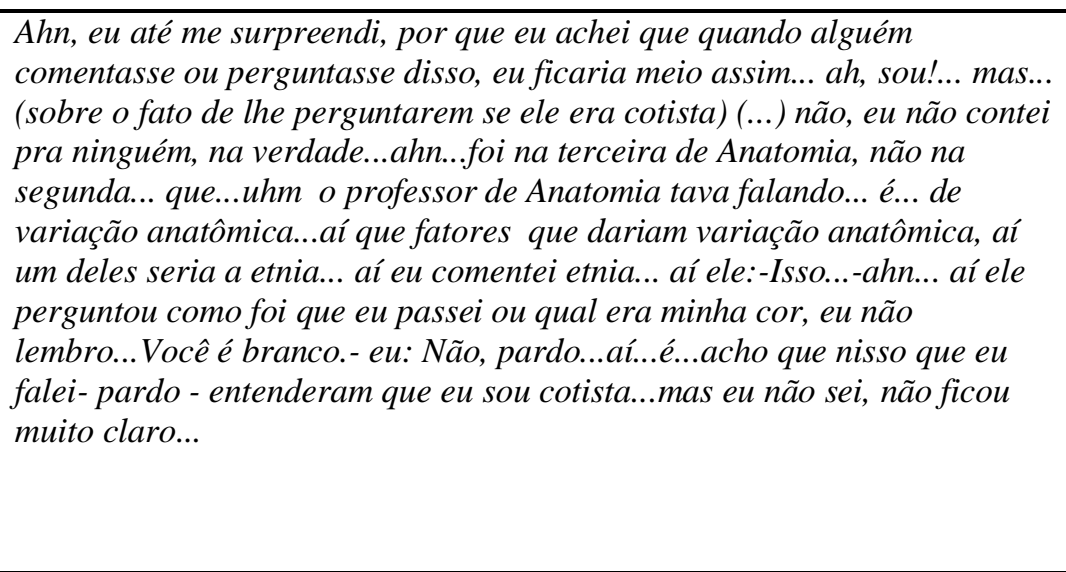 \\
\hline $\begin{array}{l}\text { 7. Formas e } \\
\text { Oportunidades } \\
\text { de elaboração } \\
\text { das } \\
\text { experiências } \\
\text { relacionadas ao } \\
\text { racismo }\end{array}$ & $\begin{array}{l}\text { oportunidades } \\
\text { de debate sobre } \\
\text { o assunto, } \\
\text { reflexão e } \\
\text { elaboração }\end{array}$ & $\begin{array}{l}\text { O fato de o entrevistado poder falar } \\
\text { sobre o assunto na entrevista } \\
\text { proporcionou a ele uma } \\
\text { oportunidade de reflexão sobre o } \\
\text { tema ("É... ahn, assim...essa } \\
\text { situação, assim... me mostrou... } \\
\text { mostrou algumas coisas que eu } \\
\text { nunca tinha pensado antes...ou que } \\
\text { eu nunca dei muita importância..."), } \\
\text { de forma a constatar a existência de } \\
\text { um vazio dentro dele ("este espaço } \\
\text { vazio...é... ficou evidenciado } \\
\text { hoje..."). Mas, evidentemente, esse } \\
\text { instrumento não oferece } \\
\text { oportunidade para a elaboração. }\end{array}$ & $\begin{array}{l}\text { Pergunta } 24 * \text { (sobre a escolha de um objeto que simbolize o que a pessoa } \\
\text { sentiu com relação à entrevista):Resposta: E... ahn, assim...essa situação, } \\
\text { assim... me mostrou... mostrou algumas coisas que eu nunca tinha pensado } \\
\text { antes...ou que eu nunca dei muita importância... ahn... hum... e que não } \\
\text { sei...acho que... hum...é algo que...ai caramba, como eu vou dizer... que } \\
\text { me vai ajudar a preencher este espaço vazio...é... ficou evidenciado hoje... } \\
\text { bom, não sei se vai ajudar mesmo a preencher...mas, pelo menos } \\
\text { evidenciou este espaço, assim, em branco...que eu não dou tanta } \\
\text { importância assim...é isso...(risos) }\end{array}$ \\
\hline
\end{tabular}




\begin{tabular}{|c|c|c|c|}
\hline $\begin{array}{l}\text { 7. Formas e } \\
\text { Oportunidades } \\
\text { de elaboração } \\
\text { das } \\
\text { experiências } \\
\text { relacionadas ao } \\
\text { racismo }\end{array}$ & $\begin{array}{l}\text { oportunidades } \\
\text { de debate sobre } \\
\text { o assunto, } \\
\text { reflexão e } \\
\text { elaboração }\end{array}$ & $\begin{array}{l}\text { No final da entrevista, o entrevistado } \\
\text { percebe a dificuldade do assunto e } \\
\text { seu próprio preconceito ("eu } \\
\text { achava que não era uma coisa } \\
\text { assim difícil de falar...mas... é.", "por } \\
\text { estar fortemente vinculada a...uma } \\
\text { formação cultural que a gente } \\
\text { teve.....) eu enxergo o negro como } \\
\text { arquétipo do... do...é...sei lá, do } \\
\text { trabalhador industrial (...) algum tipo } \\
\text { de imagem que acho estaria } \\
\text { enraizada na...na nossa cultura..") }\end{array}$ & 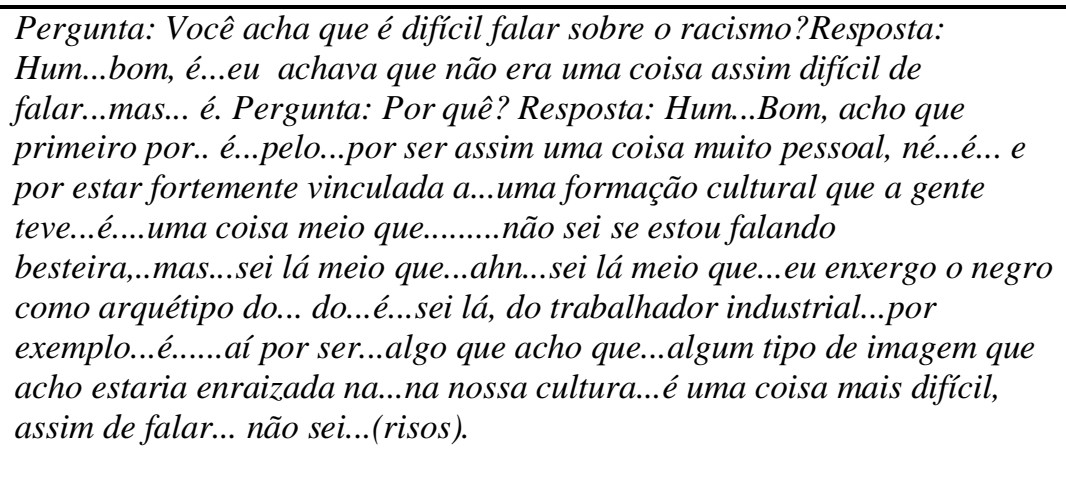 \\
\hline $\begin{array}{l}\text { 7. Formas e } \\
\text { Oportunidades } \\
\text { de elaboração } \\
\text { das } \\
\text { experiências } \\
\text { relacionadas ao } \\
\text { racismo }\end{array}$ & $\begin{array}{l}\text { forma que } \\
\text { encontra para } \\
\text { lidar com a } \\
\text { situação de } \\
\text { discriminação }\end{array}$ & $\begin{array}{l}\text { O entrevistado acredita que tem } \\
\text { todas as condições para ter um } \\
\text { desempenho acadêmico e } \\
\text { profissional satisfatório }\end{array}$ & $\begin{array}{l}\text { Pergunta: Você acredita que alunos cotistas e alunos não cotistas têm o } \\
\text { mesmo desempenho nas matérias?Resposta. Bom, até agora eu não senti } \\
\text { nada... assim eu só.. é como eu falei,tipo não vi assim diferenças... } \\
\text { Pergunta:E o desempenho profissional? Resposta:Hum, eu acho que não } \\
\text { também...se esse desempenho for profissional quando a gente já estiver } \\
\text { formado...bom eu acho que não...porque a gente tem acesso às mesmas } \\
\text { aulas, ao mesmo conteúdo, né... então acho que não há motivo pra } \\
\text { formação acabar sendo diferente. }\end{array}$ \\
\hline \multirow[t]{2}{*}{$\begin{array}{l}\text { 7. Formas e } \\
\text { Oportunidades } \\
\text { de elaboração } \\
\text { das } \\
\text { experiências } \\
\text { relacionadas ao } \\
\text { racismo }\end{array}$} & & \multirow[t]{2}{*}{$\begin{array}{l}\text { Apesar de o entrevistado imaginar } \\
\text { que o fato de ele ter entrado pela } \\
\text { política possa ser causa de um } \\
\text { desconforto na relação com os não } \\
\text { cotistas, consegue se sentir } \\
\text { confortável na relação com os } \\
\text { colegas }\end{array}$} & $\begin{array}{l}\text { Pergunta: Você acha que o processo de cotas no vestibular acirra o o } \\
\text { racismo entre as pessoas?Resposta: Acho que sim...talvez näo } \\
\text { alcance...ah, não é que...ah, deixa eu ver... acho que sim...porque, ahn... } \\
\text { acho que é meio chato você saber que você teve que se esforçar muito pra } \\
\text { conseguir fazer uma coisa e outra pessoa, por ter... só porque tem uma cor } \\
\text { diferente, conseguiu fazer isto de uma maneira mais facilitada..é...então } \\
\text { acho que isto deve...não que aconteça com todo mundo, sei lá...mas acho } \\
\text { que deve fazer a pessoa se sentir meio puta, assim... }\end{array}$ \\
\hline & $\begin{array}{l}\text { forma que } \\
\text { encontrou para } \\
\text { lidar com a } \\
\text { situação }\end{array}$ & & $\begin{array}{l}\text { Resposta:... ahn.. ah, eu não sei... eu sentei num lugar lá e conversei com o } \\
\text { pessoal... eu me senti a vontade com a turma... mesmo com os que eu não } \\
\text { conhecia pela internet, eu acabei conhecendo lá na hora...ahn, e a } \\
\text { princípio eu senti que a turma...ahn... a turma seria unida, sabe...(riso) }\end{array}$ \\
\hline
\end{tabular}




\begin{tabular}{|c|c|c|c|c|}
\hline $\begin{array}{l}\text { 7. Formas e } \\
\text { Oportunidades } \\
\text { de elaboração } \\
\text { das } \\
\text { experiências } \\
\text { relacionadas ao } \\
\text { racismo }\end{array}$ & & $\begin{array}{l}\text { forma que } \\
\text { encontrou para } \\
\text { lidar com a } \\
\text { situação }\end{array}$ & $\begin{array}{l}\text { O entrevistado demonstra que a } \\
\text { experiência na universidade está lhe } \\
\text { trazendo satisfação consigo, uma } \\
\text { maior sensação de pertencimento à } \\
\text { comunidade social e lhe } \\
\text { estimulando a desenvolver uma } \\
\text { maior integração social fora da } \\
\text { universidade }\end{array}$ & $\begin{array}{l}\text { Ah... eu tô tentando ressuscitar meu blog, aí, eu nunca tinha me } \\
\text { apresentado nele, aí eu resolvi me apresentar... aí eu coloquei que a } \\
\text { atividade que eu faço é estudar aqui, e o resto do meu tempo eu gasto... o } \\
\text { que sobra do meu tempo eu gasto no metrô, dormindo ou comendo. }\end{array}$ \\
\hline \multirow[t]{2}{*}{$\begin{array}{l}\text { 8. Abordagem } \\
\text { teórica sobre o } \\
\text { tema }\end{array}$} & \multirow[t]{2}{*}{$\begin{array}{l}\text { Diversidade } x \\
\text { Igualdade } x \\
\text { Racismo }\end{array}$} & $\begin{array}{c}\text { Confusão sobre } \\
\text { os } \\
\text { agrupamentos } \\
\text { na diversidade, } \\
\text { sobre a } \\
\text { diferenciação } \\
\text { positiva - a } \\
\text { diferenciação } \\
\text { negativa } \\
\text { (quando é um } \\
\text { valor a } \\
\text { diversidade e } \\
\text { quando não é). }\end{array}$ & \multirow[t]{2}{*}{$\begin{array}{l}\text { Confusão por meio da Contradição } \\
\text { Enquanto que na parte do relato } \\
\text { acima, o entrevistado considera os } \\
\text { aspectos sócio-econômicos como } \\
\text { um fator de diferenciação entre } \\
\text { negros e brancos ("a menos que a } \\
\text { gente considere o meio social } \\
\text { também, né... sei lá, se você fosse } \\
\text { pegar a parte bruta da população } \\
\text { negra (...) a gente ia encontrar eles } \\
\text { (...) no setor de serviços, acho... ou } \\
\text { na indústria, ....a parte branca estaria } \\
\text { mais distribuída"), nesta parte do } \\
\text { relato ele afirma "elas (pessoas } \\
\text { diferenciadas pela cor) estão no } \\
\text { mesmo contexto social". }\end{array}$} & $\begin{array}{l}\text { Pergunta: qual que é a diferença entre uma pessoa negra e uma branca e } \\
\text { qual a semelhança? Resposta:Uhm...diferença... bom, diferença física...é... } \\
\text { que seria a cor...é... algumas estruturas anatômicas diferentes...(...) acho, } \\
\text { que de resto são semelhantes... (...) assim, a menos que a gente considere o } \\
\text { meio social também, né... sei lá, se você fosse pegar a parte bruta da } \\
\text { população negra... acho, que a gente ia encontrar eles, no...no setor de } \\
\text { serviços, acho... ou na indústria, né... a parte branca estaria mais } \\
\text { distribuída, não sei... não sei... eu tô especulando...(risos) }\end{array}$ \\
\hline & & $\begin{array}{c}\text { Confusão sobre } \\
\text { os } \\
\text { agrupamentos } \\
\text { na diversidade, } \\
\text { sobre a }\end{array}$ & & $\begin{array}{l}\text { (sobre cotas) ....mas no caso de cotas não tem isso... ele só } \\
\text { escolhe...ahn............. um grupo, assim pela sua cor...ahn, não sei, não sei } \\
\text { qual...porque essa pessoa deve ter vantagem e outra não, sabe.... se elas } \\
\text { estão no mesmo contexto social. }\end{array}$ \\
\hline
\end{tabular}




\begin{tabular}{|c|c|c|c|c|}
\hline $\begin{array}{c}\text { 8. Abordagem } \\
\text { teórica sobre o } \\
\text { tema }\end{array}$ & $\begin{array}{l}\text { Diversidade } \mathrm{x} \\
\text { Igualdade } \mathrm{x} \\
\text { Racismo }\end{array}$ & $\begin{array}{l}\text { diferenciação } \\
\text { positiva - a } \\
\text { diferenciação } \\
\text { negativa } \\
\text { (quando é um } \\
\text { valor a } \\
\text { diversidade e } \\
\text { quando não é). }\end{array}$ & $\begin{array}{l}\text { Confusão entre diversidade e } \\
\text { racismo } \quad \text { entrevistado, } \\
\text { diante da sua manifesta constatação } \\
\text { da existência diversidade étnico- } \\
\text { racial, considerou e refletiu sobre o } \\
\text { aspecto racista da sua constatação } \\
\text { ("...eu não considerei aquilo um } \\
\text { pensamento racista, né? .........tá, } \\
\text { acho que por não estar } \\
\text { acostumado...ah, acho que você } \\
\text { entendeu...(risos))" }\end{array}$ & $\begin{array}{l}\text { eu viajei pra Fortaleza de ônibus... e...aí quando a gente passou pela } \\
\text { Bahia... tinha lugares que eu só via negros, assim andando, né...eu não } \\
\text { considerei aquilo um pensamento racista, mas eu me assustei quando só } \\
\text { vi...é, não de ter ficado com medo, eu fiquei surpreso, assim, sabe... } \\
\text { quando eu só vi negros assim por lá......tá, acho que por não estar } \\
\text { acostumado...ah, acho que você entendeu...(risos ) }\end{array}$ \\
\hline $\begin{array}{c}\text { 8. Abordagem } \\
\text { teórica sobre o } \\
\text { tema }\end{array}$ & $\begin{array}{l}\text { Relação do } \\
\text { racismo com } \\
\text { os princípios } \\
\text { de direito } \\
\text { fundamentais }\end{array}$ & $\begin{array}{c}\text { reconhecimento } \\
\text { da política como } \\
\text { um direito } \\
\text { fundamental }\end{array}$ & $\begin{array}{l}\text { O entrevistado não relaciona a } \\
\text { política que objetiva atender ao } \\
\text { direito coletivo específico com um } \\
\text { direito seu, mas com uma doação } \\
\text { ("por dar oportunidade pra uma } \\
\text { minoria", "eu acho que é } \\
\text { interessante darem... darem...o } \\
\text { é...darem uma vantagem assim", "só } \\
\text { que vão receber um bônus por } \\
\text { causa da ascendência deles na } \\
\text { sociedade, mesmo entre a } \\
\text { população pobre") }\end{array}$ & $\begin{array}{l}\text { (sobre política de cotas) Hum....Aham...bom, é por...ahn...por dar } \\
\text { oportunidade pra uma minoria da... sociedade... ahn, eu acho que é } \\
\text { interessante darem... darem...o é...darem uma vantagem assim pro pessoal } \\
\text { da escola pública...por que...ahn...porque já que...ahn, não como medida } \\
\text { definitiva, mas como quebra galho funciona...já que...o ensino público não } \\
\text { é bom... ai, caramba...o ensino público no Fundamental e Médio... (...) } \\
\text { Hmm... os privilegiados pelo sistema de cotas são poucos... são parte } \\
\text { desse grupo que tem pouco acesso a esse conhecimento, só que um grupo } \\
\text { assim exclusivo, os que, a meu ver tem a mesma capacidade que todos os } \\
\text { outros... só que vão receber um bônus por causa da ascendência deles na } \\
\text { sociedade, mesmo entre a população pobre, eles não são assim a } \\
\text { maioria... pelo menos em São Paulo não.. }\end{array}$ \\
\hline $\begin{array}{l}\text { 8. Abordagem } \\
\text { teórica sobre o } \\
\text { tema }\end{array}$ & $\begin{array}{l}\text { Relação do } \\
\text { racismo com } \\
\text { os princípios } \\
\text { de direito } \\
\text { fundamentais }\end{array}$ & $\begin{array}{l}\text { reconhecimento } \\
\text { do direito a ser } \\
\text { tratado } \\
\text { desigualmente ( } \\
\text { discriminação } \\
\text { positiva) }\end{array}$ & $\begin{array}{l}\text { O entrevistado não reconhece o } \\
\text { direito à diversidade como forma de } \\
\text { promoção da igualdade ("ah...bom, } \\
\text { eu acho que colocando a questão } \\
\text { racial junto com os Diretos } \\
\text { Humanos, acaba entrando o direito } \\
\text { dos negros, meio que por } \\
\text { conseqüência..") }\end{array}$ & $\begin{array}{l}\text { Pergunta: O que é Direitos Humanos pra você? Resposta:Hum... os } \\
\text { direitos a que todo mundo tem...é....acho que mínimos de ter...de ter as } \\
\text { condiçães, pelo menos minimas a sua sobrevivência...acho que é isso, } \\
\text { não?... Pergunta: você acha que discriminação racial, é uma questão de } \\
\text { Direitos Humanos?Resposta: Hum... acho que sim...Pergunta: E o direito } \\
\text { dos negros?Resposta:Hum...... ah... bom, eu acho que colocando a questão } \\
\text { racial junto com os Diretos Humanos, acaba entrando o direito dos } \\
\text { negros, meio que por conseqüência... }\end{array}$ \\
\hline
\end{tabular}




\begin{tabular}{|c|c|c|c|}
\hline $\begin{array}{c}9 . \\
\text { Manifestação da } \\
\text { solidariedade }\end{array}$ & \multirow{2}{*}{$\begin{array}{c}\text { crença de que } \\
\text { a relação } \\
\text { multi-étnica } \\
\text { enriquece e } \\
\text { auxilia a } \\
\text { coletividade, } \\
\text { na solução de } \\
\text { problemas } \\
\text { coletivos e } \\
\text { individuais; } \\
\text { disponibilidade } \\
\text { para a busca } \\
\text { real de } \\
\text { soluções para o } \\
\text { racismo }\end{array}$} & $\begin{array}{l}\text { O entrevistado não apresenta } \\
\text { disponibilidade para busca de } \\
\text { soluções }\end{array}$ & $\begin{array}{l}\text { Pergunta: se fosse falar com a Universidade, se ela pudesse ter alguma } \\
\text { proposta de fazer alguma coisa, pra melhorar o relacionamento entre } \\
\text { brancos e negros, entre cotista e não cotista... você acha que alguma coisa } \\
\text { poderia ser feita... o que você acha que poderia ser feito...pra melhorar? } \\
\text { Resposta: Hum, não sei... Pergunta: E em São Paulo? Resposta: Não, não } \\
\text { sei...Pergunta: você acha que algum conteúdo das aulas poderia ser } \\
\text { reforçado ou retirado, pra melhorar isto? Resposta: Melhorar } \\
\text { relacionamento entre brancos e negros?.. não! }\end{array}$ \\
\hline $\begin{array}{c}9 . \\
\text { Manifestação } \\
\text { da } \\
\text { solidariedade }\end{array}$ & & $\begin{array}{l}\text { O entrevistado não demonstra } \\
\text { acreditar que a relação multi-étnica } \\
\text { pode auxiliar na solução de } \\
\text { problemas coletivos e individuais } \\
\text { relacionados ao tema. }\end{array}$ & $\begin{array}{l}\text { Pergunta: Se você fosse convidado a ir assistir uma palestra sobre } \\
\text { racismo, você iria?Resposta: Depende... depende do enfoque da palestra... } \\
\text { é...não sei...... a princípio não... não ficaria no topo das } \\
\text { prioridades...Pergunta: se você fosse convidado pra uma palestra sobre } \\
\text { convívio entre as diversidades das pessoas,aí você iria?Resposta: ... ahn } \\
\text { essa não, essa eu tb não iria... }\end{array}$ \\
\hline
\end{tabular}




\begin{tabular}{|c|c|c|c|}
\hline $\begin{array}{l}\text { 10. Integração } \\
\text { com as ofertas } \\
\text { de } \\
\text { desenvolvimento } \\
\text { da Universidade }\end{array}$ & $\begin{array}{l}\text { Integração com } \\
\text { os colegas da } \\
\text { universidade; } \\
\text { oportunidades } \\
\text { profissionais } \\
\text { que surgem a } \\
\text { partir dessa } \\
\text { integração; } \\
\text { acesso às } \\
\text { oportunidades } \\
\text { que o ambiente } \\
\text { acadêmico } \\
\text { oferece }\end{array}$ & $\begin{array}{l}\text { O entrevistado está integrado com } \\
\text { as atividades da Universidade, pois } \\
\text { passa o dia inteiro na faculdade, } \\
\text { participa do DCE, faz parte do Coral } \\
\text { e está entusiasmado com isso ("Eu } \\
\text { me senti muito bem cantando lá...") } \\
\text { e participa do projeto de extensão } \\
\text { "Cananéia" ("eu acabei pegando } \\
\text { essa idéia, gostei, e tô participando } \\
\text { agora do Canonéia também"). Ele } \\
\text { ingressou no Coral e no DCE a partir } \\
\text { da divulgação geral feita pela } \\
\text { Universidade, sendo que para o } \\
\text { coral houve uma seleção pela qual } \\
\text { ele passou; Ingressou no projeto de } \\
\text { extensão estimulado por uma } \\
\text { amiga. Segundo ele, esse projeto } \\
\text { tem importância curricular. Ele } \\
\text { também participa de um estágio } \\
\text { informal de biologia celular, que } \\
\text { ingressou a partir de uma } \\
\text { aproximação com a professora e } \\
\text { com pós-graduandos que } \\
\text { acompanham a professora, sendo } \\
\text { uma delas negra ("...tem uma pós- } \\
\text { graduanda que acho que ela vai dar } \\
\text { alguma aula pra gente, em Biologia } \\
\text { Celular, que ela acompanha assim, } \\
\text { algumas aulas... ela é negra"). }\end{array}$ & 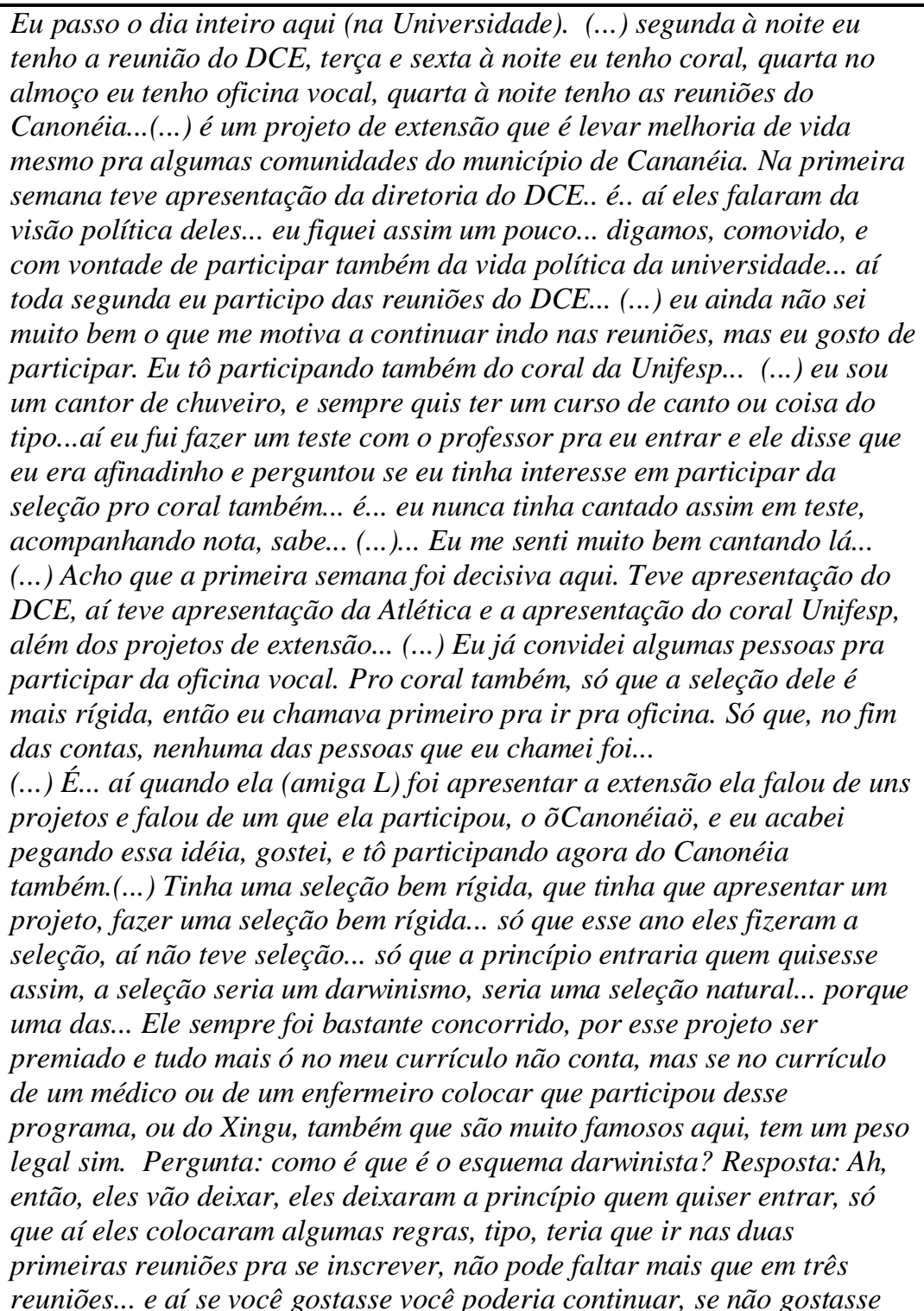 \\
\hline
\end{tabular}




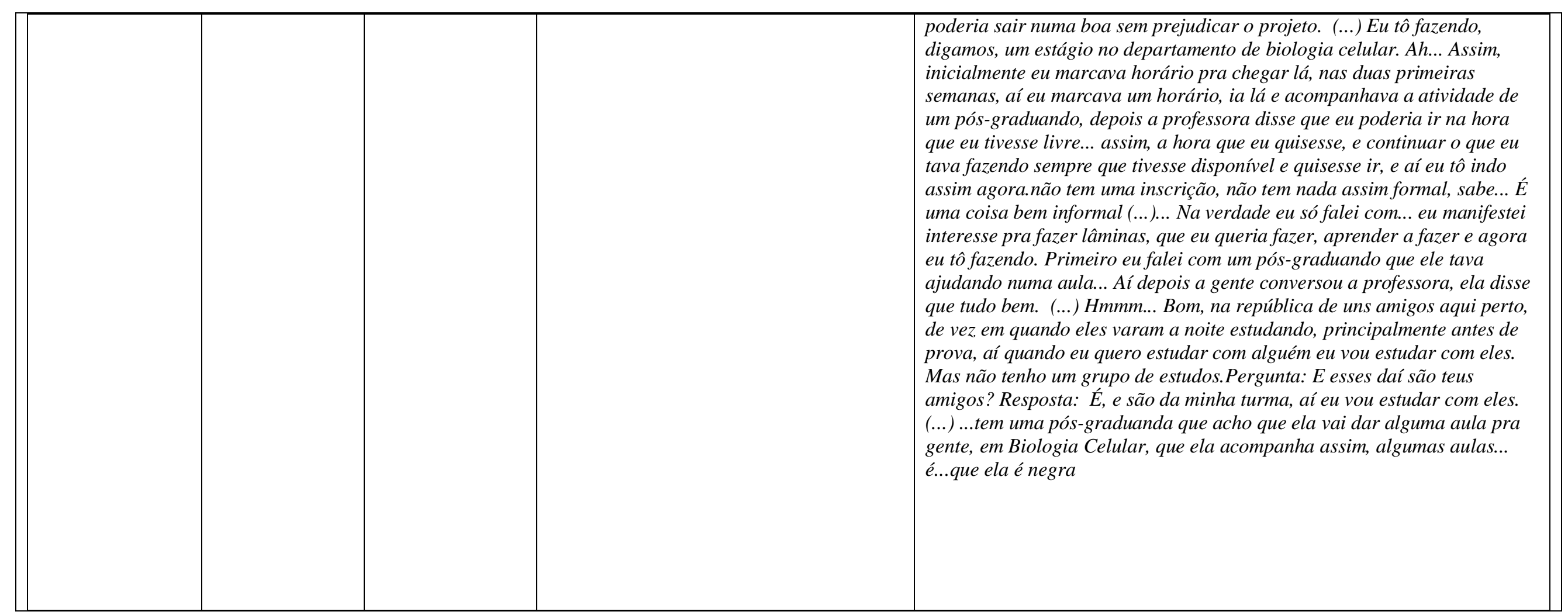




\begin{tabular}{|c|c|c|c|}
\hline $\begin{array}{l}\text { 10. Integração } \\
\text { com as ofertas } \\
\text { de } \\
\text { desenvolvimento } \\
\text { da Universidade }\end{array}$ & $\begin{array}{c}\text { relação de } \\
\text { coleguismo } \\
\text { entre o } \\
\text { entrevistado e } \\
\text { os alunos }\end{array}$ & $\begin{array}{l}\text { O entrevistado mostra ter relação de } \\
\text { coleguismo com alunos brancos e } \\
\text { asiáticos (" ela é uma oriental...Ah ,o } \\
\mathrm{G} \text { é outra pessoa que eu adoro (...) } \\
\text { Ele é branco"), e com a turma da } \\
\text { sala de aula, com quem estuda para } \\
\text { as provas algumas vezes ("aí } \\
\text { quando eu quero estudar com } \\
\text { alguém eu vou estudar com eles."). }\end{array}$ & $\begin{array}{l}\text { Pergunta: Qual são os seus melhores amigos aqui? Resposta: Ahn... Bom, } \\
\text { eu gosto bastante de alguns veteranos, a L do quarto ano, o R do segundo } \\
\text { ano que foi, digamos, o meu padrinho... ele que me deu um apelido que } \\
\text { todo mundo me chama disso...meu apelido foi aos poucos que pegou, } \\
\text { mas... É... o Y, o D o o U, também da república... bastante coisa...Humm.. } \\
\text { Pergunta: E a L, como é que ela é? Resposta: Ah, ela é uma oriental...Ah } \\
\text { o G é outra pessoa que eu adoro, ele participa da oficina vocal, só que } \\
\text { ultimamente ele tá faltando pra estudar também... é, e ele fala muito bem, } \\
\text { bastante estudioso, e eu acho que é o tipo de pessoa que vão pedir o } \\
\text { caderno dele pra conferir anotaçoes, xerocar ou coisa do tipo... É, ele é } \\
\text { mais tímido. Na primeira semana eu tentei me aproximar dele e, acho que } \\
\text { eu tinha me identificado com ele de alguma forma... Pergunta: Ele é loiro, } \\
\text { moreno? Resposta: Ah... Ele é branco, tem os cabelos castanhos escuros, } \\
\text { usa óculos... } \\
\text { Hmmm... Bom, na república de uns amigos aqui perto, de vez em quando } \\
\text { eles varam a noite estudando, principalmente antes de prova, aí quando eu } \\
\text { quero estudar com alguém eu vou estudar com eles....) É, e são da minha } \\
\text { turma, aí eu vou estudar com eles. }\end{array}$ \\
\hline
\end{tabular}




\begin{tabular}{|c|c|c|c|c|}
\hline \multicolumn{5}{|c|}{ ENTREVISTADO B - COTISTA - UNB } \\
\hline CATEGORIA & $\begin{array}{c}\text { SUB- } \\
\text { CATEGORIA }\end{array}$ & INDICADORES & ASPECTOS SIGNIFICATIVOS & RELATOS DE ENTREVISTA \\
\hline identidade étnica & $\frac{\text { negra }}{\text { parda }}$ branca / & & & A questão racial, tipo, eu me declaro negro. \\
\hline $\begin{array}{l}\text { 1. A visibilidade } \\
\text { da diversidade } \\
\text { étnico-racial e a } \\
\text { racialização de si } \\
\text { e do outro }\end{array}$ & & $\begin{array}{l}\text { utilização do } \\
\text { componente étnico- } \\
\text { racial na descrição } \\
\text { das pessoas das } \\
\text { fotos de estudantes } \\
\text { negros, brancos e } \\
\text { asiáticos }\end{array}$ & $\begin{array}{l}\text { o entrevistado descreve as fotos de } \\
\text { pessoas brancas, não identificando a } \\
\text { cor, etnia ou raça da pessoa. A partir } \\
\text { do momento que vê a foto da pessoa } \\
\text { negra, a vincula a uma cor, raça ou } \\
\text { etnia, a negra, e a pessoa asiática, a } \\
\text { japonesa. Observa-se a tendência do } \\
\text { entrevistado ver a pessoa branca como } \\
\text { um ser humano universal e a pessoa } \\
\text { negra como um ser racializado, } \\
\text { pertencente a um grupo racial. }\end{array}$ & $\begin{array}{l}\text { a) A pessoa alegre, parece bem profissional, aparentemente feliz } \\
\text { com o que está fazendo (branca) b) Uma criança estudando, alegre } \\
\text { também por estar... Cara bem esforçada (branca) c) Uma aluna } \\
\text { negra, ela não parece tão feliz como as outras. Ele parece mais } \\
\text { com a cara assim, é esforçada assim d) Parece que está divulgando } \\
\text { o livro, uma japonesa, ta num estande tal. }\end{array}$ \\
\hline $\begin{array}{l}\text { 1. A visibilidade } \\
\text { da diversidade } \\
\text { étnico-racial e a } \\
\text { racialização de si } \\
\text { e do outro }\end{array}$ & & $\begin{array}{l}\text { utilização do } \\
\text { componente étnico- } \\
\text { racial para } \\
\text { descrever } \\
\text { membros da família } \\
\text { e a si próprio }\end{array}$ & $\begin{array}{c}\text { O entrevistado identifica com clareza } \\
\text { os componentes étnico-raciais de sua } \\
\text { família (" laço com os africanos...", " } \\
\text { deve ter rolado uma miscigenação com } \\
\text { os brancos"). }\end{array}$ & $\begin{array}{l}\text { Minha Família. Até onde eu sei minha família é do Piauí, de } \\
\text { Teresina.(..) Minha avó teve dezesseis filhos. (...) Imagino eu que } \\
\text { tem essas, como se fala, esse laço com os africanos, embora creio } \\
\text { eu que até pelas características fisicas e genéticas que, claro, deve } \\
\text { ter rolado uma miscigenação com os brancos e tudo mais. Mas } \\
\text { com certeza a gente pensa essa origem dos africanos. }\end{array}$ \\
\hline
\end{tabular}




\begin{tabular}{|c|c|c|c|}
\hline $\begin{array}{l}\text { 1. A visibilidade } \\
\text { da diversidade } \\
\text { étnico-racial e a } \\
\text { racialização de si } \\
\text { e do outro }\end{array}$ & $\begin{array}{l}\text { noção sobre o } \\
\text { conceito social de } \\
\text { raça na utilização } \\
\text { do componente } \\
\text { étnico-racial na } \\
\text { descrição das } \\
\text { relações sociais }\end{array}$ & $\begin{array}{l}\text { O entrevistado, acha o termo raça } \\
\text { depreciativo e utiliza componentes } \\
\text { étnicos para definir diferenças } \\
\text { presentes nas relações sociais ("o } \\
\text { pessoal da África tem uma certa } \\
\text { cultura e no Brasil tem outra cultura. o } \\
\text { pessoal da África aqui no Brasil já tem } \\
\text { outra cultura") e o componente racial (" } \\
\text { eu me declaro negro (...) pessoa branca } \\
\text { (...) pessoa amarela"). }\end{array}$ & $\begin{array}{l}\text { Eu acho que raça é um termo muito, como se fala, um termo muito } \\
\text { físico, muito genético. Acho que hoje em dia não.É claro que é } \\
\text { fisico e genético, mas é muito depreciativo. Raça é de cachorro, } \\
\text { raça é isso e raça é aquilo. Até na antropologia a gente fala, } \\
\text { preferimos mais a etnia, que implica tanto a aparência física e a } \\
\text { questão cultural também. Eu acho que isso que tem que colocar } \\
\text { mais: a questão cultural, a diferenças do modo de ser da } \\
\text { sociedade. É claro, o pessoal da África tem uma certa cultura e no } \\
\text { Brasil tem outra cultura. O pessoal da África aqui no Brasil já tem } \\
\text { outra cultura e é isso que tem que ser visto, essas diferenças no } \\
\text { modo de ser, no modo de viver, no modo de encarar a realidade, } \\
\text { de estilo de vida, de gosto enfim. Acho que não tem a questão } \\
\text { racial. A questão racial tipo eu me declaro negro e tenho a mesma } \\
\text { capacidade de uma pessoa branca, de uma pessoa amarela. Para } \\
\text { me diferenciar deles é minhas vivências, meu modo de viver, o que } \\
\text { eu experimentei e o que eu busquei, e o que eu não busquei. }\end{array}$ \\
\hline $\begin{array}{c}\text { 2. Visibilidade } \\
\text { sobre a ocorrência } \\
\text { da discriminação } \\
\text { racial }\end{array}$ & $\begin{array}{c}\text { visibilidade do } \\
\text { tratamento desigual } \\
\text { direto ou indireto } \\
\text { que prejudica } \\
\text { socialmente o } \\
\text { negro, seja pela } \\
\text { neutralidade, seja } \\
\text { pela diferenciação } \\
\text { negativa }\end{array}$ & $\begin{array}{l}\text { O entrevistado identifica a presença do } \\
\text { racismo e da discriminação racial na } \\
\text { hierarquização dos grupos diversos. }\end{array}$ & $\begin{array}{l}\text { A questão é que a diversidade gera muito o egocentrismo, por } \\
\text { exemplo, são grupos diferentes que muitas vezes não conseguem } \\
\text { ver perspectivas em outro grupo e isso gera um choque assim. Às } \\
\text { vezes é complicado, você se identifica com um grupo e no seu } \\
\text { pensar pode ser que o seu grupo seja superior ao outro. Às vezes } \\
\text { acontece e ai que rola os choques e você não consegue respeitar a } \\
\text { existência do outro, o espaço do outro. }\end{array}$ \\
\hline
\end{tabular}




\begin{tabular}{|c|c|c|c|}
\hline $\begin{array}{l}\text { 2. Visibilidade } \\
\text { sobre a ocorrência } \\
\text { da discriminação } \\
\text { racial }\end{array}$ & $\begin{array}{l}\text { visibilidade do } \\
\text { tratamento desigual } \\
\text { direto ou indireto } \\
\text { que prejudica } \\
\text { socialmente o } \\
\text { negro, seja pela } \\
\text { neutralidade, seja } \\
\text { pela diferenciação } \\
\text { negativa }\end{array}$ & $\begin{array}{c}\text { O entrevistado manifesta a existência } \\
\text { do racismo e da discriminação racial } \\
\text { nas relações atuais, na universidade } \\
\text { ("Muitos negros que entram por cotas } \\
\text { têm problemas aqui, discriminam por } \\
\text { terem entrado por cotas, } \\
\text { principalmente aqueles que são contra } \\
\text { as cotas"). }\end{array}$ & $\begin{array}{l}\text { Que nem eu falo, essas cotas são algo que querem fazer é } \\
\text { consertar o erro de antigamente com o negro, a questão da } \\
\text { escravidão e também amenizar a questão do racismo hoje em dia. } \\
\text { Só que para mim não funciona assim. Muitos negros que entram } \\
\text { por cotas têm problemas aqui. A gente fala: nossa entrou por cotas } \\
\text { e tal. Às vezes discriminam por terem entrado por cotas, } \\
\text { principalmente aqueles que são contra as cotas. Acontece. }\end{array}$ \\
\hline $\begin{array}{l}\text { 2. Visibilidade } \\
\text { sobre a ocorrência } \\
\text { da discriminação } \\
\text { racial }\end{array}$ & $\begin{array}{l}\text { visibilidade do } \\
\text { tratamento desigual } \\
\text { direto ou indireto } \\
\text { que prejudica } \\
\text { socialmente o } \\
\text { negro, seja pela } \\
\text { neutralidade, seja } \\
\text { pela diferenciação } \\
\text { negativa }\end{array}$ & $\begin{array}{c}\text { Na Universidade, o entrevistado } \\
\text { constata a discriminação racial direta, } \\
\text { contra negros africanos. Contra si, não } \\
\text { vê ou não diz. }\end{array}$ & $\begin{array}{l}\text { Você acha que tem discriminação aqui na universidade? Resposta: } \\
\text { Assim, a gente tem o RU lá é é comum a gente ver grupos de } \\
\text { negros a parte assim, negros africanos inclusive,(...)frases } \\
\text { discriminatórias. ñAh, sai daqui negro e talò(...)Acho que é mais } \\
\text { com os africanos, com os negros africanos do que com os negros } \\
\text { aqui do Brasil. Eu sinceramente nunca vivi preconceito aqui.(...) } \\
\text { Eu sinceramente nunca vivi preconceito aqui. }\end{array}$ \\
\hline $\begin{array}{l}\text { 2. Visibilidade } \\
\text { sobre a ocorrência } \\
\text { da discriminação } \\
\text { racial }\end{array}$ & $\begin{array}{l}\text { visibilidade do } \\
\text { tratamento desigual } \\
\text { direto ou indireto } \\
\text { que prejudica } \\
\text { socialmente o } \\
\text { negro, seja pela } \\
\text { neutralidade, seja } \\
\text { pela diferenciação } \\
\text { negativa }\end{array}$ & $\begin{array}{l}\text { Nesse momento, o entrevistado } \\
\text { manifesta a ocorrência da } \\
\text { discriminação direta, que está mais } \\
\text { próxima a situação em que vive. }\end{array}$ & $\begin{array}{l}\text { Assim, eu falo por mim, eu não me sinto bem por falar que eu } \\
\text { entrei nas cotas, assim. Mas eu já vi muitas histórias assim de } \\
\text { pessoas, de galera falando mal de pessoas que entraram pelas } \\
\text { cotas e tal. Rola uma discriminação mesmo, sabe? }\end{array}$ \\
\hline
\end{tabular}




\begin{tabular}{|c|c|c|c|c|}
\hline $\begin{array}{l}\text { 2. Visibilidade } \\
\text { sobre a ocorrência } \\
\text { da discriminação } \\
\text { racial }\end{array}$ & & $\begin{array}{l}\text { visibilidade do } \\
\text { tratamento desigual } \\
\text { direto ou indireto } \\
\text { que prejudica } \\
\text { socialmente o } \\
\text { negro, seja pela } \\
\text { neutralidade, seja } \\
\text { pela diferenciação } \\
\text { negativa }\end{array}$ & $\begin{array}{l}\text { Na cidade, o entrevistado constata a } \\
\text { discriminação racial direta. }\end{array}$ & $\begin{array}{l}\text { Em Brasília tem. Até que atualmente eu nunca ouvi falar. Mas é } \\
\text { como eu falei, quando eu era criança, teve muita assim, na escola } \\
\text { ta. Isso ainda acontece, por exemplo uma pessoa negra entrar } \\
\text { numa loja a pessoa já vai mostrando e tal.(..) Eu já tive } \\
\text { experiência de preconceito e tal. Ultimamente ate que não, fica } \\
\text { mais no tempo de infância. E realmente marca a pessoa, sabe? }\end{array}$ \\
\hline $\begin{array}{l}\text { 2. Visibilidade } \\
\text { sobre a ocorrência } \\
\text { da discriminação } \\
\text { racial }\end{array}$ & & $\begin{array}{l}\text { visibilidade do } \\
\text { tratamento desigual } \\
\text { direto ou indireto } \\
\text { que prejudica } \\
\text { socialmente o } \\
\text { negro, seja pela } \\
\text { neutralidade, seja } \\
\text { pela diferenciação } \\
\text { negativa }\end{array}$ & $\begin{array}{l}\text { O entrevistado constata a } \\
\text { discriminação direta contra o negro. }\end{array}$ & $\begin{array}{l}\text { Pergunta } 20^{*} \text { primeira etapa: Acho que isso aqui é uma situação } \\
\text { clara de racismo, de discriminação, porque a pessoa branca, o } \\
\text { rapaz mais claro passou tranqüilo e o cara não pediu nada, mas } \\
\text { quando foi um negro, o cara teve que pedir. Pediu a carteirinha. }\end{array}$ \\
\hline 4. Estigma & $\begin{array}{l}\text { na } \\
\text { comunicação } \\
\text { não verbal }\end{array}$ & $\begin{array}{l}\text { escolha de papéis } \\
\text { profissionais para as } \\
\text { pessoas das fotos de } \\
\text { homens e mulheres; } \\
\text { brancos(as) e } \\
\text { negros(as); de faixas } \\
\text { etárias de } 20 \text { a } 30 \\
\text { anos, de } 31 \text { a } 59 \text { anos, } \\
\text { acima de } 60 \text { anos. } \\
\text { Indicadores: } \\
\text { profissionais brancos } \\
\text { (as) - negros (as) e } \\
\text { cargos profissionais } \\
\text { artista, que privilegia } \\
\text { conhecimento } \\
\text { intelectual, manual e }\end{array}$ & $\begin{array}{l}\text { O entrevistado, em sua escolha, não } \\
\text { reproduz o estigma social, } \\
\text { demonstrando estar atento a criar um } \\
\text { quadro mais igualitário. Das } 9 \\
\text { profissões, } 5 \text { foram preenchidas com } \\
\text { pessoas brancas e } 4 \text { com pessoas } \\
\text { negras; sendo que a profissão de artista, } \\
\text { as } 2 \text { que privilegiam conhecimento } \\
\text { intelectual foram preenchidas por pessoas } \\
\text { brancas; as } 2 \text { que são de chefia foram } \\
\text { preenchidas por pessoas negras e as } 4 \\
\text { das que privilegiam trabalho manual } \\
\text { foram preenchidas } 2 \text { por pessoas negras } \\
\text { e } 2 \text { por pessoas brancas. }\end{array}$ & $\begin{array}{l}\text { Profissional Artista: Pianista - mulher branca (figura 21); } \\
\text { Profissão que privilegia conhecimento intelectual: Médico (a) } \\
\text { plantonista - homem branco (figura 25); Professor Universitário - } \\
\text { homem branco (figura 19); } \\
\text { Posições de chefia: Gerente do hotel - homem negro (figura 30); } \\
\text { Diretor (a) de Marketing de uma loja de departamento - homem } \\
\text { negro (figura 17); } \\
\text { privilegiam o trabalho manual: Arrumador (eira) do Hotel - mulher } \\
\text { negra (figura 20); Motorista de ônibus - homem branco (figura } \\
\text { 27); Cabeleireiro(a)) - mulher branca (figura 32); Porteiro(a) do } \\
\text { Hotel - homem negro (figura 28); }\end{array}$ \\
\hline
\end{tabular}




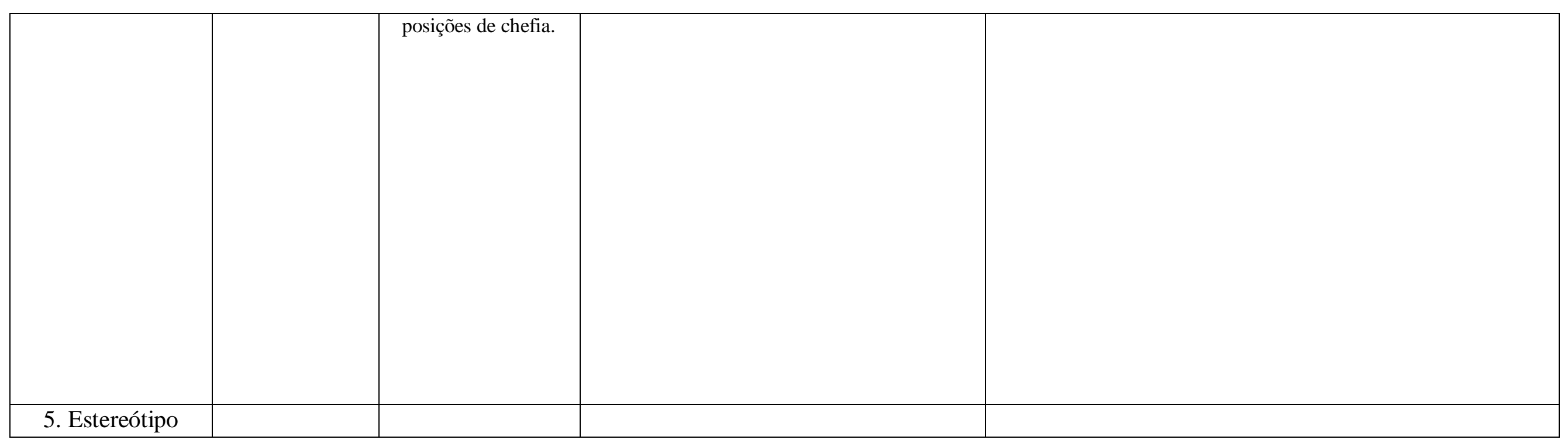




\begin{tabular}{|c|c|c|c|}
\hline $\begin{array}{l}\text { 6. Reações } \\
\text { emocionais na } \\
\text { relação com o } \\
\text { preconceito (com } \\
\text { o diverso) }\end{array}$ & $\begin{array}{l}\text { na } \\
\text { comunicação } \\
\text { verbal }\end{array}$ & $\begin{array}{l}\text { VERGONHA: O entrevistado revela o } \\
\text { desconforto de contar que é cotista. } \\
\text { Vincula as cotas à idéia de que servem } \\
\text { para quem tem menor preparo e } \\
\text { capacidade. Não quer vincular o negro, } \\
\text { nem si próprio, a essa idéia. ("eu sou } \\
\text { cotista, mas ninguém sabe que eu sou. } \\
\text { E eu nunca falei para ninguém", "Me } \\
\text { falaram que ela fez. (...) Não foi ela. } \\
\text { Nem cheguei a comentar com ela", } \\
\text { "Aqui no caso seriam.....as pessoas que } \\
\text { freqüentaram escolas públicas que é } \\
\text { uma merda. (...) E não tiveram o } \\
\text { preparo suficiente para entrar aqui, e } \\
\text { as pesquisas indicam que essas } \\
\text { pessoas são mais negras, não é? (...) } \\
\text { Na verdade as cotas já são injustas por } \\
\text { si só. Por que só para os negros? O } \\
\text { negro é como qualquer outro.) }\end{array}$ & $\begin{array}{l}\text { Pergunta: você conhece algum cotista? Resposta: Cotista?(é ) Eu } \\
\text { vou ser sincero. Eu entrei pelas cotas porque é um modo mais fácil } \\
\text { de entrar para UNB. Eu aproveitei. Então, assim, eu sou cotista, } \\
\text { mas ninguém sabe que eu sou. E eu nunca falei para ninguém. E } \\
\text { outro cotista tem essa menina que eu falei. (..) Me falaram que ela } \\
\text { fez. (...) Não foi ela. Nem cheguei a comentar com ela. (sobre } \\
\text { cotas) Aqui no caso seriam as pessoas pobres, as pessoas que } \\
\text { freqüentaram escolas públicas que é uma merda. E não tiveram o } \\
\text { preparo suficiente para entrar aqui, e as pesquisas indicam que } \\
\text { essas pessoas são mais negras, não é? Mas acho que é errado. } \\
\text { Primeiro, porque o negro é igual a qualquer outro, então eu acho } \\
\text { que muito negro ai não é pobre. O negro ai que tem capacidade e } \\
\text { tem um bom nivel de escolaridade e pode passar tranqüilo na } \\
\text { faculdade, sem precisar das cotas. (..) Na verdade as cotas já são } \\
\text { injustas por si só. Por que só para os negros? O negro é como } \\
\text { qualquer outro. Pergunta: você teria alguma idéia do que poderia } \\
\text { ser feito para melhorar a relação entre negros e brancos? } \\
\text { Resposta: ...o ofoco não deveria tratar o negro como alguém } \\
\text { diferenciado que precisa de cuidados especiais.(...)Ai é um negócio } \\
\text { que eu falo. Eu entrei porque é uma oportunidade, que muita gente } \\
\text { aproveita. Eu necessariamente talvez não precisasse. }\end{array}$ \\
\hline
\end{tabular}




\begin{tabular}{|c|c|c|c|}
\hline $\begin{array}{c}\text { 6. Reações } \\
\text { emocionais na } \\
\text { relação com o } \\
\text { preconceito (com } \\
\text { o diverso) }\end{array}$ & & $\begin{array}{l}\text { MEDO de ser discriminado ("eu não me } \\
\text { sinto bem por falar que eu entrei nas } \\
\text { cotas, assim... Rola uma discriminação } \\
\text { mesmo"). }\end{array}$ & $\begin{array}{l}\text { Assim, eu falo por mim, eu não me sinto bem por falar que eu } \\
\text { entrei nas cotas, assim. Mas eu já vi muitas histórias assim de } \\
\text { pessoas, de galera falando mal de pessoas que entraram pelas } \\
\text { cotas e tal. Rola uma discriminação mesmo, sabe? }\end{array}$ \\
\hline $\begin{array}{c}\text { 6. Reações } \\
\text { emocionais na } \\
\text { relação com o } \\
\text { preconceito (com } \\
\text { o diverso) }\end{array}$ & $\begin{array}{c}\text { culpa, vergonha, } \\
\text { irritabilidade, raiva, } \\
\text { exaustão, confusão } \\
\text { na fala, negação, } \\
\text { medo, } \\
\text { dissimulação, } \\
\text { sensação de } \\
\text { solidão, tristeza, } \\
\text { sensação de não } \\
\text { pertencimento, } \\
\text { impotência, } \\
\text { contradição, } \\
\text { justificativa } \\
\text { defensiva }\end{array}$ & $\begin{array}{l}\text { RAIVA ao se identificar com o aluno } \\
\text { negro que foi prejudicado por um ato } \\
\text { discriminatório de um funcionário. }\end{array}$ & $\begin{array}{l}\text { Pergunta } 20^{*} \text { segunda etapa (- O que você faria se fosse o Gilberto } \\
\text { (negro) na estória hipotética em que lhe foi solicitada a } \\
\text { carteirinha...): É assim ficaria indignado. Não chegaria a } \\
\text { agressão fisica, mas eu iria discutir. }\end{array}$ \\
\hline
\end{tabular}




\begin{tabular}{|c|l|l|l|}
\hline $\begin{array}{c}\text { 6. Reações } \\
\text { emocionais na } \\
\text { relação com o } \\
\text { preconceito (com } \\
\text { o diverso) }\end{array}$ & & $\begin{array}{l}\text { O entrevistado reconhece que } \\
\text { aspectos emocionais difíceis de serem } \\
\text { tratados, presentes no assunto sobre } \\
\text { discriminação. }\end{array}$ & $\begin{array}{l}\text { Pergunta: Você acha que falar sobre discriminação racial é } \\
\text { dificil? Resposta: É complicado, porque até você mesmo pode falar } \\
\text { que é contra e tal, mas pode sair naturalmente. (...). Essa } \\
\text { diferenciação acho que é natural, mas não é racional. Mas é um } \\
\text { assunto dificil, complicado. (rss) }\end{array}$ \\
\hline $\begin{array}{c}\text { 6. Reações } \\
\text { emocionais na } \\
\text { relação com o } \\
\text { preconceito (com } \\
\text { o diverso) }\end{array}$ & & Manifestou tristeza & $\begin{array}{l}\text { chorou quando falou sobre ser cotista. Perguntei sobre a razão da } \\
\text { emoção. Resposta: ... Tristeza pelo assunto, pelo modo como o } \\
\text { assunto é visto hoje em dia. A questão da discriminação do } \\
\text { racismo. }\end{array}$ \\
\hline
\end{tabular}




\begin{tabular}{|c|c|c|c|c|}
\hline $\begin{array}{l}\text { 7. Formas e } \\
\text { Oportunidades de } \\
\text { elaboração das } \\
\text { experiências } \\
\text { relacionadas ao } \\
\text { racismo }\end{array}$ & & $\begin{array}{c}\text { oportunidades de } \\
\text { reflexão sobre o } \\
\text { tema racismo nos } \\
\text { espaços sociais } \\
\text { (família, escola, } \\
\text { mídia, amigos) e } \\
\text { forma que encontra } \\
\text { para lidar com a } \\
\text { situação de } \\
\text { discriminação }\end{array}$ & $\begin{array}{l}\text { A experiência como aluno na } \\
\text { universidade, trouxe mudanças para o } \\
\text { entrevistado com relação ao assunto. } \\
\text { O entrevistado diz que não teve } \\
\text { oportunidades de tratar o assunto no } \\
\text { colégio, mas tem com amigos, e, que } \\
\text { na universidade existiu um espaço de } \\
\text { debate em uma matéria do curso. }\end{array}$ & $\begin{array}{l}\text { Pergunta: Você teve oportunidades de discutir sobre a } \\
\text { discriminação racial, no colégio, com a família, com } \\
\text { amigos? Resposta: Não muito. Tipo amigo sempre rola, às vezes a } \\
\text { gente sempre conversa: ñPô aconteceu isso, tipo pá e talò. Uma } \\
\text { discussão mais fundamentada foi na universidade. (...) Depois de } \\
\text { entrar aqui? Alterou, porque antes de entrar aqui eu tinha essa } \\
\text { visão de raças mesmo, de ter realmente essa diferenciação. Eu já } \\
\text { tive experiência de preconceito e tal. Ultimamente ate que não, } \\
\text { fica mais no tempo de infância. E realmente marca a pessoa, sabe? } \\
\text { Por que a gente tem aquele impacto assime na sociedade, vê que } \\
\text { na escola não tem muito essa instrução nesse sentido de } \\
\text { desmascarar esse mito de diferença racial. Não tem essa questão. } \\
\text { E foi uma coisa que eu vim estudar mais aqui. Por exemplo, numa } \\
\text { matéria de antropologia que eu vim estudar mais essa questão } \\
\text { aqui. De ter essas diferenças culturais, e não raciais. De ter esse } \\
\text { enfoque de diversidade cultural, de diversidade de religiões de } \\
\text { culturas, de regiões em si. }\end{array}$ \\
\hline $\begin{array}{l}\text { 8. Abordagem } \\
\text { teórica sobre o } \\
\text { tema }\end{array}$ & $\begin{array}{l}\text { Diversidade } x \\
\text { Igualdade } x \\
\text { Racismo }\end{array}$ & $\begin{array}{l}\text { Confusão sobre os } \\
\text { agrupamentos na } \\
\text { diversidade, sobre } \\
\text { a diferenciação } \\
\text { positiva - a } \\
\text { diferenciação } \\
\text { negativa (quando é } \\
\text { um valor a } \\
\text { diversidade e } \\
\text { quando não é). }\end{array}$ & $\begin{array}{l}\text { O entrevistado acha o termo raça } \\
\text { depreciativo pois lhe remete à idéia de } \\
\text { inferioridade e superioridade, associa a } \\
\text { idéia de avaliação de capacidade dos } \\
\text { membros do grupo, e não somente de } \\
\text { constatação da diversidade. }\end{array}$ & $\begin{array}{l}\text { Eu acho que raça é um termo muito, como se fala, um termo muito } \\
\text { físico, muito genético. Acho que hoje em dia não.É claro que é } \\
\text { físico e genético, mas é muito depreciativo. Raça é de cachorro, } \\
\text { raça é isso e raça é aquilo. Até na antropologia a gente fala, } \\
\text { preferimos mais a etnia, que implica tanto a aparência fisica e a } \\
\text { questão cultural também. (...). A questão racial tipo eu me declaro } \\
\text { negro e tenho a mesma capacidade de uma pessoa branca, de uma } \\
\text { pessoa amarela.... }\end{array}$ \\
\hline
\end{tabular}




\begin{tabular}{|c|c|c|c|c|}
\hline $\begin{array}{l}\text { 8. Abordagem } \\
\text { teórica sobre o } \\
\text { tema }\end{array}$ & $\begin{array}{l}\text { Diversidade } x \\
\text { Igualdade } x \\
\text { Racismo }\end{array}$ & $\begin{array}{l}\text { Confusão sobre os } \\
\text { agrupamentos na } \\
\text { diversidade, sobre } \\
\text { a diferenciação } \\
\text { positiva - a } \\
\text { diferenciação } \\
\text { negativa (quando é } \\
\text { um valor a } \\
\text { diversidade e } \\
\text { quando não é). }\end{array}$ & $\begin{array}{l}\text { O entrevistado se contradiz ao colocar } \\
\text { como um valor a especificidade do ser } \\
\text { humano, mas não acredita que negros } \\
\text { e brancos são diferenciáveis, isto é, } \\
\text { que a diferença entre negros e brancos } \\
\text { deva ser valorizada. ("valorizado na } \\
\text { medida de sua especificidade, } \\
\text { claro...Acho que o respeito à } \\
\text { diversidade", "Por que ai você está } \\
\text { diferenciando algo que não é } \\
\text { diferençável. Direitos humanos, negros } \\
\text { e brancos são humanos de qualquer } \\
\text { jeito") }\end{array}$ & $\begin{array}{l}\text { Eu acho que direitos humanos seriam tá dando esse espaço para } \\
\text { pessoa, esse valor. Vendo a pessoa como humano, valorizado na } \\
\text { medida de sua especificidade, claro...Acho que o respeito à } \\
\text { diversidade. Pergunta: Você acha que o direito dos negros é um } \\
\text { tema dos direitos humanos? Resposta: Por que ai vocêe está } \\
\text { diferenciando algo que não é diferençável. Direitos humanos, } \\
\text { negros e brancos são humanos de qualquer jeito.(...)Que você acha } \\
\text { da diversidade?Resposta: Acho fundamental. Muito bom. Bom } \\
\text { tanto para ter essa riqueza cultural. Riqueza tanto cultural como } \\
\text { acadêmica,... E cultura nem precisa falar, é fundamental ter essa } \\
\text { diferença, ter essa riqueza de modo de ser humano. }\end{array}$ \\
\hline
\end{tabular}




\begin{tabular}{|c|c|c|c|c|}
\hline $\begin{array}{l}\text { 8. Abordagem } \\
\text { teórica sobre o } \\
\text { tema }\end{array}$ & $\begin{array}{l}\text { Diversidade } \mathrm{x} \\
\text { Igualdade } \mathrm{x} \\
\text { Racismo }\end{array}$ & $\begin{array}{l}\text { Confusão sobre os } \\
\text { agrupamentos na } \\
\text { diversidade, sobre } \\
\text { a diferenciação } \\
\text { positiva - a } \\
\text { diferenciação } \\
\text { negativa (quando é } \\
\text { um valor a } \\
\text { diversidade e } \\
\text { quando não é). }\end{array}$ & $\begin{array}{l}\text { O entrevistado vincula a diferenciação } \\
\text { institucional positiva a algo } \\
\text { depreciativo, a discriminação positiva } \\
\text { à condição de "incapacidade" do grupo } \\
\text { discriminado,; apesar de valorizar } \\
\text { "muito, muito" o respeito às } \\
\text { diversidades ("as pessoas que } \\
\text { freqüentaram escolas públicas que é } \\
\text { uma merda. E não tiveram o preparo } \\
\text { suficiente para entrar aqui, e as } \\
\text { pesquisas indicam que essas pessoas } \\
\text { são mais negras, não é? Mas acho que } \\
\text { é errado. Primeiro, porque o negro é } \\
\text { igual a qualquer outro,"). }\end{array}$ & $\begin{array}{l}\text { Pergunta: Que você acha da diversidade?Resposta: Acho } \\
\text { fundamental. Muito bom. Bom tanto para ter essa riqueza cultural. } \\
\text { Riqueza tanto cultural como acadêmica, ... E cultura nem precisa } \\
\text { falar, é fundamental ter essa diferença, ter essa riqueza de modo } \\
\text { de ser humano. Acho isso muito legal, muito.(..) (sobre cotas) Aqui } \\
\text { no caso seriam as pessoas pobres, as pessoas que freqüentaram } \\
\text { escolas públicas que é uma merda. E não tiveram o preparo } \\
\text { suficiente para entrar aqui, e as pesquisas indicam que essas } \\
\text { pessoas são mais negras, não é? Mas acho que é errado. Primeiro, } \\
\text { porque o negro é igual a qualquer outro, então eu acho que muito } \\
\text { negro ai não é pobre. O negro ai que tem capacidade e tem um } \\
\text { bom nível de escolaridade e pode passar tranqüilo na faculdade, } \\
\text { sem precisar das cotas.(..) Na verdade as cotas já são injustas por } \\
\text { si só.Por que só para os negros? O negro é como qualquer } \\
\text { outro.Pergunta: você teria alguma idéia do que poderia ser feito } \\
\text { para melhorar a relação entre negros e brancos? Resposta: ...o } \\
\text { foco não deveria tratar o negro como alguém diferenciado que } \\
\text { precisa de cuidados especiais.(..) }\end{array}$ \\
\hline $\begin{array}{l}\text { 8. Abordagem } \\
\text { teórica sobre o } \\
\text { tema }\end{array}$ & $\begin{array}{l}\text { Diversidade } \mathrm{x} \\
\text { Igualdade } \mathrm{x} \\
\text { Racismo }\end{array}$ & $\begin{array}{l}\text { Confusão sobre os } \\
\text { agrupamentos na } \\
\text { diversidade, sobre } \\
\text { a diferenciação } \\
\text { positiva - a } \\
\text { diferenciação } \\
\text { negativa (quando é } \\
\text { um valor a } \\
\text { diversidade e } \\
\text { quando não é). }\end{array}$ & $\begin{array}{c}\text { O entrevistado revela uma confusão } \\
\text { com relação à definição da conduta } \\
\text { racista. Considerou racista o ato do } \\
\text { balconista que diferentemente do } \\
\text { tratamento dado ao branco, pediu-lhe a } \\
\text { carteirinha e Ihe impediu de entrar. } 0 \\
\text { fato de ele ajudar o seu amigo negro a } \\
\text { entrar, para o entrevistado, pode ser } \\
\text { considerado um ato racista ("porque } \\
\text { isso também poderia ser denunciado } \\
\text { como racismo") }\end{array}$ & $\begin{array}{l}\text { Pergunta } 20 * \text { segunda etapa: } E \text { então eu ia tentar fazer ele entrar } \\
\text { o Gilberto, colega negro), claro ciente também dos nossos } \\
\text { direitos, porque isso também poderia ser denunciado como } \\
\text { racismo. }\end{array}$ \\
\hline
\end{tabular}




\begin{tabular}{|c|c|c|c|c|}
\hline \multirow[t]{2}{*}{$\begin{array}{l}\text { 8. Abordagem } \\
\text { teórica sobre o } \\
\text { tema }\end{array}$} & $\begin{array}{l}\text { Relação do } \\
\text { racismo com } \\
\text { os princípios } \\
\text { de direito } \\
\text { fundamentais }\end{array}$ & $\begin{array}{l}\text { reconhecimento da } \\
\text { política como um } \\
\text { direito fundamental }\end{array}$ & $\begin{array}{l}\text { O entrevistado, apesar de considerar a } \\
\text { diversidade fundamental e valorizar o } \\
\text { direito à diversidade, entende a } \\
\text { discriminação positiva do negro como } \\
\text { "cuidados especiais" e não como um } \\
\text { direito. }\end{array}$ & $\begin{array}{l}\text { Pergunta: Que você acha da diversidade?Resposta: Acho } \\
\text { fundamental. Muito bom. Bom tanto para ter essa riqueza cultural. } \\
\text { Riqueza tanto cultural como acadêmica, (...)Respeito à } \\
\text { diferenciação junto com considerar todos como seres humanos, } \\
\text { independente de raça cultura, religião e tudo mais. (...)Pergunta: } \\
\text { você teria alguma idéia do que poderia ser feito para melhorar a } \\
\text { relação entre negros e brancos? Resposta: ...o foco não deveria } \\
\text { tratar o negro como alguém diferenciado que precisa de cuidados } \\
\text { especiais. }\end{array}$ \\
\hline & $\begin{array}{l}\text { Relação do } \\
\text { racismo com } \\
\text { os princípios } \\
\text { de direito } \\
\text { fundamentais }\end{array}$ & $\begin{array}{l}\text { reconhecimento do } \\
\text { direito a ser tratado } \\
\text { desigualmente ( } \\
\text { discriminação } \\
\text { positiva) }\end{array}$ & $\begin{array}{l}\text { O entrevistado não reconhece a } \\
\text { discriminação positiva como um } \\
\text { componente da aplicação do direito à } \\
\text { igualdade e à diversidade, no propósito } \\
\text { da eliminação da discriminação racial. } \\
\text { Vincula a razão das cotas à idéia de } \\
\text { incapacidade meritória, de algo que } \\
\text { alguém precisa porque não teria } \\
\text { capacidade para entrar de outra forma. } \\
\text { Assim, discorda de vincular essa idéia } \\
\text { ao negro ("O negro ai que tem } \\
\text { capacidade e tem um bom nível de } \\
\text { escolaridade e pode passar tranqüilo } \\
\text { na faculdade, sem precisar das cotas"). }\end{array}$ & $\begin{array}{l}\text { Pergunta: O que você entende por Direitos Humanos? Resposta: } \\
\text { Direito à liberdade, direito a se expressar. Eu acho que direitos } \\
\text { humanos seriam tá dando esse espaço para pessoa, esse valor. } \\
\text { Vendo a pessoa como humano, valorizado na medida de sua } \\
\text { especificidade, claro...Acho que o respeito à diversidade. } \\
\text { Pergunta: Você acha que o direito dos negros é um tema dos } \\
\text { direitos humanos? Resposta: Por que ai você está diferenciando } \\
\text { algo que não é diferençável. Direitos humanos, negros e brancos } \\
\text { são humanos de qualquer jeito. Pergunta: Discriminação racial é } \\
\text { um tema de direitos humanos para você? Resposta: É, pois é, ai eu } \\
\text { fico pensando tipo não seria um tema em sim. Eu acho que um } \\
\text { tema relacionado a isso seria respeito à diversidade. Respeito à } \\
\text { diferenciação junto com considerar todos como seres humanos, } \\
\text { independente de raça cultura, religião e tudo mais. Não ter } \\
\text { racismo, essa discriminação e essa discrepância que se cria com o } \\
\text { racismo assim. } \quad \text { (...) (sobre cotas) Mas acho que é errado. } \\
\text { Primeiro, porque o negro é igual a qualquer outro, então eu acho } \\
\text { que muito negro ai não é pobre. O negro ai que tem capacidade e } \\
\text { tem um bom nivel de escolaridade e pode passar tranqüilo na } \\
\text { faculdade, sem precisar das cotas. }\end{array}$ \\
\hline
\end{tabular}




\begin{tabular}{|c|c|c|c|}
\hline $\begin{array}{l}\text { 9. Manifestação } \\
\text { da solidariedade }\end{array}$ & $\begin{array}{l}\text { crença de que a } \\
\text { relação multi- } \\
\text { étnica enriquece e } \\
\text { auxilia a } \\
\text { coletividade, na } \\
\text { solução de } \\
\text { problemas } \\
\text { coletivos e } \\
\text { individuais; } \\
\text { disponibilidade } \\
\text { para a busca real } \\
\text { de soluções para } \\
\text { o racismo } \\
\end{array}$ & $\begin{array}{l}\text { O entrevistado acredita que a } \\
\text { convivência multi-étnica é positiva e } \\
\text { auxilia coletividade ("Riqueza tanto } \\
\text { cultural como acadêmica"). }\end{array}$ & $\begin{array}{l}\text { Pergunta: Que você acha da diversidade?Resposta: Acho } \\
\text { fundamental. Muito bom. Bom tanto para ter essa riqueza cultural. } \\
\text { Riqueza tanto cultural como acadêmica, a produçấo científica se } \\
\text { dá de várias perspectivas, de vários modos. Por exemplo, a pessoa } \\
\text { pode estar produzindo certo conhecimento diferente do outro e a } \\
\text { pessoa pode estar trabalhando a mesma coisa, completamente } \\
\text { diferente. E cultura nem precisa falar, é fundamental ter essa } \\
\text { diferença, ter essa riqueza de modo de ser humano. Acho isso } \\
\text { muito legal, muito. }\end{array}$ \\
\hline $\begin{array}{l}\text { 9. Manifestação } \\
\text { da solidariedade }\end{array}$ & $\begin{array}{c}\text { crença de que a } \\
\text { relação multi- } \\
\text { étnica auxilia a } \\
\text { coletividade, na } \\
\text { solução de } \\
\text { problemas } \\
\text { coletivos e } \\
\text { individuais; } \\
\text { disponibilidade } \\
\text { para a busca real } \\
\text { de soluções para } \\
\text { o racismo }\end{array}$ & $\begin{array}{l}\text { O entrevistado não acredita que } \\
\text { valorizar, apontar a diferença seja uma } \\
\text { forma de diminuir o racismo. }\end{array}$ & $\begin{array}{l}\text { Chamar evento só para os negros, tal. Coisa assim acaba mais } \\
\text { aumentando essa diferenciação do que diminuindo. Acho que tem } \\
\text { que tratar como qualquer outra. }\end{array}$ \\
\hline
\end{tabular}




\begin{tabular}{|c|c|c|c|}
\hline $\begin{array}{l}\text { 10. Integração } \\
\text { com as ofertas de } \\
\text { desenvolvimento } \\
\text { da Universidade }\end{array}$ & $\begin{array}{l}\text { Integração com os } \\
\text { colegas da } \\
\text { universidade; } \\
\text { oportunidades } \\
\text { profissionais que } \\
\text { surgem a partir } \\
\text { dessa integração; } \\
\text { acesso às } \\
\text { oportunidades que } \\
\text { o ambiente } \\
\text { acadêmico oferece }\end{array}$ & $\begin{array}{l}\text { O entrevistado está integrada com as } \\
\text { atividades da Universidade, trabalha e } \\
\text { estuda na empresa ligada à } \\
\text { universidade, que ficou sabendo por } \\
\text { divulgação e, junto com o colega } \\
\text { branco, apoiaram-se entrando junto. A } \\
\text { partir de relação com os professores } \\
\text { conseguem oportunidades } \\
\text { acadêmicas. ("Eu soube pela } \\
\text { divulgação das salas. Teve um amigo } \\
\text { do meu semestre que entrou junto", } \\
\text { "Essa em especifico a professora } \\
\text { divulgou a vaga lá na empresa onde eu } \\
\text { trabalho. A gente tem contatos com } \\
\text { professores e às vezes aparece") }\end{array}$ & $\begin{array}{l}\text { Pergunta: Como que é a tua vida na universidade? Resposta: } \\
\text { Praticamente o dia todo. Venho de manhã e dificilmente eu volto } \\
\text { para casa à tarde. Eu estudo e participo da empresa, ligada à } \\
\text { universidade. Porque, a maior empresa ligada à universidade são } \\
\text { as de telecomunicaçáoé Pergunta: Como você entrou nesse } \\
\text { trabalho? Resposta: Porque na empresa se faz processo seletivo } \\
\text { todo ano.... Eu soube pela divulgação das salas. Teve um amigo do } \\
\text { meu semestre que entrou junto. ... É eu estou tentando entrar } \\
\text { agora numa bolsa de iniciação científica. Essa em especifico a } \\
\text { professora divulgou a vaga lá na empresa onde eu trabalho. A } \\
\text { gente tem contatos com professores e às vezes aparece, ta rolando } \\
\text { vaga e a gente pesquisa e tal.E esse teu amigo que entrou com vocêe } \\
\text { na empresa, como ele é? Resposta: É. É a pessoa que eu mais } \\
\text { considero aqui na universidade.Ele é branco, com cabelos } \\
\text { castanhos. Ele tem uma mecha branca natural aqui. }\end{array}$ \\
\hline $\begin{array}{l}\text { 10. Integração } \\
\text { com as ofertas de } \\
\text { desenvolvimento } \\
\text { da Universidade }\end{array}$ & $\begin{array}{c}\text { relação de } \\
\text { coleguismo entre } \\
\text { o entrevistado e } \\
\text { os alunos }\end{array}$ & $\begin{array}{l}\text { O entrevistado demonstra manter } \\
\text { relações de coleguismos com os } \\
\text { alunos que acabam lhe } \\
\text { proporcionando, inclusive } \\
\text { oportunidades de trabalho e extensão } \\
\text { acadêmica.. }\end{array}$ & $\begin{array}{l}\text { Pergunta: E você além dele tem mais amigos aqui? Resposta: } \\
\text {...Tenho, o pessoal da empresa, me dou bem com todo mundo. } \\
\text { Considero todos amigos. Outras pessoas de meu semestre também } \\
\text { eu considero meus amigos, não todos, mas alguns contatos. Umas } \\
\text { sete ou oito pessoas...Tem uma que é bem próxima...Ela mora bem } \\
\text { perto de mim. Muitas vezes quando eu vou para casa ela vai } \\
\text { comigo, a gente vai junto....Ela tem a pele morena, escura assim, } \\
\text { mas não preta, mais clara que eu. ...Tem um cara que eu considero } \\
\text { bastante que está saindo da psicologia, do curso e o cara é } \\
\text { comédia demais.E fisicamente é bem alto, com cabelos escuros, e } \\
\text { branco, meio amarelado }\end{array}$ \\
\hline
\end{tabular}




\begin{tabular}{|c|c|c|c|c|}
\hline & & & $\begin{array}{c}\text { ENTREVISTADO C - COTISTA - } \\
\text { UNIFESP }\end{array}$ & \\
\hline CATEGORIA & $\begin{array}{c}\text { SUB- } \\
\text { CATEGORIA }\end{array}$ & INDICADORES & ASPECTOS SIGNIFICATIVOS & RELATOS DE ENTREVISTA \\
\hline identidade étnica & $\begin{array}{l}\text { negra / branca / } \\
\text { parda }\end{array}$ & & & ...eu mesmo sou uma mistura. \\
\hline $\begin{array}{l}\text { 1. A visibilidade } \\
\text { da diversidade } \\
\text { étnico-racial e } \\
\text { a racialização de } \\
\text { si e do outro }\end{array}$ & & $\begin{array}{c}\text { utilização do } \\
\text { componente étnico- } \\
\text { racial na descrição } \\
\text { das pessoas das } \\
\text { fotos de estudantes } \\
\text { negros, brancos e } \\
\text { asiáticos }\end{array}$ & $\begin{array}{l}\text { A entrevistada descreve todas as fotos, } \\
\text { desde o início, vinculando as pessoas a } \\
\text { uma cor, raça ou etnia. }\end{array}$ & $\begin{array}{l}\text { a) Uma mulher branca, numa biblioteca... rapaz, bem vestido, } \\
\text { louro, branco... b) É uma... acho que é japonesa... c) Aqui tem } \\
\text { uma menina negra, tá maquiada, também na biblioteca } \\
\text { estudando }\end{array}$ \\
\hline $\begin{array}{l}\text { 1. A visibilidade } \\
\text { da diversidade } \\
\text { étnico-racial e a } \\
\text { racialização de } \\
\text { si e do outro }\end{array}$ & & $\begin{array}{c}\text { utilização do } \\
\text { componente étnico- } \\
\text { racial para } \\
\text { descrever membros } \\
\text { da família e a si } \\
\text { próprio }\end{array}$ & $\begin{array}{l}\text { A entrevistada identifica com clareza os } \\
\text { componentes étnico-raciais dos } \\
\text { membros de sua família (" meu avô } \\
\text { veio da África...", " eles são brancos e } \\
\text { só os do meu pai são negros"). }\end{array}$ & $\begin{array}{l}\text { Ah, não sei... Meu pai veio da Bahia quando era pequeno... } \\
\text { Meu vô era da Bahia e parece que o pai do meu avô veio da } \\
\text { África, era escravo africano... Não sei, meu pai tava contando, } \\
\text { mas eu não lembro.E aí eu nasci aqui em São Paulo mesmo, } \\
\text { meu pai casou com minha mãe ela era bem branca, bem } \\
\text { branca mesmo, minha vó tem quase olho claro, tinha olho } \\
\text { claro... Não sei ... eram os parentes da minha mãe, eu não sei; } \\
\text { mas eles são brancos e só os do meu pai são negros. Meu pai, } \\
\text { meu vô era de alguma parte da África e minha avó parece que } \\
\text { era de Portugal, os parentes dela eram de Portugal. Então é } \\
\text { bem misturado (riso). }\end{array}$ \\
\hline $\begin{array}{l}\text { 1. A visibilidade } \\
\text { da diversidade } \\
\text { étnico-racial e a } \\
\text { racialização de } \\
\text { si e do outro }\end{array}$ & & $\begin{array}{c}\text { noção sobre o } \\
\text { conceito social de } \\
\text { raça na utilização do } \\
\text { componente étnico- } \\
\text { racial na descrição } \\
\text { das relações sociais }\end{array}$ & $\begin{array}{c}\text { Apesar de a entrevistada ter } \\
\text { tranqüilidade em expressar-se } \\
\text { racializando os grupos, não visualiza a } \\
\text { diferenciação étnico-racial nas relações } \\
\text { sociais atuais ou procura não ver. Não } \\
\text { utiliza o conceito social de raça na sua } \\
\text { avaliação ("eu penso mais em raça } \\
\text { antigamente"). }\end{array}$ & $\begin{array}{l}\text { Pergunta: Você acha que então, existem raças entre os seres } \\
\text { humanos? } \\
\text { Resposta: Ah, existe. Ta... É assim, eu penso mais em raça } \\
\text { antigamente, ah, meu vô era; porque agora já virou essa } \\
\text { bagunça né, eu mesmo sou uma mistura. E... Mas antigamente } \\
\text { sim, tinha os negros, os brancos, os japoneses, mas agora já } \\
\text { tem, já misturou tudo, agora...Sobrou assim, pardo. }\end{array}$ \\
\hline
\end{tabular}




\begin{tabular}{|c|c|c|c|}
\hline $\begin{array}{l}\text { 1. A visibilidade } \\
\text { da diversidade } \\
\text { étnico-racial e a } \\
\text { racialização de } \\
\text { si e do outro }\end{array}$ & $\begin{array}{l}\text { noção sobre o } \\
\text { conceito social de } \\
\text { raça na utilização do } \\
\text { componente étnico- } \\
\text { racial na descrição } \\
\text { das relações sociais }\end{array}$ & $\begin{array}{c}\text { A entrevistada reconhece o fenômeno } \\
\text { da racialização do grupo negro e a } \\
\text { universalização do grupo branco } \\
\text { ("então os brancos são os paulistas } \\
\text { que não tem sotaque") }\end{array}$ & $\begin{array}{l}\text { Japoneses eu penso em disciplina, eu penso em inteligência, } \\
\text { e, como é que fala, em grupo fechado, grupo mais reservado... } \\
\text { Eles são muito reservados. Hmm, branco, ah, o branco eu } \\
\text { penso que seja assim, um... Aqui em São Paulo pelo menos, é } \\
\text { como se... İ só fazendo uma comparação, o paulista fala que } \\
\text { não tem sotaque, né, quem tem sotaque é quem tem, quem é de } \\
\text { fora, então, o branco pensa que é o padrão, existem as outras } \\
\text { né. Porque a gente aqui em São Paulo vive a maioria sendo } \\
\text { branca ï quer dizer, a maioria... Ah, não sei, pelo menos no } \\
\text { meu ambiente aqui a maioria é branca, então os brancos são } \\
\text { os paulistas que não tem sotaque (riso).(...)Essa é uma } \\
\text { característica de um grupo dos negros, né, eu penso na } \\
\text { cultura negra também é uma característica, as religiões, né, } \\
\text { principalmente as religiões, músicas... Daí as músicas também } \\
\text { já misturou com a dos brancos, (...) Pra mim já ta bem } \\
\text { misturado, né... Eu não sinto tanta, tantas coisas diferentes } \\
\text { entre os dois... Só dos japoneses... (riso) }\end{array}$ \\
\hline $\begin{array}{l}\text { 2. Visibilidade } \\
\text { sobre a } \\
\text { ocorrência da } \\
\text { discriminação } \\
\quad \text { racial }\end{array}$ & $\begin{array}{c}\text { visibilidade do } \\
\text { tratamento desigual } \\
\text { direto ou indireto } \\
\text { que prejudica } \\
\text { socialmente o negro, } \\
\text { seja pela } \\
\text { neutralidade, seja } \\
\text { pela diferenciação } \\
\text { negativa }\end{array}$ & $\begin{array}{l}\text { Observa-se que só foi possível } \\
\text { constatar a discriminação racial } \\
\text { institucional quando foi invertido o } \\
\text { papel social dos grupos branco e } \\
\text { negros de ocupação de local de } \\
\text { privilégio na sociedade. }\end{array}$ & $\begin{array}{l}\text { Pergunta: Se você entrasse em uma universidade ou uma } \\
\text { escola e visse que o dono é negro e contratou só profissionais } \\
\text { negros, você acharia ele racista? Resposta: Sim.Pergunta: } \\
\text { Você acha que a universidade, ela é racista?Resposta: A } \\
\text { universidade, esta?Não. Pergunta: Você tem algum professor } \\
\text { negro? Resposta: Não, acho que não. }\end{array}$ \\
\hline
\end{tabular}




\begin{tabular}{|c|c|c|c|}
\hline $\begin{array}{l}\text { 2. Visibilidade } \\
\text { sobre a } \\
\text { ocorrência da } \\
\text { discriminação } \\
\text { racial }\end{array}$ & $\begin{array}{l}\text { visibilidade do } \\
\text { tratamento desigual } \\
\text { direto ou indireto } \\
\text { que prejudica } \\
\text { socialmente o negro, } \\
\text { seja pela } \\
\text { neutralidade, seja } \\
\text { pela diferenciação } \\
\text { negativa }\end{array}$ & $\begin{array}{l}\text { Constata a ocorrência da discriminação } \\
\text { direta na cidade. }\end{array}$ & $\begin{array}{l}\text { Pergunta: Em São Paulo você acha que tem } \\
\text { racismo?Resposta: Tem bastante...Tem... a gente } \\
\text { observa...Pergunta: Como é que assim se manifesta o } \\
\text { racismo? Da onde você tira a idéia de que tem?Resposta:Do } \\
\text { medo das pessoas, por exemplo, se uma pessoa não negra, vai, } \\
\text { digamos assim, tá andando na rua e vê um menino negro, já } \\
\text { fica preocupada, achando que vai ser assaltada, não sei o } \\
\text { que... Mas não faz sentido, já está comprovado, assim, as } \\
\text { pessoas sabem que não tem horário pra ser assaltado, o } \\
\text { bandido não tem cara de bandido sabe, qualquer pessoa pode } \\
\text { ser bandido, pode te assaltar, mas mesmo assim ainda } \\
\text { continua as pessoas achando que ñah, se eu passar na favela } \\
\text { eu vou ser assaltadoò, e na favela tem muitos negros, então eu } \\
\text { vejo que existe mas eu não concordo com isso; eu tenho medo } \\
\text { de qualquer pessoa e em qualquer horário, não por ser na tal } \\
\text { região e por ser negro, ñah, se vier um branquinho, ah, então } \\
\text { tá sossegadoò, não. }\end{array}$ \\
\hline $\begin{array}{l}\text { 2. Visibilidade } \\
\text { sobre a } \\
\text { ocorrência da } \\
\text { discriminação } \\
\text { racial }\end{array}$ & $\begin{array}{l}\text { visibilidade do } \\
\text { tratamento desigual } \\
\text { direto ou indireto } \\
\text { que prejudica } \\
\text { socialmente o negro, } \\
\text { seja pela } \\
\text { neutralidade, seja } \\
\text { pela diferenciação } \\
\text { negativa }\end{array}$ & $\begin{array}{l}\text { Visibilidade da discriminação direta; a } \\
\text { entrevistada vincula a discriminação ao } \\
\text { espaço de privilégio ("...é... esse } \\
\text { negócio da presença dos negros na } \\
\text { universidade é muito recente...elas não } \\
\text { estão acostumadas ainda a verem } \\
\text { negros na universidade", "o projeto de } \\
\text { inclusão das cotas é um bom exemplo } \\
\text { porque estaria colocando negros num } \\
\text { ambiente que era só de brancos (...) } \\
\text { Talvez as pessoas que estavam na } \\
\text { universidade nunca tinham conversado } \\
\text { com um negro") }\end{array}$ & $\begin{array}{l}\text { Pergunta } 20 \text { ï primeira etapa * Resposta: Eu acho que isso } \\
\text { que isso aconteceu porque, é... esse negócio da presença dos } \\
\text { negros na universidade é muito recente, então talvez o } \\
\text { funcionário que tava na porta, as pessoas do balcão e tal, elas } \\
\text { não estão acostumadas ainda a verem negros na universidade. } \\
\text { (...) ... o projeto de inclusão das cotas é um bom exemplo } \\
\text { porque estaria colocando negros num ambiente que era só de } \\
\text { brancos e isso acaba aumentando mesmo a convivência. } \\
\text { Talvez as pessoas que estavam na universidade nunca tinham } \\
\text { conversado com um negro, }\end{array}$ \\
\hline
\end{tabular}




\begin{tabular}{|c|c|c|c|}
\hline $\begin{array}{l}\text { 2. Visibilidade } \\
\text { sobre a } \\
\text { ocorrência da } \\
\text { discriminação } \\
\text { racial }\end{array}$ & $\begin{array}{l}\text { visibilidade do } \\
\text { tratamento desigual } \\
\text { direto ou indireto } \\
\text { que prejudica } \\
\text { socialmente o negro, } \\
\text { seja pela } \\
\text { neutralidade, seja } \\
\text { pela diferenciação } \\
\text { negativa }\end{array}$ & $\begin{array}{l}\text { A entrevistada percebe que o fato das } \\
\text { pessoas relacionarem as cotas a uma } \\
\text { questão de desvantagem econômica } \\
\text { social e não à questão racial facilita a } \\
\text { aceitação dos cotistas na universidade } \\
\text { ("tem tantas pessoas que concorda por } \\
\text { saber que essa questão... é... motivo } \\
\text { deles colocarem as cotas pode ser por } \\
\text { causa do ensino médio"). }\end{array}$ & $\begin{array}{l}\text { Pergunta: você acha que o processo de vestibular por cotas } \\
\text { aumenta o racismo?Resposta: Hum... Eu acho que ao mesmo } \\
\text { tempo que... Ah, é dificil (riso). Não sei se aumenta... Se } \\
\text { aumenta também tem o outro lado que diminui, porque tem } \\
\text { tantas pessoas que concorda por saber que essa questão... é... } \\
\text { motivo deles colocarem as cotas pode ser por causa do ensino } \\
\text { médio que não tá bom e tal, ao mesmo tempo que tem essas } \\
\text { pessoas que tomam consciência disso e dizem ñAh não, } \\
\text { verdade, eu sou a favorò }\end{array}$ \\
\hline $\begin{array}{l}\text { 3. Visibilidade } \\
\text { sobre as } \\
\text { consequências } \\
\text { do racismo, os } \\
\text { danos e os } \\
\text { privilégios }\end{array}$ & $\begin{array}{l}\text { visibilidade do } \\
\text { prejuízo social para } \\
\text { o negro }\end{array}$ & $\begin{array}{l}\text { A entrevistada, em um momento, } \\
\text { reconhece a diferença do branco e do } \\
\text { negro na ocupação do espaço social, } \\
\text { mencionando uma vulnerabilidade do } \\
\text { negro ao ter a necessidade de se } \\
\text { descaracterizar etnicamente para ser } \\
\text { incluído ("é que e a pessoa negra, eu } \\
\text { acho que ela se preocupa mais com a } \\
\text { imagem que ela vai passar porque é } \\
\text { como que se uma pessoa negra tivesse } \\
\text { sempre querendo se igualar e o branco } \\
\text { já não tem essa preocupação"); em } \\
\text { outro momento, porém, manifesta } \\
\text { considerar que os danos e privilégios } \\
\text { sociais, para os negros e brancos, são } \\
\text { semelhantes ("se mudar o presidente } \\
\text { (...) não são só os negros ou só os } \\
\text { brancos que vão ter conseqüências, } \\
\text { não, todo mundo", "economicamente } \\
\text { pode ser, algum presidente vai lá e } \\
\text { acaba prejudicando os que são mais } \\
\text { pobres, mas dentro desses pobres têm } \\
\text { brancos e negros também"). }\end{array}$ & $\begin{array}{l}\text { A diferença entre o branco e o negro (...) é que e a pessoa } \\
\text { negra, eu acho que ela se preocupa mais com a imagem que } \\
\text { ela vai passar porque é como que se uma pessoa negra tivesse } \\
\text { sempre querendo se igualar e o branco já não tem essa } \\
\text { preocupação, sabe, eu penso ï é outra analogia (riso), é como } \\
\text { se fosse os americanos e o resto do mundo. Os americanos, a } \\
\text { língua mundial assim é o inglês, então eu penso que os } \\
\text { americanos já cresceram com esse sabendo falar inglês, então } \\
\text { a gente tem que correr atrás de saber falar inglês. É uma } \\
\text { analogia que eu faço, então os brancos, eles não tem essa } \\
\text { preocupação, já os negros, a maioria deles, tem essa } \\
\text { preocupação de, dependendo do ambiente, querer se igualar. } \\
\text { Mas sempre tem exceção né, também (riso). Pergunta: E } \\
\text { semelhança? } \\
\text { Resposta: semelhança... Hmm... Ah, eu penso que ta todo } \\
\text { mundo no mesmo barco, assim, se mudar o presidente, não vai } \\
\text { só, não são só os negros ou só os brancos que vão ter } \\
\text { conseqüências, não, todo mundo, entendeu, a gente ta numa } \\
\text { comunidade que não tem mais isso ñah, eu vou proteger vocês } \\
\text { e vocês nãoò, sabe, não tem, eu penso que não tem mais isso. } \\
\text { Eu entendo que, é, economicamente pode ser, algum } \\
\text { presidente vai lá e acaba prejudicando os que são mais } \\
\text { pobres, mas dentro desses pobres têm brancos e negros } \\
\text { também. Então, essa é a semelhança: a gente ta todo mundo } \\
\text { no mesmo barco. }\end{array}$ \\
\hline
\end{tabular}




\begin{tabular}{|c|c|c|c|}
\hline $\begin{array}{l}\text { 3. Visibilidade } \\
\text { sobre as } \\
\text { consequências } \\
\text { do racismo, os } \\
\text { danos e os } \\
\text { privilégios }\end{array}$ & $\begin{array}{c}\text { visibilidade do } \\
\text { prejuízo social para } \\
\text { o negro }\end{array}$ & $\begin{array}{c}\text { A entrevistada percebe o prejuízo } \\
\text { social que sofreu o negro em } \\
\text { decorrência do racismo ("Eu acredito } \\
\text { que seja por uma questão histórica"), } \\
\text { mas no final atribui o fato do negro não } \\
\text { estar na universidade à qualidade do } \\
\text { ensino médio ("acho que é por isso que } \\
\text { existem menos negros na universidade, } \\
\text { por causa do ensino médio que não tá } \\
\text { muito bom") }\end{array}$ & $\begin{array}{l}\text { Pergunta: E por que você acha que existem menos alunos } \\
\text { negros na universidade do que brancos? } \\
\text { Resposta: Por causa... Eu acredito que seja por uma questão } \\
\text { histórica, assim, ah os... ligando mais com a questão } \\
\text { econômica né... Então as pessoas que são negras geralmente } \\
\text { elas são mais pobres porque anteriormente já não tiveram } \\
\text { oportunidade de... os pais já não tiveram bons empregos... eu } \\
\text { acho que é mais histórico assim, então chegou na gente, na } \\
\text { minha geração com os pais não tendo dinheiro para pagar } \\
\text { uma boa escola e aí põe na escola pública, e na minha } \\
\text { geração a escola pública não está boa e... Eu fiz escola } \\
\text { pública, mas eu fiz uma escola pública diferente, que foi } \\
\text { técnica, ETE, né... E elas são um pouco melhores, assim, e aí } \\
\text { meu pai teve condiçôes de pagar um semestre de cursinho, aí } \\
\text { com esse cursinho eu entrei no cursinho comunitário e aí eu } \\
\text { fui de graça e consegui entrar... Tem que ralar (riso) bastante. } \\
\text { Então acho que é por isso que existem menos negros na } \\
\text { universidade, por causa do ensino médio que não ta muito } \\
\text { bom. }\end{array}$ \\
\hline
\end{tabular}




\begin{tabular}{|c|c|c|c|c|}
\hline 4. Estigma & $\begin{array}{l}\text { na comunicação } \\
\text { não verbal }\end{array}$ & $\begin{array}{c}\text { escolha de papéis } \\
\text { profissionais para as } \\
\text { pessoas das fotos de } \\
\text { homens e mulheres; } \\
\text { brancos(as) e } \\
\text { negros(as); de faixas } \\
\text { etárias de } 20 \text { a } 30 \\
\text { anos, de } 31 \text { a } 59 \text { anos, } \\
\text { acima de } 60 \text { anos. } \\
\text { Indicadores: } \\
\text { profissionais brancos } \\
\text { (as) - negros (as) e } \\
\text { cargos profissionais } \\
\text { artista, que privilegia } \\
\text { conhecimento } \\
\text { intelectual, manual e } \\
\text { posições de chefia. }\end{array}$ & $\begin{array}{l}\text { Observa-se a tendência da entrevistada } \\
\text { de reproduzir os estigmas sociais, } \\
\text { escolhendo para os cargos que } \\
\text { privilegia conhecimento intelectual e as } \\
\text { posições de chefia as pessoas brancas } \\
\text { e para os cargos que privilegiam o } \\
\text { trabalho manual, os negros. Das } 9 \\
\text { profissões, } 5 \text { foram preenchidas com } \\
\text { pessoas brancas e } 4 \text { com pessoas negras; } \\
\text { sendo que a profissão de artista, as } 2 \text { que } \\
\text { privilegiam conhecimento intelectual e as } 2 \\
\text { que são de chefia foram preenchidas por } \\
\text { pessoas brancas e as } 4 \text { das que } \\
\text { privilegiam trabalho manual foram } \\
\text { preenchidas por pessoas negras. }\end{array}$ & $\begin{array}{l}\text { Profissional Artista: Pianista - mulher branca (figura 21); } \\
\text { Profissão que privilegia conhecimento intelectual: Médico (a) } \\
\text { plantonista - homem branco (figura 19); Professor } \\
\text { Universitário - homem branco (figura 22); } \\
\text { Posições de chefia: Gerente do hotel - homem branco (figura } \\
\text { 25); Diretor (a) de Marketing de uma loja de departamento - } \\
\text { mulher branca (figura 26); } \\
\text { Profissões que privilegiam o trabalho manual: Arrumador } \\
\text { (eira) do Hotel - mulher negra (figura 20); Motorista de } \\
\text { ônibus - homem negro (figura 17); Cabeleireiro(a)) - homem } \\
\text { negro (figura 31); Porteiro(a) do Hotel - homem negro (figura } \\
\text { 18). }\end{array}$ \\
\hline \multicolumn{5}{|l|}{ 5. Estereótipo } \\
\hline $\begin{array}{l}\text { 6. Reações } \\
\text { emocionais na } \\
\text { relação com o } \\
\text { preconceito } \\
\text { (com o diverso) }\end{array}$ & $\begin{array}{l}\text { na comunicação } \\
\text { verbal }\end{array}$ & \multirow{2}{*}{$\begin{array}{l}\text { culpa, vergonha, } \\
\text { irritabilidade, } \\
\text { raiva, exaustão, } \\
\text { confusão na fala, } \\
\text { negação, medo, } \\
\text { dissimulação, } \\
\text { sensação de } \\
\text { solidão, tristeza, } \\
\text { sensação de não } \\
\text { pertencimento, } \\
\text { impotência, }\end{array}$} & $\begin{array}{l}\text { MEDO: "eu tinha muito medo de eu não } \\
\text { conseguir acompanhar porque, ah, se } \\
\text { eu precisava de tal nota no vestibular e } \\
\text { eu não tive" }\end{array}$ & $\begin{array}{l}\vec{E} \text {, tem a dificuldade é mais, assim, no começo do ano, mais } \\
\text { por causa İ pelo menos a minha impressão ï é mais por causa } \\
\text { do medo, eu tinha muito medo de eu não conseguir } \\
\text { acompanhar porque, ah, se eu precisava de tal nota no } \\
\text { vestibular e eu não tive, então significa que eu não tenho o } \\
\text { mínimo pra eu conseguir entender. }\end{array}$ \\
\hline $\begin{array}{l}\text { 6. Reações } \\
\text { emocionais na } \\
\text { relação com o } \\
\text { preconceito } \\
\text { (com o diverso) }\end{array}$ & & & $\begin{array}{l}\text { MEDO: "Antes de eu entrar (...) eu achei } \\
\text { que eu não ia poder conversar sobre } \\
\text { isso com as pessoas que não são } \\
\text { cotistas." }\end{array}$ & $\begin{array}{l}\text { Antes de eu entrar, antes de eu conhecer as pessoas da sala, } \\
\text { eu fiquei com medo, eu achei que eu não ia poder conversar } \\
\text { sobre isso com as pessoas que não são cotistas. Eu pensei } \\
\tilde{n} A \text { h, acho que os meus amigos vão ser os cotistasò }\end{array}$ \\
\hline
\end{tabular}




\begin{tabular}{|c|c|c|c|}
\hline $\begin{array}{l}\text { 6. Reações } \\
\text { emocionais na } \\
\text { relação com o } \\
\text { preconceito } \\
\text { (com o diverso) }\end{array}$ & $\begin{array}{c}\text { contradição, } \\
\text { justificativa } \\
\text { defensiva }\end{array}$ & $\begin{array}{l}\text { NEGAÇÃO: A entrevistada tem uma } \\
\text { tendência a relacionar a discriminação } \\
\text { positiva (a cotas) com a deficiência do } \\
\text { estudo em escola pública. Evita } \\
\text { mencionar o conflito racial entre } \\
\text { brancos e negros em sua fala, e sempre } \\
\text { se refere a ele, quando perguntada, } \\
\text { como algo normal, já resolvido. ("A } \\
\text { gente nem lembra mais disso", "ou } \\
\text { porque nunca teve isso mesmo"). }\end{array}$ & $\begin{array}{l}\text { Pergunta: Você é a favor da política de cotas? RESPOSTA: } \\
\text { porque, assim, eu fiz escola pública, minhas amigas também, } \\
\text { cotistas também, fizeram escola pública, todo mundo né.. e a } \\
\text { gente ta levando uma faculdade, entendeu....Pergunta: } \\
\text { imagina que na sala de aula hoje, se } 80 \% \text { das pessoas fossem } \\
\text { negras, e } 20 \% \text { brancas, como é que você se sentiria?Resposta: } \\
\text { Ah, eu não penso que seria muito diferente... Ah gente já ta } \\
\text { tão... A gente nem lembra mais disso. Não sei se é porque a } \\
\text { gente ta no } 3^{\circ} \text { ano já, não sei, ou porque nunca teve isso } \\
\text { mesmo. Mas acho que seria... dá no mesmo. Pergunta: E } \\
\text { dentro da universidade, você acha que poderia ser feito } \\
\text { alguma coisa para aproximar mais ainda os alunos negros } \\
\text { dos brancos? Resposta: você perguntou se precisaria fazer } \\
\text { uma coisa aberta, não, não precisa, tá bom assim. Pergunta: } \\
\text { Você acha que ia ser pior? Resposta: Talvez sim, porque aí } \\
\text { vai mexer no que tá quieto, né (riso) talvez sim, mas não sei }\end{array}$ \\
\hline $\begin{array}{c}\text { 7. Formas e } \\
\text { Oportunidades } \\
\text { de elaboração } \\
\text { das experiências } \\
\text { relacionadas ao } \\
\text { racismo }\end{array}$ & $\begin{array}{l}\text { oportunidades de } \\
\text { reflexão sobre o } \\
\text { tema racismo nos } \\
\text { espaços sociais } \\
\text { (família, escola, } \\
\text { mídia, amigos) }\end{array}$ & $\begin{array}{l}\text { A experiência como aluna na } \\
\text { universidade, junto aos outros alunos } \\
\text { brancos e negros, em um espaço em } \\
\text { que é minoria e não é tranquilamente } \\
\text { seu, foi uma oportunidade para a } \\
\text { entrevistada constatar a suas iguais } \\
\text { condições de acompanhamento } \\
\text { ("depois que eu percebi que eu entrei } \\
\text { aqui, percebi que o que faz a diferença } \\
\text { é eu aqui.") }\end{array}$ & $\begin{array}{l}\text { Pergunta: Você acha que o desempenho dos alunos cotistas é } \\
\text { diferente do desempenho dos alunos não-cotistas? } \\
\text { Resposta (continuação): Não, não. (riso) É, tem a dificuldade } \\
\text { é mais, assim, no começo do ano, mais por causa İ pelo } \\
\text { menos a minha impressão İ é mais por causa do medo, eu } \\
\text { tinha muito medo de eu não conseguir acompanhar porque, } \\
\text { ah, se eu precisava de tal nota no vestibular e eu não tive, } \\
\text { então significa que eu não tenho o mínimo pra eu conseguir } \\
\text { entender. Mas não, depois que eu percebi que eu entrei aqui, } \\
\text { percebi que o que faz a diferença é eu aqui. Antes do } \\
\text { vestibular, já passou, já não influencia mais. Tanto que, sei lá, } \\
\text { as pessoas que passaram na minha frente, têm gente que já } \\
\text { repetiu o ano e eu to lá. Então pra mim... No começo a gente } \\
\text { fica com dúvida, assim, achando que.... Ainda fica preso no } \\
\text { antes do vestibular, né? Mas não influencia. }\end{array}$ \\
\hline
\end{tabular}




\begin{tabular}{|c|c|c|c|}
\hline $\begin{array}{l}\text { 7. Formas e } \\
\text { Oportunidades } \\
\text { de elaboração } \\
\text { das experiências } \\
\text { relacionadas ao } \\
\text { racismo }\end{array}$ & $\begin{array}{l}\text { oportunidades de } \\
\text { debate sobre o } \\
\text { assunto, reflexão e } \\
\text { elaboração }\end{array}$ & $\begin{array}{l}\text { A experiência como aluna na } \\
\text { universidade, junto aos outros alunos } \\
\text { brancos e negros, em um espaço em } \\
\text { que é minoria e não é tranquilamente } \\
\text { seu, foi uma oportunidade para a } \\
\text { entrevistada exercitar possibilidades de } \\
\text { integração com as pessoas brancas. }\end{array}$ & $\begin{array}{l}\text { Pergunta: E na relação com seus colegas? Você pôde pedir } \\
\text { um auxílio para outros colegas não cotistas?Resposta } \\
\text { (continuação):Antes de eu entrar, antes de eu conhecer as } \\
\text { pessoas da sala, eu fiquei com medo, eu achei que eu não ia } \\
\text { poder conversar sobre isso com as pessoas que não são } \\
\text { cotistas. Eu pensei ñAh, acho que os meus amigos vão ser os } \\
\text { cotistasò. Eu pensei assim, mas aí logo que eu entrei, eu já vi } \\
\text { que não, que não ia ser assim, foi quase imediato. Já vi que } \\
\text { não. Chegou a passar isso pela cabeça, que ñah, lá dentro, } \\
\text { com os não-cotistas, eu acho que eu não vou poder ter ajuda, } \\
\text { eu acho que eu vou correr atrás fora, sei lá, do meu } \\
\text { namorado, do meu pai. E, sei lá, acho que dentro nãoò mas aî } \\
\text { depois mudou. }\end{array}$ \\
\hline $\begin{array}{l}\text { 7. Formas e } \\
\text { Oportunidades } \\
\text { de elaboração } \\
\text { das experiências } \\
\text { relacionadas ao } \\
\text { racismo }\end{array}$ & $\begin{array}{l}\text { oportunidades de } \\
\text { debate sobre o } \\
\text { assunto, reflexão e } \\
\text { elaboração e forma } \\
\text { que encontra para } \\
\text { lidar com a situação } \\
\text { de discriminação }\end{array}$ & $\begin{array}{l}\text { Para a entrevistada, a experiência lhe } \\
\text { fez amadurecer em suas relações } \\
\text { raciais. }\end{array}$ & $\begin{array}{l}\hat{E} \text {... É bom porque a gente acaba, eu penso que, } \\
\text { amadurecendo porque a gente é obrigado a pensar mais no } \\
\text { assunto, a gente, sabe, ña gente ta aqui agora, e aí o que que } \\
\text { isso significa?ô entendeu, a gente acaba vendo mais perto } \\
\text { assim a opinião das pessoas, como elas reagem; aí a gente } \\
\text { acaba amadurecendo nesse assunto. Quem ta de fora, só tem } \\
\text { assim... não procura saber do assunto e fala ñah, eu sou a } \\
\text { favor ou eu sou contra cotasò mas a gente estando aqui de } \\
\text { perto dá pra ter uma idéia melhor do que é realmente, do que } \\
\text { que acontece, o que que é bom, o que que é ruim e aí } \\
\text { amadurece... }\end{array}$ \\
\hline $\begin{array}{l}\text { 7. Formas e } \\
\text { Oportunidades } \\
\text { de elaboração } \\
\text { das experiências } \\
\text { relacionadas ao } \\
\text { racismo }\end{array}$ & $\begin{array}{l}\text { oportunidades de } \\
\text { debate sobre o } \\
\text { assunto, reflexão e } \\
\text { elaboração e forma } \\
\text { que encontra para } \\
\text { lidar com a situação } \\
\text { de discriminação }\end{array}$ & $\begin{array}{l}\text { Além da oportunidade oferecida pela } \\
\text { discussão sobre a política de cotas, a } \\
\text { entrevistada não recorda de nenhuma } \\
\text { outra oportunidade de debate sobre o } \\
\text { tema racismo. }\end{array}$ & $\begin{array}{l}\text { Pergunta: Você se lembra de ter tido alguma oportunidade de } \\
\text { debater sobre o tema racismo, discriminação racial, em sua } \\
\text { vida, no colégio, família? Resposta: Ah, não que eu me } \\
\text { lembre... Em não me lembro, não me lembro. Deve ter havido, } \\
\text { mas eu não lembro.Ah assim, alguém conversar comigo, eu } \\
\text { estar num grupo de discussão eu acho que não. Mas eu } \\
\text { lembro que houve bastante discussão sobre esse assunto de } \\
\text { cotas... }\end{array}$ \\
\hline
\end{tabular}




\begin{tabular}{|c|c|c|c|c|}
\hline $\begin{array}{l}\text { 8. Abordagem } \\
\text { teórica sobre o } \\
\text { tema }\end{array}$ & $\begin{array}{l}\text { Diversidade } \mathrm{x} \\
\text { Igualdade } \mathrm{x} \\
\text { Racismo }\end{array}$ & $\begin{array}{l}\text { Confusão sobre os } \\
\text { agrupamentos na } \\
\text { diversidade, sobre a } \\
\text { diferenciação } \\
\text { positiva - a } \\
\text { diferenciação } \\
\text { negativa (quando é } \\
\text { um valor a } \\
\text { diversidade e } \\
\text { quando não é). }\end{array}$ & $\begin{array}{c}\text { Apesar de a entrevistada ver na } \\
\text { diversidade uma oportunidade de se } \\
\text { livrar de uma preocupação, a } \\
\text { preocupação parece ser exatamente a } \\
\text { de ser diferente. Existe uma } \\
\text { desvalorização da entrevistada pela } \\
\text { diferença, e como que um alívio diante } \\
\text { da igualdade. Diferença significa } \\
\text { preocupação pelo risco de não ser } \\
\text { visto como um ser humano igual. }\end{array}$ & $\begin{array}{l}\text { Pergunta: o que você acha de diversidade? Eu acho legal } \\
\text { porque eu penso que isso acaba tirando uma das } \\
\text { preocupações que era aquela de ñah, eu tenho que ser igual } \\
\text { aos outrosò, entendeu? A diversidade já mistura tudo, e } \\
\text { pronto, todo mundo é igual (riso). Eu acho que é bom por isso, } \\
\text { porque tira aquela preocupação de ñah, eu sou diferente e } \\
\text { tenho quer ser igualò. }\end{array}$ \\
\hline \multirow[t]{2}{*}{$\begin{array}{l}\text { 8. Abordagem } \\
\text { teórica sobre o } \\
\text { tema }\end{array}$} & $\begin{array}{l}\text { Relação do } \\
\text { racismo com os } \\
\text { princípios de } \\
\text { direito } \\
\text { fundamentais }\end{array}$ & $\begin{array}{l}\text { reconhecimento da } \\
\text { política como um } \\
\text { direito fundamental }\end{array}$ & $\begin{array}{l}\text { A entrevistada relaciona a oportunidade } \\
\text { que teve de cursar o cursinho } \\
\text { comunitário com algo pelo qual deve } \\
\text { agradecer e compensar. }\end{array}$ & $\begin{array}{l}\text { De sexta-feira eu dou plantão de matemática no cursinho. Um } \\
\text { cursinho comunitário, que inclusive eu to no cursinho porque } \\
\text { eu fiz cursinho comunitário para entrar aqui, aí eu, como } \\
\text { forma de agradecer, assim, eu entrei no cursinho também. }\end{array}$ \\
\hline & $\begin{array}{l}\text { Relação do } \\
\text { racismo com os } \\
\text { princípios de } \\
\text { direito } \\
\text { fundamentais }\end{array}$ & $\begin{array}{l}\text { reconhecimento do } \\
\text { direito a ser tratado } \\
\text { desigualmente ( } \\
\text { discriminação } \\
\text { positiva) }\end{array}$ & $\begin{array}{l}\text { A entrevistada não reconhece a } \\
\text { discriminação positiva como um } \\
\text { componente da aplicação do direito à } \\
\text { igualdade. Não vincula a política de } \\
\text { cotas, com a qual concorda, com a } \\
\text { discriminação positiva. }\end{array}$ & $\begin{array}{l}\text { Pergunta: O que é direitos humanos pra você?? } \\
\text { Resposta: Ah, o nome já diz, né. Sei lá, a defesa dos nossos } \\
\text { direitos, sei lá. O direito que você tem por ter nascido, por ser } \\
\text { humano você tem... podia ter esses direitos. } \\
\text { Pergunta: Tá bom. O direito dos negros pra você é direitos } \\
\text { humanos? Resposta: Existe direito só pros negros? Eu não } \\
\text { sei... Se existirem direitos só pros negros eu não concordo. } \\
\text { Existe? Não, eu não acho... que tá certo, não... Não é direito } \\
\text { humano, isso daí... Pergunta: E o tema de discriminação } \\
\text { racial você acha que é um tema dos direitos humanos? } \\
\text { Resposta: Sim, porque... sim, porque todo mundo tem o direito } \\
\text { de ser tratado igual, isso é um direito humano. Se tá tendo } \\
\text { discriminação tá sendo ferido um direito humano, então acho } \\
\text { que sim. }\end{array}$ \\
\hline
\end{tabular}




\begin{tabular}{|c|c|c|c|}
\hline $\begin{array}{c}9 . \\
\text { Manifestação da } \\
\text { solidariedade }\end{array}$ & $\begin{array}{l}\text { crença de que a } \\
\text { relação multi- } \\
\text { étnica enriquece e } \\
\text { auxilia a } \\
\text { coletividade, na } \\
\text { solução de } \\
\text { problemas } \\
\text { coletivos e } \\
\text { individuais; } \\
\text { disponibilidade } \\
\text { para a busca real } \\
\text { de soluções para o } \\
\text { racismo }\end{array}$ & $\begin{array}{l}\text { A entrevistada não concorda que falar } \\
\text { sobre o assunto racismo seja algo que } \\
\text { contribua para a solução do problema, } \\
\text { mas busca outras soluções: acredita } \\
\text { que a convivência multi-étnica em um } \\
\text { espaço onde brancos podem conversar } \\
\text { com negros é algo de grande resultado } \\
\text { para a questão ("Hum, eu acho que (...) } \\
\text { o projeto de inclusão das cotas é um } \\
\text { bom exemplo porque estaria colocando } \\
\text { negros num ambiente que era só de } \\
\text { brancos e isso acaba aumentando } \\
\text { mesmo a convivência (...) as pessoas } \\
\text { (...) nunca tinham conversado com um } \\
\text { negro, mas daí (...) vamos conversar e } \\
\text { ele vê que é normal, que é legal, dá um } \\
\text { jeito.") }\end{array}$ & $\begin{array}{l}\text { Pergunta: Se você fosse convidada pra uma palestra que } \\
\text { falasse sobre discriminação racial você iria?Resposta: Não, } \\
\text { eu não. (riso)Ah ,eu não iria não... sei lá, é que atualmente eu } \\
\text { tô tendo muitas outras coisas...Pergunta: E se fosse uma } \\
\text { palestra sobre convívio entre pessoas diferentes? Convívio } \\
\text { entre as diversidades?Resposta:Não, não, eu não gosto dessas } \\
\text { coisas assim.Pergunta: O que você acha que poderia ser feito } \\
\text { pra auxiliar no mundo a aproximação entre brancos e } \\
\text { negros?Resposta: Hum, eu acho que, por exemplo, inclusão... } \\
\text { o projeto de inclusão das cotas é um bom exemplo porque } \\
\text { estaria colocando negros num ambiente que era só de brancos } \\
\text { e isso acaba aumentando mesmo a convivência. Talvez as } \\
\text { pessoas que estavam na universidade nunca tinham } \\
\text { conversado com um negro, mas daí entrou agora um aluno na } \\
\text { sala, e é negro, então, vamos conversar e ele vê que é normal, } \\
\text { que é legal, dá um jeito. }\end{array}$ \\
\hline $\begin{array}{l}\text { 10. Integração } \\
\text { com as ofertas } \\
\text { de } \\
\text { desenvolvimento } \\
\text { da Universidade }\end{array}$ & $\begin{array}{l}\text { Integração com os } \\
\text { colegas da } \\
\text { universidade; } \\
\text { oportunidades } \\
\text { profissionais que } \\
\text { surgem a partir } \\
\text { dessa integração; } \\
\text { acesso às } \\
\text { oportunidades que o } \\
\text { ambiente acadêmico } \\
\text { oferece }\end{array}$ & $\begin{array}{l}\text { A entrevistada está integrada com as } \\
\text { atividades da Universidade, faz inglês, } \\
\text { iniciação científica, plantão em } \\
\text { matemática no cursinho comunitário. A } \\
\text { oportunidade da iniciação científica } \\
\text { surgiu a partir das relações com as } \\
\text { amigas e com os professores. }\end{array}$ & $\begin{array}{l}\text { Eu estudo vendo trufa, no almoço geralmente eu vou pro } \\
\text { estágio İ to fazendo iniciação científica, de tarde tenho aula } \\
\text { de novo, de noite eu faço inglês de segunda e quarta. De } \\
\text { sexta-feira eu dou plantão de matemática no cursinho. Um } \\
\text { cursinho comunitário, que inclusive eu to no cursinho porque } \\
\text { eu fiz cursinho comunitário para entrar aqui, aí eu, como } \\
\text { forma de agradecer, assim, eu entrei no cursinho também. } \\
\text { Pergunta: Como é que você entrou na iniciação } \\
\text { científica?Resposta: Eu comecei a procurar junto com as } \\
\text { minhas amigas também que estavam procurando e a gente foi } \\
\text { vendo uns andares que tinhas dos prédios, as possibilidades } \\
\text { dos professores, ia lá conversar, ver os projetos. E aí num } \\
\text { desses andares que eu via era o do professor G, que agora eu } \\
\text { to, aí eu fui lá e ele mostrou pra mim os projetos que tinha. } \\
\text { Achei interessante, ele trabalha com AIDS, o vírus da HIV, aí } \\
\text { eu achei interessante e fiquei lá... Pergunta: a seleção é por } \\
\text { conversa?Resposta:É, assim mesmo.Você faz contato como o } \\
\text { professor e se vocês se derem bem, se tiver um horário que } \\
\text { coincida, né? }\end{array}$ \\
\hline
\end{tabular}




\begin{tabular}{|c|c|c|c|}
\hline $\begin{array}{l}\text { 10. Integração } \\
\text { com as ofertas } \\
\text { de } \\
\text { desenvolvimento } \\
\text { da Universidade }\end{array}$ & $\begin{array}{c}\text { relação de } \\
\text { coleguismo entre o } \\
\text { entrevistado e os } \\
\text { alunos }\end{array}$ & $\begin{array}{l}\text { A entrevistada demonstra sentir um } \\
\text { desconforto pelo fato de não se } \\
\text { integrar com outras pessoas que } \\
\text { estariam em grupos fechados, mas, } \\
\text { mesmo assim, mantém relações } \\
\text { aparentemente proveitosas com os } \\
\text { colegas ("converso com todo } \\
\text { mundo...vendo trufa..."). }\end{array}$ & $\begin{array}{l}\text { Pergunta: Você fica aqui o dia inteiro? Resposta: } O \text { dia } \\
\text { inteiro... Eu tenho, assim... A minha sala é pequena, então, eu } \\
\text { sou uma pessoa que conversa com todo mundo porque eu } \\
\text { vendo trufa, então eu tenho que ter os meus contatos (riso). } \\
\text { Eu converso com todo mundo. Todo mundo, da minha sala né, } \\
\text { me conhece, mas eu tenho mais, assim, eu sou mais próxima } \\
\text { de } 4 \text { meninas. Uma das outras duas cotistas e mais } 3 \text { meninas } \\
\text { do interior. E... Mas assim, é... Tem gente da sala que só fica } \\
\text { no grupinho deles e não fala com as outras. (...) Mesmo a sala } \\
\text { sendo pequena, ainda tem gente que fica em grupinho. }\end{array}$ \\
\hline
\end{tabular}

\begin{tabular}{|c|c|c|c|c|}
\hline \multicolumn{5}{|c|}{ ENTREVISTADO D - NÃO COTISTA - UNB } \\
\hline CATEGORIA & $\begin{array}{c}\text { SUB- } \\
\text { CATEGORIA }\end{array}$ & INDICADORES & ASPECTOS SIGNIFICATIVOS & RELATOS DE ENTREVISTA \\
\hline identidade étnica & $\frac{\text { negra / branca }}{\text { / parda }}$ & & & Como eu, por ser negra... \\
\hline $\begin{array}{l}\text { 1. A visibilidade da } \\
\text { diversidade étnico- } \\
\text { racial e a } \\
\text { racialização de si e } \\
\quad \text { do outro }\end{array}$ & & $\begin{array}{l}\text { utilização do } \\
\text { componente } \\
\text { étnico-racial na } \\
\text { descrição das } \\
\text { pessoas das } \\
\text { fotos de } \\
\text { estudantes } \\
\text { negros, brancos } \\
\text { e asiáticos }\end{array}$ & $\begin{array}{l}\text { A entrevistada descreve as fotos de } \\
\text { pessoas, não expressando a cor, etnia } \\
\text { ou raça da pessoa negra, nem da } \\
\text { branca. Observa-se a tendência da } \\
\text { entrevistada de não racializar ou não } \\
\text { manifestar a raça das pessoas. }\end{array}$ & $\begin{array}{l}\text { a) essa aqui está estudando mas fora de livro.. (branca) } \\
\text { b) uma pessoa que está estudando e.. c) essa pessoa está } \\
\text { mais séria, está estudando...( negra) d)uma exposição, } \\
\text { uma vendedora (asiática) }\end{array}$ \\
\hline $\begin{array}{l}\text { 1. A visibilidade da } \\
\text { diversidade étnico- } \\
\text { racial e a } \\
\text { racialização de si e } \\
\quad \text { do outro }\end{array}$ & & $\begin{array}{l}\text { utilização do } \\
\text { componente } \\
\text { étnico-racial para } \\
\text { descrever } \\
\text { membros da } \\
\text { família e a si } \\
\text { próprio }\end{array}$ & $\begin{array}{l}\text { A entrevistada identifica com clareza } \\
\text { os componentes étnico raciais dos } \\
\text { membros de sua família ("mãe é de } \\
\text { descendente indígena, mas meu avô já } \\
\text { era bem branco"). }\end{array}$ & $\begin{array}{l}\text { Eu só sei que tenho descendência baiana.... (riso). Por } \\
\text { parte de mãe é de descendente indígena, mas meu avô já } \\
\text { era bem branco e eu não sei exatamente de onde, } \\
\text { possivelmente ele teria sua descendência da Europa. Sei } \\
\text { que os dois eram baianos e vieram para cá, para } \\
\text { Brasília, assim que começou a construir. }\end{array}$ \\
\hline
\end{tabular}




\begin{tabular}{|c|c|c|c|}
\hline $\begin{array}{l}\text { 1. A visibilidade da } \\
\text { diversidade étnico- } \\
\text { racial e a } \\
\text { racialização de si e } \\
\quad \text { do outro }\end{array}$ & $\begin{array}{l}\text { noção sobre o } \\
\text { conceito social } \\
\text { de raça na } \\
\text { utilização do } \\
\text { componente } \\
\text { étnico-racial na } \\
\text { descrição das } \\
\text { relações sociais }\end{array}$ & $\begin{array}{c}\text { A entrevistada acha o termo raça } \\
\text { depreciativo e inaplicável às pessoas } \\
\text { ("O conceito de raça não se aplica a } \\
\text { pessoas"). }\end{array}$ & $\begin{array}{l}\text { Meu conceito de raça não seria aplicado a pessoas. } \\
\text { Olha, minha opinião para esse negócio de raça e } \\
\text { preconceito para mim ele nem existe, então eu nem } \\
\text { discuto. Para mim ele nem existe, para mim ele é } \\
\text { irrelevante, então nem entro em discussão. Para mim, } \\
\text { não existe realmente raça entre as pessoas. O conceito } \\
\text { de raça não se aplica às pessoas. }\end{array}$ \\
\hline $\begin{array}{l}\text { 2. Visibilidade sobre } \\
\text { a ocorrência da } \\
\text { discriminação racial }\end{array}$ & $\begin{array}{l}\text { visibilidade do } \\
\text { tratamento } \\
\text { desigual direto } \\
\text { ou indireto que } \\
\text { prejudica } \\
\text { socialmente o } \\
\text { negro, seja pela } \\
\text { neutralidade, } \\
\text { seja pela } \\
\text { diferenciação } \\
\text { negativa }\end{array}$ & $\begin{array}{l}\text { A entrevistada observa a existência de } \\
\text { condutas discriminatórias no processo } \\
\text { de integração dos negros na } \\
\text { universidade, que inclusive } \\
\text { acarretaram em danos a um membro } \\
\text { do grupo discriminado ("porque muitas } \\
\text { pessoas foram contra, teve muito } \\
\text { protestos, pra mim o preconceito até } \\
\text { aumentou... eu tinha uma amiga } \\
\text { negra...que não quis fazer por cotas, } \\
\text { para não ter essa pressão quando } \\
\text { chegasse aqui"). No entanto, não } \\
\text { generaliza isso, isto é, não se pode } \\
\text { dizer que a entrevistada constata que } \\
\text { existe um racismo que gera danos } \\
\text { freqüentes ao grupo dos negros. }\end{array}$ & $\begin{array}{l}\text { Porque o meu primeiro vestibular foi em } 2004 \text { que teve } \\
\text { cotas foi uma revolução assim, oi mais complicado } \\
\text { porque muitas pessoas foram contra, teve muito } \\
\text { protestos, pra mim o preconceito até aumentou. Hoje em } \\
\text { dia está mais tranqüilo.(...)Tanto é que entrei aqui e está } \\
\text { indiferente de eu ter entrado por cotas ou não. (...) Mas } \\
\text { naquele tempo, eu tinha uma amiga negra, mais escura } \\
\text { que eu e tal, que não quis fazer por cotas, para não ter } \\
\text { essa pressão quando chegasse aqui. }\end{array}$ \\
\hline
\end{tabular}




\begin{tabular}{|c|c|c|c|}
\hline $\begin{array}{l}\text { 2. Visibilidade sobre } \\
\text { a ocorrência da } \\
\text { discriminação racial }\end{array}$ & $\begin{array}{l}\text { visibilidade do } \\
\text { tratamento } \\
\text { desigual direto } \\
\text { ou indireto que } \\
\text { prejudica } \\
\text { socialmente o } \\
\text { negro, seja pela } \\
\text { neutralidade, } \\
\text { seja pela } \\
\text { diferenciação } \\
\text { negativa }\end{array}$ & $\begin{array}{c}\text { A entrevistada identifica a } \\
\text { discriminação racial direta contra os } \\
\text { africanos, mas não identifica contra si. } \\
\text { Não identifica a discriminação indireta } \\
\text { institucional, somente quando é } \\
\text { invertido o lugar do negro e do branco } \\
\text { nos papeis sociais ("eu, pelo menos, } \\
\text { eu nunca sofri", "Talvez eu achasse } \\
\text { que era racismo assim"). }\end{array}$ & $\begin{array}{l}\text { Pergunta: você acha que existe discriminação racial aqui } \\
\text { na universidade? Resposta: Nada que eu possa afirmar, } \\
\text { porque eu, pelo menos, eu nunca sofri. Mas, é bem } \\
\text { provável que exista. Como teve aquele incêndio na casa } \\
\text { dos africanos, pode ter sido, né? De preconceito racial, } \\
\text { ou não, xenofobia, não sei. Pergunta: Se você visse } \\
\text { assim, se você entrasse no colégio e o dono do colégio } \\
\text { fosse um homem negro e todos os funcionários, } \\
\text { professores fossem negros. Você o acharia } \\
\text { racista?Resposta: Talvez eu achasse que era racismo } \\
\text { assim. Pergunta: E aqui na UNB, você tem algum } \\
\text { professor negro? Resposta: Não. Até hoje não tive } \\
\text { nenhum professor negro }\end{array}$ \\
\hline $\begin{array}{l}\text { 2. Visibilidade sobre } \\
\text { a ocorrência da } \\
\text { discriminação racial }\end{array}$ & $\begin{array}{l}\text { visibilidade do } \\
\text { tratamento } \\
\text { desigual direto } \\
\text { ou indireto que } \\
\text { prejudica } \\
\text { socialmente o } \\
\text { negro, seja pela } \\
\text { neutralidade, } \\
\text { seja pela } \\
\text { diferenciação } \\
\text { negativa }\end{array}$ & $\begin{array}{l}\text { Na cidade, a entrevistada identifica, } \\
\text { sem certeza, condutas de } \\
\text { discriminação racial direta contra si } \\
\text { ("Em Brasília(...) eu acho que } \\
\text { aconteceu comigo assim de ter esse } \\
\text { preconceito") e indireta pela } \\
\text { neutralidade produzida pela mídia ("Na } \\
\text { mídia eu acho. Aquele estereótipo do } \\
\text { branquinho"). }\end{array}$ & $\begin{array}{l}\text { Em Brasília? Em Brasília em si acho que sim. Em } \\
\text { Brasília eu acho que aconteceu comigo assim de ter esse } \\
\text { preconceito. Eu e essa minha amiga que te falei a gente } \\
\text { sentou em uma praça de alimentação e estava lotado, } \\
\text { quando é assim a gente tem que praticamente tirar a } \\
\text { mesa e ai sentou do lado uma família branca, e eles } \\
\text { simplesmente levantaram e deixaram a comida toda lá e } \\
\text { foram embora. Acho que foi um dos únicos de } \\
\text { preconceito descarado que eu já sofri em Brasília. Na } \\
\text { mídia eu acho. Aquele estereótipo do branquinho, lá. } \\
\text { Não valorizando essa beleza negra. Essa imposição } \\
\text { assim, esse imperialismo assim. Isso é bem } \\
\text { preconceituoso. }\end{array}$ \\
\hline $\begin{array}{l}\text { 3. Visibilidade sobre } \\
\text { as consequências do } \\
\text { racismo, os danos e } \\
\text { os privilégios }\end{array}$ & $\begin{array}{l}\text { visibilidade do } \\
\text { prejuízo social } \\
\text { para o negro }\end{array}$ & $\begin{array}{l}\text { A entrevistada identifica a presença do } \\
\text { racismo e da discriminação racial na } \\
\text { hierarquização dos grupos diversos. }\end{array}$ & $\begin{array}{l}\text { Acho que o único aspecto negativo (da diversidade) é } \\
\text { feito pelas próprias pessoas. De sempre ter uma relação } \\
\text { de poder, então uma fica mais valorizada que as outras; } \\
\text { e a outra acaba sendo desvalorizada. Acho que esse é um } \\
\text { ponto negativo. }\end{array}$ \\
\hline
\end{tabular}




\begin{tabular}{|c|c|c|c|c|}
\hline 4. Estigma & $\begin{array}{l}\text { na } \\
\text { comunicação } \\
\text { não verbal }\end{array}$ & $\begin{array}{l}\text { escolha de papéis } \\
\text { profissionais para } \\
\text { as pessoas das } \\
\text { fotos de homens e } \\
\text { mulheres; } \\
\text { brancos(as) e } \\
\text { negros(as); de } \\
\text { faixas etárias de } 20 \\
\text { a } 30 \text { anos, de } 31 \text { a } \\
59 \text { anos, acima de } \\
60 \text { anos. } \\
\text { Indicadores: } \\
\text { profissionais } \\
\text { brancos (as) - } \\
\text { negros (as) e } \\
\text { cargos } \\
\text { profissionais } \\
\text { artista, que } \\
\text { privilegia } \\
\text { conhecimento } \\
\text { intelectual, manual } \\
\text { e posições de } \\
\text { chefia. }\end{array}$ & $\begin{array}{l}\text { Apesar de a entrevistada ter escolhido } \\
\text { uma pessoa negra para ocupar a } \\
\text { profissão de reconhecimento } \\
\text { intelectual, e preencher o quadro de } \\
\text { profissões escolhendo } \\
\text { majoritariamente pessoas negras, das } \\
5 \text {, as } 4 \text { profissões escolhidas para as } \\
\text { pessoas negras foram as que } \\
\text { privilegiam o trabalho manual, } \\
\text { demonstrando uma tendência em } \\
\text { reproduzir o estigma social. Das } 9 \\
\text { profissões, } 4 \text { foram preenchidas com } \\
\text { pessoas brancas e } 5 \text { com pessoas } \\
\text { negras; sendo que a profissão de artista, } \\
1 \text { das que privilegiam conhecimento } \\
\text { intelectual e } 2 \text { que são posições de chefia } \\
\text { foram preenchidas por pessoas brancas; } \\
1 \text { das que privilegia o conhecimento } \\
\text { intelectual, e as } 4 \text { das que privilegiam } \\
\text { trabalho manual foram preenchidas por } \\
\text { pessoas negras. }\end{array}$ & $\begin{array}{l}\text { Profissional Artista: Pianista - mulher branca (figura 29); } \\
\text { Profissão que privilegia conhecimento intelectual: } \\
\text { Médico (a) plantonista - mulher negra (figura 23); } \\
\text { Professor Universitário - homem branco (figura 25); } \\
\text { Posições de chefia: Gerente do hotel - homem branco } \\
\text { (figura 22); Diretor (a) de Marketing de uma loja de } \\
\text { departamento - mulher branca (figura 26); } \\
\text { Profissões que privilegiam o trabalho manual: Arrumador } \\
\text { (eira) do Hotel - homem negro (figura 31); Motorista de } \\
\text { ônibus - homem negro (figura 28); Cabeleireiro(a)) - } \\
\text { mulher negra (figura 31); Porteiro(a) do Hotel - homem } \\
\text { negro (figura 30). }\end{array}$ \\
\hline 5. Estereótipo & & $\begin{array}{l}\text { características } \\
\text { atribuídas a } \\
\text { todos os } \\
\text { membros de um } \\
\text { grupo, } \\
\text { genericamente } \\
\text { que não } \\
\text { correspondem à } \\
\text { realidade ï mitos }\end{array}$ & $\begin{array}{l}\text { negros - mais fortes, batalhadores; } \\
\text { asiáticos inteligentes; brancos - } \\
\text { inteligentes "de outra forma". }\end{array}$ & $\begin{array}{l}\text { Aí já é bem mais tendencioso em minha opinião, os } \\
\text { negros são mais assim, não seié batalhadores, eu acho. } \\
\text { Eles seriam mais fortes, eu acho(riso). É bem } \\
\text { tendencioso assim. É uma característica de cada um, } \\
\text { não é? Os asiáticos eu acho assim inteligentes. Agora os } \\
\text { brancosé acho que seriam inteligentes mas de uma outra } \\
\text { forma, os brancos, né? Seria um ... como se fosse assim } \\
\text { uma esperteza, outro tipo de inteligência, não saberia } \\
\text { como explicar. }\end{array}$ \\
\hline
\end{tabular}




\begin{tabular}{|c|c|c|c|c|}
\hline $\begin{array}{l}\text { 6. Reações } \\
\text { emocionais na } \\
\text { relação com o } \\
\text { preconceito (com o } \\
\text { diverso) }\end{array}$ & $\begin{array}{l}\text { na } \\
\text { comunicação } \\
\text { verbal }\end{array}$ & \multirow{3}{*}{$\begin{array}{l}\text { culpa, vergonha, } \\
\text { irritabilidade, } \\
\text { raiva, exaustão, } \\
\text { confusão na fala, } \\
\text { negação, medo, } \\
\text { dissimulação, } \\
\text { sensação de } \\
\text { solidão, tristeza, } \\
\text { sensação de não } \\
\text { pertencimento, } \\
\text { impotência, } \\
\text { contradição, } \\
\text { justificativa } \\
\text { defensiva }\end{array}$} & $\begin{array}{l}\text { NEGAÇĀO: A entrevistada se recusa a } \\
\text { discutir sobre raça e preconceito, } \\
\text { dizendo que, para ela, isso nem existe. }\end{array}$ & $\begin{array}{l}\text { Meu conceito de raça não seria aplicado a pessoas. } \\
\text { Olha, minha opinião para esse negócio de raça e } \\
\text { preconceito para mim ele nem existe, então eu nem } \\
\text { discuto. Para mim ele nem existe, para mim ele é } \\
\text { irrelevante, então nem entro em discussão. Para mim, } \\
\text { não existe realmente raça entre as pessoas. O conceito } \\
\text { de raça não se aplica as pessoas. }\end{array}$ \\
\hline $\begin{array}{l}\text { 6. Reações } \\
\text { emocionais na } \\
\text { relaçãa com o } \\
\text { preconceito (com o } \\
\text { diverso) }\end{array}$ & & & $\begin{array}{l}\text { SOLIDÃO pela segregação: "só tinha } \\
\text { branco e eu me sentia segregada. } \\
\text { Então eu acho que numa sala onde } \\
\text { tivesse pelo menos a maioria negro eu } \\
\text { me sentiria em casa". A entrevistada } \\
\text { não acredita que essa sensação venha } \\
\text { a prejudicar o desempenho } \\
\text { profissional dela. }\end{array}$ & $\begin{array}{l}\text { Pergunta: Eu queria que você imaginasse que na sala de } \\
\text { aula a partir de hoje 80\% das pessoas fossem negras. } \\
\text { Como é que você se sentiria? Resposta: Em casa.(riso) } \\
\text { Eu me sentiria em casa. Eu já tive experiência, por } \\
\text { exemplo de estudar em cursinho de espanhol e só tinha } \\
\text { branco e eu me sentia segregada. Então eu acho que } \\
\text { numa sala onde tivesse pelo menos a maioria negro eu } \\
\text { me sentiria em casa.(..) Mas meu desempenho não } \\
\text { mudaria, não?(riso) }\end{array}$ \\
\hline $\begin{array}{l}\text { 6. Reações } \\
\text { emocionais na } \\
\text { relação com o } \\
\text { preconceito (com o } \\
\text { diverso) }\end{array}$ & & & $\begin{array}{l}\text { IMPOTËNCIA: Diante da situação que } \\
\text { julgou injusta provocada por uma } \\
\text { discriminação, a entrevistada revela } \\
\text { que, de todas as atitudes que dispõem } \\
\text { para reverter a situação, nenhuma } \\
\text { delas adiantaria. }\end{array}$ & $\begin{array}{l}\text { Pergunta } 20^{*} \text { segunda etapa: Se eu fosse Ana, não sei. } \\
\text { Acho Sinceramente que a situação estaria bem pior para } \\
\text { ela assim, como ela vai reivindicar? Eu poderia dizer o } \\
\text { quê? Eu estudo aqui, tentaria convencer ele de entrar, } \\
\text { mas temo que ela não conseguiria. }\end{array}$ \\
\hline $\begin{array}{l}\text { 7. Formas e } \\
\text { Oportunidades de } \\
\text { elaboração das } \\
\text { experiências } \\
\text { relacionadas ao } \\
\text { racismo }\end{array}$ & & $\begin{array}{l}\text { oportunidades de } \\
\text { reflexão sobre o } \\
\text { tema racismo } \\
\text { nos espaços } \\
\text { sociais (família, } \\
\text { escola, mídia, } \\
\text { amigos) }\end{array}$ & $\begin{array}{l}\text { A entrevistada revela a inexistência de } \\
\text { oportunidades para debater sobre o } \\
\text { assunto. }\end{array}$ & $\begin{array}{l}\text { Pergunta: E sobre a discriminação racial e o } \\
\text { preconceito, você antes teve a oportunidade de } \\
\text { conversar na vida sobre isso? Colégio, família, amigos? } \\
\text { Resposta: Não. }\end{array}$ \\
\hline
\end{tabular}




\begin{tabular}{|c|c|c|c|c|}
\hline $\begin{array}{l}\text { 7. Formas e } \\
\text { Oportunidades de } \\
\text { elaboração das } \\
\text { experiências } \\
\text { relacionadas ao } \\
\text { racismo }\end{array}$ & & $\begin{array}{l}\text { forma que } \\
\text { encontra para } \\
\text { lidar com a } \\
\text { situação de } \\
\text { discriminação }\end{array}$ & $\begin{array}{l}\text { A entrevistada procura não pessoalizar } \\
\text { a conduta discriminatória contra ela, e } \\
\text { entender como algo que faz parte da } \\
\text { vida em sociedade. Expressa a idéia de } \\
\text { neutralidade, o que associa ao fato de } \\
\text { existir preconceito contra o negro e o } \\
\text { branco. }\end{array}$ & $\begin{array}{l}\text { Ser preconceituosa comigo eu procuro relevar, sabe? } \\
\text { Ao mesmo tempo eu sou preconceituosa com as pessoas } \\
\text { entendeu?(...)porque ai não é apenas o preconceito } \\
\text { contra o preto, é preconceito contra o branco também } \\
\text { (...)Pergunta: Como você se sentiu na entrevista? } \\
\text { Resposta: acho que o copo De água me deu uma idéia de } \\
\text { neutralidade.(...) Ai já abrange mais um todo, porque ai } \\
\text { não é apenas o preconceito contra o preto, é preconceito } \\
\text { contra o branco também. }\end{array}$ \\
\hline $\begin{array}{l}\text { 8. Abordagem } \\
\text { teórica sobre o tema }\end{array}$ & $\begin{array}{l}\text { Diversidade } x \\
\text { Igualdade } x \\
\text { Racismo }\end{array}$ & $\begin{array}{c}\text { Confusão sobre } \\
\text { os agrupamentos } \\
\text { na diversidade, } \\
\text { sobre a } \\
\text { diferenciação } \\
\text { positiva - a } \\
\text { diferenciação } \\
\text { negativa (quando } \\
\text { é um valor a } \\
\text { diversidade e } \\
\text { quando não é). }\end{array}$ & $\begin{array}{l}\text { Apesar da entrevistada não ter } \\
\text { demonstrado entender exatamente o } \\
\text { que resulta na desigualdade (ver item } \\
\text { 3), compreende teoricamente a } \\
\text { definição sobre a diferença entre } \\
\text { diversidade e desigualdade. }\end{array}$ & $\begin{array}{l}\text { Existe diferença sim. Diferença existe, igual o professor } \\
\text { de sociologia que fala assim: a diferença não pode se } \\
\text { transformar em desigualdade. Existe diferença entre } \\
\text { diferença e desigualdade. Diferença tem que existir } \\
\text { mesmo. }\end{array}$ \\
\hline
\end{tabular}




\begin{tabular}{|c|c|c|c|c|}
\hline $\begin{array}{l}\text { 8. Abordagem } \\
\text { teórica sobre o tema }\end{array}$ & $\begin{array}{l}\text { Diversidade } \mathrm{x} \\
\text { Igualdade } \mathrm{x} \\
\text { Racismo }\end{array}$ & $\begin{array}{c}\text { Confusão sobre } \\
\text { os agrupamentos } \\
\text { na diversidade, } \\
\text { sobre a } \\
\text { diferenciação } \\
\text { positiva - a } \\
\text { diferenciação } \\
\text { negativa (quando } \\
\text { é um valor a } \\
\text { diversidade e } \\
\text { quando não é). }\end{array}$ & $\begin{array}{l}\text { A entrevistada valoriza a diversidade } \\
\text { quando se trata da possibilidade de } \\
\text { escolha livre dos papéis sociais } \\
\text { atribuídos aos grupos, no entanto, } \\
\text { rejeita a ação de falar sobre as } \\
\text { diferenças ("Acho que } \\
\text { valoriza(...)Conviver com diversas } \\
\text { culturas, conviverë Você pode ter uma } \\
\text { opção", "Acho que poderia parar de } \\
\text { falar de diferença"). }\end{array}$ & $\begin{array}{l}\text { Acho que existe diversidade mesmo acho uma coisa legal } \\
\text { (...)Acho que valoriza. Eu acho que se fosse todo mundo } \\
\text { igual seria muito ruim. A diversidade valoriza sabe? } \\
\text { Conviver com diversas culturas, conviveré Você pode } \\
\text { ter uma opção. Por exemplo, eu conheço muita gente } \\
\text { que mesmo sendo branco, vamos dizer, que gostaria de } \\
\text { ser negro, por exemplo? Que gosta das coisas que o } \\
\text { negro gosta e é uma opção para ele... querer ser } \\
\text { diferente! Poderia ser que eu também quisesse ser } \\
\text { diferente, de outro modo, não ser assim como uma } \\
\text { cultura me impõe. Por ter outras, eu posso escolher } \\
\text { numa gama de variedades. Eu acho que isso valoriza } \\
\text { mesmo.Como eu, por ser negra gosto de balé, não gosto } \\
\text { de Hip Hop. Desse tipo de coisa que estou falando. E tem } \\
\text { brancos que não gostam de música clássica, gostam de } \\
\text { Hip Hop, do Afro-reggae, entendeu? } \\
\text { Pergunta: Em sua opinião, o que poderia ser feita para } \\
\text { melhorar a relação entre brancos e negros? Resposta: } \\
\text { Acho que poderia parar de falar de diferença. Acho que } \\
\text { seria um bom começo. Eu por exemplo não tenho } \\
\text { nenhum problema com branco. Meus amigos a maioria é } \\
\text { branco. Assim para de falar de diferença e simplesmente } \\
\text { conviver }\end{array}$ \\
\hline
\end{tabular}




\begin{tabular}{|c|c|c|c|c|}
\hline $\begin{array}{l}\text { 8. Abordagem } \\
\text { teórica sobre o tema }\end{array}$ & $\begin{array}{l}\text { Relação do } \\
\text { racismo com } \\
\text { os princípios } \\
\text { de direito } \\
\text { fundamentais }\end{array}$ & $\begin{array}{l}\text { reconhecimento } \\
\text { do direito a ser } \\
\text { tratado } \\
\text { desigualmente ( } \\
\text { discriminação } \\
\text { positiva) }\end{array}$ & $\begin{array}{l}\text { A entrevistada não reconhece a } \\
\text { discriminação positiva como um } \\
\text { componente da aplicação do direito à } \\
\text { igualdade e à diversidade, no propósito } \\
\text { da eliminação da discriminação racial. }\end{array}$ & $\begin{array}{l}\text { Pergunta: Você acha que o direito dos negros é tema de } \\
\text { direitos humanos?Resposta: Acho que não deve separar. } \\
\text { Assimé porque você mesmo separa negros e brancos } \\
\text { dessa forma, você mesmo está segregando. Você deve } \\
\text { falar de direitos humanos como um todo, o mesmo direito } \\
\text { humano para o negro e para o branco. Pergunta: e o } \\
\text { tema da discriminação racial? Resposta: Ai já abrange } \\
\text { mais um todo, porque ai não é apenas o preconceito } \\
\text { contra o preto, é preconceito contra o branco também } \\
\text { (...)Talvez um projeto para o respeito humano em si, não } \\
\text { só para negro. Se fosse com o profissional da saúde, mas } \\
\text { para tratar com respeito todo o ser humano, não só com } \\
\text { o negro. }\end{array}$ \\
\hline $\begin{array}{l}\text { 9. Manifestação da } \\
\text { solidariedade }\end{array}$ & & $\begin{array}{l}\text { crença de que a } \\
\text { relação multi- } \\
\text { étnica } \\
\text { enriquece e } \\
\text { auxilia a } \\
\text { coletividade, na } \\
\text { solução de } \\
\text { problemas } \\
\text { coletivos e } \\
\text { individuais; } \\
\text { disponibilidade } \\
\text { para a busca } \\
\text { real de soluções } \\
\text { para o racismo }\end{array}$ & $\begin{array}{l}\text { A entrevistada acredita que a } \\
\text { convivência multi-étnica é positiva, } \\
\text { proporciona maior liberdade e } \\
\text { possibilidades para a coletividade } \\
\text { ("Conviver com diversas culturas, } \\
\text { conviverë Você pode ter uma opção } \\
\text { (...) mesmo sendo branco, vamos dizer, } \\
\text { que gostaria de ser negro (...) Poderia } \\
\text { ser que eu também quisesse ser } \\
\text { diferente, de outro modo, não ser } \\
\text { assim como uma cultura me impõe."). }\end{array}$ & $\begin{array}{l}\text { Acho que existe diversidade mesmo acho uma coisa legal } \\
\text { (...)Acho que valoriza. Eu acho que se fosse todo mundo } \\
\text { igual seria muito ruim. A diversidade valoriza sabe? } \\
\text { Conviver com diversas culturas, conviveré Você pode } \\
\text { ter uma opção. Por exemplo, eu conheço muita gente } \\
\text { que mesmo sendo branco, vamos dizer, que gostaria de } \\
\text { ser negro, por exemplo? Que gosta das coisas que o } \\
\text { negro gosta e é uma opção para ele... querer ser } \\
\text { diferente! Poderia ser que eu também quisesse ser } \\
\text { diferente, de outro modo, não ser assim como uma } \\
\text { cultura me impõe. Por ter outras, eu posso escolher } \\
\text { numa gama de variedades. Eu acho que isso valoriza } \\
\text { mesmo.Como eu, por ser negra gosto de balé, não gosto } \\
\text { de Hip Hop. Desse tipo de coisa que estou falando. E tem } \\
\text { brancos que não gostam de música clássica, gostam de } \\
\text { Hip Hop, do Afro-reggae, entendeu? }\end{array}$ \\
\hline
\end{tabular}




\begin{tabular}{|c|c|c|c|}
\hline $\begin{array}{l}\text { 10. Integração } \\
\text { com as ofertas de } \\
\text { desenvolvimento da } \\
\text { Universidade }\end{array}$ & $\begin{array}{l}\text { Integração com } \\
\text { os colegas da } \\
\text { universidade; } \\
\text { oportunidades } \\
\text { profissionais que } \\
\text { surgem a partir } \\
\text { dessa } \\
\text { integração; } \\
\text { acesso às } \\
\text { oportunidades } \\
\text { que o ambiente } \\
\text { acadêmico } \\
\text { oferece }\end{array}$ & $\begin{array}{l}\text { A entrevistada está integrada com as } \\
\text { atividades da Universidade, trabalha e } \\
\text { estuda na empresa ligada à } \\
\text { universidade, que ficou sabendo por } \\
\text { divulgação e, junto com o colega } \\
\text { branco, apoiaram-se entrando junto. A } \\
\text { partir de relação com os professores } \\
\text { conseguem oportunidades } \\
\text { acadêmicas. ("Eu soube pela } \\
\text { divulgação das salas. Teve um amigo } \\
\text { do meu semestre que entrou junto", } \\
\text { "Essa em especifico a professora } \\
\text { divulgou a vaga lá na empresa onde eu } \\
\text { trabalho. A gente tem contatos com } \\
\text { professores e às vezes aparece") }\end{array}$ & $\begin{array}{l}\text { Pergunta: Você tem amigos aqui? Resposta: Não muito. } \\
\text { Da minha turma posso contar uns } 5 \text { (riso). São pessoas } \\
\text { mais na deles que ficam mais estudando. As mais amigas } \\
\text { são: branquinha, magrinha (riso) traços finos, bem } \\
\text { bonequinha; as outras também são iguais... }\end{array}$ \\
\hline $\begin{array}{l}\text { 10. Integração } \\
\text { com as ofertas de } \\
\text { desenvolvimento da } \\
\text { Universidade }\end{array}$ & $\begin{array}{c}\text { relação de } \\
\text { coleguismo } \\
\text { entre o } \\
\text { entrevistado e } \\
\text { os alunos }\end{array}$ & $\begin{array}{l}\text { A entrevistada demonstra sentir um } \\
\text { desconforto pelo fato de não se } \\
\text { integrar com outras pessoas que } \\
\text { estariam em grupos fechados, mas, } \\
\text { mesmo assim, mantém relações } \\
\text { aparentemente proveitosas com os } \\
\text { colegas ("converso com todo } \\
\text { mundo...vendo trufa..."). }\end{array}$ & $\begin{array}{l}\text { Gosto do que faço, mas paço a maior parte do tempo } \\
\text { sozinha aqui na universidade.Paço o tempo todo aqui, o } \\
\text { dia inteiro. Pergunta: Participa de alguma atividade da } \\
\text { Universidade além das aulas? Não, não faço nenhuma } \\
\text { atividade por que não dá tempo. }\end{array}$ \\
\hline
\end{tabular}

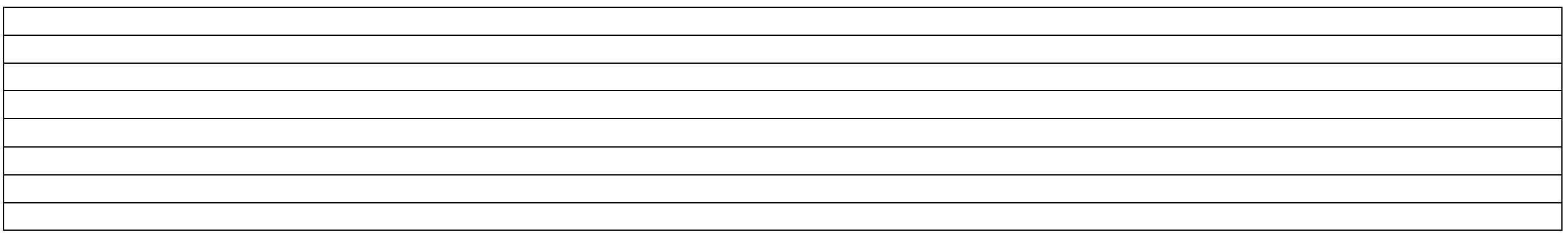




\begin{tabular}{|c|c|c|c|c|}
\hline \multicolumn{5}{|c|}{ ENTREVISTADO E - COTISTA - UERJ } \\
\hline CATEGORIA & $\begin{array}{c}\text { SUB- } \\
\text { CATEGORIA }\end{array}$ & INDICADORES & ASPECTOS SIGNIFICATIVOS & RELATOS DE ENTREVISTA \\
\hline identidade étnica & $\frac{\text { negra / branca / }}{\text { parda }}$ & & & Eu sou negro, gosto ... \\
\hline $\begin{array}{l}\text { 1. A visibilidade } \\
\text { da diversidade } \\
\text { étnico-racial e a } \\
\text { racialização de si } \\
\quad \text { e do outro }\end{array}$ & & $\begin{array}{l}\text { utilização do } \\
\text { componente étnico- } \\
\text { racial na descrição } \\
\text { das pessoas das } \\
\text { fotos de estudantes } \\
\text { negros, brancos e } \\
\text { asiáticos }\end{array}$ & $\begin{array}{l}\text { o entrevistado descreve as fotos não } \\
\text { manifestando a cor, etnia ou raça da } \\
\text { pessoa. }\end{array}$ & $\begin{array}{l}\text { a) parece a monalisa, não sabe se a pessoa está triste, ou } \\
\text { alegre... (branca) b) pessoa que está feliz, com os amigos } \\
\text { (branca) c) uma pessoa interessada no que está fazendo, } \\
\text { está feliz, e lutou pra conseguir está onde está, e está } \\
\text { trilhando um caminho para ela (negra) d) pessoa que } \\
\text { parece que tem pouco tempo pra fazer o que ela quer, está } \\
\text { se aplicando, (asiática) }\end{array}$ \\
\hline $\begin{array}{l}\text { 1. A visibilidade } \\
\text { da diversidade } \\
\text { étnico-racial e a } \\
\text { racialização de si } \\
\text { e do outro }\end{array}$ & & $\begin{array}{l}\text { utilização do } \\
\text { componente étnico- } \\
\text { racial para } \\
\text { descrever membros } \\
\text { da família e a si } \\
\text { próprio }\end{array}$ & $\begin{array}{c}\text { O entrevistado identifica com clareza } \\
\text { os componentes étnico-raciais de sua } \\
\text { família (" Tem uns portugueses na } \\
\text { Família, misturas, mas a origem é } \\
\text { negra mesmo, negra, mestiça, } \\
\text { parda..."). }\end{array}$ & $\begin{array}{l}\text { Meus pais são nordestinos (...) Tem aquela estória do } \\
\text { tráfico negreiro (...) que os negros da África (...) foram } \\
\text { trazidos para o Brasil (...) Pergunta: Toda a sua família e } \\
\text { de origem africana ou não ? Resposta: Tem uns } \\
\text { portugueses na Família, misturas, mas a origem é negra } \\
\text { mesmo, negra, mestiça, parda, é muito difícil de ... }\end{array}$ \\
\hline $\begin{array}{l}\text { 1. A visibilidade } \\
\text { da diversidade } \\
\text { étnico-racial e a } \\
\text { racialização de si } \\
\text { e do outro }\end{array}$ & & $\begin{array}{l}\text { noção sobre o } \\
\text { conceito social de } \\
\text { raça na utilização } \\
\text { do componente } \\
\text { étnico-racial na } \\
\text { descrição das } \\
\text { relações sociais }\end{array}$ & $\begin{array}{l}\text { O entrevistado entende a racialização } \\
\text { como uma forma positiva de valorizar } \\
\text { as diversidades ("Eu acho que } \\
\text { raça...é uma identificação positiva"). }\end{array}$ & $\begin{array}{l}\text { Eu acho que raça é uma especificação que veio para somar, } \\
\text { acho que é uma identificação positiva, não é uma diferença } \\
\text { segregadora assim. Eu acho que a vida de iguais é muito } \\
\text { chata, eu acho que tem que ter diferença para a gente } \\
\text { aprender alguma coisa. }\end{array}$ \\
\hline $\begin{array}{l}\text { 2. Visibilidade } \\
\text { sobre a } \\
\text { ocorrência da } \\
\text { discriminação } \\
\text { racial }\end{array}$ & & $\begin{array}{l}\text { visibilidade do } \\
\text { tratamento desigual } \\
\text { direto ou indireto } \\
\text { que prejudica } \\
\text { socialmente o } \\
\text { negro, seja pela } \\
\text { neutralidade, seja } \\
\text { pela diferenciação }\end{array}$ & $\begin{array}{c}\text { O entrevistado identifica a presença } \\
\text { da discriminação racial direta na vida } \\
\text { da universidade ("quando um } \\
\text { (cotista) tira uma nota maior numa } \\
\text { matéria, aí parece que, acham } \\
\text { estranho isso...parece que ele acha } \\
\text { um absurdo isso, "como é que pode" } \\
\text { ). }\end{array}$ & $\begin{array}{l}\text { Acontece assim quando um (cotista) tira uma nota maior } \\
\text { numa matéria, aí parece que, acham estranho isso, "como é } \\
\text { que ele tirou uma nota maior que eu que fui criado em ph } \\
\text { (?) a vida inteira", um curso notório aqui no Rio, é...parece } \\
\text { que ele acha um absurdo isso, "como é que pode," né?(...) }\end{array}$ \\
\hline
\end{tabular}




\begin{tabular}{|c|c|c|c|}
\hline & negativa & & \\
\hline $\begin{array}{l}\text { 2. Visibilidade } \\
\text { sobre a } \\
\text { ocorrência da } \\
\text { discriminação } \\
\text { racial }\end{array}$ & $\begin{array}{c}\text { visibilidade do } \\
\text { tratamento desigual } \\
\text { direto ou indireto } \\
\text { que prejudica } \\
\text { socialmente o } \\
\text { negro, seja pela } \\
\text { neutralidade, seja } \\
\text { pela diferenciação } \\
\text { negativa }\end{array}$ & $\begin{array}{l}\text { O entrevistado, quando iguala a } \\
\text { condição econômica do branco e } \\
\text { negro, não vê diferença entre a } \\
\text { situação do negro e do branco na } \\
\text { sociedade ("o que difere o filho da } \\
\text { Benedita de uma pessoa branca?"). } \\
\text { Quando discorre sobre diversidade, } \\
\text { identifica a diferença dos locais onde } \\
\text { as pessoas foram criadas. Em outro } \\
\text { momento, iguala a condição } \\
\text { econômica do branco e do negro, e } \\
\text { identifica a condição étnico-racial } \\
\text { como fator de discriminação ("negro, } \\
\text { de bermuda e camiseta, é vista de } \\
\text { outra forma do que uma pessoa } \\
\text { branca, mesmo morando lá, e com os } \\
\text { mesmos trajes... preto e pobre é } \\
\text { parecido mas não é igual para a } \\
\text { sociedade, infelizmente"). }\end{array}$ & $\begin{array}{l}\text { Por exemplo, o negro que .... O filho da Benedita, vamos } \\
\text { dizer, ele teve opções de estudos que outras pessoas não } \\
\text { tiveram, então, se ele não tivesse a complementação de } \\
\text { renda, o que difere o filho da Benedita de uma pessoa } \\
\text { branca? nada, assim. Até mesmo porque socialmente ele até } \\
\text { é mais aceito, vai ser mais aceito, também, no mercado de } \\
\text { trabalho por causa dessa questão social também. Acho que } \\
\text { tem que ter a questão financeira.... (...)... se você esteve em } \\
\text { um condomínio desde criança, se vocêe esteve em uma } \\
\text { favela, você mora no subúrbio, você tem visões diferentes } \\
\text { do mundo...(...)pego o trem todos os dias, então, eu passo } \\
\text { em frente a várias favelas, passo Vigário Geral, Bom } \\
\text { sucesso que pega perto do Alemão, então entra todo tipo de } \\
\text { gente, e quando é certo tipo de pessoa jovem, negro, de } \\
\text { bermuda e camiseta, é vista de outra forma do que uma } \\
\text { pessoa branca, mesmo morando lá, e com os mesmos trajes, } \\
\text { assim. Preto e pobre é parecido mas não é igual para a } \\
\text { sociedade, infelizmente. }\end{array}$ \\
\hline $\begin{array}{l}\text { 2. Visibilidade } \\
\text { sobre a } \\
\text { ocorrência da } \\
\text { discriminação } \\
\text { racial }\end{array}$ & $\begin{array}{l}\text { visibilidade do } \\
\text { tratamento desigual } \\
\text { direto ou indireto } \\
\text { que prejudica } \\
\text { socialmente o } \\
\text { negro, seja pela } \\
\text { neutralidade, seja }\end{array}$ & $\begin{array}{c}\text { O entrevistado constata a } \\
\text { discriminação racial direta, na estória } \\
\text { hipotética. }\end{array}$ & $\begin{array}{l}\text { Pergunta } 20^{*} \text { primeira etapa: é uma questão de } \\
\text { preconceito. (...) }\end{array}$ \\
\hline
\end{tabular}




\begin{tabular}{|c|c|c|c|}
\hline & $\begin{array}{c}\text { pela diferenciação } \\
\text { negativa }\end{array}$ & & \\
\hline $\begin{array}{l}\text { 2. Visibilidade } \\
\text { sobre a } \\
\text { ocorrência da } \\
\text { discriminação } \\
\text { racial }\end{array}$ & $\begin{array}{l}\text { visibilidade do } \\
\text { tratamento desigual } \\
\text { direto ou indireto } \\
\text { que prejudica } \\
\text { socialmente o } \\
\text { negro, seja pela } \\
\text { neutralidade, seja } \\
\text { pela diferenciação } \\
\text { negativa }\end{array}$ & $\begin{array}{c}\text { O entrevistado manifesta a ocorrência } \\
\text { da discriminação indireta na } \\
\text { universidade ("professores... na hora } \\
\text { da correção...cabe um subjetivismo... } \\
\text { uma pessoa da zona sul, que tem } \\
\text { mais afinidade, o nível social } \\
\text { dela..dele...dos professores...pesa } \\
\text { bastante") }\end{array}$ & $\begin{array}{l}\text { e alguns professores também, é...na hora da correção... } \\
\text { ca...cabe um subjetivismo na correção, assim, que eu acho } \\
\text { que uma pessoa da zona sul, que tem mais afinidade, o nivel } \\
\text { social dela..dele..dos professores, ele pesa bastante, assim, } \\
\text { nesse sentido. }\end{array}$ \\
\hline $\begin{array}{l}\text { 2. Visibilidade } \\
\text { sobre a } \\
\text { ocorrência da } \\
\text { discriminação } \\
\text { racial }\end{array}$ & $\begin{array}{l}\text { visibilidade do } \\
\text { tratamento desigual } \\
\text { direto ou indireto } \\
\text { que prejudica } \\
\text { socialmente o } \\
\text { negro, seja pela } \\
\text { neutralidade, seja } \\
\text { pela diferenciação } \\
\text { negativa }\end{array}$ & $\begin{array}{l}\text { Na cidade, o entrevistado constata a } \\
\text { discriminação racial direta. }\end{array}$ & $\begin{array}{l}\text { Eu vou até o ponto, ali, com algumas meninas pegar o } \\
\text { onibus aí... ontem teve jogo do Vasco e Botafogo, aí tem um } \\
\text { grupo de pessoas negras sem camisa, elas só chegaram } \\
\text { perto de mim, ficaram olhando assim... porque passou um } \\
\text { estereótipo lá na frente, ela vai achar que vai ser assaltada } \\
\text { ou alguma coisa... Também quando tá num trem, as pessoas } \\
\text { já ficam... }\end{array}$ \\
\hline $\begin{array}{l}\text { 3. Visibilidade } \\
\text { sobre as } \\
\text { consequências } \\
\text { do racismo, os } \\
\text { danos e os } \\
\text { privilégios }\end{array}$ & $\begin{array}{c}\text { visibilidade do } \\
\text { prejuízo social para } \\
\text { o negro }\end{array}$ & $\begin{array}{l}\text { O entrevistado constata a situação } \\
\text { desvantajosa do negro na sociedade }\end{array}$ & $\begin{array}{l}\text { Tem aquela estória do tráfico negreiro que alguns } \\
\text { professores, que um professor em especial aqui na } \\
\text { faculdade que tem aquela argumentação que os negros da } \\
\text { África venderam seus irmãos e nós somos responsáveis por } \\
\text { essa herança, como se fosse um poder punitivo...(riso) ele é } \\
\text { um dos mais progressistas. Então, mas foram trazidos para } \\
\text { o Brasil, não tiveram opção, e sofrem as consequências } \\
\text { disso. }\end{array}$ \\
\hline
\end{tabular}




\begin{tabular}{|c|c|c|c|c|}
\hline $\begin{array}{l}\text { 3. Visibilidade } \\
\text { sobre as } \\
\text { consequências } \\
\text { do racismo, os } \\
\text { danos e os } \\
\text { privilégios }\end{array}$ & & $\begin{array}{c}\text { visibilidade do } \\
\text { prejuízo social para } \\
\text { o negro }\end{array}$ & $\begin{array}{c}\text { O entrevistado identifica a presença } \\
\text { do racismo e da discriminação racial } \\
\text { na hierarquização dos grupos } \\
\text { diversos que acarretam na } \\
\text { desigualdade econômica e social } \\
\text { ("Quando a diversidade não atinge o } \\
\text { âmbito assim de segregação } \\
\text { econômica e social, tudo bem."). }\end{array}$ & $\begin{array}{l}\text { Quando a diversidade não atinge o âmbito assim de } \\
\text { segregação econômica e social, tudo bem. Agora, quando } \\
\text { parte para esse lado, acaba.., o lado negativo da } \\
\text { diversidade acaba sendo utilizado, acho que não é legal. }\end{array}$ \\
\hline 4. Estigma & $\begin{array}{l}\text { na comunicação } \\
\text { não verbal }\end{array}$ & $\begin{array}{l}\text { escolha de papéis } \\
\text { profissionais para as } \\
\text { pessoas das fotos de } \\
\text { homens e mulheres; } \\
\text { brancos(as) e } \\
\text { negros(as); de faixas } \\
\text { etárias de } 20 \text { a } 30 \\
\text { anos, de } 31 \text { a } 59 \text { anos, } \\
\text { acima de } 60 \text { anos. } \\
\text { Indicadores: } \\
\text { profissionais brancos } \\
\text { (as) - negros (as)e } \\
\text { cargos profissionais } \\
\text { artista, que privilegia } \\
\text { conhecimento } \\
\text { intelectual, manual e } \\
\text { posições de chefia. }\end{array}$ & $\begin{array}{l}\text { O entrevistado, em sua escolha, não } \\
\text { reproduz o estigma social, } \\
\text { demonstrando estar atento a criar um } \\
\text { quadro mais igualitário. Das } 9 \\
\text { profissões, } 5 \text { foram preenchidas com } \\
\text { pessoas brancas e } 4 \text { com pessoas } \\
\text { negras; sendo que a profissão de artista, } \\
1 \text { das } 2 \text { que privilegiam conhecimento } \\
\text { intelectual, } 1 \text { das } 2 \text { que são posições de } \\
\text { chefia e } 2 \text { das } 4 \text { que privilegiam trabalho } \\
\text { manual foram preenchidas por pessoas } \\
\text { brancas; } 1 \text { das } 2 \text { que privilegiam } \\
\text { conhecimento intelectual, } 1 \text { das } 2 \text { que } \\
\text { são posições de chefia e } 2 \text { das } 4 \text { que } \\
\text { privilegiam trabalho manual foram } \\
\text { preenchidas por pessoas negras. }\end{array}$ & $\begin{array}{l}\text { Profissional Artista: Pianista - mulher branca (figura 26); } \\
\text { Profissão que privilegia conhecimento intelectual: Médico } \\
\text { (a) plantonista - homem negro (figura 17); Professor } \\
\text { Universitário - homem branco (figura 19); } \\
\text { Posições de chefia: Gerente do hotel - mulher branca (figura } \\
\text { 29); Diretor (a) de Marketing de uma loja de departamento } \\
\text { - homem negro (figura 28); } \\
\text { Profissões que privilegiam o trabalho manual: Arrumador } \\
\text { (eira) do Hotel - mulher branca (figura 21); Motorista de } \\
\text { ônibus - homem negro (figura 30); Cabeleireiro(a)) - } \\
\text { mulher negra (figura 24); Porteiro(a) do Hotel - homem } \\
\text { branco (figura 32). }\end{array}$ \\
\hline 5. Estereótipo & & & & \\
\hline
\end{tabular}




\begin{tabular}{|c|c|c|c|}
\hline $\begin{array}{c}\text { 6. Reações } \\
\text { emocionais na } \\
\text { relação com o } \\
\text { preconceito (com } \\
\text { o diverso) }\end{array}$ & $\begin{array}{c}\text { culpa, vergonha, } \\
\text { irritabilidade, raiva, } \\
\text { exaustão, confusão } \\
\text { na fala, negação, } \\
\text { medo, dissimulação, } \\
\text { sensação de } \\
\text { solidão, tristeza, } \\
\text { sensação de não } \\
\text { pertencimento, } \\
\text { impotência, } \\
\text { contradição, } \\
\text { justificativa } \\
\text { defensiva }\end{array}$ & $\begin{array}{l}\text { O entrevistado sente um } \\
\text { DESCONFORTO por não ser } \\
\text { cumprimentado no elevador quando } \\
\text { está sozinho com outra pessoa na } \\
\text { universidade e manifesta uma } \\
\text { sensação de IMPOTÊNCIA diante } \\
\text { disso por não poder compreender } \\
\text { ("eu acho estranho porque eu não } \\
\text { consigo entender o porquê"). } \\
\text { Concorda que seria bom para ele } \\
\text { entender o porquê da conduta } \\
\text { discriminatória, mas na terceira } \\
\text { pergunta que tinha como objetivo } \\
\text { insistir no assunto, o entrevistado } \\
\text { recorre a DISSIMULAÇÃO e a } \\
\text { NEGAÇÃO do problema ("Pergunta: } \\
\text { Para melhorar a relação? Resposta: } \\
\text { não, eu ... eu não tenho esse tipo de } \\
\text { preconceito com essa pessoa...Mas } \\
\text { eu quero super na boa, isso não me } \\
\text { enche nem um pouco a cabeça } \\
\text { (riso)") }\end{array}$ & $\begin{array}{l}\text {...é você pensar, por exemplo, estuda na mesma sala há } \\
\text { muito tempo, mas você entra no elevador com essa pessoa } \\
\text { sozinho, parece que você nunca conheceu essa pessoa na } \\
\text { vida! Eu acho estranho isso, porque eu costumo } \\
\text { cumprimentar todo mundo, aí, quando eu vejo uma pessoa } \\
\text { assim, eu acho bem estranho. Mas eu acho estranho porque } \\
\text { eu não consigo entender o porquê, porque eu não tenho } \\
\text { esse tipo de preconceito então é difícil para eu entender } \\
\text { isso. Pergunta: Seria uma coisa boa você entender isso? } \\
\text { Resposta: para mim. Pergunta: Para melhorar a relação? } \\
\text { Resposta: não, eu ... eu não tenho esse tipo de preconceito } \\
\text { com essa pessoa... mas eu vejo essa discriminação. Mas eu } \\
\text { quero super na boa, isso não me enche nem um pouco a } \\
\text { cabeça (riso). }\end{array}$ \\
\hline $\begin{array}{c}\text { 6. Reações } \\
\text { emocionais na } \\
\text { relação com o } \\
\text { preconceito (com } \\
\text { o diverso) }\end{array}$ & $\begin{array}{l}\text { culpa, vergonha, } \\
\text { irritabilidade, raiva, } \\
\text { exaustão, confusão } \\
\text { na fala, negação, } \\
\text { medo, dissimulação, } \\
\text { sensação de } \\
\text { solidão, tristeza, } \\
\text { sensação de não } \\
\text { pertencimento, } \\
\text { impotência, } \\
\text { contradição, } \\
\text { justificativa } \\
\text { defensiva }\end{array}$ & Manifestou tristeza & Chorou ao falar sobre sua estória. \\
\hline
\end{tabular}




\begin{tabular}{|c|c|c|c|}
\hline $\begin{array}{c}\text { 6. Reações } \\
\text { emocionais na } \\
\text { relação com o } \\
\text { preconceito (com } \\
\text { o diverso) }\end{array}$ & & $\begin{array}{l}\text { O entrevistado demonstra que o fato } \\
\text { de estar em uma sala de aula em que } \\
\text { a maioria é de brancos não lhe } \\
\text { provoca reações emocionais ("já } \\
\text { estou acostumado...") }\end{array}$ & $\begin{array}{l}\text { Pergunta: Vamos imaginar que amanhã você entrasse na } \\
\text { tua sala de aula e você visse que } 80 \% \text { da sala de aula } \\
\text { eram alunos negros, o que você sentiria? Resposta: Eu me } \\
\text { sentiria estranho, já estou acostumado... }\end{array}$ \\
\hline $\begin{array}{c}\text { 7. Formas e } \\
\text { Oportunidades } \\
\text { de elaboração } \\
\text { das experiências } \\
\text { relacionadas ao } \\
\text { racismo }\end{array}$ & $\begin{array}{l}\text { oportunidades de } \\
\text { reflexão sobre o } \\
\text { tema racismo nos } \\
\text { espaços sociais } \\
\text { (família, escola, } \\
\text { mídia, amigos) }\end{array}$ & $\begin{array}{l}\text { A experiência como aluno na } \\
\text { universidade, trouxe mudanças para } \\
\text { o entrevistado com relação ao } \\
\text { assunto. } 0 \text { entrevistado diz que não } \\
\text { teve oportunidades de tratar o } \\
\text { assunto no colégio, mas tem com } \\
\text { amigos, e, que na universidade } \\
\text { existiu um espaço de debate em uma } \\
\text { matéria do curso. }\end{array}$ & $\begin{array}{l}\text { Pergunta } 20^{*} \text { segunda etapa: eu acho que eu iria na } \\
\text { Ouvidoria da faculdade para discutir essa questão de } \\
\text { preconceito. }\end{array}$ \\
\hline $\begin{array}{l}\text { 7. Formas e } \\
\text { Oportunidades } \\
\text { de elaboração } \\
\text { das experiências } \\
\text { relacionadas ao } \\
\text { racismo }\end{array}$ & $\begin{array}{l}\text { forma que encontra } \\
\text { para lidar com a } \\
\text { situação de } \\
\text { discriminação }\end{array}$ & $\begin{array}{l}\text { O entrevistado encontra a saída } \\
\text { institucional para tentar reverter a } \\
\text { situação de que julgou tratar-se de } \\
\text { discriminação racial sofrida pelo } \\
\text { Gilberto (negro) na estória hipotética. }\end{array}$ & $\begin{array}{l}\text { Pergunta } 20^{*} \text { segunda etapa: eu acho que eu iria na } \\
\text { Ouvidoria da faculade para discutir essa questão de } \\
\text { preconceito. }\end{array}$ \\
\hline $\begin{array}{c}\text { 7. Formas e } \\
\text { Oportunidades } \\
\text { de elaboração } \\
\text { das experiências } \\
\text { relacionadas ao } \\
\text { racismo }\end{array}$ & $\begin{array}{l}\text { oportunidades de } \\
\text { reflexão sobre o } \\
\text { tema racismo nos } \\
\text { espaços sociais } \\
\text { (família, escola, } \\
\text { mídia, amigos) e } \\
\text { forma que encontra } \\
\text { para lidar com a } \\
\text { situação de } \\
\text { discriminação }\end{array}$ & $\begin{array}{l}\text { O entrevistado demonstra ter tido } \\
\text { oportunidade para refletir sobre o } \\
\text { assunto e encontra uma forma de } \\
\text { entendê-lo. }\end{array}$ & $\begin{array}{l}\text { Eu acho que algumas pessoas têm um certo preconceito } \\
\text { mas não é inato, assim, uma maldade dela, é por não } \\
\text { conhecer. Parece que se encara a falta de oportunidade de } \\
\text { alguns com a incapacidade intelectual delas, e está } \\
\text { demonstrado eu não é verdade isso.Mas algumas pessoas } \\
\text { têm essa resistência com isso, parece que é uma pessoa que } \\
\text { mora na baixada, que mora em Caxias, que mora em uma } \\
\text { favela, ou é deficiente fisico é diferente...de não poder } \\
\text { conversar, não poder passar coisas importantes }\end{array}$ \\
\hline
\end{tabular}




\begin{tabular}{|c|c|c|c|c|}
\hline $\begin{array}{l}\text { 8. Abordagem } \\
\text { teórica sobre o } \\
\text { tema }\end{array}$ & $\begin{array}{l}\text { Diversidade } x \\
\text { Igualdade } x \\
\text { Racismo }\end{array}$ & $\begin{array}{l}\text { Confusão sobre os } \\
\text { agrupamentos na } \\
\text { diversidade, sobre } \\
\text { a diferenciação } \\
\text { positiva - a } \\
\text { diferenciação } \\
\text { negativa (quando é } \\
\text { um valor a } \\
\text { diversidade e } \\
\text { quando não é). }\end{array}$ & $\begin{array}{l}\text { O entrevistado vê no termo raça uma } \\
\text { forma de identificação e valorização } \\
\text { da diversidade. }\end{array}$ & $\begin{array}{l}\text { Eu acho que raça é uma especificação que veio para somar, } \\
\text { acho que é uma identificação positiva, não é uma diferença } \\
\text { segregadora assim. Eu acho que a vida de iguais é muito } \\
\text { chata, eu acho que tem que ter diferença para a gente } \\
\text { aprender alguma coisa. }\end{array}$ \\
\hline $\begin{array}{l}\text { 8. Abordagem } \\
\text { teórica sobre o } \\
\text { tema }\end{array}$ & $\begin{array}{l}\text { Relação do } \\
\text { racismo com os } \\
\text { princípios de } \\
\text { direito } \\
\text { fundamentais }\end{array}$ & $\begin{array}{l}\text { reconhecimento da } \\
\text { política como um } \\
\text { direito fundamental }\end{array}$ & $\begin{array}{l}\text { O entrevistado entende a } \\
\text { discriminação positiva e } \\
\text { especificamente a política de como } \\
\text { um direito seu, direito à educação } \\
\text { ("Porque todo mundo tem que ter } \\
\text { direito à educação. Tem concurso só } \\
\text { porque não tem vaga para todo } \\
\text { mundo"), independente do fato de } \\
\text { que teria ou não condições de passar } \\
\text { no vestibular da forma em que é feito } \\
\text { ("você não sabe matemática, física e } \\
\text { química, então você não pode entrar } \\
\text { para fazer uma faculdade de } \\
\text { direito?", "Eu acho que a justiça é } \\
\text { tratar os iguais igualmente e tratar os } \\
\text { desiguais na medida em que são } \\
\text { desiguais, "). }\end{array}$ & $\begin{array}{l}\text { Eu acho que a justiça é tratar os iguais igualmente e tratar } \\
\text { os desiguais na medida em que são desiguais, assim, então, } \\
\text { acho que tem essa diversidade, então acho que você não } \\
\text { pode falar: você não tem direito... você não sabe } \\
\text { matemática, física e química, então você não pode entrar } \\
\text { para fazer uma faculdade de direito? Porque todo mundo } \\
\text { tem que ter direito à educação. Tem concurso só porque } \\
\text { não tem vaga para todo mundo, senão não teria nem } \\
\text { concurso. Então, para você igualar... a cotas... não que } \\
\text { seja ideal, mas é o que está sendo usado no momento, eu } \\
\text { acho que a medida efetiva que não se pode abrir mão, para } \\
\text { se fazer uma justiça social que no momento se pode fazer. }\end{array}$ \\
\hline
\end{tabular}




\begin{tabular}{|c|c|c|c|c|}
\hline & $\begin{array}{l}\text { Relação do } \\
\text { racismo com os } \\
\text { princípios de } \\
\text { direito } \\
\text { fundamentais }\end{array}$ & $\begin{array}{l}\text { reconhecimento do } \\
\text { direito a ser tratado } \\
\text { desigualmente ( } \\
\text { discriminação } \\
\text { positiva) }\end{array}$ & $\begin{array}{l}\text { O entrevistado ressalta um aspecto } \\
\text { interessante da pergunta, mostrando } \\
\text { discordar dos direitos dos negros na } \\
\text { perspectiva do Multiculturalismo, por } \\
\text { entendê-la segregadora e } \\
\text { preconceituosa. No entanto, defende } \\
\text { esses direitos na perspectiva do } \\
\text { princípio da igualdade. ("não como } \\
\text { uma segreção mas como um sub- } \\
\text { tema de um tema amplo que os } \\
\text { negros sofrem na sociedade"). }\end{array}$ & $\begin{array}{l}\text { Acho que Direitos Humanos é um mínimo necessário que o } \\
\text { ser humano precisa para se auto determinar e se auto } \\
\text { estabelecer na sociedade, sem ser cerceado de qualquer } \\
\text { forma. Acho que é uma necessidade intrínseca ao ser } \\
\text { humano que não se pode abrir mão de jeito nenhum. } \\
\text { Pergunta: Você acha que direito dos negros é tema de } \\
\text { Direitos Humanos? Resposta: Não, acho que é mera } \\
\text { divisão de um tema central, mas não vejo isso como... se } \\
\text { você encarar os direitos humanos do negro como um meio } \\
\text { de segregação também preconceituosa do negro, então, } \\
\text { acho negativo, mas é um sub-tema que tem que ser } \\
\text { discutido praticamente, a realidade, e não segregar. } \\
\text { Também direito dos brancos também seria algo } \\
\text { preconceituoso se você pensar nesse sentido, mas... tem que } \\
\text { pensar não como uma segreção mas como um sub-tema de } \\
\text { um tema amplo que os negros sofrem na sociedade. } \\
\text { Pergunta: E discriminação racial? Resposta: Acho que sim. } \\
\text { Discriminação é. }\end{array}$ \\
\hline $\begin{array}{c}9 . \\
\text { Manifestação da } \\
\text { solidariedade }\end{array}$ & & $\begin{array}{l}\text { crença de que a } \\
\text { relação multi- } \\
\text { étnica enriquece e } \\
\text { auxilia a } \\
\text { coletividade, na } \\
\text { solução de } \\
\text { problemas } \\
\text { coletivos e } \\
\text { individuais; } \\
\text { disponibilidade } \\
\text { para a busca real } \\
\text { de soluções para o } \\
\text { racismo }\end{array}$ & $\begin{array}{l}\text { O entrevistado acredita que a } \\
\text { convivência multi-étnica é positiva, } \\
\text { enriquece a coletividade e auxilia } \\
\text { como uma ação contra o preconceito } \\
\text { ("acho que isso acaba vencendo os } \\
\text { preconceitos (...) núcleos sociais } \\
\text { diferentes estão convivendo (...) você } \\
\text { tem visões diferentes do mundo, tem } \\
\text { argumentos diferentes, que vocềas } \\
\text { vezes não tinha pensado nisso"). }\end{array}$ & $\begin{array}{l}\text { Acontece assim quando um (cotista) tira uma nota maior } \\
\text { numa matéria, aí parece que, acham estranho isso, "como é } \\
\text { que ele tirou uma nota maior que eu que fui criado em ph a } \\
\text { vida inteira", um curso notório aqui no Rio, é...parece que } \\
\text { ele acha um absurdo isso, "como é que pode, " né?(...) Mas } \\
\text { é isso, acho que isso acaba vencendo os preconceitos, } \\
\text { né?Acho que isso é muito positivo, essa interação, porque } \\
\text { núcleos sociais diferentes estão convivendo, estão } \\
\text { aprendendo, que as diferenças não são tão diferentes assim. } \\
\text { São formas diferentes de ver o mundo.... ve você esteve em } \\
\text { um condomínio desde criança, se você esteve em uma } \\
\text { favela, você mora no subúrbio, você tem visóes diferentes } \\
\text { do mundo, tem argumentos diferentes, que você às vezes } \\
\text { não tinha pensado nisso, né? }\end{array}$ \\
\hline
\end{tabular}




\begin{tabular}{|c|c|c|c|}
\hline $\begin{array}{c}9 . \\
\text { Manifestação da } \\
\text { solidariedade }\end{array}$ & $\begin{array}{l}\text { crença de que a } \\
\text { relação multi- } \\
\text { étnica auxilia a } \\
\text { coletividade, na } \\
\text { solução de } \\
\text { problemas } \\
\text { coletivos e } \\
\text { individuais; } \\
\text { disponibilidade } \\
\text { para a busca real } \\
\text { de soluções para o } \\
\text { racismo }\end{array}$ & $\begin{array}{l}\text { O entrevistado acredita na } \\
\text { convivência multi-ética para a } \\
\text { eliminação do racismo ("Vejo, por } \\
\text { parte de alguns, uma falta de } \\
\text { conhecimento, mas que com o tempo } \\
\text { vai se dirimindo") }\end{array}$ & $\begin{array}{l}\text { Acho que a gente tem que lutar nessa discussão de direitos } \\
\text { humanos pelos preconceitos morais que estão sedimentados } \\
\text { nas cabeças das pessoas há vários séculos que ... isso foi } \\
\text { jogado na cabeça de muita gente. E pra livrar um pouco } \\
\text { disso, pra fazer a pessoa se integrar na sociedade sendo } \\
\text { parte igual, tendo uma diversidade, claro, mas sendo uma } \\
\text { parte igual entre o semelhante, é... tem muito essa } \\
\text { discussão, assim (...)Vejo, por parte de alguns, uma falta } \\
\text { de conhecimento, mas que com a convivência e o tempo vai } \\
\text { se dirimindo }\end{array}$ \\
\hline $\begin{array}{c}9 . \\
\text { Manifestação da } \\
\text { solidariedade }\end{array}$ & $\begin{array}{c}\text { crença de que a } \\
\text { relação multi- } \\
\text { étnica auxilia a } \\
\text { coletividade, na } \\
\text { solução de } \\
\text { problemas } \\
\text { coletivos e } \\
\text { individuais; } \\
\text { disponibilidade } \\
\text { para a busca real } \\
\text { de soluções para o } \\
\text { racismo }\end{array}$ & $\begin{array}{l}\text { O entrevistado não vê na situação da } \\
\text { estória hipotética, uma proposta de } \\
\text { relação que influenciasse na } \\
\text { alteração do racismo nas relações } \\
\text { sociais ("Eu vou ser sincero, se eu } \\
\text { fosse o João (branco), eu não me } \\
\text { prejudicaria (para auxiliar o Gilberto } \\
\text { (negro)"). }\end{array}$ & $\begin{array}{l}\text { Eu acho, assim, dizer que foi... teve discriminação racial } \\
\text { sim, mas ele estava errado. Então, ele não deixou de se } \\
\text { inscrever por uma questão racial, mas porque ele estava } \\
\text { sem carteirinha. Mas lógico que a questão racial pesou } \\
\text { naquela hora. Acho então que, não se inscrever no } \\
\text { concurso, mas por vias judiciais, poderia discutir a } \\
\text { questão do racismo. Eu vou ser sincero, se eu fosse o João } \\
\text { (branco), eu não me prejudicaria. }\end{array}$ \\
\hline
\end{tabular}




\begin{tabular}{|c|c|c|c|}
\hline $\begin{array}{c}9 . \\
\text { Manifestação da } \\
\text { solidariedade }\end{array}$ & $\begin{array}{c}\text { crença de que a } \\
\text { relação multi- } \\
\text { étnica auxilia a } \\
\text { coletividade, na } \\
\text { solução de } \\
\text { problemas } \\
\text { coletivos e } \\
\text { individuais; } \\
\text { disponibilidade } \\
\text { para a busca real } \\
\text { de soluções para o } \\
\text { racismo }\end{array}$ & $\begin{array}{l}\text { O entrevistado acredita na } \\
\text { convivência multi-ética para a } \\
\text { eliminação do racismo ("acho que } \\
\text { precisa interagir... ver que não é ... só } \\
\text { enquadrar em estereótipos que essa } \\
\text { sociedade coloca... senta e } \\
\text { conversa") }\end{array}$ & $\begin{array}{l}\text { Pergunta: O que você faria para melhorar a relação entre } \\
\text { brancos e negros no Rio de Janeiro? ... conhecer realmente, } \\
\text { entrar na favela, conhecer as pessoas, conversar e.... eu } \\
\text { acho que isso vai diminuir o preconceito sim. E também, } \\
\text { acho que também o pessoal da zona sul também,... acho que } \\
\text { precisa interagir, necessita isso, ver que não é... só } \\
\text { enquadrar em estereótipos que essa sociedade coloca, que } \\
\text { ela vai oferecer um perigo pra você, senta e conversa. }\end{array}$ \\
\hline $\begin{array}{c}9 . \\
\text { Manifestação da } \\
\text { solidariedade }\end{array}$ & $\begin{array}{l}\text { crença de que a } \\
\text { relação multi- } \\
\text { étnica enriquece e } \\
\text { auxilia a } \\
\text { coletividade, na } \\
\text { solução de } \\
\text { problemas } \\
\text { coletivos e } \\
\text { individuais; } \\
\text { disponibilidade } \\
\text { para a busca real } \\
\text { de soluções para o } \\
\text { racismo }\end{array}$ & $\begin{array}{l}\text { O entrevistado acredita que a } \\
\text { diferença soma e que ela é importante } \\
\text { para a sua própria existência. }\end{array}$ & $\begin{array}{l}\text { A diversidade... Depende da pessoa que pensa (riso)... Eu } \\
\text { acho que é um fator positivo a diversidade, que leva você a } \\
\text { pensar, a conhecer... Eu não sei para que fim estamos aqui, } \\
\text { mas eu acho que um dos fins é conhecer o outro, eu acho } \\
\text { que a diversidade tem que existir, porque se não, seria } \\
\text { como escrever um livro sobre mim mesmo, todos os dias as } \\
\text { mesmas coisas, precisa da diferença para somar alguma } \\
\text { coisa e ter algum sentido para a minha existência. }\end{array}$ \\
\hline
\end{tabular}




\begin{tabular}{|c|c|c|c|}
\hline $\begin{array}{c}9 . \\
\text { Manifestação da } \\
\text { solidariedade }\end{array}$ & & $\begin{array}{l}\text { O entrevistado busca na } \\
\text { transformação dos conceitos morais } \\
\text { uma solução para o racismo ("lutar } \\
\text { nessa discussão de direitos humanos } \\
\text { pelos preconceitos morais que estão } \\
\text { sedimentados nas cabeças das } \\
\text { pessoas há vários séculos que ... } \\
\text { isso foi jogado na cabeça de muita } \\
\text { gente"). No entanto, o entrevistado } \\
\text { assinala que existe uma limitação em } \\
\text { se transformar a cabeça de pessoas } \\
\text { que já estão formadas em uma } \\
\text { cultura racista ("chega um tanto de } \\
\text { rasuras você não pode mais mudar as } \\
\text { pessoas. Então nessa discussão de } \\
\text { cotas, o que as pessoas pensam, } \\
\text { deixam de pensar, eu pensei nisso"). }\end{array}$ & $\begin{array}{l}\text { Acho que a gente tem que lutar nessa discussão de direitos } \\
\text { humanos pelos preconceitos morais que estão sedimentados } \\
\text { nas cabeças das pessoas há vários séculos que ... isso foi } \\
\text { jogado na cabeça de muita gente. E pra livrar um pouco } \\
\text { disso, pra fazer a pessoa se integrar na sociedade sendo } \\
\text { parte igual, tendo uma diversidade, claro, mas sendo uma } \\
\text { parte igual entre o semelhante, é... (...)Folha de papel em } \\
\text { branco: lembrei de uma coisa que um dia meu pai disse } \\
\text { assim que uma criança é um papel em branco, você vai } \\
\text { escrevendo nela, quando você fica na dúvida, você vai } \\
\text { apagando, escrevendo de novo, chega um tanto de rasuras } \\
\text { você não pode mais mudar as pessoas. Então nessa } \\
\text { discussão de cotas, o que as pessoas pensam, deixam de } \\
\text { pensar, eu pensei nisso }\end{array}$ \\
\hline $\begin{array}{l}\text { 10. Integração } \\
\text { com as ofertas de } \\
\text { desenvolvimento } \\
\text { da Universidade }\end{array}$ & $\begin{array}{l}\text { Integração com os } \\
\text { colegas da } \\
\text { universidade; } \\
\text { oportunidades } \\
\text { profissionais que } \\
\text { surgem a partir } \\
\text { dessa integração; } \\
\text { acesso às } \\
\text { oportunidades que o } \\
\text { ambiente } \\
\text { acadêmico oferece }\end{array}$ & $\begin{array}{l}\text { O entrevistado não está envolvido } \\
\text { com nenhuma atividade da } \\
\text { universidade além do próprio curso. } \\
\text { No entanto demonstra estar bastante } \\
\text { envolvido com o curso e com os } \\
\text { debates que tem com os colegas } \\
\text { sobre o curso ("conversar com os } \\
\text { colegas para debater os assuntos... } \\
\text { Eu estou me dedicando à Faculdade") }\end{array}$ & $\begin{array}{l}\text { Eu fazia estágio mas estava complicado conciliar estágio e } \\
\text { os estudos, porque o estágio não estava mais } \\
\text { complementando minha área de Direito, era mais uma } \\
\text { opção para ganhar dinheiro (...) e daí eu pensei que tenho } \\
\text { que fazer faculdade mais pra vida, assim, e não para o } \\
\text { momento (...) sentia falta de um momento em que eu } \\
\text { pudesse conversar com os colegas para debater os } \\
\text { assuntos... Eu estou me dedicando à Faculdade e estudo em } \\
\text { casa ou aqui. }\end{array}$ \\
\hline
\end{tabular}




\begin{tabular}{|c|c|c|c|c|}
\hline \multicolumn{5}{|c|}{ ENTREVISTADO F - COTISTA Ï UERJ } \\
\hline CATEGORIA & $\begin{array}{c}\text { SUB- } \\
\text { CATEGORIA }\end{array}$ & INDICADORES & ASPECTOS SIGNIFICATIVOS & RELATOS DE ENTREVISTA \\
\hline identidade étnica & $\frac{\text { negra / branca / }}{\text { parda }}$ & & & \\
\hline $\begin{array}{l}\text { 1. A visibilidade } \\
\text { da diversidade } \\
\text { étnico-racial e } \\
\text { a racialização de } \\
\text { si e do outro }\end{array}$ & & $\begin{array}{c}\text { utilização do } \\
\text { componente étnico- } \\
\text { racial na descrição } \\
\text { das pessoas das } \\
\text { fotos de estudantes } \\
\text { negros, brancos e } \\
\text { asiáticos }\end{array}$ & $\begin{array}{l}\text { o entrevistado descreve as fotos não } \\
\text { manifestando a cor, etnia ou raça da } \\
\text { pessoa. }\end{array}$ & $\begin{array}{l}\text { a) pessoa que está na biblioteca...estudando, está um } \\
\text { pouquinho chato...(branca) b) um estudante também, está } \\
\text { feliz...(asiática) c) também é uma estudante, está feliz com } \\
\text { que está fazendo, estudando de forma mais prazerosa que a } \\
\text { primeira (branca) d) estudante concentrada.(negra) }\end{array}$ \\
\hline $\begin{array}{l}\text { 1. A visibilidade } \\
\text { da diversidade } \\
\text { étnico-racial e a } \\
\text { racialização de } \\
\text { si e do outro }\end{array}$ & & $\begin{array}{l}\text { utilização do } \\
\text { componente étnico- } \\
\text { racial para } \\
\text { descrever } \\
\text { membros da família } \\
\text { e a si próprio }\end{array}$ & $\begin{array}{c}\text { O entrevistado fala da etnia de membros } \\
\text { da sua família ("É uma mistura de índia, } \\
\text { com colonizador") mas não sabe sobre a } \\
\text { sua origem. }\end{array}$ & $\begin{array}{l}\text { Eu sinceramente não tenho dados (riso)...sobre o passado da } \\
\text { minha família, mas eu tenho algumas questôes interessantes } \\
\text { mais atuais, assim, a minha família é bem Brasil, assim: eu } \\
\text { sou capixaba, do Espírito Santo, meu pai é da Bahia, minha } \\
\text { mãe é do Acre, eu irmão é do Acre também, então, é.. uma } \\
\text { coisa bem brasileira, assim... nordestino, do Norte, com } \\
\text { criação no Sudeste... Pergunta: A parte de fora do Brasil? } \\
\text { Resposta: Não faço a mínima idéia das origens anteriores a } \\
\text { essa. (...)Pergunta: Que raça é sua mãe? É uma mistura de } \\
\text { india, com colonizador, mas ainda carrega os traços } \\
\text { indígenas, não tão forte, ela era do Acre né? Entâo tem } \\
\text { alguma coisa indígena, não só do Brasil, né? mas da Bolívia.. }\end{array}$ \\
\hline
\end{tabular}




\begin{tabular}{|c|c|c|c|}
\hline $\begin{array}{l}\text { 2. Visibilidade } \\
\text { sobre a } \\
\text { ocorrência da } \\
\text { discriminação } \\
\text { racial }\end{array}$ & $\begin{array}{c}\text { visibilidade do } \\
\text { tratamento desigual } \\
\text { direto ou indireto } \\
\text { que prejudica } \\
\text { socialmente o } \\
\text { negro, seja pela } \\
\text { neutralidade, seja } \\
\text { pela diferenciação } \\
\text { negativa }\end{array}$ & $\begin{array}{l}\text { O entrevistado identifica a presença da } \\
\text { discriminação racial na sociedade } \\
\text { brasileira e relaciona ela com o conceito } \\
\text { social de raça. ("eu acho que esse } \\
\text { conceito é válido no Brasil porque há uma } \\
\text { exclusão direta de determinados grupos } \\
\text { sociais" ). }\end{array}$ & $\begin{array}{l}\text { Dizem que o conceito de raça não está mais vigorando, não } \\
\text { sei entre os biólogos catedráticos, mas eu acho que esse } \\
\text { conceito é válido no Brasil porque há uma exclusão direta de } \\
\text { determinados grupos sociais, então, há que se falar em raça } \\
\text { para incluí-los no contexto social mais... digno. A raça, acho } \\
\text { que já caiu esse conceito, mas no Brasil é interessante porque } \\
\text { tem grupos sociais, muitas vezes muito identificados por uma } \\
\text { determinada raça, mesmo que esse conceito tenha caído, } \\
\text { então, é interessante no Brasil para poder incluir essas } \\
\text { pessoas no contexto social. }\end{array}$ \\
\hline $\begin{array}{l}\text { 2. Visibilidade } \\
\text { sobre a } \\
\text { ocorrência da } \\
\text { discriminação } \\
\text { racial }\end{array}$ & $\begin{array}{c}\text { visibilidade do } \\
\text { tratamento desigual } \\
\text { direto ou indireto } \\
\text { que prejudica } \\
\text { socialmente o } \\
\text { negro, seja pela } \\
\text { neutralidade, seja } \\
\text { pela diferenciação } \\
\text { negativa }\end{array}$ & $\begin{array}{l}\text { O entrevistado constata a discriminação } \\
\text { racial direta, na estória hipotética. }\end{array}$ & $\begin{array}{l}\text { Pergunta } 20^{*} \text { primeira etapa: acho que isso aconteceu } \\
\text { porque é estereotipo, né? Em cima da pessoa negra. }\end{array}$ \\
\hline
\end{tabular}




\begin{tabular}{|c|c|c|c|}
\hline $\begin{array}{l}\text { 2. Visibilidade } \\
\text { sobre a } \\
\text { ocorrência da } \\
\text { discriminação } \\
\text { racial }\end{array}$ & $\begin{array}{l}\text { visibilidade do } \\
\text { tratamento desigual } \\
\text { direto ou indireto } \\
\text { que prejudica } \\
\text { socialmente o } \\
\text { negro, seja pela } \\
\text { neutralidade, seja } \\
\text { pela diferenciação } \\
\text { negativa }\end{array}$ & $\begin{array}{l}\text { O entrevistado constata a discriminação } \\
\text { racial institucional na universidade }\end{array}$ & $\begin{array}{l}\text { Pergunta: Se vocês entrassem em um colégio e visse que o } \\
\text { dono é negro e todos os seus funcionários contratados são } \\
\text { negros. Você chamaria isso de racismo? Resposta: Sim, eu } \\
\text { considero. A escola tem um leque de profissionais, né? Pô, } \\
\text { não tem nenhum branco que se enquadrou no perfil desse } \\
\text { leque?! Pergunta: Você tem algum professor negro aqui? } \\
\text { Resposta: Não }\end{array}$ \\
\hline $\begin{array}{l}\text { 2. Visibilidade } \\
\text { sobre a } \\
\text { ocorrência da } \\
\text { discriminação } \\
\text { racial }\end{array}$ & $\begin{array}{l}\text { visibilidade do } \\
\text { tratamento desigual } \\
\text { direto ou indireto } \\
\text { que prejudica } \\
\text { socialmente o } \\
\text { negro, seja pela } \\
\text { neutralidade, seja } \\
\text { pela diferenciação } \\
\text { negativa }\end{array}$ & $\begin{array}{l}\text { O entrevistado constata o fato } \\
\text { discriminatório negativo de que, ainda que } \\
\text { ele esteja exercendo um direito, as } \\
\text { pessoas o tratam como se precisasse de } \\
\text { um favor. ("O Brasil tem cultura de.. } \\
\text { qualquer coisa que você peça, que você } \\
\text { tente exercer um direito você é } \\
\text { discriminado (...) pô, parece que é um } \\
\text { favor que estão fazendo para você"). }\end{array}$ & $\begin{array}{l}\text { O Brasil tem cultura de...de talvez, em virtude de sua própria } \\
\text { história, tudo que pareça ....pareça, por exemplo, dado, não é } \\
\text { dado. Ação afirmativa não é dar as coisas, é incluir } \\
\text { socialmente determinadas pessoas (...) que por algum fator } \\
\text { cultural, economico não estariam dentro do...do sistema., do } \\
\text { lado bom do sistema (...) qualquer coisa que você passe, } \\
\text { qualquer coisa que você peça, que você tente exercer um } \\
\text { direito você é discriminado, assim, por diversas outras } \\
\text { coisas, estudante pouco que tem passe livre, pô, parece que é } \\
\text { um favor que estão fazendo para você. Não, não é um favor, é } \\
\text { um direito. }\end{array}$ \\
\hline
\end{tabular}




\begin{tabular}{|c|c|c|c|c|}
\hline $\begin{array}{l}\text { 3. Visibilidade } \\
\text { sobre as } \\
\text { consequências } \\
\text { do racismo, os } \\
\text { danos e os } \\
\text { privilégios }\end{array}$ & & $\begin{array}{c}\text { visibilidade do } \\
\text { prejuízo social para } \\
\text { o negro }\end{array}$ & $\begin{array}{c}\text { O entrevistado constata a diferença que } \\
\text { existe entre negros e brancos em } \\
\text { decorrência das posições que cada um } \\
\text { tem em uma sociedade racista. Aponta } \\
\text { vários danos decorrentes do racismo à } \\
\text { população negra ("Tem uma carga } \\
\text { histórica cultural de discriminação, de } \\
\text { rebaixamento, falta de oportunidades, de } \\
\text { desleixo do Estado") que se contrapõem a } \\
\text { situação de privilégios dos brancos, } \\
\text { relacionados exclusivamente ao aspecto } \\
\text { racial ("a pessoa pode ter as mesmas } \\
\text { condições de uma pessoa branca mas... } \\
\text { algum diferencial no meio social ela vai ter } \\
\text { por ser branca (...) São pessoas idênticas, } \\
\text { capazes e plenas das suas faculdades (...) } \\
\text { A diferença é (...) como a sociedade } \\
\text { trata."). }\end{array}$ & $\begin{array}{l}\text { Pergunta: Qual é a semelhança e a diferença de uma pessoa } \\
\text { negra e uma branca? Resposta: A diferença? Acho que tem } \\
\text { muita diferença, tem muita diferença. Tem uma carga } \\
\text { histórica cultural de discriminação, de rebaixamento, falta de } \\
\text { oportunidades, de desleixo do Estado com ela, e a pessoa } \\
\text { pode ter as mesmas condiçôes de uma pessoa branca mas... } \\
\text { algum diferencial no meio social ela vai ter por ser branca, } \\
\text { acho que tem muita diferença. Até o negro rico tem diferença. } \\
\text { O próprio professor nosso de sociologia comentou que o } \\
\text { negro rico só chega a determinado estágio, entendeu? Não } \\
\text { passa. Pergunta: E as semelhanças? Resposta: Tem, acho } \\
\text { que os dois são idênticos. A diferença é cultural, como a } \\
\text { sociedade trata. São pessoas idênticas, capazes e plenas das } \\
\text { suas faculdades. }\end{array}$ \\
\hline 4. Estigma & $\begin{array}{l}\text { na } \\
\text { comunicação } \\
\text { não verbal }\end{array}$ & $\begin{array}{c}\text { escolha de papéis } \\
\text { profissionais para as } \\
\text { pessoas das fotos de } \\
\text { homens e mulheres; } \\
\text { brancos(as) e } \\
\text { negros(as); de faixas } \\
\text { etárias de } 20 \text { a } 30 \\
\text { anos, de } 31 \text { a } 59 \\
\text { anos, acima de } 60 \\
\text { anos. } \\
\text { Indicadores: } \\
\text { profissionais brancos } \\
\text { (as) - negros (as) e } \\
\text { cargos profissionais } \\
\text { artista, que privilegia } \\
\text { conhecimento } \\
\text { intelectual, manual e } \\
\text { posições de chefia. }\end{array}$ & $\begin{array}{l}\text { O entrevistado utilizou o número de } \\
\text { negros e brancos nas profissões de forma } \\
\text { paritária nas profissões que privilegia o } \\
\text { conhecimento intelectual e de posição de } \\
\text { chefia. No entanto, escolheu } 4 \text { pessoas } \\
\text { negras para ocupar o lugar das } 4 \\
\text { profissões que privilegiam o trabalho } \\
\text { manual. Nesse ponto, demonstra uma } \\
\text { tendência em reproduzir o estigma social. } \\
\text { Das } 9 \text { profissões, } 3 \text { foram preenchidas com } \\
\text { pessoas brancas e } 6 \text { com pessoas negras; } \\
\text { sendo que a profissão de artista, } 1 \text { das } 2 \text { que } \\
\text { privilegiam conhecimento intelectual, } 1 \text { das } 2 \\
\text { que são posições de chefia foram } \\
\text { preenchidas por pessoas brancas; } 1 \text { das } 2 \\
\text { que privilegiam conhecimento intelectual, } 1 \\
\text { das } 2 \text { que são posições de chefia e as } 4 \text { que } \\
\text { privilegiam trabalho manual foram } \\
\text { preenchidas por pessoas negras. }\end{array}$ & $\begin{array}{l}\text { Profissional Artista: Pianista - homem branco (figura 25); } \\
\text { Profissão que privilegia conhecimento intelectual: Médico (a) } \\
\text { plantonista - homem branco (figura 19); Professor } \\
\text { Universitário - homem negro (figura 28); } \\
\text { Posições de chefia: Gerente do hotel - homem negro (figura } \\
\text { 18); Diretor (a) de Marketing de uma loja de departamento - } \\
\text { mulher branca (figura 29); } \\
\text { Profissões que privilegiam o trabalho manual: Arrumador } \\
\text { (eira) do Hotel - homem negro (figura 17); Motorista de } \\
\text { ônibus - homem negro (figura 28); Cabeleireiro(a)) - mulher } \\
\text { negra (figura 20); Porteiro(a) do Hotel - homem negro (figura } \\
\text { 30). }\end{array}$ \\
\hline
\end{tabular}




\begin{tabular}{|c|c|c|c|}
\hline 5. Estereótipo & & & \\
\hline $\begin{array}{l}\text { 6. Reações } \\
\text { emocionais na } \\
\text { relação com o } \\
\text { preconceito } \\
\text { (com o diverso) }\end{array}$ & $\begin{array}{c}\text { culpa, vergonha, } \\
\text { irritabilidade, raiva, } \\
\text { exaustão, confusão } \\
\text { na fala, negação, } \\
\text { medo, } \\
\text { dissimulação, } \\
\text { sensação de } \\
\text { solidão, tristeza, } \\
\text { sensação de não } \\
\text { pertencimento, } \\
\text { impotência, } \\
\text { contradição, } \\
\text { justificativa } \\
\text { defensiva }\end{array}$ & $\begin{array}{l}\text { O entrevistado demonstrou ter se sentido } \\
\text { bem em falar sobre o sobre racismo. }\end{array}$ & $\begin{array}{l}\text { copo de água porque acho que a entrevista fluiu bem, eu falei } \\
\text { o que eu pensava, contei um pouco da minha experiência... } \\
\text { Fluiu. }\end{array}$ \\
\hline $\begin{array}{l}\text { 7. Formas e } \\
\text { Oportunidades } \\
\text { de elaboração } \\
\text { das experiências } \\
\text { relacionadas ao } \\
\text { racismo }\end{array}$ & $\begin{array}{l}\text { oportunidades de } \\
\text { reflexão sobre o } \\
\text { tema racismo nos } \\
\text { espaços sociais } \\
\text { (família, escola, } \\
\text { mídia, amigos) e } \\
\text { forma que encontra } \\
\text { para lidar com a } \\
\text { situação de } \\
\text { discriminação }\end{array}$ & $\begin{array}{l}\text { O entrevistado demonstrou não ter tido } \\
\text { oportunidades significativas }\end{array}$ & \\
\hline
\end{tabular}




\begin{tabular}{|c|c|c|c|c|}
\hline $\begin{array}{l}\text { 8. Abordagem } \\
\text { teórica sobre o } \\
\text { tema }\end{array}$ & $\begin{array}{l}\text { Diversidade } \mathrm{x} \\
\text { Igualdade } \mathrm{x} \\
\text { Racismo }\end{array}$ & $\begin{array}{l}\text { Confusão sobre os } \\
\text { agrupamentos na } \\
\text { diversidade, sobre } \\
\text { a diferenciação } \\
\text { positiva - a } \\
\text { diferenciação } \\
\text { negativa (quando é } \\
\text { um valor a } \\
\text { diversidade e } \\
\text { quando não é). }\end{array}$ & $\begin{array}{l}\text { O entrevistado relaciona a diversidade } \\
\text { com a democracia. }\end{array}$ & $\begin{array}{l}\text { Acho a diversidade boa... boa. A diversidade é a democracia, } \\
\text { né? Tem que está muito ligado. É o que a gente quer para o } \\
\text { Brasil e é isso que a gente não tem, né? Acho que o conceito } \\
\text { de diversidade é maravilhoso mas como tudo na vida pode } \\
\text { ser usado de uma maneira que não seja interessante... }\end{array}$ \\
\hline $\begin{array}{c}\text { 8. Abordagem } \\
\text { teórica sobre o } \\
\text { tema }\end{array}$ & $\begin{array}{l}\text { Relação do } \\
\text { racismo com } \\
\text { os princípios } \\
\text { de direito } \\
\text { fundamentais }\end{array}$ & $\begin{array}{l}\text { reconhecimento da } \\
\text { política como um } \\
\text { direito fundamental }\end{array}$ & $\begin{array}{l}\text { O entrevistado concebe a discriminação } \\
\text { positiva, a cotas, como um direito ("Ação } \\
\text { afirmativa não é dar as coisas, é incluir } \\
\text { socialmente determinadas pessoas (...) } \\
\text { que por algum fator cultural, econômico } \\
\text { não estariam dentro do...do sistema., do } \\
\text { lado bom do sistema (...) não é dado (...) } \\
\text { Não, não é um favor, é um direito"). }\end{array}$ & $\begin{array}{l}\text { O Brasil tem cultura de...de talvez, em virtude de sua própria } \\
\text { história, tudo que pareça ....pareça, por exemplo, dado, não é } \\
\text { dado. Ação afirmativa não é dar as coisas, é incluir } \\
\text { socialmente determinadas pessoas (...) que por algum fator } \\
\text { cultural, econômico não estariam dentro do...do sistema., do } \\
\text { lado bom do sistema (...) qualquer coisa que você passe, } \\
\text { qualquer coisa que você peça, que você tente exercer um } \\
\text { direito você é discriminado, assim, por diversas outras } \\
\text { coisas, estudante publico que tem passe livre, pô, parece que } \\
\text { é um favor que estão fazendo para você. Não, não é um favor, } \\
\text { é um direito. }\end{array}$ \\
\hline
\end{tabular}




\begin{tabular}{|c|c|c|c|c|}
\hline & $\begin{array}{l}\text { Relação do } \\
\text { racismo com } \\
\text { os princípios } \\
\text { de direito } \\
\text { fundamentais }\end{array}$ & $\begin{array}{l}\text { reconhecimento do } \\
\text { direito a ser tratado } \\
\text { desigualmente ( } \\
\text { discriminação } \\
\text { positiva) }\end{array}$ & $\begin{array}{l}\text { O entrevistado rejeita a idéia de direitos } \\
\text { universais na medida em que vê a } \\
\text { necessidade da afirmação das demandas } \\
\text { específicas dos negros para uma } \\
\text { sociedade justa ("mas eu não sou a favor } \\
\text { dos direitos humanos universais (...) } \\
\text { Determinados grupos sociais têm umas } \\
\text { demandas especiais em relação aos } \\
\text { direitos humanos"). No entanto, em outro } \\
\text { momento, afirma que acha que não haveria } \\
\text { discriminação se fosse implementado os } \\
\text { direitos fundamentais para todos. }\end{array}$ & $\begin{array}{l}\text { Eu entendo Direitos Humanos como.... Os direitos universais. } \\
\text { É uma construção histórica ocidental que, na nossa maneira } \\
\text { de se organizar, é um caminho... um caminho para uma } \\
\text { sociedade mais justa(...) mas eu não sou a favor dos direitos } \\
\text { humanos universal. Pergunta: Você acha que direito dos } \\
\text { negros é tema de Direitos Humanos? Resposta: Eu acho que } \\
\text { é. Acho que é muito pertinente. (...) Determinados grupos } \\
\text { sociais têm umas demandas especiais em relação aos direitos } \\
\text { humanos. Acho que é sim. Pergunta: E discriminação racial? } \\
\text { Resposta: é um tema de Direitos Humanos. Precisa manter a } \\
\text { dignidade da pessoa humana. (...)você... você implementando } \\
\text { os direitos fundamentais para todos, a gente teria uma } \\
\text { sociedade mais igualitária, acho que não teria motivos para a } \\
\text { discriminação, }\end{array}$ \\
\hline $\begin{array}{c}9 . \\
\text { Manifestação da } \\
\text { solidariedade }\end{array}$ & & $\begin{array}{l}\text { crença de que a } \\
\text { relação multi- } \\
\text { étnica enriquece e } \\
\text { auxilia a } \\
\text { coletividade, na } \\
\text { solução de } \\
\text { problemas } \\
\text { coletivos e } \\
\text { individuais; } \\
\text { disponibilidade } \\
\text { para a busca real } \\
\text { de soluções para } \\
\text { o racismo }\end{array}$ & $\begin{array}{l}\text { O entrevistado acredita que a convivência } \\
\text { multi-étnica é positiva enriquece a } \\
\text { coletividade e auxilia como uma ação } \\
\text { contra o preconceito ("acho que isso } \\
\text { acaba vencendo os preconceitos (...) } \\
\text { núcleos sociais diferentes estão } \\
\text { convivendo (...) você tem visões diferentes } \\
\text { do mundo, tem argumentos diferentes, que } \\
\text { você às vezes não tinha pensado nisso"). }\end{array}$ & $\begin{array}{l}\text { Acho a diversidade boa...boa. A diversidade é a democracia, } \\
\text { né? Tem que está muito ligado. É o que a gente quer para o } \\
\text { Brasil e é isso que a gente não tem, né? Acho que o conceito } \\
\text { de diversidade é maravilhoso mas como tudo na vida pode } \\
\text { ser usado de uma maneira que não seja interessante... }\end{array}$ \\
\hline
\end{tabular}




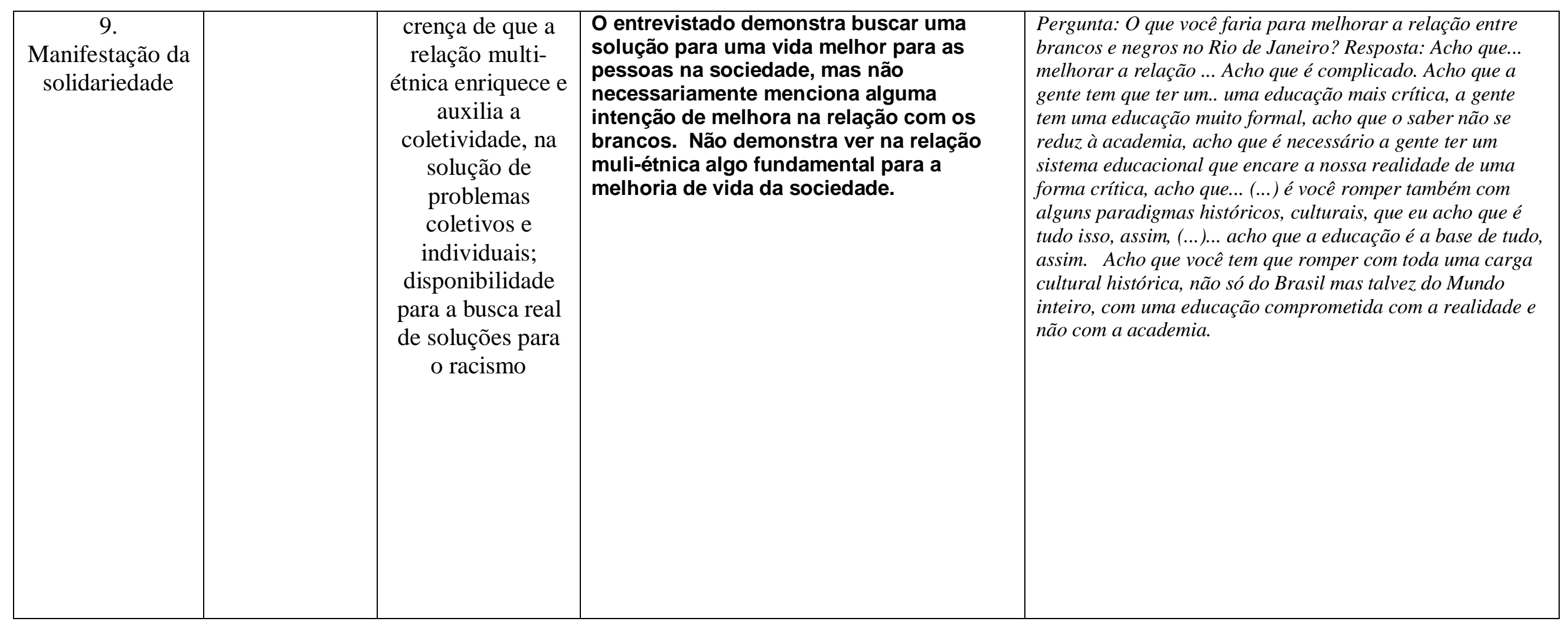




\begin{tabular}{|c|c|c|c|}
\hline $\begin{array}{c}9 . \\
\text { Manifestação da } \\
\text { solidariedade }\end{array}$ & $\begin{array}{l}\text { crença de que a } \\
\text { relação multi- } \\
\text { étnica auxilia a } \\
\text { coletividade, na } \\
\text { solução de } \\
\text { problemas } \\
\text { coletivos e } \\
\text { individuais; } \\
\text { disponibilidade } \\
\text { para a busca real } \\
\text { de soluções para } \\
\text { o racismo }\end{array}$ & $\begin{array}{l}\text { O entrevistado acredita que criar } \\
\text { oportunidades para se falar sobre o } \\
\text { assunto é positivo para a diminuição da } \\
\text { discriminação racial. }\end{array}$ & $\begin{array}{l}\text { Pergunta: Se tivesse palestras, workshops sobre o racismo, o } \\
\text { convivio entre a diversidade na faculdade ajudaria a diminuir } \\
\text { a discriminação? Resposta: Sim, nós tivemos aqui, temos } \\
\text { atualmente. }\end{array}$ \\
\hline
\end{tabular}




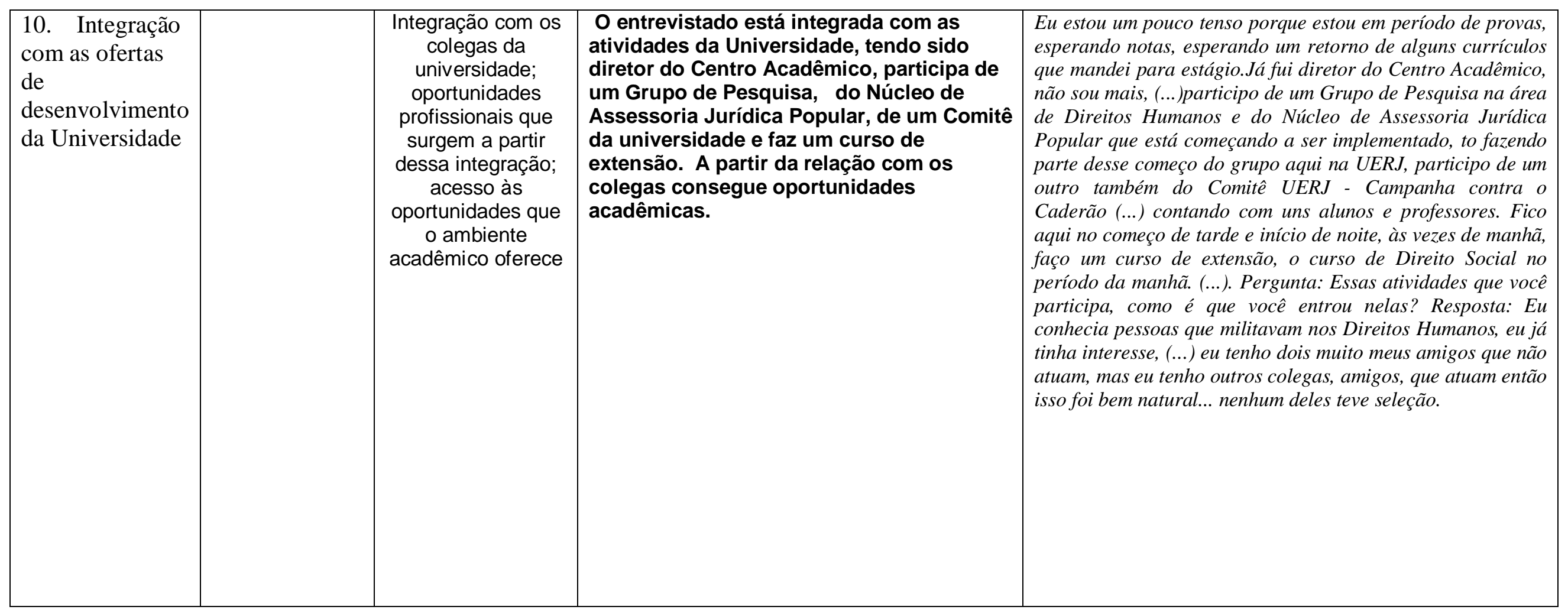




\begin{tabular}{|c|c|c|c|c|}
\hline \multicolumn{5}{|c|}{ ENTREVISTADO G - COTISTA Ï UERJ } \\
\hline CATEGORIA & $\begin{array}{c}\text { SUB- } \\
\text { CATEGORIA }\end{array}$ & INDICADORES & ASPECTOS SIGNIFICATIVOS & RELATOS DE ENTREVISTA \\
\hline identidade étnica & $\frac{\text { negra / branca / }}{\text { parda }}$ & & & \\
\hline $\begin{array}{l}\text { 1. A visibilidade } \\
\text { da diversidade } \\
\text { étnico-racial e } \\
\text { a racialização de } \\
\text { si e do outro }\end{array}$ & & $\begin{array}{c}\text { utilização do } \\
\text { componente } \\
\text { étnico-racial na } \\
\text { descrição das } \\
\text { pessoas das fotos } \\
\text { de estudantes } \\
\text { negros, brancos e } \\
\text { asiáticos } \\
\end{array}$ & $\begin{array}{l}\text { o entrevistado descreve as fotos não } \\
\text { manifestando a cor, etnia ou raça da } \\
\text { pessoa. }\end{array}$ & $\begin{array}{l}\text { a) Uma pessoa concentrada, simpática... talvez } \\
\text { estudiosa, com um livro (branca) b) rapaz mais } \\
\text { extrovertido, simpático, tal, alegre...(branco) c) essa } \\
\text { aqui é mais compenetrada nos estudos, comparando, tal, } \\
\text { copiando um livro (negra) d) uma pessoa está expondo } \\
\text { um tipo de trabalho (asiática) }\end{array}$ \\
\hline $\begin{array}{l}\text { 1. A visibilidade } \\
\text { da diversidade } \\
\text { étnico-racial e a } \\
\text { racialização de } \\
\text { si e do outro }\end{array}$ & & $\begin{array}{l}\text { utilização do } \\
\text { componente } \\
\text { étnico-racial para } \\
\text { descrever } \\
\text { membros da } \\
\text { família e a si } \\
\text { próprio }\end{array}$ & $\begin{array}{l}\text { O entrevistado menciona a origem da } \\
\text { família "geração em geração desde a } \\
\text { escravidão". }\end{array}$ & $\begin{array}{l}\text { Bom, é aquilo que eu ouvi falar: por parte de mãe, meus } \\
\text { parentes maternos, estou sabendo que são do Espírito } \\
\text { Santo(..) já o meu pai, embora ele seja carioca, o } \\
\text { parentesco todo dele é de Minas Gerais, tem até uma } \\
\text { tradição da cultura lá de Minas Gerais, que vem de } \\
\text { geração em geração, tal, desde a escravidão, que vem se } \\
\text { desenvolvendo, tal. }\end{array}$ \\
\hline
\end{tabular}




\begin{tabular}{|c|c|c|c|}
\hline $\begin{array}{l}\text { 2. Visibilidade } \\
\text { sobre a } \\
\text { ocorrência da } \\
\text { discriminação } \\
\text { racial }\end{array}$ & $\begin{array}{c}\text { visibilidade do } \\
\text { tratamento } \\
\text { desigual direto ou } \\
\text { indireto que } \\
\text { prejudica } \\
\text { socialmente o } \\
\text { negro, seja pela } \\
\text { neutralidade, seja } \\
\text { pela diferenciação } \\
\text { negativa }\end{array}$ & $\begin{array}{c}\text { O entrevistado constata a } \\
\text { discriminação racial direta, na estória } \\
\text { hipotética. }\end{array}$ & $\begin{array}{l}\text { Pergunta } 20^{*} \text { primeira etapa: Você não tem perfil da } \\
\text { universidade então você tem que provar que você é } \\
\text { aluno, né? }\end{array}$ \\
\hline
\end{tabular}




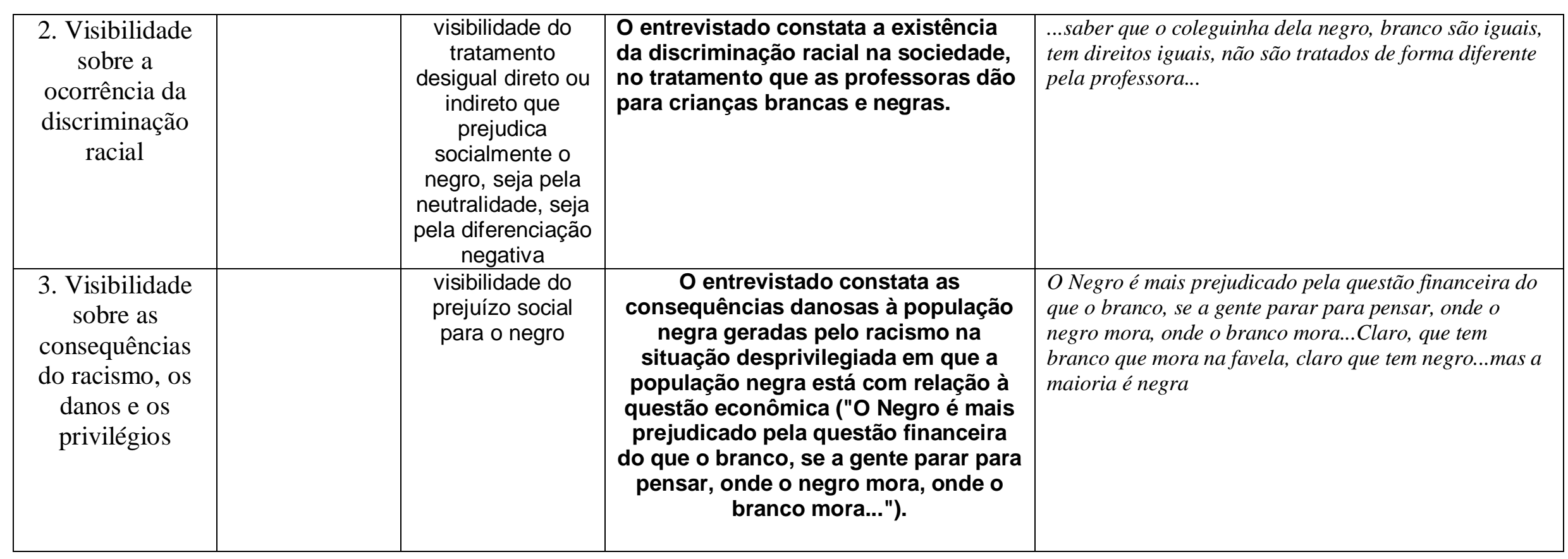




\begin{tabular}{|c|c|c|c|}
\hline $\begin{array}{l}\text { 3. Visibilidade } \\
\text { sobre as } \\
\text { consequências } \\
\text { do racismo, os } \\
\text { danos e os } \\
\text { privilégios }\end{array}$ & $\begin{array}{l}\text { visibilidade do } \\
\text { prejuízo social } \\
\text { para o negro }\end{array}$ & $\begin{array}{l}\text { O entrevistado constata os danos } \\
\text { decorrentes do racismo à população } \\
\text { negra ("se já prejudicam o negro de } \\
\text { tantas formas, discriminam de tanta } \\
\text { forma pro mal, de forma negativa") e } \\
\text { a diferença de desafios que tem que } \\
\text { enfrentar, em comparação ao branco, } \\
\text { para ter acesso à educação superior, } \\
\text { atribuindo essa diferença à condição } \\
\text { social desigual provocada pelas } \\
\text { relações raciais, e não ao fato de ele } \\
\text { pessoalmente ter menos capacidade. ( } \\
\text { "se não fosse a política de cotas eu } \\
\text { não estaria aqui (...) porque vê é } \\
\text { impossível, eu estaria concorrendo } \\
\text { com pessoas .... não tem condições } \\
\text { de me preparar tão bem como as } \\
\text { outras pessoas, não tem como ... não } \\
\text { tem um paralelo, não tem como eu } \\
\text { competir... ela tem mais condições, se } \\
\text { preparou melhor, tem um ensino de } \\
\text { melhor qualidade, bem mais superior } \\
\text { ao que eu tive no ensino médio (...) } \\
\text { discriminar de forma positiva } \\
\text { inserindo o negro na universidade, } \\
\text { dando a oportunidade de ele mudar, } \\
\text { reverter essa situação e ser alguém"). }\end{array}$ & 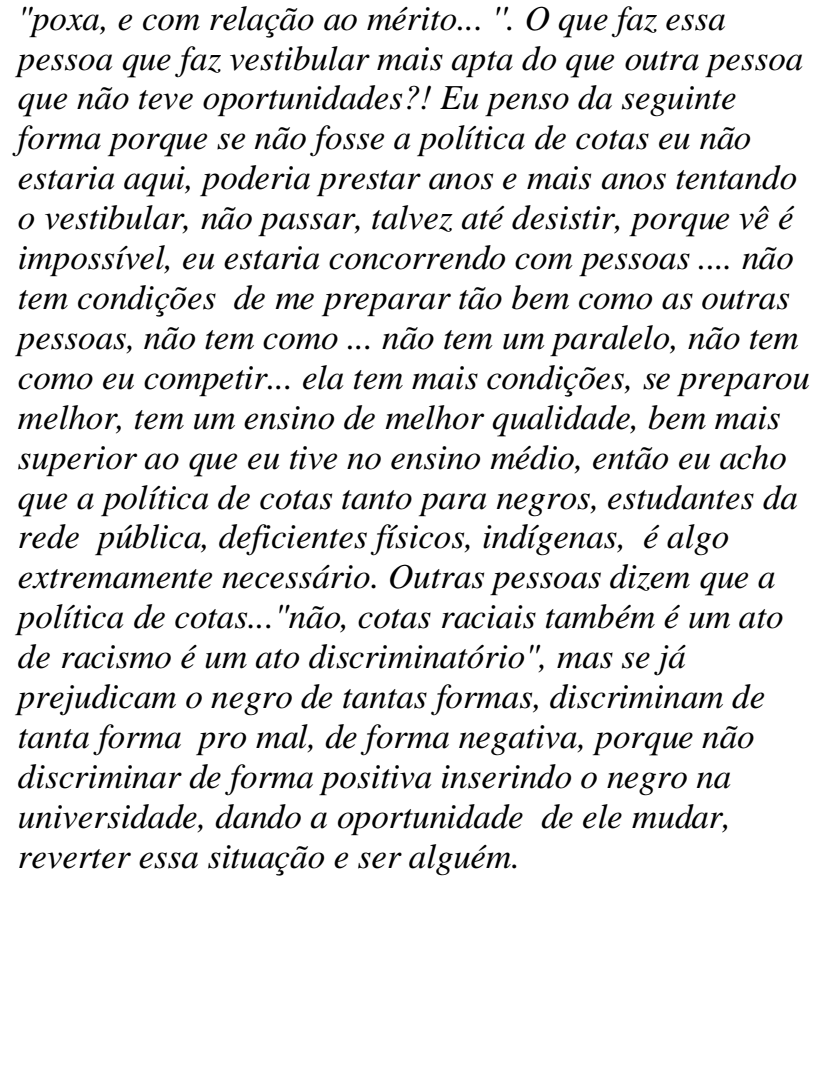 \\
\hline
\end{tabular}




\begin{tabular}{|c|c|c|c|c|}
\hline 4. Estigma & $\begin{array}{l}\text { na } \\
\text { comunicação } \\
\text { não verbal }\end{array}$ & $\begin{array}{l}\text { escolha de papéis } \\
\text { profissionais para as } \\
\text { pessoas das fotos de } \\
\text { homens e } \\
\text { mulheres; } \\
\text { brancos(as) e } \\
\text { negros(as); de } \\
\text { faixas etárias de } 20 \\
\text { a } 30 \text { anos, de } 31 \text { a } \\
59 \text { anos, acima de } \\
60 \text { anos. } \\
\text { Indicadores: } \\
\text { profissionais } \\
\text { brancos (as) - } \\
\text { negros (as) e cargos } \\
\text { profissionais } \\
\text { artista, que } \\
\text { privilegia } \\
\text { conhecimento } \\
\text { intelectual, manual } \\
\text { e posições de } \\
\text { chefia. }\end{array}$ & $\begin{array}{l}\text { O entrevistado, em sua escolha, não } \\
\text { reproduz o estigma social, } \\
\text { demonstrando estar atento a criar um } \\
\text { quadro diferente, em que as pessoas } \\
\text { brancas ocupam majoritariamente as } \\
\text { profissões que privilegiam o trabalho } \\
\text { manual e, dentre outras, as profissões } \\
\text { de posição de chefia foram ocupadas } \\
\text { por pessoas negras. Das } 9 \text { profissões, } \\
5 \text { foram preenchidas com pessoas } \\
\text { brancas e } 4 \text { com pessoas negras; sendo } \\
\text { que } 1 \text { das } 2 \text { profissões que privilegia o } \\
\text { conhecimento intelectual e } 4 \text { das que } \\
\text { privilegia o trabalho manual foram } \\
\text { preenchidas por pessoas brancas; a } \\
\text { profissão de artista, } 1 \text { das } 2 \text { que } \\
\text { privilegiam conhecimento intelectual e } 2 \\
\text { das que são posições de chefia foram } \\
\text { preenchidas por pessoas negras; } 1 \text { das } 2 \\
\text { que privilegiam conhecimento intelectual, } \\
1 \text { das } 2 \text { que são posições de chefia e } 2 \\
\text { das } 4 \text { que privilegiam trabalho manual } \\
\text { foram preenchidas por pessoas negras. }\end{array}$ & $\begin{array}{l}\text { Profissional Artista: Pianista - homem negro (figura 30); } \\
\text { Profissão que privilegia conhecimento intelectual: } \\
\text { Médico (a) plantonista - homem branco (figura 19); } \\
\text { Professor Universitário - homem negro (figura 28); } \\
\text { Posições de chefia: Gerente do hotel - homem negro } \\
\text { (figura 17); Diretor (a) de Marketing de uma loja de } \\
\text { departamento - homem negro (figura 18); } \\
\text { Profissões que privilegiam o trabalho manual: } \\
\text { Arrumador (eira) do Hotel - mulher branca (figura 29); } \\
\text { Motorista de ônibus - homem branco (figura 27); } \\
\text { Cabeleireiro(a)) - homem branco (figura 32); Porteiro(a) } \\
\text { do Hotel - homem branco (figura 25). }\end{array}$ \\
\hline 5. Estereótipo & & & & \\
\hline
\end{tabular}




\begin{tabular}{|c|c|c|c|}
\hline $\begin{array}{l}\text { 6. Reações } \\
\text { emocionais na } \\
\text { relação com o } \\
\text { preconceito } \\
\text { (com o diverso) }\end{array}$ & $\begin{array}{l}\text { culpa, vergonha, } \\
\text { irritabilidade, } \\
\text { raiva, exaustão, } \\
\text { confusãa na fala, } \\
\text { negação, medo, } \\
\text { dissimulação, } \\
\text { sensação de } \\
\text { solidão, tristeza, } \\
\text { sensação de não } \\
\text { pertencimento, } \\
\text { impotência, } \\
\text { contradição, } \\
\text { justificativa } \\
\text { defensiva }\end{array}$ & $\begin{array}{l}\text { O entrevistado demonstrou satisfação } \\
\text { em estar falando sobre racismo } \\
\text { ("Fiquei feliz de ser ouvido e tal"). }\end{array}$ & $\begin{array}{l}\text { folha de papel em branco porque acredito que através } \\
\text { da discussão a gente pode escrever novas histórias, uma } \\
\text { nova realidade, transformar a sociedade, nossas ações, } \\
\text { modo de pensar e tal, discutindo o assunto em si. Fiquei } \\
\text { feliz de ser ouvido e tal. Alguém quer ouvir minha } \\
\text { opinião, alguém quer ouvir o que eu penso, me senti } \\
\text { importante. }\end{array}$ \\
\hline $\begin{array}{l}\text { 7. Formas e } \\
\text { Oportunidades } \\
\text { de elaboração } \\
\text { das experiências } \\
\text { relacionadas ao } \\
\text { racismo }\end{array}$ & $\begin{array}{c}\text { oportunidades de } \\
\text { reflexão sobre o } \\
\text { tema racismo nos } \\
\text { espaços sociais } \\
\text { (família, escola, } \\
\text { mídia, amigos) e } \\
\text { forma que } \\
\text { encontra para } \\
\text { lidar com a } \\
\text { situação de } \\
\text { discriminação }\end{array}$ & $\begin{array}{l}\text { O entrevistado demonstra contar em } \\
\text { utilizar a ferramenta judiciária para } \\
\text { lidar com a discriminação racial }\end{array}$ & $\begin{array}{l}\text { Pergunta } 20^{*} \text { segunda etapa: Não sendo possivel ele } \\
\text { entrar, eu acho que eu procuraria umas instâncias que } \\
\text { poderiam resolver esse problema talvez ... o juizado } \\
\text { especial civel (riso). }\end{array}$ \\
\hline $\begin{array}{l}\text { 7. Formas e } \\
\text { Oportunidades } \\
\text { de elaboração } \\
\text { das experiências } \\
\text { relacionadas ao } \\
\text { racismo }\end{array}$ & & $\begin{array}{l}\text { O entrevistado demonstrou não ter } \\
\text { tido oportunidades significativas }\end{array}$ & \\
\hline
\end{tabular}




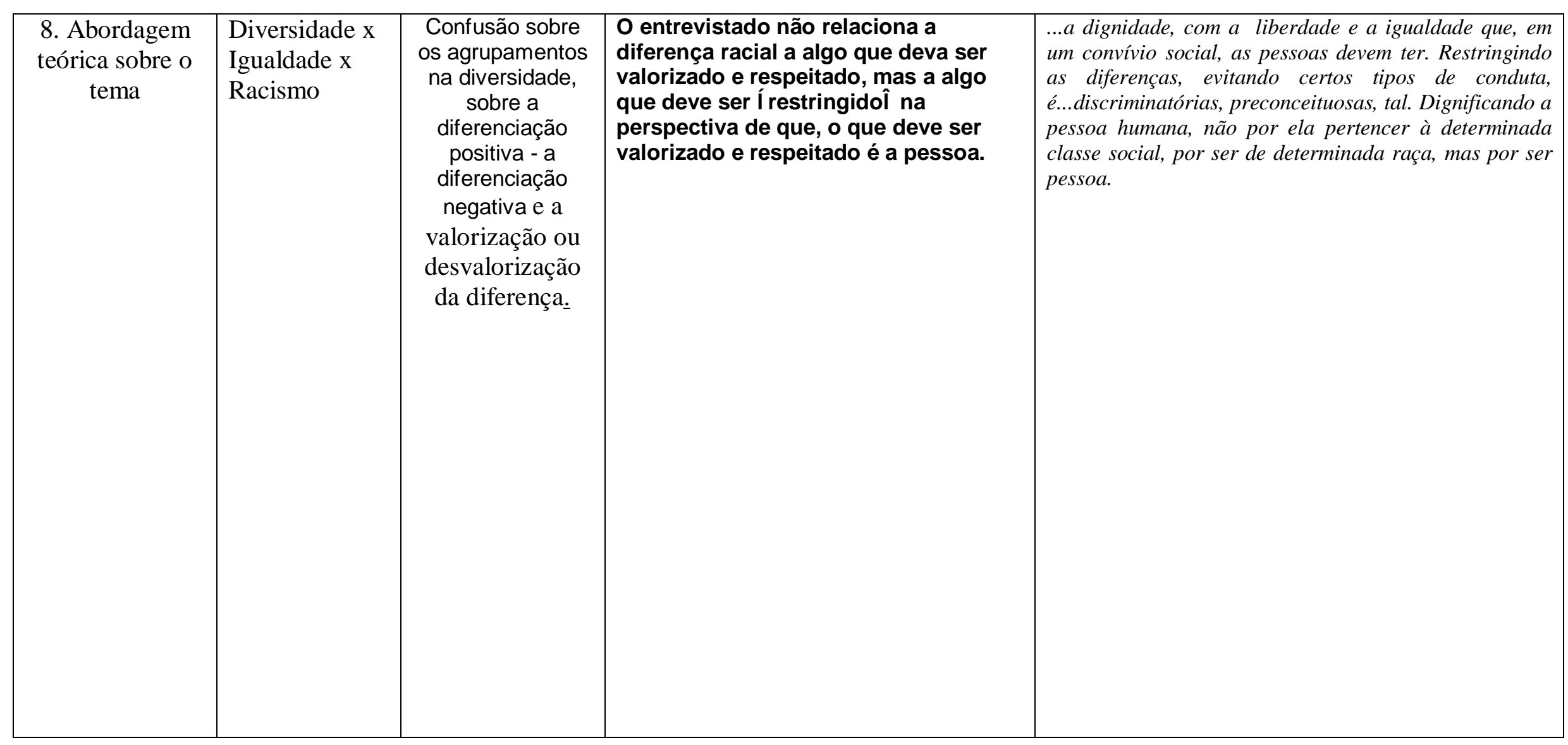




\begin{tabular}{|c|c|c|c|c|}
\hline $\begin{array}{c}\text { 8. Abordagem } \\
\text { teórica sobre o } \\
\text { tema }\end{array}$ & $\begin{array}{l}\text { Relação do } \\
\text { racismo com } \\
\text { os princípios } \\
\text { de direito } \\
\text { fundamentais }\end{array}$ & $\begin{array}{c}\text { reconhecimento } \\
\text { da política como } \\
\text { um direito } \\
\text { fundamental }\end{array}$ & $\begin{array}{l}\text { O entrevistado entende a } \\
\text { oportunidade de ser um aluno } \\
\text { universitário pelas cotas como um } \\
\text { direito, justamente por ter menores } \\
\text { condições de competir no processo } \\
\text { seletivo do vestibular, o que decorre } \\
\text { do fato de ter tido menos } \\
\text { oportunidade para isso, durante sua } \\
\text { vida até ali. }\end{array}$ & $\begin{array}{l}\text { Eu acho que a curto e médio prazo a política de cotas é } \\
\text { extremamente necessária. Pessoas discutem muito a } \\
\text { questão: "poxa, e com relação ao mérito... A pessoa faz } \\
\text { um vestibular e tal, estuda e daí vem outra pessoa que, } \\
\text { entre aspas, não tem aquele mérito...". O que faz essa } \\
\text { pessoa que faz vestibular mais apta do que outra pessoa } \\
\text { que não teve oportunidades?! Eu penso da seguinte } \\
\text { forma porque se não fosse a política de cotas eu não } \\
\text { estaria aqui, poderia prestar anos e mais anos tentando } \\
\text { o vestibular, não passar, talvez até desistir, porque vê é } \\
\text { impossível, eu estaria concorrendo com pessoas ......não } \\
\text { tem condiç̃es de me preparar tão bem como as outras } \\
\text { pessoas, não tem como ... não tem um paralelo, não tem } \\
\text { como eu competir.. ela tem mais condiçâs, se preparou } \\
\text { melhor, tem um ensino de melhor qualidade, bem mais } \\
\text { superior ao que eu tive no ensino médio, então eu acho } \\
\text { que a política de cotas tanto para negros, estudantes da } \\
\text { rede pública, deficientes fisicos, indigenas, é algo } \\
\text { extremamente necessário. Outras pessoas dizem que a } \\
\text { politica de cotas... "não, cotas raciais também é um ato } \\
\text { de racismo é um ato discriminatório", mas se já } \\
\text { prejudicam o negro de tantas formas, discriminam de } \\
\text { tanta forma pro mal, de forma negativa, porque não } \\
\text { discriminar de forma positiva inserindo o negro na } \\
\text { universidade, dando a oportunidade de ele mudar, } \\
\text { reverter essa situação e ser alguém. }\end{array}$ \\
\hline
\end{tabular}




\begin{tabular}{|c|c|c|c|c|}
\hline & $\begin{array}{l}\text { Relação do } \\
\text { racismo com } \\
\text { os princípios } \\
\text { de direito } \\
\text { fundamentais }\end{array}$ & $\begin{array}{c}\text { reconhecimento } \\
\text { do direito a ser } \\
\text { tratado } \\
\text { desigualmente ( } \\
\text { discriminação } \\
\text { positiva) }\end{array}$ & $\begin{array}{l}\text { O entrevistado reconhece o direito a } \\
\text { ser tratado desigualmente como um a } \\
\text { discriminação positiva, como uma } \\
\text { forma de promoção da igualdade e da } \\
\text { dignidade humana. }\end{array}$ & $\begin{array}{l}\text { Eu assemelho Direitos Humanos com a dignidade, com a } \\
\text { liberdade e a igualdade que, em um convivio social, as } \\
\text { pessoas devem ter. Restringindo as diferenças, evitando } \\
\text { certos tipos de conduta, é...discriminatórias, } \\
\text { preconceituosas, tal. Dignificando a pessoa humana, } \\
\text { não por ela pertencer à determinada classe social, por } \\
\text { ser de determinada raça, mas por ser pessoa.Pergunta: } \\
\text { Você acha que direito dos negros é tema de Direitos } \\
\text { Humanos? E discriminação racial? Resposta:Acho que é } \\
\text { sim. Discriminação racial também. }\end{array}$ \\
\hline $\begin{array}{c}9 . \\
\text { Manifestação da } \\
\text { solidariedade }\end{array}$ & & $\begin{array}{l}\text { crença de que a } \\
\text { relação multi- } \\
\text { étnica enriquece } \\
\text { e auxilia a } \\
\text { coletividade, na } \\
\text { solução de } \\
\text { problemas } \\
\text { coletivos e } \\
\text { individuais; } \\
\text { disponibilidade } \\
\text { para a busca real } \\
\text { de soluções para } \\
\text { o racismo } \\
\end{array}$ & $\begin{array}{l}\text { O entrevistado acredita que a } \\
\text { convivência multi-étnica é positiva } \\
\text { enriquece e auxilia a coletividade. }\end{array}$ & $\begin{array}{l}\text { Se cada um respeitasse essas coisas da diversidade, as } \\
\text { diferenças, que as pessoas não são iguais, são oriundas } \\
\text { de famílias, de pessoas diferentes, costumes diferentes e } \\
\text { tal, mesmo sendo o mesmo Brasil, o mesmo povo, são } \\
\text { pessoas diferentes, de raças diferentes, pensamento e } \\
\text { ideologias diferentes, se cada um respeitasse a ideologia } \\
\text { do outro, com certeza seria uma sociedade ... melhor do } \\
\text { que ela é hoje. A diversidade para mim eu considero } \\
\text { como sendo uma coisa boa. É boa porque a diversidade } \\
\text { proporciona uma melhor discussão sobre determinados } \\
\text { assuntos, determinado tema, sobre um pensamento } \\
\text { social da coletividade, tal... }\end{array}$ \\
\hline
\end{tabular}




\begin{tabular}{|c|c|c|c|}
\hline $\begin{array}{c}9 . \\
\text { Manifestação da } \\
\text { solidariedade }\end{array}$ & $\begin{array}{l}\text { crença de que a } \\
\text { relação multi- } \\
\text { étnica enriquece } \\
\text { e auxilia a } \\
\text { coletividade, na } \\
\text { solução de } \\
\text { problemas } \\
\text { coletivos e } \\
\text { individuais; } \\
\text { disponibilidade } \\
\text { para a busca real } \\
\text { de soluções para } \\
\text { o racismo } \\
\end{array}$ & $\begin{array}{l}\text { O entrevistado demonstra se envolver } \\
\text { com a idéia de promoção de um } \\
\text { mundo mais justo e melhor para se } \\
\text { viver, e não necessariamente com a } \\
\text { melhora das relações raciais na } \\
\text { diversidade. }\end{array}$ & $\begin{array}{l}\text { Pergunta: Alguma mudança no conteúdo das matérias } \\
\text { para que melhora a questão racial?Resposta: Acho que } \\
\text { deveria ser mais enfatizado o interesse público, da } \\
\text { coletividade, e menos o caráter privado, os interesses } \\
\text { que são comuns à população, aquilo que corresponde } \\
\text { com as expectativas da população... formar pessoas com } \\
\text { a mente crítica, capazes, de amanhã ou depois } \\
\text { representar bem a população em geral e ter uma opinião } \\
\text { formada. (...)Um apoio psicológico para que os alunos } \\
\text { cotistas enfrentar todas as diversidades, e o apoio } \\
\text { econômico para estudar na universidade ajudaria. }\end{array}$ \\
\hline $\begin{array}{l}\text { 10. Integração } \\
\text { com as ofertas } \\
\text { de } \\
\text { desenvolvimento } \\
\text { da Universidade }\end{array}$ & $\begin{array}{l}\text { Integração com } \\
\text { os colegas da } \\
\text { universidade; } \\
\text { oportunidades } \\
\text { profissionais que } \\
\text { surgem a partir } \\
\text { dessa integração; } \\
\text { acesso às } \\
\text { oportunidades } \\
\text { que o ambiente } \\
\text { acadêmico } \\
\text { oferece }\end{array}$ & $\begin{array}{l}\text { O entrevistado participa de um grupo } \\
\text { de pesquisa na Universidade, } \\
\text { atividade que teve empeceu a partir de } \\
\text { um contato com uma professora. }\end{array}$ & $\begin{array}{l}\text { Estou meio afastado do convívio com os amigos nesse } \\
\text { momento, tal, um pouco reservado, comodista, para me } \\
\text { dedicar à Universidade. Sou tranqüilo aqui, mais } \\
\text { reservado, mais centrado aos estudos do que aquilo que } \\
\text { está à volta. Fico na universidade no período da tarde e } \\
\text { noite. Aqui só estudo, fora daqui eu trabalho. Tem um } \\
\text { grupo de pesquisa de direito eleitoral. Me inscrevi no } \\
\text { grupo e participei... No período de inscrição a faculdade } \\
\text { disponibiliza uns temas e tal, me interessei pelo tema, } \\
\text { tinha feito uma matéria com uma professora que eu } \\
\text { gostei, achei que era interessante e tal ... Pergunta: } \\
\text { Algum colega te estimulou, te falou do curso? Resposta: } \\
\text { Não, não, fui por mim mesmo. }\end{array}$ \\
\hline
\end{tabular}




\begin{tabular}{|c|c|c|c|c|}
\hline \multicolumn{5}{|c|}{ ENTREVISTADO H - NÃO COTISTA - UNIFESP } \\
\hline CATEGORIA & $\begin{array}{c}\text { SUB- } \\
\text { CATEGORIA }\end{array}$ & INDICADORES & ASPECTOS SIGNIFICATIVOS & RELATOS DE ENTREVISTA \\
\hline identidade étnica & $\begin{array}{l}\text { negra / branca } \\
\text { / parda }\end{array}$ & & não declarou & \\
\hline $\begin{array}{l}\text { 1. A visibilidade } \\
\text { da diversidade } \\
\text { étnico-racial e } \\
\text { a racialização de } \\
\text { si e do outro }\end{array}$ & & $\begin{array}{l}\text { utilização do } \\
\text { componente } \\
\text { étnico-racial na } \\
\text { descrição das } \\
\text { pessoas das fotos } \\
\text { de estudantes } \\
\text { negros, brancos e } \\
\text { asiáticos }\end{array}$ & $\begin{array}{l}\text { o entrevistado descreve as fotos de } \\
\text { pessoas brancas, não identificando a } \\
\text { cor, etnia ou raça da pessoa. A partir } \\
\text { do momento que vê a foto da pessoa } \\
\text { asiática, a vincula a uma cor, raça ou } \\
\text { etnia, assim como com a pessoa } \\
\text { negra. Observa-se a tendência do } \\
\text { entrevistado de ver a pessoa branca } \\
\text { como um ser humano universal e a } \\
\text { pessoa negra como um ser racializado, } \\
\text { pertencente a um grupo racial. }\end{array}$ & $\begin{array}{l}\text { a) Está sentada com uma camisa na mão, lendo um livro, } \\
\text { sorri para a foto, de batom rosa e maquiagem. (branca) b) } \\
\text { Sentada, com livro aberto mas escrevendo, fazendo um } \\
\text { resumo ou algo do tipo, cabelos lisos, sorridente, apoiada } \\
\text { num armário na escola. (branca) c) Tá mostrando um livro } \\
\text { né, de origem oriental numa exposição ou algo do tipo d) } \\
\text { Uma moça negra, sentada, com um casaco verde, também } \\
\text { lendo um livro. e) Um rapaz negro, com blusa quadriculada } \\
\text { parece estar escrevendo, não consigo enxergar. }\end{array}$ \\
\hline $\begin{array}{l}\text { 1. A visibilidade } \\
\text { da diversidade } \\
\text { étnico-racial e a } \\
\text { racialização de } \\
\text { si e do outro }\end{array}$ & & $\begin{array}{c}\text { utilização do } \\
\text { componente } \\
\text { étnico-racial para } \\
\text { descrever } \\
\text { membros da } \\
\text { família e a si } \\
\text { próprio }\end{array}$ & $\begin{array}{l}\text { O entrevistado identifica com clareza e } \\
\text { tranqüilidade os componentes étnico } \\
\text { raciais de sua família ("Minha avó } \\
\text { branca... meu avô...indígena'). }\end{array}$ & $\begin{array}{l}\text { Pergunta: Me fala assim um pouco da sua família, como sua } \\
\text { família é no Brasil, como que ela chegou? } \\
\text { Resposta: É uma história meio complicada, mais assim o } \\
\text { pessoal da minha mãe, meu pai não conheço não.mas meu } \\
\text { avô é mulato, filho de índio com português da Bahia, antes } \\
\text { disso eu não vou saber. A minha avó tem origem judaica e a } \\
\text { família veio para o Brasil (...) origem européia mais } \\
\text { espanhola e portuguesa. } \\
\text { Pergunta: De que raça é tua avó? } \\
\text { Resposta: Minha avó branca, meu avô é mais baiano, } \\
\text { indígena. }\end{array}$ \\
\hline
\end{tabular}




\begin{tabular}{|c|c|c|c|}
\hline $\begin{array}{l}\text { 1. A visibilidade } \\
\text { da diversidade } \\
\text { étnico-racial e a } \\
\text { racialização de } \\
\text { si e do outro }\end{array}$ & $\begin{array}{l}\text { noção sobre o } \\
\text { conceito social de } \\
\text { raça na utilização } \\
\text { do componente } \\
\text { étnico-racial na } \\
\text { descrição das } \\
\text { relações sociais }\end{array}$ & $\begin{array}{l}\text { O entrevistado, apesar de utilizar um } \\
\text { conceito genético para classificar os } \\
\text { seres humanos por raças, não as } \\
\text { diferencia socialmente. Salienta que a } \\
\text { diferença racial não deve servir como } \\
\text { "base de discriminação racial ou } \\
\text { preconceito" }\end{array}$ & $\begin{array}{l}\text { Pergunta: Você acha que raça entre os seres humanos } \\
\text { existe?Resposta: Raça? Como conceito biologico existe. } \\
\text { Porque raça não é nada mais do que uma especialização } \\
\text { genética de certas características, isso existe. Tem raça } \\
\text { caucasiana, ariana, escandinava, temos negros, raça } \\
\text { oriental, biologicamente existe, mas não como base de } \\
\text { discriminação ou preconceito, isso não existe... }\end{array}$ \\
\hline $\begin{array}{l}\text { 2. Visibilidade } \\
\text { sobre a } \\
\text { ocorrência da } \\
\text { discriminação } \\
\text { racial }\end{array}$ & $\begin{array}{l}\text { visibilidade do } \\
\text { tratamento } \\
\text { desigual direto ou } \\
\text { indireto que } \\
\text { prejudica } \\
\text { socialmente o } \\
\text { negro, seja pela } \\
\text { neutralidade, seja } \\
\text { pela diferenciação } \\
\text { negativa } \\
\end{array}$ & $\begin{array}{l}\text { O entrevistado não vê a ocorrência da } \\
\text { discriminação racial, nem na } \\
\text { universidade, nem na cidade ("eu não } \\
\text { enxergo, eu não vejo"). }\end{array}$ & $\begin{array}{l}\text { Pergunta: Você acha que existe discriminação racial aqui na } \\
\text { universidade? Resposta: olha, racial não. Pergunta: E em } \\
\text { São Paulo, Brasil?Resposta: Assim o que é invisivel eu não } \\
\text { enxergo, mas o que eu vejo falar são queixas, são processos, } \\
\text { eu não vejo. No meu dia a dia é mais aqui porque não dá } \\
\text { para falar muito do centro, das lojas, dos bares, do metrô, eu } \\
\text { não enxergo, eu não vejo. Eu tenho informação pelo jornal é } \\
\text { o que vejo }\end{array}$ \\
\hline $\begin{array}{l}\text { 2. Visibilidade } \\
\text { sobre a } \\
\text { ocorrência da } \\
\text { discriminação } \\
\text { racial }\end{array}$ & $\begin{array}{c}\text { visibilidade do } \\
\text { tratamento } \\
\text { desigual direto ou } \\
\text { indireto que } \\
\text { prejudica } \\
\text { socialmente o } \\
\text { negro, seja pela } \\
\text { neutralidade, seja } \\
\text { pela diferenciação } \\
\text { negativa }\end{array}$ & $\begin{array}{l}\text { O entrevistado não entende o fato } \\
\text { ocorrido na estória hipotética como } \\
\text { uma conduta de discriminação racial. }\end{array}$ & $\begin{array}{l}\text { Pergunta } 20^{*} \text { primeira etapa (porque você acha que isso } \\
\text { aconteceu?): Prudência com atenção, porque, uma coisa né, } \\
\text { porque só bateu um, outro porque o Gilberto (negro) não é } \\
\text { tão amigo do rapaz que estava na fila, por exemplo, não tem } \\
\text { intimidade, coisa do tipo.(..) se eu fosse o João (branco) eu } \\
\text { nunca testemunharia, não com essa queixa, que não fica } \\
\text { nítido nenhum racismo, é subjetivo, o Gilberto (negro) por } \\
\text { ser negro sentiu naquela hora, ele teria enviesado a análise } \\
\text { dele, que é assim ele não tem uma prova que foi por racismo, } \\
\text { assim você foi porque você caracteriza, é isso que eu critico, } \\
\text { maçante. }\end{array}$ \\
\hline
\end{tabular}




\begin{tabular}{|c|c|c|c|}
\hline $\begin{array}{l}\text { 2. Visibilidade } \\
\text { sobre a } \\
\text { ocorrência da } \\
\text { discriminação } \\
\text { racial }\end{array}$ & $\begin{array}{l}\text { visibilidade do } \\
\text { tratamento } \\
\text { desigual direto ou } \\
\text { indireto que } \\
\text { prejudica } \\
\text { socialmente o } \\
\text { negro, seja pela } \\
\text { neutralidade, seja } \\
\text { pela diferenciação } \\
\text { negativa }\end{array}$ & $\begin{array}{l}\text { Para o entrevistado existe uma } \\
\text { tranqüilidade para o cotista em contar } \\
\text { que é cotista e estar nesse ambiente } \\
\text { universitário pelas cotas ("não tem } \\
\text { nenhuma vergonha de contar") }\end{array}$ & $\begin{array}{l}\text { Então você acaba sabendo quem é pelo modo, e também } \\
\text { porque a pessoa não tem nenhuma vergonha de contar }\end{array}$ \\
\hline $\begin{array}{l}\text { 3. Visibilidade } \\
\text { sobre as } \\
\text { consequências } \\
\text { do racismo, os } \\
\text { danos e os } \\
\text { privilégios }\end{array}$ & $\begin{array}{l}\text { visibilidade do } \\
\text { prejuízo social } \\
\text { para o negro }\end{array}$ & $\begin{array}{c}\text { O entrevistado não acredita que é } \\
\text { correta a política que define como } \\
\text { sendo "de você oprimir a maioria em } \\
\text { beneficio da minoria". Relaciona o fato } \\
\text { de se pretender privilegiar a mulher } \\
\text { negra nas políticas públicas ao fato } \\
\text { dela ser "coitada" e demonstra não } \\
\text { visualizar as consequências danosas } \\
\text { do provocadas pelo racismo à } \\
\text { população negra. }\end{array}$ & $\begin{array}{l}\text {... deixa eu me expressar melhor, hoje em dia é quase um } \\
\text { pecado você ser branco homem e classe média, isso tá } \\
\text { errado, você não pode porque o certo é você ser mulher } \\
\text { negra e pobre, você está educando a pessoa a pensar que ela } \\
\text { é uma coitada, "não eu sou maioria mais sou uma coitada" } \\
\text { (...) Parece que a política atual é uma política de você } \\
\text { oprimir a maioria em beneficio da minoria, isso é o que eu } \\
\text { penso em relação às cotas, à homossexualidade, esse tipo de } \\
\text { coisa. }\end{array}$ \\
\hline $\begin{array}{l}\text { 3. Visibilidade } \\
\text { sobre as } \\
\text { consequências } \\
\text { do racismo, os } \\
\text { danos e os } \\
\text { privilégios }\end{array}$ & $\begin{array}{l}\text { visibilidade do } \\
\text { prejuízo social } \\
\text { para o negro }\end{array}$ & $\begin{array}{l}\text { O entrevistado não visualiza os danos } \\
\text { à população negra, ou dissimula ao } \\
\text { falar sobre isso. }\end{array}$ & $\begin{array}{l}\text { Pergunta: Você acha que pelo de fato de uma pessoa ser } \\
\text { branca lhe auxilia de alguma a estar na faculdade?Resposta: } \\
\text { Não Pergunta: Por que você acha que existem menos negros } \\
\text { na universidade? Primeiro motivo inicial tem menos negros } \\
\text { na população do que brancos, pelo menos aqui em São } \\
\text { Paulo, (...) e também eu não sei se existe algum estudo } \\
\text { biológico ou estatístico que associe entre a série de ensino e } \\
\text { a pobreza tudo fica em estimativas, então como eles vão, com } \\
\text { o termo, assim, em média os negros são poucos a grande } \\
\text { maioria dos negros que existem não tem acesso ao ensino } \\
\text { particular ao cursinho com qualidade ou se existe esse } \\
\text { público também não, ele é deficitário, então esse deve ser um } \\
\text { fator. }\end{array}$ \\
\hline
\end{tabular}




\begin{tabular}{|c|c|c|c|c|}
\hline $\begin{array}{l}\text { 3. Visibilidade } \\
\text { sobre as } \\
\text { consequências } \\
\text { do racismo, os } \\
\text { danos e os } \\
\text { privilégios }\end{array}$ & & $\begin{array}{l}\text { visibilidade do } \\
\text { prejuízo social } \\
\text { para o negro }\end{array}$ & $\begin{array}{l}\text { O entrevistado identifica, nos grupos } \\
\text { de negros e orientais, uma } \\
\text { característica própria das pessoas que } \\
\text { se encontram em uma condição de } \\
\text { minoria, de segregar-se, mas não } \\
\text { associa isso a uma consequência do } \\
\text { processo do racismo. Ao contrário, } \\
\text { identifica como sendo uma } \\
\text { característica dos negros, dos } \\
\text { asiáticos e de vários grupos étnicos. }\end{array}$ & $\begin{array}{l}\text { (...) só, assim, o que acontece é que muitos assim, por } \\
\text { exemplo, não só os negros mas vários grupo étnicos, } \\
\text { orientais eles tendem a manter uma cultura oriental muitas } \\
\text { vezes, vivendo naquelas colônias, se encontram em fã clubes } \\
\text { e tal só que só vão japoneses, é como tem os negros também } \\
\text { tentam preservar a religião ou preservar os costumes e fora } \\
\text { isso, assim no dia-a-dia não vejo diferença nenhuma. }\end{array}$ \\
\hline 4. Estigma & $\begin{array}{l}\text { na } \\
\text { comunicação } \\
\text { não verbal }\end{array}$ & $\begin{array}{c}\text { escolha de papéis } \\
\text { profissionais para as } \\
\text { pessoas das fotos de } \\
\text { homens e mulheres; } \\
\text { brancos(as) e } \\
\text { negros(as); de } \\
\text { faixas etárias de } 20 \\
\text { a } 30 \text { anos, de } 31 \text { a } \\
59 \text { anos, acima de } \\
60 \text { anos. } \\
\text { Indicadores: } \\
\text { profissionais } \\
\text { brancos (as) - negros } \\
\text { (as) e cargos } \\
\text { profissionais artista, } \\
\text { que privilegia } \\
\text { conhecimento } \\
\text { intelectual, manual e } \\
\text { posições de chefia. }\end{array}$ & $\begin{array}{l}\text { O entrevistado, em sua escolha, não } \\
\text { reproduz o estigma social. Das } 9 \\
\text { profissões, } 4 \text { foram preenchidas com } \\
\text { pessoas brancas e } 5 \text { com pessoas } \\
\text { negras; sendo que as profissões de } \\
\text { posição de chefia e } 2 \text { das } 4 \text { que } \\
\text { privilegiam o trabalho manual foram } \\
\text { preenchidas por pessoas brancas; a } \\
\text { profissão e artista, as } 2 \text { que privilegiam o } \\
\text { trabalho intelectual foram preenchidas } \\
\text { por pessoas negras e } 2 \text { das } 4 \text { que } \\
\text { privilegiam o trabalho manual foram } \\
\text { preenchidas por pessoas negras. }\end{array}$ & $\begin{array}{l}\text { Profissional Artista: Pianista - homem negro (figura 18); } \\
\text { Profissão que privilegia conhecimento intelectual: Médico (a) } \\
\text { plantonista - homem negro (figura 30); Professor } \\
\text { Universitário - mulher negra (figura 23); } \\
\text { Posições de chefia: Gerente do hotel - mulher branca (figura } \\
\text { 26); Diretor (a) de Marketing de uma loja de departamento - } \\
\text { mulher branca (figura 21); } \\
\text { Profissões que privilegiam o trabalho manual: Arrumador } \\
\text { (eira) do Hotel - mulher negra (figura 24); Motorista de } \\
\text { ônibus - homem branco (figura 27); Cabeleireiro(a)) - mulher } \\
\text { negra (figura 20); Porteiro(a) do Hotel - mulher branca } \\
\text { (figura 29). }\end{array}$ \\
\hline 5. Estereótipo & & & & \\
\hline
\end{tabular}




\begin{tabular}{|c|c|c|c|}
\hline $\begin{array}{l}\text { 6. Reações } \\
\text { emocionais na } \\
\text { relação com o } \\
\text { preconceito } \\
\text { (com o diverso) }\end{array}$ & $\begin{array}{l}\text { na } \\
\text { comunicação } \\
\text { verbal }\end{array}$ & $\begin{array}{l}\text { DISSIMULAÇÃO: O entrevistado foge } \\
\text { da pergunta, parecendo não querer se } \\
\text { comprometer com a acusação de } \\
\text { racismo. ("ele como julgador escolheu } \\
\text { pela competência porque é uma } \\
\text { pessoa, se ele terceirizasse, colocasse } \\
\text { uma fundação, uma Fundesp, para } \\
\text { selecionar para ele, claro que é um } \\
\text { plano mirabolante, e ela selecionasse } \\
\text { por acaso não seria problema.") }\end{array}$ & $\begin{array}{l}\text { Pergunta: Imagine o seguinte, se um homem negro fosse } \\
\text { dono de uma escola e contratasse só professores negros para } \\
\text { dar aula você acha que ele estaria sendo racista?Se } \\
\text { contratar porque eles são negros sim, se ser negro é um } \\
\text { requisito ou um ponto extra, dá um bônus pra pessoa negra } \\
\text { na seleção, acho que é racista também. } \\
\text { Pergunta: E se não tiver um requisito, mas ele naturalmente } \\
\text { for compondo o seu quadro com pessoas negras? } \\
\text { Resposta: claro isso é natural, isso eu não vejo problema, ele } \\
\text { como julgador escolheu pela competência porque é uma } \\
\text { pessoa, se ele terceirizasse, colocasse uma fundação, uma } \\
\text { Fundesp, para selecionar para ele, claro que é umplano } \\
\text { mirabolante, e ela selecionasse por acaso não seria } \\
\text { problema. }\end{array}$ \\
\hline $\begin{array}{l}\text { 6. Reações } \\
\text { emocionais na } \\
\text { relação com o } \\
\text { preconceito } \\
\text { (com o diverso) }\end{array}$ & & $\begin{array}{l}\text { DISSIMULAÇĀO: ("estatísticas... } \\
\text { estimativas....") fala confusa. }\end{array}$ & $\begin{array}{l}\text { Pergunta: Por que você acha que existem menos negros na } \\
\text { universidade? Primeiro motivo inicial tem menos negros na } \\
\text { população do que brancos, pelo menos aqui em São Paulo, } \\
\text { (...)e também eu não sei se existe algum estudo biológico ou } \\
\text { estatístico que associe entre a série de ensino e a pobreza } \\
\text { tudo fica em estimativas, então como eles vão, com o termo, } \\
\text { assim, em média os negros são poucos a grande maioria dos } \\
\text { negros que existem não tem acesso ao ensino particular ao } \\
\text { cursinho com qualidade ou se existe esse público também } \\
\text { não, ele é deficitário, então esse deve ser um fator. }\end{array}$ \\
\hline
\end{tabular}




\begin{tabular}{|c|c|c|c|}
\hline $\begin{array}{l}\text { 6. } \text { Reações } \\
\text { emocionais na } \\
\text { relação com o } \\
\text { preconceito } \\
\text { (com o diverso) }\end{array}$ & $\begin{array}{l}\text { culpa, vergonha, } \\
\text { irritabilidade, } \\
\text { raiva, exaustão, } \\
\text { confusão na fala, } \\
\text { negação, medo, } \\
\text { dissimulação, } \\
\text { sensação de } \\
\text { solidão, tristeza, } \\
\text { sensação de não } \\
\text { pertencimento, } \\
\text { contradição, } \\
\text { justificativa } \\
\text { defensiva }\end{array}$ & $\begin{array}{l}\text { O entrevistado demonstra uma } \\
\text { IRRITABILIDADE que atribui ao fato } \\
\text { dos negros por critérios "subjetivos" } \\
\text { denunciarem serem vítimas de } \\
\text { condutas racistas ("maçante"). }\end{array}$ & $\begin{array}{l}\text { que não fica nítido nenhum racismo, é subjetivo, o Gilberto } \\
\text { (negro) por ser negro sentiu naquela hora, ele teria } \\
\text { enviesado a análise dele, que é assim ele não tem uma prova } \\
\text { que foi por racismo, assim você foi porque você caracteriza, } \\
\text { é isso que eu critico, maçante. }\end{array}$ \\
\hline $\begin{array}{l}\text { 6. } \text { Reações } \\
\text { emocionais na } \\
\text { relação com o } \\
\text { preconceito } \\
\text { (com o diverso) }\end{array}$ & & $\begin{array}{l}\text { DISSIMULAÇÃO: O entrevistado não } \\
\text { responde a pergunta, busca ter "um } \\
\text { pensamento um pouco mais além" e } \\
\text { desvia da pergunta. }\end{array}$ & $\begin{array}{l}\text { Pergunta:Eu queria que você imaginasse agora, na classe } \\
\text { que você estuda ou estudou esses anos se } 80 \% \text { dos alunos } \\
\text { fossem negros, como você se sentiria?Resposta: Me sentiria } \\
\text { uma minoria, racial. Não, sinceramente, assim eu tenho um } \\
\text { pensamento um pouco mais além, não só essa coisa de vê } \\
\text { uma multidão negra na sala. Tem que ver por trás disso, se } \\
\text { isso vem de uma ação afirmativa ou se isso vem de uma } \\
\text { política de cotas, podia ser um sistema de cotas, se elas estão } \\
\text { lá eu iria me dar tão bem quanto me dei, tenho certeza }\end{array}$ \\
\hline $\begin{array}{c}\text { 7. Formas e } \\
\text { Oportunidades } \\
\text { de elaboração } \\
\text { das experiências } \\
\text { relacionadas ao } \\
\text { racismo }\end{array}$ & $\begin{array}{l}\text { oportunidades de } \\
\text { reflexão sobre o } \\
\text { tema racismo nos } \\
\text { espaços sociais } \\
\text { (família, escola, } \\
\text { mídia, amigos) }\end{array}$ & $\begin{array}{l}\text { Sobre o tema do racismo, } \\
\text { institucionalmente o entrevistado só se } \\
\text { recorda de ter tido oportunidade de } \\
\text { discutir no colégio, situação que foi } \\
\text { provocada pelo debate em torno das } \\
\text { cotas. Manifesta que teve conversas na } \\
\text { família, com certa frequência ("Já na } \\
\text { família também, acaba surgindo né"). }\end{array}$ & $\begin{array}{l}\text { Pergunta: Antes de entrar teve a oportunidade de discutir } \\
\text { sobre essa questão racial? Resposta: Eu discutia muito no } \\
\text { colégio também, é o que eles falam desde que não sei quando } \\
\text { planejavam, os EUA que fez isso, é assim, desde o colégio se } \\
\text { discute cotas. (...)Já na família também, acaba surgindo, né. }\end{array}$ \\
\hline
\end{tabular}




\begin{tabular}{|c|c|c|c|c|}
\hline $\begin{array}{l}\text { 8. Abordagem } \\
\text { teórica sobre o } \\
\text { tema }\end{array}$ & $\begin{array}{l}\text { Diversidade } x \\
\text { Igualdade } x \\
\text { Racismo }\end{array}$ & $\begin{array}{c}\text { Confusão sobre } \\
\text { os agrupamentos } \\
\text { na diversidade, } \\
\text { sobre a } \\
\text { diferenciação } \\
\text { positiva - a } \\
\text { diferenciação } \\
\text { negativa (quando } \\
\text { é um valor a } \\
\text { diversidade e } \\
\text { quando não é). }\end{array}$ & $\begin{array}{c}\text { O entrevistado, com base na genética, } \\
\text { racializa as pessoas, e ressalta que } \\
\text { essas características não servem de } \\
\text { base para o racismo (hierarquização } \\
\text { das raças) }\end{array}$ & $\begin{array}{l}\text { Pergunta: Você acha que raça entre os seres humanos } \\
\text { existe?Resposta: Como conceito biológico existe. Porque } \\
\text { raça não é nada mais do que uma especialização genética de } \\
\text { certas características, isso existe. Tem raça caucasiana, } \\
\text { ariana, escandinava, temos negros, raça oriental, } \\
\text { biologicamente existe, mas não como base de discriminação } \\
\text { ou preconceito, isso não existe, (...). No Brasil é um pouco } \\
\text { complicado falar de raça porque ele é muito miscigenado, } \\
\text { mas você tem características dos orientais, isso existe de fato. }\end{array}$ \\
\hline $\begin{array}{l}\text { 8. Abordagem } \\
\text { teórica sobre o } \\
\text { tema }\end{array}$ & $\begin{array}{l}\text { Diversidade } x \\
\text { Igualdade } x \\
\text { Racismo }\end{array}$ & $\begin{array}{c}\text { Confusão sobre } \\
\text { os agrupamentos } \\
\text { na diversidade, } \\
\text { sobre a } \\
\text { diferenciação } \\
\text { positiva - a } \\
\text { diferenciação } \\
\text { negativa (quando } \\
\text { é um valor a } \\
\text { diversidade e } \\
\text { quando não é). }\end{array}$ & $\begin{array}{c}\text { Confusão em torno do tema: "o } \\
\text { preconceito sempre vai existir o que } \\
\text { não pode ter é discriminação (...) é um } \\
\text { trabalho um pouco maior é uma coisa } \\
\text { da cultura, não é você mudar um } \\
\text { código, uma lei, uma moral". Observa- } \\
\text { se que o entrevistado fala em mudar a } \\
\text { cultura e não a moral, para acabar com } \\
\text { a discriminação e não com o } \\
\text { preconceito. }\end{array}$ & $\begin{array}{l}\text { Isso sempre existiu, você vê as pessoas, assim como tem } \\
\text { orientais que não gostam de ficar com as pessoas que não } \\
\text { sejam da raça, eu também vejo pessoas que não gostam de } \\
\text { ficar com pessoas negras por exemplo essa preferência, mas } \\
\text { não é uma coisa pra se discutir é uma coisa, o preconceito } \\
\text { sempre vai existir o que não pode ter é discriminação, vocêe } \\
\text { não querer ficar com uma pessoa, beijar a pessoa porque ela } \\
\text { é negra é uma opção sua, é um trabalho um pouco maior é } \\
\text { uma coisa da cultura, não é você mudar um código, uma lei, } \\
\text { uma moral }\end{array}$ \\
\hline
\end{tabular}




\begin{tabular}{|c|c|c|c|c|}
\hline $\begin{array}{l}\text { 8. Abordagem } \\
\text { teórica sobre o } \\
\text { tema }\end{array}$ & $\begin{array}{l}\text { Diversidade } \mathrm{x} \\
\text { Igualdade } \mathrm{x} \\
\text { Racismo }\end{array}$ & $\begin{array}{c}\text { Confusão sobre } \\
\text { os agrupamentos } \\
\text { na diversidade, } \\
\text { sobre a } \\
\text { diferenciação } \\
\text { positiva - a } \\
\text { diferenciação } \\
\text { negativa (quando } \\
\text { é um valor a } \\
\text { diversidade e } \\
\text { quando não é). }\end{array}$ & $\begin{array}{l}\text { O entrevistado no primeiro momento } \\
\text { iguala a experiência do cotista a sua } \\
\text { própria e no segundo demonstra a } \\
\text { diferença que os cotistas têm para } \\
\text { conseguir estar se desempenhando } \\
\text { bem na universidade, como ele. ("igual } \\
\text { a mim (...) a grande maioria vai até } \\
\text { melhor por causa dessa luta, } \\
\text { conseguir passar por volta depois de } \\
\text { uma vida mais difícil ou não, coisa do } \\
\text { tipo, ele é mais dedicado, mais } \\
\text { atencioso, mais presente nas aulas, } \\
\text { acabando sendo melhor") }\end{array}$ & $\begin{array}{l}\text { Pergunta: você acha que o aluno cotista que está cursando a } \\
\text { sua universidade, ele está vivendo uma boa } \\
\text { experiência?Resposta: Com certeza, igual a mim. Pergunta: } \\
\text { Você acha que ele tem mais dificuldade? Resposta: Não, ele } \\
\text { não tem, não existe, o desempenho deles é ótimo no nosso } \\
\text { curso a grande maioria vai até melhor por causa dessa luta, } \\
\text { conseguir passar por volta depois de uma vida mais difícil } \\
\text { ou não, coisa do tipo, ele é mais dedicado, mais atencioso, } \\
\text { mais presente nas aulas, acabando sendo melhor. }\end{array}$ \\
\hline & & & $\begin{array}{l}\text { O entrevistado, sobre sua reflexão em } \\
\text { torno no tema das cotas, manifesta a } \\
\text { opinião de que se estaria roubando } \\
\text { vagas de alguém. Não vê como um } \\
\text { direito da pessoa negra de ter acesso a } \\
\text { um espaço público que não ocupa. }\end{array}$ & $\begin{array}{l}\text {... implantou logo depois que eu entrei, o ultimo ano que não } \\
\text { teve cotas. Te dá uma duvida porque vão te roubar a vaga, } \\
\text { não o menino roubou a vaga não sei o quê, ai acabaram } \\
\text { criando vagas extras, o que resolveu as crises. }\end{array}$ \\
\hline
\end{tabular}




\begin{tabular}{|c|c|c|c|c|}
\hline & $\begin{array}{l}\text { Relação do } \\
\text { racismo com } \\
\text { os princípios } \\
\text { de direito } \\
\text { fundamentais }\end{array}$ & $\begin{array}{l}\text { reconhecimento } \\
\text { do direito a ser } \\
\text { tratado } \\
\text { desigualmente ( } \\
\text { discriminação } \\
\text { positiva) }\end{array}$ & $\begin{array}{l}\text { O entrevistado não reconhece a } \\
\text { discriminação positiva como um } \\
\text { componente da aplicação do direito à } \\
\text { igualdade e à diversidade, no } \\
\text { propósito da eliminação da } \\
\text { discriminação racial. Acredita que a } \\
\text { afirmação da diferença do grupo negro } \\
\text { é um "preconceito ao contrário pelo } \\
\text { poder público". }\end{array}$ & $\begin{array}{l}\text {... eu até defenderia cotas um pouco melhor se fosse por nível } \\
\text { social economico acho mais plausível, mais por linha racial é } \\
\text { um preconceito ao contrário pelo poder público(...) deixa eu } \\
\text { me expressar melhor, hoje em dia é quase um pecado você } \\
\text { ser branco homem e classe média, isso tá errado, você não } \\
\text { pode porque o certo é você ser mulher negra e pobre, vocêe } \\
\text { está educando a pessoa a pensar que ela é uma coitada, "não } \\
\text { eu sou maioria mais sou uma coitada" (..) Tem o mesmo } \\
\text { direito de ser negro e afirmar que ele é negro e é assim uma } \\
\text { pessoa tem até uma brincadeira na televisão né,ôl100\% } \\
\text { branco na camiseta e ele quase apanha na rua, enquanto um } \\
\text { negro afirmar é um direito é uma afirmação o outro é racista } \\
\text { porque está falando que é branco }\end{array}$ \\
\hline $\begin{array}{l}\text { 8. Abordagem } \\
\text { teórica sobre o } \\
\text { tema }\end{array}$ & $\begin{array}{l}\text { Relação do } \\
\text { racismo com } \\
\text { os princípios } \\
\text { de direito } \\
\text { fundamentais }\end{array}$ & $\begin{array}{c}\text { reconhecimento } \\
\text { do direito a ser } \\
\text { tratado } \\
\text { desigualmente ( } \\
\text { discriminação } \\
\text { positiva) }\end{array}$ & $\begin{array}{l}\text { O entrevistado não relaciona a } \\
\text { discriminação positiva e a } \\
\text { discriminação racial com temas de } \\
\text { direitos fundamentais e direitos } \\
\text { humanos. }\end{array}$ & $\begin{array}{l}\text { Pergunta: O que é Direitos Humanos para você? O que é } \\
\text { uma questão de DH? Resposta: Direitos Humanos, ainda } \\
\text { acho que é o mínimo para considerar uma vida digna, (...) } \\
\text { por menor que seja. (...) garantir atendimento, hospital, (..) } \\
\text { alimentos, (...), saúde, a busca é para isso, não vejo assim } \\
\text { uma coisa racial entendeu, não fortemente. Pergunta: Vocêe } \\
\text { acha que os direitos dos negros ou discriminação racial é } \\
\text { uma questão de Direitos Humanos? Resposta: Não. } \\
\text { Discriminação racial pode ser, mas eu não vejo sendo. }\end{array}$ \\
\hline
\end{tabular}




\begin{tabular}{|c|c|c|c|}
\hline $\begin{array}{c}9 . \\
\text { Manifestação da } \\
\text { solidariedade }\end{array}$ & $\begin{array}{c}\text { crença de que a } \\
\text { relação multi- } \\
\text { étnica enriquece } \\
\text { e auxilia a } \\
\text { coletividade, na } \\
\text { solução de } \\
\text { problemas } \\
\text { coletivos e } \\
\text { individuais; } \\
\text { disponibilidade } \\
\text { para a busca real } \\
\text { de soluções para } \\
\text { o racismo }\end{array}$ & $\begin{array}{l}\text { O entrevistado não demonstra } \\
\text { acreditar que a diversidade que existe } \\
\text { entre as pessoas é um fator que } \\
\text { enriquece e auxilia coletividade. } \\
\text { Mesmo se relacionando com "pessoas } \\
\text { diversas", não é esse o fator delas que } \\
\text { enriquecem a relação. Também } \\
\text { demonstra não ser solidário àquele } \\
\text { que luta contra uma violação que } \\
\text { julgou ser decorrente de discriminação } \\
\text { racial ("Eu faria (...) mas não com uma } \\
\text { alegação dessa"). }\end{array}$ & $\begin{array}{l}\text { Pergunta: O que você acha da diversidade? Resposta: Eu } \\
\text { não me importo, não que não me interessa assim, é que não é } \\
\text { uma preocupação que eu tenho, não, eu tenho que me } \\
\text { relacionar com pessoas diversas, eu acabo me relacionando } \\
\text { com pessoas diversas do jeito que eu sou, mas eu não tenho } \\
\text { essa preocupação não, "eu tenho que falar com aquela } \\
\text { pessoa com aquele rapaz porque ele é gay" (...) "eu tenho que } \\
\text { falar com ele porque ele é negro, ele está excluído da } \\
\text { sociedade", não eu não tenho essa preocupação, eu vou falar } \\
\text { com ele naturalmente como se fosse um amigo meu } \\
\text { qualquer.(...) Pergunta } 20^{*} \text { segunda etapa: se eu fosse o } \\
\text { Gilberto (negro) Eu faria, até poderia elaborar uma carta } \\
\text { falando se poderia, solicitando encarecidamente, mas não } \\
\text { com uma alegação dessa. }\end{array}$ \\
\hline $\begin{array}{l}\text { 10. Integração } \\
\text { com as ofertas } \\
\text { de } \\
\text { desenvolvimento } \\
\text { da Universidade }\end{array}$ & $\begin{array}{l}\text { Integração com os } \\
\text { colegas da } \\
\text { universidade; } \\
\text { oportunidades } \\
\text { profissionais que } \\
\text { surgem a partir } \\
\text { dessa integração; } \\
\text { acesso às } \\
\text { oportunidades que } \\
\text { o ambiente } \\
\text { acadêmico } \\
\text { oferece }\end{array}$ & $\begin{array}{l}\text { O entrevistado está integrada com as } \\
\text { atividades da Universidade, faz } \\
\text { estágio, participa do Centro } \\
\text { Acadêmico, do cursinho comunitário e } \\
\text { outras atividades. A partir de relação } \\
\text { com os professores consegue } \\
\text { oportunidades acadêmicas. }\end{array}$ & $\begin{array}{l}\text { moro a duas quadras daqui da faculdade e fico o dia inteiro } \\
\text { aqui, agora estou no quarto ano, então é só estágio período } \\
\text { integral, fora o período de estágio, participo de política na } \\
\text { área acadêmica do DCE, projetos, cursinho comunitário e } \\
\text { outras atividades. normal de estágio você está cursando a } \\
\text { graduação aí você procura um laboratório que te interessa } \\
\text { ou uma linha que te interessa, uma opção que te agrade } \\
\text { começa a freqüentar o laboratório e depois de um tempo vocêe } \\
\text { está fazendo um projeto para pedir bolsa. No meu caso eu } \\
\text { fiquei um ano no laboratório, já abril do primeiro ano até o } \\
\text { segundo no laboratório, quando saí para outro passou uns } \\
\text { seis meses fizo projeto pedindo a bolsa e estou lá até hoje }\end{array}$ \\
\hline
\end{tabular}




\begin{tabular}{|c|c|c|c|}
\hline $\begin{array}{l}\text { 10. Integração } \\
\text { com as ofertas } \\
\text { de } \\
\text { desenvolvimento } \\
\text { da Universidade }\end{array}$ & $\begin{array}{c}\text { relação de } \\
\text { coleguismo entre } \\
\text { o entrevistado e } \\
\text { os alunos }\end{array}$ & $\begin{array}{l}\text { O entrevistado mostra-se confortável } \\
\text { com suas relações de coleguismo na } \\
\text { universidade. }\end{array}$ & $\begin{array}{l}\text { Pergunta: quem são seus amigos mais chegados? } \\
\text { Resposta: São os amigos da minha sala, mais da minha sala, } \\
\text { de outras salas também, de outros anos seguintes cada vez, } \\
\text { menos, os calouros diretos tem mais amigos, depois tem } \\
\text { pouco menos, tem os amigos que entraram também comigo } \\
\text { na faculdade também somos amigos, mas em geral são os da } \\
\text { minha sala que são mais amigos } \\
\text { Pergunta: Você não tem um melhor amigo assim? } \\
\text { Resposta: ah, podia eleger, eu elejo a Luciana amiga minha } \\
\text { daqui da minha sala, participou de política comigo sempre. } \\
\text { Pergunta: Como é que ela é? } \\
\text { Resposta: Oriental, japonesa,... }\end{array}$ \\
\hline
\end{tabular}




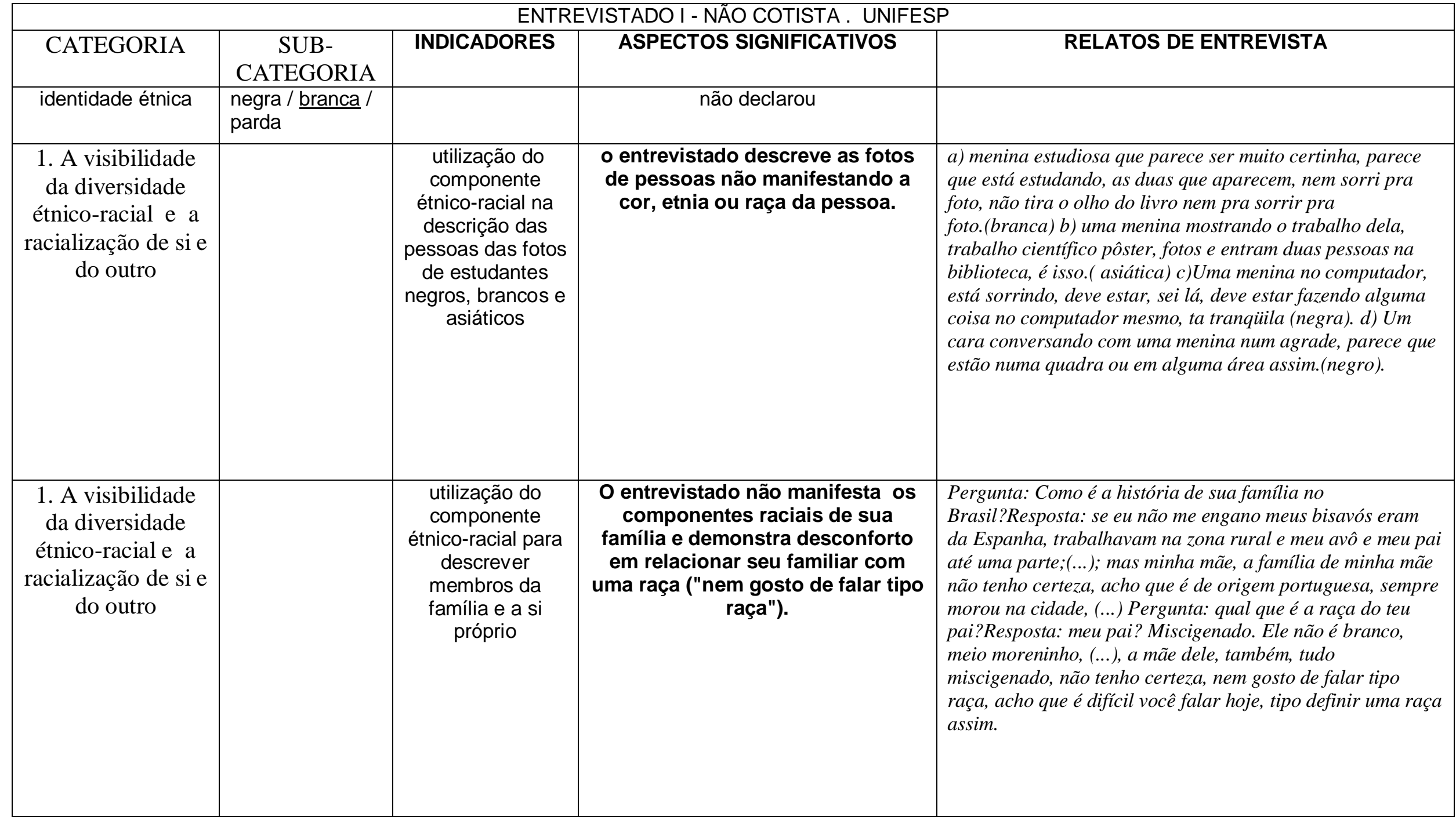




\begin{tabular}{|c|c|c|c|}
\hline $\begin{array}{l}\text { 1. A visibilidade } \\
\text { da diversidade } \\
\text { étnico-racial e a } \\
\text { racialização de si e } \\
\text { do outro }\end{array}$ & $\begin{array}{l}\text { noção sobre o } \\
\text { conceito social de } \\
\text { raça na utilização } \\
\text { do componente } \\
\text { étnico-racial na } \\
\text { descrição das } \\
\text { relações sociais }\end{array}$ & $\begin{array}{l}\text { O entrevistado não utiliza o } \\
\text { componente étnico-racial para } \\
\text { descrever as relações sociais. }\end{array}$ & $\begin{array}{l}\text { Pergunta: você acha que tem raças entre os seres } \\
\text { humanos?Resposta: tem, mas acho muito difícil generalizar } \\
\text { e de usar no sentido que, a maioria das pessoas são, ah você } \\
\text { não pode falar que ele é branco ou que ele é negro, várias } \\
\text { pessoas têm a mistura dessas raças, são miscigenados }\end{array}$ \\
\hline $\begin{array}{l}\text { 2. Visibilidade } \\
\text { sobre a ocorrência } \\
\text { da discriminação } \\
\text { racial }\end{array}$ & $\begin{array}{l}\text { Visibilidade do } \\
\text { tratamento } \\
\text { desigual direto ou } \\
\text { indireto que } \\
\text { prejudica } \\
\text { socialmente o } \\
\text { negro, seja pela } \\
\text { neutralidade, seja } \\
\text { pela diferenciação } \\
\text { negativa }\end{array}$ & $\begin{array}{c}\text { O entrevistado visualiza o } \\
\text { preconceito na conduta da estória } \\
\text { hipotética. }\end{array}$ & $\begin{array}{l}\text { Pergunta } 20^{*} \text { primeira etapa: acho que isso aconteceu, sei } \\
\text { lá, por puro preconceito. (...) ficou claro pra mim que não } \\
\text { tinham me deixado entrar só porque eu, pelo pressuposto de } \\
\text { que se eu sou negro não sou estudante universitário. }\end{array}$ \\
\hline $\begin{array}{l}\text { 2. Visibilidade } \\
\text { sobre a ocorrência } \\
\text { da discriminação } \\
\text { racial }\end{array}$ & $\begin{array}{l}\text { visibilidade do } \\
\text { tratamento } \\
\text { desigual direto ou } \\
\text { indireto que } \\
\text { prejudica } \\
\text { socialmente o } \\
\text { negro, seja pela } \\
\text { neutralidade, seja } \\
\text { pela diferenciação } \\
\text { negativa }\end{array}$ & $\begin{array}{c}\text { O entrevistado não constata a } \\
\text { discriminação racial na } \\
\text { universidade. Observa-se que só } \\
\text { foi possível visualizar a } \\
\text { discriminação racial institucional } \\
\text { quando foi invertido o papel social } \\
\text { dos grupos branco e negros de } \\
\text { ocupação de local de privilégio na } \\
\text { sociedade. }\end{array}$ & $\begin{array}{l}\text { Pergunta: Se um homem negro fosse o dono de uma escola e } \\
\text { tivesse só professores negros, você acha que esse cara seria } \\
\text { racista? Resposta: acho.Pergunta: Você acha que existe } \\
\text { discriminação racial aqui na universidade? Resposta: eu } \\
\text { acho que sinceramente não que eu tenha visto, também } \\
\text { nunca conheci, eles tratam normalmente independente da } \\
\text { cor da pele.Pergunta: você tem professores negros } \\
\text { aqui?Resposta: não }\end{array}$ \\
\hline
\end{tabular}




\begin{tabular}{|c|c|c|c|}
\hline $\begin{array}{c}\text { 2. Visibilidade } \\
\text { sobre a ocorrência } \\
\text { da discriminação } \\
\text { racial }\end{array}$ & $\begin{array}{c}\text { visibilidade do } \\
\text { tratamento } \\
\text { desigual direto ou } \\
\text { indireto que } \\
\text { prejudica } \\
\text { socialmente o } \\
\text { negro, seja pela } \\
\text { neutralidade, seja } \\
\text { pela diferenciação } \\
\text { negativa }\end{array}$ & $\begin{array}{l}\text { O entrevistado constada a } \\
\text { discriminação racial na cidade. }\end{array}$ & $\begin{array}{l}\text { Pergunta: e em são Paulo?Resposta: existe. (...) nossa } \\
\text { própria mentalidade hoje por exemplo, você ta andando na } \\
\text { rua aí você vê um moleque negro com boné e tal você, por } \\
\text { exemplo, ta de longe você fala ou ele é assim tipo ou tá indo } \\
\text { pra casa e tal, ás vezes você fica indiferente ou você pensa } \\
\text { tudo, tenho que tomar cuidado e tal a mesma coisa não } \\
\text { acontece quando você vê a pessoa é branca, você falar ela tá } \\
\text { indo pra casa tal, mas acho mais pelo, a gente ainda tem um } \\
\text { pouco de preconceito, por ele ser negro você pensa assim, } \\
\text { mas também pela roupa que ele está vestindo, com certeza se } \\
\text { tiver um cara negro de terno voltando pra casa você fala } \\
\text { está voltando do trabalho, um cara branco de roupa toda } \\
\text { rasgada tal andando por aí você fala tomar cuidado. }\end{array}$ \\
\hline $\begin{array}{c}\text { 2. Visibilidade } \\
\text { sobre a ocorrência } \\
\text { da discriminação } \\
\text { racial }\end{array}$ & $\begin{array}{c}\text { visibilidade do } \\
\text { tratamento } \\
\text { desigual direto ou } \\
\text { indireto que } \\
\text { prejudica } \\
\text { socialmente o } \\
\text { negro, seja pela } \\
\text { neutralidade, seja } \\
\text { pela diferenciação } \\
\text { negativa }\end{array}$ & $\begin{array}{l}\text { O entrevistado constata que } \\
\text { haveria um maior desafio a } \\
\text { enfrentar se estivesse em uma } \\
\text { situação de minoria, mas dá uma } \\
\text { solução fácil para lidar com a } \\
\text { situação. }\end{array}$ & $\begin{array}{l}\text { Pergunta: Imagine se na tua classe } 80 \% \text { das pessoas fossem } \\
\text { negras, como é que você se sentiria?Resposta: não sei. } \\
\text { Sinceramente eu não sei... acho que não tem porque me } \\
\text { sentir, tudo bem eu posso ser minoria ali, mas com certeza } \\
\text { vai ter muita gente legal que vai virar meu amigo entendeu, } \\
\text { não porque você fala: "nossa, esse é aí é diferente", então } \\
\text { você o exclui.. }\end{array}$ \\
\hline
\end{tabular}




\begin{tabular}{|c|c|c|c|}
\hline $\begin{array}{l}\text { 3. Visibilidade } \\
\text { sobre as } \\
\text { consequências do } \\
\text { racismo, os danos } \\
\text { e os privilégios }\end{array}$ & $\begin{array}{l}\text { visibilidade do } \\
\text { prejuízo social } \\
\text { para o negro }\end{array}$ & $\begin{array}{c}\text { Vislumbra o aumento do racismo } \\
\text { na situação de competição } \\
\text { provocada pelo processo de } \\
\text { seleção que reserva vagas já } \\
\text { existente para negros. }\end{array}$ & $\begin{array}{l}\text { Pergunta: você acha que essa medida de cotas aumenta o } \\
\text { racismo?Resposta: não, eu acho que não, não na forma que } \\
\text { ele é implementado aqui por existirem vagas a mais, tanto } \\
\text { que todo mundo que se conhece diz, ah eu passei por cotas } \\
\text { tal, mas eu não sei como seria em outra faculdade onde sei } \\
\text { lá, se reservasse parte das vagas já existentes para negros, } \\
\text { acho que por mais que tenham algumas pessoas que se } \\
\text { esforçam pra poder conviver bem com todo mundo sempre } \\
\text { vai ter alguém que vai exacerbar até com o tempo vai se } \\
\text { importar com isso. }\end{array}$ \\
\hline
\end{tabular}




\begin{tabular}{|c|c|c|c|c|}
\hline 4. Estigma & $\begin{array}{l}\text { na } \\
\text { comunicação } \\
\text { não verbal }\end{array}$ & $\begin{array}{l}\text { escolha de papéis } \\
\text { profissionais para } \\
\text { as pessoas das fotos } \\
\text { de homens e } \\
\text { mulheres; } \\
\text { brancos(as) e } \\
\text { negros(as); de } \\
\text { faixas etárias de } 20 \\
\text { a } 30 \text { anos, de } 31 \text { a } \\
59 \text { anos, acima de } \\
60 \text { anos. } \\
\text { Indicadores: } \\
\text { profissionais } \\
\text { brancos (as) - } \\
\text { negros (as) e cargos } \\
\text { profissionais } \\
\text { artista, que } \\
\text { privilegia } \\
\text { conhecimento } \\
\text { intelectual, manual } \\
\text { e posições de } \\
\text { chefia. }\end{array}$ & $\begin{array}{l}\text { Observa-se a tendência do } \\
\text { entrevistado de reproduzir os } \\
\text { estigmas sociais, escolhendo } \\
\text { majoritariamente para os cargos } \\
\text { que privilegia conhecimento } \\
\text { intelectual as pessoas brancas e } \\
\text { para os cargos que privilegiam o } \\
\text { trabalho manual e artístico, os } \\
\text { negros. Das } 9 \text { profissões, } 1 \text { ele não } \\
\text { respondeu, } 4 \text { foram preenchidas por } \\
\text { pessoas brancas e } 4 \text { por pessoas } \\
\text { negras; sendo que as } 2 \text { profissões } \\
\text { que privilegiam o trabalho intelectual, } \\
1 \text { das } 2 \text { posições de chefia e } 1 \text { das } 4 \\
\text { que privilegiam o trabalho manual } \\
\text { foram preenchidas por pessoas } \\
\text { brancas; a profissão de artista, } 1 \text { das } \\
2 \text { posições de chefia e } 2 \text { das } 4 \text { que } \\
\text { privilegiam o trabalho manual foram } \\
\text { preenchidas por pessoas negras. }\end{array}$ & $\begin{array}{l}\text { Profissional Artista: Pianista - homem negro (figura 30); } \\
\text { Profissão que privilegia conhecimento intelectual: Médico } \\
\text { (a) plantonista - mulher branca (figura 26); Professor } \\
\text { Universitário - homem branco (figura 27); } \\
\text { Posições de chefia: Gerente do hotel - mulher negra (figura } \\
\text { 24); Diretor (a) de Marketing de uma loja de departamento - } \\
\text { homem branco (figura 19); } \\
\text { Profissões que privilegiam o trabalho manual: Arrumador } \\
\text { (eira) do Hotel - mulher negra (figura 20); Motorista de } \\
\text { ônibus - homem negro (figura 18); Cabeleireiro(a)) - não } \\
\text { respondeu; Porteiro(a) do Hotel - mulher branca (figura 21). }\end{array}$ \\
\hline 5. Estereótipo & & & & \\
\hline
\end{tabular}




\begin{tabular}{|c|c|c|c|}
\hline $\begin{array}{c}\text { 6. Reações } \\
\text { emocionais na } \\
\text { relação com o } \\
\text { preconceito (com } \\
\text { o diverso) }\end{array}$ & $\begin{array}{l}\text { na } \\
\text { comunicação } \\
\text { verbal }\end{array}$ & $\begin{array}{l}\text { CONTRADIÇÃO: O entrevistado } \\
\text { manifesta a importância que a } \\
\text { suposta diferença de nível } \\
\text { meritório entre os alunos } \\
\text { referindo-se ao fato dos cotistas } \\
\text { não terem passado pelo processo } \\
\text { de vestibular "normalmente", } \\
\text { sugerindo que se fossem } \\
\text { avaliadas as suas condições para } \\
\text { estarem lá na universidade, por } \\
\text { meio desse vestibular, não } \\
\text { conseguiriam passar ("as pessoas } \\
\text { que entraram, algumas delas ... se } \\
\text { tivessem feito o vestibular } \\
\text { normalmente, sem precisar utilizar } \\
\text { as cotas, não estariam aqui } \\
\text { dentro"). Em outro momento, diz: } \\
\text { "acho que todo mundo aqui tem } \\
\text { mais ou menos o mesmo nível"). } \\
\text { Logo em seguida, ao primeiro } \\
\text { assunto, diz que, "mas não tem } \\
\text { nenhum preconceito", como se } \\
\text { sentisse mal (VERGONHA) por ter } \\
\text { o preconceito e não gostar de se } \\
\text { incomodar com a diferença por ele } \\
\text { apontada. }\end{array}$ & $\begin{array}{l}\text { sou contra as cotas raciais (...) acho que deveria ser sempre } \\
\text { uma melhoria para todo mundo na educação básica, mas } \\
\text { aqui dentro acho que, tudo bem essa medida foi paliativa e } \\
\text { tal, as pessoas que entraram, algumas delas ... se tivessem } \\
\text { feito o vestibular normalmente, sem precisar utilizar as } \\
\text { cotas, não estariam aqui dentro, mas não tem nenhum } \\
\text { preconceito(...) eu acho que a maioria das pessoas não,é } \\
\text { são só } 10 \text { vagas pra cotistas, então essas } 10 \text { vagas a nota } \\
\text { deles é mais ou menos igual a nossa, acho que todo mundo } \\
\text { aqui tem mais ou menos o mesmo nível }\end{array}$ \\
\hline
\end{tabular}




\begin{tabular}{|c|c|c|c|}
\hline $\begin{array}{l}\text { 6. Reações } \\
\text { emocionais na } \\
\text { relação com o } \\
\text { preconceito (com } \\
\text { o diverso) }\end{array}$ & $\begin{array}{l}\text { culpa, vergonha, } \\
\text { irritabilidade, } \\
\text { raiva, exaustão, } \\
\text { confusão na fala, } \\
\text { negação, medo, } \\
\text { dissimulação, } \\
\text { sensação de } \\
\text { solidão, tristeza, } \\
\text { sensação de não } \\
\text { pertencimento, } \\
\text { contradição, } \\
\text { justificativa } \\
\text { defensiva }\end{array}$ & $\begin{array}{l}\text { O entrevistado demonstra uma } \\
\text { IRRITABILIDADE que atribui ao } \\
\text { fato de se falar muito no assunto } \\
\text { da diferença entre negros e } \\
\text { brancos ("o tempo todo } \\
\text { martelando nisso"). }\end{array}$ & $\begin{array}{l}\text {...por exemplo, essa entrevista, o tempo todo perguntando se } \\
\text { o negro tivesse alguma coisa e o branco tivesse uma coisa, } \\
\text { ta sempre querendo saber se a pessoa tem alguma coisa } \\
\text { contra os negros ou alguma coisa contra os brancos ... ficar } \\
\text { o tempo todo martelando nisso, nossa porque os negros são } \\
\text { assim porque os brancos são assim }\end{array}$ \\
\hline $\begin{array}{l}\text { 6. Reações } \\
\text { emocionais na } \\
\text { relação com o } \\
\text { preconceito (com } \\
\text { o diverso) }\end{array}$ & & $\begin{array}{l}\text { O entrevistado demonstra } \\
\text { encontrar dificuldades em saber } \\
\text { qual reação teria diante da } \\
\text { situação. }\end{array}$ & $\begin{array}{l}\text { Pergunta: Imagine se na tua classe } 80 \% \text { das pessoas fossem } \\
\text { negras, como é que você se sentiria?Resposta: não sei. } \\
\text { Sinceramente eu não sei...acho que não tem porque me } \\
\text { sentir, tudo bem eu posso ser minoria ali, mas com certeza } \\
\text { vai ter muita gente legal que vai virar meu amigo entendeu, } \\
\text { não porque você falar:" nossa, esse é aí é diferente", então } \\
\text { vocêe oxclui.. }\end{array}$ \\
\hline
\end{tabular}




\begin{tabular}{|c|c|c|c|c|}
\hline $\begin{array}{l}\text { 7. Formas e } \\
\text { Oportunidades de } \\
\text { elaboração das } \\
\text { experiências } \\
\text { relacionadas ao } \\
\text { racismo }\end{array}$ & & $\begin{array}{l}\text { oportunidades de } \\
\text { reflexão sobre o } \\
\text { tema racismo nos } \\
\text { espaços sociais } \\
\text { (família, escola, } \\
\text { mídia, amigos) }\end{array}$ & $\begin{array}{l}\text { O entrevistado revela ter tido } \\
\text { oportunidades de debater o } \\
\text { assunto com amigos, mas nunca } \\
\text { em ambientes institucionais, } \\
\text { educacionais. }\end{array}$ & $\begin{array}{l}\text { Pergunta: Você teve alguma oportunidade de discutir sobre } \\
\text { racismo alguma vez? Em escolas, etc. Resposta: Não, só com } \\
\text { amigos. }\end{array}$ \\
\hline \multirow[t]{2}{*}{$\begin{array}{l}\text { 8. Abordagem } \\
\text { teórica sobre o } \\
\text { tema }\end{array}$} & $\begin{array}{l}\text { Diversidade } \mathrm{x} \\
\text { Igualdade } \mathrm{x} \\
\text { Racismo }\end{array}$ & $\begin{array}{l}\text { Confusão sobre } \\
\text { os agrupamentos } \\
\text { na diversidade, } \\
\text { sobre a } \\
\text { diferenciação } \\
\text { positiva - a } \\
\text { diferenciação } \\
\text { negativa (quando } \\
\text { é um valor a } \\
\text { diversidade e } \\
\text { quando não é). }\end{array}$ & $\begin{array}{l}\text { Confusão sobre o tema: } 0 \\
\text { entrevistado não relaciona o tema } \\
\text { do racismo ao tema da } \\
\text { diversidade, demonstra que } \\
\text { acredita que a diferenciação é uma } \\
\text { forma negativa, pois pode } \\
\text { segregar as pessoas e introduz } \\
\text { novo tema que é "todas as formas } \\
\text { diferentes das pessoas viverem } \\
\text { juntas". }\end{array}$ & $\begin{array}{l}\text { Pergunta: Esse tema diversidade, o que você acha disso? } \\
\text { Resposta: eu acho legal(...) Pergunta: Se fosse convidado } \\
\text { para assistir a um palestra sobre o racismo você } \\
\text { iria?Resposta:eu acho que talvez, mas provavelmente nã, } \\
\text { por mais que possa ser o problema, eu ainda acho que só } \\
\text { ficar discutindo se ainda existe o racismo é só uma forma de, } \\
\text { não incentivar, mas sei lá, de segregar as pessoas, acho que } \\
\text { tem que tratar todo mundo igual. Pergunta:se tivesse uma } \\
\text { palestra sobre ño convívio em diversidadeò? Resposta: eu } \\
\text { iria, interessante que não fala só tipo o racismo, fala o } \\
\text { convivio em todos os aspectos bons e ruins das pessoas, a } \\
\text { todas as formas diferentes das pessoas viverem juntas. }\end{array}$ \\
\hline & $\begin{array}{l}\text { Relação do } \\
\text { racismo com } \\
\text { os princípios } \\
\text { de direito } \\
\text { fundamentais }\end{array}$ & $\begin{array}{l}\text { reconhecimento } \\
\text { do direito a ser } \\
\text { tratado } \\
\text { desigualmente ( } \\
\text { discriminação } \\
\text { positiva) }\end{array}$ & $\begin{array}{l}\text { O entrevistado não concorda com } \\
\text { a discriminação positiva como } \\
\text { uma forma de promoção dos } \\
\text { direitos fundamentais. Acredita } \\
\text { que todos têm direito à educação, } \\
\text { mas não entende a política de } \\
\text { cotas como um meio de garantia } \\
\text { desse direito. }\end{array}$ & $\begin{array}{l}\text {...se existe mesmo a diferença de oportunidade pra as } \\
\text { pessoas nas diferentes classes sociais ou raciais deveria ser } \\
\text { feito mudança no ensino básico para todo mundo sem essas } \\
\text { diferenças... }\end{array}$ \\
\hline
\end{tabular}




\begin{tabular}{|c|c|c|c|c|}
\hline $\begin{array}{c}\text { 8. Abordagem } \\
\text { teórica sobre o tema }\end{array}$ & $\begin{array}{l}\text { Relação do } \\
\text { racismo com } \\
\text { os princípios } \\
\text { de direito } \\
\text { fundamentais }\end{array}$ & $\begin{array}{l}\text { reconhecimento } \\
\text { do direito a ser } \\
\text { tratado } \\
\text { desigualmente ( } \\
\text { discriminação } \\
\text { positiva) }\end{array}$ & $\begin{array}{l}\text { O entrevistado não relaciona a } \\
\text { discriminação positiva e a } \\
\text { discriminação racial com temas de } \\
\text { direitos fundamentais e direitos } \\
\text { humanos. }\end{array}$ & $\begin{array}{l}\text { Pergunta: você acha que direito dos negros ou } \\
\text { discriminação racial é uma questão dos Direitos Humanos? } \\
\text { Resposta: ...é um fato que a maioria das pessoas pobres hoje } \\
\text { são negras, por exemplo, mas acho que não seja próprio das } \\
\text { políticas públicas, tem que ser pra todo mundo, todo mundo } \\
\text { culturalmente é brasileiro, tem o mesmo pensamento e tem } \\
\text { diferenças de classes sociais, mas falar, ah, hoje o negro } \\
\text { está sendo discriminado e implementar cota é uma coisa que } \\
\text { apenas incentiva a discriminação. ...tentar o máximo } \\
\text { possível superar essa idéia, essa idéia de que a raça influi } \\
\text { em alguma coisa é muito absurda, todo mundo tem que ser } \\
\text { tratado igualmente... }\end{array}$ \\
\hline $\begin{array}{l}\text { 9. Manifestação } \\
\text { da solidariedade }\end{array}$ & & $\begin{array}{l}\text { crença de que a } \\
\text { relação multi- } \\
\text { étnica enriquece } \\
\text { e auxilia a } \\
\text { coletividade, na } \\
\text { solução de } \\
\text { problemas } \\
\text { coletivos e } \\
\text { individuais; } \\
\text { disponibilidade } \\
\text { para a busca real } \\
\text { de soluções para } \\
\text { o racismo }\end{array}$ & $\begin{array}{l}\text { Apesar do entrevistado, em um } \\
\text { primeiro momento, manifestar que } \\
\text { gosta da diversidade, em um } \\
\text { segundo, revela que não relaciona } \\
\text { o racismo à diversidade, e, quando } \\
\text { fala em diversidade, quer abordar } \\
\text { os atributos individuais que } \\
\text { diferenciam as pessoas e não os } \\
\text { atributos coletivos. Não } \\
\text { demonstra acreditar que a relação } \\
\text { multi-étnica enriquece e auxilia a } \\
\text { coletividade. Mesmo dizendo que } \\
\text { aprecia a diversidade, revela que } \\
\text { ela representa para ele um } \\
\text { "esforço para aceitar"e não algo } \\
\text { que Ihe venha enriquecer. }\end{array}$ & $\begin{array}{l}\text { Esse tema diversidade, o que você acha disso? Resposta: eu } \\
\text { acho legal, mas eu me esforço o máximo para tentar aceitar } \\
\text { todo mundo(...) eu sinto certa atração, eu gosto das coisas } \\
\text { mais diferentes mesmo, sei lá, a diferença que temos nós } \\
\text { humanos.(...)Pergunta: se você fosse convidado para assistir } \\
\text { a um palestra sobre o racismo você iria?Resposta:eu acho } \\
\text { que talvez, mas provavelmente não, (...)é só uma forma de, } \\
\text { não incentivar, mas sei lá, de segregar as pessoas, acho que } \\
\text { tem que tratar todo mundo igual. Pergunta:se tivesse uma } \\
\text { palestra sobre ño convívio em diversidadeò ? Resposta: eu } \\
\text { iria, interessante que não fala só tipo o racismo, fala o } \\
\text { convivio em todos os aspectos bons e ruins das pessoas, a } \\
\text { todas as formas diferentes das pessoas viverem juntas. }\end{array}$ \\
\hline
\end{tabular}




\begin{tabular}{|c|c|c|c|}
\hline $\begin{array}{l}\text { 9. Manifestação } \\
\text { da solidariedade }\end{array}$ & $\begin{array}{l}\text { crença de que a } \\
\text { relação multi- } \\
\text { étnica enriquece } \\
\text { e auxilia a } \\
\text { coletividade, na } \\
\text { solução de } \\
\text { problemas } \\
\text { coletivos e } \\
\text { individuais; } \\
\text { disponibilidade }\end{array}$ & $\begin{array}{l}\text { O entrevistado demonstra ter se } \\
\text { identificado com algo que } \\
\text { supostamente seria a emoção do } \\
\text { personagem negro na estória } \\
\text { hipotética ("com certeza eu iria } \\
\text { ficar muito ofendido se eu fosse o } \\
\text { Gilberto (negro), porque ficou } \\
\text { claro pra mim...") }\end{array}$ & $\begin{array}{l}\text { Pergunta } 20 * \text { segunda etapa: e o que eu faria se eu fosse o } \\
\text { João (branco) eu falava para o funcionário que também } \\
\text { estou sem carteirinha, tem que deixar ele entrar também e } \\
\text { com certeza eu iria ficar muito ofendido se eu fosse o } \\
\text { Gilberto (negro), porque ficou claro pra mim que não } \\
\text { tinham me deixado entrar só porque eu, pelo pressuposto de } \\
\text { que se eu sou negro não sou estudante universitário. Eu } \\
\text { penso que também ajudaria se fosse o João (branco), }\end{array}$ \\
\hline $\begin{array}{l}\text { 9. Manifestação } \\
\text { da solidariedade }\end{array}$ & $\begin{array}{c}\text { para a busca real } \\
\text { de soluções para } \\
\text { o racismo }\end{array}$ & $\begin{array}{l}\text { O entrevistado busca valorizar a } \\
\text { dignidade humana de todas as } \\
\text { pessoas. No entanto, não encontra } \\
\text { na afirmação das diferenças um } \\
\text { caminho para isso. Observa-se } \\
\text { que o preconceito lhe incomoda } \\
\text { mas teme que a afirmação da } \\
\text { diferença venha aumentar o } \\
\text { preconceito e dividir as pessoas. } \\
\text { Não busca soluções. }\end{array}$ & $\begin{array}{l}\text { eu acredito hoje que existe sim o preconceito, mas existem } \\
\text { muitas pessoas que são indiferentes a isso e que acham que } \\
\text { não tem diferença que todo mundo é igual, acho que ficar o } \\
\text { tempo todo martelando nisso, nossa porque os negros são } \\
\text { assim porque os brancos são assim é só ficar dividindo } \\
\text { todas as pessoas, igual a segregar tipo você é um Punk você } \\
\text { é uma skinheads entendeu, ninguém conhece as pessoas a } \\
\text { fundo para julgar assim eu acho, eu não sei, eu não tenho } \\
\text { nenhuma política concreta para pensar nisso. }\end{array}$ \\
\hline
\end{tabular}




\begin{tabular}{|c|c|c|c|}
\hline $\begin{array}{l}\text { 10. Integração } \\
\text { com as ofertas de } \\
\text { desenvolvimento } \\
\text { da Universidade }\end{array}$ & $\begin{array}{l}\text { Integração com } \\
\text { os colegas da } \\
\text { universidade; } \\
\text { oportunidades } \\
\text { profissionais que } \\
\text { surgem a partir } \\
\text { dessa integração; } \\
\text { acesso às } \\
\text { oportunidades } \\
\text { que o ambiente } \\
\text { acadêmico } \\
\text { oferece }\end{array}$ & $\begin{array}{l}\text { O entrevistado parece estar } \\
\text { integrado com as atividades da } \\
\text { Universidade, faz esportes, tem } \\
\text { seus amigos e projetos. }\end{array}$ & $\begin{array}{l}\text { Tá muito boa. Fico aqui o dia inteiro, tenho aula das } 8 \text { da } \\
\text { manhã até às } 6 \text { da tarde, quase todo dia, menos sexta-feira, } \\
\text { eu tô aqui fazendo esporte (...) agora to fazendo só handebol } \\
\text { (...) iniciação científica, grupo de estudo?por enquanto não. } \\
\text { eu sei que a partir do segundo ano que eu vou me interessar } \\
\text { mais por isso.. A maioria são os amigos da minha turma por } \\
\text { enquanto, mas assim, eu sei que, por exemplo, a gente } \\
\text { acaba conhecendo pessoas de todos os anos, principalmente } \\
\text { aqui na atlética, a gente fica conhecendo todo mundo e } \\
\text { acaba ficando amigo de todo mundo, mas os mais próximos } \\
\text { mesmo são os do primeiro ano. }\end{array}$ \\
\hline
\end{tabular}

\begin{tabular}{|c|c|c|c|c|}
\hline \multicolumn{5}{|c|}{ ENTREVISTADA J - NÃO COTISTA Ï UNIFESP } \\
\hline CATEGORIA & $\begin{array}{c}\text { SUB- } \\
\text { CATEGORIA }\end{array}$ & INDICADORES & ASPECTOS SIGNIFICATIVOS & RELATOS DE ENTREVISTA \\
\hline identidade étnica & $\begin{array}{l}\text { negra / branca / } \\
\text { parda }\end{array}$ & & não declarou & \\
\hline $\begin{array}{l}\text { 1. A visibilidade } \\
\text { da diversidade } \\
\text { étnico-racial e } \\
\text { a racialização de } \\
\text { si e do outro }\end{array}$ & & $\begin{array}{c}\text { utilização do } \\
\text { componente } \\
\text { étnico-racial na } \\
\text { descrição das } \\
\text { pessoas das fotos } \\
\text { de estudantes } \\
\text { negros, brancos e } \\
\text { asiáticos }\end{array}$ & $\begin{array}{l}\text { A entrevistada descreve as fotos de } \\
\text { pessoas brancas, não identificando a } \\
\text { cor, etnia ou raça da pessoa. A partir do } \\
\text { momento que vê a foto da pessoa } \\
\text { asiática, a vincula a uma cor, raça ou } \\
\text { etnia ("uma japonesa"),e também não } \\
\text { manifesta a cor, etnia ou raça da } \\
\text { pessoa negra que são das fotos que } \\
\text { vêem sem seguida. Observa-se a } \\
\text { tendência do entrevistado de ver a } \\
\text { pessoa branca como um ser humano } \\
\text { universal. }\end{array}$ & $\begin{array}{l}\text { Pergunta: Me descreva a pessoa dessas fotos. Resposta:a) } \\
\text {...muitos livros em volta, provavelmente numa biblioteca, bem } \\
\text { branquinha, um ñsorrizinhoò... parece que está contente. } \\
\text { (branca) b) Parece uma exposição de trabalhos, provavelmente } \\
\text { sobre a natureza, uma japonesa mostrando um livro e outro, } \\
\text { dois ambientes parece uma biblioteca e uma moça bem } \\
\text { compenetrada assim, no ar ... c) um garoto parece está } \\
\text { prestando atenção em alguma coisa que está anotando, mas dá } \\
\text { para ver direito onde ele está. (negro). d) uma menina mexendo } \\
\text { no teclado de um computador, alguma coisa no computador } \\
\text { (negra). }\end{array}$ \\
\hline
\end{tabular}




\begin{tabular}{|c|c|c|c|}
\hline $\begin{array}{l}\text { 1. A visibilidade } \\
\text { da diversidade } \\
\text { étnico-racial e a } \\
\text { racialização de } \\
\text { si e do outro }\end{array}$ & $\begin{array}{l}\text { utilização do } \\
\text { componente } \\
\text { étnico-racial para } \\
\text { descrever } \\
\text { membros da } \\
\text { família e a si } \\
\text { próprio }\end{array}$ & $\begin{array}{l}\text { A entrevistada não utiliza o componente } \\
\text { étnico-racial na descrição de sua } \\
\text { família e demonstra dificuldade em } \\
\text { relacionar os membros de sua família } \\
\text { com uma raça ("Como assim ? .... Não } \\
\text { sei."). }\end{array}$ & $\begin{array}{l}\text { Pergunta: Me fala um pouco agora da sua família. Resposta: } \\
\text { Meu pai e minha mãe são portugueses. Eles vieram para cá } \\
\text { quando eram pequenos, minha mãe tinha quatro anos e meu } \\
\text { pai tinha nove anos, meus avós paternos e maternos vieram } \\
\text { primeiro, depois vieram minhas avós e os filhos. Meu pai veio } \\
\text { em } 1964 . \text { Pergunta: Qual é a raça do seu pai ? Resposta: Como } \\
\text { assim? .... Não sei. (entrevistada fica assustada) }\end{array}$ \\
\hline $\begin{array}{l}\text { 1. A visibilidade } \\
\text { da diversidade } \\
\text { étnico-racial e a } \\
\text { racialização de } \\
\text { si e do outro }\end{array}$ & $\begin{array}{l}\text { noção sobre o } \\
\text { conceito social de } \\
\text { raça na utilização } \\
\text { do componente } \\
\text { étnico-racial na } \\
\text { descrição das } \\
\text { relações sociais }\end{array}$ & & \\
\hline $\begin{array}{l}\text { 2. Visibilidade } \\
\text { sobre a } \\
\text { ocorrência da } \\
\text { discriminação } \\
\text { racial }\end{array}$ & $\begin{array}{l}\text { visibilidade do } \\
\text { tratamento } \\
\text { desigual direto ou } \\
\text { indireto que } \\
\text { prejudica } \\
\text { socialmente o } \\
\text { negro, seja pela } \\
\text { neutralidade, seja } \\
\text { pela diferenciação } \\
\text { negativa }\end{array}$ & $\begin{array}{c}\text { A entrevistada visualiza a discriminação } \\
\text { racial direta na universidade ("é o que } \\
\text { eu falei aquela olhada assim estranha") } \\
\text { e na cidade. }\end{array}$ & $\begin{array}{l}\text { Pergunta:Você pode me dizer como o racismo se manifesta em } \\
\text { São Paulo?Resposta: Pelo olhar, você claramente reprova as } \\
\text { pessoas.Pergunta: Você acha que existe racismo aqui na } \\
\text { faculdade?Resposta: Nada concreto, que leve às vias de fato ou } \\
\text { xingue, mas é o que eu falei aquela olhada assim estranha. }\end{array}$ \\
\hline $\begin{array}{l}\text { 2. Visibilidade } \\
\text { sobre a } \\
\text { ocorrência da } \\
\text { discriminação } \\
\text { racial }\end{array}$ & $\begin{array}{l}\text { visibilidade do } \\
\text { tratamento } \\
\text { desigual direto ou } \\
\text { indireto que } \\
\text { prejudica } \\
\text { socialmente o } \\
\text { negro, seja pela } \\
\text { neutralidade, seja } \\
\text { pela diferenciação } \\
\text { negativa }\end{array}$ & $\begin{array}{l}\text { A entrevistada visualiza o preconceito } \\
\text { na conduta da estória hipotética. }\end{array}$ & $\begin{array}{l}\text { Pergunta } 20^{*} \text { primeira etapa: } O \text { tema, acho que é o preconceito } \\
\text { inconsciente às vezes, que meio se materializa, nessas atitudes } \\
\text { bobas. }\end{array}$ \\
\hline
\end{tabular}




\begin{tabular}{|c|c|c|c|}
\hline $\begin{array}{l}\text { 2. Visibilidade } \\
\text { sobre a } \\
\text { ocorrência da } \\
\text { discriminação } \\
\text { racial }\end{array}$ & $\begin{array}{l}\text { visibilidade do } \\
\text { tratamento } \\
\text { desigual direto ou } \\
\text { indireto que } \\
\text { prejudica } \\
\text { socialmente o } \\
\text { negro, seja pela } \\
\text { neutralidade, seja } \\
\text { pela diferenciação } \\
\text { negativa }\end{array}$ & $\begin{array}{l}\text { A entrevista não explicita as questões } \\
\text { que envolvem a discriminação racial } \\
\text { entre maiorias e minorias. Mas } \\
\text { manifesta a idéia do impacto que } \\
\text { acontece com as pessoas brancas e } \\
\text { negras, diante uma das outras ("você } \\
\text { veria menos coisas impactando a gente } \\
\text { sabe, às vezes as pessoas se } \\
\text { impactam") }\end{array}$ & $\begin{array}{l}\text { Imagine se na tua sala de aula hoje, } 80 \% \text { das pessoas fossem } \\
\text { negras e } 20 \% \text { brancas, como é que você se sentiria?Resposta: } \\
\text { Assim, se mudasse do dia para a noite? Não sei, eu ia achar que } \\
\text { entrei na sala errada porque minha sala não é assim ... não, } \\
\text { mas num... não sei, é... acho que eu iria ficar feliz... você veria } \\
\text { menos coisas impactando a gente sabe, às vezes a pessoa se } \\
\text { impactam, está na hora de se desfazer isso, mas a gente não } \\
\text { pode controlar as pessoas. }\end{array}$ \\
\hline $\begin{array}{l}\text { 3. Visibilidade } \\
\text { sobre as } \\
\text { consequências } \\
\text { do racismo, os } \\
\text { danos e os } \\
\text { privilégios }\end{array}$ & $\begin{array}{l}\text { visibilidade do } \\
\text { prejuízo social } \\
\text { para o negro }\end{array}$ & $\begin{array}{c}\text { A entrevistada visualiza as } \\
\text { consequências danosas à população } \\
\text { negra, no entanto, as atribui a qualidade } \\
\text { do ensino de quem tem uma condição } \\
\text { social menos privilegiada. }\end{array}$ & $\begin{array}{l}\text { Pergunta: Você acha que ser branca te auxiliou entrar numa } \\
\text { universidade?Resposta: Não. Pergunta:Porque você acha que } \\
\text { tem menos alunos negros na universidade?Por ter essa } \\
\text { marginalização na sociedade. Querendo ou não você tem um } \\
\text { caminho muito longo a percorrer para chegar ... a um sucesso } \\
\text { profissional, um sucesso em qualquer área, tanto num emprego } \\
\text { quanto numa faculdade. Acho que por ele ter entrado numa } \\
\text { escola pública é difícil, mesmo numa escola estadual pra } \\
\text { estudar melhor mais dificill, por todo o recurso que ele não teve } \\
\text { anteriormente. }\end{array}$ \\
\hline
\end{tabular}




\begin{tabular}{|c|c|c|c|c|}
\hline 4. Estigma & $\begin{array}{l}\text { na } \\
\text { comunicação } \\
\text { não verbal }\end{array}$ & $\begin{array}{c}\text { escolha de papéis } \\
\text { profissionais para as } \\
\text { pessoas das fotos de } \\
\text { homens e mulheres; } \\
\text { brancos(as) e } \\
\text { negros(as); de } \\
\text { faixas etárias de } 20 \text { a } \\
30 \text { anos, de } 31 \text { a } 59 \\
\text { anos, acima de } 60 \\
\text { anos. } \\
\text { Indicadores: } \\
\text { profissionais } \\
\text { brancos (as) - negros } \\
\text { (as) e cargos } \\
\text { profissionais artista, } \\
\text { que privilegia } \\
\text { conhecimento } \\
\text { intelectual, manual e } \\
\text { posições de chefia. }\end{array}$ & $\begin{array}{l}\text { Observa-se a tendência da entrevistada } \\
\text { de reproduzir os estigmas sociais, } \\
\text { escolhendo majoritariamente para os } \\
\text { cargos que privilegia conhecimento } \\
\text { intelectual as pessoas brancas e para } \\
\text { os cargos que privilegiam o trabalho } \\
\text { manual e artístico, os negros. Das } 9 \\
\text { profissões, } 5 \text { foram preenchidas por } \\
\text { pessoas brancas e } 4 \text { por pessoas negras; } \\
\text { sendo que as } 1 \text { das } 2 \text { profissões que } \\
\text { privilegiam o trabalho intelectual, } 2 \text { das } \\
\text { posições de chefia e } 2 \text { das } 4 \text { que } \\
\text { privilegiam o trabalho manual foram } \\
\text { preenchidas por pessoas brancas; a } \\
\text { profissão de artista, } 1 \text { das } 2 \text { profissões que } \\
\text { privilegiam o trabalho intelectual, e } 2 \text { das } 4 \\
\text { que privilegiam o trabalho manual foram } \\
\text { preenchidas por pessoas negras. }\end{array}$ & $\begin{array}{l}\text { Profissional Artista: Pianista - homem negro (figura 18); } \\
\text { Profissão que privilegia conhecimento intelectual: Médico (a) } \\
\text { plantonista - mulher branca (figura 26); Professor Universitário - } \\
\text { mulher negra (figura 23); } \\
\text { Posições de chefia: Gerente do hotel - mulher branca (figura } \\
\text { 29); Diretor (a) de Marketing de uma loja de departamento - } \\
\text { mulher branca (figura 29); } \\
\text { Profissões que privilegiam o trabalho manual: Arrumador (eira) } \\
\text { do Hotel - mulher negra (figura 20); Motorista de ônibus - } \\
\text { homem branco (figura 27); Cabeleireiro(a)) - homem negro } \\
\text { (figura 30); Porteiro(a) do Hotel - homem branco (figura 25). }\end{array}$ \\
\hline 5. Estereótipo & & $\begin{array}{c}\text { características } \\
\text { atribuídas } \\
\text { genericamente a } \\
\text { todos os membros } \\
\text { de um grupo, } \\
\text { mitos }\end{array}$ & $\begin{array}{l}\text { A entrevistada menciona uma relação } \\
\text { supostamente científica entre a pessoa } \\
\text { negra e a força física. }\end{array}$ & $\begin{array}{l}\text {...pessoas mulatas tem assim... um físico... até pelas fibras } \\
\text { musculares que eles têm são diferentes, eles têm fibras mais... } \\
\text { que demonstram mais resistência que nem os corredores da } \\
\text { África.... }\end{array}$ \\
\hline
\end{tabular}




\begin{tabular}{|c|c|c|c|c|}
\hline 5. Estereótipo & & $\begin{array}{l}\text { características } \\
\text { atribuídas } \\
\text { genericamente a } \\
\text { todos os membros } \\
\text { de um grupo, } \\
\text { mitos }\end{array}$ & $\begin{array}{l}\text { A entrevistada atribui genericamente a } \\
\text { todos os negros a característica de ser } \\
\text { uma pessoa que não teve recursos e } \\
\text { teve estudo em escola pública, por isso } \\
\text { maior dificuldade para ter sucesso } \\
\text { profissional. }\end{array}$ & $\begin{array}{l}\text { Pergunta: Você acha que ser branca te auxiliou entrar numa } \\
\text { universidade?Resposta: Não. Pergunta:Porque você acha que } \\
\text { tem menos alunos negros na universidade?Por ter essa } \\
\text { marginalização na sociedade. Querendo ou não você tem um } \\
\text { caminho muito longo a percorrer para chegar ... a um sucesso } \\
\text { profissional, um sucesso em qualquer área, tanto num emprego } \\
\text { quanto numa faculdade. Acho que por ele ter entrado numa } \\
\text { escola pública é dificil, mesmo numa escola estadual pra } \\
\text { estudar melhor mais dificill, por todo o recurso que ele não teve } \\
\text { anteriormente. }\end{array}$ \\
\hline $\begin{array}{l}\text { 6. Reações } \\
\text { emocionais na } \\
\text { relação com o } \\
\text { preconceito } \\
\text { (com o diverso) }\end{array}$ & $\begin{array}{l}\text { na } \\
\text { comunicação } \\
\text { verbal }\end{array}$ & & $\begin{array}{l}\text { NEGAÇÃO: A entrevistada utiliza um } \\
\text { recurso de camuflar a diferenciação } \\
\text { racial que ela própria fez, querendo } \\
\text { negar o conflito que surge com relação } \\
\text { à diversidade e igualdade ("Quem é } \\
\text { muito branquinho pega sol e fica } \\
\text { moreno, quem é moreno e quer fica } \\
\text { loiro fica loiro,") }\end{array}$ & $\begin{array}{l}\text { Pergunta: Você acredita que existem raças entre os seres } \\
\text { humanos. Quais seriam as raças que existem?Resposta:Não, } \\
\text { acho que é que nem eu te falei, cada um tem um jeito. Seria } \\
\text { negro, moreno, branco, mulato...Pergunta: Então você acha que } \\
\text { tem cor? Resposta: É. Quem é muito branquinho pega sol e fica } \\
\text { moreno, quem é moreno e quer fica loiro fica loiro, não faço } \\
\text { uma diferença essencial. }\end{array}$ \\
\hline $\begin{array}{l}\text { 6. Reações } \\
\text { emocionais na } \\
\text { relação com o } \\
\text { preconceito } \\
\text { (com o diverso) }\end{array}$ & & $\begin{array}{c}\text { culpa, vergonha, } \\
\text { irritabilidade, raiva, } \\
\text { exaustão, } \\
\text { confusão na fala, } \\
\text { negação, medo, } \\
\text { dissimulação, } \\
\text { sensação de } \\
\text { solidão, tristeza, } \\
\text { sensação de não } \\
\text { pertencimento, } \\
\text { contradição, } \\
\text { justificativa } \\
\text { defensiva }\end{array}$ & $\begin{array}{c}\text { A entrevista manifesta uma certa } \\
\text { dificuldade em entender a emoção que } \\
\text { teria mas manifesta a reação de impacto } \\
\text { que acontece com as pessoas brancas e } \\
\text { negras, diante uma das outras ("você } \\
\text { veria menos coisas impactando a gente } \\
\text { sabe, às vezes a pessoa se impactam") }\end{array}$ & $\begin{array}{l}\text { Imagine se na tua sala de aula hoje, } 80 \% \text { das pessoas fossem } \\
\text { negras e } 20 \% \text { brancas, como é que você se sentiria?Resposta: } \\
\text { Assim, se mudasse do dia para a noite? Não sei, eu ia achar que } \\
\text { entrei na sala errada porque minha sala não é assim ... não, } \\
\text { mas num... não sei, é... acho que eu iria ficar feliz... você veria } \\
\text { menos coisas impactando a gente sabe, às vezes a pessoa se } \\
\text { impactam, está na hora de se desfazer isso, mas a gente não } \\
\text { pode controlar as pessoas. }\end{array}$ \\
\hline
\end{tabular}




\begin{tabular}{|c|c|c|c|c|}
\hline $\begin{array}{c}\text { 7. Formas e } \\
\text { Oportunidades } \\
\text { de elaboração } \\
\text { das experiências } \\
\text { relacionadas ao } \\
\text { racismo }\end{array}$ & & $\begin{array}{l}\text { oportunidades de } \\
\text { reflexão sobre o } \\
\text { tema racismo nos } \\
\text { espaços sociais } \\
\text { (família, escola, } \\
\text { mídia, amigos) }\end{array}$ & $\begin{array}{l}\text { A entrevistada manifesta não ter tido } \\
\text { oportunidades para debater e refletir } \\
\text { sobre a questão do racismo durante a } \\
\text { sua vida. Apresenta uma reflexão que se } \\
\text { limita à relação que sua família tem com } \\
\text { a empregada doméstica, atribuindo a ela } \\
\text { aspectos afetivos, reproduzindo a idéia } \\
\text { de, assim, reduzir os aspectos danosos } \\
\text { e desiguais da população negra criada } \\
\text { pelo mito da democracia racial. }\end{array}$ & $\begin{array}{l}\text { Pergunta: Durante sua vida você lembra de ter tido alguma } \\
\text { oportunidade de discussão sobre discriminação } \\
\text { racial?Resposta: Todo mundo é muito apegado à funcionária lá } \\
\text { de casa,(...) eu tenho carinho por ela, ela sentava na mesa com } \\
\text { a gente, no meu aniversário ela está, sempre com a gente... }\end{array}$ \\
\hline $\begin{array}{l}\text { 8. Abordagem } \\
\text { teórica sobre o } \\
\text { tema }\end{array}$ & $\begin{array}{l}\text { Diversidade } \mathrm{x} \\
\text { Igualdade } \mathrm{x} \\
\text { Racismo }\end{array}$ & $\begin{array}{c}\text { Confusão sobre } \\
\text { os agrupamentos } \\
\text { na diversidade, } \\
\text { sobre a } \\
\text { diferenciação } \\
\text { positiva -a } \\
\text { diferenciação } \\
\text { negativa (quando } \\
\text { é um valor a } \\
\text { diversidade e } \\
\text { quando não é). }\end{array}$ & $\begin{array}{l}\text { Confusão sobre o tema: A entrevistada } \\
\text { não se sente confortável em classificar } \\
\text { as pessoas por raça, prefere classificar } \\
\text { por "jeito" ("cada um tem um jeito") e } \\
\text { explica essa diferença, a partir da } \\
\text { classificação racial ("negro, moreno, } \\
\text { branco, mulato.."). Em seguida, } \\
\text { preocupa-se em igualar todas essas } \\
\text { pessoas, preferindo camuflar as } \\
\text { diferenças ("Quem é muito branquinho } \\
\text { pega sol e fica moreno, quem é moreno } \\
\text { e quer fica loiro fica loiro, não faço uma } \\
\text { diferença essencial."). Observa-se que, } \\
\text { apesar da entrevistada achar que a } \\
\text { diversidade "é legal", a diferenciação } \\
\text { entre as pessoas não lhe parecer ser } \\
\text { uma coisa boa. }\end{array}$ & $\begin{array}{l}\text { Pergunta: Você acredita que existem raças entre os seres } \\
\text { humanos. Quais seriam as raças que existem?Resposta:Não, } \\
\text { acho que é que nem eu te falei, cada um tem um jeito. Seria } \\
\text { negro, moreno, branco, mulato...Pergunta: Então você acha que } \\
\text { tem cor? Resposta: É. Quem é muito branquinho pega sol e fica } \\
\text { moreno, quem é moreno e quer fica loiro fica loiro, não faço } \\
\text { uma diferença essencial. (...)Pergunta: Essa idéia de } \\
\text { diversidades entre as pessoas, o que você acha disso? } \\
\text { Resposta:Eu acho legal. Pergunta: Como você convive com a } \\
\text { diversidade?Resposta: Acho que tem muita gente que tenta } \\
\text { travar este processo, acho que é uma coisa que não tem } \\
\text { necessidade. Não tem porque ser, nada diferencia a pessoa,.... }\end{array}$ \\
\hline
\end{tabular}




\begin{tabular}{|c|c|c|c|c|}
\hline $\begin{array}{l}\text { 8. Abordagem } \\
\text { teórica sobre o } \\
\text { tema }\end{array}$ & $\begin{array}{l}\text { Relação do } \\
\text { racismo com os } \\
\text { princípios de } \\
\text { direito } \\
\text { fundamentais }\end{array}$ & $\begin{array}{l}\text { reconhecimento } \\
\text { do direito a ser } \\
\text { tratado } \\
\text { desigualmente ( } \\
\text { discriminação } \\
\text { positiva) }\end{array}$ & $\begin{array}{l}\text { A entrevista reconhece que a pessoa } \\
\text { negra é humana e portanto deve ser } \\
\text { incluída ao rol dos sujeitos de direitos } \\
\text { humanos, mas não compreende o que } \\
\text { seria o direito específico dos negros } \\
\text { gerado pela discriminação positiva. }\end{array}$ & $\begin{array}{l}\text { Pergunta: O que você entende por Direitos Humanos? } \\
\text { Reposta:Direito à escola, saúde, educação, comida, casa, são os } \\
\text { direitos que as pessoas têm para se manter bem nessa } \\
\text { vida.Pergunta: Direito dos Negros é Direitos Humanos para } \\
\text { você ? Resposta: É, eu não estou entendo, como assim, os } \\
\text { direitos dos negros... é um direito que só os negros têm ? Tipo } \\
\text { direitos a cotas, é isso ? Acho que sim, eles são humanos. }\end{array}$ \\
\hline $\begin{array}{l}9 . \\
\text { Manifestação da } \\
\text { solidariedade }\end{array}$ & & $\begin{array}{c}\text { crença de que a } \\
\text { relação multi- } \\
\text { étnica enriquece } \\
\text { e auxilia a } \\
\text { coletividade, na } \\
\text { solução de } \\
\text { problemas } \\
\text { coletivos e } \\
\text { individuais; } \\
\text { disponibilidade } \\
\text { para a busca real } \\
\text { de soluções para } \\
\text { o racismo }\end{array}$ & $\begin{array}{l}\text { A entrevistada demonstra se relacionar } \\
\text { com pessoas negras e gostar disso. No } \\
\text { entanto, o seu interesse não é atribuído } \\
\text { à diversidade dessas pessoas. Ao } \\
\text { contrário, a entrevistada demonstra } \\
\text { querer desaparecer com as diferenças, } \\
\text { e manter a idéia da igualdade, para que } \\
\text { a relação se mantenha. }\end{array}$ & $\begin{array}{l}\text { Pergunta: Aqui na universidade você já teve alguma } \\
\text { experiência que você lembra, uma experiência legal com uma } \\
\text { pessoa negra? Resposta: Sim, por exemplo, o presidente da } \\
\text { atlética, é cotista, ele é da nossa turma de diretoria, ele é uma } \\
\text { pessoa excepcional.Pergunta: E uma experiência ao contrário } \\
\text { desta, negativa? Resposta: Só se acontecer alguma atitude. Mas } \\
\text { qualquer pessoa teria essa mesma atitude, mas não é uma } \\
\text { atitude porque ela é negra, são atitudes que as pessoas têm } \\
\text { independente de...entendeu? }\end{array}$ \\
\hline $\begin{array}{l}9 . \\
\text { Manifestação da } \\
\text { solidariedade }\end{array}$ & & $\begin{array}{l}\text { crença de que a } \\
\text { relação multi- } \\
\text { étnica enriquece } \\
\text { e auxilia a } \\
\text { coletividade, na } \\
\text { solução de }\end{array}$ & $\begin{array}{l}\text { A entrevistada acredita na convivência } \\
\text { cotidiana como uma forma da relação } \\
\text { multi-étnica vir a enriquecer a } \\
\text { coletividade, mas não em medidas que } \\
\text { fiquem enfatizando no plano teórico as } \\
\text { questões da diversidade (" parece muito } \\
\text { forçado") }\end{array}$ & $\begin{array}{l}\text { Pergunta: Você teria mais alguma idéia do que mais se poderia } \\
\text { fazer para aproximar brancos e negros? Resposta: Dependendo } \\
\text { do que você faz parece muito forçado. Eu acho que as pessoas } \\
\text { vão se integrando aos poucos... }\end{array}$ \\
\hline
\end{tabular}




\begin{tabular}{|c|c|c|c|}
\hline & $\begin{array}{c}\text { problemas } \\
\text { coletivos e } \\
\text { individuais; } \\
\text { disponibilidade } \\
\text { para a busca real } \\
\text { de soluções para } \\
\text { o racismo }\end{array}$ & $\begin{array}{l}\text { A entrevistada leva a questão para o } \\
\text { plano afetivo que existe na amizade } \\
\text { entre as pessoas, demonstrando uma } \\
\text { propensão a ter uma conduta solidária à } \\
\text { solução dos danos causados pelo } \\
\text { racismo, mas demonstra não escolher o } \\
\text { caminho de valorizar as diferenças, não } \\
\text { releva os aspectos da discriminação na } \\
\text { diversidade na busca para uma melhora } \\
\text { nas relações étnico-raciais. }\end{array}$ & $\begin{array}{l}\text { Pergunta } 20^{*} \text { segunda etapa: Ah, se eu fosse a Cláudia (branca) } \\
\text { eu diria que a outra menina era da minha sala, que eu estudo } \\
\text { com ela, e se fosse a Ana (negra) eu chamaria a Cláudia } \\
\text { (branca) para ajudar. Se eu fosse a Cláudia eu testemunharia } \\
\text { porque ela é minha amiga. Um amigo vale muito, você consegue } \\
\text { chegar muito mais longe se tiver uma pessoa que você possa } \\
\text { contar. Eu acho que ela ajudaria.(..) Pergunta: Em sua opinião } \\
\text { qual é a diferença e semelhança entre uma pessoa negra e uma } \\
\text { pessoa branca?Resposta: Gêmeas. Muita coisa em comum. (...) } \\
\text { foi por isso que eu te falei que a discriminação vai acabar cedo } \\
\text { ou tarde. Então dependendo da atitude que você queira fazer } \\
\text { parece que vocêe está delimitando mais é forçando um encontro, } \\
\text { você dá as opcóes para as pessoas conviverem mais com um } \\
\text { princípio. Elas vão se entender cedo ou tarde. }\end{array}$ \\
\hline $\begin{array}{l}10 . \text { Integração } \\
\text { com as ofertas } \\
\text { de } \\
\text { desenvolvimento } \\
\text { da Universidade }\end{array}$ & $\begin{array}{l}\text { Integração com os } \\
\text { colegas da } \\
\text { universidade; } \\
\text { oportunidades } \\
\text { profissionais que } \\
\text { surgem a partir } \\
\text { dessa integração; } \\
\text { acesso às } \\
\text { oportunidades que } \\
\text { o ambiente } \\
\text { acadêmico } \\
\text { oferece }\end{array}$ & $\begin{array}{l}\text { A entrevistada, na integração com a } \\
\text { Universidade, faz estágio e esportes. } \\
\text { Revela que em torno dessa atividade } \\
\text { esportiva existem relações sociais de } \\
\text { coleguismos. }\end{array}$ & $\begin{array}{l}\text { Pergunta: O que você faz aqui na Universidade? Resposta: Fico } \\
\text { aqui na hora do almoço, a gente treina ou fica só batendo papo, } \\
\text { participo de atividade extracurricular; por exemplo tem estágio } \\
\text { de Ortopedia, tem as festas aqui. Pergunta: Como você entrou } \\
\text { nos treinos? Resposta: tem pôsteres bem variados; algumas } \\
\text { ligas são mais conhecidas, as pessoas perguntam: ñde qual liga } \\
\text { você participa?ò;; ñvocê gosta?ò; aparece na prova que vai ter } \\
\text { tal dia...as próprias pessoas falam. Pergunta: Você já falou isso } \\
\text { para alguém, que precisa treinar?Resposta: Sim, já falei, para } \\
\text { uma amiga de esporte e outra da geriatria.São amigos e } \\
\text { amigas, tem mais calouros... } O \text { pessoal que entra na Atlética é } \\
\text { tipo assim, quem treina tende a fazer as mesmas ligas, tem as } \\
\text { mesmas preferências e tem uns que é para as festas, é um grupo } \\
\text { assim aqui (...) o presidente da atlética, é cotista, ele é da nossa } \\
\text { turma de diretoria, ele é uma pessoa excepcional. }\end{array}$ \\
\hline
\end{tabular}




\begin{tabular}{|c|c|c|c|}
\hline $\begin{array}{l}\text { 10. Integração } \\
\text { com as ofertas } \\
\text { de } \\
\text { desenvolvimento } \\
\text { da Universidade }\end{array}$ & $\begin{array}{l}\text { Integração com os } \\
\text { colegas da } \\
\text { universidade; } \\
\text { oportunidades } \\
\text { profissionais que } \\
\text { surgem a partir } \\
\text { dessa integração; } \\
\text { acesso às } \\
\text { oportunidades que } \\
\text { o ambiente } \\
\text { acadêmico } \\
\text { oferece }\end{array}$ & $\begin{array}{l}\text { A entrevistada revela que suas amigas } \\
\text { mais próximas são brancas. }\end{array}$ & $\begin{array}{l}\text { Pergunta: Quem é seu grupo?Como essas pessoas } \\
\text { são?Resposta: Sou eu e mais quatro meninas. Tem duas mais } \\
\text { estressadas e preocupadas e têm duas que são mais calmas, as } \\
\text { mais calmas são loiras as outras duas são morenas; mas todas } \\
\text { têm o mesmo interesse, o mesmo cotidiano aqui na escola. }\end{array}$ \\
\hline
\end{tabular}

\begin{tabular}{|c|c|c|c|c|}
\hline \multicolumn{5}{|c|}{ ENTREVISTADA K - NÃO COTISTA - UERJ } \\
\hline CATEGORIA & $\begin{array}{c}\text { SUB- } \\
\text { CATEGORIA }\end{array}$ & INDICADORES & ASPECTOS SIGNIFICATIVOS & RELATOS DE ENTREVISTA \\
\hline identidade étnica & $\begin{array}{l}\text { negra / branca } \\
\text { / parda }\end{array}$ & & & $\begin{array}{l}\text { eu nunca disse que deixei de sofrer racismo por ser mulher, } \\
\text { nem por ser branca. }\end{array}$ \\
\hline $\begin{array}{l}\text { 1. A visibilidade } \\
\text { da diversidade } \\
\text { étnico-racial e a } \\
\text { racialização de si } \\
\text { e do outro }\end{array}$ & & $\begin{array}{c}\text { utilização do } \\
\text { componente } \\
\text { étnico-racial na } \\
\text { descrição das } \\
\text { pessoas das fotos } \\
\text { de estudantes } \\
\text { negros, brancos e } \\
\text { asiáticos }\end{array}$ & $\begin{array}{c}\text { A entrevistada descreve as primeiras } \\
\text { fotos de pessoas brancas, não } \\
\text { identificando a cor, etnia ou raça da } \\
\text { pessoa. A partir do momento que vê a } \\
\text { foto da pessoa negra, utiliza o } \\
\text { componente cor, raça ou etnia, para } \\
\text { descrevê-la. Em seguida, faz o mesmo } \\
\text { com a pessoa asiática. Observa-se a } \\
\text { tendência do entrevistado ver a pessoa } \\
\text { branca como um ser humano universal } \\
\text { e a pessoa negra como um ser } \\
\text { racializado, pertencente a um grupo } \\
\text { racial. }\end{array}$ & $\begin{array}{l}\text { a) A primeira é o menino branco, loiro, camisa abóbora,... } \\
\text { b) Esta é uma menina de cabelos castanhos, nariz fino, blusa } \\
\text { azul, uma caneta na mão (branca) c)Essa aqui é uma menina } \\
\text { negra, com casaco verde, lápis na mão... d) Essa aqui é uma } \\
\text { menina de cabelos escuros, asiática, .... }\end{array}$ \\
\hline
\end{tabular}




\begin{tabular}{|c|c|c|c|}
\hline $\begin{array}{l}\text { 1. A visibilidade } \\
\text { da diversidade } \\
\text { étnico-racial e a } \\
\text { racialização de si } \\
\text { e do outro }\end{array}$ & $\begin{array}{l}\text { utilização do } \\
\text { componente } \\
\text { étnico-racial para } \\
\text { descrever } \\
\text { membros da } \\
\text { família e a si } \\
\text { próprio }\end{array}$ & $\begin{array}{l}\text { A entrevistada manifesta a origem e } \\
\text { não manifesta os aspectos étnico- } \\
\text { raciais dos membros da sua família, no } \\
\text { primeiro momento, mas o faz quando é } \\
\text { provocada ("branca, né? Caucasiana"). }\end{array}$ & $\begin{array}{l}\text { Pergunta: Como é a história de sua família no } \\
\text { Brasil?Resposta:Ah, é estranho assim. Meu avô materno } \\
\text { veio da Itália (...) Mas meu Pai é descendente de português } \\
\text { com uma neta de índia. A mãe de meu pai era neta de índia, } \\
\text { ai, tiveram meu pai. A família de minha avó materna, de } \\
\text { minha mãe, é portuguesa. Meu avô é italiano direto. } \\
\text { Pergunta: Qual a raça de sua mãe? Resposta:Acho que } \\
\text { minha mãe é branca, né? Caucasiana. }\end{array}$ \\
\hline $\begin{array}{l}\text { 1. A visibilidade } \\
\text { da diversidade } \\
\text { étnico-racial e a } \\
\text { racialização de si } \\
\text { e do outro }\end{array}$ & $\begin{array}{l}\text { noção sobre o } \\
\text { conceito social de } \\
\text { raça na utilização } \\
\text { do componente } \\
\text { étnico-racial na } \\
\text { descrição das } \\
\text { relações sociais }\end{array}$ & $\begin{array}{l}\text { Quando perguntada, a entrevistada } \\
\text { utiliza componentes étnicos raciais na } \\
\text { descrição social, no entanto, não utiliza } \\
\text { o conceito de raça socialmente } \\
\text { construído na sua descrição, ao } \\
\text { contrário, com relação a esse aspecto, } \\
\text { acha que já estamos misturados } \\
\text { ("Características ideológicas e } \\
\text { psicológicas eu não saberia dizer por } \\
\text { que hoje em dia a gente vive, } \\
\text { principalmente no Brasil, uma mistura } \\
\text { de raça tão grande"). Então, recorre às } \\
\text { características físicas. }\end{array}$ & $\begin{array}{l}\text { Pergunta: Você acha que entre os seres humanos têm essa } \\
\text { divisão de raça?Resposta: Ah, eu acho que no fundo tem. } \\
\text { Acho que no fundo acaba tendo. (...) Brancos, negros e } \\
\text { amarelos.(..) Características ideológicas e psicológicas eu } \\
\text { não saberia dizer por que hoje em dia a gente vive, } \\
\text { principalmente no Brasil, uma mistura de raça tão grande } \\
\text { que não tem como. Fisicamente que eu acho queé }\end{array}$ \\
\hline $\begin{array}{l}\text { 2. Visibilidade } \\
\text { sobre a } \\
\text { ocorrência da } \\
\text { discriminação } \\
\text { racial }\end{array}$ & $\begin{array}{c}\text { visibilidade do } \\
\text { tratamento } \\
\text { desigual direto ou } \\
\text { indireto que } \\
\text { prejudica } \\
\text { socialmente o } \\
\text { negro, seja pela } \\
\text { neutralidade, seja } \\
\text { pela } \\
\text { diferenciação } \\
\text { negativa }\end{array}$ & $\begin{array}{c}\text { A entrevistada constata a } \\
\text { discriminação racial contra os negros } \\
\text { na universidade e um dos prejuízos } \\
\text { decorrentes - a sensação de vergonha. }\end{array}$ & $\begin{array}{l}\text { Pergunta: Como você soube, ele te falou que ele era } \\
\text { cotista?Resposta: Ele me falou. A pessoa fala. Geralmente a } \\
\text { pessoa fala, mas assim, a pessoa tem vergonha. Quando a } \\
\text { gente alguém zoa, ai se fala assim: ñmas não eu não sou } \\
\text { cotista nào!ò As pessoas ficam assim: ñnão entrei por } \\
\text { cotas! Ò. É meio assim, é pressão. } \\
\text { É assim é pressão entrar por cotas. Tem gente que fala que } \\
\text { só entrar por cotas e está tudo bem, não está tudo bem não. }\end{array}$ \\
\hline
\end{tabular}




\begin{tabular}{|c|c|c|c|}
\hline $\begin{array}{l}\text { 2. Visibilidade } \\
\text { sobre a } \\
\text { ocorrência da } \\
\text { discriminação } \\
\text { racial }\end{array}$ & $\begin{array}{c}\text { visibilidade do } \\
\text { tratamento } \\
\text { desigual direto ou } \\
\text { indireto que } \\
\text { prejudica } \\
\text { socialmente o } \\
\text { negro, seja pela } \\
\text { neutralidade, seja } \\
\text { pela } \\
\text { diferenciação } \\
\text { negativa }\end{array}$ & $\begin{array}{l}\text { Observa-se que só foi possível } \\
\text { constatar a discriminação racial } \\
\text { institucional quando foi invertido o } \\
\text { papel social dos grupos branco e } \\
\text { negros de ocupação de local de } \\
\text { privilégio na sociedade. }\end{array}$ & $\begin{array}{l}\text { Eu não acho que as pessoas sejam racistas na } \\
\text { faculdade.Pergunta: Se você entrasse em uma escola em que } \\
\text { o diretor é negro e visse que todos os funcionários } \\
\text { contratados são negros, você ia achar que ele é racista? } \\
\text { Resposta: Ia. Assim como se eu entrasse na escola e o } \\
\text { diretor fosse branco e todos os funcionários fossem brancos, } \\
\text { eu ia achar a mesma coisa deles. Pergunta: Você tem algum } \\
\text { professor negro aqui na Universidade?... Deixa eu ver... } \\
\text { Hum... Aqui na faculdade não. }\end{array}$ \\
\hline $\begin{array}{l}\text { 2. Visibilidade } \\
\text { sobre a } \\
\text { ocorrência da } \\
\text { discriminação } \\
\text { racial }\end{array}$ & $\begin{array}{c}\text { visibilidade do } \\
\text { tratamento } \\
\text { desigual direto ou } \\
\text { indireto que } \\
\text { prejudica } \\
\text { socialmente o } \\
\text { negro, seja pela } \\
\text { neutralidade, seja } \\
\text { pela } \\
\text { diferenciação } \\
\text { negativa }\end{array}$ & $\begin{array}{l}\text { A entrevistada constata a ocorrência da } \\
\text { discriminação racial direta na cidade. }\end{array}$ & $\begin{array}{l}\text { Pergunta: E no Rio, existe racismo?Resposta: Ah, aquela } \\
\text { famosa história clichêe. Você tá numa loja e tipo o alarme da } \\
\text { loja disparar e todo mundo olhar para a pessoa que é negra, } \\
\text { sabe? Pergunta: E você já viveu isso? Resposta: Já, já } \\
\text { aconteceu com uma amiga minha, de acharem que ela tinha } \\
\text { roubado alguma coisa numa loja. Eu estava com ela. Eu } \\
\text { falava assim: ñpô, porque é que não perguntaram para mim, } \\
\text { perguntaram direto para ela?ò Achei um absurdo, um } \\
\text { absurdo. }\end{array}$ \\
\hline $\begin{array}{l}\text { 3. Visibilidade } \\
\text { sobre as } \\
\text { consequências do } \\
\text { racismo, os } \\
\text { danos e os } \\
\text { privilégios }\end{array}$ & $\begin{array}{l}\text { visibilidade do } \\
\text { prejuízo social } \\
\text { para o negro }\end{array}$ & $\begin{array}{l}\text { A entrevistada não identifica as } \\
\text { diferenças decorrentes dos danos e } \\
\text { privilégios causados pelo racismo na } \\
\text { comparação entre brancos e negros. }\end{array}$ & $\begin{array}{l}\text { Pergunta: No teu ponto de vista qual é diferença e a } \\
\text { semelhança entre a pessoa negra e a pessoa branca? } \\
\text { Resposta: Diferença nenhuma, semelhança todas...Aqui no } \\
\text { Brasil não tem como você identificar um grupo assim. Ah, } \\
\text { esse grupo é assime esse grupo é assado. }\end{array}$ \\
\hline
\end{tabular}




\begin{tabular}{|c|c|c|c|c|}
\hline $\begin{array}{l}\text { 3. Visibilidade } \\
\text { sobre as } \\
\text { consequências do } \\
\text { racismo, os } \\
\text { danos e os } \\
\text { privilégios }\end{array}$ & & $\begin{array}{l}\text { visibilidade do } \\
\text { prejuízo social } \\
\text { para o negro }\end{array}$ & $\begin{array}{c}\text { A entrevistada constata que a } \\
\text { discriminação por condição econômica } \\
\text { traria desafios difíceis para o } \\
\text { desempenho dela na universidade. Mas } \\
\text { não associa a situação de } \\
\text { discriminação racial que passam os } \\
\text { negros a esses mesmos desafios e } \\
\text { dificuldades. }\end{array}$ & $\begin{array}{l}\text { Você acha que essa diferença (relativa aos "milionários") } \\
\text { iria te dificultar no desempenho das disciplinas?Resposta: } \\
\text { Claro, porque é aquela velha história. O rico não aceita } \\
\text { uma outra pessoa que não seja rica.... não ia conseguir. } \\
\text { Como que eu iria fazer os trabalhos...?... (...) } \\
\text { Pergunta: Você acha que ele (o cotista) vai ter dificuldade } \\
\text { de acompanhar o curso? Resposta: A mesma que a gente } \\
\text { tem. ... Não vai ter dinheiro para chegar aqui, não vai ter } \\
\text { dinheiro para almoçar (...) para tirar a xérox, (...) comprar } \\
\text { os livros... }\end{array}$ \\
\hline 4. Estigma & $\begin{array}{l}\mathrm{Na} \\
\text { comunicação } \\
\text { não verbal }\end{array}$ & $\begin{array}{l}\text { escolha de papéis } \\
\text { profissionais para } \\
\text { as pessoas das fotos } \\
\text { de homens e } \\
\text { mulheres; } \\
\text { brancos(as) e } \\
\text { negros(as); de } \\
\text { faixas etárias de } 20 \\
\text { a } 30 \text { anos, de } 31 \text { a } \\
59 \text { anos, acima de } \\
60 \text { anos. } \\
\text { Indicadores: } \\
\text { profissionais } \\
\text { brancos (as) - } \\
\text { negros (as) e cargos } \\
\text { profissionais } \\
\text { artista, que } \\
\text { privilegia } \\
\text { conhecimento } \\
\text { intelectual, manual } \\
\text { e posições de } \\
\text { chefia. }\end{array}$ & $\begin{array}{l}\text { Observa-se a tendência da entrevistada } \\
\text { de reproduzir os estigmas sociais, } \\
\text { escolhendo para os cargos de } \\
\text { posições de chefia as pessoas brancas } \\
\text { e para os cargos que privilegiam o } \\
\text { trabalho manual, os negros. Das } 9 \\
\text { profissões, } 1 \text { não respondeu, } 4 \text { foram } \\
\text { preenchidas com pessoas brancas e } 4 \\
\text { com pessoas negras; sendo que a } \\
\text { profissão de artista, } 1 \text { das } 2 \text { que } \\
\text { privilegiam conhecimento intelectual e as } \\
2 \text { que são de chefia foram preenchidas por } \\
\text { pessoas brancas; } 1 \text { das } 2 \text { que privilegiam } \\
\text { conhecimento intelectual e das } 4 \text { que } \\
\text { privilegiam trabalho manual, } 1 \text { não foi } \\
\text { respondida e as } 3 \text { faltantes foram } \\
\text { preenchidas por pessoas negras. }\end{array}$ & $\begin{array}{l}\text { Profissional Artista: Pianista - mulher branca (figura 21); } \\
\text { Profissão que privilegia conhecimento intelectual: Médico } \\
\text { (a) plantonista - homem negro (figura 17); Professor } \\
\text { Universitário - homem branco (figura 25); } \\
\text { Posições de chefia: Gerente do hotel - homem branco (figura } \\
\text { 27); Diretor (a) de Marketing de uma loja de departamento - } \\
\text { mulher branca (figura 26); } \\
\text { Profissões que privilegiam o trabalho manual: Arrumador } \\
\text { (eira) do Hotel - mulher negra (figura 24); Motorista de } \\
\text { ônibus - homem negro (figura 30); Cabeleireiro(a)) - mulher } \\
\text { negra (figura 20); Porteiro(a) do Hotel - não respondeu. }\end{array}$ \\
\hline
\end{tabular}




\begin{tabular}{|c|c|c|c|c|}
\hline 5. Estereótipo & & $\begin{array}{l}\text { características } \\
\text { atribuídas } \\
\text { genericamente a } \\
\text { todos os } \\
\text { membros de um } \\
\text { grupo, mitos }\end{array}$ & $\begin{array}{l}\text { A entrevistada associa a idéia do negro } \\
\text { cotista não ter passado pelo sistema } \\
\text { normal de vestibular ao fato de ele ter } \\
\text { menor capacidade para se desenvolver } \\
\text { academicamente. ("Infelizmente ele não } \\
\text { vai ter a mesma base de ensino que eu } \\
\text { tive"). }\end{array}$ & $\begin{array}{l}\text { (sobre cotas) eu acho que isso mesmo é um próprio jeito de } \\
\text { ver o negro, que ele tem menos capacidade de passar na } \\
\text { universidade que eu. Pela cor da minha pele, acho isso sim } \\
\text { racismo.Acho que todo mundo é igual e que todo mundo tem } \\
\text { direito de ter uma educação igual.Quando você chegar na } \\
\text { faculdade ter uma mesma base que eu que estudei na escola } \\
\text { particular e agora numa pública. Infelizmente ele não vai ter } \\
\text { a mesma base de ensino que eu tive. }\end{array}$ \\
\hline $\begin{array}{l}\text { 6. Reações } \\
\text { emocionais na } \\
\text { relação com o } \\
\text { preconceito (com } \\
\text { o diverso) }\end{array}$ & $\begin{array}{l}\mathrm{Na} \\
\text { comunicação } \\
\text { verbal }\end{array}$ & $\begin{array}{c}\text { culpa, vergonha, } \\
\text { irritabilidade, } \\
\text { raiva, exaustão, } \\
\text { confusão na } \\
\text { fala, negação, } \\
\text { medo, } \\
\text { dissimulação, } \\
\text { sensação de } \\
\text { solidão, tristeza, } \\
\text { sensação de não } \\
\text { pertencimento, } \\
\text { impotência, } \\
\text { contradição, } \\
\text { justificativa } \\
\text { defensiva }\end{array}$ & $\begin{array}{l}\text { A entrevistada expressa a sensação de } \\
\text { INTIMIDAÇÃO gerada pelo fato de se } \\
\text { sentir uma minoria. Na hipótese de se } \\
\text { colocar no lugar do negro, na relação } \\
\text { entre negros e brancos, acredita que } \\
\text { reverter essa situação de intimidação } \\
\text { seria relativamente simples, dizendo: } \\
\text { "Mas depois não tem isso não, a gente } \\
\text { fica amigo". No entanto, na hipótese } \\
\text { levantada por ela da intimidação que } \\
\text { sente gerada na relação entre alunos } \\
\text { de condição econômica diferente, a } \\
\text { entrevistada expressa a sensação de } \\
\text { SOLIDÃO ("eu ia ficar sozinha"), de } \\
\text { INSEGURANÇA ("não ia conseguir. } \\
\text { Como que eu iria fazer os } \\
\text { trabalhos...?") e que a dificuldade } \\
\text { apresentada seria impossível de ser } \\
\text { revertida (" mas eu acho que eu não sei } \\
\text { se eu iria conseguir (...) Acho que eles } \\
\text { não iam aceitar. Acho que no fundo no } \\
\text { fundo eles não iam aceitar"). }\end{array}$ & $\begin{array}{l}\text { Pergunta: Vamos imaginar que amanhã você entrasse na tua } \\
\text { sala de aula e você visse que 80\% da sala de aula eram } \\
\text { alunos negros, o que você sentiria? Resposta:Acho que no } \\
\text { começo eu até ficaria intimidada.(..) Mas depois não tem } \\
\text { isso não, a gente fica amigo. (...) Por exemplo, ao invés (...), } \\
\text { se você me fizesse essa pergunta para a sala da PUC, cheio } \\
\text { de filhos de milionários, eu me sentiria muito mais } \\
\text { intimidada do que entrar numa sala repleta de pessoas } \\
\text { negras. Muito mais. Pergunta: Por quê? Resposta:(...) Eles } \\
\text { são um mundo de gente é outro mundo a parte. É muito } \\
\text { diferente.(...) Claro, porque é aquela velha história. O rico } \\
\text { não aceita uma outra pessoa que não seja rica. Rico não } \\
\text { aceita pobre no meio deles, ou seja eu já ia me sentir } \\
\text { excluída, né? Ia me sentir totalmente excluída, não ia } \\
\text { conseguir. Como que eu iria fazer os trabalhos, se eu } \\
\text { faltasse uma aula com que eu iria pegar as matérias? Acho } \\
\text { que eu ia ficar perdida na faculdade, o que eu ia fazer? eu } \\
\text { ia ficar sozinha. Não sei se eu iria conseguir relacionar com } \\
\text { alguém só no papo. Apesar de eu ser uma pessoa } \\
\text { extrovertida, mas eu acho que eu não sei se eu iria } \\
\text { conseguir. Eu acho que não. Acho que eles não iam aceitar. } \\
\text { Acho que no fundo no fundo eles não iam aceitar. }\end{array}$ \\
\hline
\end{tabular}




\begin{tabular}{|c|c|c|c|}
\hline $\begin{array}{l}\text { 6. Reações } \\
\text { emocionais na } \\
\text { relação com o } \\
\text { preconceito (com } \\
\text { o diverso) }\end{array}$ & & $\begin{array}{l}\text { A entrevistada revela a sua sensação } \\
\text { de OBRIGAÇÃO, RESPONSABILIDADE } \\
\text { por não ser injusta. ("eu tenho que } \\
\text { fazer o máximo para não cometer } \\
\text { nenhuma injustiça") }\end{array}$ & $\begin{array}{l}\text { Sempre vi as pessoas como elas são. Somos todos iguais, } \\
\text { sabe? Âs vezes, não perante a sociedade, mas pelo menos } \\
\text { para mim eu tenho que fazer o máximo para não cometer } \\
\text { nenhuma injustiça, mas eu vou fazer a minha parte, é claro? }\end{array}$ \\
\hline $\begin{array}{c}\text { 6. Reações } \\
\text { emocionais na } \\
\text { relação com o } \\
\text { preconceito (com } \\
\text { o diverso) }\end{array}$ & $\begin{array}{l}\text { culpa, vergonha, } \\
\text { irritabilidade, } \\
\text { raiva, exaustão, } \\
\text { confusão na fala, } \\
\text { negação, medo, } \\
\text { dissimulação, } \\
\text { sensação de } \\
\text { solidão, tristeza, } \\
\text { sensação de não } \\
\text { pertencimento, } \\
\text { impotência, } \\
\text { contradição, } \\
\text { justificativa } \\
\text { defensiva }\end{array}$ & $\begin{array}{l}\text { RAIVA: a competição para a vaga, junto } \\
\text { ao critério racial, e a confusão sobre o } \\
\text { tema, gera raiva nas pessoas } \\
\text { envolvidas. }\end{array}$ & $\begin{array}{l}\text { Pergunta: Você acha que a política de cotas acirra o } \\
\text { racismo?Resposta:Eu acho que sim. Eu acho não, eu tenho } \\
\text { certeza. Porque as pessoas têm raiva.Pergunta: Como } \\
\text { assim, tem raiva?Resposta: Eu, pôxa, eu posso ser pobre, } \\
\text { estudar num bom colégio, ter uma base legal. Tem tanto } \\
\text { colégio particular ai que não é bom. Você não tem base, } \\
\text { você não tem cota pra passar ninguém vai te ajudar, sabe? } \\
\text { Eu não concordo,Ah, porque eu sou negro eu tenho direito a } \\
\text { cotas, e você é branco, você não tem.E aquela frase que eu } \\
\text { disse para você: por que parece que pessoa negra tem } \\
\text { menos capacidade do que eu. Eu concordo que tinham que } \\
\text { oferecer as mesmas chances desde baixo. Ai sim você vai ser } \\
\text { justo.estar ali no mesmo patamar.Eu não passei porque eu } \\
\text { tive mais capacidade que você, não é por minha cor da pele } \\
\text { que você vai dizer que alguém é melhor ou pior do que } \\
\text { outro. }\end{array}$ \\
\hline
\end{tabular}




\begin{tabular}{|c|c|c|c|c|}
\hline $\begin{array}{l}\text { 7. Formas e } \\
\text { Oportunidades de } \\
\text { elaboração das } \\
\text { experiências } \\
\text { relacionadas ao } \\
\text { racismo }\end{array}$ & & $\begin{array}{l}\text { oportunidades de } \\
\text { reflexão sobre o } \\
\text { tema racismo nos } \\
\text { espaços sociais } \\
\text { (família, escola, } \\
\text { mídia, amigos) }\end{array}$ & $\begin{array}{l}\text { A entrevistada revela ter tido discussão } \\
\text { sobre o assunto no âmbito familiar e na } \\
\text { igreja. No colégio e na universidade, e } \\
\text { outras oportunidades institucionais, } \\
\text { não. }\end{array}$ & $\begin{array}{l}\text { Pergunta: você se lembra de ter alguma discussão sobre } \\
\text { discriminação, diversidade, antes na sua vida? Resposta: } \\
\text { Várias vezes...Meu pai é a pessoa mais racista que eu } \\
\text { conheci em toda a minha vida. E assim eu já briguei com ele } \\
\text { várias vezes por causa disso...Já discuti com.. discussão é } \\
\text { essa história de conversar sobre essa história de cotas aqui } \\
\text { na faculdade. Sobre história de cotas no curso no } \\
\text { colégio...Meu pai tem origem índia, né? E ele é assim. Foi } \\
\text { ela (minha mãe) quem me passou esses valores, sabe? A } \\
\text { igreja também, eu freqüentava a igreja quando era mais } \\
\text { nova, sabe?... Mas sobre curso, palestra, workshop assim } \\
\text { não. Ninguém na faculdade fala...que eu sei é que os cotistas } \\
\text { têm que ir todo mês, numa reunião, numa palestra } \\
\text { assim,mas isso é só para o pessoal cotista, para o pessoal } \\
\text { que não é cotista não tem. }\end{array}$ \\
\hline $\begin{array}{l}\text { 7. Formas e } \\
\text { Oportunidades de } \\
\text { elaboração das } \\
\text { experiências } \\
\text { relacionadas ao } \\
\text { racismo }\end{array}$ & & $\begin{array}{l}\text { oportunidades de } \\
\text { reflexão sobre o } \\
\text { tema racismo nos } \\
\text { espaços sociais } \\
\text { (família, escola, } \\
\text { mídia, amigos) }\end{array}$ & $\begin{array}{l}\text { A entrevistada demonstra ter tido a } \\
\text { oportunidade de refletir sobre o } \\
\text { assunto, encontrando em si mesmas } \\
\text { atitudes preconceituosas e } \\
\text { discriminatórias ("Minha mente mesmo } \\
\text { eu falei as violências que fiz e eu } \\
\text { comecei a analisar que caramba"), } \\
\text { percebendo a dificuldade em } \\
\text { transformá-las ("pensar muito para não } \\
\text { agir assim, para não pensar assim"). }\end{array}$ & $\begin{array}{l}\text { Eu faço um curso de ética aqui na faculdade. Virou um } \\
\text { paradigma na vida das pessoas. Você vai tomar um choque, } \\
\text { sabe?(...)Por que sabe? Infelizmente é assim, a gente tem } \\
\text { que pensar muito para não agir assim, para não pensar } \\
\text { assim, sabe?Para tentar não ser hipócrita. Minha mente } \\
\text { mesmo eu falei as violências que fiz e eu comecei a analisar } \\
\text { que caramba. Eu que to rotulando, sabe?e isso é difícil. }\end{array}$ \\
\hline $\begin{array}{l}\text { 8. Abordagem } \\
\text { teórica sobre o } \\
\text { tema }\end{array}$ & $\begin{array}{l}\text { Relação do } \\
\text { racismo com } \\
\text { os princípios } \\
\text { de direito } \\
\text { fundamentais }\end{array}$ & $\begin{array}{l}\text { reconhecimento } \\
\text { da política como } \\
\text { um direito } \\
\text { fundamental }\end{array}$ & $\begin{array}{l}\text { A entrevistada associa a política de } \\
\text { cotas com uma ajuda, não com um } \\
\text { direito. ("ninguém vai te ajudar") }\end{array}$ & $\begin{array}{l}\text { Você não tem base, você não tem cota pra passar, ninguém } \\
\text { vai te ajudar, sabe? }\end{array}$ \\
\hline
\end{tabular}




\begin{tabular}{|c|c|c|c|c|}
\hline & $\begin{array}{l}\text { Relação do } \\
\text { racismo com } \\
\text { os princípios } \\
\text { de direito } \\
\text { fundamentais }\end{array}$ & $\begin{array}{l}\text { reconhecimento } \\
\text { do direito a ser } \\
\text { tratado } \\
\text { desigualmente ( } \\
\text { discriminação } \\
\text { positiva) }\end{array}$ & $\begin{array}{l}\text { A entrevistada acredita que recurso } \\
\text { para enfrentar a questão do racismo } \\
\text { está ligada a uma educação sobre } \\
\text { ética. E demonstra não compreender a } \\
\text { discriminação positiva como um } \\
\text { caminho para o enfretamento da } \\
\text { discriminação racial. }\end{array}$ & $\begin{array}{l}\text {...Eu acho que o grande problema da discriminação eu acho } \\
\text { que é a ignorancia por falta de ética, sabe?eu acho que teria } \\
\text { que ter um trabalho muito grande de ética na vida das } \\
\text { pessoas.Só com muita consciência e ética que você um dia } \\
\text { talvez mude a realidade, essa triste realidade... }\end{array}$ \\
\hline $\begin{array}{c}9 . \\
\text { Manifestação da } \\
\text { solidariedade }\end{array}$ & & $\begin{array}{l}\text { crença de que a } \\
\text { relação multi- } \\
\text { étnica enriquece } \\
\text { e auxilia a } \\
\text { coletividade, na } \\
\text { solução de } \\
\text { problemas } \\
\text { coletivos e } \\
\text { individuais; } \\
\text { disponibilidade } \\
\text { para a busca real } \\
\text { de soluções para } \\
\text { o racismo }\end{array}$ & $\begin{array}{l}\text { A entrevistada demonstra acreditar que } \\
\text { as experiências das pessoas na } \\
\text { diversidade são enriquecedoras para a } \\
\text { coletividade, com as quais ela pode } \\
\text { aprender ("Você vê que outras pessoas } \\
\text { vivem numa maneira diferente da sua e } \\
\text { vivem bem e elas são felizes..(..."). No } \\
\text { entanto, em outro momento demonstra } \\
\text { que nas suas relações, as } \\
\text { contribuições adquiridas na relação } \\
\text { com uma pessoa diversa não se atribui } \\
\text { à diversidade racial, mas a sócio- } \\
\text { econômica. Busca soluções por meio } \\
\text { de uma educação em ética para todos. }\end{array}$ & $\begin{array}{l}\text { Pergunta: o que você acha da diversidade?Resposta: Eu } \\
\text { acho legal.(riso) Sei lá, eu acho diferente porque de uma } \\
\text { forma ou de outra se você não conhecer culturas diferentes, } \\
\text { pessoas diferentes. Acho isso bom, acho ruim todas as } \\
\text { pessoas serem iguais. Se todo mundo fosse igual que graça } \\
\text { teria a vida? (riso) Nenhuma, sabe?... Você vê que outras } \\
\text { pessoas vivem numa maneira diferente da sua e vivem bem e } \\
\text { elas são felizes..(..) Pergunta: É você aqui já teve uma } \\
\text { experiência, que você lembra,legal, com algum cotista } \\
\text { negro? Resposta: Ah, tá! Esse meu amigo J eu converso } \\
\text { muito com ele, então eu o acho assim uma pessoa excelente, } \\
\text { sabe? Fundamental e essencial, sabe? Troca muita idéia, } \\
\text { fala sobre muita coisa, sobre trabalho, (...), conselhos assim } \\
\text { até amorosos (riso) Pergunta: você acha que essa pessoa } \\
\text { contribuiu na sua vida?Resposta: Claro com } \\
\text { certeza.Pergunta: você acha que essa contribuição veio por } \\
\text { causa da diferença? Resposta:Acho que mais pela diferença } \\
\text { de idade, e não pela diferença racial e social. (...)eu acho } \\
\text { que teria que ter um trabalho muito grande de ética na vida } \\
\text { das pessoas. }\end{array}$ \\
\hline
\end{tabular}




\begin{tabular}{|c|c|c|c|}
\hline $\begin{array}{l}\text { 10. Integração } \\
\text { com as ofertas de } \\
\text { desenvolvimento } \\
\text { da Universidade }\end{array}$ & $\begin{array}{l}\text { Integração com } \\
\text { os colegas da } \\
\text { universidade; } \\
\text { oportunidades } \\
\text { profissionais que } \\
\text { surgem a partir } \\
\text { dessa integração; } \\
\text { acesso às } \\
\text { oportunidades } \\
\text { que o ambiente } \\
\text { acadêmico } \\
\text { oferece }\end{array}$ & $\begin{array}{l}\text { A entrevistada na Universidade, realiza } \\
\text { a atividade de iniciação científica, na } \\
\text { qual ingressou a partir da relação com } \\
\text { um amigo negro e professores. }\end{array}$ & $\begin{array}{l}\text { Pergunta: Qual o tempo que você passa na Universidade? } \\
\text { Resposta: Geralmente a tarde toda. E uma parte da noite. } \\
\text { Eu tenho iniciação. Um amigo meu passou e ele viu um } \\
\text { anúncio na página do site, como ele não tinha inglês } \\
\text { avançado e o meu é bastante avançado, e ele passou para } \\
\text { meu namorado e meu namorado passou para mim. (é ) E eu } \\
\text { mandei o currículo e ai me chamaram para entrevista e } \\
\text { eram seis pessoas e tal. E ai os orientadores me escolheram } \\
\text { e eu fiquei. Pergunta: Comoé esse amigo que indicou? } \\
\text { Resposta: Ele é alto, é negro,.. }\end{array}$ \\
\hline $\begin{array}{l}\text { 10. Integração } \\
\text { com as ofertas de } \\
\text { desenvolvimento } \\
\text { da Universidade }\end{array}$ & $\begin{array}{c}\text { relação de } \\
\text { coleguismo } \\
\text { entre o } \\
\text { entrevistado e os } \\
\text { alunos }\end{array}$ & $\begin{array}{l}\text { A entrevistada é branca e demonstra } \\
\text { sentir-se excluída das relações dos } \\
\text { colegas na universidade ("O pessoal } \\
\text { não chama ninguém para participar de } \\
\text { nada. Muita panelinha, muito fechados } \\
\text { (...) Você participa se for amigo deles"). } \\
\text { Revela ter "colegas próximos" na } \\
\text { universidade, sendo colegas negros e } \\
\text { brancos. }\end{array}$ & $\begin{array}{l}\text { Pergunta: O CA e essas coisas..? Resposta: Não. O pessoal } \\
\text { não chama ninguém para participar de nada. Muita } \\
\text { panelinha, muito fechados. Isso é ruim, não tem } \\
\text { oportunidade de participar das coisas. Você participa se for } \\
\text { amigo deles. As bibliotecas só. O que eu faço na biblioteca é } \\
\text { só isso. } \\
\text { Pergunta: Você tem amigos na universidade? } \\
\text { Resposta: Tenho. Colegas, amigos é mais difícil conseguir. } \\
\text { Colegas próximos. Uns três. Amigos, mesmo, eu posso } \\
\text { contar três. (Uma) é baixa, é morena, quase negra, cabelo } \\
\text { cumprido, olhos escuros, rosto quadrado...Um é mais } \\
\text { moreno e o outro é branquinho... }\end{array}$ \\
\hline
\end{tabular}




\begin{tabular}{|c|c|c|c|c|}
\hline \multicolumn{5}{|c|}{ ENTREVISTADA L - NÃO COTISTA Ï UNB } \\
\hline CATEGORIA & $\begin{array}{c}\text { SUB- } \\
\text { CATEGORIA }\end{array}$ & INDICADORES & ASPECTOS SIGNIFICATIVOS & RELATOS DE ENTREVISTA \\
\hline identidade étnica & $\begin{array}{l}\text { negra / branca / } \\
\text { parda }\end{array}$ & & & Eu sou branca, entendeu? \\
\hline $\begin{array}{l}\text { 1. A visibilidade } \\
\text { da diversidade } \\
\text { étnico-racial e } \\
\text { a racialização de } \\
\text { si e do outro }\end{array}$ & & $\begin{array}{l}\text { utilização do } \\
\text { componente } \\
\text { étnico-racial na } \\
\text { descrição das } \\
\text { pessoas das fotos } \\
\text { de estudantes } \\
\text { negros, brancos e } \\
\text { asiáticos }\end{array}$ & $\begin{array}{l}\text { A entrevistada descreve as fotos } \\
\text { identificando a cor, etnia ou raça das } \\
\text { pessoas, desde o início. }\end{array}$ & $\begin{array}{l}\text { a) É uma moça jovem, que está com a pele bem pálida } \\
\text { assim parece clara, parece que tem um holofote perto } \\
\text { dela, cabelo curtinho, castanho claro.... (branca) b) Essa } \\
\text { parece ser mais jovem do que a outra, cabelo cumprido, } \\
\text { liso, parece um louro meio escuro, uma camisa } \\
\text { roxa...(branca) c) Esse é um cara jovem também, cabelo } \\
\text { curto, sorridente, blusa laranja. ... Ah, é branco. d) É } \\
\text { uma moça morena do cabelo liso, também ta lendo, blusa } \\
\text { verde, stá lendo um livro grosso.(negra) e) É uma moça } \\
\text { japonesa, parece que está numa feira, não sei se é } \\
\text { científica, mostrando algum trabalho dela num estande, } \\
\text { num mural. }\end{array}$ \\
\hline $\begin{array}{l}\text { 1. A visibilidade } \\
\text { da diversidade } \\
\text { étnico-racial e a } \\
\text { racialização de } \\
\text { si e do outro }\end{array}$ & & $\begin{array}{l}\text { utilização do } \\
\text { componente } \\
\text { étnico-racial para } \\
\text { descrever } \\
\text { membros da } \\
\text { família e a si } \\
\text { próprio }\end{array}$ & $\begin{array}{l}\text { O entrevistado não utiliza o componente } \\
\text { étnico-racial na descrição de sua família } \\
\text { e demonstra dificuldade em relacionar } \\
\text { seu familiar com uma raça (" Raça é meio } \\
\text { difícil de falar .... Mas a cor de pele, } \\
\text { assim, nós somos brancos"). }\end{array}$ & $\begin{array}{l}\text { Meu pai é do Recife e minha mãe é do Rio Grande do Sul } \\
\text { e eles se encontraram aqui por acaso em Brasília. Aí eu } \\
\text { sempre tive mais contato com os meus tios e primos por } \\
\text { parte de mãe...parece que eles chegaram aqui em } 1890 \\
\text {...que veio da Alemanha para cá fugida, da guerra lá. } \\
\text { Pergunta: de que raça é tua mãe?Resposta: Raça é meio } \\
\text { difícil de falar, porque tem estudos que falam que não tem } \\
\text { raça e tal. Mas a cor de pele, assim, nós somos brancos. }\end{array}$ \\
\hline
\end{tabular}




\begin{tabular}{|c|c|c|c|}
\hline $\begin{array}{l}\text { 2. Visibilidade } \\
\text { sobre a } \\
\text { ocorrência da } \\
\text { discriminação } \\
\text { racial }\end{array}$ & $\begin{array}{c}\text { visibilidade do } \\
\text { tratamento } \\
\text { desigual direto ou } \\
\text { indireto que } \\
\text { prejudica } \\
\text { socialmente o } \\
\text { negro, seja pela } \\
\text { neutralidade, seja } \\
\text { pela diferenciação } \\
\text { negativa }\end{array}$ & $\begin{array}{l}\text { A entrevistada constata a discriminação } \\
\text { nas relações dentro da universidade. }\end{array}$ & $\begin{array}{l}\text { Pergunta: Tem muito preconceito aqui dentro?Resposta: } \\
\text { De todo mundo, tanto com quem é aluno, professor, } \\
\text { servidor, como quem está de fora, entendeu? ñEles estão } \\
\text { roubando nossas vagas!'̀, né? E o povo fica olhando } \\
\text { assim estranho, então eu acho que é complicado assim, } \\
\text { entendeu? }\end{array}$ \\
\hline $\begin{array}{l}\text { 2. Visibilidade } \\
\text { sobre a } \\
\text { ocorrência da } \\
\text { discriminação } \\
\text { racial }\end{array}$ & $\begin{array}{c}\text { visibilidade do } \\
\text { tratamento } \\
\text { desigual direto ou } \\
\text { indireto que } \\
\text { prejudica } \\
\text { socialmente o } \\
\text { negro, seja pela } \\
\text { neutralidade, seja } \\
\text { pela diferenciação } \\
\text { negativa }\end{array}$ & $\begin{array}{l}\text { A entrevistada confirma a presença do } \\
\text { racismo nas relações raciais da } \\
\text { universidade e sociedade. }\end{array}$ & $\begin{array}{l}\text { Pergunta: você acha que a universidade é } \\
\text { racista?Resposta: É sim, como parte de uma sociedade } \\
\text { maior, que não está solta, que esta dentro deste } \\
\text { contexto.Acho que sim. }\end{array}$ \\
\hline $\begin{array}{l}\text { 2. Visibilidade } \\
\text { sobre a } \\
\text { ocorrência da } \\
\text { discriminação } \\
\text { racial }\end{array}$ & $\begin{array}{c}\text { visibilidade do } \\
\text { tratamento } \\
\text { desigual direto ou } \\
\text { indireto que } \\
\text { prejudica } \\
\text { socialmente o } \\
\text { negro, seja pela } \\
\text { neutralidade, seja } \\
\text { pela diferenciação } \\
\text { negativa }\end{array}$ & $\begin{array}{c}\text { A entrevistada percebe a existência da } \\
\text { discriminação racial nas relações e a } \\
\text { invisibilidade da mesma para algumas } \\
\text { pessoas. }\end{array}$ & $\begin{array}{l}\text { O que se vê hoje é falar: o preconceito não existe, isso é } \\
\text { bobagem, isso deixa muito de lado. Mas quando você vai } \\
\text { agir, o que você mais vê é discriminação. São pessoas } \\
\text { que fazem isso e muitas vezes não sabem por quê. Tem } \\
\text { crianças que nem sabem por que. Porque isso é passado } \\
\text { pelos pais, pelos vizinhos. }\end{array}$ \\
\hline
\end{tabular}




\begin{tabular}{|c|c|c|c|}
\hline $\begin{array}{l}\text { 3. Visibilidade } \\
\text { sobre as } \\
\text { consequências } \\
\text { do racismo, os } \\
\text { danos e os } \\
\text { privilégios }\end{array}$ & $\begin{array}{l}\text { visibilidade do } \\
\text { prejuízo social } \\
\text { para o negro }\end{array}$ & $\begin{array}{c}\text { A entrevistada manifesta a semelhança } \\
\text { física entre brancos e negros e constata a } \\
\text { diferença cultural e de suas experiências. } \\
\text { Não associa as diferenças às } \\
\text { experiências de discriminador e } \\
\text { discriminado, e as conseqüências do } \\
\text { racismo para cada grupo. }\end{array}$ & $\begin{array}{l}\text { Pergunta: Em sua opinião qual é a diferença e a } \\
\text { semelhança entre uma pessoa branca e uma pessoa } \\
\text { negra? Resposta:A semelhança ... a semelhança física } \\
\text { toda. O que muda é a pele. Fora isso o que muda é a } \\
\text { cultura da pessoa. Onde ela foi criada com quem. Tipo é } \\
\text { assim como falam que tem muito branco que também é } \\
\text { criado em favela e tem negros que são ricos também. } \\
\text { Acho que nesse ponto vale até mais falar(é ) como é que } \\
\text { chama éé sobre quando separar por faixa de salário. } \\
\text { Acho que pessoas que tem um rendimento menor, elas se } \\
\text { parecem mais do que quem tem mais. Sejam elas negras } \\
\text { ou brancas. }\end{array}$ \\
\hline $\begin{array}{l}\text { 3. Visibilidade } \\
\text { sobre as } \\
\text { consequências } \\
\text { do racismo, os } \\
\text { danos e os } \\
\text { privilégios }\end{array}$ & $\begin{array}{l}\text { visibilidade do } \\
\text { prejuízo social } \\
\text { para o negro }\end{array}$ & $\begin{array}{l}\text { A entrevistada constata que o fato da } \\
\text { universidade ser ocupada por uma } \\
\text { grande maioria branca, já caracterizaria } \\
\text { um espaço de privilégio onde só estão os } \\
\text { brancos, o que chama de cotas "para } \\
\text { brancos de classe média alta". Por outro } \\
\text { lado, menciona que existem os brancos } \\
\text { que tem renda baixa e que estes, então, } \\
\text { seriam "os excluídos dos excluídos" pois } \\
\text { não estariam sendo contemplados por } \\
\text { nenhuma política. Há uma contradição. }\end{array}$ & $\begin{array}{l}\text { Algo que a gente falou em aula sobre cotas era talvez não } \\
\text { por cota para negros, mas pra quem tem renda baixa, } \\
\text { porque tem brancos que são pobres e dai? São os } \\
\text { excluídos dos excluídos, entendeu? Então isso foi algo que } \\
\text { foi pensado ai falaram: ñAh, que eles falam quantos por } \\
\text { centos de quem é pobre é negroò (...) Porque o [Paz] jáe é } \\
\text { uma cota. Foi dito assim, o [Paz?] é uma cota muito forte. } \\
\text { Por quê? Porque são para brancos de classe média alta. }\end{array}$ \\
\hline $\begin{array}{l}\text { 3. Visibilidade } \\
\text { sobre as } \\
\text { consequências } \\
\text { do racismo, os } \\
\text { danos e os } \\
\text { privilégios }\end{array}$ & $\begin{array}{l}\text { visibilidade do } \\
\text { prejuízo social } \\
\text { para o negro }\end{array}$ & $\begin{array}{l}\text { Visibilidade de consequências } \\
\text { psicológica do preconceito. }\end{array}$ & $\begin{array}{l}\text { Então precisa de um apoio, porque aqui dentro já é difícil } \\
\text { e com mais esse preconceito.Pergunta: Que tipo de } \\
\text { suporte seria?Pergunta: Que tipo de suporte seria? } \\
\text { Resposta: Ah, eu não sei. É algo que já até falamos em } \\
\text { aula, mas agora não sei é Psicológico para enfrentar } \\
\text { esses preconceitos, }\end{array}$ \\
\hline
\end{tabular}




\begin{tabular}{|c|c|c|c|c|}
\hline 4. Estigma & $\begin{array}{l}\text { na } \\
\text { comunicação } \\
\text { não verbal }\end{array}$ & $\begin{array}{c}\text { escolha de papéis } \\
\text { profissionais para as } \\
\text { pessoas das fotos de } \\
\text { homens e } \\
\text { mulheres; } \\
\text { brancos(as) e } \\
\text { negros(as); de } \\
\text { faixas etárias de } 20 \\
\text { a } 30 \text { anos, de } 31 \text { a } \\
59 \text { anos, acima de } \\
60 \text { anos. } \\
\text { Indicadores: } \\
\text { profissionais } \\
\text { brancos (as) - } \\
\text { negros (as) e cargos } \\
\text { profissionais } \\
\text { artista, que } \\
\text { privilegia } \\
\text { conhecimento } \\
\text { intelectual, manual } \\
\text { e posições de } \\
\text { chefia. }\end{array}$ & $\begin{array}{l}\text { Observa-se a tendência da entrevistada } \\
\text { de reproduzir os estigmas sociais, } \\
\text { escolhendo para os cargos de posições } \\
\text { de chefia as pessoas brancas e para os } \\
\text { cargos que privilegiam o trabalho manual, } \\
\text { os negros. Das } 9 \text { profissões, } 1 \text { não } \\
\text { respondeu, } 4 \text { foram preenchidas com } \\
\text { pessoas brancas e } 4 \text { com pessoas negras; } \\
\text { sendo que a profissão de artista, } 1 \text { das } 2 \text { que } \\
\text { privilegiam conhecimento intelectual e as } 2 \\
\text { que são de chefia foram preenchidas por } \\
\text { pessoas brancas; } 1 \text { das } 2 \text { que privilegiam } \\
\text { conhecimento intelectual e das } 4 \text { que } \\
\text { privilegiam trabalho manual, } 1 \text { não foi } \\
\text { respondida e as } 3 \text { faltantes foram } \\
\text { preenchidas por pessoas negras. }\end{array}$ & $\begin{array}{l}\text { Profissional Artista: Pianista - mulher branca (figura 29); } \\
\text { Profissão que privilegia conhecimento intelectual: Médico } \\
\text { (a) plantonista - homem branco (figura 19); Professor } \\
\text { Universitário - homem branco (figura 27); } \\
\text { Posições de chefia: Gerente do hotel - homem branco } \\
\text { (figura 25); Diretor (a) de Marketing de uma loja de } \\
\text { departamento - homem negro (figura 17); } \\
\text { Profissões que privilegiam o trabalho manual: Arrumador } \\
\text { (eira) do Hotel - mulher negra (figura 23); Motorista de } \\
\text { onibus - homem branco (figura 22); Cabeleireiro(a)) - } \\
\text { mulher branca (figura 26); Porteiro(a) do Hotel - homem } \\
\text { negro (figura 28). }\end{array}$ \\
\hline \multicolumn{5}{|l|}{ 5. Estereótipo } \\
\hline $\begin{array}{l}\text { 6. Reações } \\
\text { emocionais na } \\
\text { relação com o } \\
\text { preconceito } \\
\text { (com o diverso) }\end{array}$ & $\begin{array}{l}\text { na } \\
\text { comunicação } \\
\text { verbal }\end{array}$ & & $\begin{array}{l}\text { A entrevistada revela que não sabe a } \\
\text { reação que teria diante da situação de } \\
\text { estar em um ambiente em que a maioria } \\
\text { das pessoas fosse negras. }\end{array}$ & $\begin{array}{l}\text { Pergunta: Vamos imaginar que amanhã você entrasse na } \\
\text { tua sala de aula e você visse que } 80 \% \text { da sala de aula } \\
\text { eram alunos negros, o que você sentiria?Resposta: Eu ia } \\
\text { estranhar se fosse de uma hora para outra. Porque hoje } \\
\text { quando você entra em aula, tem mais brancos que negros. } \\
\text { Seria meio estranho na hora. De onde surgiu tanta gente, } \\
\text { né? Eu não sei como seria não.Eu teria que ver como ia } \\
\text { ser. Como é que iria acontecer. }\end{array}$ \\
\hline
\end{tabular}




\begin{tabular}{|c|c|c|c|}
\hline $\begin{array}{l}\text { 6. Reações } \\
\text { emocionais na } \\
\text { relação com o } \\
\text { preconceito } \\
\text { (com o diverso) }\end{array}$ & & $\begin{array}{l}\text { A entrevistada manifesta que sentiu um } \\
\text { desconforto por estar falando sobre o } \\
\text { racismo. E reconhece a delicadeza do } \\
\text { assunto. }\end{array}$ & $\begin{array}{l}\text { Flor porque é um assunto delicado e bonito assime } \\
\text { deveria ser tratado como bonito e delicado. (...) } \\
\text { desconforto, um pouco por estar falando sobre isso. }\end{array}$ \\
\hline $\begin{array}{l}\text { 6. Reações } \\
\text { emocionais na } \\
\text { relação com o } \\
\text { preconceito } \\
\text { (com o diverso) }\end{array}$ & \multirow{2}{*}{$\begin{array}{l}\text { culpa, vergonha, } \\
\text { irritabilidade, } \\
\text { raiva, exaustão, } \\
\text { confusão na fala, } \\
\text { negação, medo, } \\
\text { dissimulação, } \\
\text { sensação de } \\
\text { solidão, tristeza, } \\
\text { sensação de não } \\
\text { pertencimento, } \\
\text { impotência, } \\
\text { contradição, } \\
\text { justificativa } \\
\text { defensiva }\end{array}$} & Manifestou tristeza & $\begin{array}{l}\text { chorou quando falou sobre injustiça. Perguntei: o que } \\
\text { você sentiu? Resposta: ... tristeza por ver que isso é tão } \\
\text { forte e vê que eu sou parte disso, agir com esses } \\
\text { preconceitos... }\end{array}$ \\
\hline $\begin{array}{l}\text { 6. Reações } \\
\text { emocionais na } \\
\text { relação com o } \\
\text { preconceito } \\
\text { (com o diverso) }\end{array}$ & & $\begin{array}{l}\text { CONFUSÃO de emoções e dificuldade de } \\
\text { escolher uma posição com relação ao } \\
\text { evento de discriminação racial. }\end{array}$ & $\begin{array}{l}\text { Pergunta } 20^{*} \text { segunda etapa: Vixe, ai seria difícil.Eu acho } \\
\text { que antes de entrar com esse processo, eu acho que eu ia } \\
\text { tentar falar com ele para ver.Isso é difícil mesmo } \\
\text { falar.Eé A Cláudia que era branca, eu também não } \\
\text { saberia o que fazer. Sei lá se assim, se você faz é porque } \\
\text { você tem pena dela. E quando não faz é porque não está } \\
\text { colaborando, sempre tem aquele julgamento externo, } \\
\text { sempre tem aquela coisa.... }\end{array}$ \\
\hline $\begin{array}{l}\text { 7. Formas e } \\
\text { Oportunidades } \\
\text { de elaboração } \\
\text { das experiências } \\
\text { relacionadas ao } \\
\text { racismo }\end{array}$ & $\begin{array}{l}\text { oportunidades de } \\
\text { reflexão sobre o } \\
\text { tema racismo nos } \\
\text { espaços sociais } \\
\text { (família, escola, } \\
\text { mídia, amigos) }\end{array}$ & $\begin{array}{l}\text { A entrevistada revela não ter tido } \\
\text { oportunidades para a discussão e } \\
\text { reflexão sobre o assunto. }\end{array}$ & $\begin{array}{l}\text { Você teve antes de entrar na faculdade alguma } \\
\text { oportunidade para discutir, conversar sobre } \\
\text { discriminação racial? Resposta: Muito pouco. }\end{array}$ \\
\hline
\end{tabular}




\begin{tabular}{|c|c|c|c|c|}
\hline $\begin{array}{l}\text { 7. Formas e } \\
\text { Oportunidades } \\
\text { de elaboração } \\
\text { das experiências } \\
\text { relacionadas ao } \\
\text { racismo }\end{array}$ & & $\begin{array}{l}\text { oportunidades de } \\
\text { reflexão sobre o } \\
\text { tema racismo nos } \\
\text { espaços sociais } \\
\text { (família, escola, } \\
\text { mídia, amigos) }\end{array}$ & $\begin{array}{l}\text { A entrevistada declara que uma matéria } \\
\text { em seu curso que aborda a questão do } \\
\text { racismo para ela foi significativa para } \\
\text { entender e elaborar o assunto ("me abriu } \\
\text { a mente"). }\end{array}$ & $\begin{array}{l}\text { Pergunta: Em termos das matérias, do conteúdo de seu } \\
\text { curso?Resposta: uma matéria que eu fiz em meu primeiro } \\
\text { semestre foi antropologia. Foi uma questão que me abriu } \\
\text { a mente. Assim, mais por questões de cultura, porque teve } \\
\text { isso raça, se é preto ou branco. Como é que é? Nós lemos } \\
\text { vários textos sobre isso. Mas pela questão de cultura, de } \\
\text { ver que não há só uma que é a certa ou a errada, } \\
\text { entendeu? De ver que existem não só dois ou três, mas } \\
\text { existem centenas e milhares, diversas culturas. Eo que se } \\
\text { precisa fazer é saber que existe e respeitar. E saber como } \\
\text { conviver junto. E essa foi maravilhosa. }\end{array}$ \\
\hline $\begin{array}{l}\text { 8. Abordagem } \\
\text { teórica sobre o } \\
\text { tema }\end{array}$ & $\begin{array}{l}\text { Relação do } \\
\text { racismo com os } \\
\text { princípios de } \\
\text { direito } \\
\text { fundamentais }\end{array}$ & $\begin{array}{c}\text { reconhecimento } \\
\text { do direito a ser } \\
\text { tratado } \\
\text { desigualmente ( } \\
\text { discriminação } \\
\text { positiva) }\end{array}$ & $\begin{array}{l}\text { A entrevistada não entende a } \\
\text { discriminação positiva como uma forma } \\
\text { de garantir os direitos fundamentais, os } \\
\text { direitos humanos ("...Então nesse ponto } \\
\text { eu acho que viola um grande direito (...) } \\
\text { você perde isso o direito humano de todo } \\
\text { mundo"). } E \text {, na sua fala, demonstra uma } \\
\text { confusão em torno do assunto. }\end{array}$ & $\begin{array}{l}\text { Direitos humanos é aquele direito de que todos sejam } \\
\text { tratados iguais, que todos tenham saúde, família, comida, } \\
\text { casa, coisas assim, básicas.Direitos humanos, tipo de todo } \\
\text { mundo. Pergunta: Você acha que Direito dos Negros é } \\
\text { Direitos Humanos? Resposta: ...Então nesse ponto eu } \\
\text { acho que viola um grande direito, porque está } \\
\text { aprendendo um monte de coisa ali. Não só a escola em si } \\
\text { mas uma rede social, você está aprendendo o crescimento } \\
\text { pessoal e um monte de coisa. Então como que você perde } \\
\text { isso o direito humano de todo mundo. Se não tivesse esse } \\
\text { preconceito assim não ia precisar de um direito só para } \\
\text { os negros. }\end{array}$ \\
\hline
\end{tabular}




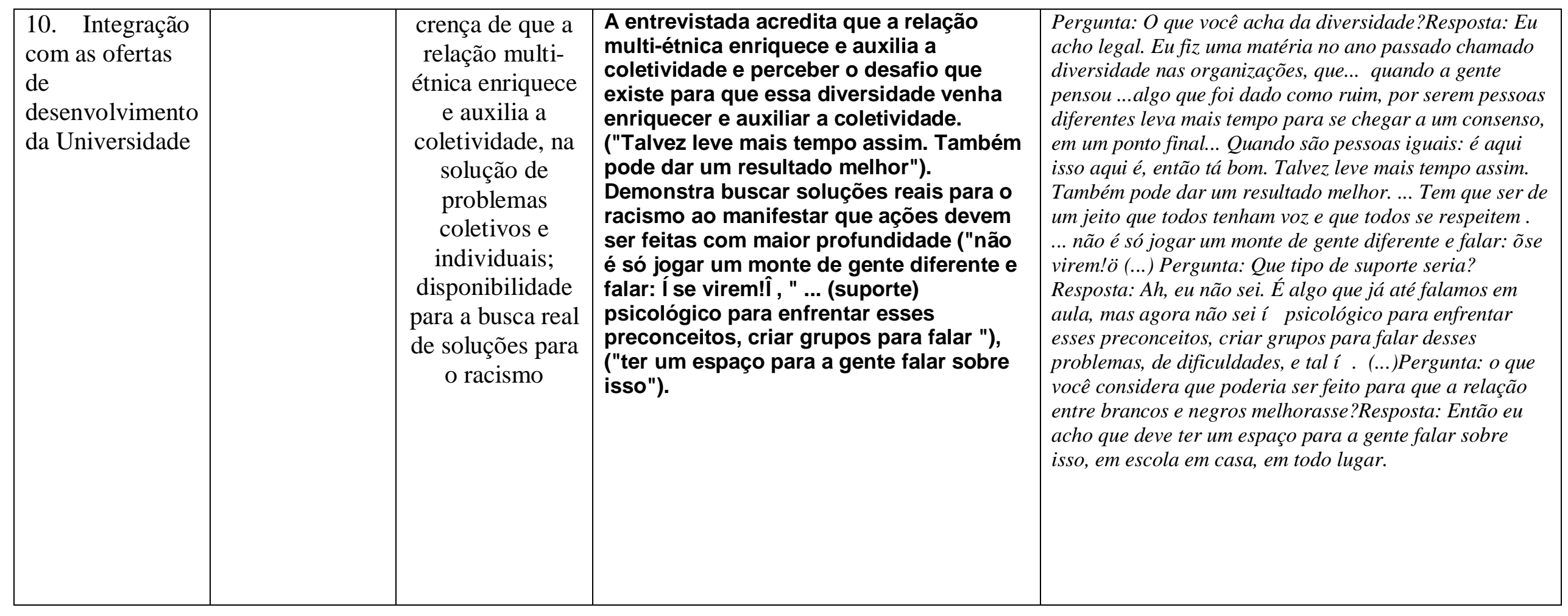




\begin{tabular}{|c|c|c|c|}
\hline $\begin{array}{l}\text { 10. Integração } \\
\text { com as ofertas } \\
\text { de } \\
\text { desenvolvimento } \\
\text { da Universidade }\end{array}$ & $\begin{array}{l}\text { Integração com } \\
\text { os colegas da } \\
\text { universidade; } \\
\text { oportunidades } \\
\text { profissionais que } \\
\text { surgem a partir } \\
\text { dessa integração; } \\
\text { acesso às } \\
\text { oportunidades } \\
\text { que o ambiente } \\
\text { acadêmico } \\
\text { oferece }\end{array}$ & $\begin{array}{l}\text { A entrevistada mostra-se integrada com } \\
\text { as atividades da Universidade, realiza } \\
\text { atividade com bolsa, que teve acesso por } \\
\text { estímulos de colegas, participou do CA } \\
\text { junto com colegas. }\end{array}$ & 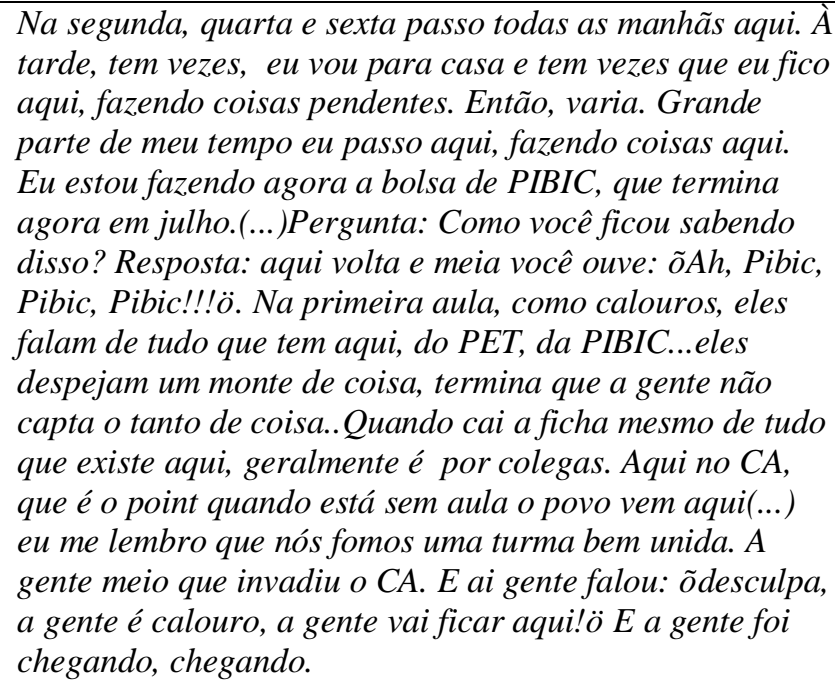 \\
\hline $\begin{array}{l}\text { 10. Integração } \\
\text { com as ofertas } \\
\text { de } \\
\text { desenvolvimento } \\
\text { da Universidade }\end{array}$ & $\begin{array}{l}\text { relação de } \\
\text { coleguismo } \\
\text { entre o } \\
\text { entrevistado e os } \\
\quad \text { alunos }\end{array}$ & $\begin{array}{l}\text { A entrevistada demonstra ter uma relação } \\
\text { de coleguismo boa. Descreve as } \\
\text { características de seus colegas que } \\
\text { define como uma grande diversidade } \\
\text { ("tem gente de tudo o que é tipo aqui"), } \\
\text { mas revela que não convive com nenhum } \\
\text { cotista. }\end{array}$ & $\begin{array}{l}\text { Pergunta: Você tem muitos amigos aqui? Resposta: ...eu } \\
\text { conheço muita gente, mas os meus amigos mesmo são } \\
\text { poucos. Assim, que você convive que você conta coisas } \\
\text { pessoais, eles são poucos. Pergunta: como eles são? Eles } \\
\text { são bem diferentes. Tem uma que é bem básica, assim, } \\
\text { que nem eu: uma blusa, calça jeans. Tem outro que é bem } \\
\text { despojado e descolado. Já é todo cheio de celular novo e } \\
\text { essas coisas novas. Tem outra que é pop. Olegal é que } \\
\text { tem gente de tudo o que é tipo aqui. Tem desde patricinha } \\
\text { e o hippie, até aquele nerd. Aqui tem de tudo que você } \\
\text { imaginar. Isso é bem legal aqui.(..) se existe cotista aqui } \\
\text { não sei quem é. Eu não conheço e não convivo com muita } \\
\text { gente cotista assim }\end{array}$ \\
\hline
\end{tabular}




\begin{tabular}{|c|c|c|c|c|}
\hline \multicolumn{5}{|c|}{ ENTREVISTADA M - NÃO COTISTA ï UNB } \\
\hline CATEGORIA & $\begin{array}{c}\text { SUB- } \\
\text { CATEGORIA }\end{array}$ & INDICADORES & ASPECTOS SIGNIFICATIVOS & RELATOS DE ENTREVISTA \\
\hline identidade étnica & $\begin{array}{l}\text { negra / branca } \\
\text { / parda }\end{array}$ & & não declarou & \\
\hline $\begin{array}{l}\text { 1. A visibilidade } \\
\text { da diversidade } \\
\text { étnico-racial e } \\
\text { a racialização de } \\
\text { si e do outro }\end{array}$ & & $\begin{array}{l}\text { utilização do } \\
\text { componente } \\
\text { étnico-racial na } \\
\text { descrição das } \\
\text { pessoas das } \\
\text { fotos de } \\
\text { estudantes } \\
\text { negros, brancos } \\
\text { e asiáticos }\end{array}$ & $\begin{array}{l}\text { A entrevistada descreve as primeiras } \\
\text { fotos de pessoas brancas, não } \\
\text { identificando a cor, etnia ou raça da } \\
\text { pessoa. A partir do momento que vê a } \\
\text { foto da pessoa negra, utiliza o } \\
\text { componente cor, raça ou etnia, para } \\
\text { descrevê-la. Em seguida, faz o mesmo } \\
\text { com a pessoa asiática. Observa-se a } \\
\text { tendência do entrevistado ver a pessoa } \\
\text { branca como um ser humano universal e } \\
\text { a pessoa negra como um ser racializado, } \\
\text { pertencente a um grupo racial. }\end{array}$ & 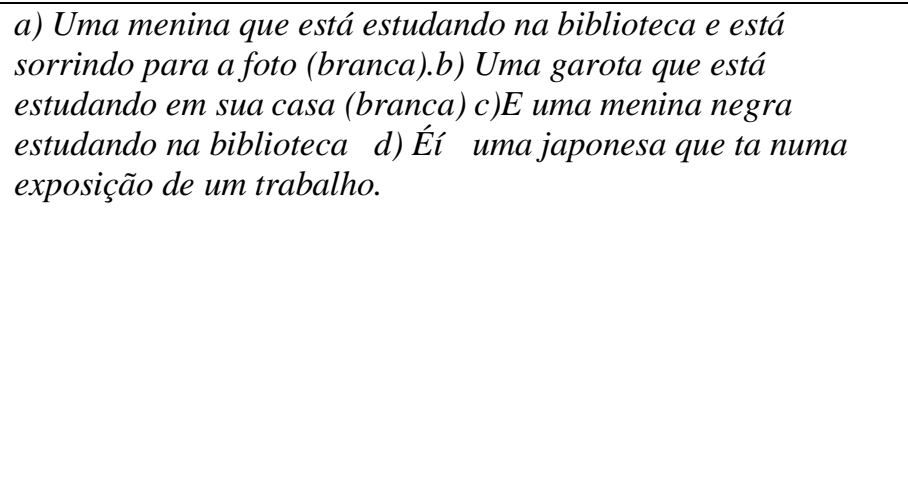 \\
\hline $\begin{array}{l}\text { 1. A visibilidade } \\
\text { da diversidade } \\
\text { étnico-racial e a } \\
\text { racialização de } \\
\text { si e do outro }\end{array}$ & & $\begin{array}{c}\text { utilização do } \\
\text { componente } \\
\text { étnico-racial para } \\
\text { descrever } \\
\text { membros da } \\
\text { família e a si } \\
\text { próprio }\end{array}$ & $\begin{array}{c}\text { A entrevistada manifesta a origem e não } \\
\text { manifesta os aspectos étnico-raciais dos } \\
\text { membros da sua família com clareza. } \\
\text { Tem dificuldade em atribuir uma raça a } \\
\text { seu membro familiar, mas aquilo que } \\
\text { recusa fazer para sua família, faz com } \\
\text { relação aos indígenas, grupo que estaria } \\
\text { "mais afastados". }\end{array}$ & $\begin{array}{l}\text { Eu não sei... (riso) ......Minha mãe tem descendência portuguesa. } \\
\text { Então ...... riso) vieram por aqui se misturaram. Meu pai } \\
\text { biológico é de Costa Rica, então eu tenho um pouco de sangue } \\
\text { latino, né? E....não, minha mãe também tem um pouco de } \\
\text { descendência negra, indígena..... Então é uma mistura total } \\
\text { assim...(riso). Pergunta: De que raça é sua mãe?Resposta: } \\
\text { Acho que hoje em dia no Brasil não se classifica por raça. No } \\
\text { máximo, os índios que estão muito afastados que não tiveram } \\
\text { contato com a sociedade, assim. Sim, vamos dizer que eles } \\
\text { também são sociedade, mas não a nossa sociedade. Tudo bem, } \\
\text { ai a gente pode falar a raça indígena, mas acho que não existe } \\
\text { mais esse tipo. }\end{array}$ \\
\hline
\end{tabular}




\begin{tabular}{|c|c|c|c|}
\hline $\begin{array}{l}\text { 2. Visibilidade } \\
\text { sobre a } \\
\text { ocorrência da } \\
\text { discriminação } \\
\text { racial }\end{array}$ & $\begin{array}{l}\text { visibilidade do } \\
\text { tratamento } \\
\text { desigual direto } \\
\text { ou indireto que } \\
\text { prejudica } \\
\text { socialmente o } \\
\text { negro, seja pela } \\
\text { neutralidade, } \\
\text { seja pela } \\
\text { diferenciação } \\
\text { negativa }\end{array}$ & $\begin{array}{c}\text { A entrevistada constata a discriminação } \\
\text { racial direta contra os negros, na } \\
\text { universidade. }\end{array}$ & $\begin{array}{l}\text { Pergunta: Você acha que existe discriminação na } \\
\text { universidade? Resposta: Acho que sim. Pergunta: Como se } \\
\text { manifesta? Resposta: Tem os negros africanos aqui que fazem } \\
\text { intercâmbio. E há um tempo atrás você ficou sabendo que teve } \\
\text { a coisa do CEU e tal e eles foram fazer uma manifestação e } \\
\text { fizeram uma passeata. Tinham uns gritos de guerra contra o } \\
\text { racismo. E ai tinha um cara que falou assim: ñEu sou racista } \\
\text { mesmo!ò. ñSou e eu não quero vocês aqui nãoò.foi uma coisa } \\
\text { queé nossa como que ele tem coragem de falar na cara dura, } \\
\text { na frente daquele tanto de negro manifestando aqui, falando } \\
\text { que estão sofrendo assim e fala isso, sabe? }\end{array}$ \\
\hline $\begin{array}{l}\text { 2. Visibilidade } \\
\text { sobre a } \\
\text { ocorrência da } \\
\text { discriminação } \\
\text { racial }\end{array}$ & $\begin{array}{l}\text { visibilidade do } \\
\text { tratamento } \\
\text { desigual direto } \\
\text { ou indireto que } \\
\text { prejudica } \\
\text { socialmente o } \\
\text { negro, seja pela } \\
\text { neutralidade, } \\
\text { seja pela } \\
\text { diferenciação } \\
\text { negativa }\end{array}$ & $\begin{array}{l}\text { Constata a discriminação racial } \\
\text { institucional quando foi invertido o papel } \\
\text { social dos grupos branco e negros de } \\
\text { ocupação de local de privilégio na } \\
\text { sociedade, a universidade. }\end{array}$ & $\begin{array}{l}\text { E se você entrasse numa escola e o dono da escola fosse negro } \\
\text { e todos os funcionários fossem negros. Você acha que ele é } \\
\text { racista? Eu acho que é racismo, porque não precisa todos serem } \\
\text { negros, sabe? Será que ele fez uma seleção e só queria que } \\
\text { negros trabalhassem lá, sabe? Não precisa disso, tem que } \\
\text { tratar com igualdade. Pergunta: Você tem algum professor } \\
\text { negro na UNB?Resposta: Não. }\end{array}$ \\
\hline $\begin{array}{l}\text { 2. Visibilidade } \\
\text { sobre a } \\
\text { ocorrência da } \\
\text { discriminação } \\
\text { racial }\end{array}$ & $\begin{array}{l}\text { visibilidade do } \\
\text { tratamento } \\
\text { desigual direto } \\
\text { ou indireto que } \\
\text { prejudica } \\
\text { socialmente o } \\
\text { negro, seja pela } \\
\text { neutralidade, } \\
\text { seja pela } \\
\text { diferenciação } \\
\text { negativa }\end{array}$ & $\begin{array}{l}\text { A entrevistada constata a ocorrência da } \\
\text { discriminação racial na estória hipotética. }\end{array}$ & $\begin{array}{l}\text { Pergunta } 20 * \text { primeira etapa: Esse é o tipo de situação que } \\
\text { não tem como não falar que não foi racismo, né? Porque é que } \\
\text { a negra pediu a carteirinha e a branca não, né?(é ) Eu acho } \\
\text { que isso aconteceué porque além de racismo, isso é um } \\
\text { preconceito. Ele tinha o preconceito que achava que negros } \\
\text { não estudavam na universidade. Seria mais dificil ter um negro } \\
\text { lá. Pode ser que a branca tivesse mais bem vestida ou alguma } \\
\text { coisa bem assim. é }\end{array}$ \\
\hline
\end{tabular}




\begin{tabular}{|c|c|c|c|}
\hline $\begin{array}{l}\text { 2. Visibilidade } \\
\text { sobre a } \\
\text { ocorrência da } \\
\text { discriminação } \\
\text { racial }\end{array}$ & & $\begin{array}{l}\text { A entrevistada demonstra perceber a } \\
\text { sensação de maior vulnerabilidade que } \\
\text { enfrenta a minoria ("Não posso te dizer } \\
\text { que me sentiria totalmente à vontade } \\
\text { assim, porque isso seria mentira"). E } \\
\text { demonstra ter dificuldade em entender } \\
\text { qual seria sua reação emocional se } \\
\text { estivesse nessa situação. }\end{array}$ & $\begin{array}{l}\text { Pergunta: E se você entrasse na tua classe a partir de hoje e } \\
\text { você visse que 80\% da tua classe são de pessoas negras. Como } \\
\text { você acha que você se sentiria? Resposta: A primeira coisa que } \\
\text { eu iria pensar é: o que mudou aqui?(riso) Porque isso é muito } \\
\text { difícil de acontecer. Mas eu me sentiria(é ), não sei. Não posso } \\
\text { te dizer que me sentiria totalmente à vontade assim, porque isso } \\
\text { seria mentira. }\end{array}$ \\
\hline $\begin{array}{l}\text { 2. Visibilidade } \\
\text { sobre a } \\
\text { ocorrência da } \\
\text { discriminação } \\
\text { racial }\end{array}$ & & $\begin{array}{c}\text { A entrevistada demonstra constatar a } \\
\text { discriminação que acontece na relação } \\
\text { entre negros e brancos na universidade } \\
\text { associada à implementação da política de } \\
\text { cotas. De forma mais confusa, visualiza } \\
\text { as conseqüências disso para as pessoas } \\
\text { negras ("poderia ter essa dificuldade de } \\
\text { estudar") }\end{array}$ & $\begin{array}{l}\text { Pergunta: Você acha que isso alteraria teu desempenho nas } \\
\text { aulas (o fato de ela ser minoria em uma sala em que } 80 \% \text { das } \\
\text { pessoas seriam negras)? Não. Pergunta: Que dificuldades que } \\
\text { você imagina que o cotista possa ter? Resposta: Primeiro é } \\
\text { social, se as pessoas souberem que ele é cotista, e ai tem } \\
\text { aquela coisa: ele entrou muito mais fácil que eu e tal. Então } \\
\text { seria mais difícil de me relacionar com as pessoas. Rolaria esse } \\
\text { preconceito. E poderia ter essa dificuldade de estudar, de não } \\
\text { estudar tanto que nem as outras. }\end{array}$ \\
\hline $\begin{array}{l}\text { 3. Visibilidade } \\
\quad \text { sobre as } \\
\text { consequências } \\
\text { do racismo, os } \\
\text { danos e os } \\
\text { privilégios } \\
\end{array}$ & $\begin{array}{l}\text { visibilidade do } \\
\text { prejuízo social } \\
\text { para o negro }\end{array}$ & $\begin{array}{l}\text { A entrevistada reconhece a condição } \\
\text { privilegiada dos brancos e os danos à } \\
\text { população negra na ocupação do espaço } \\
\text { universitário. }\end{array}$ & $\begin{array}{l}\text { Na minha sala você pode contar nos dedos as pessoas negras.é } \\
\text { porque eu sei que tem muita gente negra no país e a gente não } \\
\text { convive com essas pessoas, ta muito dividido }\end{array}$ \\
\hline
\end{tabular}




\begin{tabular}{|c|c|c|c|c|}
\hline 4. Estigma & $\begin{array}{l}\mathrm{Na} \\
\text { comunicação } \\
\text { não verbal }\end{array}$ & $\begin{array}{l}\text { escolha de papéis } \\
\text { profissionais para } \\
\text { as pessoas das } \\
\text { fotos de homens e } \\
\text { mulheres; } \\
\text { brancos(as) e } \\
\text { negros(as); de } \\
\text { faixas etárias de } 20 \\
\text { a } 30 \text { anos, de } 31 \text { a } \\
59 \text { anos, acima de } \\
60 \text { anos. } \\
\text { Indicadores: } \\
\text { profissionais } \\
\text { brancos (as) - } \\
\text { negros (as) e } \\
\text { cargos } \\
\text { profissionais } \\
\text { artista, que } \\
\text { privilegia } \\
\text { conhecimento } \\
\text { intelectual, manual } \\
\text { e posições de } \\
\text { chefia. }\end{array}$ & $\begin{array}{l}\text { Observa-se a tendência da entrevistada } \\
\text { de reproduzir os estigmas sociais, } \\
\text { escolhendo para os cargos de posições } \\
\text { de chefia as pessoas brancas e para os } \\
\text { cargos que privilegiam o trabalho } \\
\text { manual, pessoas negras. Das } 9 \\
\text { profissões, } 3 \text { foram preenchidas com } \\
\text { pessoas brancas e } 6 \text { com pessoas negras; } \\
\text { sendo que } 1 \text { das } 2 \text { profissões que } \\
\text { privilegiam o trabalho intelectual e as } 2 \text { de } \\
\text { posição de chefia foram preenchidas por } \\
\text { pessoas brancas; a de artista, } 1 \text { das } 2 \text { que } \\
\text { privilegiam conhecimento intelectual e as } 4 \\
\text { que privilegiam trabalho manual foram } \\
\text { preenchidas por pessoas negras. }\end{array}$ & $\begin{array}{l}\text { Profissional Artista: Pianista - homem negro (figura 28); } \\
\text { Profissão que privilegia conhecimento intelectual: Médico (a) } \\
\text { plantonista - homem branco (figura 25); Professor Universitário } \\
\text { - mulher negra (figura 20); } \\
\text { Posições de chefia: Gerente do hotel - homem branco (figura } \\
\text { 22); Diretor (a) de Marketing de uma loja de departamento - } \\
\text { homem branco (figura 19); } \\
\text { Profissões que privilegiam o trabalho manual: Arrumador (eira) } \\
\text { do Hotel - mulher negra (figura 23); Motorista de ônibus - } \\
\text { homem negro (figura 30); Cabeleireiro(a)) - homem negro } \\
\text { (figura 17); Porteiro(a) do Hotel - homem negro (figura 31). }\end{array}$ \\
\hline 5. Estereótipo & & $\begin{array}{l}\text { características } \\
\quad \text { atribuídas } \\
\text { genericamente a } \\
\quad \text { todos os } \\
\text { membros de um } \\
\text { grupo, mitos }\end{array}$ & $\begin{array}{l}\text { A entrevistada associa a todos os } \\
\text { membros do grupo negro a idéia de que } \\
\text { se aproveitam da condição de serem } \\
\text { inferiorizados para obter vantagens } \\
\text { injustas ("o negro aproveita de que ele é } \\
\text { negro e fala que aconteceu um ato de } \\
\text { racismo, né?"). }\end{array}$ & $\begin{array}{l}\text { Pergunta } 20^{*} \text { primeira etapa: é Isso também tem essas } \\
\text { histórias que o negro aproveita de que ele é negro e fala que } \\
\text { aconteceu um ato de racismo, né? }\end{array}$ \\
\hline
\end{tabular}




\begin{tabular}{|c|c|c|c|c|}
\hline $\begin{array}{l}\text { 6. Reações } \\
\text { emocionais na } \\
\text { relação com o } \\
\text { preconceito } \\
\text { (com o diverso) }\end{array}$ & $\begin{array}{l}\mathrm{Na} \\
\text { comunicação } \\
\text { verbal }\end{array}$ & $\begin{array}{l}\text { culpa, } \\
\text { vergonha, } \\
\text { irritabilidade, } \\
\text { raiva, exaustão, } \\
\text { confusão na } \\
\text { fala, negação, }\end{array}$ & $\begin{array}{l}\text { Diante da situação, a entrevistada revela } \\
\text { que sentiria desconforto mais não } \\
\text { consegue manifestar qual seria sua } \\
\text { reação. }\end{array}$ & $\begin{array}{l}\text { Pergunta: E se você entrasse na tua classe a partir de hoje e } \\
\text { você visse que } 80 \% \text { da tua classe são de pessoas negras. Como } \\
\text { você acha que você se sentiria? Resposta: A primeira coisa que } \\
\text { eu iria pensar é: o que mudou aqui?(riso) Porque isso é muito } \\
\text { difíil de acontecer. Mas eu me sentiria(é ), não sei. Não posso } \\
\text { te dizer que me sentiria totalmente à vontade assim, porque isso } \\
\text { seria mentira. }\end{array}$ \\
\hline $\begin{array}{l}\text { 6. Reações } \\
\text { emocionais na } \\
\text { relação com o } \\
\text { preconceito } \\
\text { (com o diverso) }\end{array}$ & & $\begin{array}{c}\text { medo, } \\
\text { dissimulação, } \\
\text { sensação de } \\
\text { solidão, } \\
\text { tristeza, } \\
\text { sensação de } \\
\text { não } \\
\text { pertencimento, } \\
\text { impotência, } \\
\text { contradição, } \\
\text { justificativa } \\
\text { defensiva }\end{array}$ & $\begin{array}{l}\text { A entrevistada revela que o tema tratado } \\
\text { na entrevista é difícil, e que tem } \\
\text { dificuldade de saber as emoções e } \\
\text { reações que teria em torno dele. }\end{array}$ & $\begin{array}{l}\text { As últimas perguntas foram difíceis. Eu me senti à vontade. Me } \\
\text { abri e falei o que achava. Eu acho que é difícil, nem eu mesmo } \\
\text { sei. Como você falou assim da sala com alunos negros. Eu } \\
\text { acho que eu agiria assim, mas será que na aula mesmo eu } \\
\text { agiria assim? Eu não tenho tanta certeza. }\end{array}$ \\
\hline $\begin{array}{c}\text { 7. Formas e } \\
\text { Oportunidades } \\
\text { de elaboração } \\
\text { das experiências } \\
\text { relacionadas ao } \\
\text { racismo }\end{array}$ & & $\begin{array}{l}\text { oportunidades } \\
\text { de reflexão } \\
\text { sobre o tema } \\
\text { racismo nos } \\
\text { espaços sociais } \\
\text { (família, escola, } \\
\text { mídia, amigos) }\end{array}$ & $\begin{array}{l}\text { A entrevistada teve poucas } \\
\text { oportunidades de debater o assunto, } \\
\text { sendo um delas decorrente do debate } \\
\text { sobre política de cotas. }\end{array}$ & $\begin{array}{l}\text { Eu discuti em minha sala de aula (sobre cotas), com o professor } \\
\text { de redação, no colegial. Na família não, mas com amigos sim. }\end{array}$ \\
\hline
\end{tabular}




\begin{tabular}{|c|c|c|c|c|}
\hline $\begin{array}{l}\text { 7. Formas e } \\
\text { Oportunidades } \\
\text { de elaboração } \\
\text { das experiências } \\
\text { relacionadas ao } \\
\text { racismo }\end{array}$ & & $\begin{array}{l}\text { oportunidades } \\
\text { de reflexão } \\
\text { sobre o tema } \\
\text { racismo nos } \\
\text { espaços sociais } \\
\text { (família, escola, } \\
\text { mídia, amigos) }\end{array}$ & $\begin{array}{l}\text { A entrevistada demonstra ter tido a } \\
\text { oportunidade de debater e refletir sobre } \\
\text { o assunto com amigos, e consegue } \\
\text { perceber e falar sobre alguns } \\
\text { mecanismos das pessoas em torno da } \\
\text { questão racial ("De querer demonstrar } \\
\text { para as pessoas que não tem } \\
\text { preconceito"). }\end{array}$ & $\begin{array}{l}\text { Pergunta: sobre discriminação racial, alguma vez você } \\
\text { discutiu?Resposta: No colegial. Tem uma amiga que é muito } \\
\text { racista. E ela não gosta, porque ela diz esse preto, não sei o } \\
\text { que, não sei o que. E a gente fica discutindo com ela, sabe? } \\
\text { Porque não dá para pensar assim, sabe? E tem uma outra } \\
\text { amiga que o sonho dela é casar com o negro. E eu não sei se é } \\
\text { uma forma de impressionar as pessoas, sabe? De querer } \\
\text { demonstrar para as pessoas que não tem preconceito. }\end{array}$ \\
\hline $\begin{array}{l}\text { 7. Formas e } \\
\text { Oportunidades } \\
\text { de elaboração } \\
\text { das experiências } \\
\text { relacionadas ao } \\
\text { racismo }\end{array}$ & & $\begin{array}{l}\text { oportunidades } \\
\text { de reflexão } \\
\text { sobre o tema } \\
\text { racismo nos } \\
\text { espaços sociais } \\
\text { (família, escola, } \\
\text { mídia, amigos) }\end{array}$ & $\begin{array}{l}\text { A entrevistada analisando o quadro que } \\
\text { ela mesma fez na entrevista, pôde } \\
\text { perceber que pratica o preconceito e a } \\
\text { conduta discriminatória. }\end{array}$ & $\begin{array}{l}\text { Após montar o quadro com os personagens e as profissões, ela } \\
\text { olhou para o quadro e disse: Bem preconceituosa a minha } \\
\text { escolha }\end{array}$ \\
\hline $\begin{array}{l}\text { 8. Abordagem } \\
\text { teórica sobre o } \\
\text { tema }\end{array}$ & $\begin{array}{l}\text { Relação do } \\
\text { racismo com } \\
\text { os princípios } \\
\text { de direito } \\
\text { fundamentais }\end{array}$ & $\begin{array}{l}\text { reconhecimento } \\
\text { do direito a ser } \\
\text { tratado } \\
\text { desigualmente ( } \\
\text { discriminação } \\
\text { positiva) }\end{array}$ & $\begin{array}{l}\text { A entrevistada não entende a } \\
\text { discriminação positiva como uma forma } \\
\text { de promover a igualdade e os direitos } \\
\text { humanos. }\end{array}$ & $\begin{array}{l}\text { Direitos humanos? (é )Acho que não sei muito bem o que é } \\
\text { não. Ė difícil. São direito que as pessoas (riso) têm em uma } \\
\text { sociedade, assim. Pergunta: Você acha que o direito dos negros } \\
e ́ \text { direitos humanos? Resposta: Eu acho que é. Mas estaria } \\
\text { excluindo os negros dos humanos. Já tem que tá lá dentro dos } \\
\text { direitos humanos. Pergunta: E o tema da discriminação racial, } \\
\text { você acha que é tema de direitos humanos? Resposta: É. }\end{array}$ \\
\hline
\end{tabular}




\begin{tabular}{|c|c|c|c|}
\hline $\begin{array}{c}9 . \\
\text { Manifestação da } \\
\text { solidariedade }\end{array}$ & $\begin{array}{l}\text { crença de que a } \\
\text { relação multi- } \\
\text { étnica } \\
\text { enriquece e } \\
\text { auxilia a } \\
\text { coletividade, na } \\
\text { solução de } \\
\text { problemas } \\
\text { coletivos e } \\
\text { individuais; } \\
\text { disponibilidade } \\
\text { para a busca } \\
\text { real de soluções } \\
\text { para o racismo }\end{array}$ & $\begin{array}{l}\text { A entrevistada demonstra acreditar que } \\
\text { as experiências das pessoas na } \\
\text { diversidade são enriquecedoras para a } \\
\text { coletividade e percebe o desafio que } \\
\text { existe para que essa diversidade venha } \\
\text { enriquecer e auxiliar a coletividade. } \\
\text { ("Então com a diversidade é difícil, por } \\
\text { que..."). }\end{array}$ & $\begin{array}{l}\text { Diversidade?Eu acho que o sistema queria deixar todo mundo } \\
\text { igual, porque seria mais fácil de... controlar.Então com a } \\
\text { diversidade é dificill, porque a diversidade tem pensamentos } \\
\text { diferentes, tem pessoas com gosto diferentes e cultura diferente. } \\
\text { E eu acho que tem que ser assim, é muito mais interessante } \\
\text { conhecer uma pessoa diferente do que uma pessoa igual a } \\
\text { você.Porque eu acho que o conhecimento vai crescendo, você } \\
\text { vai conhecendo pessoas diferentes. Você adiciona o seu } \\
\text { conhecimento a outra pessoa e forma outra. Por exemplo, se } \\
\text { você tiver o mesmo pensamento dela, vão continuar naquilo, } \\
\text { não vão discutir, não vai estar concentrando. }\end{array}$ \\
\hline & & $\begin{array}{l}\text { Apesar de a entrevistada ter manifestado } \\
\text { que a conduta da estória hipotética } \\
\text { caracteriza-se como uma conduta racista, } \\
\text { demonstra não ser solidária àquilo que a } \\
\text { pessoa negra explicita como algo que lhe } \\
\text { prejudica. Demonstra não ser solidária } \\
\text { aos mecanismos de luta explícita contra } \\
\text { o racismo por via institucional. }\end{array}$ & $\begin{array}{l}\text { Pergunta } 20^{*} \text { primeira etapa: é Éé Isso também tem essas } \\
\text { histórias que o negro aproveita de que ele é negro e fala que } \\
\text { aconteceu um ato de racismo, né? (riso) Eu acho que é uma } \\
\text { situação de que ela se atrasou.é Pode se dizer que o cara } \\
\text { deixou ela entrar porque era branca, né.(riso) Então foi } \\
\text { racismo dele. Mas ela deixou as coisas caírem e se atrasou ali } \\
\text { na porta(riso). }\end{array}$ \\
\hline
\end{tabular}




\begin{tabular}{|c|c|c|c|}
\hline & & $\begin{array}{l}\text { A entrevistada demonstra buscar } \\
\text { soluções para a eliminação do racismo, } \\
\text { como uma questão importante ("eu acho } \\
\text { que um assunto que tem que se } \\
\text { discutir"). }\end{array}$ & $\begin{array}{l}\text { Pergunta: Em sua opinião o que se poderia se fazer para } \\
\text { melhorar a situação de brancos e negros? Resposta: Nossa!!! } \\
\text { Que pergunta!! (riso) Meu Deus, o que eu faria? Isso é uma } \\
\text { coisa que tem que educar desde pequeno, as criancinhas, os } \\
\text { bebês que estão nascendo tem que começar a criar com uma } \\
\text { visão diferente. Não é só as novelas colocarem sempre as } \\
\text { empregadas negras. Eé uma vez ou outra vamos mudar, vamos } \\
\text { colocar um negro que é rico que vai se chamar foguinho e vai } \\
\text { ter uma barba engraçada. E ele vai ser o engraçado da novela. } \\
\text { Tem que começar ai, dos desenhos serem diferentes, os } \\
\text { programas de televisão, os pais se conscientizarem e falarem } \\
\text { com os filhos...Começa ai, na formação, né? (...) Pergunta: se } \\
\text { você fosse convidada a assistir uma palestra sobre } \\
\text { discriminação racial você iria? Resposta: Eu iria. Eu hesitaria } \\
\text { um pouco. Porque as pessoas estão falando a mesma coisa, não } \\
\text { acrescenta nada, sabe como que é? Mas eu acho que um } \\
\text { assunto que tem que se discutir. }\end{array}$ \\
\hline $\begin{array}{l}\text { 10. Integração } \\
\text { com as ofertas } \\
\text { de } \\
\text { desenvolvimento } \\
\text { da Universidade }\end{array}$ & $\begin{array}{l}\text { Integração com } \\
\text { os colegas da } \\
\text { universidade; } \\
\text { oportunidades } \\
\text { profissionais que } \\
\text { surgem a partir } \\
\text { dessa } \\
\text { integração; } \\
\text { acesso às } \\
\text { oportunidades } \\
\text { que o ambiente } \\
\text { acadêmico } \\
\text { oferece }\end{array}$ & $\begin{array}{l}\text { A entrevistada revelou que não participa } \\
\text { das atividades acadêmicas oferecidas } \\
\text { pela universidade, mas que passa } \\
\text { bastante tempo na universidade } \\
\text { "conversando com os amigos"). }\end{array}$ & $\begin{array}{l}\text { eu chego aqui umas oito horas e saio só às seis. Mas nem } \\
\text { sempre eu tenho aula o dia inteiro. Eu tenho alguns intervalos, } \\
\text { só geralmente nesses intervalos ou eu vou para alguma sala } \\
\text { estudar com os amigos ou fico só conversando com eles e tal. E } \\
\text { não participo de CA, não gosto disso. }\end{array}$ \\
\hline
\end{tabular}




\begin{tabular}{|c|c|c|c|}
\hline $\begin{array}{l}\text { 10. Integração } \\
\text { com as ofertas } \\
\text { de } \\
\text { desenvolvimento } \\
\text { da Universidade }\end{array}$ & $\begin{array}{c}\text { relação de } \\
\text { coleguismo } \\
\text { entre o } \\
\text { entrevistado e } \\
\text { os alunos }\end{array}$ & $\begin{array}{l}\text { A entrevistada demonstra ter uma } \\
\text { relação de coleguismo com outros } \\
\text { alunos que possuem característica } \\
\text { étnico-racial diferentes. }\end{array}$ & $\begin{array}{l}\text { Meus amigos? Eu converso com todo mundo da minha sala. Eu } \\
\text { converso com todo mundo, mas naturalmente começam a se } \\
\text { formar os grupinhos, né? Então tem umas meninas que eu } \\
\text { converso muito, a J e a M. Tem os meninos do terceiro semestre } \\
\text { que a gente conheceu também. Me é pardinha. (...) J, morena } \\
\text { clara, moreno nosso assim, que não é escuro. Tem o W que é } \\
\text { bem moreno, é alto e é magrinho. Tem o outro, o H. Ele é bem } \\
\text { clarinho assime ele é baixinho.Pergunta: Você conhece algum } \\
\text { cotista aqui na Universidade? (...) Cotista? Não. Acho que na } \\
\text { minha sala não tem. Pergunta: Mas amigos negros você tem? } \\
\text { Resposta: Tenho, mas eu não perguntei para eles. }\end{array}$ \\
\hline
\end{tabular}

\begin{tabular}{|c|c|c|c|c|}
\hline \multicolumn{5}{|c|}{ ENTREVISTADO N - NÃO COTISTA - UERJ } \\
\hline CATEGORIA & $\begin{array}{c}\text { SUB- } \\
\text { CATEGORIA }\end{array}$ & INDICADORES & ASPECTOS SIGNIFICATIVOS & RELATOS DE ENTREVISTA \\
\hline identidade étnica & $\begin{array}{l}\text { negra / branca } \\
\text { / parda }\end{array}$ & & & ela é assim como eu, branquinha, assim. \\
\hline $\begin{array}{l}\text { 1. A visibilidade } \\
\text { da diversidade } \\
\text { étnico-racial e } \\
\text { a racialização de } \\
\text { si e do outro }\end{array}$ & & $\begin{array}{l}\text { utilização do } \\
\text { componente } \\
\text { étnico-racial na } \\
\text { descrição das } \\
\text { pessoas das fotos } \\
\text { de estudantes } \\
\text { negros, brancos e } \\
\text { asiáticos }\end{array}$ & $\begin{array}{l}\text { o entrevistado descreve as fotos de } \\
\text { pessoas brancas, não manifesta a cor, } \\
\text { etnia ou raça das pessoas. }\end{array}$ & $\begin{array}{l}\text { a) a pessoa está com um sorriso, não muito espontâneo, tá } \\
\text { em cima do livro...blusa azul, cabelo longo. (branca) b) é } \\
\text { uma menininha, tá fazendo um trabalhinho...muito novinha, } \\
\text { bonitinha...(banca) c) parece uma daquelas pessoas que faz } \\
\text { evento para a natureza... distribuindo panfleto... (asiática) } \\
\text { d) parece uma pessoa estudiosa, não tira o olho do livro, de } \\
\text { blusa verde.....(negra) e) pessoa que eu me simpatizei } \\
\text { também, um cara montando um átomo... (branco) f) } \\
\text { estudando, mais na dele, não olha pra câmera.... (negro) }\end{array}$ \\
\hline
\end{tabular}




\begin{tabular}{|c|c|c|c|}
\hline $\begin{array}{l}\text { 1. A visibilidade } \\
\text { da diversidade } \\
\text { étnico-racial e a } \\
\text { racialização de } \\
\text { si e do outro }\end{array}$ & $\begin{array}{l}\text { utilização do } \\
\text { componente } \\
\text { étnico-racial para } \\
\text { descrever } \\
\text { membros da } \\
\text { família e a si } \\
\text { próprio }\end{array}$ & $\begin{array}{c}\text { O entrevistado não identifica os } \\
\text { componentes étnico-raciais de sua } \\
\text { família, tem dificuldade de racializar } \\
\text { membros da sua família e manifesta ter } \\
\text { ficado incomodado com a pergunta } \\
\text { ("ela não é cachorro, não, mas....Fiquei } \\
\text { meio chateado"). }\end{array}$ & $\begin{array}{l}\text { Pelo que sei, minha família veio da Itália, por parte de mãe, } \\
\text { e, por parte de pai, veio de Portugal, é mais ou menos } \\
\text { assim....Pergunta: Que raça que é sua mãe? Resposta: Não } \\
\text { sei, ela não é cachorro, não, mas....ela é assim como eu, } \\
\text { branquinha, assim, .... Fiquei meio chateado. }\end{array}$ \\
\hline $\begin{array}{l}\text { 1. A visibilidade } \\
\text { da diversidade } \\
\text { étnico-racial e a } \\
\text { racialização de } \\
\text { si e do outro }\end{array}$ & $\begin{array}{l}\text { noção sobre o } \\
\text { conceito social de } \\
\text { raça na utilização } \\
\text { do componente } \\
\text { étnico-racial na } \\
\text { descrição das } \\
\text { relações sociais }\end{array}$ & $\begin{array}{l}\text { O entrevistado manifesta que acha } \\
\text { "errado" dividir as pessoas por raças. } \\
\text { Prefere utilizar o termo etnia. E utiliza } \\
\text { mais as características fenótipicas e as } \\
\text { diferentes cores de pele das pessoas } \\
\text { para fazer a diferenciação, sem atribuir } \\
\text { o conteúdo social da divisão desses } \\
\text { grupos na descrição que faz. }\end{array}$ & $\begin{array}{l}\text { Pergunta: Você dividiria as pessoas em raças, como é isso } \\
\text { pra você? Reposta: Não sei, eu fui criado educado achando } \\
\text { isso errado, então... Eu chamaria de etnia. Pergunta: E } \\
\text { como é que você dividiria? Resposta: Ah, normal, tem cara } \\
\text { que é preto, tem cara que é branco, tem cara que é a mistura } \\
\text { dos dois, tem cara que é mais asiático, ...tem os índios } \\
\text { também, tem muita mistura. A diferença é a cor... o índio } \\
\text { tem menos pêlo, são morenos, não é um moreno da mistura } \\
\text { do negro com o branco, é um pouco diferente, o... cabelo é } \\
\text { liso... o negro é negro, a maioria deles costuma ser mais } \\
\text { bruto, sabe?... mais forte.... E o branco, também tem as } \\
\text { mistura no branco, né? Tem branco mais para o urso polar, } \\
\text { alemão, tem o branco que não é tão branco assim, nem é } \\
\text { negro,que é como a maioria da gente é... }\end{array}$ \\
\hline $\begin{array}{l}\text { 2. Visibilidade } \\
\text { sobre a } \\
\text { ocorrência da } \\
\text { discriminação } \\
\text { racial }\end{array}$ & $\begin{array}{l}\text { visibilidade do } \\
\text { tratamento } \\
\text { desigual direto ou } \\
\text { indireto que } \\
\text { prejudica } \\
\text { socialmente o } \\
\text { negro, seja pela } \\
\text { neutralidade, seja } \\
\text { pela diferenciação } \\
\text { negativa }\end{array}$ & $\begin{array}{c}\text { O entrevistado constata as } \\
\text { dificuldades que os cotistas enfrentam } \\
\text { na relação com outros alunos } \\
\text { ("inimizades", "piadas", "alguns têm } \\
\text { vergonha de falar"). }\end{array}$ & $\begin{array}{l}\text { Pergunta: Tem alguma dificuldade que você acha que o } \\
\text { cotista passa, além das dificuldades nas matérias?Resposta: } \\
\text { às vezes tem umas inimizades com as pessoas, mas é porque } \\
\text { o cara não gosta da pessoa, mas não tem nada a ver, assim, } \\
\text { com...(...) algumas pessoas devem fazer piadas, de vez em } \\
\text { quando, ... mas fora a piada, não.(...)Pergunta: Como você } \\
\text { soube que eles eram cotistas? Resposta: Conheço alguns... } \\
\text { Falo com todo mundo, né?......Aqui, metade são cotistas. Às } \\
\text { vezes um fala.... Alguns têm vergonha de falar, mas.. }\end{array}$ \\
\hline
\end{tabular}




\begin{tabular}{|c|c|c|c|}
\hline $\begin{array}{l}\text { 2. Visibilidade } \\
\text { sobre a } \\
\text { ocorrência da } \\
\text { discriminação } \\
\text { racial }\end{array}$ & $\begin{array}{c}\text { visibilidade do } \\
\text { tratamento } \\
\text { desigual direto ou } \\
\text { indireto que } \\
\text { prejudica } \\
\text { socialmente o } \\
\text { negro, seja pela } \\
\text { neutralidade, seja } \\
\text { pela diferenciação } \\
\text { negativa }\end{array}$ & $\begin{array}{l}\text { Na Universidade, o entrevistado não } \\
\text { constata a discriminação racial, nem } \\
\text { direta, nem a indireta constitucional. }\end{array}$ & $\begin{array}{l}\text { Pergunta: Você acha que existe racismo aqui na } \\
\text { universidade? Resposta: Aqui é uma universidade pública, } \\
\text { então, tem todo tipo de pessoa: pessoa com dinheiro, pessoa } \\
\text { pobre, pessoa negra, pessoa branca, tem índio, tem tudo. E } \\
\text { você não tem como... É complicado até você ter separação, } \\
\text { pelo menos no meu curso...então, não tem esse negócio de } \\
\text { racismo, não vejo isso... Pergunta: Você tem algum } \\
\text { professor negro? Resposta: que eu lembre, não...é possivel... }\end{array}$ \\
\hline $\begin{array}{l}\text { 2. Visibilidade } \\
\text { sobre a } \\
\text { ocorrência da } \\
\text { discriminação } \\
\text { racial }\end{array}$ & $\begin{array}{c}\text { visibilidade do } \\
\text { tratamento } \\
\text { desigual direto ou } \\
\text { indireto que } \\
\text { prejudica } \\
\text { socialmente o } \\
\text { negro, seja pela } \\
\text { neutralidade, seja } \\
\text { pela diferenciação } \\
\text { negativa }\end{array}$ & $\begin{array}{l}\text { Observa-se que só foi possível } \\
\text { constatar a discriminação racial } \\
\text { institucional quando foi invertido o } \\
\text { papel social dos grupos branco e } \\
\text { negros de ocupação de local de } \\
\text { privilégio na sociedade. }\end{array}$ & $\begin{array}{l}\text { Pergunta: Se você entrasse em um colégio e visse que o } \\
\text { dono é negro e todos os funcionários são negros, você ia } \\
\text { achar que ele é racista? Respostas: depende o que ele fosse } \\
\text { falar, é por que... Se tivesse todo mundo mesmo negro, eu } \\
\text { ia começar a achar que era sim. É estranho, né? Pensa } \\
\text { bem,é um tanto quanto estranho.... }\end{array}$ \\
\hline $\begin{array}{l}\text { 2. Visibilidade } \\
\text { sobre a } \\
\text { ocorrência da } \\
\text { discriminação } \\
\text { racial }\end{array}$ & $\begin{array}{c}\text { visibilidade do } \\
\text { tratamento } \\
\text { desigual direto ou } \\
\text { indireto que } \\
\text { prejudica } \\
\text { socialmente o } \\
\text { negro, seja pela } \\
\text { neutralidade, seja } \\
\text { pela diferenciação } \\
\text { negativa } \\
\end{array}$ & $\begin{array}{l}\text { O entrevistado demonstra não estar } \\
\text { certo de que ocorreu ou não a } \\
\text { discriminação racial na conduta da } \\
\text { estória hipotética. }\end{array}$ & $\begin{array}{l}\text { Pergunta } 20^{*} \text { primeira etapa: Esse caso aqui é meio } \\
\text { pesado...ou o cara conhecia a menina e já sabia que ela era } \\
\text { aluna, ou se ele não conhecia, é um tanto quanto... a atitude } \\
\text { é assim... racista. }\end{array}$ \\
\hline
\end{tabular}




\begin{tabular}{|c|c|c|c|}
\hline $\begin{array}{l}\text { 2. Visibilidade } \\
\text { sobre a } \\
\text { ocorrência da } \\
\text { discriminação } \\
\text { racial }\end{array}$ & $\begin{array}{c}\text { visibilidade do } \\
\text { tratamento } \\
\text { desigual direto ou } \\
\text { indireto que } \\
\text { prejudica } \\
\text { socialmente o } \\
\text { negro, seja pela } \\
\text { neutralidade, seja } \\
\text { pela diferenciação } \\
\text { negativa }\end{array}$ & $\begin{array}{l}\text { O entrevistado constata a ocorrência } \\
\text { de discriminação racial direta praticada } \\
\text { contra os negros, e pelos negros } \\
\text { contra os negros também, na cidade. }\end{array}$ & $\begin{array}{l}\text { Pergunta: Você acha que existe racismo na sociedade? } \\
\text { Resposta: Na sociedade existe. Eu sou contra, mas existe. } \\
\text { Pergunta: Como ele se manifesta? Resposta: Às vezes fica } \\
\text { nítido na cara da pessoa. Que ela olhou assim, que ela ficou } \\
\text { olhando muito, sabe?.Estranho... ou então, por exemplo, às } \\
\text { vezes a pessoa fala...to meio enrolado para explicar, né? as } \\
\text { vezes a pessoa fala como se fosse racismo mas brincando, } \\
\text { não chega a ser racismo mas uma brincadeira. Eu já vi uma } \\
\text { figura aqui na faculdade mesmo, ele é o mais escuro de } \\
\text { todos os meninos assim, aí o outro menino que era mais } \\
\text { moreno fez uma besteira, daí: "oh, esse aí, tinha que ser } \\
\text { para fazer uma besteira.". (...) ... O cara vai falar alguma } \\
\text { coisa, mas, ele também é moreno... as vezes, é engraçado, } \\
\text { você pode ver...tem muita pessoa que é .... negra e fala } \\
\text { assim: "aquele lá é negro, tá fazendo merd..." mas ele } \\
\text { também é? }\end{array}$ \\
\hline
\end{tabular}




\begin{tabular}{|c|c|c|c|c|}
\hline 4. Estigma & $\begin{array}{l}\text { na } \\
\text { comunicação } \\
\text { não verbal }\end{array}$ & $\begin{array}{c}\text { escolha de papéis } \\
\text { profissionais para as } \\
\text { pessoas das fotos de } \\
\text { homens e mulheres; } \\
\text { brancos(as) e } \\
\text { negros(as); de } \\
\text { faixas etárias de } 20 \text { a } \\
30 \text { anos, de } 31 \text { a } 59 \\
\text { anos, acima de } 60 \\
\text { anos. } \\
\text { Indicadores: } \\
\text { profissionais } \\
\text { brancos (as) - negros } \\
\text { (as) e cargos } \\
\text { profissionais artista, } \\
\text { que privilegia } \\
\text { conhecimento } \\
\text { intelectual, manual e } \\
\text { posições de chefia. }\end{array}$ & $\begin{array}{l}\text { Observa-se a tendência da } \\
\text { entrevistada de reproduzir os estigmas } \\
\text { sociais, escolhendo para os cargos } \\
\text { que privilegiam o trabalho intelectual } \\
\text { as pessoas brancas e para a maioria } \\
\text { dos cargos que privilegiam o trabalho } \\
\text { manual, as pessoas negras. Das } 9 \\
\text { profissões, } 3 \text { foram preenchidas com } \\
\text { pessoas brancas e } 6 \text { com pessoas } \\
\text { negras; sendo que as } 2 \text { profissões que } \\
\text { privilegiam o trabalho intelectual e as } 1 \\
\text { das } 4 \text { que privilegiam trabalho manual } \\
\text { foram preenchidas por pessoas brancas; } \\
\text { a profissão de artista, as } 2 \text { de posição de } \\
\text { chefia e as } 3 \text { das } 4 \text { que privilegiam } \\
\text { trabalho manual foram preenchidas por } \\
\text { pessoas negras. }\end{array}$ & $\begin{array}{l}\text { Profissional Artista: Pianista - homem negro (figura 28); } \\
\text { Profissão que privilegia conhecimento intelectual: Médico } \\
\text { (a) plantonista - homem branco (figura 19); Professor } \\
\text { Universitário - homem branco (figura 27); } \\
\text { Posições de chefia: Gerente do hotel - mulher negra (figura } \\
\text { 23); Diretor (a) de Marketing de uma loja de departamento - } \\
\text { homem negro (figura 18); } \\
\text { Profissões que privilegiam o trabalho manual: Arrumador } \\
\text { (eira) do Hotel - mulher negra (figura 24); Motorista de } \\
\text { ônibus - homem negro (figura 17); Cabeleireiro(a)) - } \\
\text { homem negro (figura 31); Porteiro(a) do Hotel - homem } \\
\text { branco (figura 32). }\end{array}$ \\
\hline 5. Estereótipo & & $\begin{array}{l}\text { características } \\
\text { atribuídas } \\
\text { genericamente a } \\
\text { todos os membros } \\
\text { de um grupo, } \\
\text { mitos }\end{array}$ & $\begin{array}{l}\text { O entrevistado atribui característica } \\
\text { física, ou comportamental, não } \\
\text { comprovada a um grupo étnico que } \\
\text { define como negro. }\end{array}$ & $\begin{array}{l}\text {...o negro é negro, a maioria deles costuma ser mais bruto, } \\
\text { sabe?... }\end{array}$ \\
\hline $\begin{array}{l}\text { 6. Reações } \\
\text { emocionais na } \\
\text { relação com o } \\
\text { preconceito } \\
\text { (com o diverso) }\end{array}$ & & & $\begin{array}{l}\text { O entrevistado manifesta as } \\
\text { dificuldades que os cotistas enfrentam } \\
\text { na relação com outros alunos, mas } \\
\text { JUSTIFICA, NEGANDO a causa racial. }\end{array}$ & $\begin{array}{l}\text { Pergunta: Tem alguma dificuldade que você acha que o } \\
\text { cotista passa, além das dificuldades nas matérias?Resposta: } \\
\text { às vezes tem umas inimizades com as pessoas, mas é porque } \\
\text { o cara não gosta da pessoa, mas não tem nada a ver, assim, } \\
\text { com......) algumas pessoas devem fazer piadas, de vez em } \\
\text { quando, ... mas fora a piada, não. }\end{array}$ \\
\hline
\end{tabular}




\begin{tabular}{|c|c|c|c|}
\hline $\begin{array}{l}\text { 6. Reações } \\
\text { emocionais na } \\
\text { relação com o } \\
\text { preconceito } \\
\text { (com o diverso) }\end{array}$ & $\begin{array}{c}\text { culpa, vergonha, } \\
\text { irritabilidade, } \\
\text { raiva, exaustão, } \\
\text { confusão na fala, } \\
\text { negação, medo, } \\
\text { dissimulação, } \\
\text { sensação de } \\
\text { solidão, tristeza, } \\
\text { sensação de não } \\
\text { pertencimento, } \\
\text { contradição, } \\
\text { justificativa } \\
\text { defensiva }\end{array}$ & $\begin{array}{l}\text { O entrevistado NEGA-se a enfrentar o } \\
\text { conflito da pergunta - não responde. }\end{array}$ & $\begin{array}{l}\text { Pergunta: Se você entrasse na sua sala hoje e } 80 \% \text { das } \\
\text { pessoas fossem negros, o que você sentiria?Resposta: (riso) } \\
\text { não posso sentir isso porque } 70 \% \text { das pessoas da minha } \\
\text { classe são brancas (riso). }\end{array}$ \\
\hline $\begin{array}{l}\text { 6. Reações } \\
\text { emocionais na } \\
\text { relação com o } \\
\text { preconceito } \\
\text { (com o diverso) }\end{array}$ & & $\begin{array}{l}\text { O assunto provoca uma } \\
\text { AGRESSIVIDADE. O entrevistado } \\
\text { manifesta um desejo de agir com } \\
\text { agressividade física no caso de } \\
\text { injustiça representado na estória } \\
\text { hipotética. }\end{array}$ & $\begin{array}{l}\text { Pergunta } 20^{*} \text { : Se eu fosse a Ana (negra) eu estrangulava o } \\
\text { cara. Eu ia tentar argumentar, mas se não desse, eu ia } \\
\text { estrangular o cara. }\end{array}$ \\
\hline $\begin{array}{l}\text { 6. Reações } \\
\text { emocionais na } \\
\text { relação com o } \\
\text { preconceito } \\
\text { (com o diverso) } \\
\end{array}$ & & $\begin{array}{l}\text { O entrevistado percebe e revela que o } \\
\text { assunto lhe provoca confusão. }\end{array}$ & $\begin{array}{l}\text { Uma pedra. Tive dificuldade de expressar minhas idéias. } \\
\text { Ficaram confusas... }\end{array}$ \\
\hline $\begin{array}{l}\text { 6. Reações } \\
\text { emocionais na } \\
\text { relação com o } \\
\text { preconceito }\end{array}$ & & Chateação & $\begin{array}{l}\text { Pergunta: Que raça que é sua mãe? Resposta: (...) Fiquei } \\
\text { meio chateado. }\end{array}$ \\
\hline
\end{tabular}




\begin{tabular}{|c|c|c|c|c|}
\hline $\begin{array}{l}\text { 7. Formas e } \\
\text { Oportunidades } \\
\text { de elaboração } \\
\text { das experiências } \\
\text { relacionadas ao } \\
\text { racismo }\end{array}$ & & $\begin{array}{l}\text { oportunidades de } \\
\text { reflexão sobre o } \\
\text { tema racismo nos } \\
\text { espaços sociais } \\
\text { (família, escola, } \\
\text { mídia, amigos) }\end{array}$ & $\begin{array}{l}\text { O entrevistado manifesta que teve } \\
\text { oportunidades de constatar a } \\
\text { ocorrência da discriminação racial } \\
\text { direta durante sua vida ("Bom, eu } \\
\text { cansei de vê gente falando:" porque é } \\
\text { negro, tinha que fazer besteira"); } \\
\text { Demonstra não ter tido oportunidades } \\
\text { significativas de debater e refletir } \\
\text { sobre o assunto, mas teve orientações } \\
\text { morais sobre o que é correto ou } \\
\text { incorreto pensar ou agir ("desde } \\
\text { pequeno, tanto na minha família, como } \\
\text { na escola, se mostrava que não é um } \\
\text { bom caminho ser racista", " eu fui } \\
\text { criado educado achando isso errado"). }\end{array}$ & $\begin{array}{l}\text { Pergunta: Você alguma vez teve a oportunidade de } \\
\text { conversar sobre o assunto preconceito, racismo, na vida, na } \\
\text { família, escola? Resposta: Bom, eu cansei de vê gente } \\
\text { falando:" porque é negro, tinha que fazer besteira"..não, só } \\
\text { desde pequeno, tanto na minha família, como na escola, se } \\
\text { mostrava que não é um bom caminho ser racista.(..) } \\
\text { Pergunta: Você dividiria as pessoas em raças, como é isso } \\
\text { pra vocêe? Reposta: Não sei, eu fui criado educado achando } \\
\text { isso errado, então... }\end{array}$ \\
\hline $\begin{array}{l}\text { 8. Abordagem } \\
\text { teórica sobre o } \\
\text { tema }\end{array}$ & $\begin{array}{l}\text { Diversidade } x \\
\text { Igualdade } x \\
\text { Racismo }\end{array}$ & $\begin{array}{c}\text { Confusão sobre } \\
\text { os agrupamentos } \\
\text { na diversidade, } \\
\text { sobre a } \\
\text { diferenciação } \\
\text { positiva - a } \\
\text { diferenciação } \\
\text { negativa (quando } \\
\text { é um valor a } \\
\text { diversidade e } \\
\text { quando não é). }\end{array}$ & $\begin{array}{l}\text { Para o entrevistado, o fato de } \\
\text { simplesmente existirem pessoas com } \\
\text { especificidades diversas no mesmo } \\
\text { espaço, não existe racismo, que, nesse } \\
\text { momento, define como sendo uma } \\
\text { "separação" ("Aqui (...) tem todo tipo } \\
\text { de pessoa(...) E você não tem (...) } \\
\text { separação, (...) não tem esse negócio } \\
\text { de racismo"). }\end{array}$ & $\begin{array}{l}\text { Pergunta: Você acha que existe racismo aqui na } \\
\text { universidade? Resposta: Aqui é uma universidade pública, } \\
\text { então, tem todo tipo de pessoa: pessoa com dinheiro, pessoa } \\
\text { pobre, pessoa negra, pessoa branca, tem índio, tem tudo. E } \\
\text { você não tem como... É complicado até você ter separação, } \\
\text { pelo menos no meu curso...então, não tem esse negócio de } \\
\text { racismo, não vejo isso... }\end{array}$ \\
\hline
\end{tabular}




\begin{tabular}{|c|c|c|c|}
\hline $\begin{array}{c}9 . \\
\text { Manifestação da } \\
\text { solidariedade }\end{array}$ & $\begin{array}{l}\text { crença de que a } \\
\text { relação multi- } \\
\text { étnica enriquece } \\
\text { e auxilia a } \\
\text { coletividade, na } \\
\text { solução de } \\
\text { problemas } \\
\text { coletivos e } \\
\text { individuais; } \\
\text { disponibilidade } \\
\text { para a busca real } \\
\text { de soluções para } \\
\text { o racismo }\end{array}$ & $\begin{array}{l}\text { O entrevistado, apesar de dizer que a } \\
\text { diversidade é uma coisa boa, não } \\
\text { demonstra acreditar que ela venha lhe } \\
\text { enriquecer e auxiliar ("respeito, mas } \\
\text { não quero, mas pra conversar, acho } \\
\text { legal.."). }\end{array}$ & $\begin{array}{l}\text { Diversidade: Acho diversidade boa, tem que ter bastante } \\
\text { diversidade, se não iria ser tudo igualzinho e não ia ter } \\
\text { graça. Porque você acha boa diversidade? Resposta: sei } \\
\text { lá... Eu não sei explicar assim...Se chega um menina com um } \\
\text { chapéu na cabeça, meias até o joelho, para ser minha } \\
\text { namorada, respeito mas não quero, mas pra conversar, acho } \\
\text { legal... }\end{array}$ \\
\hline $\begin{array}{c}9 . \\
\text { Manifestação da } \\
\text { solidariedade }\end{array}$ & $\begin{array}{l}\text { crença de que a } \\
\text { relação multi- } \\
\text { étnica auxilia a } \\
\text { coletividade, na } \\
\text { solução de } \\
\text { problemas } \\
\text { coletivos e } \\
\text { individuais; } \\
\text { disponibilidade } \\
\text { para a busca real } \\
\text { de soluções para } \\
\text { o racismo }\end{array}$ & $\begin{array}{l}\text { O entrevistado não demonstra } \\
\text { acreditar que a relação multi-étnica } \\
\text { enriquece e auxilia a coletividade, pois } \\
\text { não busca soluções reais para a } \\
\text { melhora da relação multi-étnica. } \\
\text { Acredita que o fato de juntar as } \\
\text { pessoas ("todo mundo ficar junto") é a } \\
\text { "melhor coisa" para melhor a relação } \\
\text { entre negros e brancos, } \\
\text { desconsiderando os desafios para a } \\
\text { eliminação das condutas } \\
\text { discriminatórias. Com relação a outros } \\
\text { eventos, acha "que não precisa". }\end{array}$ & $\begin{array}{l}\text { Pergunta: Alguma coisa para melhorar a relação entre } \\
\text { brancos e negros, como eventos na universidade? Resposta: } \\
\text { Acho que não precisa, já tem muito, já. Teve muito aqui, } \\
\text { mas eram eventos na época do início da política de } \\
\text { cotas........) O que você faria para melhorar a relação entre } \\
\text { brancos e negros no Rio de Janeiro? Resposta: primeiro, } \\
\text { acabar com as cotas, (...) Porque eu estou separando, estou } \\
\text { começando a tratar as pessoas que deveriam ser iguais, } \\
\text { desiguais.....Me perdi...o que fazer?.. Não sei, não tenho uma } \\
\text { idéia. (...) Resposta: Fazer atividades que os dois convivam } \\
\text { juntos... atividades esportivas, por exemplo, é a melhor coisa } \\
\text { para todo mundo ficar junto, ... esporte tanto une que na } \\
\text { nossa faculdade tem campeonato de futebol e está todo } \\
\text { mundo lá misturado. }\end{array}$ \\
\hline
\end{tabular}




\begin{tabular}{|c|c|c|c|}
\hline $\begin{array}{l}\text { 10. Integração } \\
\text { com as ofertas } \\
\text { de } \\
\text { desenvolvimento } \\
\text { da Universidade }\end{array}$ & $\begin{array}{l}\text { Integração com os } \\
\text { colegas da } \\
\text { universidade; } \\
\text { oportunidades } \\
\text { profissionais que } \\
\text { surgem a partir } \\
\text { dessa integração; } \\
\text { acesso às } \\
\text { oportunidades que } \\
\text { o ambiente } \\
\text { acadêmico } \\
\text { oferece }\end{array}$ & $\begin{array}{l}\text { O entrevistado está integrada com as } \\
\text { atividades da Universidade, tendo sido } \\
\text { membro do Centro Acadêmico, } \\
\text { atualmente só estuda e tem uma } \\
\text { relação de coleguismo com os alunos. }\end{array}$ & $\begin{array}{l}\text { Uma pessoa que conversa com todo mundo, é brincalhão, já } \\
\text { fui membro do Centro Acadêmico, tentando melhorar a } \\
\text { universidade, agora estou fazendo muitas matérias, então } \\
\text { não estou estagiando...passo o dia inteiro na universidade. }\end{array}$ \\
\hline $\begin{array}{l}\text { 10. Integração } \\
\text { com as ofertas } \\
\text { de } \\
\text { desenvolvimento } \\
\text { da Universidade }\end{array}$ & $\begin{array}{c}\text { relação de } \\
\text { coleguismo entre } \\
\text { o entrevistado e } \\
\text { os alunos }\end{array}$ & $\begin{array}{l}\text { O entrevistado demonstra ser bastante } \\
\text { relacionado com os colegas. } \\
\text { Demonstra não ter relações mais } \\
\text { profundas com os colegas da } \\
\text { universidade, e o mesmo ocorre com } \\
\text { os alunos cotistas, com quem mantém } \\
\text { uma relação de coleguismo. }\end{array}$ & $\begin{array}{l}\text { Aqui eu tenho várias turmas que eu saio, mas amigos } \\
\text { mesmos são mais os que moram perto da minha casa. Falo } \\
\text { com todo mundo, mas os mais próximos são mais ou menos } \\
\text { como eu, assim, .... (...) O meu contato assim (com os } \\
\text { cotistas) é só de conversar, jogar alguma coisa..., mas não } \\
\text { tenho contato disso tudo com eles. }\end{array}$ \\
\hline
\end{tabular}




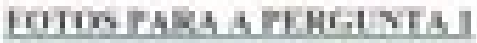
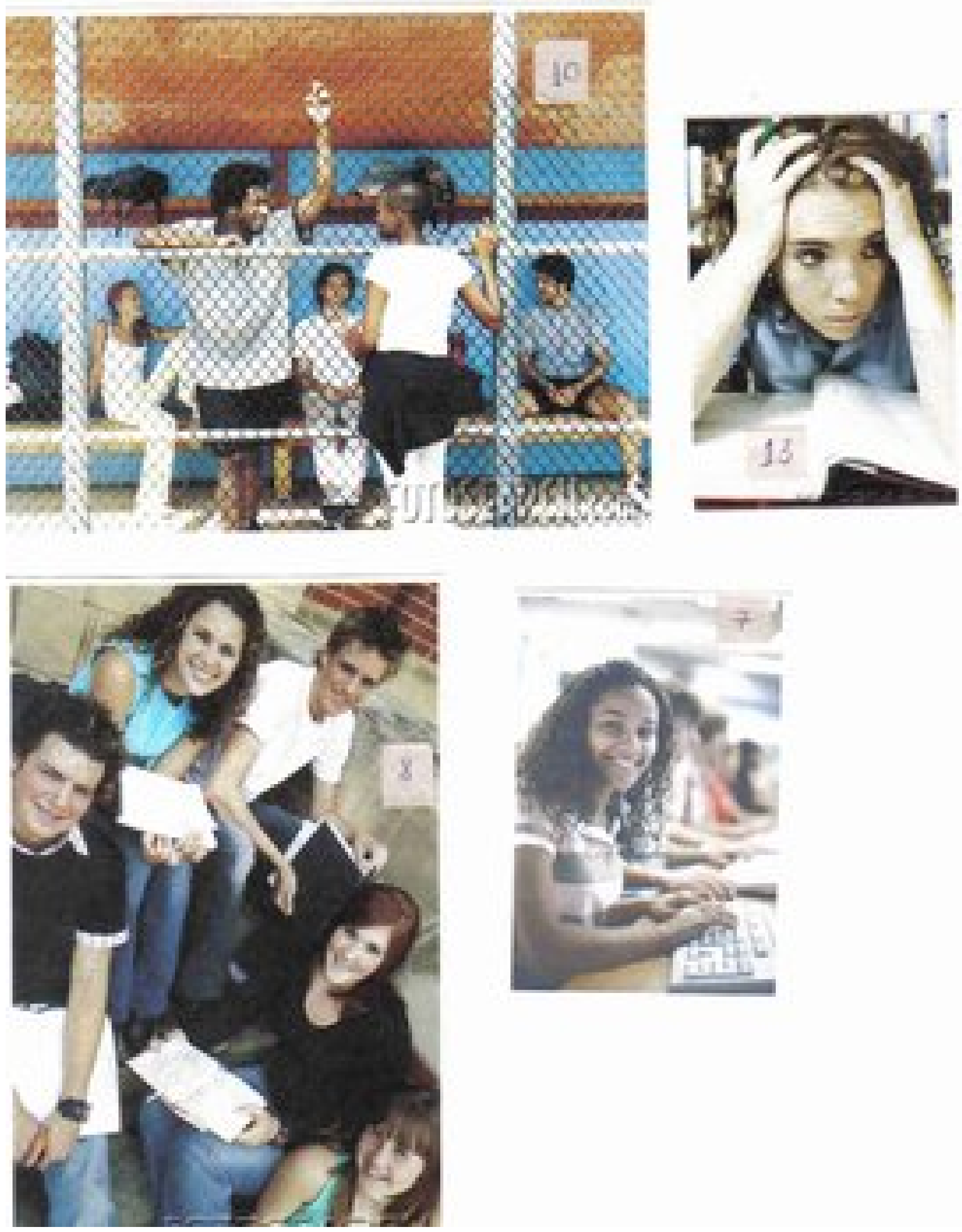

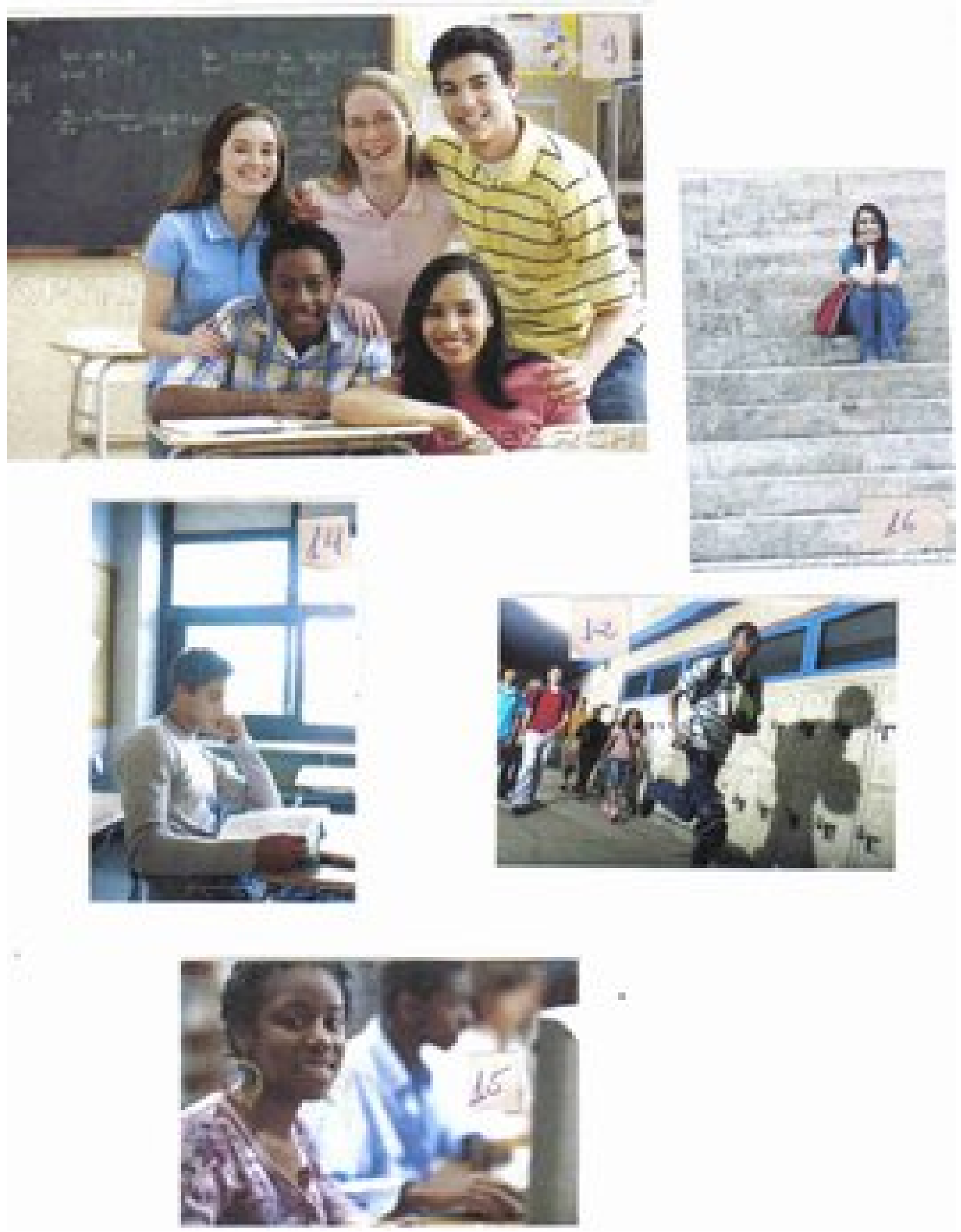
BMTGS DAFESH QIA
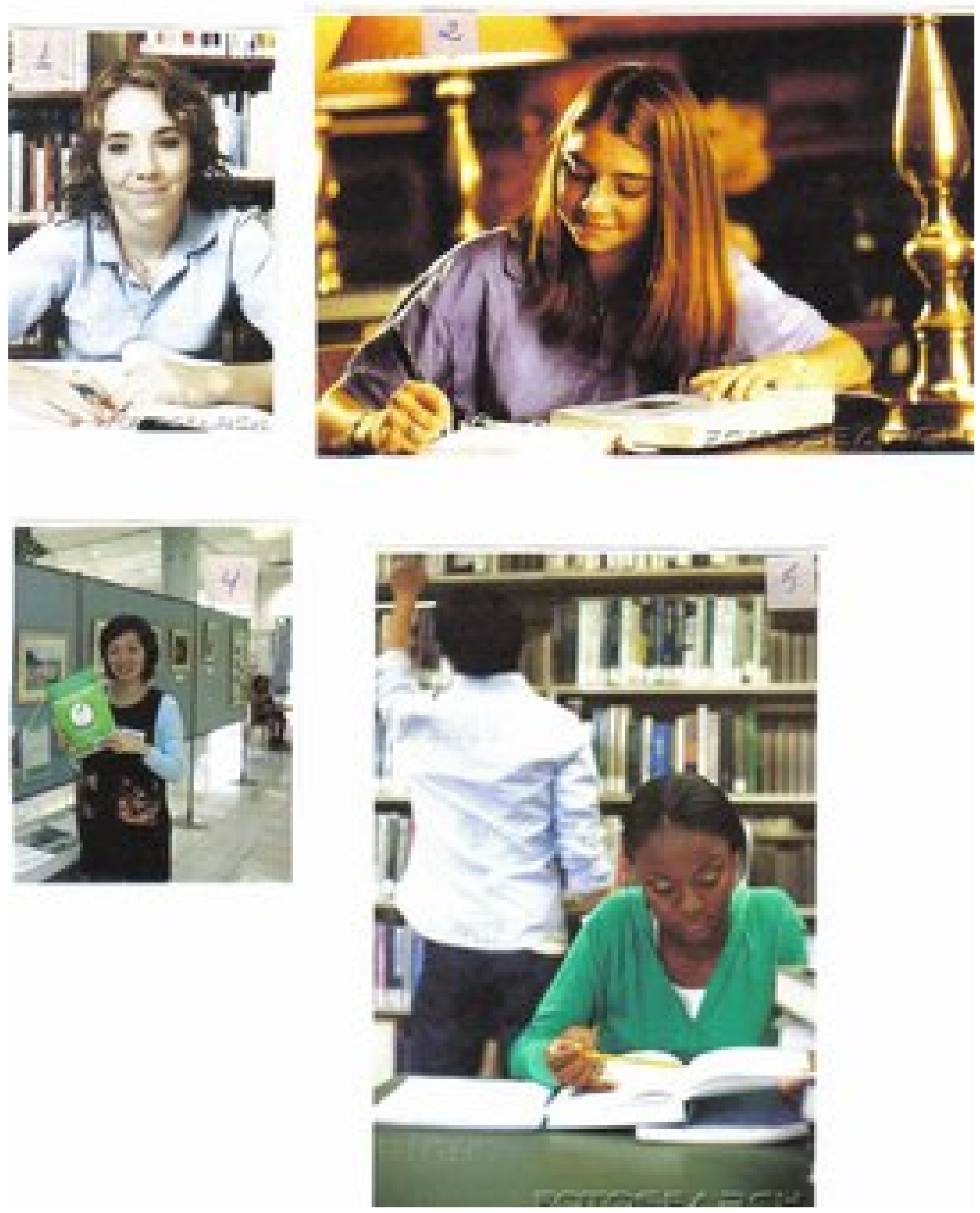


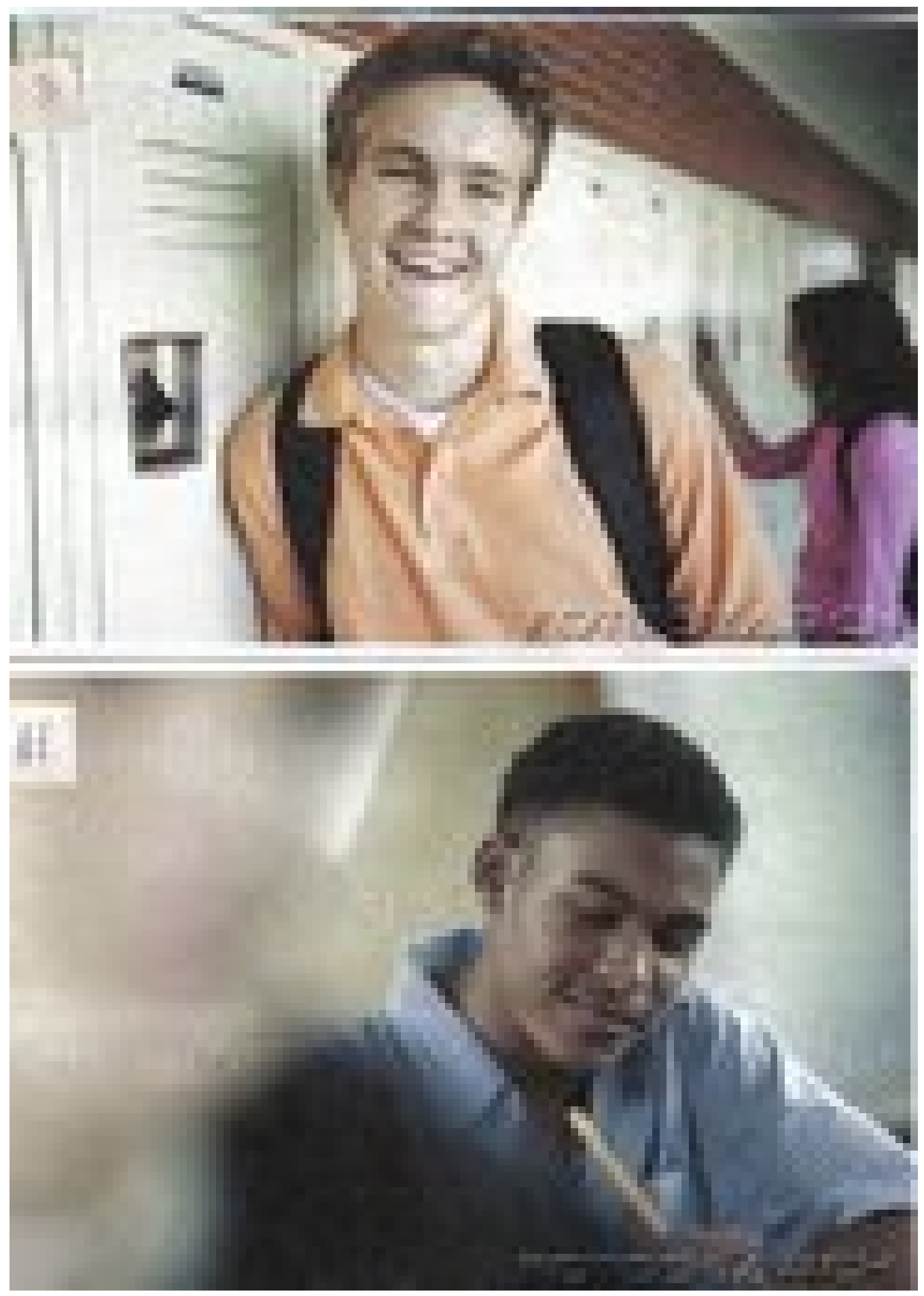


FOTOS PARA A PERGUNTA 3

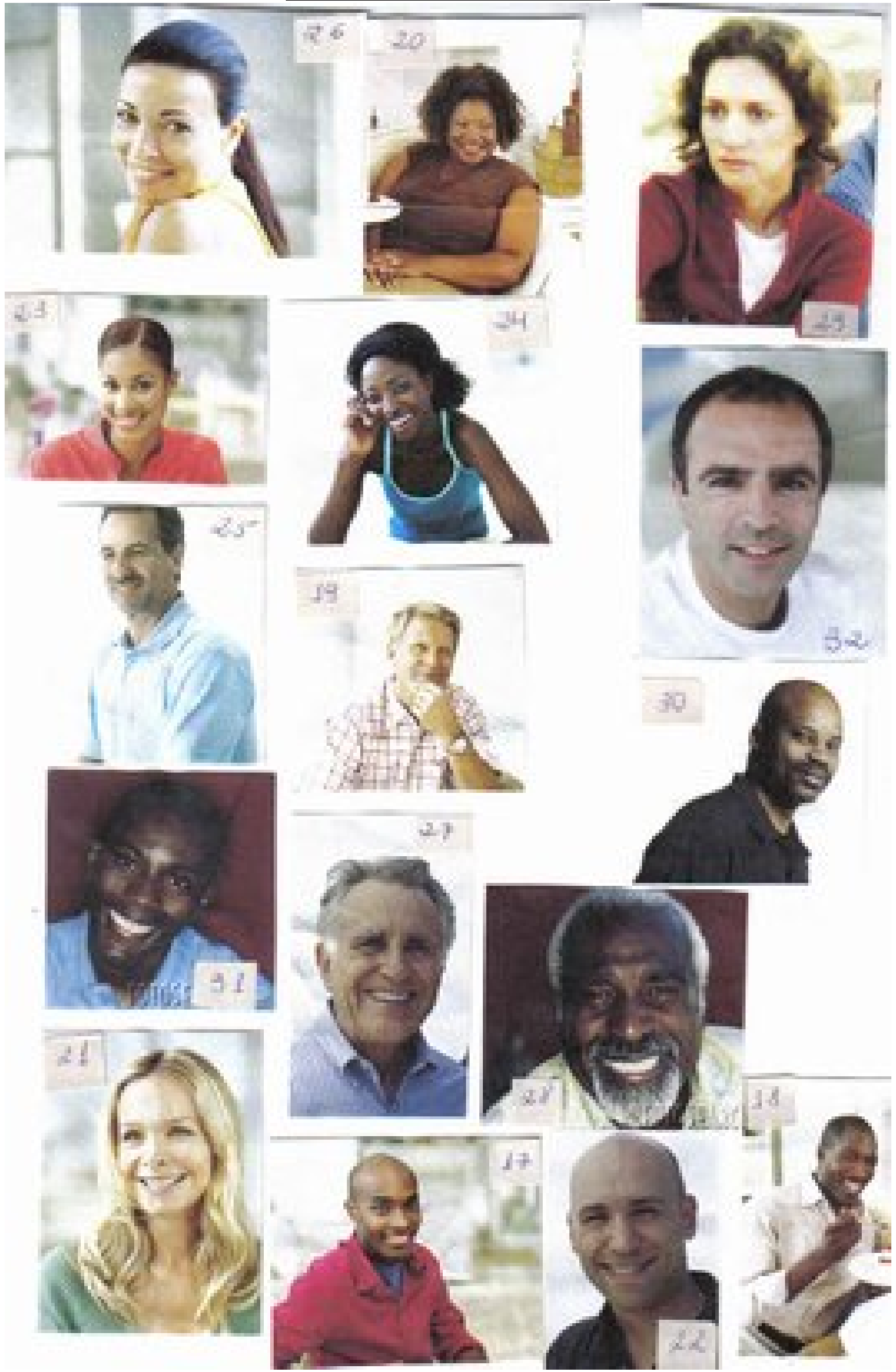




\section{REFERÊNCIAS BIBLIOGRÁFICAS}

ADORNO, Theodor W. Educação e Emancipação. São Paulo: Paz e Terra, 2003.

AGRAVO DE INSTRUMENTOS N. 2005.04.01.006358-2/PR. Sistema de cotas Raciais e Sociais.

ALVES, José Augusto Lindgren. A Arquitetura Internacional dos Direitos Humanos. São Paulo: Editora FDT, 1997.

ALVES, José Augusto Lindgren. Diferencialismo e igualitarismo na luta contra a discriminação racial. Revista da USP, dez/jan/fev, 2005/2006.

ALVES, José Augusto Lindgren. Os direitos humanos na pós modernidade. São Paulo: Editora Perspectiva, 2005.

ANDORNO, Roberto. The paradoxal notion of human dignity. Rivista Internazionale de Filosofia del Diritto, serie V, ano LXXVIII, n. 2, aprile/giugno, 2001, p. 151 a 168.

BARDIN, L. Análise de conteúdo. Lisboa: Edições 70, 1979.

BARRETO, Vincente. Universalismo, Multiculturalismo e Direitos Humanos. In: PINHEIRO, Paulo Sérgio e GUIMARÃES, Samuel Pinheiro (orgs.). Direitos Humanos no Séc XXI. Brasília, Senado Federal, 2002.

BENEVIDES, Maria Victoria de Mesquita. Cidadania e direitos humanos. Caderno de pesquisa Fundação Carlos Chagas, n ${ }^{\circ}$ 104, Direitos Humanos, Cidadania e Educação, 1998.

Artigo: Educação em Direitos Humanos: de que se trata? Palestra de abertura do Seminário de Educação em Direitos Humanos. São Paulo, 18/02/2000.

BENTO, Maria Aparecida Silva. Branquitude ï o lado oculto do discurso sobre o negro. In: CARONE, Iray e BENTO, Maria Aparecida Silva (orgs.). Psicologia Social do Racismo. Petrópolis: Editora Vozes, 2003.

BOBBIO, Norberto. A Era dos Direitos. Rio de Janeiro: Editora Campus Ltda., 1991.

Elogio da serenidade e outros escritos morais. São Paulo: Editora Unesp, 2002.

BRASIL. Constituição Federal República Federativa do Brasil. Brasília: Senado Federal. Centro Gráfico. 1988.

CANDAU, V. Educação em Direitos Humanos. Revista Novamerica, n. 78. Rio de Janeiro, 1998. 
CANDAU, Vera Maria. Oficinas Pedagógicas de Direitos Humanos. Petrópolis: Vozes, 1995.

CARVALHO, José Sérgio de. Educação e Direitos Humanos: experiências em formação de professores e em prática escolares. In: SCHILLING, Flávia (org.). Direitos Humanos e Educação Ï Outras palavras, outras práticas. São Paulo: Editora Cortez, 2005.

CARVALHO, Adalberto Dias de. Utopia e Educação. Porto, PT: Porto Editora, 1994.

CARVALHO, José Sérgio Fonseca de (org.). Educação, Cidadania e Direitos Humanos, Petrópolis: Editora Vozes, 2004.

. Democratização do ensino. Revista e Pesquisa, São Paulo, v. 30, n. 2, p. 327-334, maio/ago, 2004.

Educação e Direitos Humanos: experiências em formação de professores e em prática escolares. In: SCHILLING, Flávia (org.). Direitos Humanos e Educação ï Outras palavras, outras práticas. São Paulo: Editora Cortez, 2005.

CHAUÍ, Marelena. Cultura e racismo. Aula inaugural na Faculdade de Filosofia Letras e Ciências Humanas da Universidade de São Paulo em 10.03.1993. Revista [on line] Vermelho ï Revista Teórica, Política e de Informação. Disponível em: < http://www.vermelho.org.br/museu/principios/anteriores.asp?edicao=29\&cod_not=1062>. Acesso em: <13 ago. 2007>.

CHNAIDERMAN, Miriam. Racismo, o estranhamento familiar: uma abordagem psicanalítica. In: SCHWARCZ, Lilia Moritz; QUEIROZ, Renato da Silva (orgs.). Raça e diversidade. São Paulo: EDUSP, 1996.

COMPARATO, Fábio Konder. Igualdades, Desigualdades. Revista Trimestral de Direitos Público, Capítulo 27. Editora Senado Federal, São Paulo, 1993.

COMPARATO, Fabio Konder. Ética. São Paulo: Cia das Letras, 2006.

. A Afirmação Histórica dos Direitos Humanos. São Paulo: Saraiva, 2005.

74.

Fundamento dos Direitos Humanos. Revista de Estudos Avançados, 2000, p. 53 a

CROCHIK, José Leon. Preconceito, indivíduo e cultura. São Paulo: Editora Robe, 1995.

DISKIN, Lia e ROIZMAN, Laura. Paz como se Faz ? ï Semeando cultura e paz nas escolas. Rio de Janeiro: UNESCO, Associação Palas Athena, 2002.

DONOSO, Patrício. Três conceptos em um debate sobre educación y derechos humanos. In: Democracia Pedagógica y Derechos Humanos. Lima: CEAAL e Instituto Peruano de Educación em Derechos Humanos y la Paz, 1995. 
FREEMAN, Michael, Direitos Humanos Universais e Particularidades Nacionais. In: PINHEIRO, Paulo Sérgio e GUIMARÃES, Samuel Pinheiro (orgs.). Direitos Humanos no Século XXI. Brasília: Senado Federal, 2002.

FRY, Peter. Discriminação e Racismo. São Paulo: Editora Daedalus, 2000.

FRY, Peter. Ciência social e política ñacialò no Brasil. In: Revista da USP, dez/jan/fev 2005/2006.

GOFFMAN, Erving. Estigma. Rio de Janeiro: Editora Guanabara koogan, 1982.

GOMES, Joaquim Barbosa. O debate constitucional sobre as ações afirmativas. In: SANTOS, R. E.; LOBATO, F. Ações afirmativas: Políticas Públicas contras as desigualdades raciais. Rio de Janeiro: DP\&A,2003.

KAMEL, Ali. Não somos racistas. Rio de Janeiro: Nova Fronteira, 2006.

LAFER, Celso, A Internacionalização dos Direitos Humanos, Constituição, Racismo e Relações Internacionais. Barueri: Editora Manole, 2005.

MAGENDZO, Abraham. Educación em derechos humanos ï um desafio para los docentes. Santiago: LOM Ediciones, 2006.

MAGENDZO, Abraham. Educación en la no-discriminación: Una condición para la democracia. In: Democracia Pedagógica y Derechos Humanos. Lima: CEAAL e Instituto Peruano de Educación en Derechos Humanos y la Paz, 1995.

MOEHLECKE, Sabrina. Ação Afirmativa: História e debates no Brasil. Caderno de Pesquisa, n. 117, novembro/2002.

MUNANGA, Kabngele. Psicologia e Racismo: Uma Autocrítica Necessária I. In: COMISSÃO NACIONAL DE DIREITOS HUMANOS do Conselho Federal de Psicologia. Psicologia e Direitos Humanos: Subjetividade e Exclusão. São Paulo: Casa do Psicólogo; Brasília, DF: Conselho Federal de Psicologia, 2004.

PAREKH, Bhikhu. Rethinking Multiculturalism ï Cultural Diversity and Political Theory. Cambridge, Massachusetts: Harvard University Press, 2000.

RIOS, Roger Raupp. Direito da Antidiscriminação. Discriminação Direta, Indireta e Ações Afirmativas. Porto Alegre: Editora Livraria do Advogado, 2008.

SANTOS, Gislene Aparecida dos Santos. Filosofia e as Gentes ï um estudo sobre a origem das diferenças. In: Valores, Preconceito e Práticas Educativas. São Paulo: Editora Casa do Psicólogo, 2005.

SARMENTO, Daniel. Livres e Iguais ï Estudos de Direito Constitucional. Rio de Janeiro: Editora Lumen Juris, 2006.

SEGATO, Rita Laura. Cotas: por que reagimos? Revista da USP, dez/jan/fev 2005/2006. 
SCHILLING, Flávia. Da declaração à ação: desafios para o trabalho de educação em direitos humanos. Observatório de Políticas Públicas de Derechos Humanos em el Mercosul ï um compromisso regional. Montevidéu, 2004.

SEN, Amartya. Desenvolvimento como liberdade. São Paulo:Editora Schwarcz Ltda, 2004.

SILVA, Humberto Pereira da. Educação em Direitos Humanos: Conceitos, Valores e Hábitos. Dissertação apresentada ao Programa de Pós Graduação da Faculdade de Educação da USP, sob a orientação da Profa. Dra. Maria Victória de Mesquita Benevides. São Paulo, 1995. 